Szegedi Tudományegyetem Bölcsésztudományi Kar Nyelvtudományi Doktori Iskola Történeti Szlavisztika alprogram

PHD disszertáció

\title{
Милятино евангелие - источник изучения истории русского языка
}

(A Miljatyin-evangélium mint az orosz nyelvtörténet tanulmányozásának forrása)

Antoskiv Galina

2014

Doktori iskola vezetője:

Témavezető:

Dr. Kenesei István

Dr. Balázs L. Gábor

Alprogram vezetője:

Dr. Kocsis Mihály 
Особою благодарность хочу выразить профессору И. Х. Тоту, за предоставленный мне материал (фотокопии) рукописи Милятиного евангелия, за руководство и помощь в работе. А также выражаю благодарность руководителю темы Др. Г. Л. Балажу; преподавателям Др. М. Кочишу, Др. А. Кацибе, профессору К. Адягаши и Ирине Багмут (кандидат филологических наук). 


\section{Содержание}

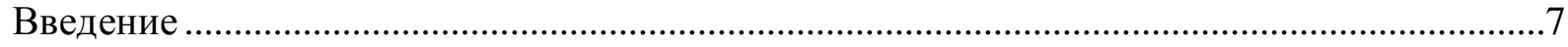

I Кодикологическое и палеографическое описание рукописи .............................................11

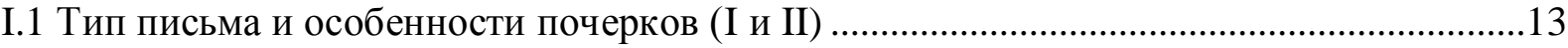

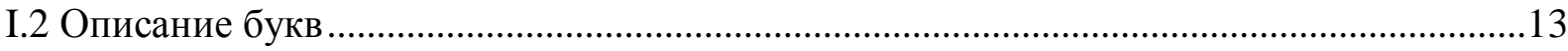

I.3 Особенности письма и некоторых букв, влияющих на определение даты рукописи.18

I.4 Литтеральные отличия между I и II почерком ................................................................18

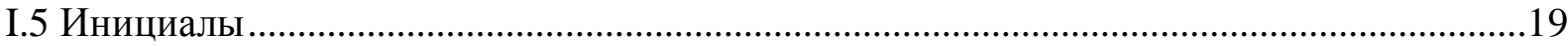

I.6 Слова под титлом и выносом и их полные формы .........................................................19

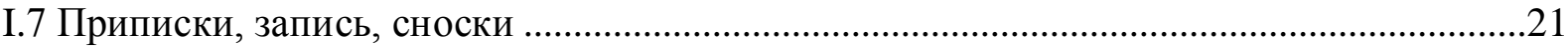

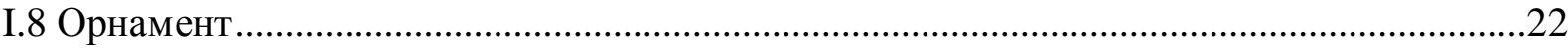

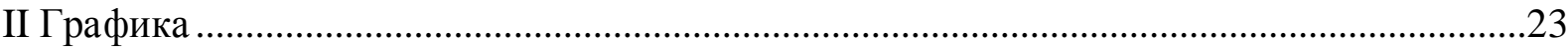

II.1 Употребление графем греческого алфавита .....................................................................23

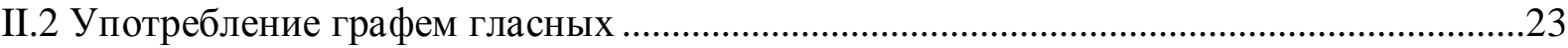

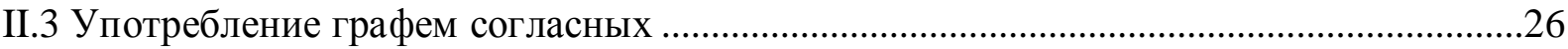

II.4 Диалектные особенности графической системы ..........................................................28

III Фонетико-орфографические особенности рукописи ........................................................29

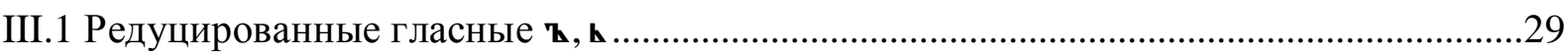

III.1.2 Рефлексы континуантов праславянских сочетаний *tъrt, *tbrt, *tъlt, *tblt ..............35

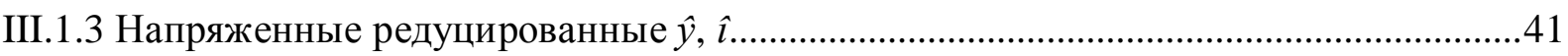

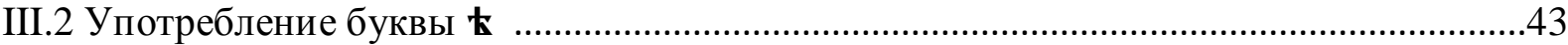

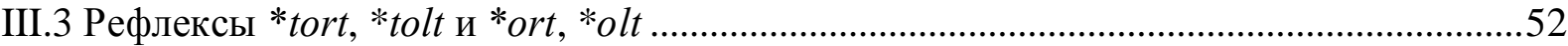

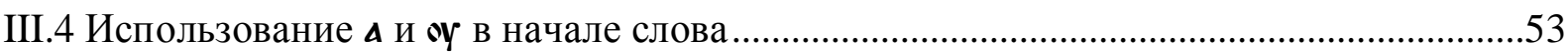

III.5 Маловажные изменения в системе гласныхё.................................................................53

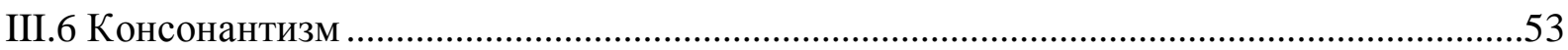

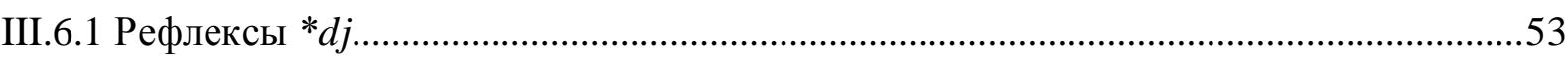

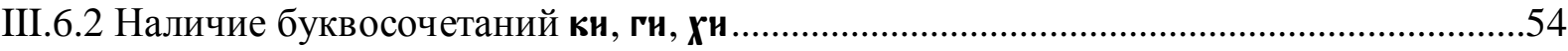

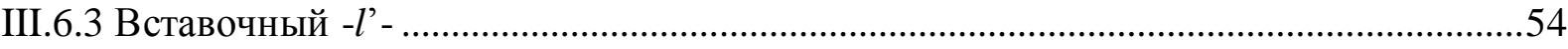

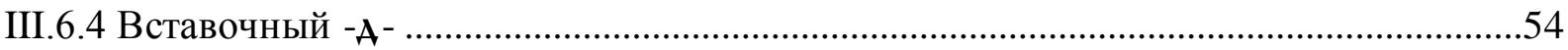

III.6.5 Маловажные изменения в системе согласных ..........................................................55

III.7 Диалектные особенности согласных ..........................................................................56

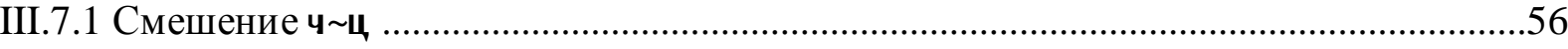

III.7.2 Рефлексы II и III палатализации..................................................................................57

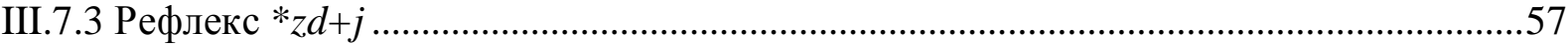




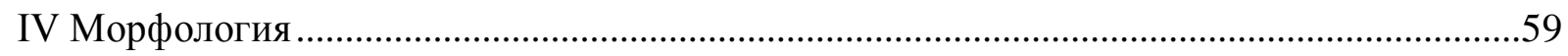

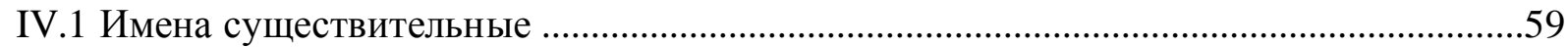

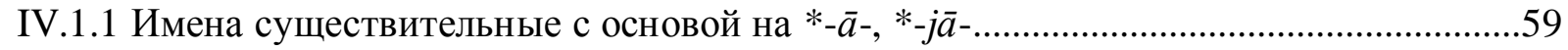

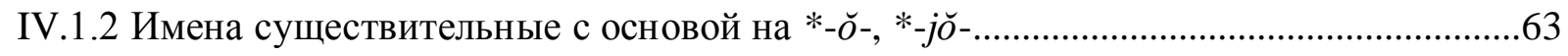

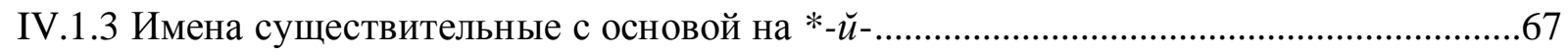

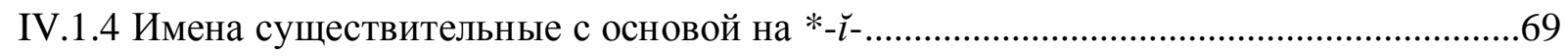

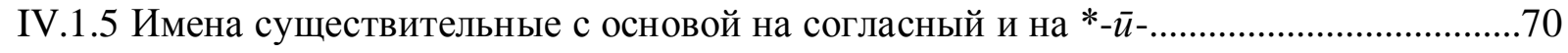

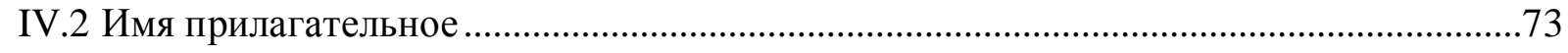

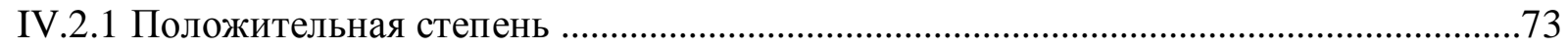

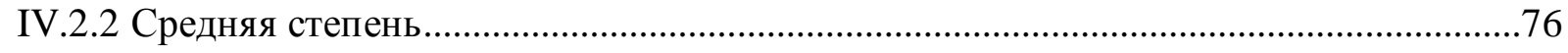

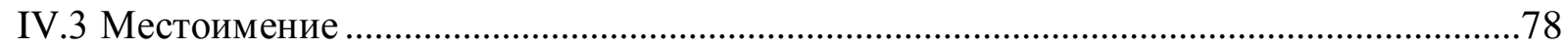

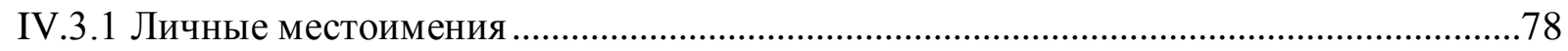

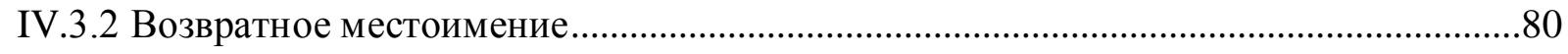

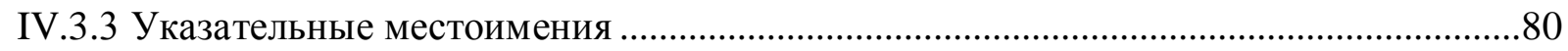

IV.3.4 Анафорическое и относительное местоимения .......................................................82

IV.3.5 Притяжательные и притяжательное возвратное местоимения ……..........................84

IV.3.6 Вопросительно-относительные и отрицательные местоимения ................................85

IV.3.7 Определительные и совокупные местоимения ............................................................86

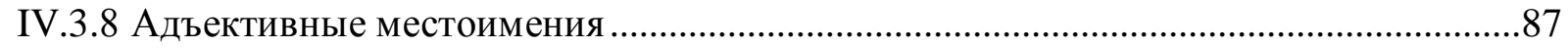

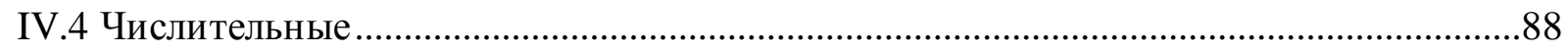

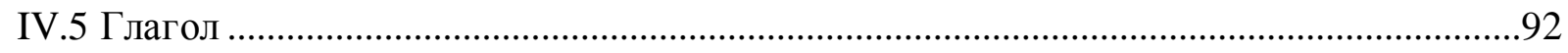

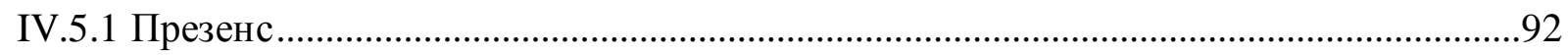

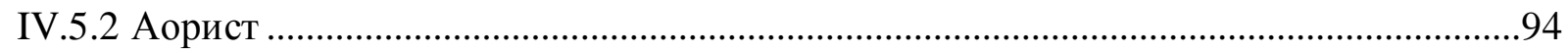

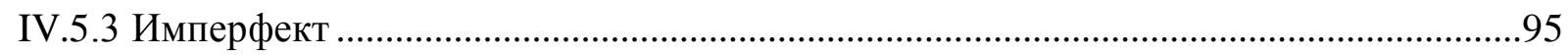

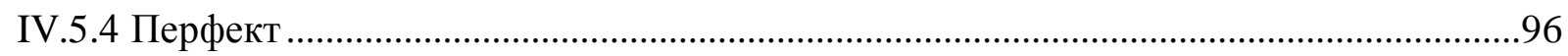

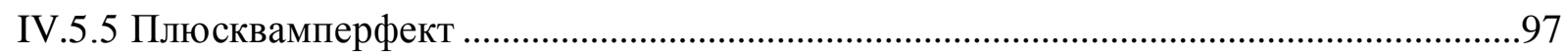

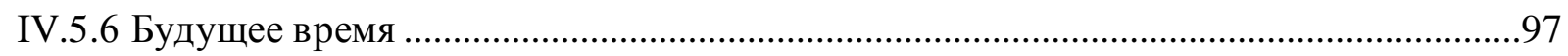

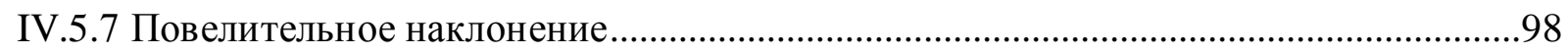

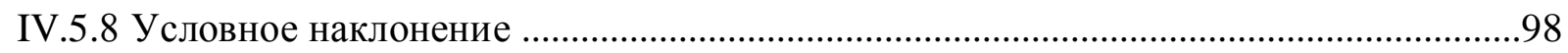

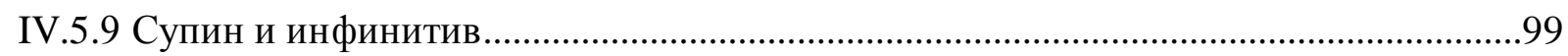

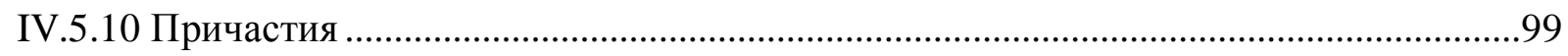

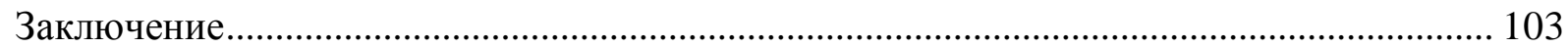

Церковный календарь с соответствующими чтениями Милятиного евангелия и их

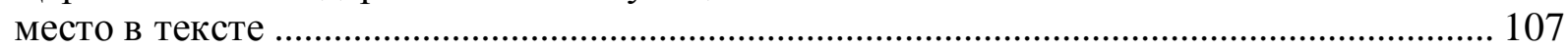

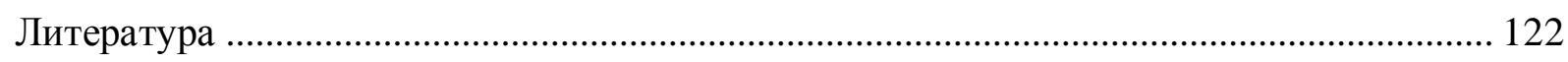




\section{Условные сокращения}

Биб. - Библия книги Священного Писания Ветхого и Нового Завета

Буд. - Будапештское евангелие

Гал. - Галицкое евангелие

Зогр. - Зографское евангелие

Мар. - Мариинское евангелие

Ост. - Остромирово евангелие

Сав. - Саввина книга

Суnр. - Супральская рукопись

aоp. - аорист

буд. вр. - будущее время

В. п. - винительный падеж

РНБ -Российская национальная библиотека

Д. п. - дательный падеж

дв. ч. - двойственное число

ед. ч. - единственное число

ж. p. - женский род

Зв. ф. - звательная форма

И. п. - именительный падеж

и т. д. - и так далее

л. - лицо

М. п. - местный падеж

мн. ч. - множественное число

м. p. - мужской род

п. - падеж

Р. п. - родительный падеж

c. p. - средний род

Т. п. - творительный падеж 
Введение

Приступая к изучению древнерусской рукописи конца XII - начала XIII вв., которой является Милятино евангелие $(M m E)$ уточним, в каком направлении будет вестись анализ работы и какие аспекты берутся к расмотрению.

Во-первых, установим почему $M m E$ может выступать источником для изучения истории русского языка, а также общие критерии анализа рукописи. По мнению БакроНадь, древние письменные памятники ( $M m E$ - рукопись) для изучения истории языка являются первоисточниками и по сегоднешний день, так как язык прошлого дошел к нам в письменном виде (к другому, по важности, источнику принадлежит звукозапись) (Bakró-Nagy 2010: 151). Ко вниманию берется, что текст нашей рукописи библейского содержания (проза) и является продуктом переписи с протографа двумя писцами. Язык рукописи изучается комплексно: а) влияние протографа; б) книжных норм написания; в) древнерусского языка; г) учитывается диалект переписчиков, а также их квалифицированность. Рукопись $M m E$ упоминается в Сводном каталоге славянорусских рукописных книг, хранящихся в СССР XI-XIII вв. (опись рукописи сделана Е. В. Афанасьевой (Шмидт 1984: 14)).

Во-вторых, определим понятия, которые встречаются в работе. По мнению Елкиной, в первых рукописях восточных славян «сочетаются две языковых стихий: старославянская и древнерусская» (Елкина 1960: 32). Старославянский язык - первый язык славян зафиксированный на письме. Иногда его называют еще и староболгарским (старомакедонским), так как на основе одного из наречий болгарского языка Кириллом и Мефодием (солунские братья) был разработан первый славянский алфавит (Селищев 1951: 10-11; Н. Tóth 2003: 52). Но термин старославянский более распространен и принят, так как в первых же переводах староболгарский язык подвергся влиянию тех славянских языков, где сотрудничали братья, таким образом создавая изводы, адаптацию старославянского языка (Живов 2006: 239).

Об определении названия старославянского языка Ван-Вейк писал следующее: «Название древнецерковнославянский (=старославянский) все же правильнее, так как его можно применять к текстам и не чисто болгарским, каковым являются, например, Киевские листки; в тех случаях, когда речь идет о позднейшем периоде, когда наряду с болгаро-церковнославянскими (среднеболгарскими) существуют тексты русскоцерковнославянские [...] мы должны употреблять термин «церковнославянский», а не древнецерковнославянский (=старославянский)» (Ван-Вейк 1957: 19). Первые рукописи 
это переводы с греческого богослужебных книг, то есть это был церковный язык. От сюда и термин цеерковнославянский (Иванова 1998: 87).

В то время, когда с принятием христианства на Руси появляются первые богослужебные книги на старославянском языке, древние восточные славяне имели свой язык - древнерусский и свои диалекты (в данном случае древненовгородский). Разница между старославянским и древнерусским была незначительна в том смысле, что старославянский был понятным для восточных славян. Но очень быстро произношение восточных переписчиков стало проникать графически в рукописи, создавая церковнославянский язык русского извода. Живов в своей статье Автономность письменного узуса... как раз занимается проблемой соотношения церковнославянского и древнерусского (диалектов восточных славян) языков. Он отвергает теорию о модели двуязычия: а) нет переводов с одного языка на другой; б) церковнославянский язык никогда не был мертвым языком; в) «Что еще существеннее, церковнославянский у восточных славян эволюционировал, в какой-то мере отражая в своей эволюции развитие живых языков восточных славян, что вообще говоря, с мертвыми языками не случается»; г) «церковнославянский язык не воспринимался как «чужой» иностранный язык» (Живов 1998: 214). По мнению Успенского: «[В] языковом сознании при диглоссии книжный и некнижный языки воспринимаются как один язык - книжный язык выступает в этих условиях как кодифицированная и нормированная разновидность языка. Между тем, для внешнего наблюдателя (включая сюда и исследователя-лингвиста) естественно в этой ситуации видеть два разных языка. Таким образом, если считать вообще известным, что такое разные языки, диглоссию можно определить как такую языковую ситуацию, когда два разных языка воспринимаются (в языковом коллективе) и функционируют как один язык» (Успенский 1987: 15). С мнением Успенкого соглашается Живов, называя концепцию церковнославянско-русской диглоссии, более адекватной моделью (Живов 1998: 214).

По мнению Живова, книжный язык отличался от разговорного нормированным характером (Живов 1998: 218). Здесь важно определить понятие термина норма. Со временем, изучая рукописи древнеславянского языка, стал вопрос об определении разницы между «ошибками» (последовательными, единичными) писцов, то есть разницы - между проникающими в старославянские рукописи русизмами. «Выходом из этого положения является предположение некоторыми учеными (А. А. Шахматов, Н. Дурново, Н. И. Толстой, Б. А. Успенский) определенной нормы, которая, исходя из 
функции древнеболгарских рукописей, открыла доступ для проникновения в рукописи определенных русизмов. Те русизмы, которые с течением времени входили в нормы церковно-книжного языка, отражаются в рукописях более или менее выдержано и последовательно. Те же русизмы, которые не составляют постоянно распространяющуюся норму древнерусских рукописей, попадают в них действительно по недосмотру» (Х. Тот 1985: 263). Другими словами, церковно-книжный язык стал посредником для проникновения в старославянские рукописи русизмов.

В свою очередь, Дурново так характеризует систему древнерусского языка: «Из соединения восточно-болгарских и македонских с русскими, вызванными необходимостью приспособить этот язык к русскому произношению, получился церковнославянский язык древнерусских памятников» (Дурново 1969: 39). Живов дополняет: «[...] русская книжность и русский литературный язык древнейшей эпохи (церковнославянский язык русского извода) возникли на основе инославянской книжности, на основе общего для всех славян кирилло-мефодиевского наследия» (Живов 2006: 234).

По мнению Х. Тота, первые древнерусские рукописи по проникновению русизмов разделяются на два периода. Перый период характеризуется непоследовательным использованием русизмов, этот период Х. Тот называет русским изводом; второй период характеризует некоторое постоянство проникновения древнерусских графических, фонетических, морфологических форм, явлений - этому периоду ученый дает термин русской редакции (Х. Тот 1985: 265). Такая разница между понятиями (русским изводом и русской редакции) не всеми исследователями принята, но дает возможность различать рукописи, где «без всякой последовательности» проводятся русизмы (Остромирово евангелие 1056) от уже «обрусевших» (Архангельское евангелие 1092) (Соболевский 1980: 29-30). Таким образом, в первых русских изводах старославянского языка постепенно вырабатывалась церковно-книжная норма, что привело к образованию русской редакции старославянского языка. «К началу ХІІ в. была выработана система древнерусского правописания вместе со свойственными ей дистрибутивными и импликационными нормами» (Х. Тот 1985: 266).

Изменения, происходящие под давлением древнерусского языка, не были всеобщими. К тому же $M m E$ - апракос-полный - богослужебная книга, то есть это вершина литературного языка XII - XIII вв., и в отношении письма характеризуется крайним консерватизмом. Быстрее всего русизмы проникали в фонетические слои языка (через произношения переписчиков), это отображалось на письме графически и 
закреплялось, в последствии, церковно-книжными нормами. Изменения на морфологическом уровне допускались реже (Живов 1998: 219; Толстой 1961: 53, 54, 57, 59).

В самых первых рукописях древнерусского языка, когда еще не наблюдается установившаяся норма книжного правописания, диалектные явления практически отсутствуют. Самое раннее датирование $M m E$ приходится на 1188 [Шмидт 1984:143], что причисляет евангелие к древним рукописям, но уже с установившимися грамматическими нормами церковно-книжного правописания (как это будет видно из исследования рукописи). Поэтому, в данном случае возможно проникновение и диалектических явлений (древненовгородских). Из древнерусских земель XI - XIV вв. «Большая часть дошедших до нас древнерусских письменных памятников относится к Новгороду и его землям» (Филин 2006: 89). Письменность Новгорода настолько широко представленна, что дает возможность исследователям представить особенности новгородских говоров XI - XIV вв. [Филин 2006: 89], «к тому же новгородские традиции письма допускали большии возможности отражения местных особенностей, чем в других культурных центрах Древней Руси» (Горшкова 1981: 178). Так как рукопись происходит из новгородских земель, особое внимание уделяется древненовгородскому диалекту.

Цель исследования - комплексное изучение древнерусской рукописи Милятиного евангелия. Достижение поставленной цели возможно благодаря реализации конкретных задач. Задачи исследования $M m E$ (выходя из вышенаписанного), привлекая графический, фонетическо-фонологический и морфологический уровни языка: установить принадлежность рукописи (время и место написания); описать элементы старославянского языка; проследить влияние древнерусского языка; выделить нормы церковно-книжного написания; выявить характерные древненовгородскому диалекту элементы, объяснить их (говор переписчиков). 
I Кодикологическое и палеографическое описание рукописи

Милятино евангелие $(\mathrm{MmE})$ - древняя пергаменная рукопись, древнерусского языка. Сохраняется в РНБ (Россия, Санкт-Петербург, Садовая ул. 18; до 1992 Государственная публичная библиотека им. М. Е. Салтыкова-Щедрина) под №117, F. п. I. $7^{1}$. Написана уставом, двумя переписчиками: I-п. 1а-44г, 64а-71г, 77в-160б; II-п. 45а-63г, 72а-77б. Время создания рукописи определяется концом XII или началом XIII вв (точная дата написания в рукописи не найдена). В определении даты написания $M m E$ большую роль сыграла запись писца Домки (I переписчик), попа монастыря святого Лазоря (Новгород), в которой он пишет об окончании работы над рукописью в голодный год

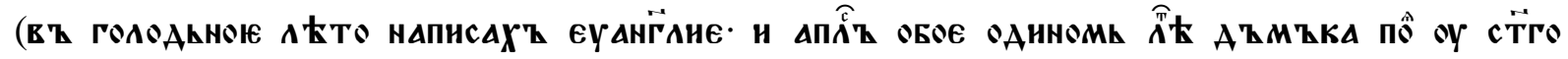

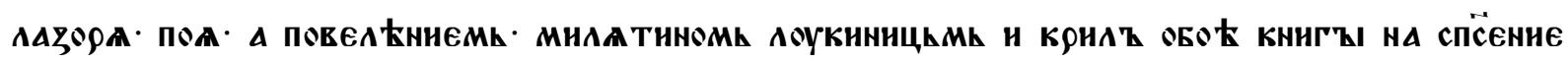

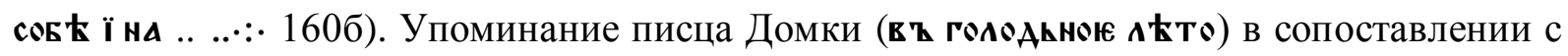

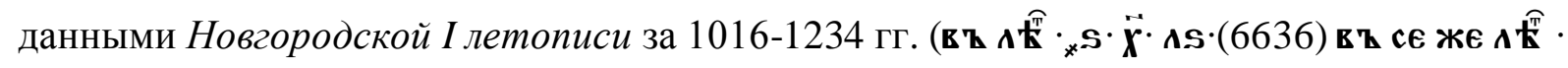

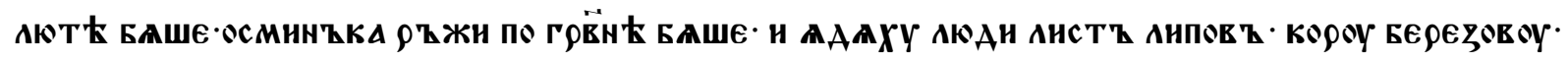

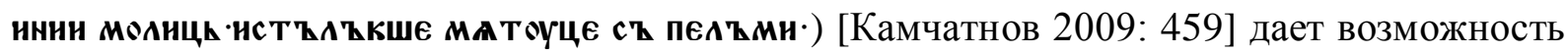
определить дату написания рукописи, предположительно идет речь о 1188, 1215 гг. или 1230 г. Приписка первого переписчика содержит точное место создания рукописи (оу ст̈го ^Азора): монастырь святого Лазаря Новгорода (изучение рукописи (графика, фонетика) подтверждает ее принадлежность к древненовгородскому диалекту). Из записи Домки также узнаем об имени заказчика рукописи - повел Еннємь мнлатнномь лоукиннцьми, от сюда происходит название рукописи - Милятино евангелие. Формат 1 $(30 \times 23,5)$. Рукопись состоит из 1+160 листов без начала и конца (самый последний лист сохранился), лист 78 выпадает, у листа 1 оборван край внешнего поля, у листа 2 внешнее поле надорвано. (Археографический ежегодник 1966: 199; Жуковская 1976: 289; Карский 1979: 46, 294; Шмидт 1984: 143).

Переплет - картон в тисненой золотом коже, одна из застежек оборвана.

«На листе I об. полустертая миниатюра: евангелист Иоан и другая фигура. Определение фигуры у исследователей различно, так как лицо ее стерто: Иоан и ангел

\footnotetext{
${ }^{1}$ Буква F обозначает формат (в лист), русская буква «п» означает, что рукопись пергаменная; следующие затем римские цифры указывают на принадлежность рукописи к тематическому разделу (разд. I - богословие [...]) и арабские - номер единицы хранения (Шмидт 1984: 17).
} 
(А. И. Некрасов, Е. Э. Гранстрем); Иоан и Премудрость - София или Матфей и ангел (Ю. Н. Дмитриев, В. Н. Лазарев, А. Н. Свирин); Иоан и ап. Павел (Г. И. Вздорнов, О.С. Попова). Миниатюра присоединена к рукописи из другой книги и рядом исследователей датируется кон. XI - нач. XII в. (Ю. Н. Дмитриев, Г. И. Вздорнов, а также В. Н. Лазарев, А. Н. Свирин, О. С. Попова)» (Шмидт 1984: 143).

Работа затрудняется тем, что, к сожалению, приходится работать не с оригиналом рукописи, а только с фотокопией, поэтому, например, разлиновка совсем не видна, не возможно определить и нажимы, которые делал писец при написании рукописи, а также не возможно определить чернила и др.

Рукопись написана в два столбца по 23 строки (1а-65г); по 24 (66а-67г, 686-68в, 69а77в, 78а-98в, 99а-111г, 146в ); по 25 (68а, 68г, 77г, 80б, 98г, 107a, 112a-119г, 120б-120в, 121a-129в, 130a-135г, 138a-146б, 147a-160a); по 26 (120a, 120г, 127г, 129г, 136а-137г, 142а-143г); по 28 (160б). 


\section{I.1 Тип письма и особенности почерков (I и II)}

Общие замечания о почерках писцов.

$M m E$ написано уставом.

В рукописи над листами (столпцами) 1а-44г, 64а-71г, 77в-160б работал первый переписчик. Можно определить, что у первого писца строки написаны ровно (почти), буквы выведены четко. Сжатость письма стабильна. Размер одних и тех же букв одинаков. Характерна симметричность, геометричность и квадратность древнейшего устава. Между буквами соблюдается одинаковое расстояние. Наблюдается минимальный уклон влево.

У второго переписчика строки не совсем ровные. Размер одних и тех же букв не всегда одинаков. Буквы выглядят тоньше и «легче». Наблюдается некий наклон вправо. Стиль второго переписчика (особенно 45а-63г) характеризуется «беглостью» букв по сравнению с первым переписчиком. Однако, вторая половина 72а-77б работы переписчика намного сдержанней и устанавливается такая же геометричность и квадратность букв как и у первого писца. Для второго переписчика характерно то, что наполненность строки на пару букв (или даже слово) меньше, чем у первого переписчика (Приложение).

\section{І.2 Описание букв}

В рукописи употребляются следующие буквы кириллического алфавита: буквы

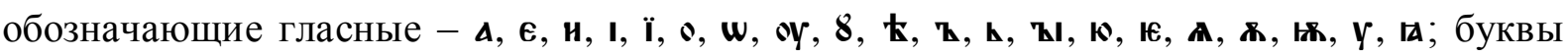

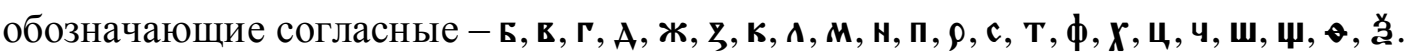

Описание букв, обозначающих гласные звуки:

$\boldsymbol{\Delta}$ - стержень буквы пишется с некоторым наклоном влево. Левая часть похожа на о, нижняя часть буквы не касаеться нижней линии строки. Стержень вдвое толще левой половины буквы.

ґ - буква состоит из двух букв: І и А соединенных поперечной чертой, которая касается петли и лежит чуть выше середины стержня.

$\boldsymbol{\epsilon}, \mathfrak{E}-$ буква очень узкая. Стенка очень открытого овала толстая и оканчивается с обеих сторон (сверху и снизу) заострением. Средняя часть иногда чуть-чуть 
выдвигается, расположена по середине, поэтому буква имеет пропорциональную форму. Буква ю имеет стержень, который соединяется с серединой буквы $\mathbf{\epsilon}$.

и - буква и состоит из двух толстых вертикальных линий, которые соединяются по середине горизонтальной тонкой линией. «вполне подобное гражданскому печатному эн» (Щепкин 1967: 112).

I- стержень буквы прямой, иногда имеет легкий наклон влево. Такой тип написания буквы используется в основном в слове $\overrightarrow{\mathbf{c} \mathbf{z}}$, а также для обозначения чисел; с двоеточием используется часто в конце слов, строк, с титлом образует числа.

• - буква имеет довольно узкую продолговатую форму без всякого наклона. Овал довольно толстый, поэтому середины иногда не видно.

$\boldsymbol{w}$ - буква пишется с тремя одинаково высокими черточками. Средняя часть не ниже боковых и где-то на середине стержня разветвляется, но есть примеры, когда разветвление происходит сразу, еще на верхней точке. Боковые овальные линии почти что параллельны, иногда слегка загибаются до середины. Общая форма буквы иногда не совсем пропорцианальна, потому что иногда овал левой стороны буквы выведен шире, чем правый, который уже, острее. «В XI в. омега почти без исключений имеет высокую середину... В первой половине XII в. омега с высокой серединой еще встречается (в роскошном Мстиславовом евангелии, в Юрьевском, в Галицком, в некоторых недатированных памятниках) (Щепкин 1967: 112-113).

у, 8 - состоит из двух букв без всякого соединения. Написание у состоит из двух линий. Правая линия начинается вверху круглым нажимом, закруглением и, опускаясь вниз, загибается до середины, проходит через нижнюю линию строки и оканчивается заострением. Левая линия имеет иногда легкий уклон влево, а иногда вертикальна, довольно толстая, касается правой на нижней линии строки. В рукописи встречается лигатура 8, которая используеться вместо oу в основном в конце строк. Буква размерами выходит за пределы верхней линии строки. Буква состоит из двух частей: нижняя - это овал, то есть буква \&, с верхней части которой расходятся две короткие линии. Такое написание архаично.

Ł - прямой стержень немного выходит за верхнюю линию строки. Коромысло лежит на верхней линии строки. Нижняя линия петли лежит на нижней линии строки, а верхняя касается стержня ниже его середины. Петля довольно маленького размера и обыкновенно треугольной формы. «В XII в. \$ своею мачтою по большей части 
несколько (очень мало) возвышается над верхним уровнем строки, а коромысло буквы лежит в этом уровне или приближается к нему...» (Щепкин 1967: 112). стар қишинғы $143 б$ петля буквы полностью заполняет по высоте строку, возможно, что произошло исправление неправильно написанной буквы $\bullet$.

z - стержень буквы прямой, толстый, иногда имеет наклон вправо. Петля небольшая, ее нижняя тонкая линия обыкновенно лежит на нижней линии строки. Петля имеет треугольную форму и обыкновенно касается середины стержня. Буква имеет вверху стержня горизонтальную линию влево. Линия небольшая, тонкая, с кончиком на конце, который образуется нажимом пера. Буква, за некоторыми редкими случаями, не выходит за пределы строки.

$\mathbf{h}-$ буква пишется так как $\mathbf{z}$, только без верхней горизонтальной линии.

$\mathbf{h}$ - буква состоит из двух букв: І и из $\mathbf{z}$ без всякого соединения.

w - буква состоит из двух букв: І и s, соединенных поперечной чертой, которая выходит из середины стержня.

А - буква состоит из двух наклоненных линий, соединяющихся на верхней линии строки. Линии прямые, редко ввогнутые ввнутрь, правая сторона иногда длиннее и невыразительнее. Линии соединяются посередине поперечной черточкой, от которой вниз опускается штрих.

ж - два наклоненных стержня, пересекающиеся в верхней своей части и горизонтальная черточка, лежащая на верхней части строки, образуют маленькую головку. От середины пересекающихся линий вниз опускается штрих, как у буквы А.

$\mathfrak{k}$ - буква состоит из І и $\boldsymbol{\AA}$, соединяющихся поперечной линией, которая выходит выше середины стержня и касается точки пересечения стержней. Буква встречается только один раз.

Описание букв, обозначающих согласные звуки:

в - вертикальный стержень прямой. Петля начинается около половины стержня и нижней частью соприкасается с нижней линией строки. Петля иногда треугольной формы, иногда овальной. Верхняя горизонтальная линия лежит на верхней линии строки. Она очень тонкая на окончании имеет кончик, который сделан нажимом пера. 
в - вертикальный стержень прямой. К стержню присоединяются две петли, которые встречаются на его середине. По форме петли пропорциональны, треугольной формы, но имеются примеры, когда нижняя петля округлена.

г - стержень вертикальный, прямой. Горизонтальная тонкая линия лежит на верхней линии строки, на окончании имеется заострение, сделанное нажимом пера.

A - буква состоит из двух наклоненных линий, которые соединяются на верхней линии строки. Внизу они соединяются горизонтальной тонкой линией, которая своими размерами чуть выходит за их пределы. Горизонтальная линия имеет на двух концах заострения, выходящие под нижнюю линию строки. Заострения сделаны нажимом пера.

ж - буква состоит из вертикальной мачты и двух диагоналей и написана в три приема. Буква не совсем пропорциональна, ее верхняя часть меньше нижней. Диагонали не прямые, а округлены к стержню. «...симметричное ж; симметричное ч - с округлой или с угловатой чашей. Вообще, оба века (XI - XII) объединяются преимущественно геометричностью их частей» (Щепкин 1967: 112). «Буква в XI в. была очень симметрична. Она писалась тогда (по наблюдению Срезневского) в три приема, или взмаха: «вертикальная мачта, дуга вверху, дуга внизу» или чаще: «вертикальная мачта и две диагонали», идущие сверху вниз, - одна справа влева, другая слева вправо» (Щепкин 1967: 115).

3 - буква состоит из стержня с наклоном вправо. От него выходит горизонтальная тонкая линия влево, которая лежит на верхней линии строки и оканчивается заострением, сделанным нажимом пера. В нижней части стержня начинается округлый тонкий хвостик. Хвостик полностью находится под нижней линией строки.

к - буква состоит из вертикального стержня. Правая сторона не соединяется с стержнем (левой стороной). Правая сторона состоит из двух под углом, соединенных линий. Верхняя немного короче нижней и имеет заокругление, сделанное нажимом пера.

^ - буква состоит из двух прямых накланенных линий, соединяющихся на верхней линии строки.

м - буква, очевидно, написана в три приема. Буква состоит из двух наклоненных к друг другу прямых стержней, которые соединяются овальной петлей. Петля доходит до нижней линии строки. Ширина больше длины. 
н - буква состоит из двух вертикальных стержней, которые соединяются косой тонкой линией. Линия выходит из верхней точки левого стержня (иногда немного ниже) и касается середины правой, но есть варианты, когда линия касается выше или ниже середины стержня. «тождественное с латинским, а равно три других варианта энс несколько укороченной перекладиной» (Щепкин, 1967: 112), что соответствует XII веку.

п - буква состоит из двух вертикальных прямых стержней, которые соединяются тонкой горизонтальной линией. Горизонтальная линия лежит на верхней линии строки.

$\rho$ - головка буквы по написанию похожа на букву ॰. Линия нижней части буквы выходит за нижнюю линию строки. Линия имеет легкий изгиб и оканчивается заострением.

c - буква очень узка. Стенка очень открытого овала толстая, оканчивается незаостренными, очень короткими концами.

$\mathbf{T}$ - буква имеет вертикальный прямой стержень с легким наклоном влево. Горизонтальный стержень имеет два заострения. Заострение левой стороны иногда чуть длиннее правой.

$\phi$ - стержень вертикальный прямой. Нижняя часть выходит за пределы нижней линии строки, также и верхняя за верхнюю линию строки, но намного меньше. Овал касается верхней линии строки, но не доходит к нижней. Овал симметричен.

$\boldsymbol{X}$ - буква состоит из двух, примерно на середине высоты, пересекающихся линий. Нижняя часть буквы выходит за нижнюю линию строки. Правая линия длиннее левой, но есть примеры, когда линии одинаковой длинны.

ц - буква состоит из двух вертикальных прямых стержней, где правый стержень выходит за нижнюю линию строки. На нижней линии строки стержни соединяются тонкой горизонтальной линией.

ч - буква состоит из вертикальной линии, к которой в ее верхней части присоединяется неглубокая, симметричная чашечка. Иногда чашечка имеет треугольную форму. «Буква в XI и XII вв. была симметрична и имела мелкую чашечку, - по большей части округлую, иногда треугольную...» (Щепкин 1967: 115).

ш - буква состоит из трех вертикальных прямых стержней, которые на нижней линии строки соединяются тонкой линией. Ширина буквы больше длины. 
$\boldsymbol{\Psi}$ - средний стержень буквы выходит за нижнюю линию строки. Ширина буквы больше длины.

- - буква состоит из буквы ^, через середину которой проходит горизонтальная линия. На концах линии имеются заострения, сделанные нажимом пера. Буква помещается в строке, это указывает на архаичность ее написания.

æ - буква написана широким зигзагом сверху вниз и выходит далеко за пределы нижней строки .

I.3 Особенности письма и некоторых букв, влияющих на определение даты рукописи

Определение даты написания $M m E$, исходя только из палеографического описания, сталкивается с малоразличимыми почерками XI, XII, XIII (первая половина) вв.

«...почерки конца XI в., особенно почерки прочные, очень похожи на почерки первой половины XII в., а почерки второй половины XII в. - на почерки начала XIII в.» (Щепкин 1967:114). $M m E$ уже не свойственны буквы так называемого «малого маштаба» $\boldsymbol{4}, \boldsymbol{\rho}, \boldsymbol{4}, \boldsymbol{\Psi}$, которые употреблялись в продолжении XI в. Буква $\mathbf{z}$ в XI в. не выходит за пределы верхней строки, а коромысло лежит ниже уровня верхней строки. Такое написание не характерно в $M m E$. В рукописи начертание буквы $\mathbf{k}$ отражают написание XII в. В первой половине XII в. происходит видоизменение в написании буквы w. Середина буквы сокращается и петли разводятся. В $M m E$ сохраняется старая форма $\boldsymbol{w}$, где середина буквы в одну высоту с двумя к ней прилегающими овальными линиями, которые внизу не расходятся.

По наблюдениям Щепкина, к середине XII в. старославянские буквы, обозначавшие

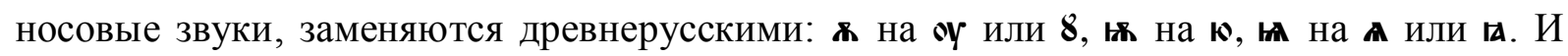
отсутствие этих старославянских архаизмов характеризует последующую русскую письменность (Щепкин 1967: 113-114). В $M m E$ наблюдаются ж и один раз њæ. Если брать к примеру только палеографические сведения, то датировка $M m E$ выпадает примерно на середину (вторую половину) XII в.

\section{I.4 Литтеральные отличия между I и II почерком}

Различие выявлено в написании буквы ж. У первого писца наблюдается начертание данной буквы в три приема: стержень и две волнообразные линии, пересекающиеся в одной точке, чуть выше середины стержня (такой прием написания описан выше). 
Предполагается, что у второго переписчика буква ж пишется в черыре приема. К вертикальному стержню с левой стороны (приблизительно на середине стержня) присоединяется тонкая линия под углом (второй прием), от этой линии выходит толстая вниз (третий прием). С правой стороны написание проводится, как у буквы к, с той разницей, что зигзагоподобная линия дотрагивается к стержню (четвертый прием). Не всегда правая и левая стороны имеют общую точку пересечения, иногда левая сторона выше, а правая немного ниже.

\section{І.5 Инициалы}

В рукописи находим три размера букв. Самые большие - инициалы (длина буквы проходит через четыре строки), инициалы старовизантийского типа, выведены киноварью и чернилами (Шмидт 1984: 143). Четыри буквы написаны таким способом: в, $\rho$ и по одному разу п и с. Это объясняется содержанием и структурой книги (апракос полный), где в начале зачал всегда имеются вступительные слова, среди них наиболее

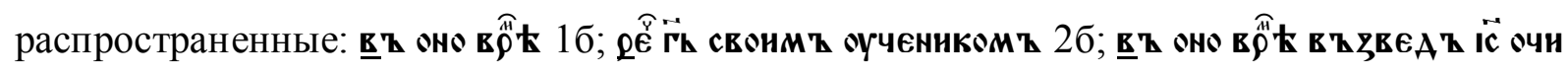

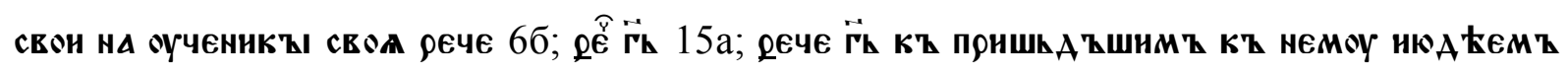

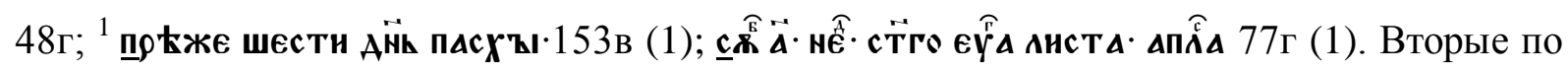
величине буквы (высота не выходит за верхнюю строку, низ буквы лежит на верхней линии нижней строки и вдвое толще за буквы в тексте) использовались для написания дней недели. Таким образом, размер буквы не только служил украшением рукописи, но и выступал в разделительном и распознавательном значении (текст рукописи написан

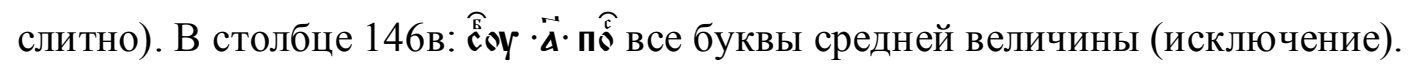

\section{I.6 Слова под титлом и выносом и их полные формы}

Сокращения слов в рукописи происходят двумя средствами. Наблюдаются сокращение под титлом (слово-титло) и вынос (буква-титло). И титло ${ }^{-}$и вынос относятся к надстрочным знакам. В рукописи титло - небольшая, прямая, горизонтальная, относительно толстая, но аккуратная черточка с двумя небольшими заострениями вниз. Вынос - круглая тонкая дуга, если употребляется над кратким словом, то ее края, распространяются на все слово. Слова под титлом носили религиозные понятия (nomina sacra); слова с выносом буквы над строку имели часто встречающееся бытовое значение (Щепкин 1967: 134; Н. Tóth 2005: 8). 
Слова под титлом и их полные формы (наиболее употребляемые):

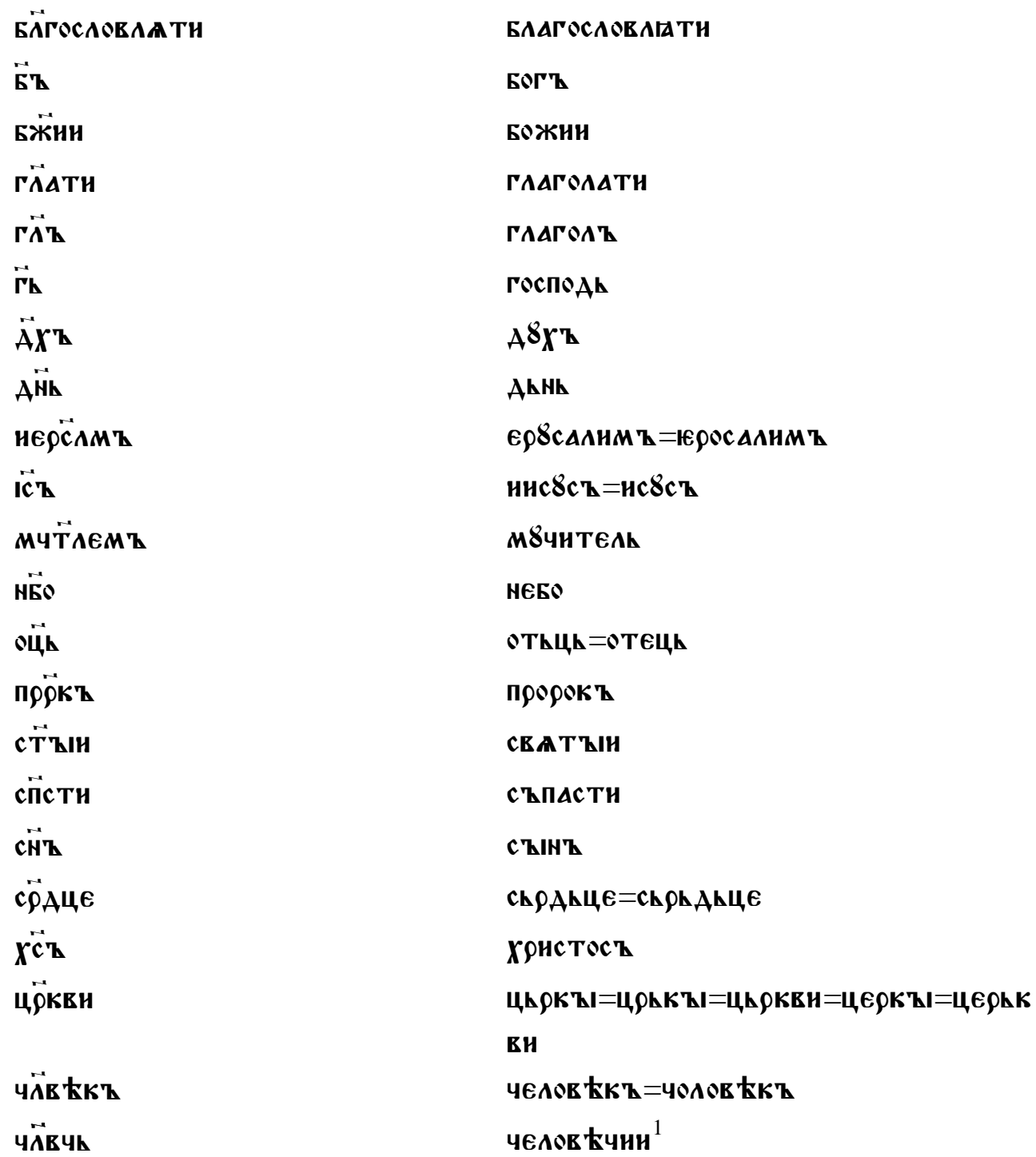

Примечание: ${ }^{1}$ под титлом именная форма прилагательного, полное слово соответствует местоименной форме данного прилагательного. Полные формы слов взяты из словаря Срезневского (Срезневский 1893).

За редким исключением, в тексте можно найти вышеприведенные слова и в полной форме: Аххти 18в, цксариствнга 24в.

Титло над буквой (буквами) обозначало и соответствующее число (числа). Буквы с цифровым значением, встречающиеся в рукописи:

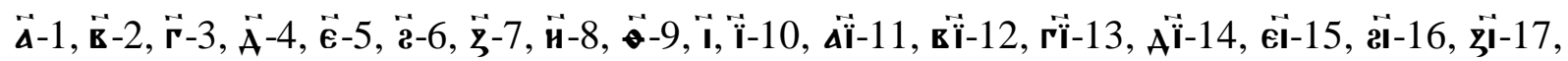
ні-18 и. т. д. 
В следующей таблице собраны слова с выносом и их полные формы:
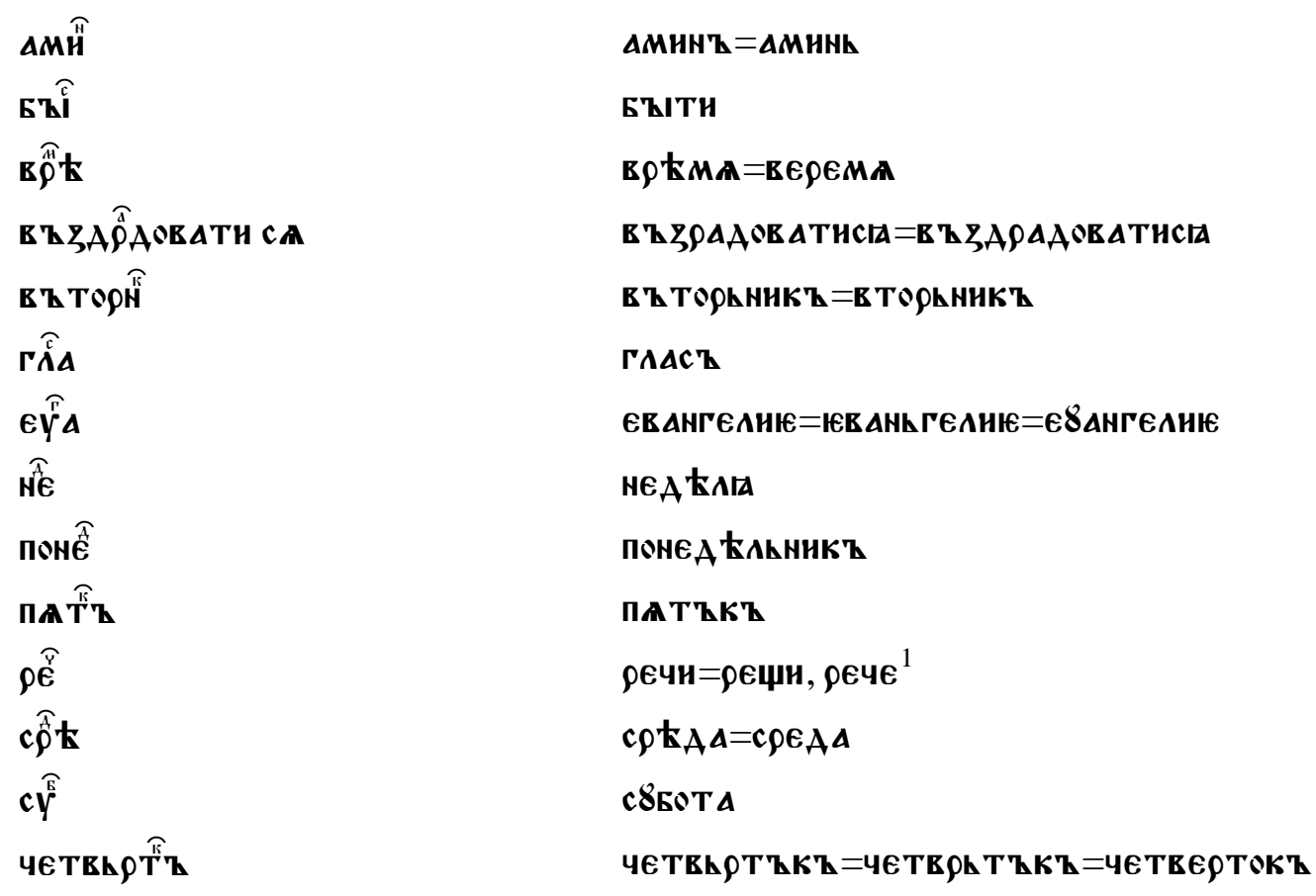

Примечания: ${ }^{1}$ сокращенное слово - глагол прошедшего времени, форма простого aоp. 3-го л. ед. ч.. Предлог ш्w (также активно используется, как префикс для словообразования глаголов) пишется без дуги, которая является частью графического начертания выноса. Полные формы слов взяты из словаря Срезневского (Срезневский 1893).

К надстрочным знакам также относятся точки, стоящие над некоторыми гласными, но к сожалению из-за качества фотокопии они неразличимы. А также имеются точки, стоящие на середине высоты строки. В некоторых случаях их невозможно различить, функция неясная, они не указывают на окончание предложения, мысли.

В словах нłсти 45в, постави 46г буква т возвышается над остальными буквами, возможно, с целью экономии места.

\section{I.7 Приписки, запись, сноски}

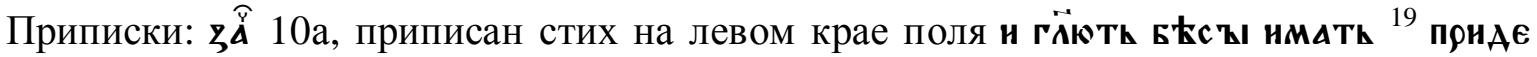

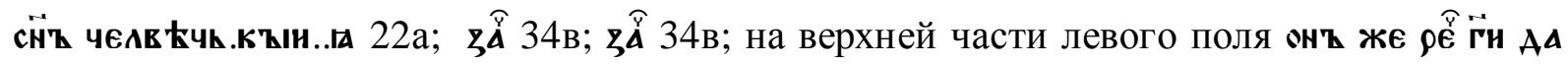
прозирк-123в. 


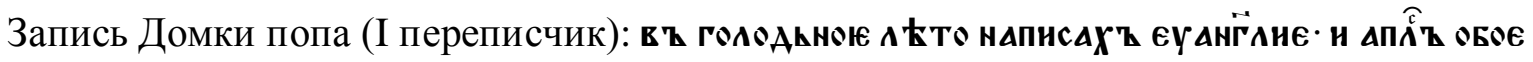

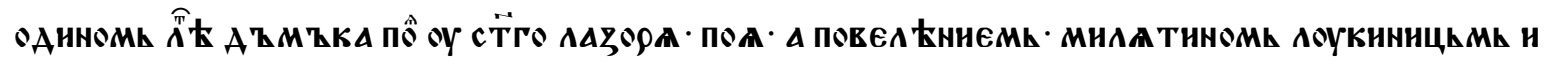

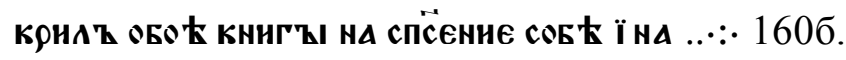

Сноски: в строке 48а, между слов встречается крест: †, на поле. Крест, нарисованный перписчиком, нельзя считать элементом украшения, потому что символ имеет чисто практическое значение. Это - указатель сноски: $†$..й̈вкъ

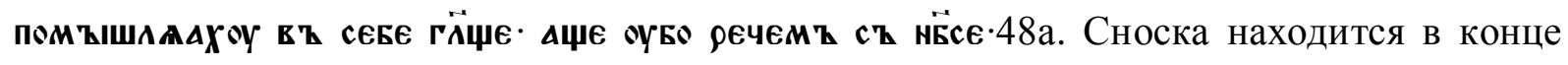
столбца. В столбце 77г между двумя столбцами по середине и в конце листа находятся

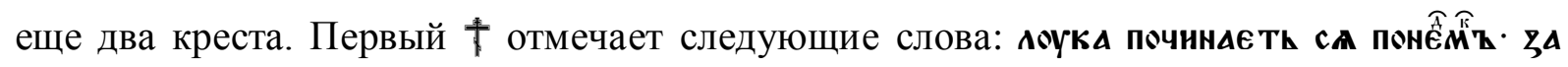
HЕึં

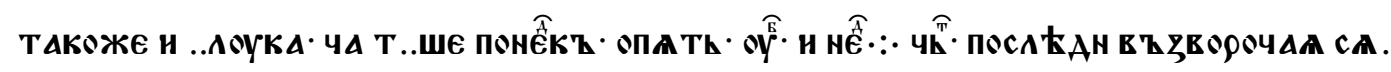

\section{I.8 Орнамент}

Находящийся в рукописи орнамент далек от роскошной формы. Обычно, каждый зачал оканчивается вариациями: четыре точки, образующие форму ромба, к ним на высоте середины строки добавляется или еще одна точки, или небольшой розчерк пера с нажимом (вроде лежащей запятой) - •:• (иногда трудно различить розчерк от точки из-за плохого состояния фотокопии, хвостик розчерка теряется). Скромные завитушки

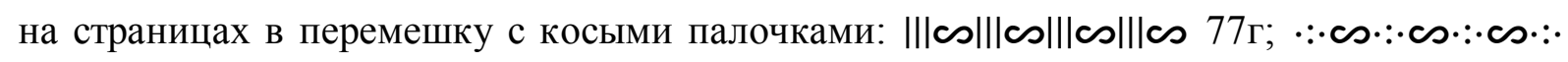
146в; и крестики с четырьмя точками на полях: ※ 47в,47г, 68г, 148а, 1346 (и завитушки и крестики совпадают по величине с высотой строки); а также внизу 160а столбца нарисованы сплетающиеся три линии - они и составляют украшение рукописи. 
II Графика

II.1 Употребление графем греческого алфавита

В рукописи используются некоторые буквы греческого алфавита: $\boldsymbol{w}, \boldsymbol{\bullet}, \mathbf{v}$, ॐ. Из них самой распрастраненной буквой является w. Она используется самостоятельно в 132 случаях: wБА 45б, w sью 45в, wrнh 47a, а также в предлоге $\overline{\boldsymbol{w}} 1102$.

Буква используется довольно редко, в словах греческого происхождения. Примеры - в существительных в ə̈-9. Второй переписчик употребляет эту букву в существительном и его формах -Арнсћи 48г в первой части своей работы (45а-63г), однако, во второй половине (72а77б) в этом же слове употребляет $\phi$.

Буква $\boldsymbol{y}$-〈нжнцА», в значении звука $v$ пишется в слове греческого происхождения єүิ

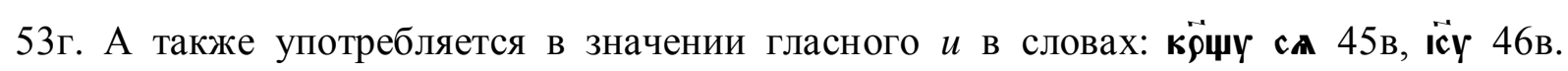
Следующие примеры на букву ү (u) находятся в конце строки: нємү 45б, кӧщу са 45в, icy 46в, помнлун 46г, вөАу 47а, күю 55б, в этом случае предполагается экономия места. В словах сүрофуницкска 75г, мүрА 153 в, $\overline{\mathbf{w}}$ фүннкъ 154а буква у выступает в значении звука $i$. Написание буквы распределяется следующим образом: в существительном єү̊ А буква ү одинаково используется двумя писцами. Первый переписчик употребляет $\boldsymbol{y}$ в словах греческого происхождения Алмүิ А 8а, түрюу 226 (32) и в местоимении всу 69г, 109а, вьсу $140 \mathrm{a}$ (3). Второй переписчик использует букву намного шире, а также у него

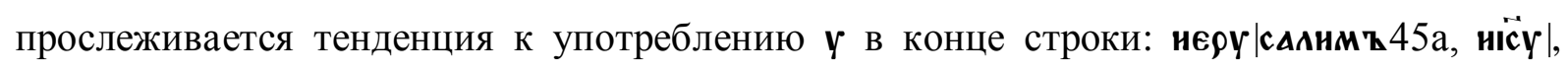
помнлу|н 46г, воду|, воуау|47а (31), в середине строки су

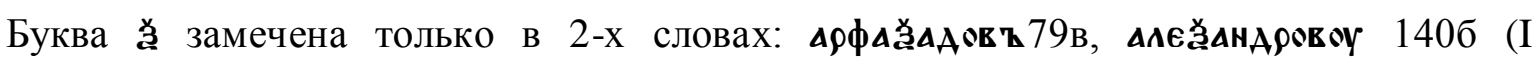
переписчик).

\section{II.2 Употребление графем гласных}

В рукописи находим четыри буквы, обозначающие гласный звук $i$ : н, І, ї и $\mathbf{Y}$. Буква н широко используется, ее можно найти практически во всех позициях слова (в начале слова; в середине после палатальной согласной, гласной; в конце слова). Буквой и в 
большинстве случаев обозначается союз. Намного реже используется буква ї. Ее тоже можно найти в разных, перечисленных выше местах слова, но в незначительном количестве. Из рукописи (к рассмотрению не принимаются листы с нечетким, неразборчивым текстом) видно, что используется ї в основном в целях экономии места (335), то есть в конце строки: внаї|те 1в, ов ћтов Анї| 2а, нстї|нА 2в; а также этой буквой обозначается число $\ddot{\mathbf{i ̈}}-10$ (в роли числа букву использует только второй

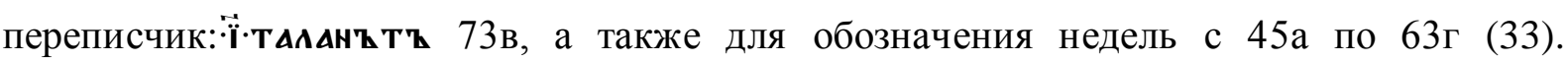
Интерестно, что во второй половине работы 72а-77б II переписчик использует в качестве числа (для обозначения счета недель) уже букву $\mathbf{\imath}$. Для обозначения звука второй переписчик букву не использует). В остальных случаях (в середине строки не зависимо от позиции буквы в слове) ї употребляется 93 раза. Буква I пишется, за исключением нескольких редких примеров, последовательно обоими переписчиками только в одном слове и его формах: $\overrightarrow{\mathbf{c}} 17 \mathrm{~B}$, $\overrightarrow{\mathbf{c}} \mathbf{\mathbf { z }} 216$. Употребление ү в качестве звука $i$ рассматривалось в II.1.

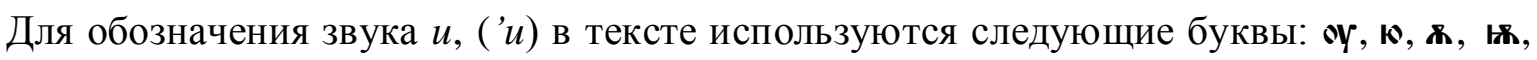

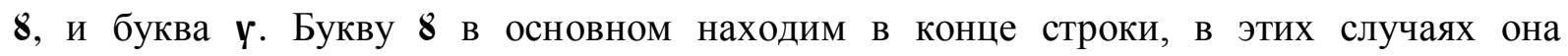
используется в целях экономии места. Всего в рукописи насчитывается 61 пример написания 8, из них в конце строки 46: Аомовнт8 44а; в начале слова 2.

В рукописи насчитываются четыре буквы, обозначающие йотированные гласные звуки, образованные следующим образом: $j+a, j+u, j+e$. Йотированный малый юс в рукописи отсутствует, йотированный большой юс используется лишь один раз в слове: - шюжю 150г. MmE относится к так называемым трехюсовым рукописям. По мнению Живова, «йотированные юсы исчезают с прекращением прямого влияния иностранных оригиналов, т. е. к началу ХІІ. Хотя двухъюсовые рукописи составляют меньшинство уже и для XII в., однако такую графическую систему можно наблюдать даже в Симоновской псалтыри последней четверти XIII ст.» (Живов 2006: 253).

Буква ґ пишется в начале слова: ґъъщи 1б, пжє, ґкө 1г и т. д.; а также в середине слова после гласных: в фоуган, мог 1а; пнсаннга 1г и т.д. Имеется лишь несколько примеров, где буква ґ выступает после согласной: творґащюю 4а, прнставлґґть

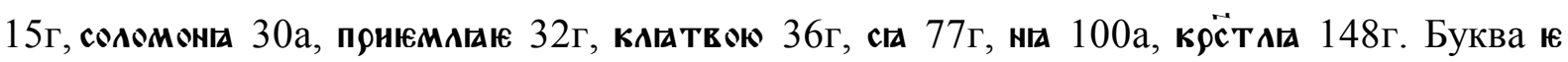


используется сходно, в начале слова: єге 1а, юсмь 1б, ющє 1в и т.д.; и в середине после

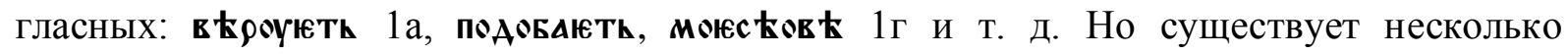
примеров, где буква є следует согласной: всњ 6в, къ нњмоу 24а, 526, 69в, оүслъшнтю

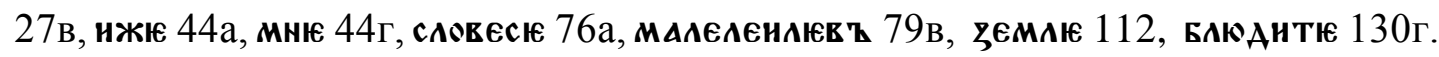

В $M m E$ носовые звуки уже не существуют. По мнению Щепкина, «к середине XII в. многие черты древнеболгарской орфографии исчезли совершенно: сообразно русской

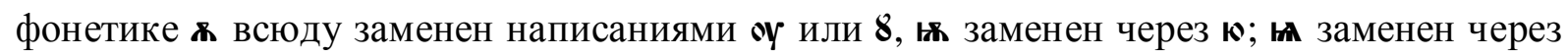
А и через ґА (Щепкин 1967: 114). Но в $M m E$ (самую раннюю дату написания, определяют 1188 г.) буквы, когда-то обозначавшие носовые, графически еще используются.

Шевелев попытался установить закономерность (или ее отсутствие) в использовании малого юса и буквы ґ. Он распределяет древние рукописи на основании использования в них малого юса следующим образом. К первой группе он относит те рукописи, в которых происходит безпорядочное использование малого юса. Самые древние рукописи свидетельствуют о таком правописании.

В рукописях второй группы происходит попытка (не всегда удачная) к упорядоченному написанию $\mathbf{A}$ и ґ. Букву ґ начинают использовать в начале слова или в начале слога. К этой группе и относится $M m E$.

Незначительное количество составляют рукописи, которые были написаны на Украине. Они относятся к третьей группе, где А и ґ пишутся после согласных, но ґ выступает только после первичных палатальных (восходящих к общеславянскому языку) $l$ ', $n$ ', а буква м после всех непалатальных (Шевельов 2002: 181-182).

По мнению Живова, «в условиях эквивалентности А и г в рукописях русского извода это создавало возможность вариантных написаний с $\mathbf{A}$, $\mathbf{A}$ или п после шипящих и ц (написания с г ограничены, постольку, поскольку действует тенденция не употреблять ґ после согласных). Эта вариативность и наблюдается в рукописях, она допускается нормой» (Живов 2006:243).

Буква ю используется намного шире, не только в начале слова и в середине после гласных, но и после согласных, в том числе палатальных (ниже в таблице 1). 


\section{II.3 Употребление графем согласных}

В рукописи употребляется, так называемая, оборотная буква «sћ৯s»-z, но лишь в значении цифры $\overrightarrow{\mathbf{z}}-6$.

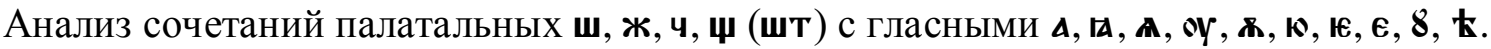

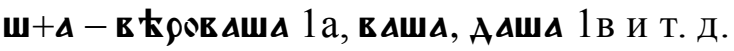

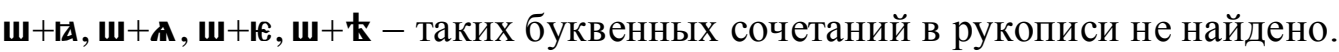

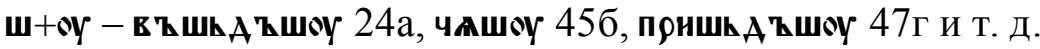

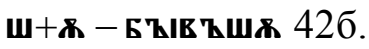

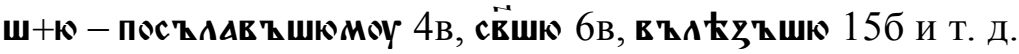

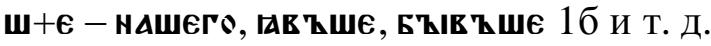

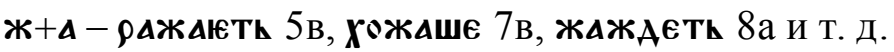

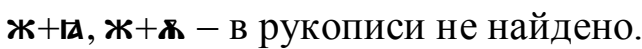

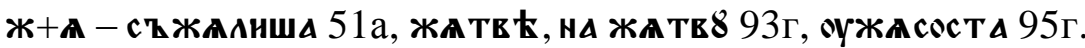

ж+оу - межоу 53в, стражоу 55б, знжоушен 60в, стражоу 72в.

ж+ю-соужю 1б, межю 9в, Аъжющє 10г и т. д.

ж+є - нєжє, жє 1а, пжє 1г, Амюжє 2в и т. д.

ж+њ - нжњ 44a.

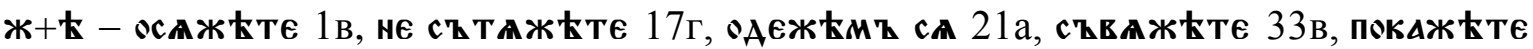

115г, 116г, 157б, съ тажћте 118a, жћтинскамн 141a.

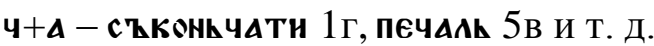

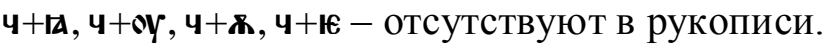

ч+А - отрОчА 5в, ЧАШоУ 45б, нАЧАША 45в И Т. Д.

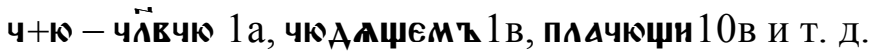

ч+є - оБАче, пАчє 1а, ९єче $1 б$ и т. Д.

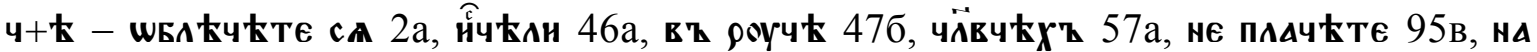

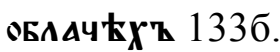

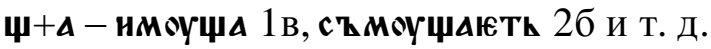

$\boldsymbol{\Psi}+\boldsymbol{\Perp}, \boldsymbol{\Psi + 1}-$ отсутствуют. 


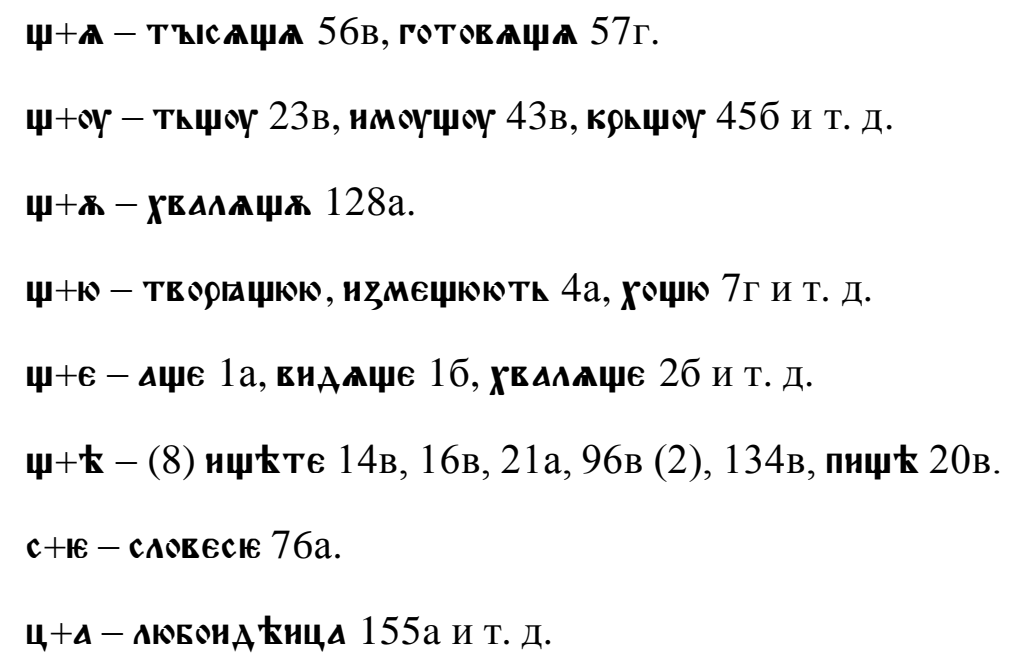

Таблица 1. Таблица сочетаемости букв

\begin{tabular}{cccccccccccc}
\hline & $\boldsymbol{\Lambda}$ & $\boldsymbol{\Lambda}$ & $\boldsymbol{A}$ & $\boldsymbol{⿰ y}$ & $\boldsymbol{\alpha}$ & $\boldsymbol{\kappa}$ & $\boldsymbol{8}$ & $\boldsymbol{\epsilon}$ & $\boldsymbol{1}$ & $\boldsymbol{Y}$ & $\mathbf{t}$ \\
\hline $\boldsymbol{\omega}$ & 884 & 0 & 0 & 11 & 1 & 70 & 1 & 659 & 0 & 2 & 0 \\
\hline $\boldsymbol{\Psi}$ & 182 & 0 & 4 & 4 & 0 & 46 & 1 & 2109 & 1 & 0 & 9 \\
\hline $\boldsymbol{\Psi}$ & 259 & 0 & 43 & 0 & 0 & 81 & 0 & 754 & 0 & 2 & 6 \\
\hline $\boldsymbol{4}$ & 387 & 0 & 2 & 22 & 1 & 115 & 1 & 729 & 0 & 2 & 8 \\
\hline $\boldsymbol{c}$ & 143 & 0 & 21 & 1 & 0 & 45 & 0 & 73 & 0 & 0 & \\
\hline $\boldsymbol{3}$ & 251 & 3 & 1255 & 282 & 57 & 10 & 1 & 621 & 1 & 19 & \\
\hline
\end{tabular}

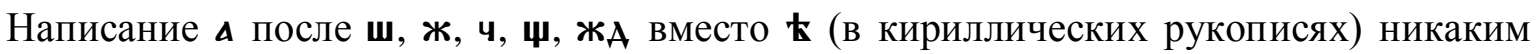
образом не связано с отвердением данных согласных. Древнейшее славянское изменение $\bar{e}>a$ после $j, \check{c}, \check{s}, \check{z}$ не свидетельствует об отвердении предшествующих согласных, и скорее отражает диспалатализацию (диссимиляцию) гласного после мягкого согласного (Елкина 1960: 53; Селищев 1951: 260-261). В рукописи отмечены численные примеры сочетания шипящих с $\mathbf{k}$, которые подтверждают чисто графическое использование А после данных согласных.

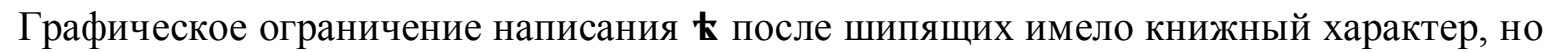
со временем эта особенность проникла и в графику берестяных грамот (при чем это не отражает твердость-мягкость согласных) (Зализняк 2004: 35). 
В рукописи в редких случаях отмечаются примеры употребления $\mathbf{\mathbf { k }}$ после $j, \check{c}, \check{s}, \check{z}$. Объяснение таких написаний в отдельно взятых случаях находятся в главе III.2.

Графическое явление наблюдается в написании сту (с твердой), в местоимении всу 69г, вьсу 140а (2). Предполагается влияние оригинала. «Был твердым с в местоимениях всь, всљ по болгарским диалектам XI в. Несомненно, таким он был в говорах, отразившихся в языке Супрасльской рукописи, Саввиной книги. С таким с были эти местоимения и в восточноболгарском оригинале Остромирова евангелия» (Селищев 1951: 326).

\section{II.4 Диалектные особенности графической системы}

По мнению Зализняка, графику древненовгородского диалекта характеризует смешение в парах $\mathbf{h} \rightarrow \boldsymbol{0}, \mathbf{h} \rightarrow \boldsymbol{\epsilon}$. Численные примеры в берестяных грамотах опровергают предположение о прояснении редуцированных (гласные полного образования стоят на месте редуцированных, которые находятся в слабой позиции) (Зализняк 2004: 23). В рукописи отмечается исправление буквы • на правильное $\mathbf{z}$ в окончании существительного чйвкөмо $\rightarrow$ чйвкөмъ 3 а, в существительном иноплємєникъ 116 г-117а наблюдается колебание в выборе графем между ө и $\mathbf{z}$, неясно какая буква исправленная на какую.

А также отмечается написание буквы \& в флексиях существительных И. п. м. р. ед. ч.: раво 20б, В. п. м. р. ед. ч.: АъАго 50г, в наречии тъкомо 70а; и є вместо и в Д. п. м. р. мн. ч.: стлрєчемъ 143б. Во всех этих случаях редуцированные стоят в слабой позиции. Я предполагаю, что в этих случаях произошло влияние древненовгородской графической системы, которой владел переписчик. 
III Фонетико-орфографические особенности рукописи

III.1 Редуцированные гласные

Исследование текста $M m E$ дает возможность установить, что рукопись принадлежит к двуеровым памятникам древнерусского письма: и, қ. Слова, содержащие редуцированные разобьем на следующие группы:

1. Редуцированные в корнях и основах:
а) сильная позищия;
б) слабая позищия.

2. Редуцированные в суффиксах.

3. Редуцированные в окончаниях.

4. Редуцированные в предлогах и в префиксах.

1. Редуцированные в корнях и основах

а) сильная позиция

Редуцированные в сильной позиции отмечаются в следующих примерах: нъ (2),

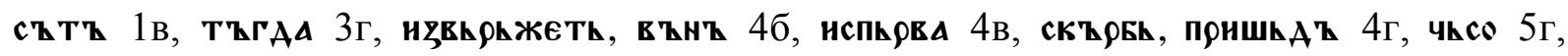

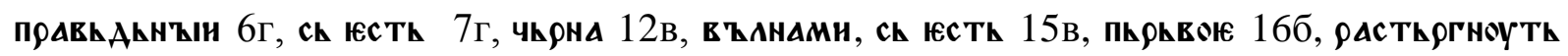

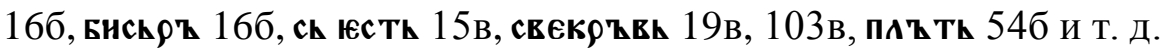

В словах, где присутствуют рефлексы континуантов праславянских сочетаний *tъrt, *tbrt, *tъlt, *tblt, редуцированные в восточнославянских языках при любых обстоятельствах находятся в сильной позиции (Елкина 1960: 76) (см. III.1.2).

Прояснение к (вокализация) в гласный полного образования $\mathbf{\epsilon}$ происходит правильно в: прншєльцА 159а (прншкльць Срезневский 1893: 1497).

Написание существительного греческого происхождения киньсқ 59в (киньсқ Срезневский 1893:1209) подвергается влиянию, во-первых, древненовгородскому диалекту: киннсқ 466 (4), где к>н; во-вторых, влиянию оригинала, по мнению Селищева, это слово книжного происхождения [Селищев 1951: 292]: киносъ 1576 в таком виде (к>0) уже употреблялось в старославянских рукописях.

Влияние древненовгородского диалекта отмечено также в следующих примерах:

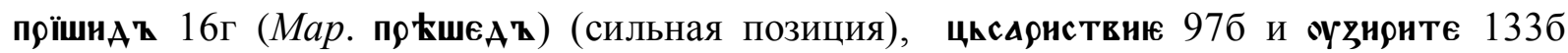


(слабая позиция) наблюдается к>н. «По-видимому, в каких-то древненовгородских говорах сильный к мог прояснятся в $i \ldots$. (Зализняк 2004: 67). То есть к прояснялся в закрытый тип $\hat{e}$ звука. У него примером выступают ворнцк (из ворьць), правнцик прдвкАьшнки) и т. Д. К этому Же явлению он причисляет и>h.

Утрата редуцированного к происходит не только в слабой позиции, но есть примеры выпадения редуцированного, стоящего в сильной позиции. Такое написание происходит в местоимении И. п. м. р. ед. ч.: вск 58в, 62г, 84a, 84б; В. п. м. р. ед. ч.: вск 51a, 516 (2), вск ндродт 75а (2), 92в, 131б. А также в наречии вскдє 73в. Два таких примера зафиксированы и в фрагменте Софийского евангелия (XIII-XIV вв.), рукописи древнерусского языка [Х. Тот 2006: 95], а также в Саввиной книге (Х. Тот 1995: 14). Употребление местоимения всь (вместо вьск) объясняется [Селищев 1951: 284] переносом формы без и в восточнославянские рукописи из старославянских оригиналов. «Такая передача появилась в старославянских текстах,- вследствие уравнения звукового вида основы по другим формам... вс-еге, всь» (Селищев 1951: 284). Следовательно, явление связано с влиянием оригинала.

В слове стигнахъ145в происходит смешение редуцированных, употребляется к вместо $\mathbf{k}$.

\section{б) слабая позиичия}

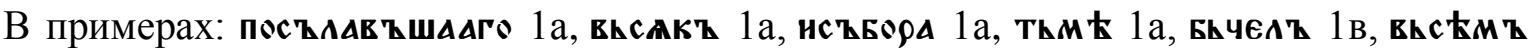

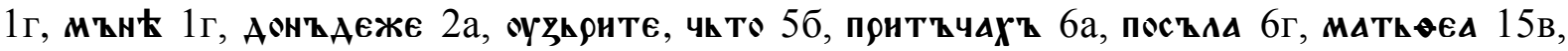

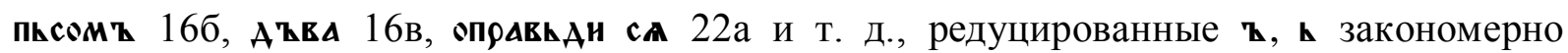
выступают в слабой позиции.

В наречии тъкөм॰ 70а и существительном ст Арєчємъ 1436 вокализация исключается по той причине, что редуцированные стоят в слабой позиции. Предполагается, что это след древненовгородской графической системы (см. II.4).

Утрачены редуцированные в следующих словах: мнєзи 1а, кнази 1а, псн 77г, 91б, 1086 (3), кто 1а, тъкмо 11a, 22г, соупра 128г, гнаше 1476 и т. д. 
Падение редуцированных между с-н (Аєсноє 11г, 12а, 12в, 45б, 45в, тұснłи 14в,

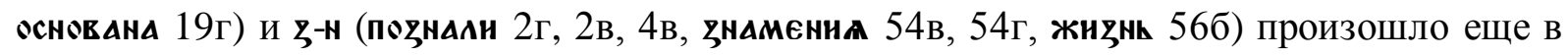
праславянский период (Ван-Вейк 1957: 147).

Утрата к, з между м-н (мнөзи 1а), к-н (кнази 1а), п-с (псн 77г, 91б, 1086 (3)), п-т (в слове птнц и его формах 14а, 20в, 23г, 25г, 33в (13)), в-с (всл 3б) в начале слова, объясняется изолированным положением этих редуцированных («если далее следовал гласный полного образования» [Селищев 1951: 281]). С точки зрения специалистов [Елкина 1960: 48], изучающих древние рукописи, такая утрата в начале слова хронологически происходит второй (первой - утрата еров происходила сначала в конце слова, но писцы научились, вскоре, их автоматически дописывать [Селищев 1951: 281]). Не наблюдается выпадение и между пьш-: пьшєницю 25в, 33а, 33в, 65г, 107в-107г (5).

Утрата қ и к в кто 1а (108), (но къто (30)), чтө 20в (16) (но чкто (145)), тұкмо 11а объясняется не только фонологическим явлением, но и «ударением в связном предложении» [Ван-Вейк 1957: 147], то есть имеет синтаксический аспект. «Более ранняя утрата еров перед слогом с гласным полного образования была обусловленна не только артикуляцией соседних согласных и положением в начале слова, но известную роль здесь играл и синтаксический фактор» (Елкина 1960: 48). Произношение местоимений и наречий было более слабое, чем произношение существительных или глаголов (Селищев 1951: 282).

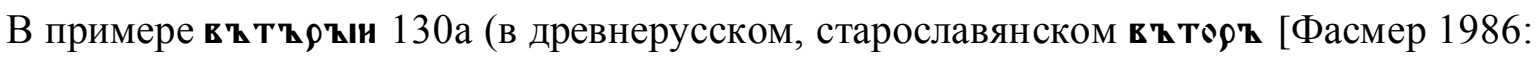
364]) имеем написание через қ на месте ө. В существительном көпьрқндоум қ 24a, 78а, 90г, 147в [капє९ънаоумъ Цейтлин 1994: 282] наблюдается $\mathbf{\epsilon} \rightarrow \mathbf{k}$ и один раз слово пишется правильно 1226.

В глаголе възльґ 134а (възлигатн Миклошич 1977: 90), в существительных

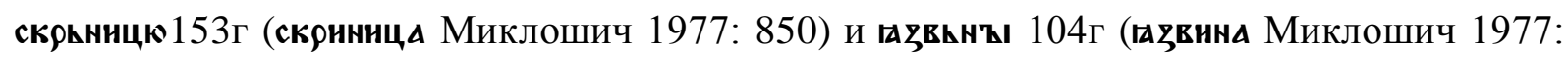
1144) наблюдается переход $\mathbf{~ > \mathbf { h } .}$

В рукописи отмечается написание и на месте правильного $\mathbf{e}$ : ннктожи 105а, ААжи

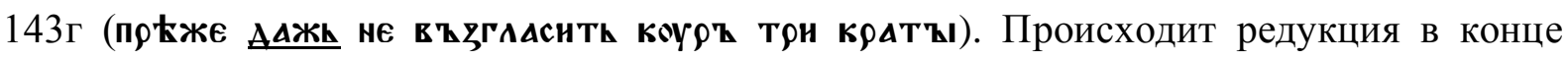
слова $\boldsymbol{\epsilon}>\mathbf{h}$. 
В слове посл $\mathbf{k}$ [Стоянов 1972: 179] наблюдается мена редуцированных: посл $\mathbf{A} \mathbf{z}$ 48в (и вместо и).

\section{2. Редуцированные в суффиксах}

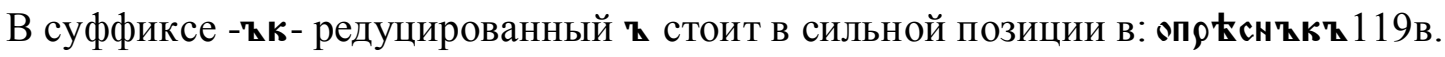

Редуцированный к в -ьц- находится в слабой позиции: съкөнкчати сл 1г, лөвьцА 16в, өвьцА 7б, көнцц 19г и т. Д. В сильной позиции он наблюдается в соучкци 16а и т. д.

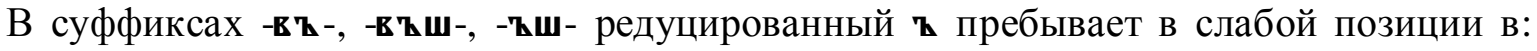

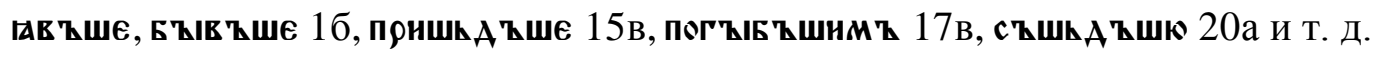

В суффиксе -нш- редуцированный к стоит в слабой позиции в: горьшн $15 г$, врашьшє 16б, ост АвАьшА 16г и т. Д.

Слабая позиция редуцированного в суффиксах -кск-, -кств- наблюдается в нерёлмисц $\mathbf{2} 2$ a, с зв

В сильной позиции отмечается редуцированный в примере: чєльв ћчкск т 29Г и т. д.

В суффиксе -к5- редуцированный стоит в слабой позиции в слове слюүжккоу 4а.

В суффиксе -нн- редуцированный зафиксирован в слабой позиции в следующих

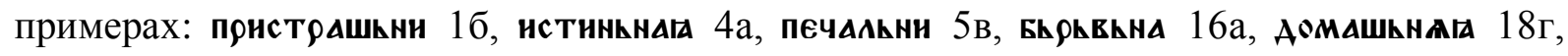
кннжкннци 20а и т. д. По наблюдениям Селищева, многочисленные формы слов с пропуском редуцированных в русских рукописях также наблюдаются в суффиксах в позиции с сонорными $t$, $л$, если после них стоят гласные полного образования (Селищев 1951: 284). В этих условиях выпадение началось (как и в начале слова или в местоимениях и наречиях) быстрее, «чем осуществился общий процесс утраты $\mathbf{k}, \mathbf{k} »$ (Селищев 1951: 283). В MmE отмечается пропуск и в в фрнъ 122г (в фркнъ Стоянов 1972: 119).

3. Редуцированные в окончаниях

Редуцированные $\mathbf{z}, \mathbf{k}$ стоят в сильной позиции в конце слова в следующих случаях:

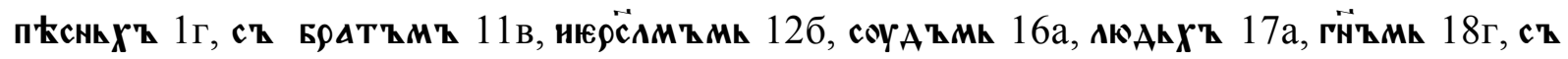
родами 29г и т. д. 
В окончаниях существительных Т. п. м. и с. р. ед. ч. -zмм (-кмz) наблюдаются редуцированные вместо гласных полного образования, что характерно для древнерусского языка (влияние существительных на -ц̌-) (Ван-Вейк 1957: 242-243; Balázs 1999: 55). В новообразованной флексии редуцированные в предпоследнем слоге находились в сильной позиции.

Окончания, где $\mathbf{\mathbf { \epsilon }}$, употребляющиеся в следующих примерах, отмечаются и в старославянском языке: слосємь 8а (написано неразборчиво, но окончание видно

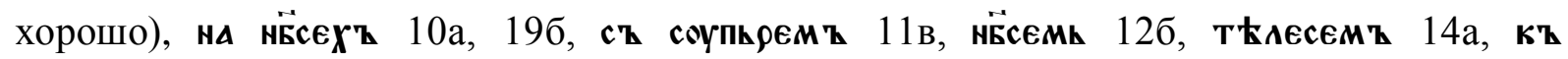
А $\mathbf{\wedge} \mathbf{T} є \Lambda є м \mathbf{m} 1556$ и т. д. По наблюдениям Селищева, такие формы употребляются у существительных на -ємь (Т. п. ед. ч. и Д. п. мн. ч. в существительных с основой на -ь и с основой на согласный), на -єхъ (М. п. мн. ч. в тех же основах). «Эти формы образованы вновь, по образцу форм с давней основой на -јо- (-'h, - ’є)...» (Селищев 1951: 292). Такие примеры, отмеченные в $M m E$ не являются следствием вокализации редуцированного, а восходят к протографу рукописи.

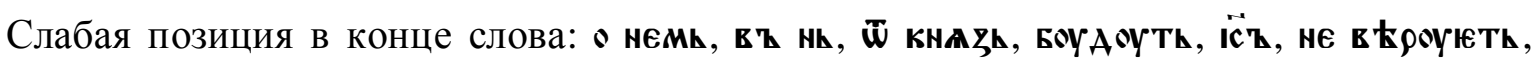

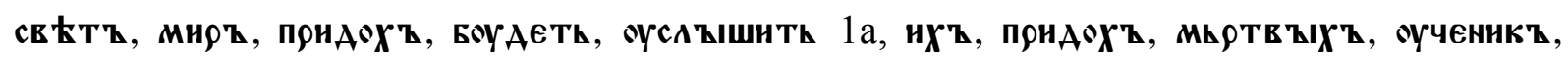

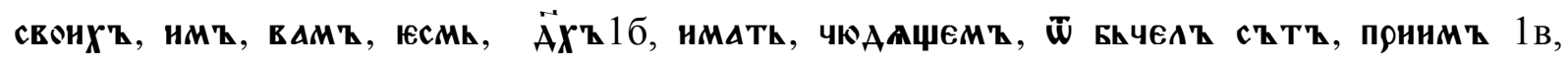

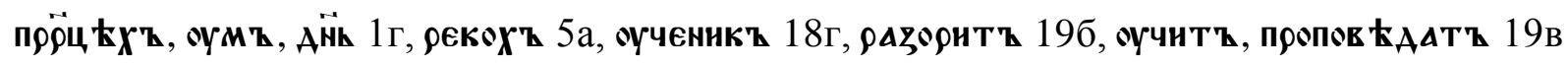
и т. д.

Редкий случай, когда у существительного отсутствует конечный $\mathbf{z}:$ ic 6в.

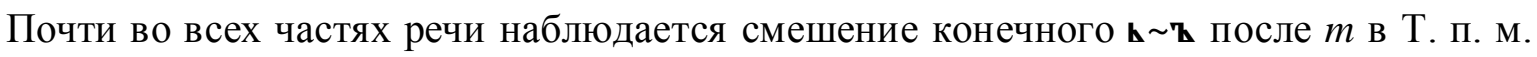
р. ед. Ч.: А 103а, имқ 1596 и т. д. Такое явление отмечается уже в старославянских рукописях.

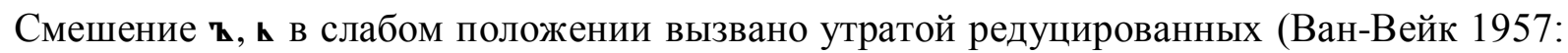
163-164; Селищев 1951: 286).

Наблюдается регулярное употребление древнерусского личного окончания в глаголах 3-го л. ед. и мн. ч. в формах настоящего и простого будущего времени в виде -тh вместо старославянского -тұ. Палатальный редуцированный в этом окончании пребывал в слабой позиции (абсолютный конец слова). 


\section{4. Редуцированные в предлогах, префиксах}

В старославянских предлогах и префиксах использование редуцированных (в

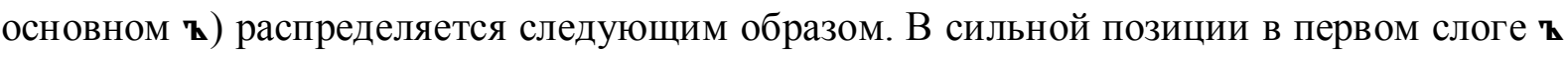

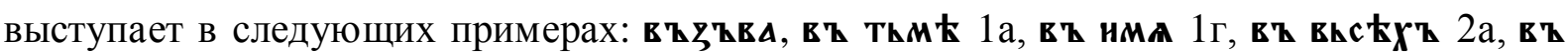

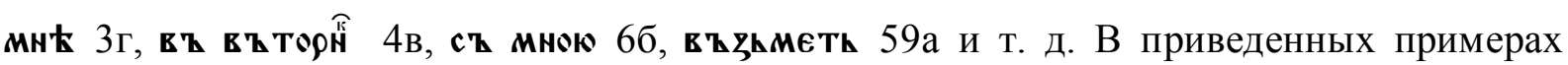
сильная позиция редуцированного объясняется слабой позицией последующего редуцированного.

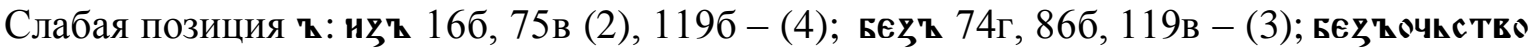

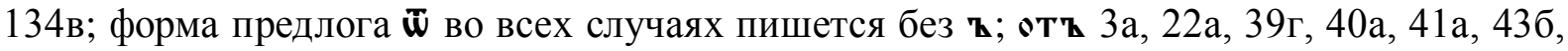
44a (2), 60г, 68a, 80a, 84a, 87a, 92в, 98б,101г, 109б, 110a, 125б, 131б, 136а, 137б, 139а,

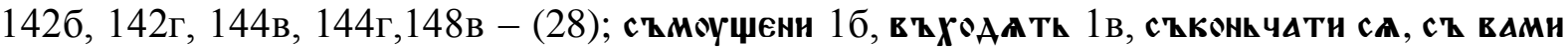

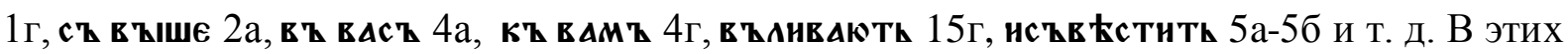
случаях слабая позиция редуцированного объясняется присутствием гласного полного образования в последующем слоге, или редуцированным (реже), стоящем в сильной позиции (Ван-Вейк 1957: 135-136).

Отмечаются случаи пропуска редуцированного з в слабой позиции: нз 1б, 4а, 18, 69в, 75б, 75г, 76а, 76б, 78а, 79г, 81б, 84а, 84б, 84г, 91в, 91г (34); кез 4б, 11б, 38а, 119в (4); к 5б, 11a, 53а, 69б, 93в, 94в, 104г, 115г, 117в, 124г, 126в, 127б (2), 128г (2), 130г, 142в, 144a, 144г, 149в, 1586 (20). Предлог к употреблялся без редуцированного уже в старославянском языке (Супрасльская рукопись). Среди примеров без қ не отмечаются

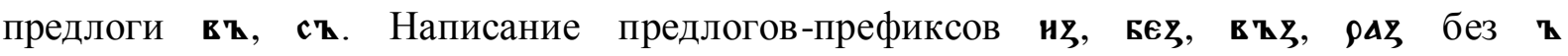
устанавливается уже в старословянском языке (Кульбакин 1899: 29).

Вокализация состоялась под воздействием последующего гласного в таких примерах: нзо очєсє 85г, нзоу оүности 111в (предполагается влияние начального гласного оу- последующего слова), нзо отрочнны 1496.

На первый взгляд, в словосочетании в қ нма $1 г$ редуцированный $\mathbf{z}$ стоит в слабой позиции. Для правильного определения позиции редуцированного рассмотрим происхождение слова нма. Гласный $i$, стоящий в начале слова нма, образовался следующим образом $i->j \breve{l}$ - $(j b-<j \breve{l}-<j \breve{u}$-) [Елкина 1960: 65; Семериньи 1980:50; Brugmann 1904: zu S. 399]. Для группы слов с таким звукосочетанием jb- («сочетание выступает 
постоянно как и $(\mathbf{I}, \mathbf{\imath}) »)$, «установленные правила не имеют значения...например, има (слабое положение), игъмх (сильное положение)» (Ван-Вейк 1957: 139). Таким образом *vъ jbme, то есть ер, стоящий после согласной $\mathbf{v}$, будет находиться в сильной позиции, перед последующим ером, стоящим в слабой позиции, и закономерным образом происходит $\mathbf{z}>\mathbf{0}$.

III.1.2 Рефлексы континуантов праславянских сочетаний *tъrt, *tbrt, *tъlt, *tblt

Приведем несколько примеров древнерусских континуантов общеславянских

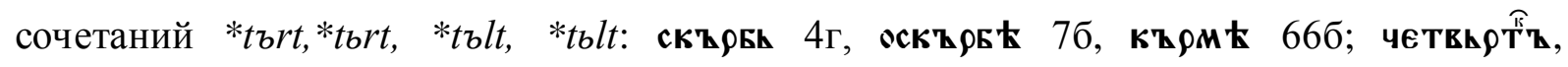

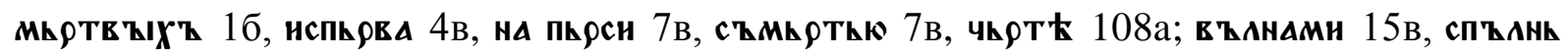
79в и т. д.

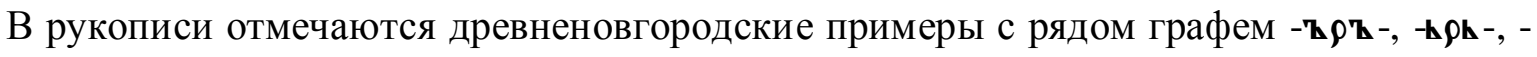

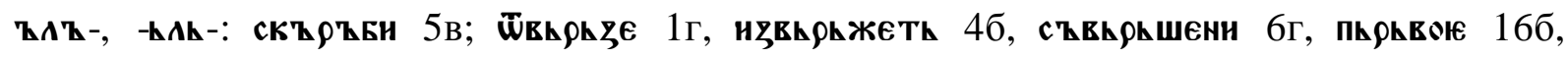

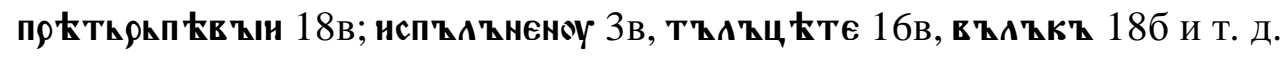

В $M m E$ наблюдаются следующие примеры старославянского языка: нс трьгнети 119г;

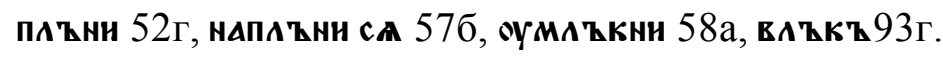

Число примеров собраны в таблице 2. 
Таблица 2.

\begin{tabular}{|c|c|c|c|}
\hline & е Старославянский & Древнерусский & Древненовгородский \\
\hline$-\rho \mathbf{h}-$ & 0 & - & - \\
\hline$-\rho \mathbf{h}-$ & 1 & - & - \\
\hline$-\Lambda \mathbf{h}-$ & 4 & - & - \\
\hline$-\Lambda \mathbf{h}-$ & 0 & - & - \\
\hline$-\mathbf{h} \rho-$ & - & 17 & - \\
\hline $\mathbf{h} \rho-$ & - & 129 & - \\
\hline$-\mathbf{h} \Lambda-$ & - & 18 & - \\
\hline $\mathbf{h} \Lambda-$ & - & 0 & - \\
\hline$-\mathbf{h} \rho \mathbf{h}-$ & & & 10 \\
\hline$-\mathbf{h} \rho \mathbf{h}-$ & - & - & 164 \\
\hline$-\mathbf{h} \Lambda \mathbf{h}-$ & - & - & 63 \\
\hline $\mathbf{L} \boldsymbol{\Lambda} \mathbf{h}-$ & - & - & 0 \\
\hline
\end{tabular}

Следующие примеры не вошли в таблицу 2. В рукописи отмечаются примеры

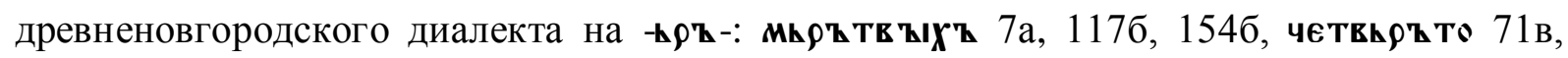

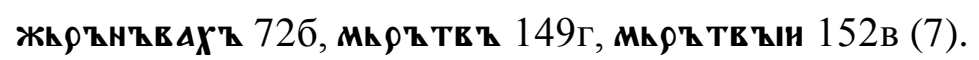

В слове прнскър.б.на 137в невозможно точно определить буквы (из-за нечеткости фотокопии).

В слове съмюти 416 пропущен ерь.

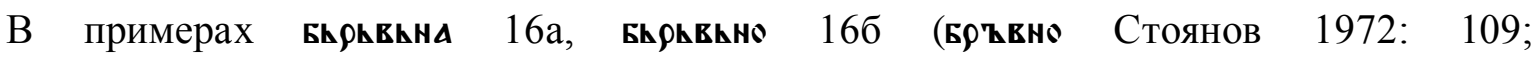

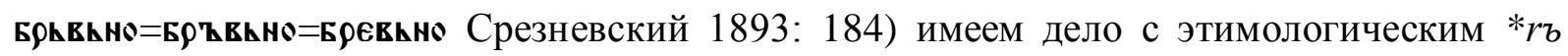
$\left(*_{r b}\right)$, а не с рефлексами праславянского *tbrt $(* t b r t)$. А также в счет не берется слово и

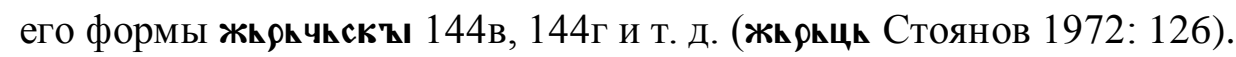

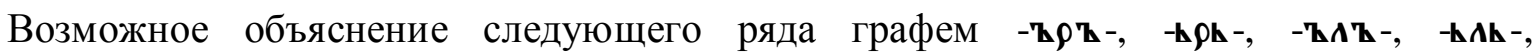
наблюдаемого в выше приведенных примерах (Antoskiv 2010: 9-14).

Общеизвестно, что в индоевропейском языке $\underset{o}{r}$ и $\underset{o}{l}$ употреблялись как слоговые

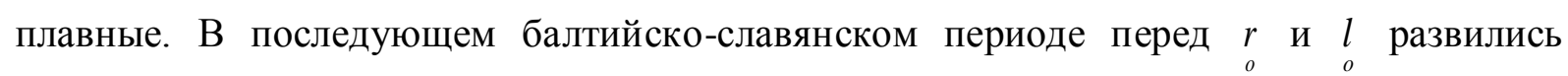


гласные $\breve{l}, \breve{u}$, после чего сонантные плавные перестают быти слоговыми. В последующем прославянском периоде процесс развития данных звукосочетаний разделяется на два периода. В первом, древнейшем периоде, под влиянием преобразования праславянской фонологической системы произношение $\breve{\imath}$ и $\breve{u}$ делается открытым, а также гласный $\breve{u}$ делабилизируется (См. Таблица 3).

Таблица 3.

\begin{tabular}{|c|c|c|c|c|}
\hline \multirow{2}{*}{ Индоевропейский } & \multirow{2}{*}{$\begin{array}{l}\text { Балтийско- } \\
\text { славянский }\end{array}$} & \multicolumn{2}{|c|}{ Праславянский } & \multirow{2}{*}{ Старославянский } \\
\hline & & $\begin{array}{c}\text { Первый } \\
\text { период }\end{array}$ & $\begin{array}{l}\text { Второй } \\
\text { период }\end{array}$ & \\
\hline$\underset{o}{r}, l_{o}^{l}$ & 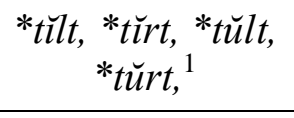 & $\begin{array}{l}*_{t b r t,}{ }^{*}{ }_{t b r t} \\
{ }^{*} t b l t, *^{*}{ }^{2} l t\end{array}$ & $\underset{o}{r}, l_{o}$ & $\begin{array}{c}-\rho \mathbf{h}-,-\rho \mathbf{h}-,-\boldsymbol{- \lambda \mathbf { h }}- \\
-\mathbf{- \Lambda \mathbf { h }}-\end{array}$ \\
\hline$*_{m i t i s s}$ & 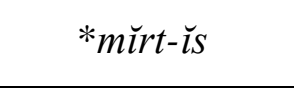 & $*_{m b r t-b}$ & $*_{\substack{m \\
r}} t-b$ & c'kmph Th \\
\hline$*_{\wedge} u \mid k^{w} o s$ & *vilkăs & $*_{v b l k-b}$ & $*_{0} v l_{0}-b$ & вАKK' \\
\hline$* \underset{o}{r d} d$ & *gŭrdăs & $* g b r d b$ & $* g \underset{o}{r} d-b$ & retzath \\
\hline
\end{tabular}

(X. Тот 1996: 88-90)

Во втором периоде под влиянием тенденции к восходящей звучности слога гласные выпадают и $\underset{o}{r}, \underset{o}{l}$ делаются слоговыми. По мнению Ван-Вейка, нет доказательств, что редуцированные в звукосочетаниях $\mathbf{r b}, \mathbf{r b}, \mathbf{l} \mathbf{b}, \mathbf{l} \mathbf{b}$ произносились. Тогда бы в позднем старославянском в некоторых его говорах произошла бы вокализация. Возможное произношение: «1) $r, l$ с последующим очень слабым звуком, похожим на $b$, что-то вроде $\left.l^{b}, r^{b} ; 2\right) \underset{o}{r}, \underset{o}{l}, \underset{o}{r}, l_{o}^{\prime} \gg($ Ван-Вейк 1957: 91).

В старославянском языке между двумя согласными наблюдается следующий графемный ряд -ръ-, -рь-, -лъ-, -ль-. То есть исконные праславянские звукосочетания $*_{r b}, * r b, * l b, * l_{b}$ совпадают с рефлексами праславянских *tbrt, *tbrt, *tblt, *tblt. Проследить различие в происхождении возможно лишь с помощью древнерусского или русского языков (Таблица 4.). Восточнославянские языки относятся к такому диалекту праславянского языка, которому слоговые $\underset{o}{r}, \underset{o}{l}$ были чужды. В древнерусском языке на месте слоговых плавных находим -ьр-, -ьр-, -ьл-, -ьл-. 
Таблица 4.

\section{Старославянский \\ Русский \\ Старославянский \\ Русский}

Рефлексы праславянских *tbrt, *tbrt, *tblt,

$$
\text { *tblt }
$$

Исконные *rb, *rb, *lb, *lb

c'kmph Th

BヘhK' смерть

ВоЛк

гордый
Б९ZKK

K९ZKh

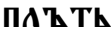

бровь

кровь

(X. Тот 1996: 90-92)

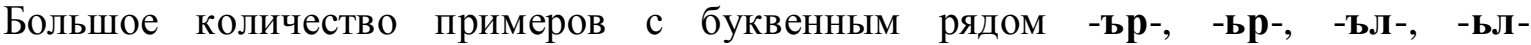
подтверждают древнерусское происхождение рукописи. Разницу между рефлексами праславянских звукосочетаний *tъrt, *tbrt, *tblt, *tblt в старославянском и в древнерусском языках можно установить, сравнивая конкретные примеры. Представителем старославянского языка является Мариинское евангелие, написанное в конце Х века глаголицей. Примеры $M m E$ и Мap. сравниваются в таблице 5.

Таблица 5.

\begin{tabular}{|c|c|c|}
\hline & $\begin{array}{c}\text { Милятино евангелие } \\
\text { древнерусский }\end{array}$ & $\begin{array}{c}\text { Мариинское евангелие } \\
\text { старославянский }\end{array}$ \\
\hline Матфей XIII: 22 & Тһрнин & т९ънин \\
\hline Матфей XV: 11 & 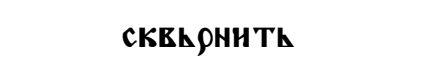 & сКЕ $\rho \mathbf{~}$ \\
\hline Матфей XV: 30 & 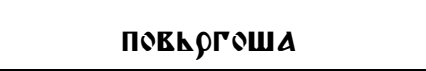 & прнв \\
\hline Матфей XVIII: 6 & 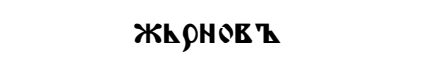 & 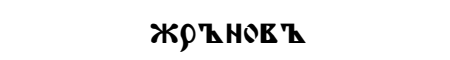 \\
\hline Матфей XIX: 21 & CҚKһ ГШен' & 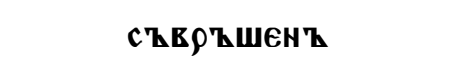 \\
\hline Марк VII: 4 & Аһ९жАти & 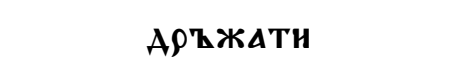 \\
\hline Лука XVII: 24 & МҚАнин & МА ҚАни \\
\hline Лука XIV: 28 & ст'h & 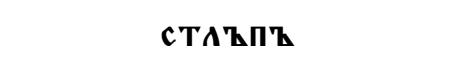 \\
\hline Марк XIII: 19 & 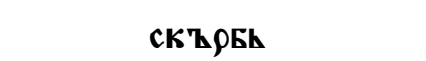 & ск९ҚБни \\
\hline
\end{tabular}

(Ягич 1960)

В древнерусских рукописях, кроме вышеприведенных примеров, существуют и

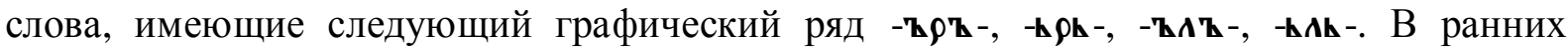


древнерусских рукописях существуют и написания этого же буквенного сочетания, но

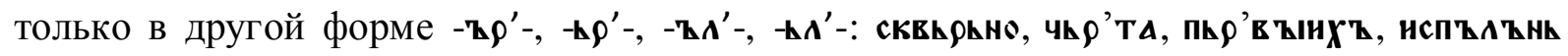
(Изборник 1073).

Термин «полногласие» впервые использовался украинским ученым (филологом) Максимовичем в 1839 г. Значение термина распространялось не только на праславянские звукосочетания *tort, *tert, *tolt, *telt, но и на *tъrt, *tbrt, *tъlt, *tblt.

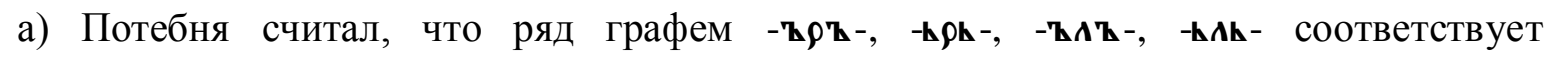
фонетическому явлению живого языка (ограничивая это явление древненовгородским диалектом), и назвал его вторым полногласием (Шевельов 2002: 369). Распространяя второе полногласие на все древнерусские рукописи, с некоторыми дополнениями теорию Потебни поддерживают Шахматов, Кульбакин, Ван-Вейк, Марков, Филин (Шевельов 2002: 369).

б) по мнению Ягича, наличие двух еров свидетельствует о педантичности переписчиков. Возможно, чтобы облегчить произношение к старославянскому

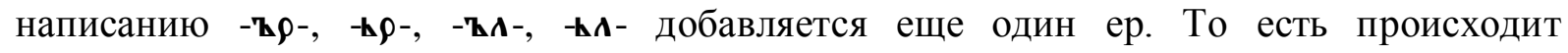
контаминация. Эту теорию поддерживают Шахматов (в некоторой степени), Фортунатов, Бузук (Jagić 1876: 360-377).

Шевелев поддерживает теорию о так называемом втором полногласии, но со своими дополнениями. Ученый разделил территориально древнерусский язык на северную часть (современный русский язык и его диалекты) и южную (украинский язык и его диалекты). Сперва проанализировал фонетическое явление на южной территории. По его мнению, в первых древнейших рукописях древнерусского языка в данных звукосочетаниях пишется апостроф. Апостроф обозначал глухой звук, который развился на месте второго ера, стоящего в слабой позиции. Это происходит тогда, когда редуцированные стали выходить из употребления. Впоследствии замена апострофа ером носит штучный характер. Приблизительно звукосочетаниях начинают распределятся на редуцированные, стоящие в сильной позиции и стоящие в слабой позиции. Начиная с 1150 г., утрата редуцированных зависит не от позиции, а зависит от продолжительности редуцированного. Если гласный был глухим, то автоматически выпадал, а по счету таким гласным всегда выступал второй ер. Подытоживая, Шевелев предполагает, что теория Потебни правильна примерно к 1150 г., после 1150 г. отдает предпочтение взглядам Ягича. 
Шевелев полностью соглашается с мнением Потебни о развитии в северных районах второго полногласия (Шевельов 2002: 370). Общность в развитии фонетического явления (для обоих территорий) наблюдается до образования глухого редуцированного. Однако, на южных территориях второе полногласие до конца не развивается, потому что еры выходят из употребления. На северных территориях это произошло на 100 лет позже, поэтому было время для вокализации редуцированных.

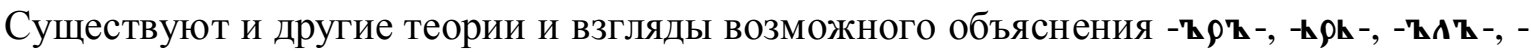
клk-. Например: апостроф указывает на слоговые $\underset{o}{r}, \underset{o}{l}$; апостороф - это знак обозначающий или мягкость, или твердость сонанта (Шевельов 2002: 366-377).

По мнению Грунского, ряд графем с двумя ерами - это попытка переписчиков передать в греческих словах или через греческое правописание мягкое произношение согласных. Позже, в древнерусском произношении мягкость согласных утрачивается, поэтому сначало пишется апостроф, а после и апостроф изымается из употребления (Грунський 1946: 57).

По мнению Х. Тота, «в некоторых случаях на месте звукосочетания *tьrt образуется сочетание *ter't, что часто встречается в древнем языке: [ser'p], [per'vъ^j], [ver'chnij], [ver'ba]. Появление er'< br' можно объяснить ассимиляциеи гласного ь (>e) на согласный [r], но возможен и такой вариант, когда в звукосочетании ьr', стоящем между двумя согласными после [r'], вследствии второго полногласия развивается временный [ә], который и смягчил стоящий перед ним плавный согласный. Примером служит [ver'och], где наблюдается второе полногласие. Вообще-то произношение [r'] в современном развитии сочетания tbrt относится к исчезающему архаизму» (Х. Тот 2008: 226).

Использование второго ера не зависело ни от стоящего первого редуцированного перед плавным, ни от (после 1150 г.) гласных полного образования е или о. Это дает возможность распределить рукописи в зависимости от количества встречаемых в нем данных буквенных сочетаний следующим образом (буквосочетание -九ль- в $M m E$ не найдено):

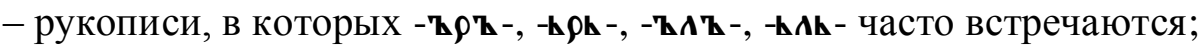

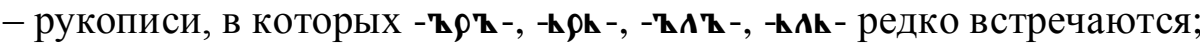

- рукописи, в которых данный ряд графем встречается в единичных случаях (Шевельов 2002: 369). 
Теоретический анализ второго полногласия и численные примеры подтверждают существование такого фонологического явления в $M m E$, которое пренадлежит древненовгородскому диалекту:

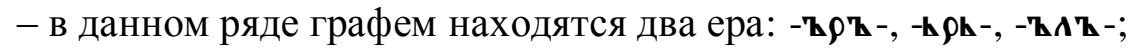

$-M m E$ происходит из новгородских земель;

- датируется кон. XII. в.-нач. XIII в.;

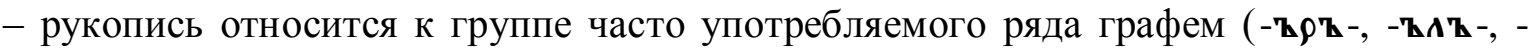
крк-) (237 из Таблицы 2.).

В последней таблице (Таблица 6.) этого раздела есть возможность сравнить древненовгородские примеры $M m E$ с одноименными старославянскими Map.

Таблица 6.

\begin{tabular}{|c|c|c|}
\hline & $\begin{array}{l}\text { Милятино евангелие } \\
\text { древненовгородский }\end{array}$ & $\begin{array}{c}\text { Мариинское евангелие } \\
\text { старославянский }\end{array}$ \\
\hline Матфей XIII: 31 & 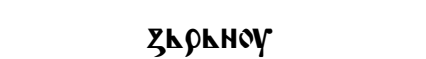 & зртаноу \\
\hline Матфей XVI: 2 & Чh & чрҚминоуетт \\
\hline Матфей XIV: 27 & 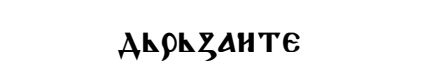 & А९ЋそАнте \\
\hline Лука XV: 22 & Пирһстени & прһстени \\
\hline Марк XIII: 14 & 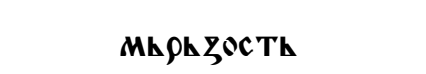 & 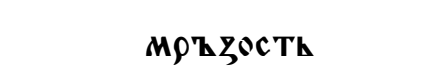 \\
\hline Матфей XXI: 36 & ПL $\rho$ в ZIX'Z & 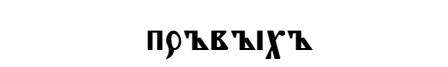 \\
\hline Матфей IX: 23 & MҚАҚЕАШН & MАҚЕАНК \\
\hline Матфей XIII: 48 & НАПҚА ҚНИ & НСПАҚНК \\
\hline Марк IX: 26 & 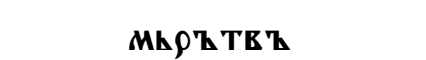 & 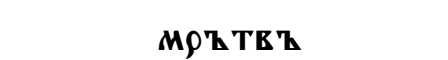 \\
\hline
\end{tabular}

(Ягич 1960)

III.1.3 Напряженные редуцированные $\hat{\imath}, \hat{y}$

Редуцированные $\mathbf{z}, \mathbf{k}$ легко подвергались воздействию соседних звуков. Особенно влияли на них последующие $j(\breve{l}), i$. При этом произношение несколько повышалось $\mathbf{b}>\hat{y}, \mathbf{b}>\hat{\imath}$.

Напряженные редуцированные также могут стоять в слабой (не найдены следы редуцированного $\mathbf{z}$, стоящего в слабой позиции в рукописях, даже в самых ранних, поэтому логично, что в $M m E$ он отсутствует) и в сильной позиции (Елкина 1960: 49-50; Иванова 1998: 64). 
Редуцированные, стоящие в сильной позиции, прояснялись $\mathbf{k}>\mathbf{n}, \mathbf{z}>\mathbf{z}:$ a) в начальном слоге под ударением: бкєнъ 103а, оүвьєноу 121г; оүмын 146б; б) перед конечным

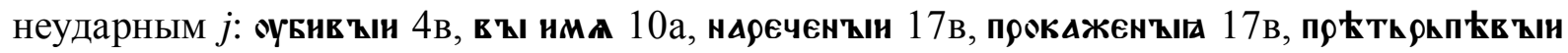
18в, Ароугын 18г, 88г, нұмын 36а и т. д. На стыке морфем имеем нестяженную форму จтннде 38 и стяженную в б̄нмети 15 г.

Иногда прояснение не отражается переходом: висакқи 4в, 101а, прншидъи 8Г,

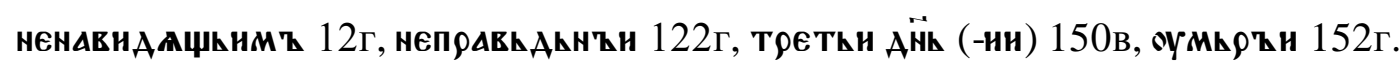

В следующих примерах наблюдается к в слабой позиции: лнствьє 55а (лнствнє Миклошич 1977: 337), кюакє 77в. В старославянском языке к, и обозначали гласную $i$ только графически, потому что к ХІ в. этот звук в слабой позиции уже не существовал (Елкина 1960: 49).

В рукописи редуцированные $\mathbf{z}, \mathbf{k}$ употребляются в основном правильно (не считая позиции в абсолютном конце слова, особенно после $m$ ). Редуцированные в сильной позиции не переходили в гласные полного образования. Редуцированные в слабой позиции в начале слова выпадают (кроме пкш-). Но слабые редуцированные, стоящие в середине слова, на границе соприкосновения морфем не выпадают (исключение в суффиксах в позиции с сонорными $н$ ).

Напряженные редуцированные в рукописи употребляются правильно.

В рукописи наличие древнерусских континуантов праславянских сочетаний *tbrt,*tbrt, *tъlt, *tblt составляет важную (один из первых русизмов, появляющийся в изводах русского языка) часть церковно-книжного правописания. Древнерусские формы регулярно используются в рукописи и отображают произношение писцов.

В рукописи соответственно церковно-книжному правописанию восточных славян, в

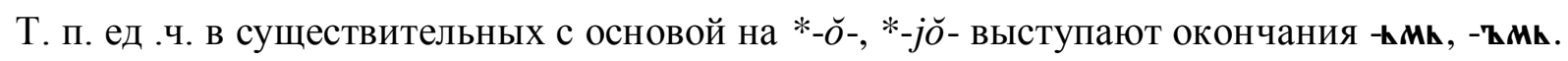
К нормам книжного правописания принадлежит также регулярное написание глаголов 3-го л. ед. и мн. ч. настоящего (простого будущего) времени с древнерусской флексией -Th.

Параллельно в рукописи, превышая по количеству формы древнерусского языка

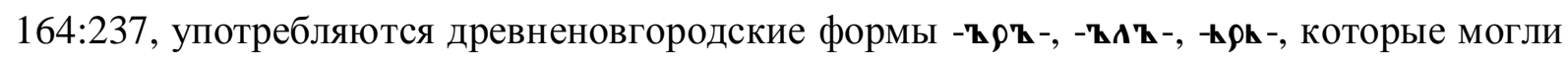
отображать живую речь древненовгородского диалекта. К древненовгородскому 
диалекту относится $\mathbf{h}>\mathbf{n}$ и наоборот (не включаются в это явление напряженные редуцированные).

\section{III.2 Употребление буквы $\mathbf{k}$}

По мнению специалистов, изучающих древнерусский язык, «рефлекс праславянского гласного е̌ в древнерусском языке был дифтонгическим сочетанием $\underset{n}{e}$ или близким к этому сочетанию звуком» (Жовтобрюх 1979: 232-247; Зализняк 2004: 5253; Соколова 1962: 12).

Написание гласного, обозначаемого буквой $\mathbf{k}$, разделим на 4 группы. Изучение е̌ в рефлексах праславянских сочетаний *tert, *telt дает возможность проследить развитие церковнославянского произношения восточных славян. Изучение е̌ в морфемах дает возможность определить правильное (или неправильное) употребление гласного с этимологической точки зрения (Antoskiv 2011: 176-183).

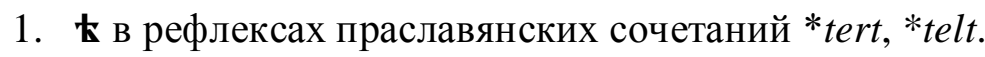

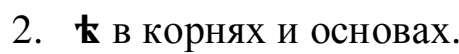

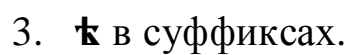

4. в в окончаниях.

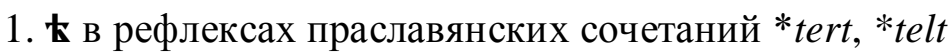

В континуантах праславянских сочетаний типа *tert, *telt доминируют слова

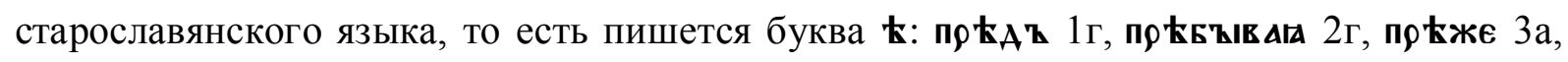

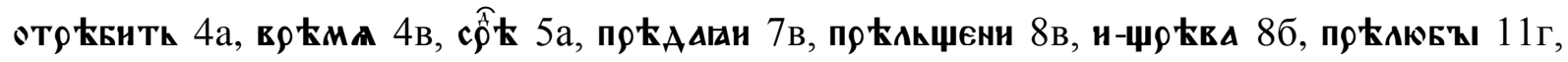

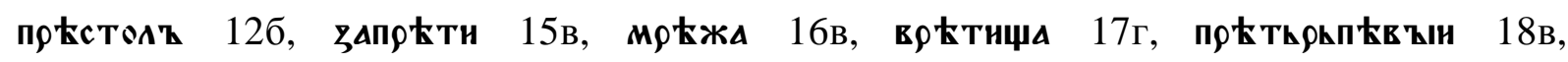

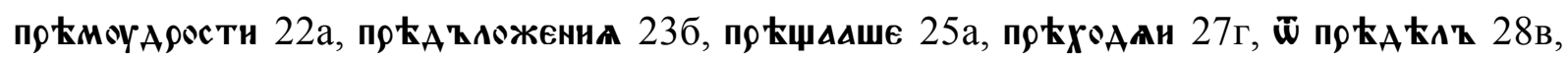

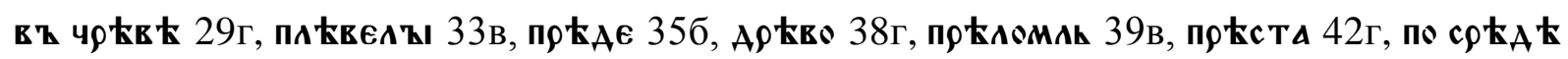

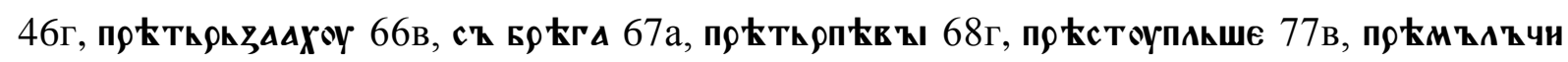

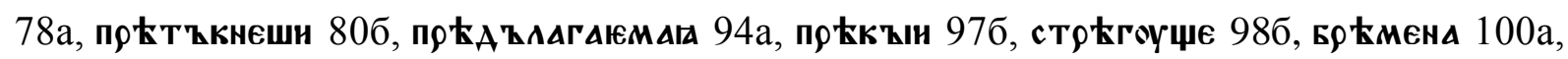

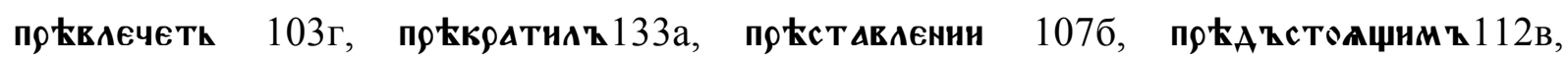

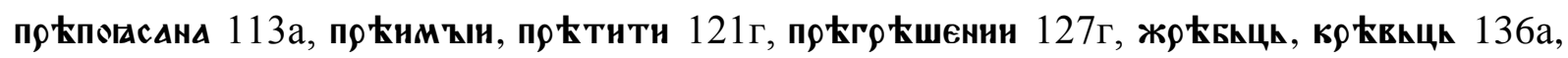

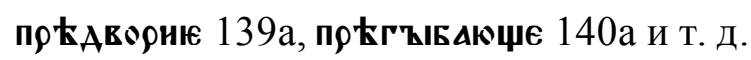


Но также имеются примеры рефлексов древнерусского языка, образовавшиеся

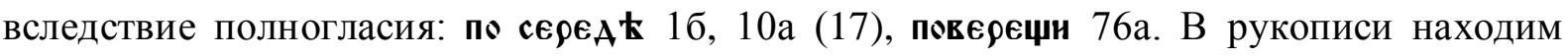
пример, где на месте ожидаемого полногласия имеем: по сє९А $\mathbf{k} 93$ г.

Селищев о восточнославянском произношении гласного, обозначаемого буквой $\mathbf{k}$, писал следующее: «В языке восточных славян образование $\mathbf{k}$ было иное: это был гласный закрытый, произносившийся при подъеме языка, более высоком, чем при $e,-$ гласный $\hat{e}\left(e^{\prime}\right)$. В старославянских памятниках нет написаний, которые указали бы на гласный $\mathbf{\epsilon}$ вместо $\mathbf{k}$ в речи их писцов. В русских же рукописях встречаются написания с $\boldsymbol{\epsilon}$ вместо $\mathbf{k}$. При этом смешение $\boldsymbol{\epsilon}$ и $\mathbf{k}$ находится главным образом в словах, которых не было в обыденной речи восточных славян, - в словах церковных, книжных. Восточнославянские писцы при передаче этих слов руководствовались не своим

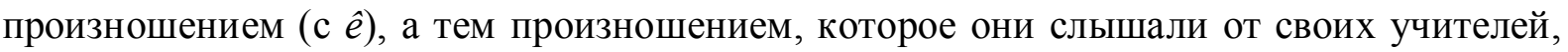
от славян, прибывших из Болгарии. То было произношение с $\ddot{a},-$ с гласным, который русские книжники передавали буквою $є$, так как гласный $e$ был ближе к $\ddot{a}$, чем $\hat{e}\left(e^{\prime}\right) »,-$ таким образом объясняется не только восточнославянское произношение, но и происходжение книжного или, другими словами, церковнославянского произношения и написания звука, обозначаемого буквой $\mathbf{k}$ (Селищев 1951: 265; Шевельов 2002: 258). С выше написанным совпадает и мнение Мейе: «В части славянской области е̌ имело тенденцию к закрытому произношению: в русском языке произношение е̌ очень рано совпало с $e$; в украинском е̌ представлено как $i$ [...]. Эта тенденция к закрытому произношению основана на том, что «йотация» перед е̌ очень рано изменила гласную в направлении к произношению е закрытого и $i \gg$ (Мейе 1951: 40).

По мнению Пожгаи, «что касается написаний старославянский рефлексов праславянских сочетаний *tert, *telt через букву є, здесь следует обратить внимание на предположение А. И. Соболевского, согласно которому букву $\mathbf{\epsilon}$ вместо $\mathbf{k}$ в сочетаниях такого рода может указывать на церковно-книжное произношение писца. Кроме того, тут можно учитывать и возможность контаминации между древнерусскими формами с полногласием и старославянскими формами с метатезой и удлинением» (Пожгаи 2008: 177).

Живов и Успенский проблему восточнославянского правописания буквы $\mathbf{k}$ и ее смешения с $\mathbf{\epsilon}$ объясняют следующим образом: «противопоставление /е̌/ и /e/ в книжном 
произношении реализовалось иначе, чем в произношении разговорном, во всяком случае на северо-западе восточнославянской территории. В книжном произношении склад Бе произносился как [be] (как в современном украинском языке), а склад къ - как [b'e] или [b'ê] (качество гласного, видимо, было безразлично). В разговорном произношении согласный смягчался и перед/е̌/, и перед/e/ и фонологическое противопоставление реализовалось за счет качества гласного ([b'e] vs. [b'ê])» (Живов 2006: 64-65; Успенский 2002: 163-173).

Как видно из вышеприведенного материала, мнение о закрытом $\hat{e}$ поддерживается всеми славистами (есть несколько ранних примеров в диалектах кривического ареала, где наблюдается открытое произношение [Зализняк 2004: 52]). Проблему развития закрытого $\hat{e}$ в славянских языках (кроме «ляхитов, болгар и словенцев, сохранивших былую широкаю артикуляцию») разрабатывает Журавлев в «Из истории вокализма в праславянском языке позднего периода» (Журавлев 1963: 8-19). Журавлев предполагает, что развитие «изофона праславянского *е̌ [...] полностью совпадает с изофоной рефлексов праславянских носовых: там, где на месте праславянского $Q$ наблюдается $u$, в качестве рефлексов праславянского е̌ представлены гласные, легко возводимые к «узкому» $е$ » (Журавлев 1963: 8).

В этой группе $(* t e r t)$ написание гласного $\boldsymbol{\epsilon}$ вместо $\mathbf{k}$ имеет место в слове А९єв॰ $36 б$ (1). Правильное написание этого слова встречается лишь в очень древних рукописях. Слово Арєво не было ни церковнославянским, ни местным. В этом случае произношение гласного є ближе стояло к болгарскому открытому е̌, чем произношение

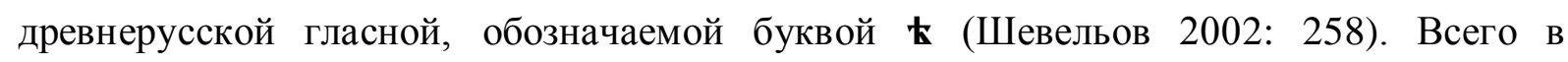
рукописи насчитывается 19 примеров слова д९ $\mathbf{~ в о ~ и ~ е г о ~ ф о р м ~ и ~ т о л ь к о ~ о д и н ~ п р и м е р ~}$ слова Арєвє, что подтверждает древность $M m E$.

Примеры замены буквы Ł буквой є в словах прєндє 27б, нсплєв кте 33в, прєжє 41б,

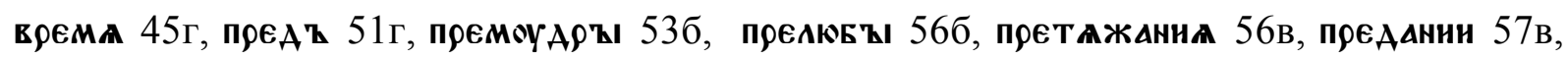
преААсти 61б, чресқ 99Г и т. д. объясняются также, как со словом Арево, то есть книжными нормами правописания (Х. Тот 1995: 20). Нормы написания буквы $\mathbf{k}$ «выбор $\mathbf{k}$ или є в рефлексах *tert, требовавших обращения к их полногласным коррелятам в живом языке и предполагавший отождествление этих коррелятов с неполногласными формами книжного языка», относятся к сложным правилам 
правописания (Живов 2006: 68).

По словам Живова, явление $\mathbf{k} \mathbf{\epsilon}$ существует лишь в рефлексах *tert и отсутствует в звукосочетании *telt: «материал не дает для этого оснований, а позднейшая норма

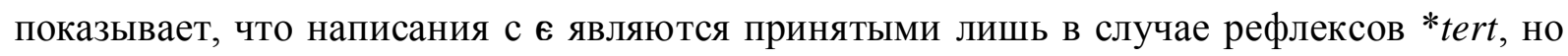
не в случае рефлексов *telt» (Живов 2006: 232). В $M m E$ наблюдается пример $\mathbf{k} \mathbf{\epsilon}$ в

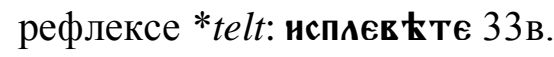

По аналогии со словом А९ $\mathbf{k s}$ буква $\mathbf{k}$ встречается в следующих случаях: А९ $\mathbf{k и н н м ь ~}$

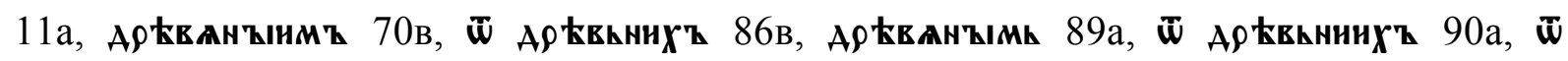
А९Квиних' 926, А९ КваноЮ $102 \mathrm{a}$.

\section{2 Ł в корнях и основах}

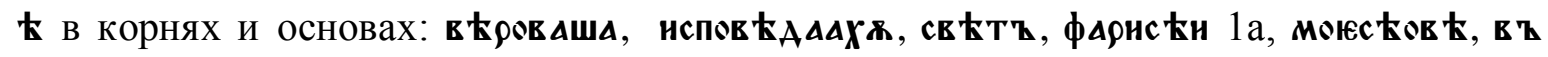

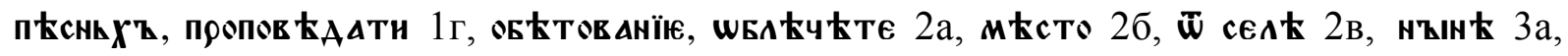

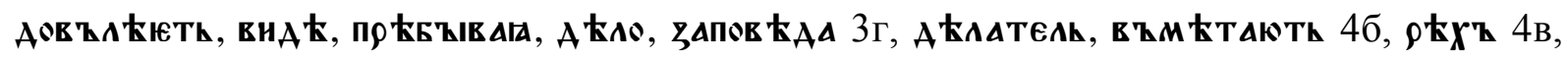

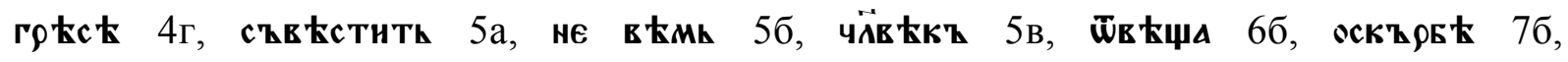

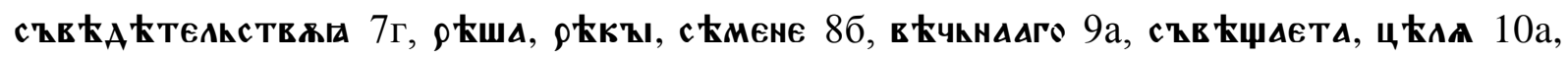

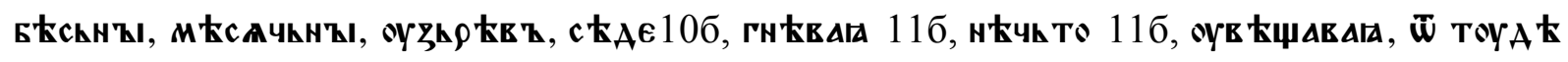

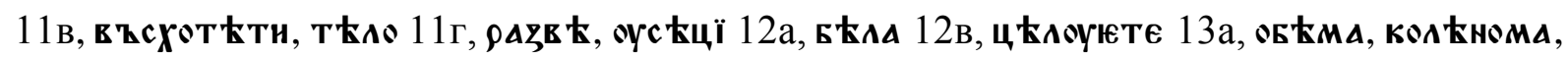
А

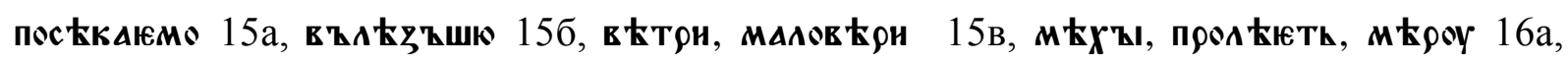

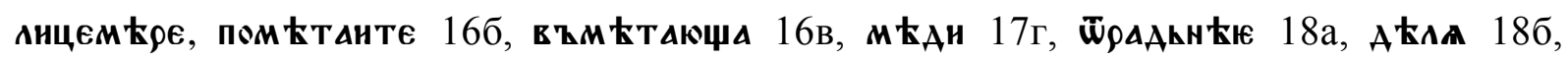

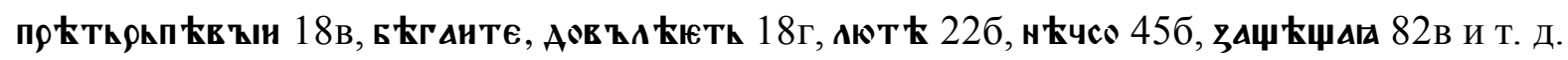

\section{3 в в суффиксах}

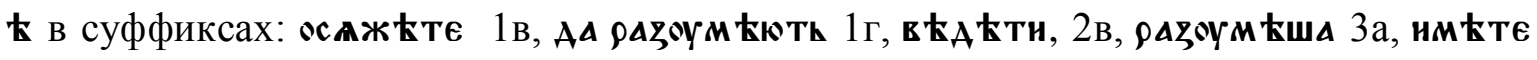

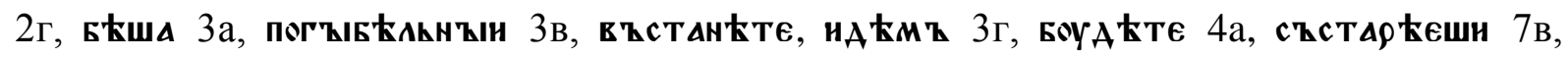

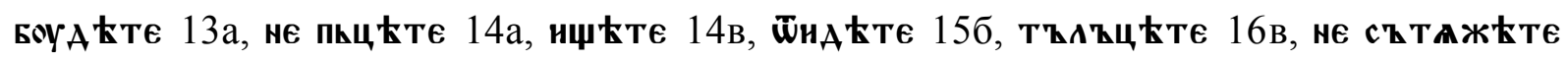

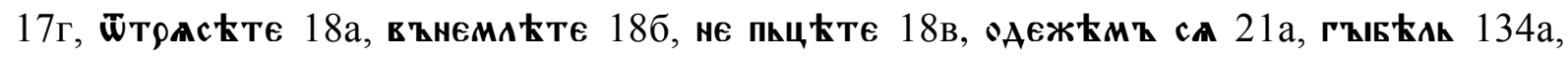


өБнтћль 136в и т. д.

Эти группы $(2 ; 3)$ состоят из большинства слов, где буква $\mathbf{t}$ употребляется

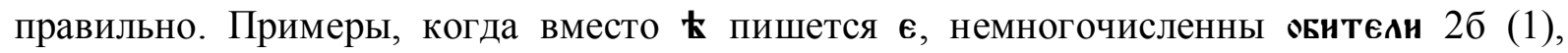
возможно, произошло смешивание суффикса -Łл- (*-ěl-) [Елкина 1960: 109-110] существительных с основой на *-ц- женского рода с суффиксом -тель (*tel-io-s) существительных с основой на *-о̆-, *-јо̆- мужского рода [Мейе 1951: 281].

Замена $\mathbf{k}$ на $\mathbf{e}$ происходит и в глаголах зАпрєтити 55г (зАпрtтити Стоянов 1972:

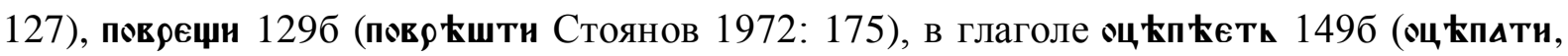

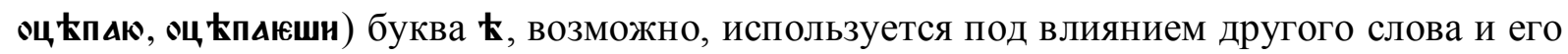
форм өц Łпћн

Написание таких слов осажћте 1в, шБлћчћте са 2а, ищћте 14в (6), не сқтажћте

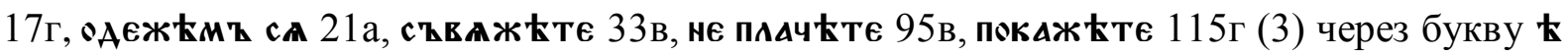
объясняется влиянием глаголов типа нєсти (повелительное наклонение 2 -ого л. мн. ч. нєсћтє) переносом морфемы -ћтє в III класс тематических глаголов (Ван-Вейк 1957: 188).

Для новгородской школы характерно смешение ц ч, которое объясняет $\mathbf{k}$ после ч в

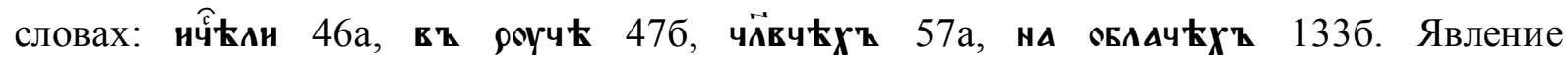
«новгородской письменности смешение знаков ч и ц исчезает в XV в.» (Зализняк 2004: 39; Щепкин 1967: 173).

В глаголе и его формах қсти 1в (16), Асти 41г (4), гасти 103a (1), Łмқ 14a, 1266 (2), Aмz 146 (1), гамқ 21a (1) для написания используются как $\mathbf{k}$, так и $\mathbf{A}$ (ґ). В общеславянском языке после $\check{c}, \check{s}, \check{z}, j$ звук е̌ перешел в $а$ (Шевельов 2002: 153), поэтому в старославянском языке имеем гамк, гасти (Фасмер 1986: 18). В русском в словах ем, еду предполагается более поздняя йотация, чем в словах яд, язва, в древнерусском отмечаются $\mathbf{k} \mathbf{A} \mathbf{z}, \mathbf{k}$ зв (Ван-Вейк 1957: 122).

В рукописи имеется определенная группа слов, где происходит переход $\mathbf{k}>\mathbf{A}(\mathbf{a})$. Такое явление характерно для древнерусского языка. В основном это глаголы, стоящие

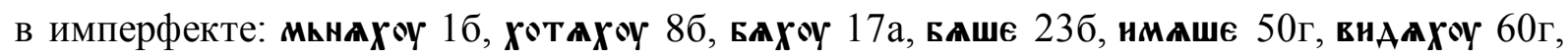

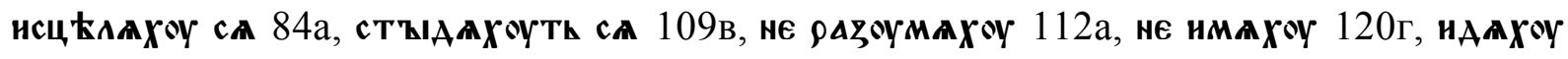


149г. В слове вєльзавола 18г, 29а, 61г, 97а (2) и его формах вместо Ł последовательно пишется гласный $\boldsymbol{\Delta}$, что исключает ошибку переписчика. Примеры написания через $\boldsymbol{\Delta}$

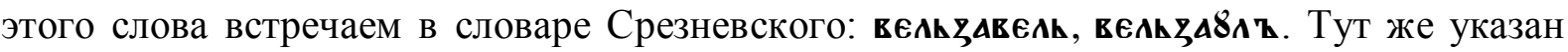
источник: Изборник 1073 г. (Срезневский 1893: 240). Так как это не единичный случай, возможно, здесь тоже произошла древнерусская замена $\mathbf{k}>\mathbf{A}(\mathbf{a})$. Сочетание $\mathbf{3}+\boldsymbol{\Delta}$ объясняется графико-орфографическими особенностями $M m E$, так как в рукописи не найдено ни единого примера буквосочетаний: $\xi+\ltimes, \xi+1, \xi+\infty$.

В следующем примере имеем написание буквы $\boldsymbol{\Delta}$ вместо $\mathbf{k}$ : в $\mathbf{4} \boldsymbol{\Delta}$ 154a (старославянский в ћнє Стоянов 1972: 119).

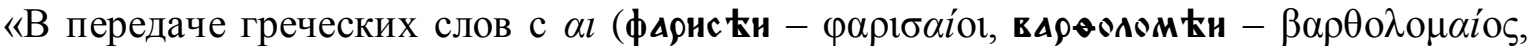
зевєА $\mathbf{k н}-\zeta \varepsilon \beta \varepsilon \delta \alpha \iota$ ov) неодинаково передается в старославянских памятниках греческий гласный, заменивший собою этот дифтонг. В Ассеманиевом кодексе, в Саввиной книге, Остромировом евангелии в передаче таких слов пишется почти всегда $\boldsymbol{\epsilon}$. В Мариинском и Зографском кодексах эти слова передаются неодинаково: и с $\mathbf{\epsilon}$ и с $\mathbf{k} »$

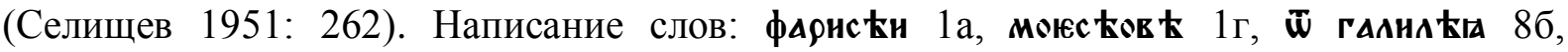

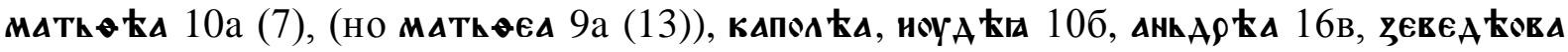

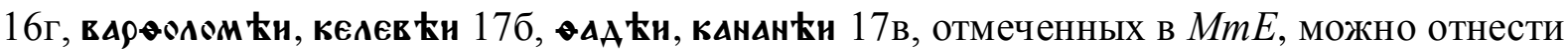
к влиянию протографа.

В словах нћc ть 9в, 546 (44), нłсмь 66 (8), \$ обьясняется стяжением двух гласных $\mathbf{e}:$ нє+ほсмь (Мейе 1951: 40). В рукописи есть пример этого слова, где вместо Ł пишется $\mathbf{\epsilon}$ нес те 49в.

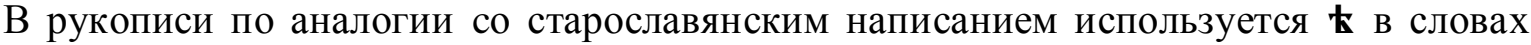
срћв $\rho 417 г$, с (Петер 1976: 75; Стоянов 1972: 200).

В примере с пюћшєнна 127г возможно влияние близко стоящего слова пюћгৎћшєнни 127 г.

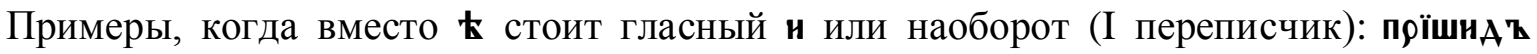

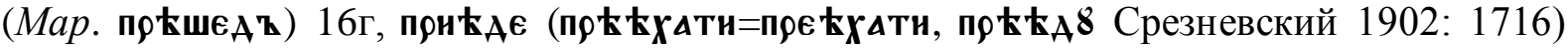
28в, прнмоуарости 30а, прнстжпањте 37в (в смысле преступает заповедь), прнд $\mathbf{~ қ ы ~ 4 2 б , ~}$ 


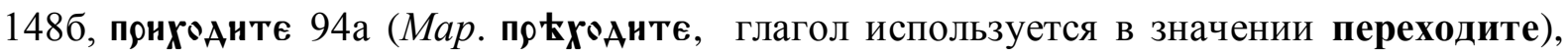

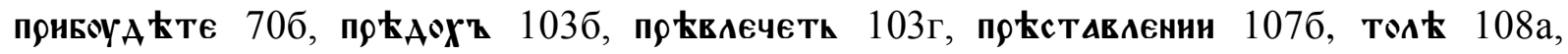

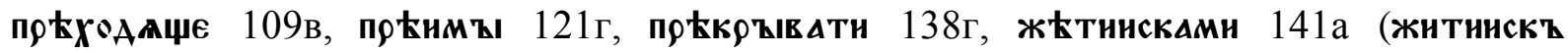
Стоянов 1972: 125), прндъ 147г, ш̈нєлћ 149б. А также у первого писца отмечаются

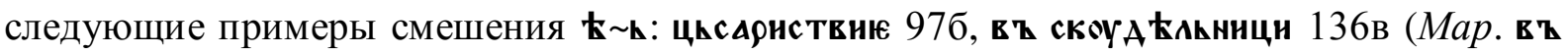

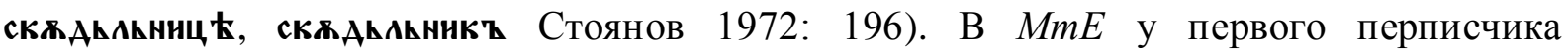
отмечается 18 примеров с $\mathbf{k}$ н (в префиксе (старославянский пр $\mathbf{k}-$, церковнославянский пює-, древнерусский пєрє - Фасмер 1987: 356) 15, в основе 3).

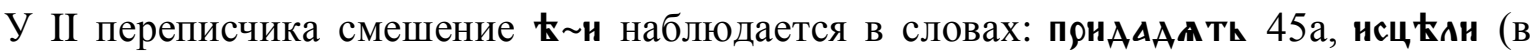
этом случае, возможно, произошла мена глаголов: вместо нсц қићтн, нсц $\mathbf{\Lambda} \mathbf{k}$,

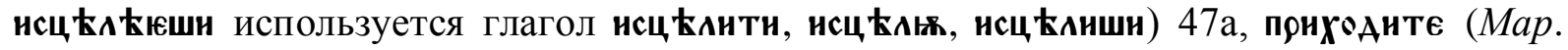
прћх॰днте, глагол используется в значении переходите) 51г. В $M m E$ у второго переписчика насчитывается 2 примера смешения $\mathbf{k} \mathbf{\text { н }}$ (в префиксе 2, пример в окончании аориста не совсем надежный). Сходным явлением смешения $\mathbf{k} \sim \mathbf{4}$ является смешение $\boldsymbol{\varepsilon} \mathbf{H}$, которое отмечается только у второго писца и, в основном, происходит в префиксе и в предлоге прн- (старославянское пюн, древнерусское пюн Фасмер 1987: 362):

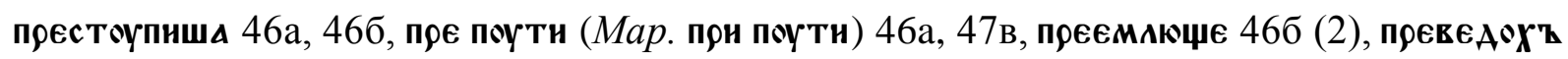
47а, претъчю (пюнтъча Стоянов 1972: 185)) 48б, -и 55а, 59г, 62г, 63г, 76г, преступль (прнстжпль от прнстжпнти Стоянов 1972: 184) 48б, прєАє (Мар. прндє) 48в, 76г, 77б, престоупнша (Мар. прнстоупиша) 49в, прекћпнти са (Мар. прнлћпнтъ са) 49Г, превеАошА

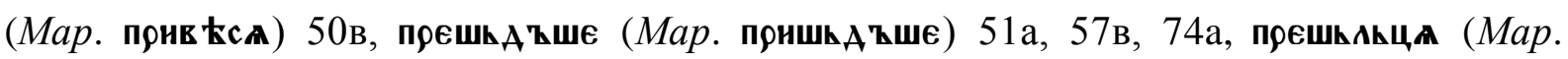

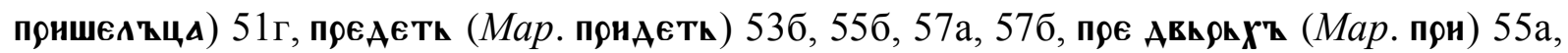

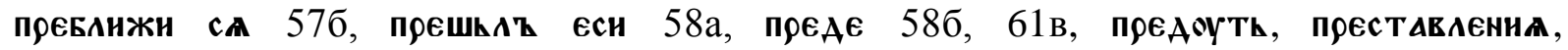

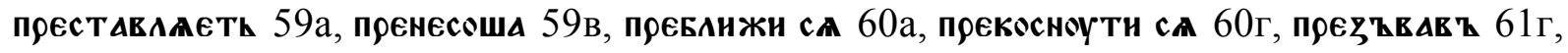

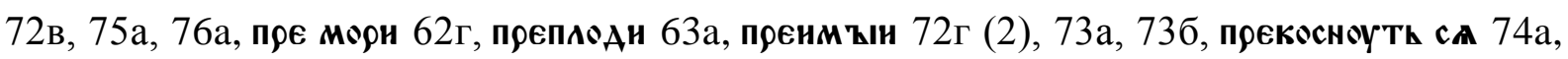
пресћалти 76б, пренмиша 76г (2), прєлежА 102а (54). Предполагается, что такое количество примеров смешения є н в префиксе прн- (фактически имеем написание $\boldsymbol{\epsilon}$ 
вместо н), происходит от неумения второго переписчика распознать и различить пюн- от пюt - (церковнославянского прє-).

Приведенные выше примеры смешение $\mathbf{~ п ~ п о д т в е р ж д а ю т ~ п р и н а д л е ж н о с т ь ~}$ рукописи к новгородской школе («Опріч цього, новгородські тексти можна розпізнати 3

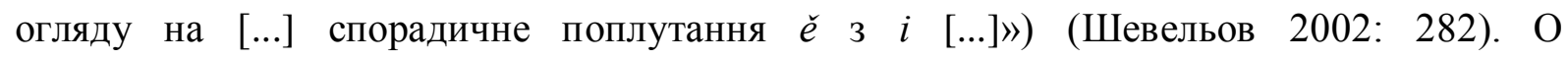

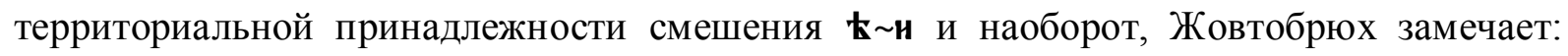
«Аналогічне явище зміни $\mathbf{k}$ літерами и та $\mathbf{\epsilon}$ і навпаки було властиве не тільки київським чи взагалі південним пам'яткам східнослов'янської писемності того часу, а й деяким західним та північним, зокрема новгородським, у яких [е̌] теж характеризувався більшою чи меншою варіантністю, а можливо, нестійкістю» (Жовтобрюх 1979: 240). Из работы Зализняка: «Картина, открывающаяся из новгородских берестяных грамот, такова. Начиная со 2 пол. XII в. здесь проявляется та или иная форма смешивания $\mathbf{k}$ с н - вначале редкого, в XIV-XV вв. уже весьма частого. Это говорит о рефлексе узкого типа» (Зализняк 2004: 52). Зализняк объясняет незначительное количество примеров смешения $\mathbf{k} \mathbf{н :}$ :Для раннего периода ситуация менее ясна. Ранее рубежа XII и XIII вв. надежных примеров смешения $\mathbf{\mathbf { c }}$ и нет; но это, вероятно, говорит только о том, что переход $\mathbf{\mathbf { } > \mathbf { н }}$ начался в данной зоне лишь в это время или немногим ранее» (Зализняк 2004: 52-53).

Древненовгородским произношением $\mathbf{k}$ занимался Шахматов. Шахматов после изучения \ в древненовгородских грамотах пришел к убеждению, что древненовгородский диалект XIII - XIV вв. имел в своем составе особый гласный звук,

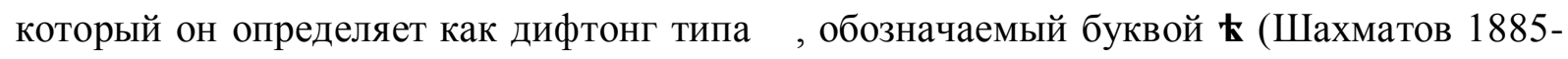
1895: 149-153; 209-226). Горшкова характеризует древненовгородский $\mathbf{k}$, как особый верхне-среднего подъема звук, который использовался до XV в. Фонологический процесс, в результате которого в древненовгородском говоре наблюдаются $\hat{e}>>i$ или $\hat{e}>>e$ зависит от длительности компонентов. Если первый компонент дифтонга длиннее второго, тогда аккустически сближался с $i$ и наоборот, если второй компонент был длиннее первого, тогда > (Горшкова 1981: 93). По мнению Филина, «смешение буквы $\mathbf{t}$ с $\mathbf{\epsilon}$, н, иногда с $\mathbf{k}$, скорее всего, отражает наличие в древненовгородском диалекте разных аллофонов фонемы $е$, причем под ударением и в безударных позициях, перед твердыми и перед мягкими согласными. Как звучали 
варианты фонемы е̌, определить невозможно» (Филин 2006: 170).

Анализ примеров $M m E$ подтверждает предположение о наличии в речи писцов рукописи характерного древненовгородскому диалекту верхнего подъема звука, обозначаемого буквой $\mathbf{k}$.

4 в в окончаниях

Буква $\mathbf{k}$ в окончаниях употребляется правильно, за исключением некоторых групп слов:

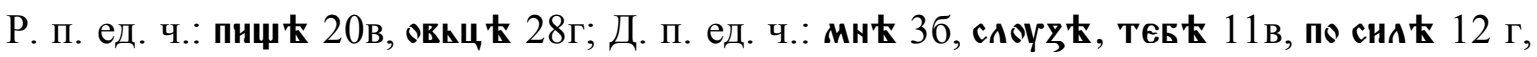

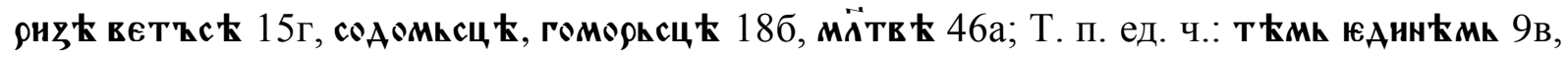

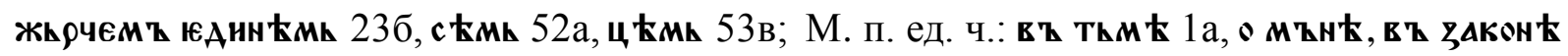

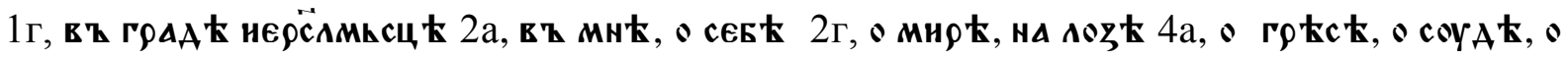

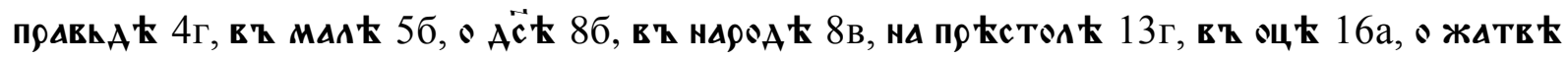

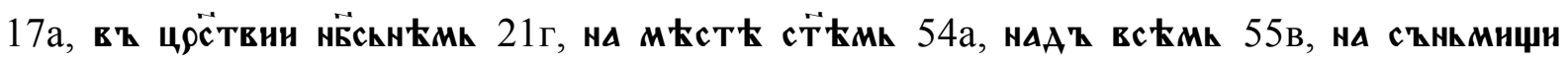

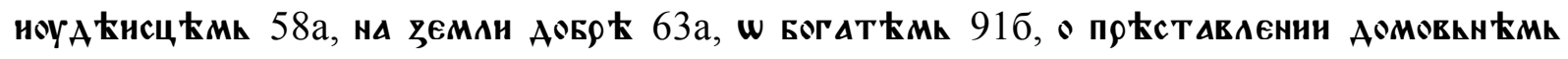

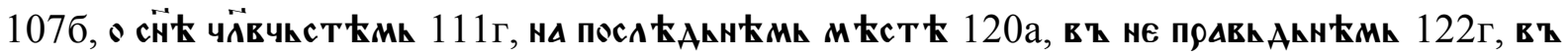

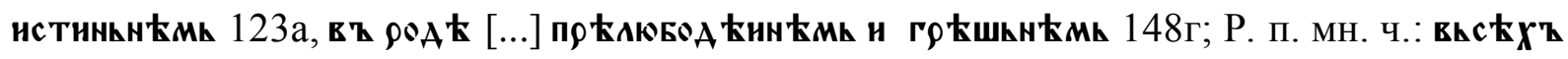

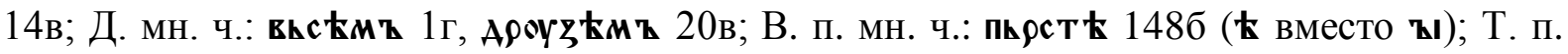

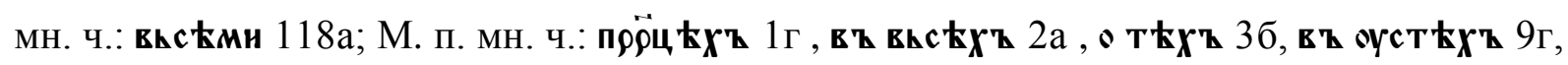

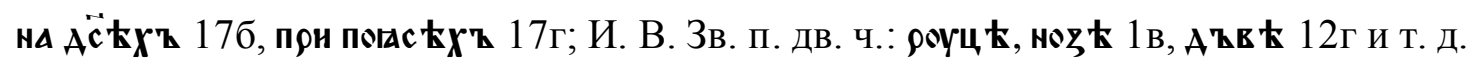

Живая речь восточных славян не знала форм сєь $\mathbf{2 г ~ ( 3 6 ) , ~ т є к ~} 7 б$ (16) (Шахматов предполагал, что формы древнерусского языка - соь 316 (4), төк 226 (1)), а также в

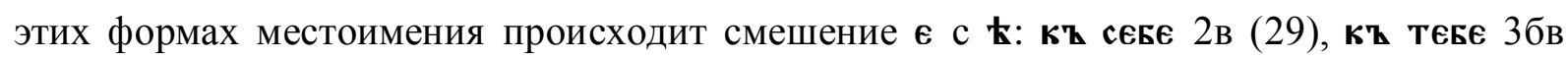
(65). В окончаниях местоимений происходит то же явление, что и в праславянских

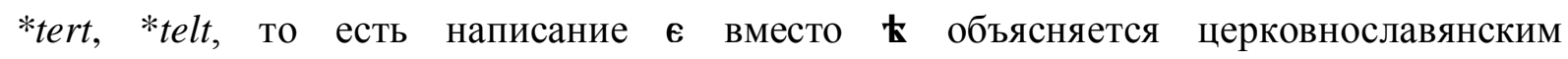
произношением (Шахматов 1957: 159).

Между окончаниями членных и нечленных прилагательных, стоящих в М. п. ед. ч.,

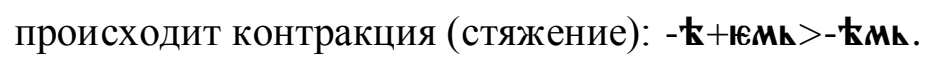


Звук, обозначавшийся буквой $\mathbf{k}$, существовал, так как его находим во всех морфемах слова. Примеры, где имеет место смешение $\mathbf{t} \sim \mathbf{\epsilon}$ отображают закрытое $\hat{e}$ произношение этого звука в древнерусском языке (что расходилось с древнеболгарским произношением). Замена буквы $\mathbf{k}$ на $\mathbf{\epsilon}$ в рефлексах праславянских сочетаний *tert, *telt относится к нормам книжного правописания. Сюда же относится мена $\mathbf{k} \sim \mathbf{\epsilon}$ в формах 2го л. ед. ч. личного и возвратного местоимений в Д. и М. п. В рукописи встречаются 18 рефлексов древнерусского языка (полногласие) праславянских сочетаний *tert, *telt.

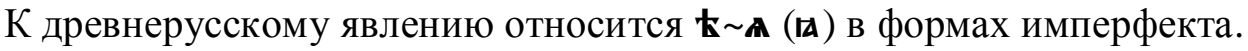

Смешение $\mathbf{k}, \mathbf{\epsilon}$ с и является ярким примером древненовгородского диалекта. Отсюда предположение, что книжное призношение и написание $\mathbf{t}$ отличалось от живого произношения этой гласной новгородскими переписчиками.

III.3 Рефлексы *tort, *tolt и *ort, *olt

Результаты изучения общеславянских звукосочетаний *tart, *tert, *talt, *telt и их рефлексов в рукописи свидетельствуют о сильном влиянии старославянского языка.

Рефлексы праславянских дифтонгоидов (звукосочетаний) *tort, *tolt и *ort, *olt:

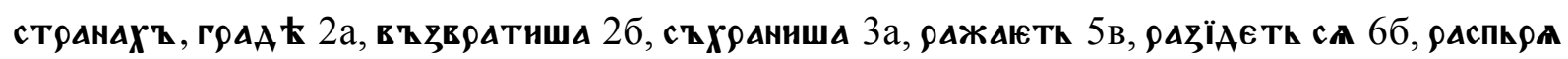

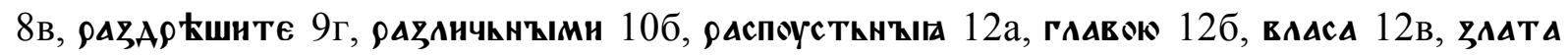

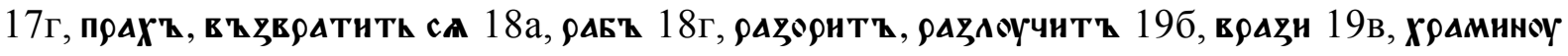

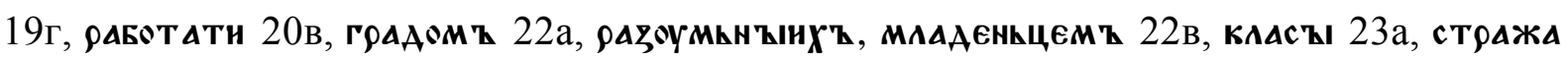

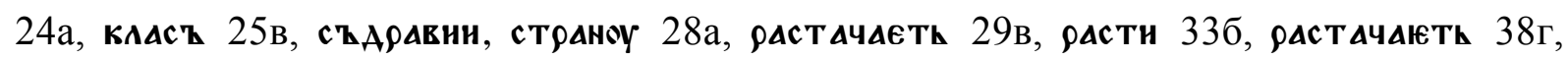

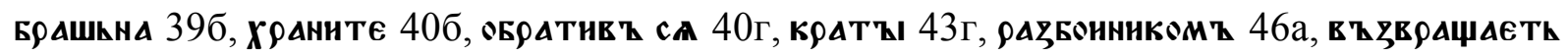

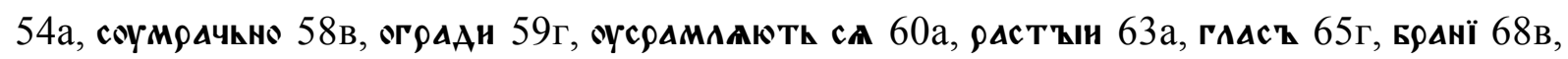

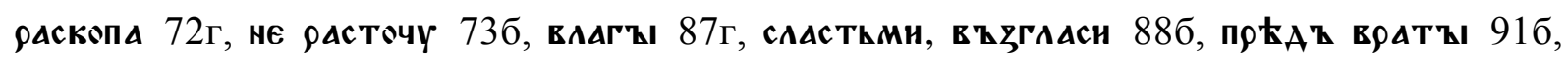

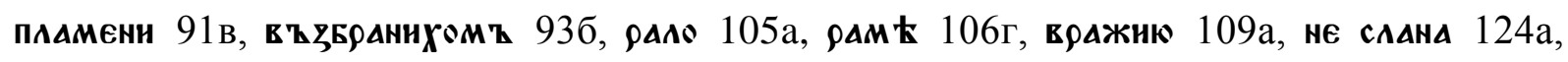
ГАААТ 134Г, ОАСПАША 1406 И Т. Д.

В приписке писца (слова не относятся к библейскому тексту) встречается один пример древнерусского полногласия на -өрө-: възворочал са 77г. Из приписки Домки об окончании работы над апракосом отмечается древнерусское полногласие -өль- в 


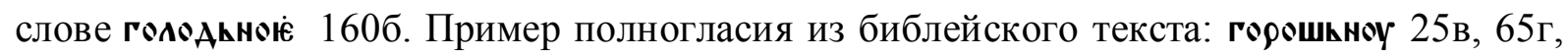
челов ЋपҺск' 29Г.

Проблемы связанные с рефлексами праславянских *tert, *telt объясняются в III.2.

\section{III.4 Использование А и оу в начале слова}

Использование букв оу, ю в начале слова: оүже 4а, 151г, оүнъ 7б, оужинаг 30a, оу (В.

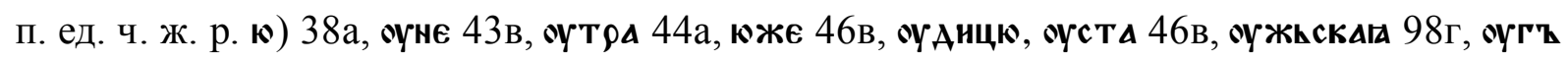
103в, оуности 111в, оу (Map. ж) 121а, оуноша 1386.

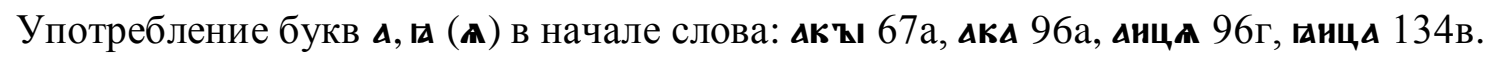

III.5 Маловажные изменения в системе гласных

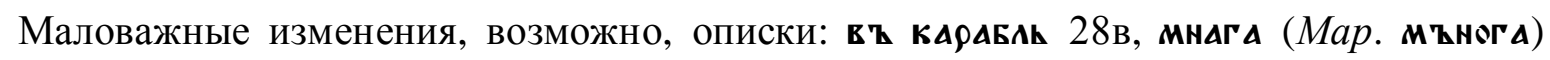

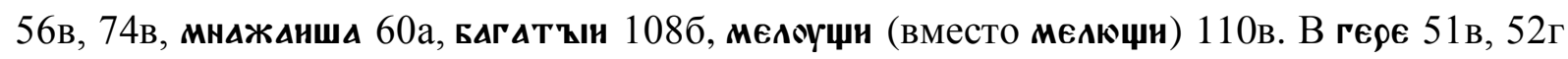
вместо • употредляется $є$ (предполагается, что написано по недосмотру и неопытности вторым переписчиком). В рукописи не наблюдаются примеры перехода $e>$ 'o (Антошків 2011: 29-35).

III.5 Консонантизм

III.6.1 Рефлексы * $d j$

В $M m E$ на месте *dj употребляются старославянское жА и древнерусское ж:

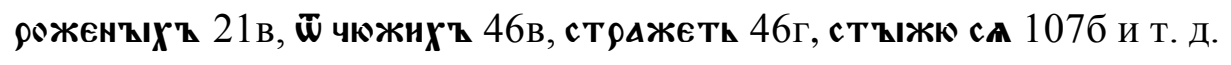

В рукописи преобладают старославянские примеры: кнжАк 8г, 152б, жАєноути 10г,

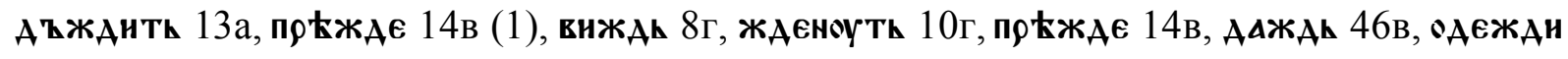

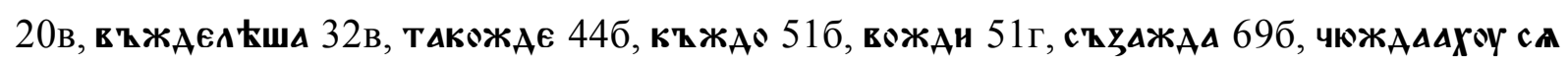

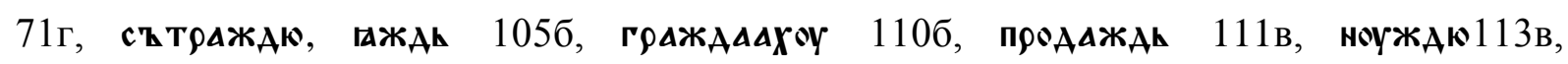

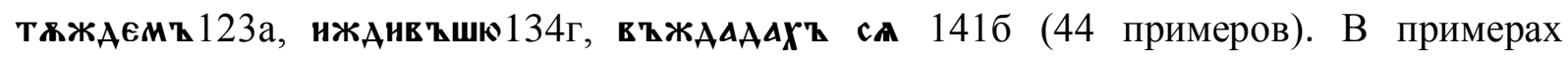
мұнагАшиды 47а, көлишиды 53Г имеем Продолжение старославянского жА (жд - жьд $-u b \partial)$.

По мнению Живова, большое количество примеров с жА, находящихся в рукописи, или, например, ни единого глагола 3-го л. ед. ч. настоящего времени с 
древнеболгарским окончанием -тъ и т. д., связано с хронологией образования нормы написания данного явления: «Формирование русского извода церковнославянского языка было сложным и длительным процессом, включавшим переработку иностранных номр литературного языка по целому комплексу признаков. [...] Это сближение шло неравномерно по разным признакам. Так, скажем, -ть в окончаниях 3 л. презенса входит в норму русского извода со времени самых первых известных нам памятников [...]. * на месте *dj вытесняет жА существенно медленнее: в найболее ранних памятниках ж встречается значительно реже, чем жА, в памятниках рубежа XI-XII вв. ж постепенно берет верх над жА, и лишь в начале XIII в. жА оказывается за пределами нормы [...]. Еще медленнее идет замена $\rho \mathbf{t}$ на $\rho \in$ в рефлексах *tert: и в рукописях XIII в.

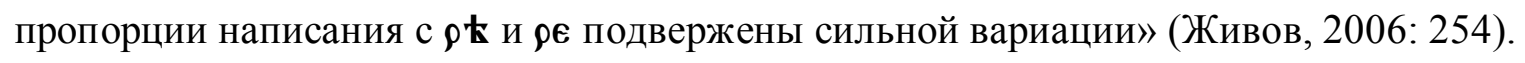

Вариативность использования жА, ж в $M m E$, указывает на архаичность, консерватизм орфографии рукописи.

В примере пюқан (Мар. пюқжає) 133а не происходит изменение. Возможно влияние протографа.

\section{III.6.2 Наличие буквосочетаний кн, гн, $\boldsymbol{\chi} \mathbf{H}$}

Наличие буквосочетаний кн, ги, хн. Слова, содержащие данные буквосочетания, в основном иностранного происхождения (греческого): кнтов $\mathbf{2 9}$ г (11), киннсқ 466 (4),

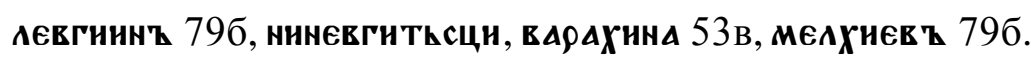

\section{III.6.3 Вставочный -l’-}

Безошибочно используется, характерный для древнерусского языка вставочный -l'-:

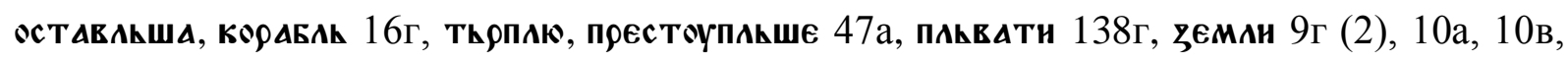
11a, 18б, БлюА॰ 52в, 99в, ост АвльшА 16Г и т. Д.

III.6.4 Вставочный -А-

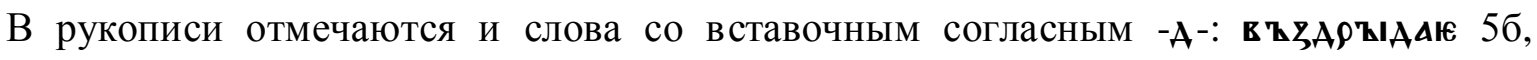

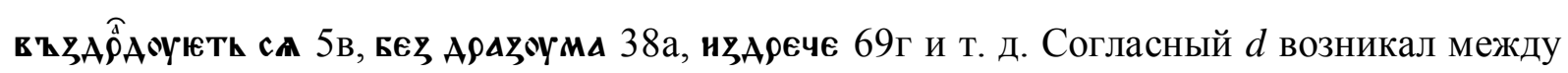
звонким $z$ и сонорным $r$. Фонетическое явление принадлежит церковнославянскому 
языку и по мнению Жовтобрюха [1976: 204]: «Вставний [d] відомий давньоруським пам'ятникам лише південно-західного походження, та й то фіксується в них досить пізно. [...] Вставний [d] в давньоруській мові локалізувався, певно, лише на території іiі південно-західних діалектів...». Вайан дополняет: «В церковнославянских языках формы с за९ имеют тенденцию к исчезновению, особенно на стыке предлога с именем,

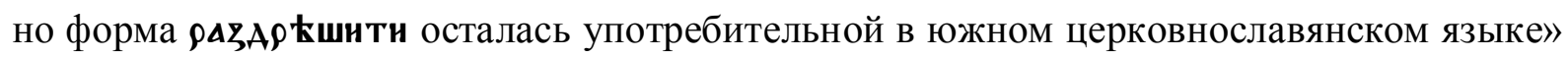
(Вайан 1952: 83-84).

III.6.5 Маловажные изменения в системе согласных

Объяснение следующих примеров: нж неге 47a, 58a, нжє те 75 г, нж нєґ 89в «s, Z перед n', l' через посредство мягких s', z' изменяются в š, ž» [Ван-Вейк 1957: 112]; изменение согласных (слитие) происходит «при соединении предлогов-приставок, не

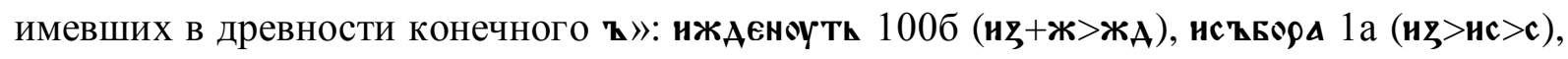

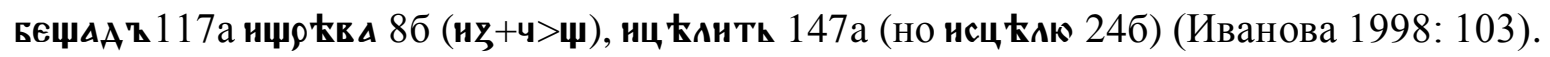

В слове пюнжиствье 72в пишется буква ж вместош.

В числительном сємь 129г отсутствует буква А. Употребляется древнерусская форма слова сємь [Срезневский 1912: 333] (старославянское сєАми Стоянов 1972: 197).

В слове прослеживается удвоение -нн- сқ хомнн $138 \mathrm{a}$.

В существительном влдсвнмню 81 г буква ф заменяется на в (влдсфнмнга Стоянов 1972: 111). Это объясняется тем, что согласный $f$ проник в древнерусский язык с заимствованными словами [Иванова 1998: 75] и был чужд разговорному языку. В истории развития буквы отмечаются ее замены на п (Степан), на $\boldsymbol{X}$ (такая замена характерна исключительно для юго-восточных славян «зміна $f$ на $\boldsymbol{X}$ є суто українська 3 походження» (Шевельов 2002: 805). Однако и Зализняк [2004: 92] представляет

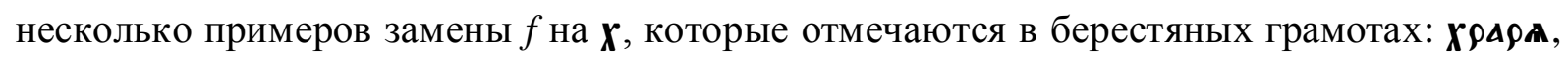
пє९Хурни - «одно из проявлений адаптации иноязычных имен с необычными для древнерусского языка фонемами») и редко на в. В русском языке звук $f$ развился и утвердился после выпадения редуцированных в ходе оглушения $(v>f) v$ в конце слова и перед глухим согласным (Горшкова 1981: 63; Шевельов 2002: 803-807). 


\section{III.7 Диалектные особенности согласных}

\section{III.7.1 Смешение ч ц}

В рукописи встречаются фонетические элементы древненовгородского диалекта. Самым характерным элементом древненовгородского диалекта является смешивание ч ц букв. «Во всей древненовгородской зоне произошло совпадение в единой фонеме (которую можно условно обозначить как $c$ ' [в кириллице - $u$ '’]) продуктов первой регрессивной и прогрессивной палатализации для *k и рефлекса сочетания *kj (в восточно-новгородских говорах - также продукта второй регрессивной палатализации для *k и рефлекса сочетаний * $t j$ и *kt’)» (Зализняк 2004: 39).

По мнению Горшковой, «писцы, в родном диалекте которых была лишь одна аффриката, в целом стремясь употреблять «правильно» буквы $u$ и $ч$, временами путали их, так как в их сознании обе буквы соотносились с одной фонемой...» (Горшкова 1981: 63).

Явление цоканья не относится к реализации общеславянских тенденций отмеченых в развитии фонологии древненовгородского диалекта, а носит «внешний» характер. Развитие цоканья произошло в связи с усвоением языком-победителем (восточнославянским) некоторых особенностей исчезнувшего языка. В данном случае произошла славянизация прибалтийско-финского диалекта, в котором отмечается лишь одна глухая аффриката. Стало быть, явление цоканья, во-первых, «связано с внутриструктурными фонетико-фонологическими отношениями, сложившимися еще в позднем праславянском в связи с отсутствием функциональной противопоставленности шипящей и свистящей аффрикат»; во-вторых, «реализованными эти структурные возможности оказались там, где распространение славянской речи осуществлялось за счет поглощения ею языков, знавших лишь одну глухую аффрикату» (Хабургаев 1980: 106-108).

«Начало цоканья относится примерно к VIII-IX вв.» В своей работе Филин расскрывает две теории образования явления: «1) цоканье - спонтанное явление северных диалектов древнерусского языка; 2) цоканье - явление субстратное, возникшее под воздействием неславянских языков» (Филин 2006: 263). Впервые гипотезу финно-угорского субстрата выдвинул Будуэн де Куртенэ в 1901 г., а затем независимо от него в 1902 г. Чернышев. Эта теория была поддержана многими лингвистами и в настоящее время является господствующей (Филин 2006: 265). 
Примеры смешивания ч ц букв в $M m E$ : нарнчањть са 17б, оцнщанте 17 г, 83a,

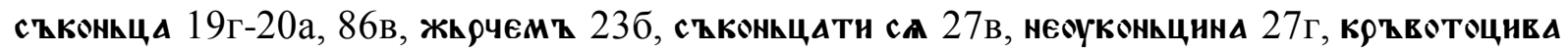

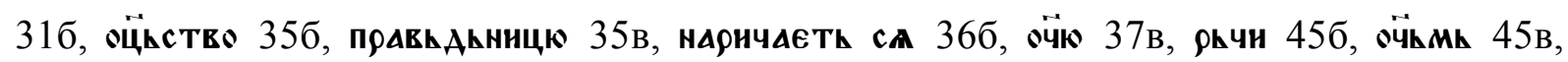

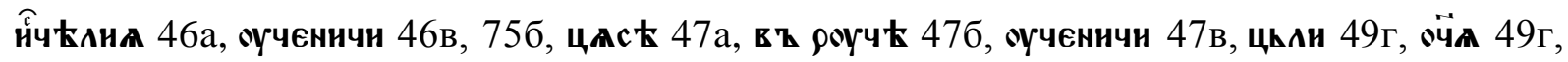

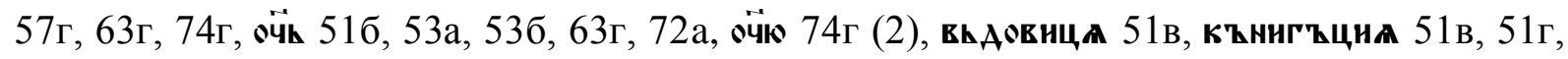

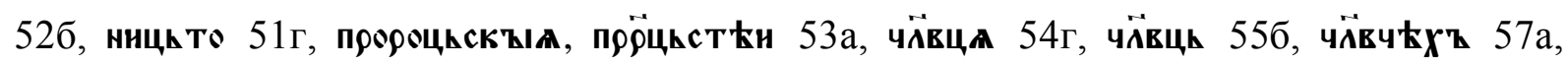

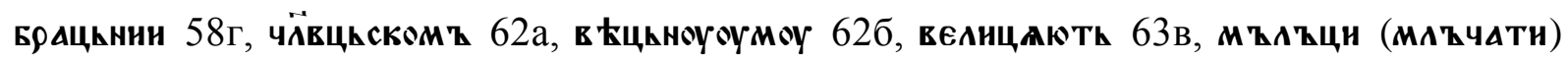

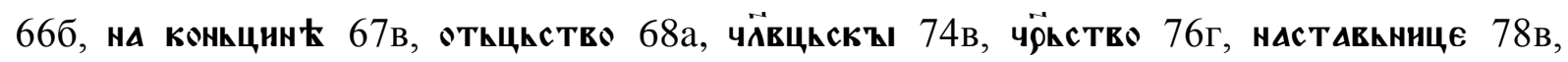

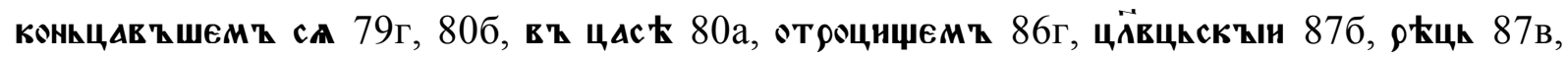

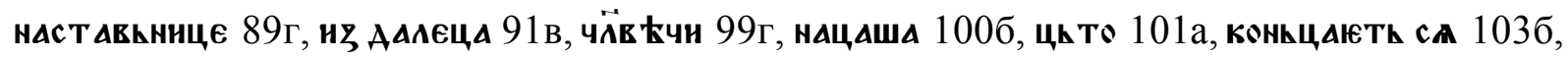
ШЦнстишА сА 116г, цкАн 130б, ААлєце 131a, 131г, чАтћ 131a, процин 131a,

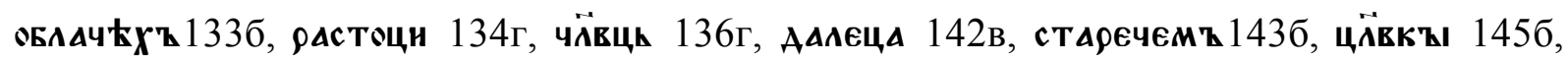

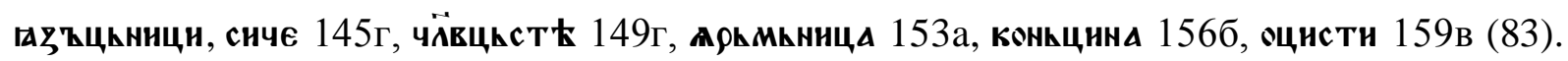
Смешивание ч ц отмечается как у первого переписчика (48), так и у второго (36).

\section{III.7.2 Рефлексы II и III палатализации}

Отсутствие рефлексов II и III палатализаций характерно для древненовгородского диалекта. В $M m E$ примеров отсутствия II палатализации не наблюдается: рөуц $\mathbf{k} 1$ в, в қ

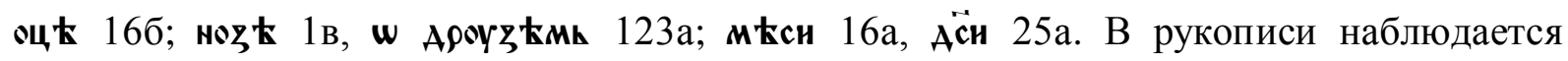
единственный пример соучккъ 85г (древнерусский, старославянский сжкъ Фасмер 1987: 798), где отсутствует рефлекс III палатализации. Однако, в рукописи отмечается реализация III палатализации в том же слове соүчцц 16а. По наблюдению Зализняка, «для *k эффект прогрессивной палатализации в древненовгородском диалекте несомненно был...» (Зализняк 2004: 47). То есть в данном случае отсутствие III палатализации не связано с древненовгородским диалектом.

\section{III.7.3 Рефлекс * $z d+j$}

Особенный случай представляет звукосочетание $z d+j$, древненовгородский рефлекс которого в единственном примере отмечен в рукописи: өАъжги $110 б$ (древнерусский 
өАъжАн). Такой рефлекс часто встречается в новгород-псковских рукописях (Горшкова 1981: 65). Образование жг в новгород-псковских рукописях Горшкова объясняет цоканьем: «Неразличение аффрикат [ц’] и [ч'], их совпадение в [ц’] не только сокращало общее число фонем в цокающих говорах, но и определенным образом сказывалось на в с е й системе оппозиций согласных фонем, т. е. затрагивало как распределение согласных фонем, так и состав их дифференциальных признаков» (Горшкова 1972: 67).

Фонетические явления, наблюдаемые в $M m E$, отражают широкое проникновение в этот уровень языка русизмов.

В рукописи господствуют старославянские рефлексы *tort, *tolt и *ort, *olt (древнерусских примеров насчитывается всего 5); в рефлексах праславянского звукосочетании *dj наблюдаются как старославянское жА, так и древнерусское ж (вариативность форм объясняется древностью рукописи, как следствие, еще не установившимися нормами церковно-книжного правописания). Старославянские формы языка отмечаются и в рефлексах праславянских сочетаний *tert, *telt, однако написание $\mathbf{\epsilon}$ вместо $\mathbf{k}$, отмеченное в рукописи, характеризует церковно-книжную норму восточных славян.

В последующих, приведенных фонетических явлениях побеждают элементы языка восточных славян. В рефлексах континуантов праславянских сочетаний *tъrt, *tbrt, *tъlt, *tblt насчитывается только 5 примеров старославянского языка, 164 древнерусского и 237 древненовгородского диалекта. Рефлексы древнерусского языка мотивировались книжными нормами. К явлениям древнерусского языка, которые закреплялись нормами церковно-книжного письма относится безукоризненное употребление вставочного $l$, a также употребление вставочного А.

Несмотря на древность и нормированность письменной речи рукописи, исследования фонетических явлений отображают большое число элементов древненовгородского диалекта. Это довольно частое смешение $\mathbf{k}, \mathbf{\epsilon \sim н ; ~} \sim$ ц;

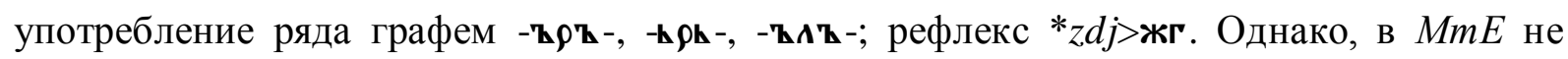
найдены примеры, которые бы свидетельствовали об отсутствии рефлексов II и (надежного примера) III палатализации, что характерно для древненовгородского говора. 
IV Морфология

\section{IV.1 Имя существительное}

Склонение имен существительных лучше всего изучать разделив их по исконным тематическим гласным (согласным), не забывая, однако, что в словообразовании старославянского языка наделенные такой функцией гласные уже не существовали (под воздействием фонологических и морфологических явлений, проходящих еще в общеславянском языке - слились с окончаниями). В старославянском языке Лескин различает 6 типов склонений (парадигм), выделяя существительные с основами на твердую и мягкую основы с указанием рода (Leskien 1919: 107-108). С помощью этой системы изучаются имена существительные, находящиеся в $M m E$.

Ко вниманию предоставляются случаи с нарушениями, ошибками в старославянских падежных окончаниях (для сравнения берутся несколько примеров «правильного» использования флексий); рассматриваются и объясняются древнерусские окончания; обнаруживаются примеры книжного (русско-церковнославянского) написания флексии; и отдельно подлежат изучению окончания древненовгородского диалекта (если имеются таковые).

IV.1.1 Склонение имен существительных с основой на $*_{-} \bar{a}-, *_{-j} \bar{a}-$

\section{Единственное число}

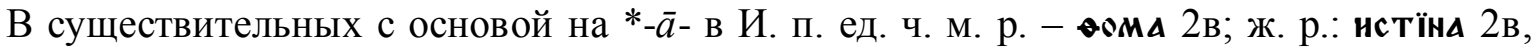

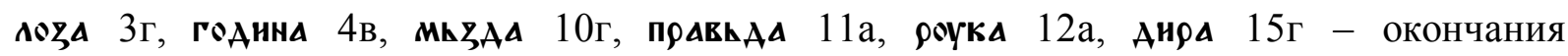
соответствуют норме. В этом падеже у существительных на*-j $\bar{a}-$, кроме исконного окончания, данную функцию выполняет буква -А, которая объясняется исчезновением носовых гласных и в последствии использовалась как вариант буквы -ға: рАспьра 8в, вола 9в.

В $M m E$ встречается древнейший тип существительных на *-jā- И. п. ед. ч. м. р.:

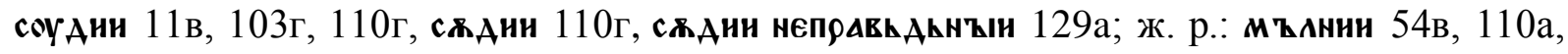
мұлұнӥн с ху॰Анти 156г. По мнению Ван-Вейка, такое написание характерно русским или сербским писцам (Ван-Вейк 1957: 255-256). В существительном с мягкой основой юcти Аш̈є 137в (Мар., Буд. Аш̈山) наблюдается є вместо А. В берестяных грамотах отмечается явление перехода 'a>e (Зализняк 2004: 74-75). Если это не описка, то, 
возможно, имеем пример древненовгородского говора. Написание окончания -\$ в женА

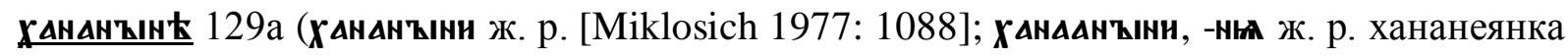

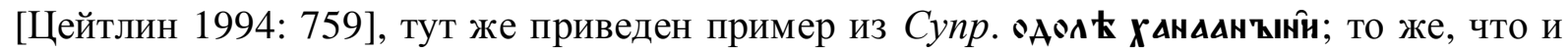
Хананћв [Kurz 1983: 759]; Мар. жена ХАнаненска) объясняется или древненовгородским смешением $\mathbf{k} \sim \mathbf{H}$, или переносом сокращенного окончания из другого существительного XанAн KIA.

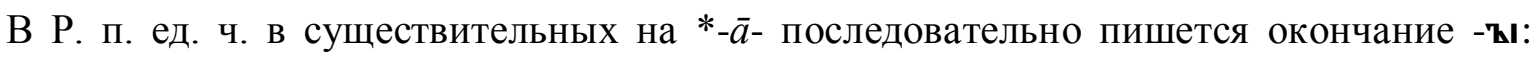

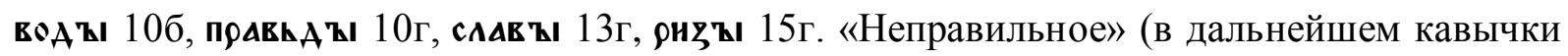

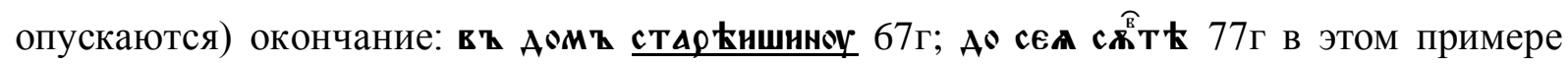
окончание восходит к древненовгородскому говору, «довольно многочисленны примеры с $\mathbf{P}$ имен типа вода с флексией $\mathbf{\mathbf { \epsilon }} \mathbf{\mathbf { E }}$, явно восходящей к древней форме $\mathbf{P}$ имен типа земля〉 (Горшкова 1981: 177).

По своему происхождению окончания Р. п. ед. ч. существительных с основой на мягкий согласный, встречающиеся в рукописи, делятся на следующие группы:

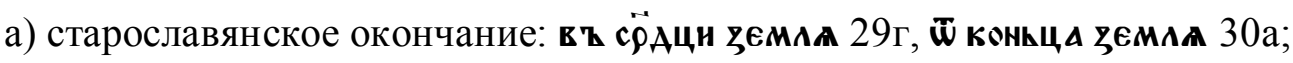

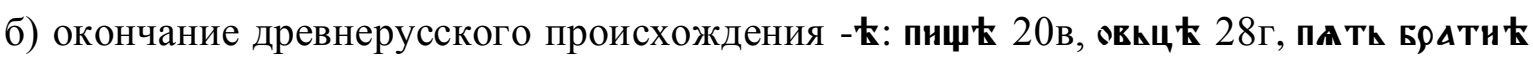
(слово употреблено в единственном числе) 91г, в қ годт вєчєр қ 113в. Образование данного окончания труднообъяснимо (Мейе 1951: 121). По мнению Елкиной, гласный, выступающий в роли флексии, «неясный в своем происхождении» (Елкина 1960: 128). Попытку более глубокого объяснения флексии е̌ находим у Балажа [Balazs 1999: 72-73] и Х. Тота [Н. Tóth 1996: 125-127];

в) гибридное окончание (соответствует нормам русско-церковнославянского языка) -

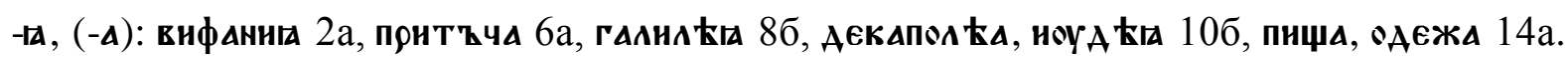
Флексия является результатом скрещения древнерусского произношения и старославянского написания (Х. Тот 2006: 105; 1962: 15);

г) для объяснения -н, -ни в словах: глоүвнны земли 62г, ш̈ Аслни 109в, прамо

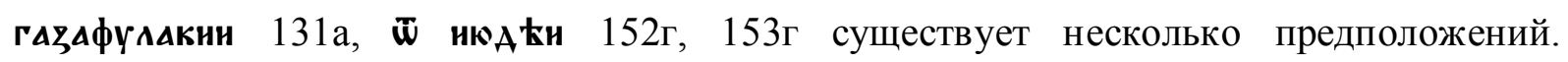
Возможно, флексия древненовгородского происхождения и объясняется орфографически $\mathbf{k}$ н. В новгородских берестяных грамотах примеры $\mathbf{c}$-н в существительных с мягкой основой крайне редки, преобладает -ł (Зализняк 2004: 97). 
У Х. Тота [1962: 15] и Горшковой [1981: 178] читаем, что «под влиянием родительного падежа твердой разновидности возникла форма родительного падежа на $-i \gg: \overline{\boldsymbol{w}}$ икА $\mathbf{k}$ $152 г, 153 г$. Окончание -нн появляется уже в первых рукописях русской редакции, по

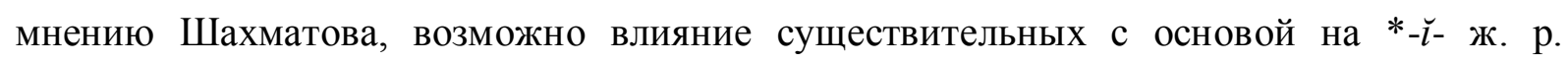
(Шахматов 1957: 81-82).

Сходная ситуация (из-за синкретизма падежей Balázs [1999: 81-86]) наблюдается и в

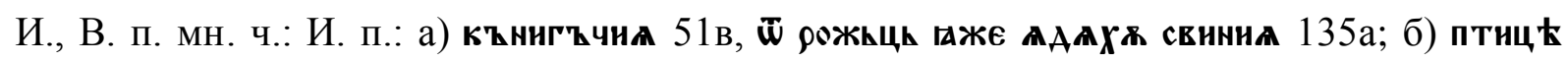

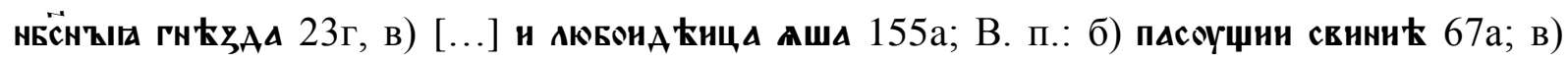

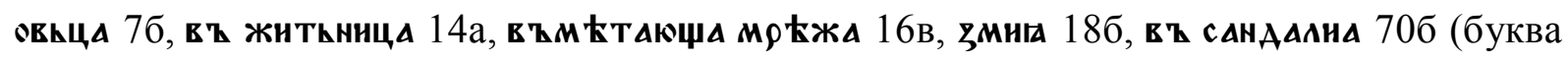
А, стоящая после некоторых согласных, объясняется графико-орфографической системой $M m E) ;$ г) пастт скинни $135 \mathrm{a}$.

В Д. п. ед. ч. существительных с основой, оканчивающейся на твердый согласный,

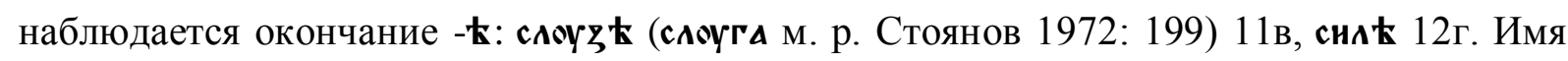
өнъł 15г склоняется по твердому варианту; в существительных с основой, оканчивающейся на мягкий согласный, пишется -н: с.рнн 10б, соль зємлн $11 \mathrm{a}$.

В парадигме существительных на *-ā- в В. п. ед. ч. кроме нормативного -ж, встречается -оу: слдвоу 1а, вт нстиноу 3 а, розгоу 4а, слоуживоу 4в, нстннж 5а, роукоу 8в, гороу 10б, на женж, геонж 11г, потаъгоу (так!) 12а, мАннтоу, рїзоу 12в, мизауу 13а, въ пагоувоу 14в, көньчнноу 15г, мұроу 16а. Неправильное окончание наблюдается: моужю жєна поүстїти 124б, возможно, это ошибка переписчика. В существительных с основой

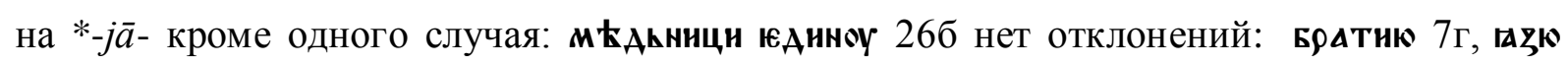
$10 б$, тьмкницю 11 в, срачнцю 12 в.

Существительные с основой на $*_{-} \bar{a}-$, стоящие в Т. п. ед. ч. имеют окончание -sю:

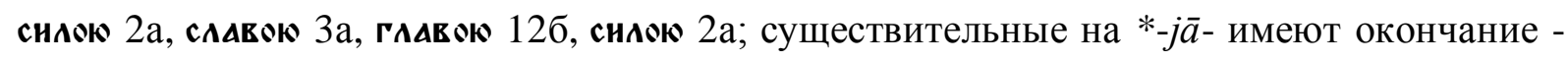
єю: землек 12б, сқ төрнцек 13г. Отклонение от нормы наблюдается: напонти въ чашю вөды 122г. Такое окончание более позднего образования, которое развилось из -єю (Ван-Вейк 1957: 254).

В парадигме существительных на *-ā- в М. п. ед. ч. нет отклонений от нормы: в $\mathbf{z}$

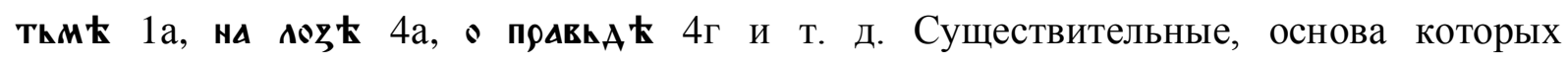


оканчивается на мягкий согласный, иногда попадают под влияние имен с твердой

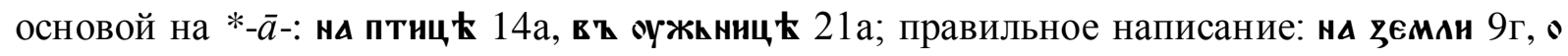
พАєжї 146.

Флексии Зв. ф. существительного ж. р. с основой на *-ā-: жєно 77г, 109б, 129б; и существительного с мягкой основой Аш̈є 66г, 102в, 105б, 149в употребляются правильно.

\section{Множественное число}

Флексии И. п. мн. ч. существительных, оканчивающихся на твердый согласный, соответствуют нормам: кънигъ 3в, р қкы 8б, слюүгъ 8 в.

В существительных с основой на $*-\bar{a}-$, стоящих в Р. п. мн. ч. имеется единственно

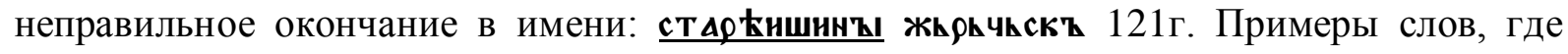
флексия соответствует норме: Бьчєлъ 1в, кънигъ 8 a.

В Д. мн. м. р. слово стА९ћишнномъ 136 попадает под влияние существительных м. p. с основой на *-о̆-. Существительное ж. р. тъсашємъ 121а выступает с окончанием существительных с основой на *-јо̆-. В остальных случаях (твердый, мягкий вариант) окончание используется правильно.

Существительные с основой на $*_{-} \bar{a}-$ в В. п. мн. ч. имеют правильные окончания:

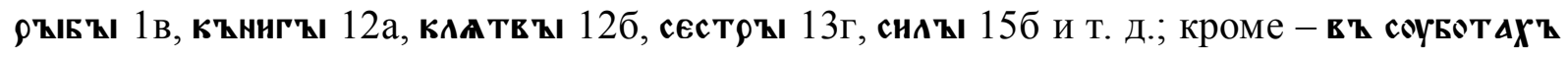
146в.

Флексия Т. п. существительных с основой на ${ }^{*}-\bar{a}-$ используется правильно: жнлАмн $10 б$, в \Анамн 15 в; в основах на $*_{-j} \bar{a}-:$ свнннамн $16 б$.

Неправильное окончание в М. п. мн. ч. имеется в слове: на роүкав z $80 б$. В остальных случаях как у существительных с основой на $*-\bar{a}-$, так и у существительных с основой

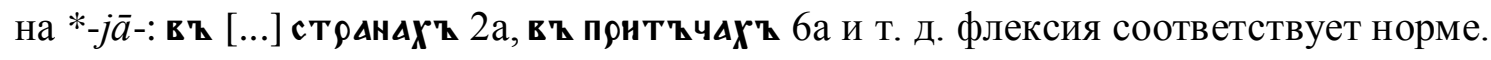

\section{Двойственное число}

В двойственном числе в существительных на $*_{-} \bar{a}-, *_{-j} \bar{a}-$ нет отклонений от нормы.

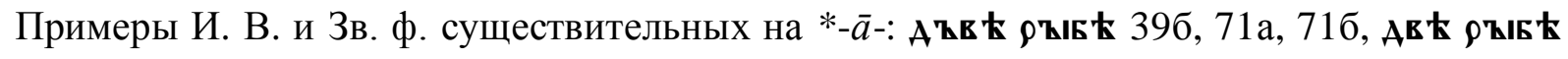
39в; с основой на *-jāa-: А тв ћ на Аєсате кошиници 39в. 


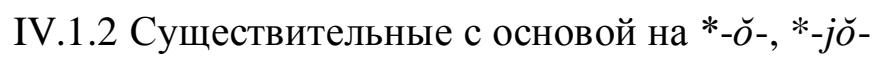

\section{Единственное число}

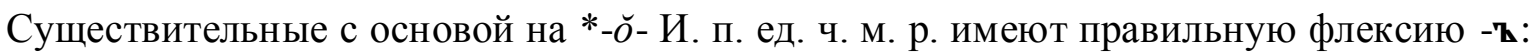

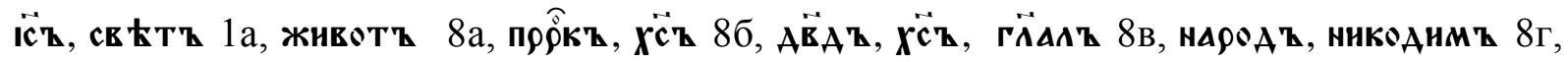

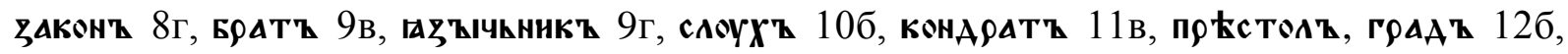
зоувт 12в, соломонт 14б, төоуст 156 и т. Д. В слове рдБо 206 вместо -z пишется -о. Можно предположить влияние графической системы древненовгородского диалекта. В слове иноплємєннкъ (буква • исправлена на и или наоборот) 116г-117а. В имени скрьжети 24в, 64в вместо правильного окончания -z выступает - (возможно, что писец существительное принял за форму глагола настоящего времени 3-го л. ед. ч.). В существительном $\overrightarrow{\mathbf{5}}$ 129а окончание -А объясняется наличием в предложении

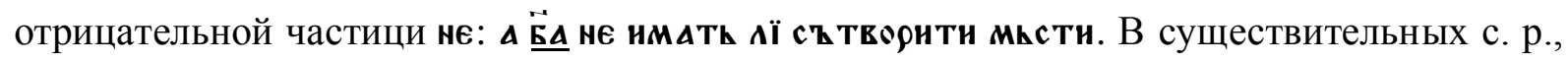

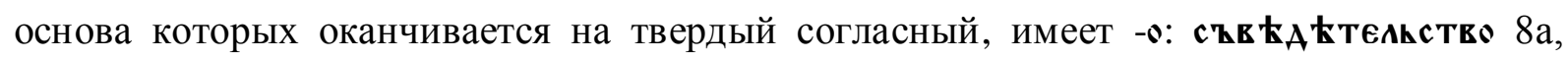

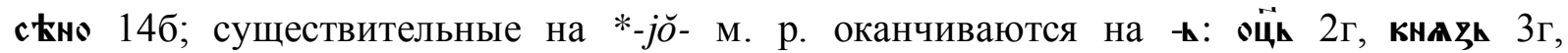
А ŁлАтель, съв А 4б, цисарнствиє 10г, подъножнє 12б, сӥнце 13а. В следующем примере употребляется

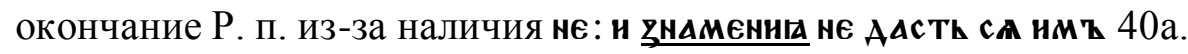

Несколько существительных твердого варианта в Р. п. ед. ч. имеют окончание -оу:

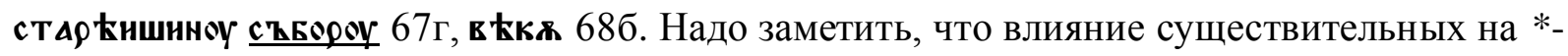
$\breve{u}$ - распространяется на краткие слова, которые состоят из одного или двух слогов. В

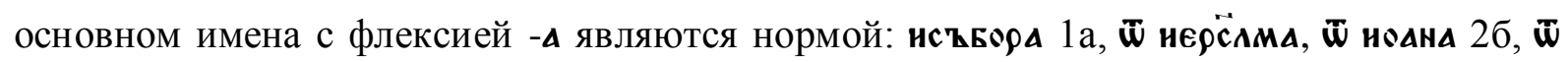

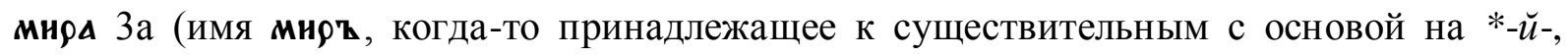
переходит к основам на *-о̆-. В Музейном евангелии (перепись данной книги совершалась в конце XII века или в начале XIII века на севере [X. Тот 1962: 5], по времени и месту близка к написанию $M m E$ ), примеры этого слова с флексией -өу не

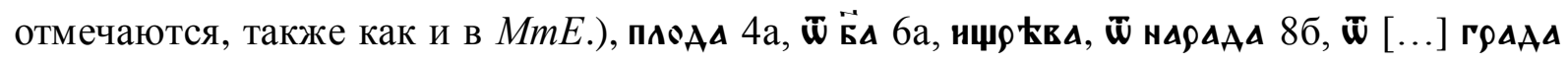

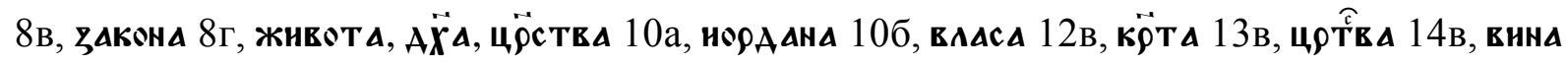
15г. Неправильное окончание: вузъ (глагол, относящийся к существительному, стоит в 
ед. ч. Буд. ж்з厶) 1486 объясняется ошибкой писца. Несколько примеров имен мягкого

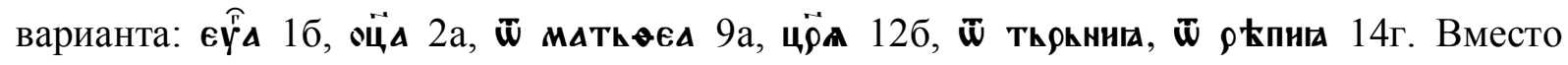

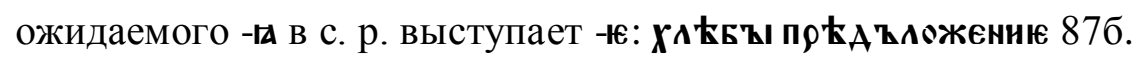

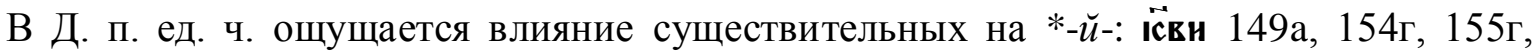

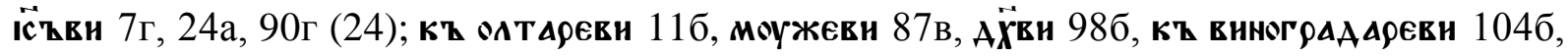
Бён 132а, кесАрєвн 157б, 157в, Б̈г̈н 157в (16). И в древних старославянских рукописях, и в ранних новгородских берестяных грамотах известно окончание -оки, -єки дательного падежа, который использовался лишь в греческих названиях лиц и собственных именах (Ван-Вейк 1957: 243; Зализняк 2004:108). Таким образом, древность рукописи и ее принадлежность к древненовгородскому диалекту способствовали частому употреблению -ови, -еви.

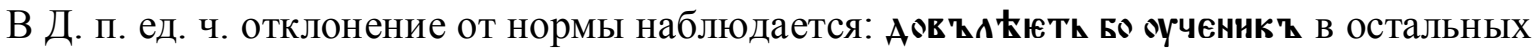

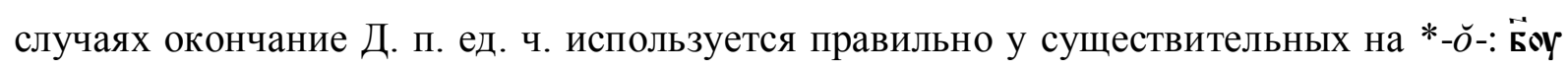
4в, 116а, снмоноу, петроу 7а, чӥвкоу 8Г, мноу 9а, соудоу, врдтоу, рөАоу, зъАоу 12в, Ансоу

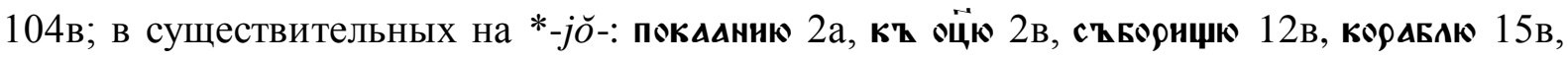
нєрћю $20 б$.

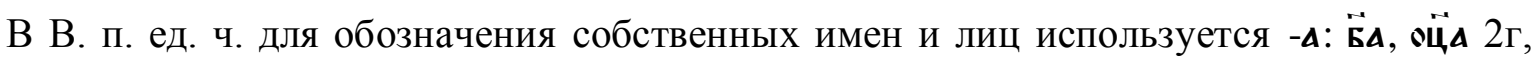
оүченика 7в, на врдт А 11б, врагА 12г. Из материала берестяных грамот следует, что: «для ранне-др.-новг. периода характерно весьма ограниченное употребление В. ед. на -а»

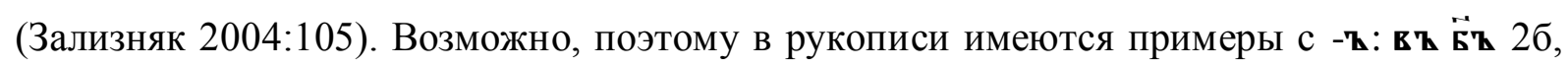

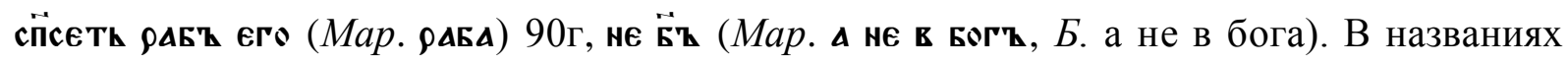
животных окончание -А еще не используется (различие между животными и неодушевленными названиями начинает проявлятся лишь со второй половины XIV в. [Зализняк 2004:107]): тельци 135в. Отклонение от нормы наблюдается - в Атаго 50г вместо -қ пишется -ө, возможно влияние древненовгородской графической системы (Зализняк 2004: 23-25). Окончания В. п. ед. ч. соответствующие норме

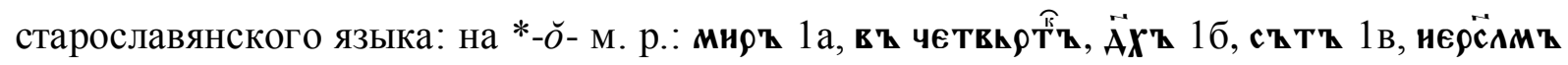

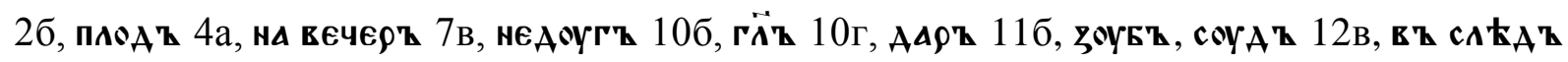


13в, жнвотт 13Г; с. р.: мћсто 2б, АөБро 12г; *-јо̆- м. р.: ААкт ти 14б, соүчкци 16а; с. р.:

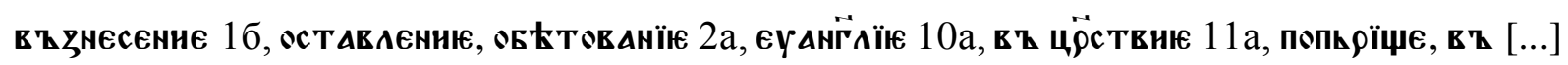
БҚттне 13в и т. Д.

В Т. п. ед. ч., кроме нескольких примеров со старославянским окончанием у

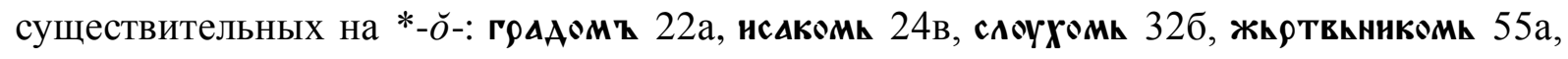

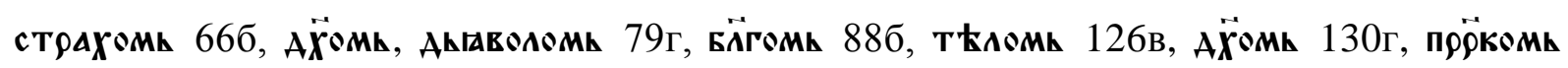
ААннломи 132Г, оүвроусоми 152Г, оплотоми 155б, прұстоломи 159б; на *-јо̆-: соупьремъ 11 в, коцченнеми 45в, нмћннеми 55в, наАт оүчїтелемъ свонмъ 85г, БлнсцАннеми 99б,

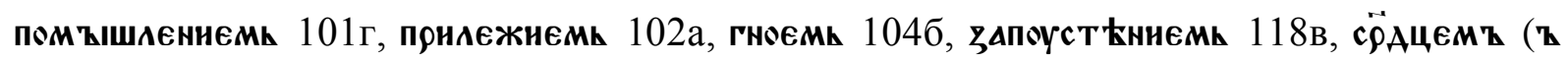
написан невыразительно: хвостик укорочен, трудно определить) 130в, өроужнњмь,

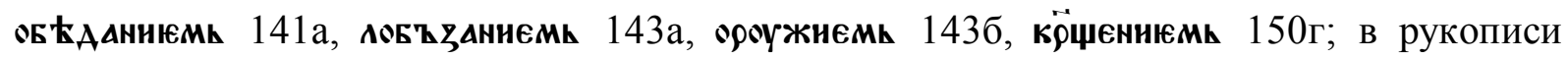
преобладает форма древнерусского языка, которая образовалась под воздействием

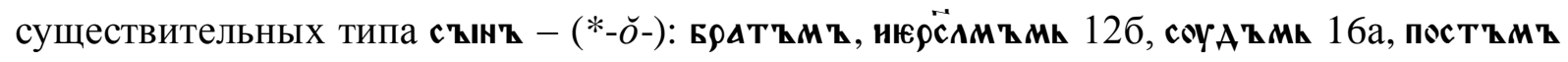
47б; (*-јо̆-): прқат оц̈ими 9в, олтаримқ 116 и т. д. (Ван-Вейк 1957: 242-243; Селищев

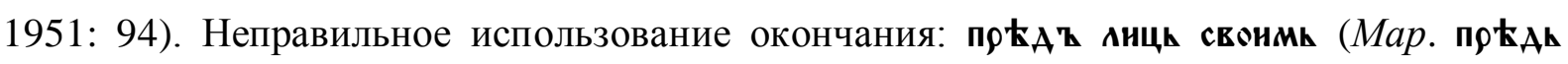
Анцемъ свонми ) 936.

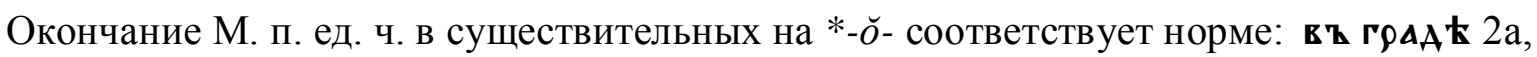

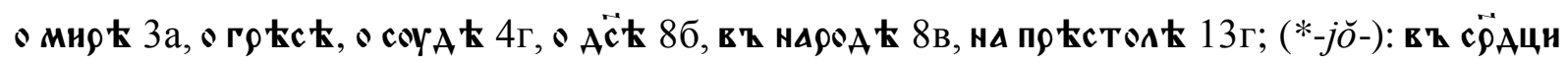

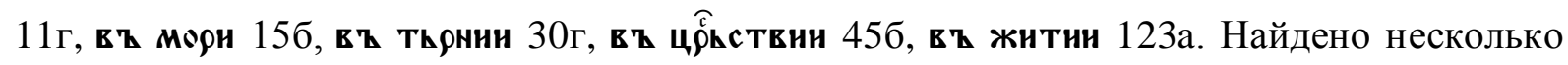
примеров, где наблюдается влияние существительных мягкой основы: въ скоүА $\mathbf{л ь н и ц и ~}$ 136в, на өскли 154а, о грқшкници 106г, 107а. В основе слов прослеживается результат второй регрессивной палатализации, что для древненовгородского диалекта не свойственно. «Важнейшая особенность древнего новг.-пск. диалекта состоит в том, что в нем отсутствует эффект второй регрессивной палатализации заднеязычных» (Зализняк 2004: 42).

В существительных твердого варианта в Зв. ф. ед. ч. окончания соответствуют старославянской форме: фнлнпе 2г, оччє $3 \mathrm{a}$, снмоне $7 \mathrm{a}$, лнцемћрє 16б, наставьннце (древненовгородское ч ц) 89г, чєльв ћчє 102б; пример существительного на *-jо̆-: цёю

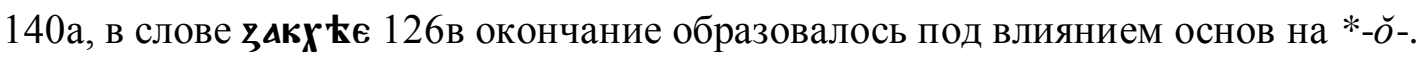


В И. п. мн. ч. м. р. окончание существительных на *-о̆-, *-јо̆- старославянское -н:

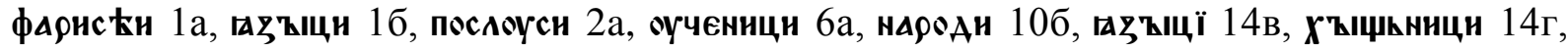

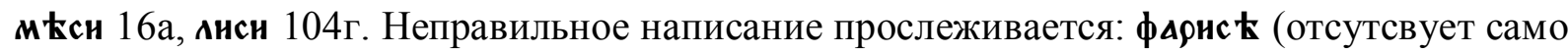

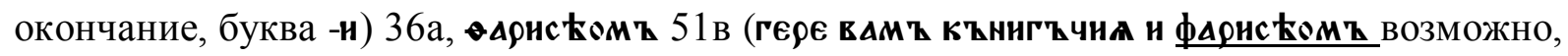
что переписчик попал под влияние местоимения вамқ формы Д. п. мн. ч.). В с. р.

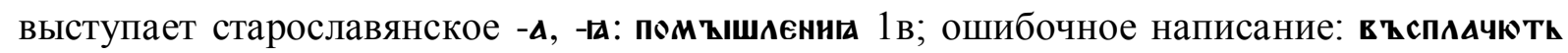
CA KhCA KOA KHO 156 Г.

Разнообразность флексий наблюдается у существительных смешаного типа

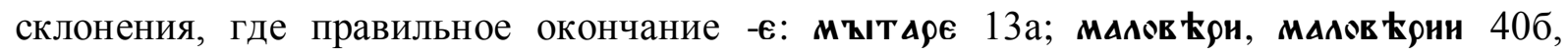

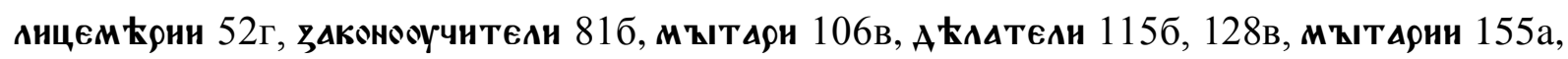
лнцєм ћрн 1576 - в этих примерах флексия -н отражает влияние существительных на *о̆- [Иванова 1998: 123]; Анцємћрнє 103г - такая форма начинает появлятся в конце существования старославянского языка под влиянием существительных типа пжть

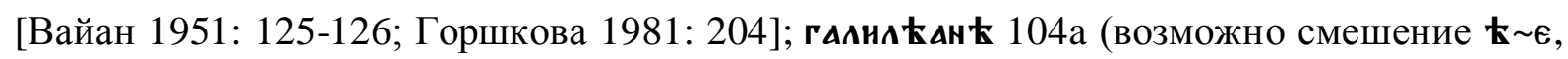

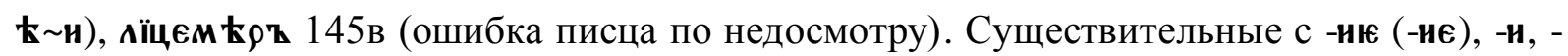
нн отмечаются и в других рукописях древнерусского языка (Ocmp.).

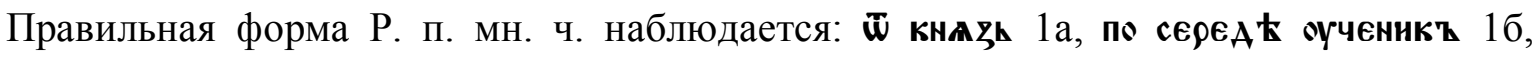

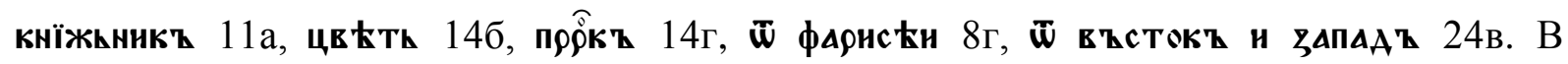
рукописи существует пример ошибочного написания существительного с. p. с основой

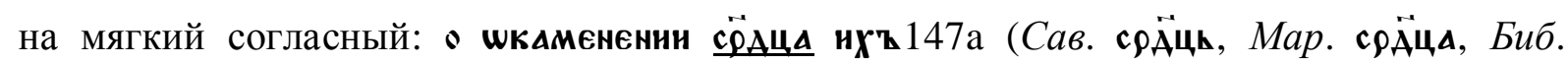
сердец). Возможно, что написание существительного с падежным окончанием Р. п. ед. ч. восходит к протографу (см. Мар.). В мн. ч. только один раз в Р. п. наблюдается

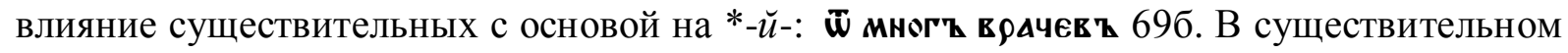
сқсоуды 62а последняя черточка буквы ыы прервана. Возможно, переписчик заметив ошибку, таким образом пробовал исправить ее на букву $\mathbf{z}$.

Использование окончания Д. п. мн. ч. соответствует нормам старославянского языка: оүченнкөмъ 2б, чйвкөмъ 3а, пксомъ 16б; окончание существительных с основой на

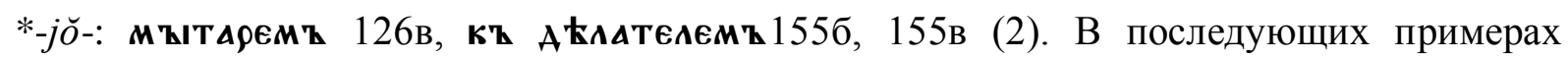




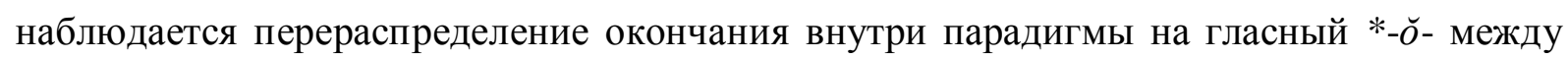

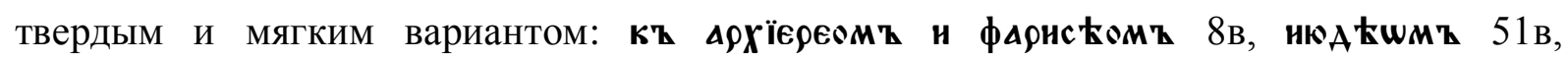

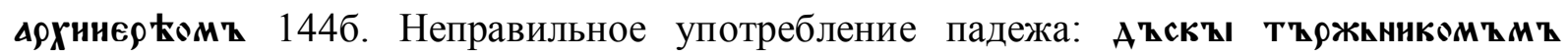
нспровкрже 45г (ошибка писца).

Флексия В. п. мн. ч. в большинстве случаев используется правильно - в именах с

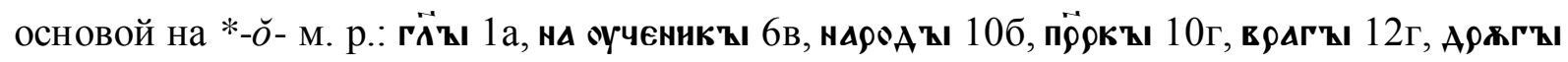

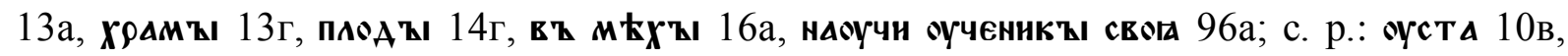
сєлА 13г. Не соответствуют норме твердого варианта слова с окончанием -н: сқсоудн 29в; въ Блнжинаґ виси и грААи 1476 здесь, Возможно, окончание -и существительного кһсн повлияло на выбор флексии в имени грАдн. В примере въАюжи пкрстћ свон (Мар. прқстұ) 148 писец использует древнерусское окончание существительных на мягкий согласный. В именах на *-јо̆-м. р. наблюдается церковно-книжное написание: АгнццА

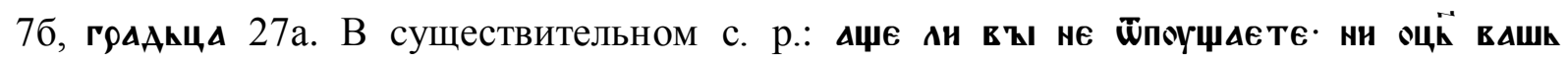

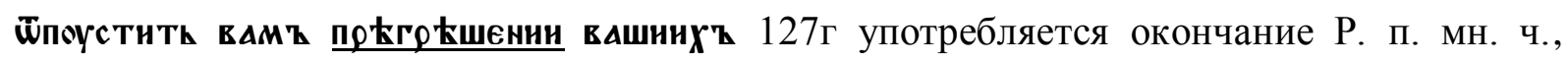
которое объясняется отрицательным смыслом текста (Биб. Если же не прощаете, то и Отец ваш Небесный не простит вам согрешений ваших). Существительное змамєнїє вєлна 156в употребляется в ед. ч. вместо правильного мн. Ч. (Мар. знаменнћ велн $)$ ).

Окончание Т. п. мн. ч. используется правильно: недоугы 10б, чйвкъ 11 а, врдтұы 14в, oусты 37 г.

В М. п. флексии существительные употребляются правильно. Пример твердого

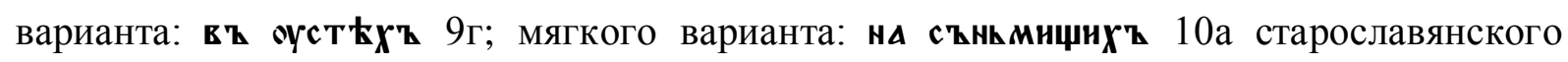
окончания.

Двойственное число

Примеры правильного употребления окончаний И. В. п. и Зв. ф. существительных с

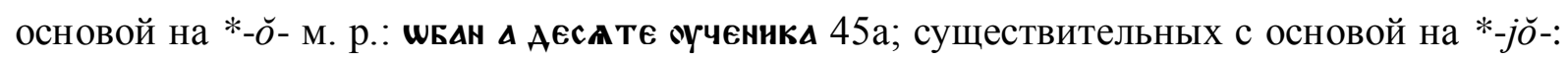
АһвАс А КПицА 55Г И Т. Д.

IV.1.3 Существительные с основой на ${ }^{*}-\breve{u}$ -

Единственное число 


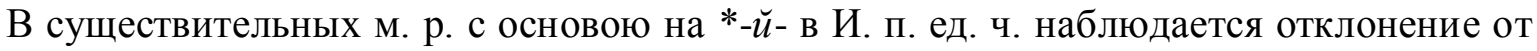

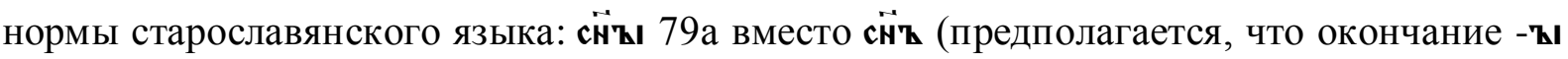
написано по ошибке).

Если в существительных м. р. с основой на *-б̆-, особенно в ед. ч., отмечалось частое

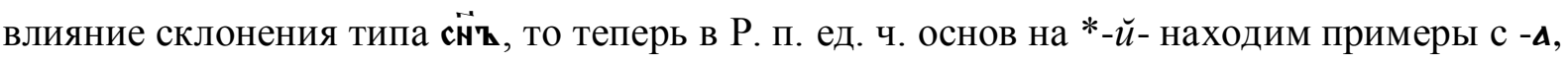
то есть между двумя типами склонений происходит обоюдное влияние, продолжается

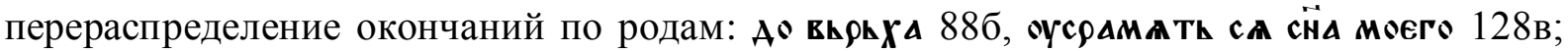

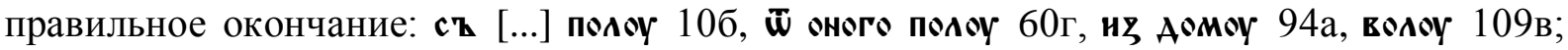
ошибочное написание прослеживается: до вьрь х’h (Map. -оу) 816.

Окончание существительных с основой на *-о̆- проникают и в Д. п. ед. ч.: къ төмюу Аомоу 107б, сноу 64а, 926, 121в, 142б, 149а (5), но Аомови 59г, 1556.

В В. п. ед. ч. появляется флексия -А в одушевленных существительных под влиянием

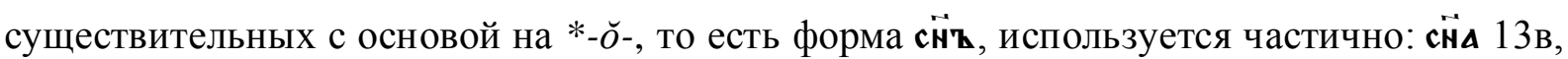
но на с̈̈ъ $101 \mathrm{a}, 140$, посълА къ ннмъ сн̈ъ свон 155б. В большинстве случаев падежное окончание в склонении этого типа соответствует норме: Асмъ 13г. В примере нъ домоу в z домоу 94а отмечается неправильное окончание (возможно, ошибка произошла под влиянием первого слова).

В тексте, не относящемуся к библейскому (запись первого переписчика), не совсем понятно употребление окончания -А Р. п. ед. ч. существительных с основой на *-о̆- в:

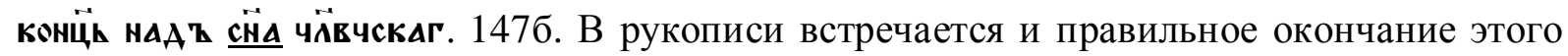
падежа (если не принимать во внимание смешения конечного редуцированного) прt丸 $\mathbf{z}$ сH'kMr $141 \mathrm{a}$.

Влияние м. р. существительных на *-о̆- отмечается и в М. п. ед. ч.: o č̈t 111 г, 122а (правильное окончание в з Аом⿰у 2б) и в Зв. ф. ед. ч.: сн̈є 35 г, 66г, 98а (но сн̈оу 48б, 55г, 56 а, 77в, 123б, 123в, 127а).

\section{Множественное число}

Под воздействием форм домоми (Т. П. ед. ч.) и домомт (Д. П. мн. ч ) [Иванова 1998: 128] образовалась форма М. п. в қ Аөм॰хқ 21в. «Этот процесс опять-таки является 
достаточно старым, встречающимся уже в старославянских письменных памятниках» (Балаж 2003: 55).

Двойственное число

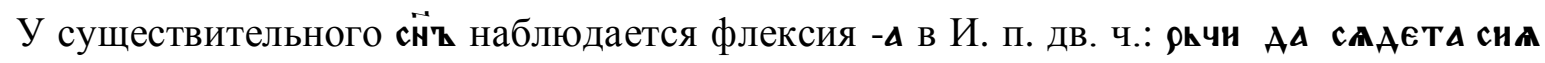

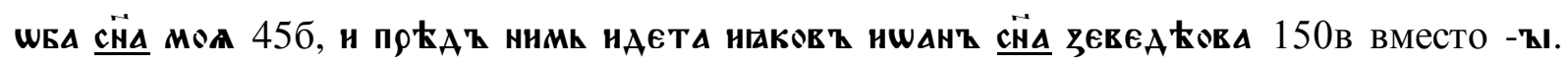
Слово принимает окончание существительных на *-о̆-. В Р. и М. п. отмечается

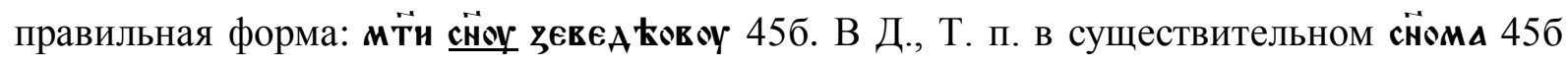
отмечается тематическая гласная имен с основой на *-ら̆-.

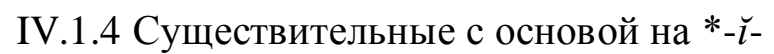

Единственное число

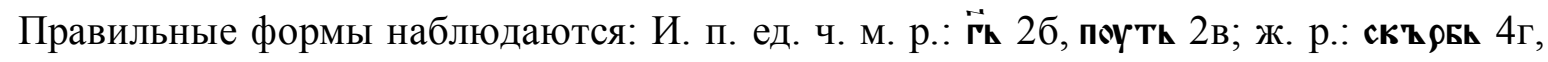
печаль 5в, рАдости 6а, соль 11 a.

В Р. П. ед. ч. М. р. норме соответствуют: съ поути 136б; ж. р.: плт ти, костн, ш̈ рААости

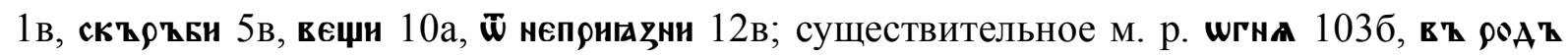
югна 123г получило флексию существительных на *-јо̆-.

В Д. п. ед. ч. м. р. наблюдаются следующие окончания: ґ̈юу 126 (влияние м. р. существительных на *-б-), поути Бӝкю 59в, 115г, 129в.

Несколько примеров В. п. ед. ч., где флексия соответствует нормам

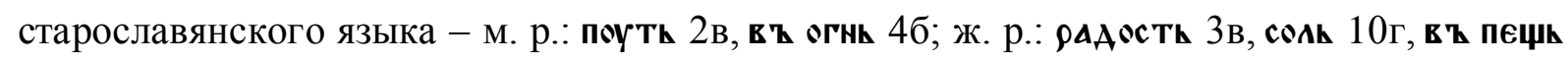
14б. Неправильное написание отмечается: пр қмоудрости 22а (слово стоит в В. П. мн. ч.) такая форма слова отмечается и в старославянском языке, въ сктрби 68в в Зогр. нА

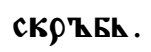

В соответствии со старославянским правописанием используются окончания Т. п.

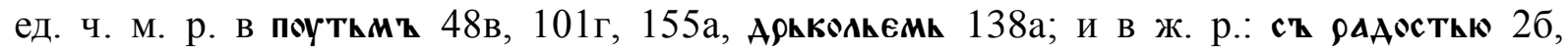
çмиятик 7в, ночhю 8 г.

Не наблюдаются отклонения в следующих парадигмах: М. п. ед. ч. м. р.: нА поүти 11в, 64г, прє поути 46а; Зв. ф. ед. ч. м. р.: г̈н 2 в. 
Правильная флексия И. п. старославянского языка м. р.: гөлоүБнє 18б; ж. р.: өБнтєли 26.

В Р. п. мн. ч. в рукописи прослеживается форма падежного окончания на -нн: запов Қани 130в. В примере слюухты крани 27в флексия существительного ж. р. пишется с одним и (Мар. слоуХһы Бранин).

В Д. п. мн. ч. не наблюдаются изменения, отклонения от норм.

В В. п. мн. ч. кроме единственного случая: трқсти [...] көл қьлемы (Мар. төқсти)

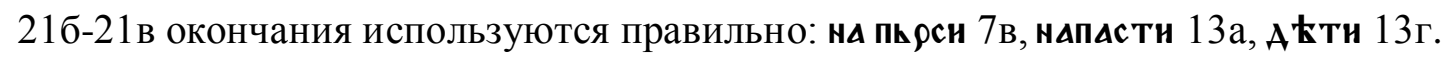

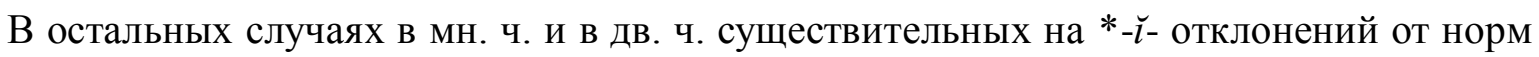
старославянского языка не наблюдается.

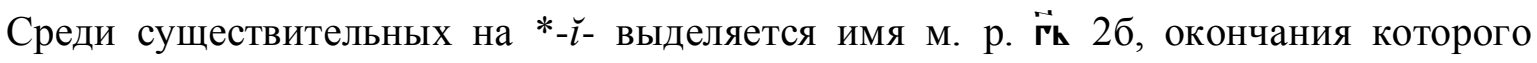

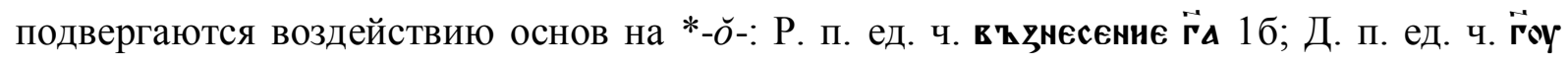
126.

IV.1.5 Имена существительные с основой на согласный и на *-u-

\section{Единственное число}

В И. п. ед. ч. встречаются древние формы: камы 110б, любы 7а, смюкы 46б, свекрұы 103в. Форма В. п. ед. ч. слова: люьы 11г совпадает с И. п. ед. ч.

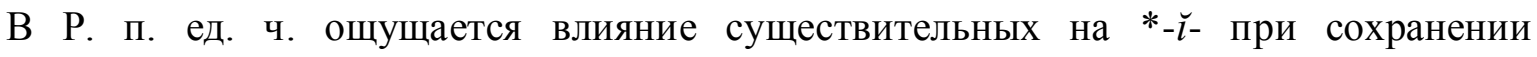
тематического элемента: т Ћлесн 14б, смөкъви 14Г, слөвеси 50б, көрєни (Мар. көрєне) 65а,

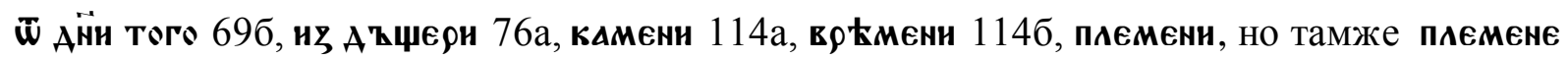
130а, А॰ көнццА нЁсн 133б. Окончание слова н马 очєса 166 происходит из

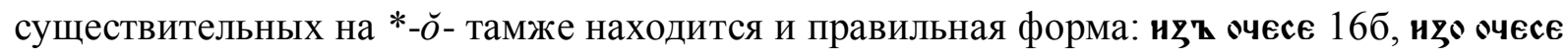
85 г.

В Д. п. ед. ч. форма слова нєбоу 108 а утратила тематический согласный $*_{-}$-s- и приобрела окончание существительных на *-ॅ-.

Существительные, стоящие в Т. п. ед. ч.: сльвоми (4) 23в, 91а, 129в, 157б, өкөмь 43в, Едннtмm wкомқ 124a (происходит мена редуцированных в окончании 
существительного), тћлюми 69в лишились своих тематических основ и склоняются по твердому варианту имен на *-о̆- старославянского языка. В окончании слова имєнкмъ 156 вместо и написан қ. Середина слова слюсємь 8а в рукописи написана невыразительно, но в окончании видна гласная полного образования $\mathbf{\epsilon}$.

Как и в Р. п. ед. ч., так и в М. п. ед. ч. наблюдается сильное влияние

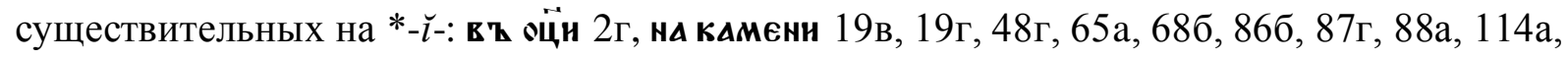

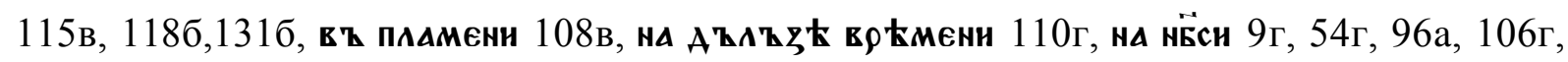
125б, 146а, 146в, о словеси 72г, 125б, нА жрћБати 154а, въ цр̈кви 2б, 46а, 114в, 128а, 136б, 138б, 142в, 143б, на смокви 104б. Существительные с основой на согласный также попадают под влияние существительных на *-ॅ-, причем в некоторых случаях

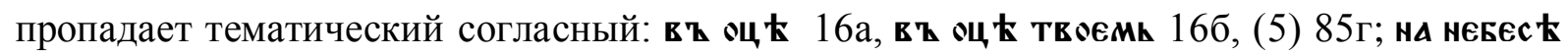
49в, о словес қ 50в.

\section{Множественное число}

В мн. ч. существительных с основой на согласный и далее продолжается влияние

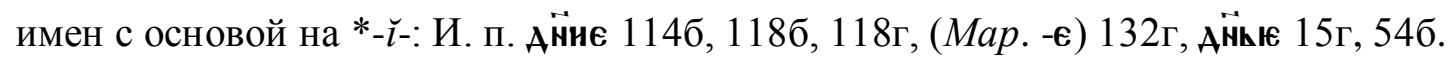

В Р. П. мн. ч. в окончании имени вис $\mathbf{k} \mathbf{z} \mathbf{c} \mathbf{k} \mathbf{k} \mathbf{k n z} 25$ в, возможно, произошло смешение $\boldsymbol{\epsilon} \sim \mathbf{t}$. Существительное с основой на согласный *-en- м. р. в Р. п. мн. ч.: Ан̈нн·57в, 109в, 133а совсем лишается своего истинного окончания под влиянием имен с

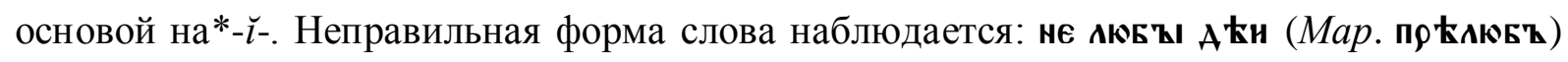
$125 \mathrm{a}$.

В Д. п. мн. ч. в окончании слова тłлєсєм қ 14 а наблюдается прояснение и в гласную полного образования.

В рукописи существует интересная форма существительного с. р. слюво в В. П. мн. ч.: сльв \ا 144в, используется без тематического элемента *-es- с окончанием имен с

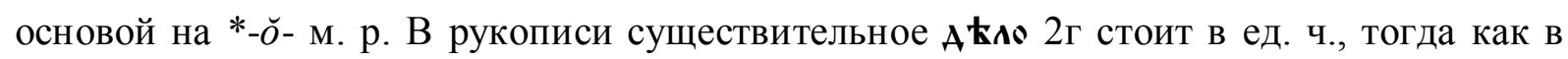
Мар. принимает форму мн. ч. с окончанием -А.

В Т. П. мн. ч.: сльвєсқы 6в, где тематический элемент сохраняется, окончание же относится к именам с основой на *-o-. 
Вокализация редуцированного переднего ряда происходит в окончаниях М. п. мн.

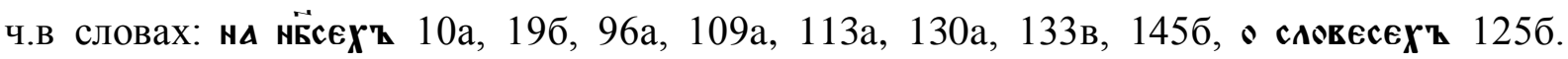

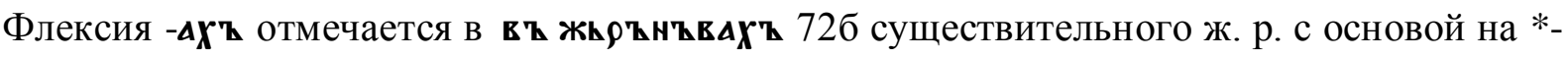
$\bar{u}$ - (старославянская форма жркны, древнерусская жєрны Преображенский 1910-1914: 230).

\section{Двойственное число}

В Р. М. П. дв. ч. слово өчню 56a, 114б, 128г имеет форму существительных на *-ц-.

Бодуэн де Куртенэ распределяет изменения в развитии типов склонения на три периода. Первый период, уже упомянутый в начале раздела, характеризуется слиянием тематического элемента с флексией. Второй период - «период распределения склонения по родословным различиям, свойственным почти всем нынешним языкам славянским» [Бодуэн де Куртенэ 1902: 247] - такого мнения придерживается Селищев [1951: 93]. Третий период не имеет отношения к развитию русского языка, характеризует морфологические явления связанные с болгарским языком. $M m E$ дает возможность для изучения второго периода, который длился до XVIII в. (X. Тот 1962: 6). Анализ падежных окончаний существительных $M m E$ - безусловное доказательство общего процесса перераспределения окончаний у существительных с учетом родовой принадлежности.

К первым выработанным и установившимся нормам правописания церковнокнижного языка восточных славян относится окончание существительных с основой на

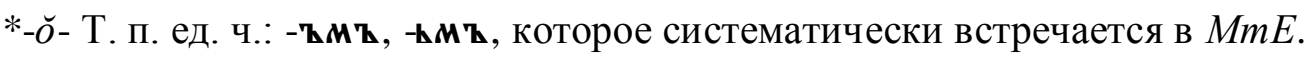

Древнерусское окончание -\$ проявляет себя в существительных ж. р. мягкого варианта в Р. п. ед. ч., И. и В. п. мн. ч.. В этих же падежах в рукописи имеются примеры гибридного написания окончаний через -г (-4). Эти и другие морфологические явления составляют древнерусскую редакцию старославянского языка $\mathrm{MmE}$.

В главе «Введение» уже упоминалось, что русизмы проникающие в старославянские рукописи, распределяются в частях речи неравномерно. По сравнению с количеством фонетических явлений древненовгородского диалекта наблюдаемых в рукописи, среди падежных окончаний (кроме ненадежных примеров существительных с основой на *-о̆И. п. ед. ч.) влияние диалекта не ощущается. 


\section{IV.2. Имя прилагательное}

\section{IV.2.1 Положительная степень}

В $M m E$ встречаются две формы прилагательного: краткая (именная) и полная (местоименная).

Кроме некоторых отклонений от старославянской грамматики, наблюдаемых в рукописи, краткие прилагательные используются в основном правильно. В М. п. ед. ч.

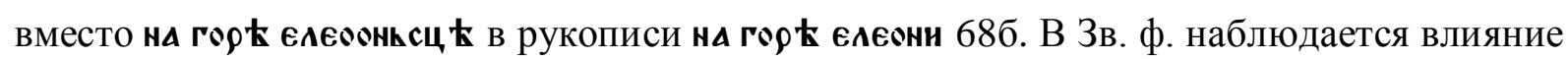

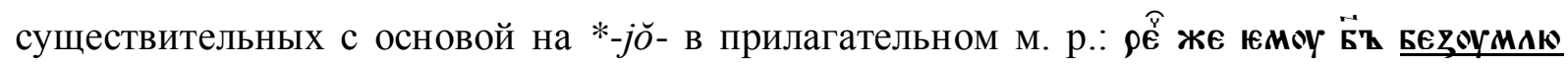
102г, 105в (Мар. Безоүмьне, Саввина кн. -млю). В И. П. М. р. МН. Ч. Ан̈не скърбь 132Г

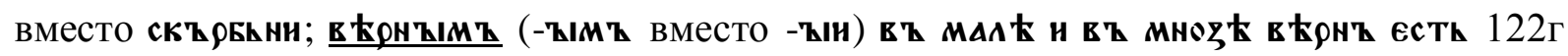
(Мар., Зогр. в қрқны) предполагается, что это описка. В В. п. м. р. мн. ч. старицы Жндов.ска (Мар. -ұы) 90г. В рукописи в примере Аомы вьАовнца 51в употребляется

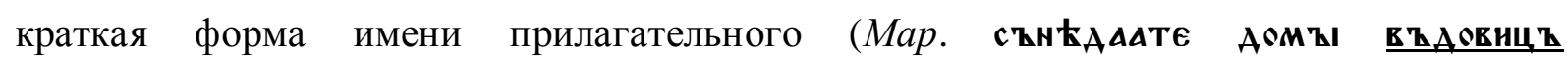
существительное В. П. Мн. Ч. Ж. р., вьАовицА Kurz 1958: 362-364; Буд. Аомови в' АовичА, въдовични прилагательное, Срезневский 1893: 332), в прилагательном отмечается древненовгородское смешение ч ц.

\section{Единственное число}

Полные прилагательные выступают в рукописи широкой палитрой в виде стяженных и нестяженных форм.

В словосочетании Аш̈є нєчнстқи 66г, нћмқи глоухъи Аш̈є 149 наблюдается несогласование (по роду) окончаний между существительным Зв. ф. ед. ч. ж. р. с формой прилагательного И. п. ед. ч. м. р. Окончаниями прилагательных в Зв. ф.

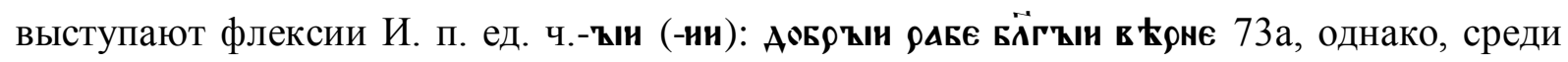
прилагательных имеется пример с окончанием на -є. Местоименные прилагательные ж.

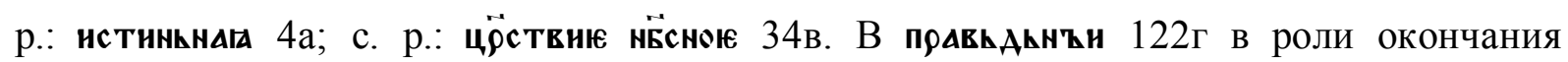
выступает - $\mathbf{~ н . ~}$

В Р. п. м. р. находим примеры «переходного» стяженного варианта полной формы

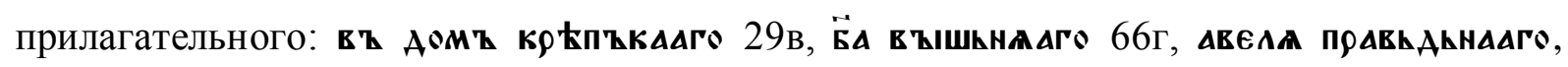

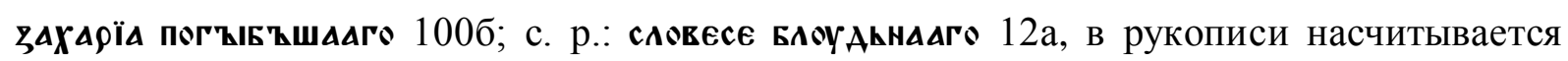


примерно 13 такого вида окончаний, и 18 примеров (в том числе окончания и В. п., но

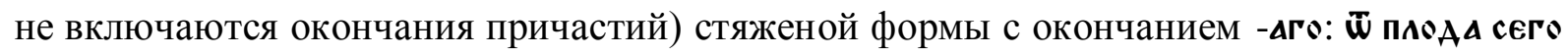

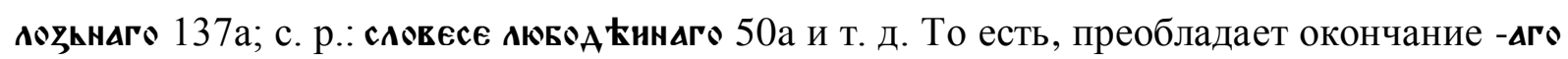
стяженной формы. Но не найдено ни единого примера с -sге, соответствующего

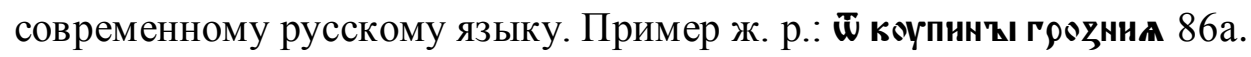

В Д. п. ед. ч. м. р. происходит окончательное стяжение полной формы: црествню нЁсноумоу 35а, такая форма употребляется чаще чем с -оуоүмоу: моукАв оуоумоу $30 б$, в ћцкноуоумоу соудоу 62б. В прилагательных ж. р. наблюдается стяжение: АкБрн өгнкнћ 51г (вместо - -ћи).

В В. П. м. р. (окончание Р. п.) в прилагательном нскрьна дго своюго 12г полустяженная

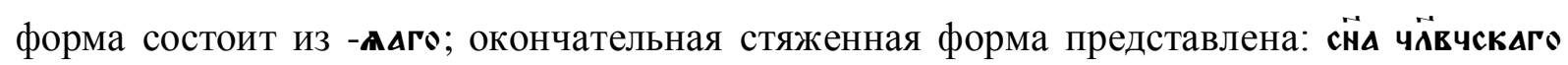

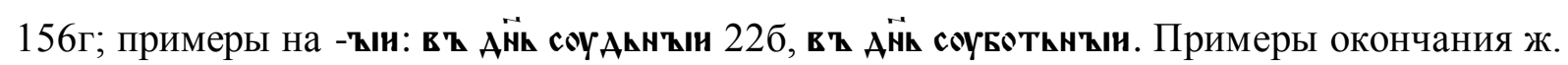
р.: шююю 141б, 150в. В с. р.: въ цёьство некс̈ьнеє 56г вместо ө написана буква є, окончание мягкого варианта.

В стяженном виде полные прилагательные, основа которых оканчивается на твердый

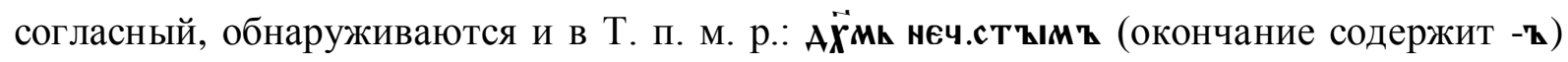

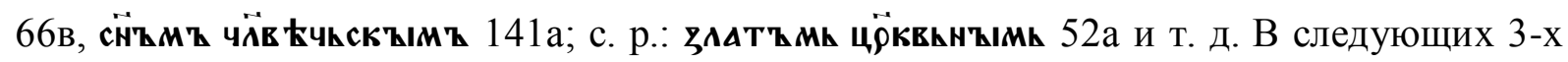

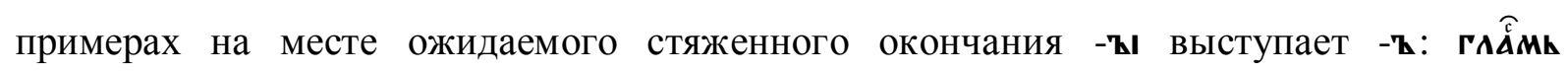

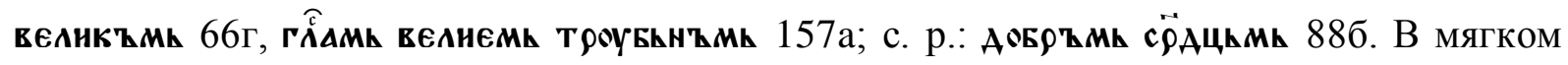
варианте притяжательного прилагательного м. р. полная форма сохраняется: $а \ddot{\boldsymbol{X}} \mathbf{м и}$ Бӝнємь 29б, 29в, прћстоломи ьӝнюмь·159б (вместо -ннмь). По мнению Шахматова, «возможно, что это старое окончание, не вытесненное еще через -ьjb'mь под влиянием

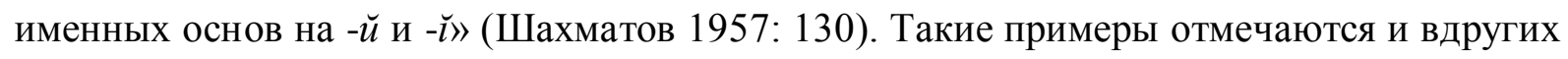
древнерусских рукописях (Новгородская первая летопись) (Шахматов: 1957: 129). В ж. р. отклонения не наблюдаются: рАдосткю вєлнкюю 26 и т. д.

В М. п. находим стяженные формы полных прилагательных в м. p.: въ

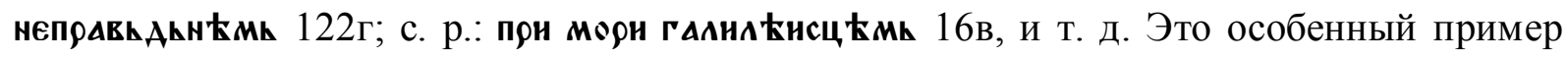
формы притяжательного прилагательного, где окончание состоит из -ъм (части 
стяженного варианта флексии полной формы прилагательного) и $\mathbf{\mathbf { n }}$ именного

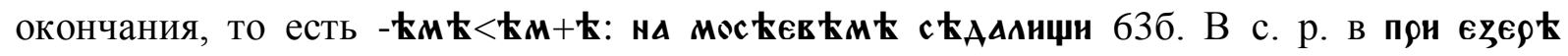
геннсдретьсцен 786 наблюдается окончание ж. p. -łн, с таким окончанием словосочетание встречается и в старославянском языке.

\section{Множественное число}

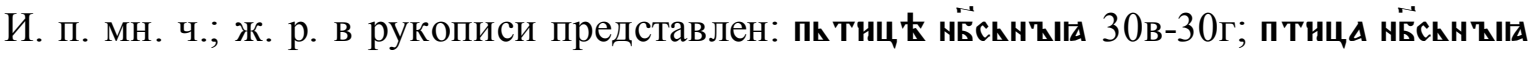
116а и т. Д. В с. р. находим: көл Łно земьскАА 156г (падежное окончание существительного неправильно).

В Р. п. мн. ч. повторяется явление стяжения флексии полной формы

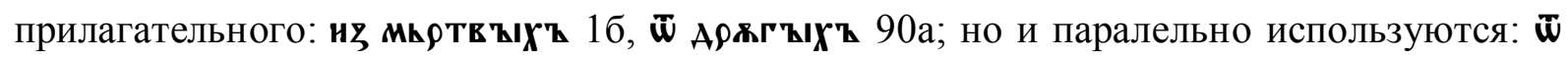

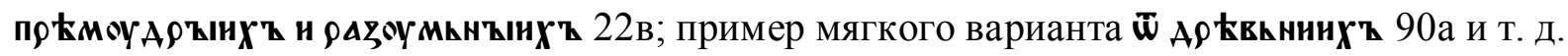

Пример стяженной формы в Д. П.: къ өвццмъ погыбқшнмъ 17в; и нестяженой

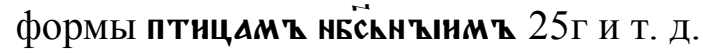

Примеры полных форм, соответствующие старославянскому написанию в В. П. (к

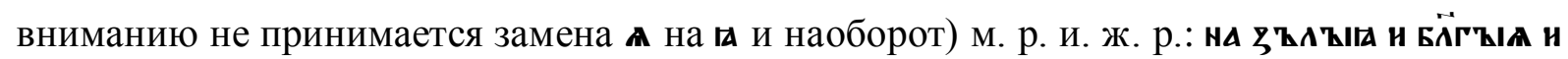

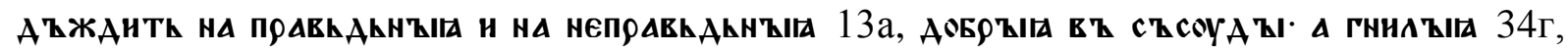

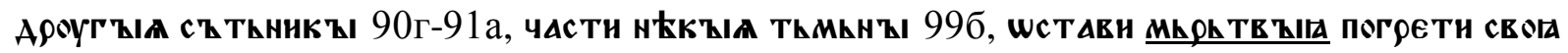

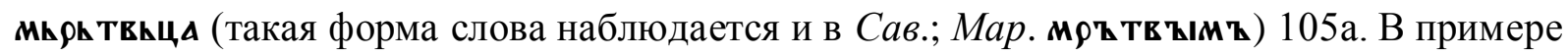
в окристинаға всн и селА $90 б$ употребляется правильное окончание мягкого варианта (окристинь Стоянов 1972: 163) прилагательного (старославянское окончание мягкого

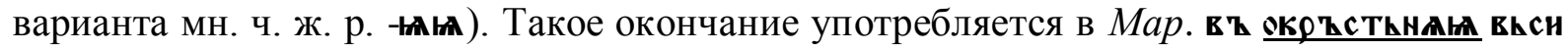

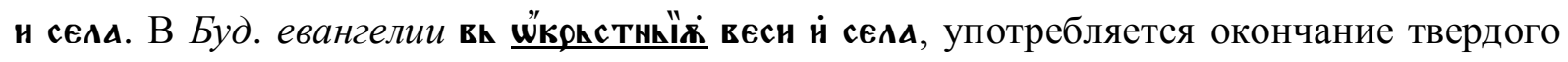
варианта.

Нестяженная форма окончания Т. п. мн. ч. -ұимн в рукописи не встречается.

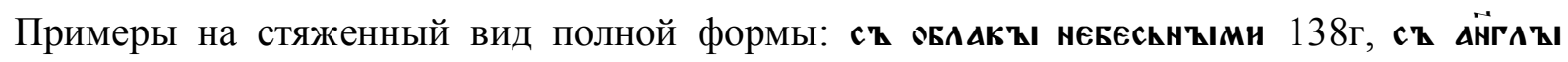

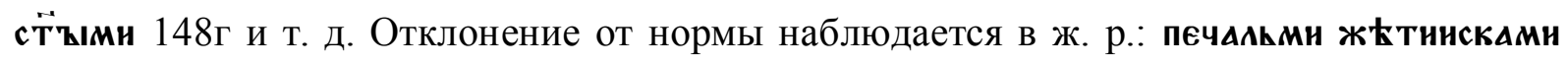
$141 \mathrm{a}$, вероятно влияние существительных ж. р. Но возможно, эта флексия каким-то образом связана с древненовгородским диалектом. В берестяных грамотах в Т. п. мн. ч. 
имеются примеры только на -ұммн, но в Д. п. ед. ч. имеются два окончания на -дмоу. По мнению Зализняка, «мы имеем здесь дело либо с некоей орфографической условностью, либо с морфологическим влиянием формы Р. ед. (-аго) на Д. ед.». Исследование также дополняет, что эта проблема разрешима только после накопления большего материала (Зализняк 2004: 120-121).

В М. п. в стяженном виде полной формы прилагательных имеем: нА өБлАц $\mathbf{x} \mathbf{z}$

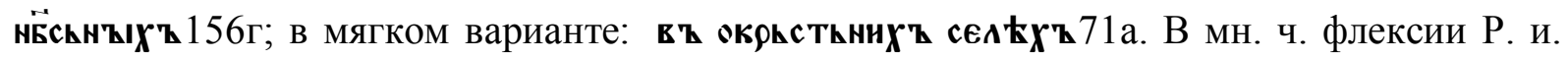
М. п. совпадают. При подсчитывании стяженных и нестяженных форм в этих

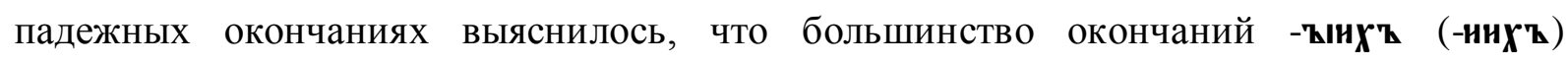

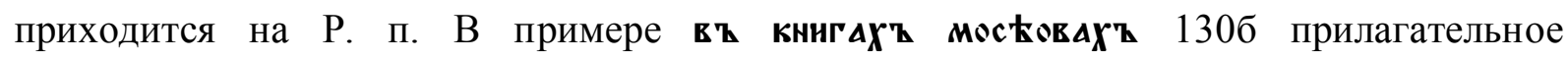
подвергается влиянию существительного с основой на *-̄̄- ж. р. мн. ч.

\section{Двойственное число}

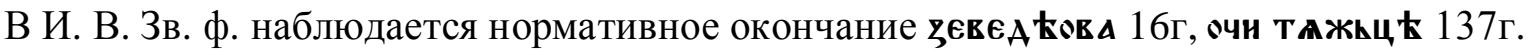

\section{IV.2.2 Средняя степень}

В рукописи находим прилагательные сравнительной степени, которые делятся на полные и неполные. В этом разделе приводим несколько примеров.

\section{Единственное число}

Пример окончаний И. п. краткой и самой распространенной формы прилагательного

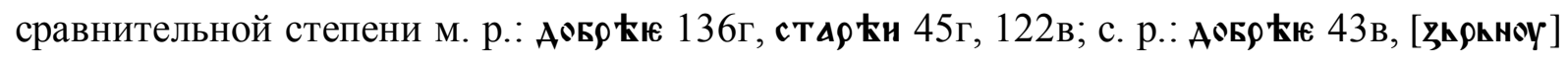
Боле, мине 65Г, множаң 99а; Ж. р.: горьши АнрА 15Г, Аш̈А Ан Больши 14а и т. Д.

В рукописи представленны краткий тип на -нн [Вайан 1952: 162] м. р.: вөлнн 3г, вөлн

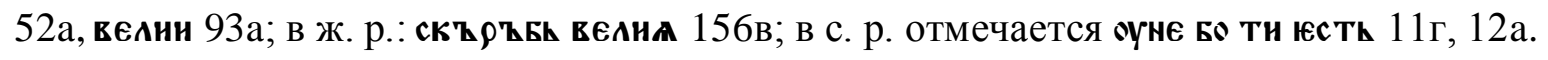

Правильная краткая форма сравнительной степени Р. п. м. р. употребляется в м. р.: чӥвка того гериша $30 б$.

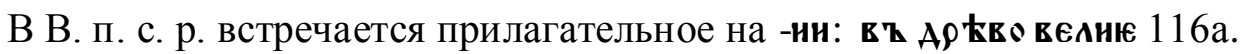

В Т. п. наблюдаются правильные окончания кратких форм прилагательного м. р. в

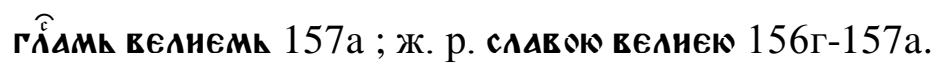


В И. п. м. р. краткие прилагательные сравнительной степени употребляются в следующих формах: чнсте 4а, лоүчьше 14a, 19б, оүньше 100г-101a, множАїше 153a, сн̈ве в ККА сеГО МоУА९ Кнше 107Г; Больше 131Г и т. Д.

В Р. п. наблюдается аномалия в краткой форме, прилагательное сравнительной

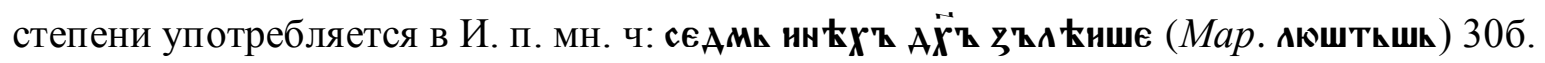

В В. п. м. р. в рукописи зафиксированы следующие примеры краткой формы

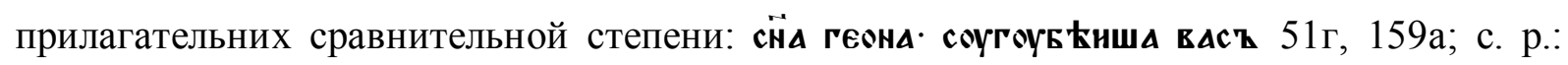

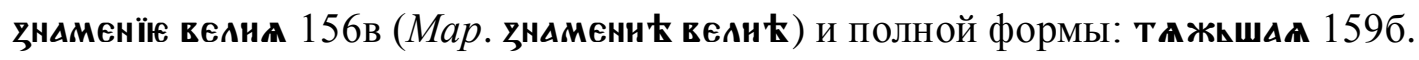

В Т. п. употребляется стяженный вариант полной формы сравнительной степени в ед. ч. миньшнм з 89б, вместо формы мн. ч. (Мар. миньшими).

В примере нъ пАч. нагорцше прншид ъши 69а возможен вариант превосходной степени прилагательного.

Из анализа проведенного в системе склонений прилагательных, отмеченых в $M m E$, ясно прослеживается процесс стяжения (упрощения) падежных окончаний полных прилагательных. Примеры берестяных грамот того времени свидетельствуют об употреблении полных причастий в стяженном виде «в ранних берестяных грамотах засвидетельствовано только окончание -аго» [Зализняк 2004: 120], что, безусловно, имело влияние на работу переписчика. $M m E$ сохраняет то состояние языка, когда образуются стяженные формы, но без гласного элемента $о$. Самый ранний пример окончания -ого Р. п. ед. ч. в берестяных грамотах находим в 20 -е - 60-е гг. XIII в., и только с XIV - XV вв. употребляется -ому в Д. п. ед. ч. (Зализняк 2004: 120-121). 


\section{IV.3 Местоимение}

\section{IV.3.1 Личные местоимения}

1-е л. ед. ч. Местоимение 1-го л. в $M m E$ употребляется соответственно нормам старославянского языка, отклонение налюдается лишь в Р. п.

В И. п. нет изменений: $\Delta \xi \mathbf{z} 1 \mathrm{a}$.

В Р. п. кроме правильной формы мєне 2г отмечаются и формы, где пропущен

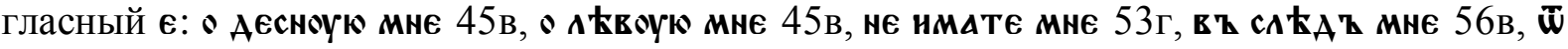
мне 74в, послоушанте мне 75a, мё 106а (в этом случае точно не возможно определить, какая по счету буква є выпадает). По материалам исследования берестяных грамот, проведенного Зализняком, такой формы личного местоимения он не фиксирует (Зализняк 2004: 130-131). Однако Мещерский, который занимался вопросами по русской диалектологии, отмечает: «Для северновеликорусского наречия характерная форма Р-В меня, тебя, себя, варьирующаяся в частных диалектных системах: миня, тибя, сибя (отмечено в части поморских, псковских и нек. др.); мене, тебе, себе (отмечено в части архаических архангельских говоров); в конструкциях с предлогом возможны формы: $y$ мня, $y$ mя, y ся (в значении вин. п. эти краткие формы не отмечены)» (Мещерский 1972: 171). У Елкиной находим, что форма мнє часто встречается в Синайской псалтири и особенно в Синайском требнике, то есть в рукописях старославянского языка. «Предполагают, что эта форма была получена из моравского языка» (Елкина 1960: 136). Интересно, что пропуск буквы є (буквенное окружение тождественно ряду графем, встречаемому в местоимении 1 - го л. Р. п. ед. ч.) отмечается в существительном сқмне 62г, что, на мой взгляд, неслучайно.

В Д. п. отклонений не наблюдается. В форме местоимения мнł 3a (3), 3б (2), 6г, 8а, 33г, 40г, 43г, 44a, 41г, 45в, 48a, 69в, 76б, 80a, 86a, 95a, 95б, 96б, 98a, 106a, 111a, 141г, 149б, 154г пропущен к.. В рукописи также правильно представлена энклитическая форма ГӒАн мн 15 a.

В В. П. употребляется полуэнклитическая форма: кого ма чєлюв Łци гӥти Бътти 148Г.

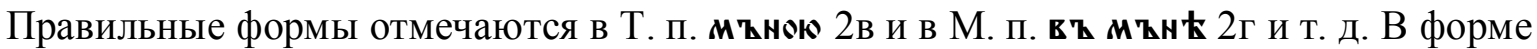
М. п., как и в Д. п. (совпадение форм) наблюдается выпадение к: нА мнћ 2г (2), 80в; по 
мнћ 7г, 9а, 13в, 24а, 92в, 111в, 112г, 120в, 121г, 134а, 137а, 148в; в ти мнъ 3г, 4б (4), 6б, $6 \Gamma$

2-е л. ед. ч. Местоимение 2-го л. на протяжении всей рукописи используется правильно. Особого объяснения требуют формы Д. и. М. п.

В Д. п. и М. п., где отмечается синкретизм падежных окончаний, встречаются три различные по происхождению формы местоимения 2-го л. Наиболее распространенной формой, употребляемой в рукописи является: тєєє Збв (65), где происходит смешение є c $\mathbf{k}$, соответственно нормам книжноцерковного произношения. В окончаниях местоимений происходит то же явление, что и в праславянских *tert, *telt. Старославянская форма, вторая по употребляемости: тєк 7 (16), которую, по мнению Шахматова, восточные славяне не знали. Формы живой речи восточных славян, то есть древнерусского языка представлены лишь двумя примерами: төк 226 (2) (Баймут 1957: 99; Шахматов 1957: 159; Селищев 1951: 266).

1-е л. мн. ч. В употреблении 1-го л. мн. ч. в рукописи не наблюдаются какие-либо отклонения от старославянского языка. И. п. мұ 3б; Р. п. моүчнтъ насъ 28б; Д. п. намұ 2г; В. П. нъы 15в; Т. П. намн 45в; М. П. насъ 6в и т. Д.

2-е л. мн. ч. В рукописи не наблюдаются отклонения в использовании местоимения

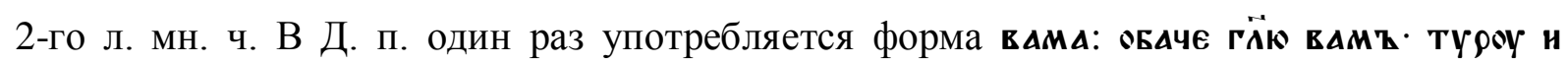

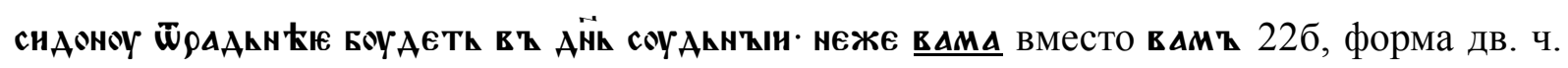
Местоимения, возможно, произошла под влиянием числа городов (2), упоминающихся в тексте. Использование окончания дв. ч. Т. п. -дмд на месте -дми (что привело к

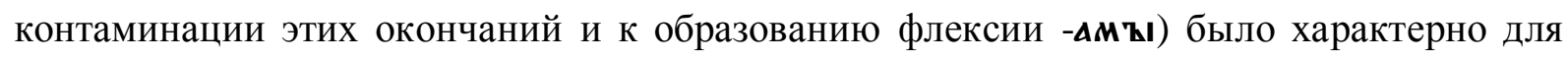
отдельных северо-западных говорах, а также для Псковщины и вдоль границ с белорусским языком (Горшкова 1981: 201). Возможно, это явление диалекта тоже имело влияние на написание формы в мх. Соответственно нормам старославянского языка в рукописи употребляются следующие формы местоимения - И. п.: в қы 2а, 107г;

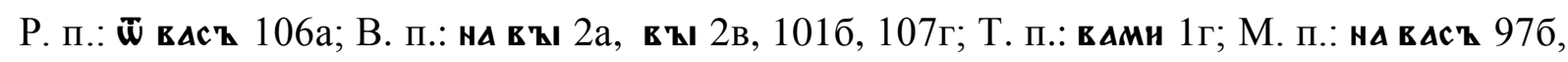
1016 и т. д. Формы мн. ч. 1-го и 2-го лица (кроме энклитических) сохранились (в полных формах этих местоимений произошли лишь фонетические изменения - падение редуцированных) во всех восточнославянских языках (Баймут 1967: 99). 
1-е л. дв. ч. В дв. ч. отмечаются следующие формы личного местоимения: Р. М. п.: наю 56а; Д. Т. П.: нама 150в.

2-е л. Дв. ч. В И. В. П. один раз употребляется въы 16г вместо ва. В Р. М. п. в хю 36а, 94б; Д. Т. п.: вам А 94б, 135г, 136а, 142а (2), 150в и т. д.

\section{IV.3.2 Возвратное местоимение}

В возвратном местоимении неправильное окончание наблюдается в форме Р. п. сєь 123а вместо правильного секе.

В Д. и М. П. употребляются три формы возвратного местоимения: сєьє 2в (29), сєь $\mathbf{E}$ $2 \Gamma$ (36), cos $\mathbf{2} 27 \mathrm{a}, 316,396,160 б$ (4), которые по присходжению идентичны происхождению форм личного местоимения 2-го л. ед. ч. в этих же падежах (IV.3.1). Интересно, что в возвратном местоимении формы старославянского языка преобладают над двумя другими.

В В. п. наблюдается неправильная форма сєьћ 130в вместо сєье.

\section{IV.3.3 Указательные местоимения}

В $M m E$ сохраняются все три вида указательных местоимений: м. p. ск 3г (использовалось для указания на ближайшие предметы); м. p. тқ 2г (для безотносительного указания) ; с. р.мно в (Горшкова 1981: 262; Иванов 1964: 332). В памятниках ХІІІ-го в. уже отмечаются случаи удвоенной формы местоимения тъ. В рукописи такие формы (это относится и к мягкому варианту ск) не употребляются. Возможно, что здесь играет роль и географическое место образования формы тот, так как удвоенная форма диалектного происхождения, а точнее распространилась из Ростово-Суздальской земли [Горшкова 1981: 260], тогда когда $M m E$ принадлежит к древненовгородскому диалекту. В рукописи не только не употребляются формы, характерные современному русскому языку (вышеупомянутые), но также не употребляется древнерусское -t [Бевзенко 1978: 149] в окончаниях ж. р. ед. ч. Р. п. и мн. ч. И. и В. падежей местоимения ск. В этих падежах отмечается только старославянская флексия -А (-ға). Неправильное написание форм указательных местоимений носит, в основном, случайный характер. 


\section{Единственное число}

В И. п. употребляются следующие указательные местоимения в м. p.: тъ 2 г, ск $3 г$; ж.

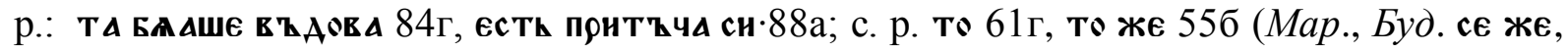
Ocтр. тө жє) и т. д. В данном примере указательное местоимение м. р. тъ пишется через в: и то како юс.. с̈̈н ємоу 69а. В с. р. отмечается неправильное употребление

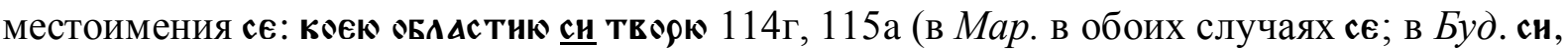
сє), возможно, влияние существительного ж. р. В рукописи употребляется тө 55б, тогда когда в Мар. в этом месте текста стоит местоимение сє.

В Р. п. формы указательных местоимений в м. и с. р. пишутся правильно: того100г, 103а и. т. д. В ж. р. этого падежа в рукописи не отмечается флексия древнерусского

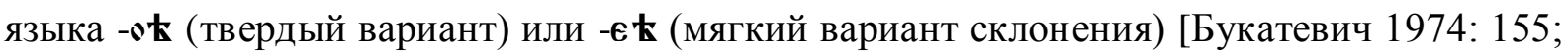
Иванов 1964: 331; Медведєв 1964: 171] употребляется старославянская форма: А॰ сєА c⿱乛龰⿱⺈ $\mathbf{T} \mathbf{k} 77$.

В Д. п. отклонений от норм старославянского языка не наблюдается: м. p. сємоу 2a; Ж. р.: горћ сен 47Г, Ходмннћ тон 86 и т. д.

Правильно используются формы В. П. Ж. р.: оБлАсти сню 114г; с. р.: въ оно веึћ1б и т. д.

В Т. п. происходит смешение редуцированных в следующих примерах м. р.: поүтьм қ тћмъ 101г, 103а. В рукописи вместо указательного местоимения өнћмқ 32а

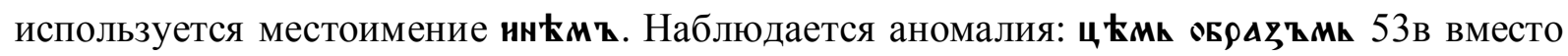
тłми (употребляется форма вопросительно-относительного местоимения).

В М. п. м. и с. р. флексия пишется правильно: по төмк 110б, въ грАА t төмк 110г и т. д. В этом падежном окончании имеются два примера мены редуцированных: по том қ 65a, 88a. В ж. р. также не наблюдается отклонений от нормы ө гөдннћ тон 72a, нА странћ тон 134 г и т. д. 
Множественное число

Несколько правильных примеров И. п. м. р.: өнн 1в, ти За, сн рєчє 151в, сн көрєнє 886

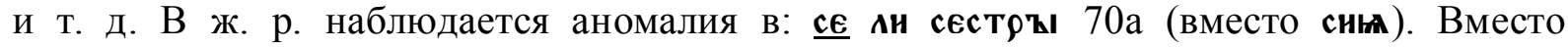

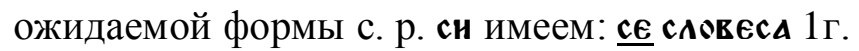

Формы Р. П. и М. П. (окончания трех родов совпадают) соответствуют норме грамматики старославянского языка: т $\mathbf{k} \mathbf{x} \mathbf{z} 36$.

В В. п. наблюдается совпадение окончаний указательного местоимения мягкой группы сь (как уже не раз упоминалось, в следствие утраты носовых): м. р. гйł сиг 86в,

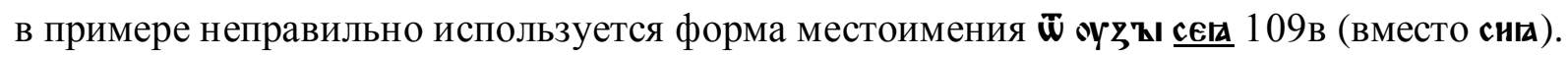

В Т. п. наблюдается правильная форма мягкого варианта указательного местоимения: снмн 91г.

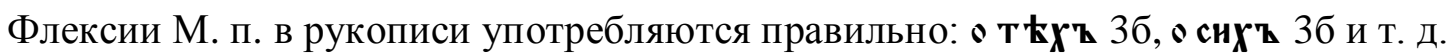

\section{Двойственное число}

В И. В. п. м. р. отмечаются следующие примеры на твердую группу указательных местоимений: өнА 16г (2), тА 57в и т. д. Правильная форма мягкого варианта

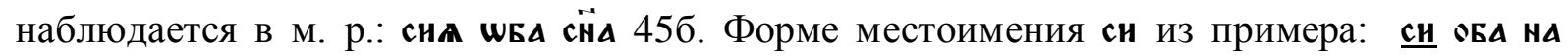
Аєса тє 17в возможно два объяснения: а) это старославянская форма м. р. мн. ч.; б) это форма дв. ч. древнерусского языка (по материалам [Бевзенко 1978: 149; Иванов 1964: 331-332]).

Отклонение от нормы отмечается в Р. М. П. ви ск шбюю запев переписчик употребляет стяженную форму.

В рукописи отмечается пример Д. Т. п. на твердый вариант: тұм凶 36а и т. д.

\section{IV.3.4 Анафорическое и относительное местоимения}

\section{Единственное число}

В И. п., независимо от категории числа, анафорическое местоимение 3-го лица не имеет своей формы. Формы И. п. имеет относительное местоимение, которое отличается от анафорического частицей -жє (Вайан 1952: 173; Елкина 1960: 137). В остальных парадигмах флексии обоих местоимений совпадают. 
В И. П. употребляется єжє вместо нжє в следующем примере: єжє 7в в внА

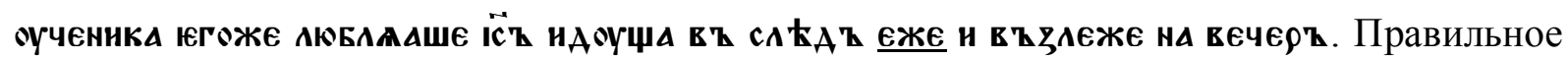

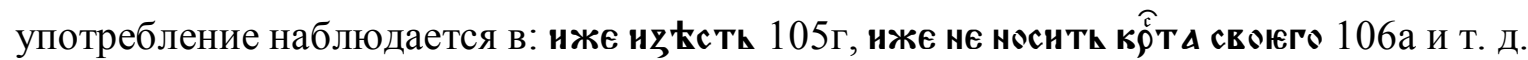

В Р. п. один раз отмечается усеченная форма м. р. є 756 без -ге. В остальных случаях формы м. и с. р. Р. п. употредляются правильно юго 1а, єгожє 23а; ж. р.: єА 151б, 153г, ЄАพЕ 75 Г.

В Д. п. формы местоимений, кроме одного случая (употребляется форма личного местоимения Д. П. мн. ч. в $\mathbf{\Delta M \mathbf { z }} 256$ вместо анафорического ед. ч. (Мар. ємоу), используются правильно: ємж 1б, ємж 69б, вамъ (Мар. ємоу ) 25б; ж. .р.: къ нєи 46а и т. д.

Формы анафорического (относительного) местоимения в В. п. выглядят следующим

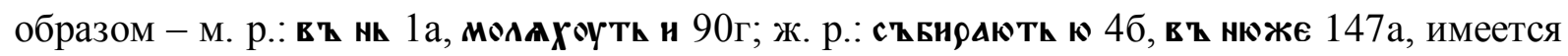
форма оу 38 а вместо к; с. р.: зА сльво єжє 4а и т. Д. В В. П. м. р. используется єжє вместо правильной формы нжє - єжє 62Г в падє нА кАмєнь єжє. Такое неправильное употребление этих форм (в И. п. тоже наблюдается мена нжє єжє) характерно уже и для старославянских рукописей. В народном языке утверждалась тенденция к использованию вопросительного местоимения кұн на месте данной формы относительного местоимения. В церковном языке форму нжє продолжали использовать, несмотря на исскуственность конструкций (Вайан 1952: 174).

В Т. п. кроме правильной формы: имь 16а, нмьже 136г употребляется имъ 159б, где наблюдается мена редуцированных, в ж. р. наблюдается форма: єю сқмиртью 7в и т. д.

Формы М. П. м. р.: о неми 1а, вт неми 4б; ж. р.: о нен 9в, на нен 46а используются правильно.

\section{Множественное число}

Приводим несколько форм относительного местоимения, наблюдаемых в рукописи в

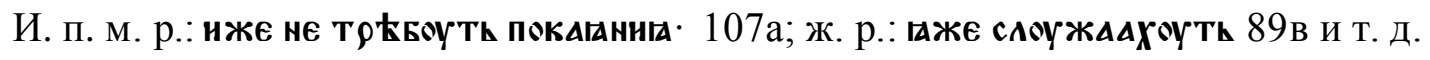

В использовании флексии Р. п. нхъ 1б, ש्w ннхz 1386 нет отклонений.

В Д. п. наблюдается нормативная форма: нмқ 1 б, къ ннм 80 г. 
В силу особенностей графической системы древнерусского языка в В. п. мн. ч. флексии по родам совпадают. Правильное использование форм местоимения в В. п. м.

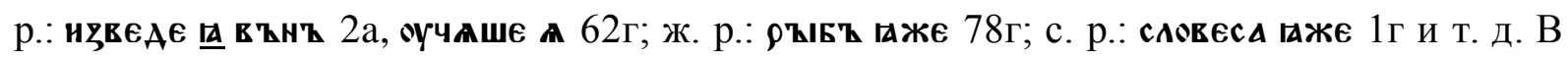

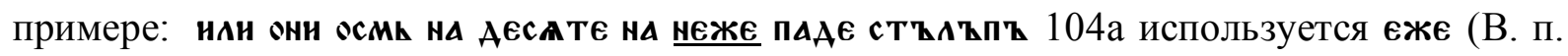
еД. Ч. с. р.) вместо аже (паже) (Мар. на наже). Вместо союза пко (Мар., Буд. пако) в рукописи фиксируется форма местоимения ґжє За.

Формы Т. п. употребляются соответственно старославянским грамматическим нормам: ннми 1г, нмн 45в и. т. д. Один раз отмечается написание съ ннмк 90г вместо правильного ннмн.

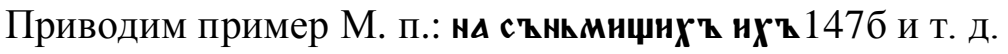

\section{Двойственное число}

Некоторые примеры дв. ч., соответствующие нормам старославянского языка в И. В. П.: паже БаАста 78г; Р. М. П.: ๒上 16г; Д. Т. П.: имА 16в и т. Д.

\section{IV.3.5 Притяжательные и притяжательное возвратное местоимения}

Притяжательные местоимения в рукописи употребляются правильно, соответственно старославянской грамматической норме. Древнерусские окончания -њ $\mathbf{E}$ ж. р. в Р. П. ед. ч. и -Ł в И. В. П. мн. ч. не отмечаются в $M m E$ (Иванов 1964: 335). Приведем несколько примеров из $M m E$.

\section{Единственное число}

Правильные формы отмечаются в И. П. м. р.: өц̆ мон 4а; ж. р.: мол, твол 3б; Р. п.

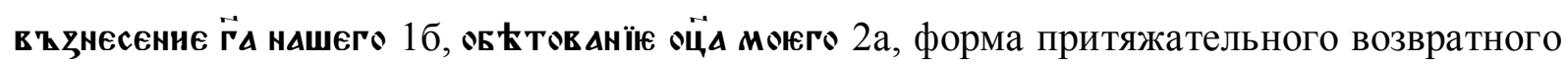

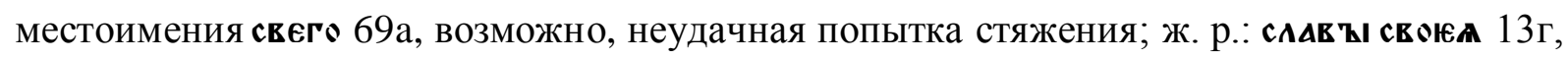

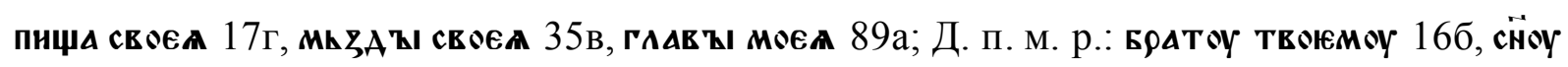

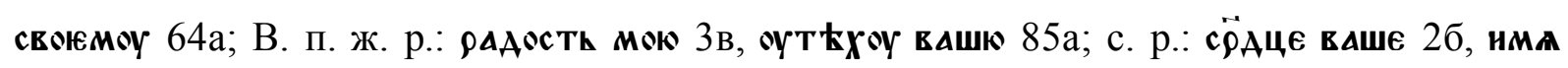

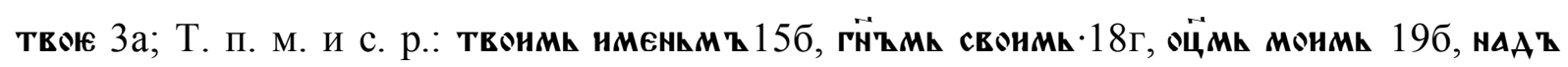
оучїтелємъ свонмъ 85 г происходит характерная мена редуцированных; М. п. м. и с. р.:

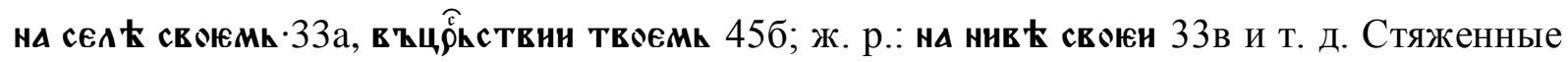


формы, представленные Вайаном в ж. р. Р. п.: мюж и т. д., Д. М. п.: твө и т. д., Т. п.: мож; М. П. дв.: мюю; м. р. М. П. ед. ч.: мюмт [Вайан 1952: 178] в рукописи не наблюдаются.

Множественное число

В рукописи употребляются следующие правильные формы в И. п. м. и с. р.: твон

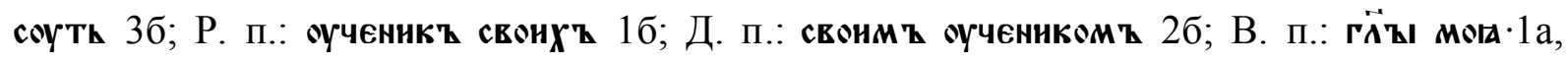

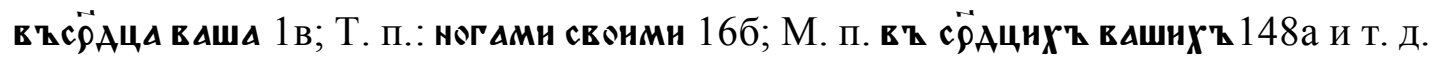

\section{Двойственное число}

В дв. ч. встречаются следующие формы притяжательных местоимений в И. В. п. м.

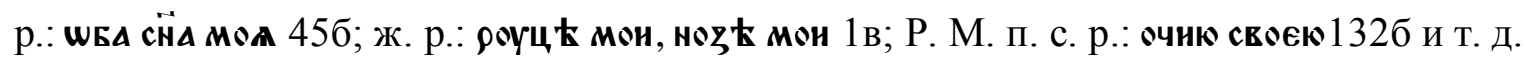

Такое последовательное правильное употребление притяжательных местоимений объясняется еще и тем, что в современный русский язык формы этих местоимений вошли из древнерусского, не подвергаясь каким-то масштабным фонетическим изменениям (утрата дв. ч., которое морфологическое явление) (Иванов 1966: 335).

IV.3.6 Вопросительно-относительные и отрицательные местоимения

Местоимения ктө 1 , чктө 16 используются в рукописи соответственно нормам старославянского языка. Отклонения, наблюдаемые в этих вопросительных местоимениях, не затрагивают окончаний, и в основном сводятся к проблеме употребления редуцированных. Ед. ч. И. п.: ктө 1а, чк тө $1 б$.

Примеры форм Р. п.: көго 100г, чсо қсти 71a, чксо 153г (чесо, чкго, чго такие формы местоимения не наблюдаются в $\mathrm{MmE}$ ). В рукописи употребляется только форма чксо (чс⿰) (это характерно и для отрицательных и неопределенных местоимений), но отсутствуют формы: чксего, чесего.

В Д. п. употребляются следующие формы местоимений: көмюу 21г, чємюу 25в. Такая форма «встречается и в старославянских письменных памятниках» (Балаж 2003: 63). Формы чесомоу, чксомоу и т. д. не наблюдаются в рукописи.

В В. п. употребляются правильные формы: көго 92б, нмате ян чите ұсти1в. 
В Т. п. употребляются следующие формы: чнмк 29б; чнмъ 14в, 21a, 124a, 126г. В этом падежном окончании мена редуцированных не новое явление, это фонологическое явление наблюдалось и в именах существительных.

В М. п. форма местоимения представлена примером: в т чємъ 134a, где в окончании наблюдается мена редуцированных гласных.

Приведем несколько примеров отрицательных местоимений, употребляющихся в рукописи: И. П.: никтө 2в, ннктө (в Мар. кто) 20г, никтожи 105а вместо є имеем к; Р. П.: ннчисоже 3 г, ннчьсо 1546 ; Д. П.: ннкомоуже $147 \mathrm{~B}$, ннчемоуже $11 \mathrm{a}$; В. п.: никогоже 75 г; Т. П.: ничнмьже 47б; М. П.: нн о коми же 59в.

С правильной формой неопределенного местоимения встречаемся в В. п.: нtкøго $122 \mathrm{~B}$.

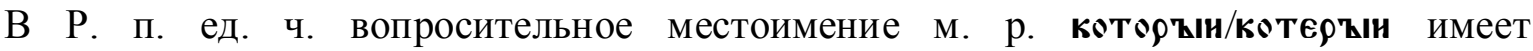
нестяженную форму окончания: көтєрАьго 49б. В Т. п. повторяется смешение редуцированных: көлнц кмъ 107в.

Вопросительное местоимение ктын (по мнению Вайана [1952: 71-172]), это вопросительное прилагательное) употребляется в стяженной форме къы 106б.

\section{IV.3.7 Определительные и совокупные местоимения}

Определительное местоимение вись в основном употребляется правильно. Характерной чертой является пропуск $\mathbf{n}$ в основе местоимения, даже если редуцированный стоял в сильной позиции. Буква $\mathbf{k}$ используется правильно во всех

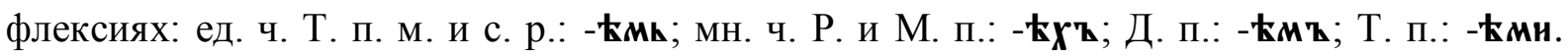
Характерен синкретизм окончаний И. п. ед. ч. ж. и. с. р. с флексиями В. п. мн. ч. м., ж. и. с. p., что объясняется утратой носовых. В этих же падежных окончаниях не наблюдается древнерусское -\$ (Букатевич 1974: 157).

\section{Единственное число}

Правильное использование местоимения имеем в И. П. вкск мїрт 148в, вкск граАт 153б. В этом же падеже наблюдается форма: вск 58в, 62г, 84а, 846 (см. III. 1). В

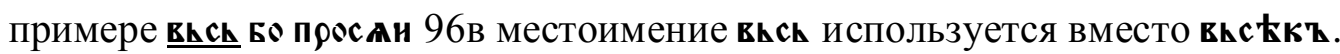


В Р. п. наблюдаются две формы написания местоимения: вксєго 99в, всєго 34а (2).

В В. п. ед. ч. наблюдаются несколько примеров, где опущен редуцированный к: в м. р. вск 51 a, 516 (2), вск нареат 75а (2), 92в, 131б, вскає 73в; в ж. р. вск 4а, всу 69Г, вису 140а (в двух последних примерах вместо ю пишется у).

В Т. п. наблюдается отклонение в основе местоимения при правильной флексии:

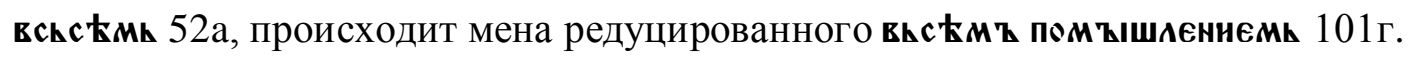

Старославянской норме соответствует окончание М. п. ж. р. пю вьсєн с.рни 106 и т. д.

\section{Множественное число}

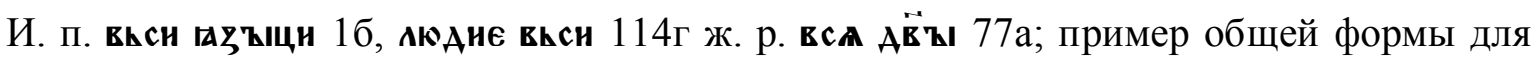

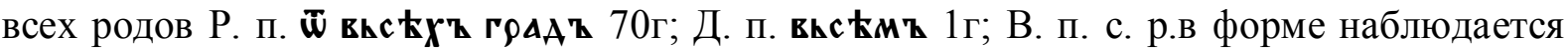

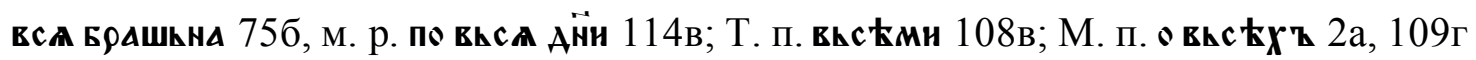

В местоимении висакъ последовательно употребляется $\mathbf{a}$ вместо $\mathbf{k}$ : И. П. м. р.: вһсакт 1а, 4в, 108а, 115в; ПоЛНая форма вһсакти 4в; Д. П. М. р. вһсакомоу 112Г; В. П. Ж. р.: висакоY ९ОZГоY 4а; М. П. Ж. р.: О вһсакон вещн 10а и Т. Д.

\section{IV.3.8 Адъективные местоимения}

В адъективных местоимениях замечены незначительные отклонения в Д. п. ед. ч.:

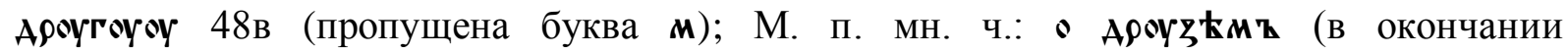
неправильный редуцированный, происходит мена) 20в, в рукописи также находим и правильный пример этой формы: ш Ароуз кмк $123 \mathrm{a}$. 


\section{IV.4 Имя числительное}

\section{1. Количественные числительные}

\section{Единственное число}

Склонение числительного юАннъ

В рукописи числительное єАннъ используется правильно в следующих случаях - И.

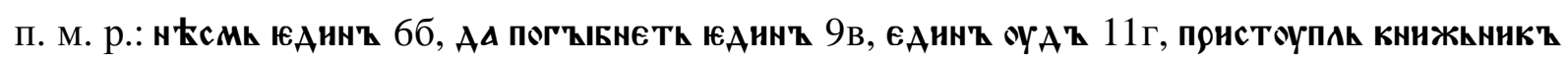

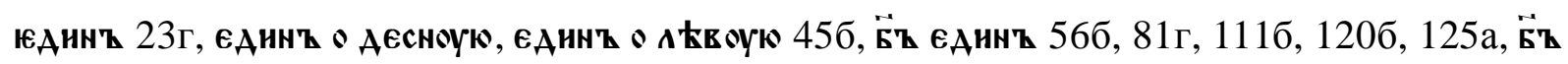

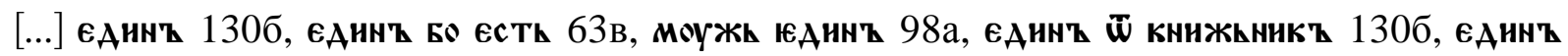

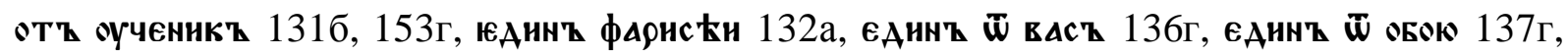

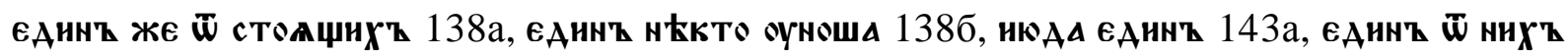

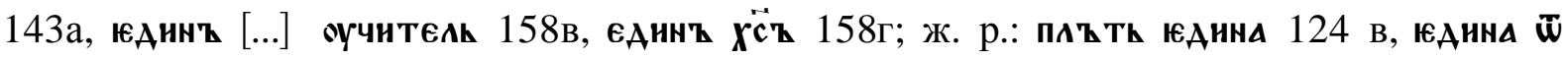

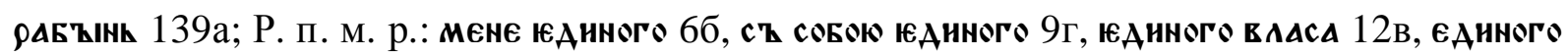

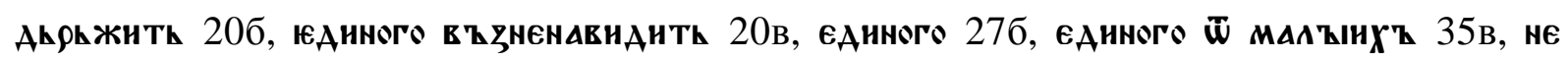

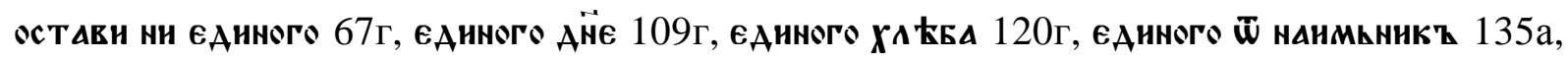

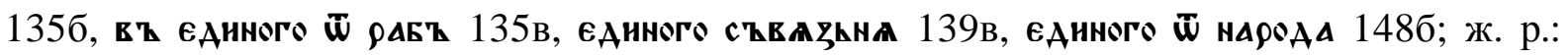

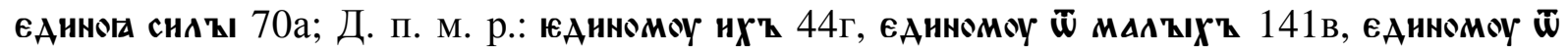

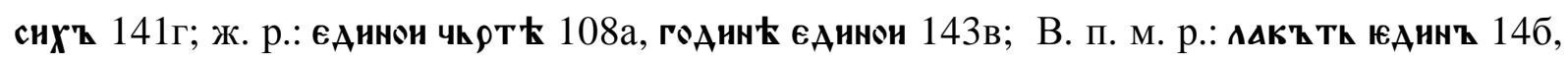

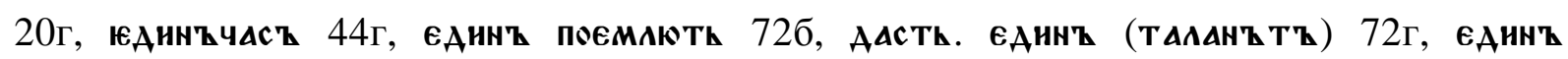

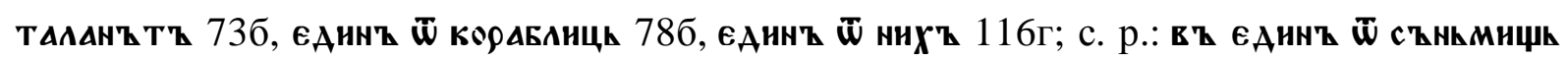

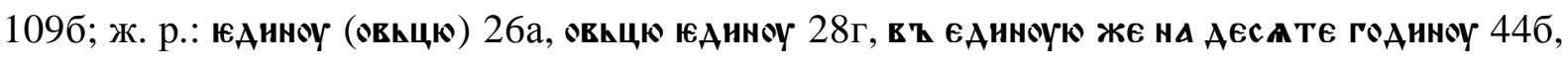

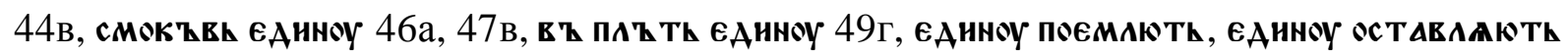

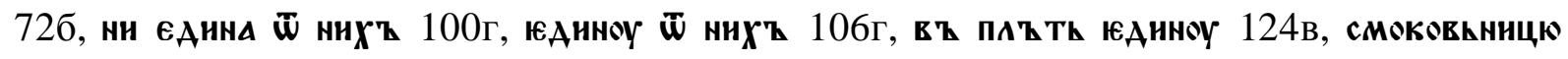

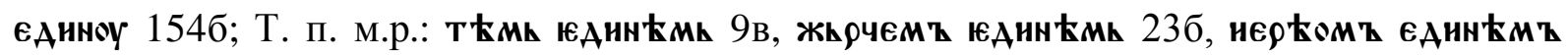
876 (происходит смешение конечного редуцированного), ck єАннћмh шкомъ 124a; М. п.

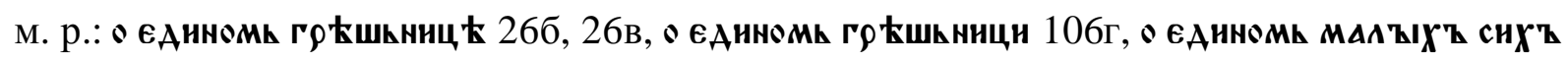
123 в. 
Двойственное число

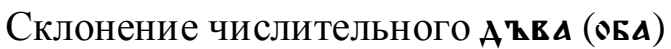

Склонение числительного Атқа (оБа) представленно в следующих формах: И. В. м.

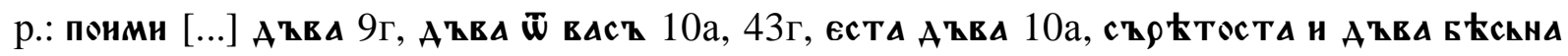

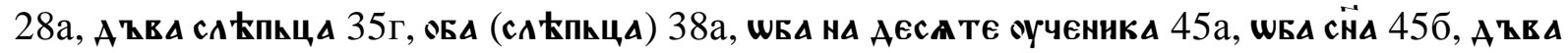

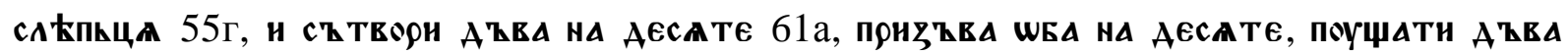

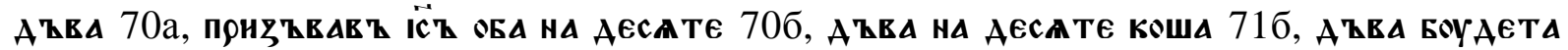

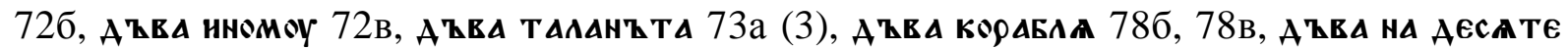

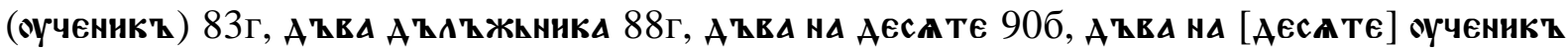

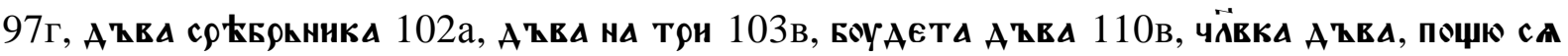

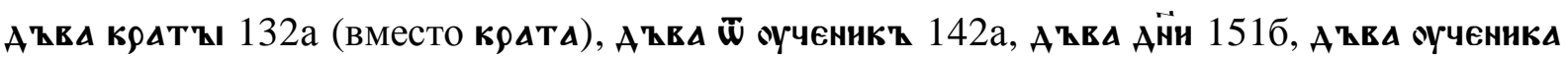
$152 \Gamma$.

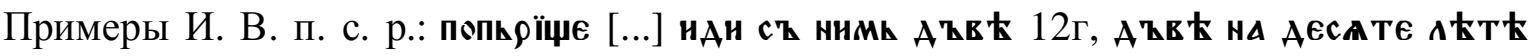

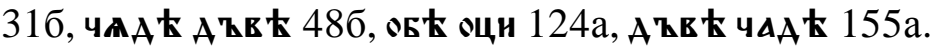

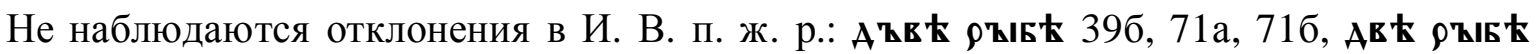

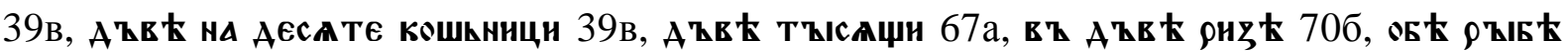

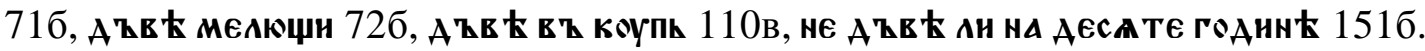

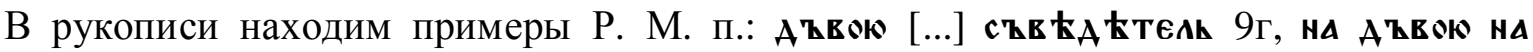

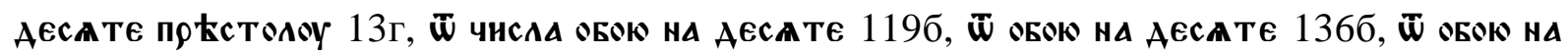
aеcate 137 ,

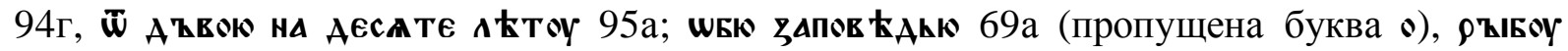
А $\mathbf{Z B \% ю ~ 9 0 б . ~}$

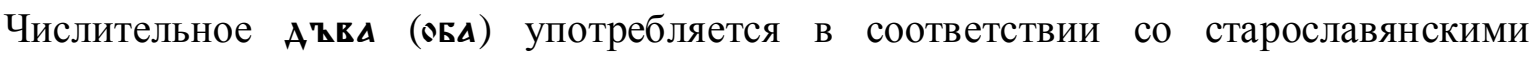

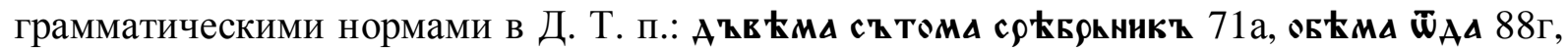

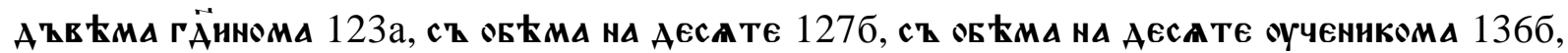

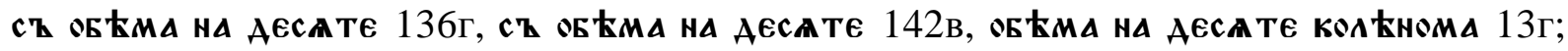

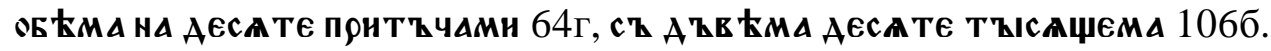


Множественное число

Склонение числительных трнє, чєтъцє

Примеры числительного төнњ, стоящего в И. П. м. р.: єстА [...] төнњ 10а, төнњ нА A ZKE 103B.

В Р. П. м. р. встречаются следующие формы данных числительных: трнн

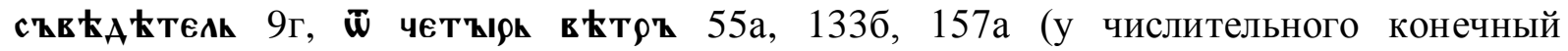

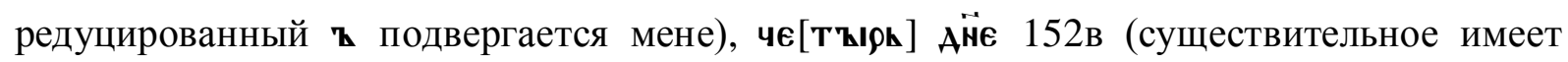
парадигму Р. п. ед. ч. вместо мн. ч.).

В Д. п. ж. р. наблюдается аномалия в словосочетании: четыреми тысашеми 121а, (во-первых, отсутствует согласование между числительным и существительным; вовторых, существительное с основой на *-jā- выступает с окончанием существительных

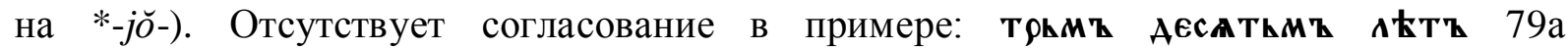
(существительное с. р. соответственно правильная форма числительного трн).

В В. п. отклонения отмечаются в следующих словосочетаниях: төн крдтт 139б (правильно төн крдты 143г), төн сқтт 134а (вместо төн сқты). Не наблюдаются

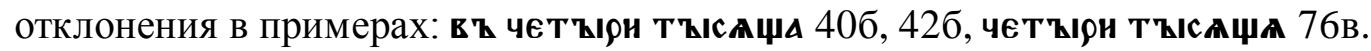

В Т. п. числительные употребляются правильно в следующих примерах: тркми

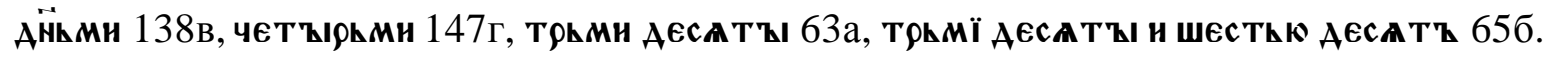

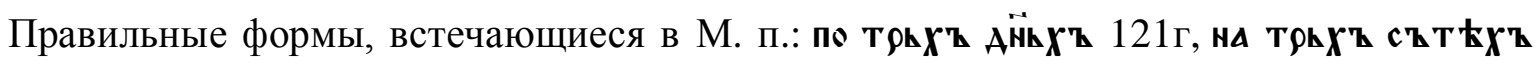

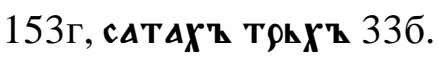

Склонение числительныХ Пати, шести, сеАми, осми, Аєва тh, Аєса тh

В И. п. отмечаются следующие формы данных числительных: па тh в қ єАїном қ 103в,

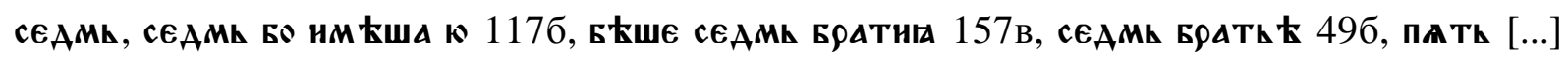

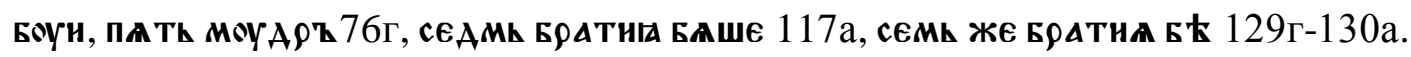

В Р. П. употребляются следующие формы числительных: пати ХАћвъ 40б, сєАмн

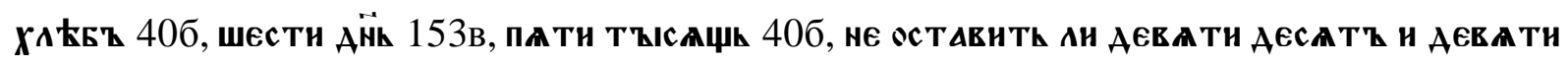
106Г, Па ти TZICAџh 121a. 
В рукописи выявлено числительное с окончанием Д. п.: по пати Аєсат т 71б, 90в.

В В. П. отклонение отмечается в следующем словосочетании: Аө сєАми Аєсатқ крат Қы 43Г (вместо кратұ). В соответствии со старославянской нормой используются:

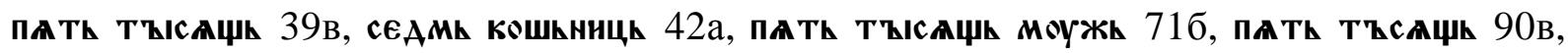
пать Брдтић 91Г (в существительном правильно употребляется древнерусское

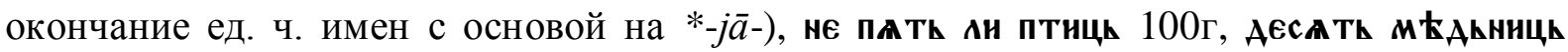
107a, Пат ти БрАтһґ 108 г.

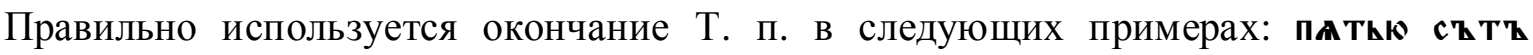

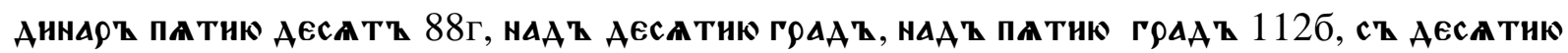
ThICAщh 1066.

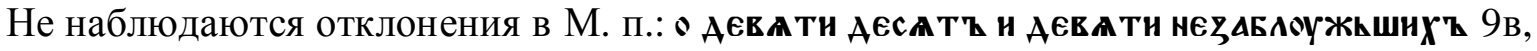

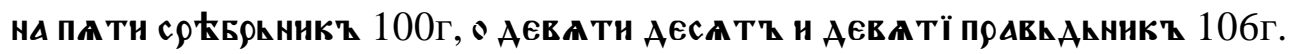

Склонение числительного Аєса ть

Наблюдается правильное использавание числительного в Д. п. ед. ч. Аєса ти А $\mathbf{t в \mathbf { z }}$ 76 .

2. Порядковые числительные

Порядковые числительные склоняются как имена прилагательные. В рукописи отмечаются стяженные (полустяженные) формы полных порядковых числительных. Приведем несколько примеров стяженного вида полных форм: Р. п. ед. ч. м. и с. р.:

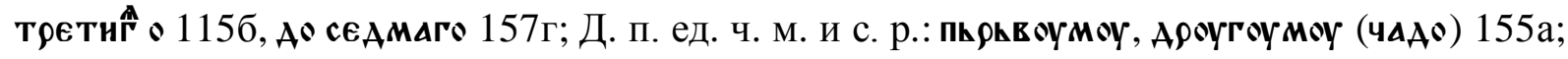

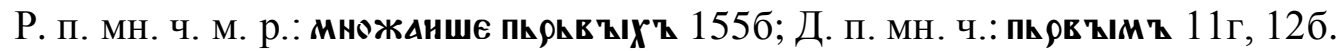

В $M m E$ имеется пример порядкового числительного сравнительной степени: И. п. ед.

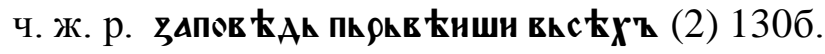


IV.5 Глагол

\section{IV.5.1 Презенс}

Окончание настоящего времени в тематических глаголах 1 -го л. ед. ч. соответствует старославянскому -ф (- оу, -ю): соужю, сйсоу 1б, посълю 2а, рекюу 2б, гйю 2Г и т. д.

Изменений не наблюдается и в окончаниях нетематических глаголов: юсмь 16 , в $\mathbf{k м ~}$ 2в и т. д.

В тематических глаголах 2-го л. ед. ч. последовательно пишется окончание -шн: ндеши 2в, гӥшн, в фроүешн 2Г и т. д.

Нет отклонений от старославянского написания и в нетематических глаголах: юсн $3 \mathrm{a}$ (часть перфекта), в ћсн 6б, АА Асн пасхоу 136в.

Окончание глаголов 3-го л. ед. ч. и мн. ч.: -ти - то есть сохраняет первичную форму,

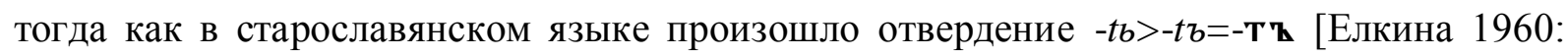
161], [Baleczky 1968: 139-140]. Использование древнерусского окончания относится к церковно-книжным нормам русской редакции старославянского языка. В $M m E$ в окончаниях, во всех случаях выступает н: 3-е л. ед. ч. не в вроүюти, оуслишшнти 1а, подоБдњть 1г. Отклонения от нормы имеем в следующих глаголах: оүмкрти (отсутствует тематическая гласная є) 37в; съ творнте (Мар. съ творнтн, Зогр. створнте,

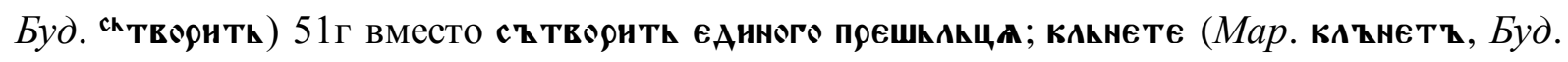
кльнет) $51 г$; тирпнти (окончательный к выведен из буквы ї) 129а; в tсте во өци (Мар.

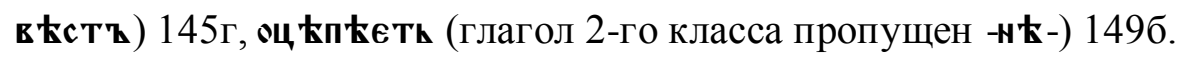

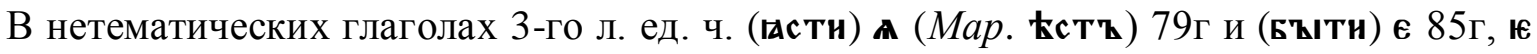
(часть перфекта) 99в, 131а отсутствует -сти. Формы глаголов без -ти встречаются уже и в старославянских рукописях (Супр. ев.) (Елкина 1960: 159). В остальных случаях

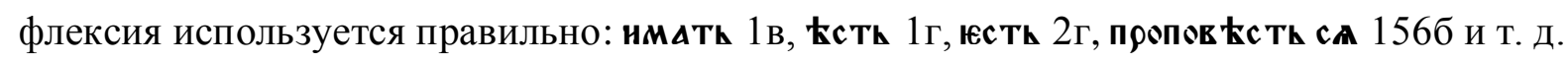

Глаголы, стоящие в 3-м л. мн. ч. имеют только древнерусское окончание -тh:

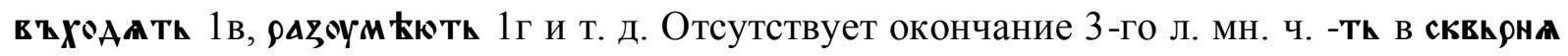


23б. Неправильное окончание отмечается в өь доуеть (Мар. -оути) 996 (возможно, ошибка переписчика).

Не наблюдаются отклонения в 3-м л. мн. ч. в нетематических глаголах: сөуть 2б, сж тh 3а и т. д., где также используется древнерусское окончание -ти .

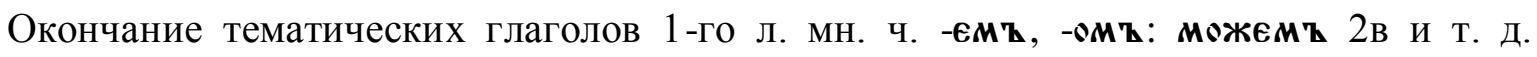
Окончания тематических и нетематических глаголов совпадают со старославянскими

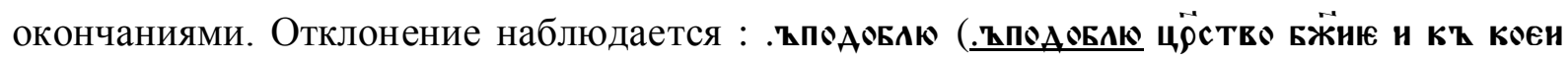
пюнтъчн пюнАежнмъ, Мар. оупеА ББнмъ ) 65 г.

Отклонения, наблюдаемые в следующих нетематических глаголах, объясняются

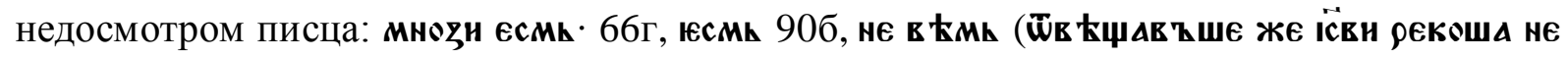
в 太ми ) 154 г.

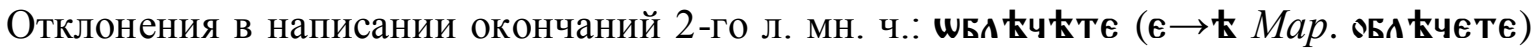

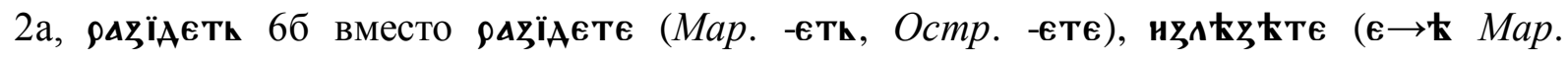

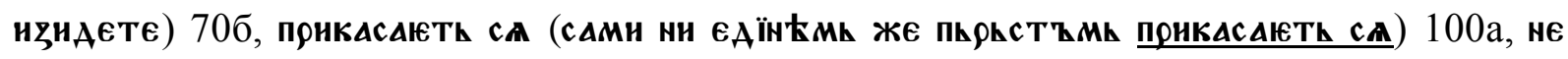
слұшити (не виднте и оуши имоушен не слҚшнти) 121а. Текст начинается глаголом 2-л. мн. ч. рєчєтє в продолжении же число и лицо меняется на 3 -л. ед. ч. оүсоумнн (без -ть)

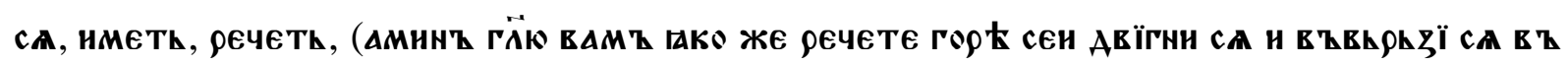

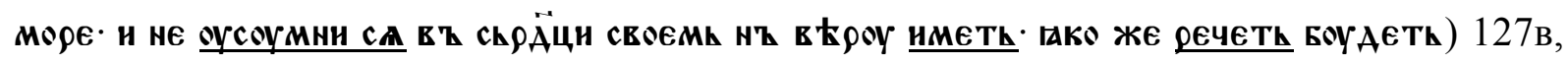
такая же ситуация в контексте с нє оусоумннти са 154в. В остальных случаях окончания соответствуют норме старославянского языка: внднтє 1в и т. д.

Формы нетематических глаголов 2-го л. мн. ч. употребляются в рукописи правильно (кроме нметь 127в описанного выше) юсте, нмате 1в, в қсте 2в и т. д.

В рукописи наблюдаются следующие формы дв. ч.: 1-е л. накөв и нонъ рекөста г̈н

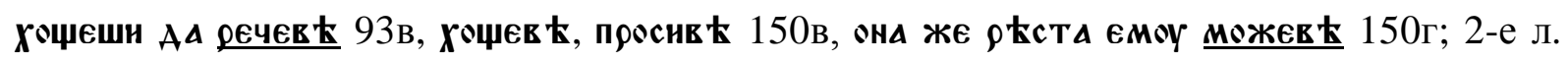

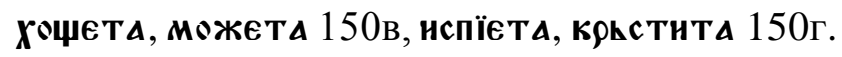


IV.5.2 Аорист

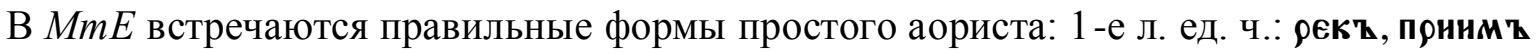

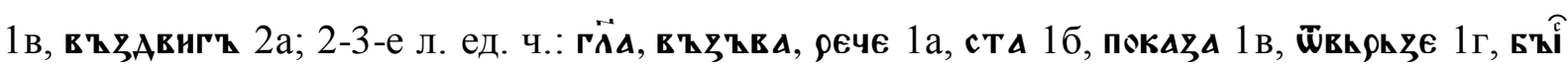
За и т. д.

Примеры простого аориста 1-ого л. ед. ч. указывают на архаичность, консервативность рукописи. Для живой речи XI в. (старославянский язык) формы этого аориста уже не характерны (в Супральской рукописи найден лишь один пример простого аориста) (Грунський 1946: 96; Елкина 1960:172).

Кроме простого, в рукописи используются и формы нового типа аориста, отдается

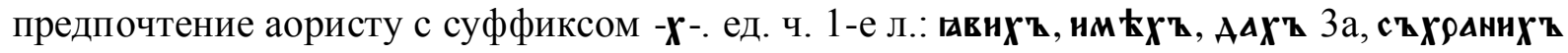

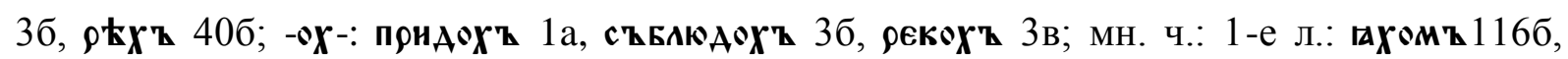

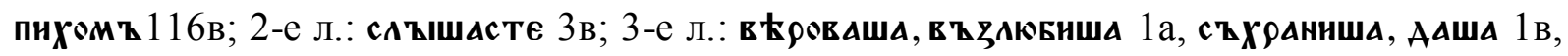
оумълъчА 119Г и т. Д.

Из сравнения форм аориста, находящихся в $M m E$ и в $M a p$., следует, что в $M m E$ больше форм нового типа (сигматический аорист -х्), чем в Мap., где преобладает простой и сигматический аорист с суффиксом -s-: мн. ч.: 1-е л.: възадомъ (Мар.

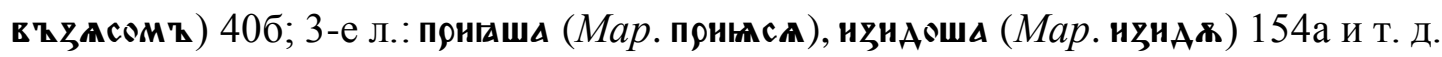

Для древнерусского языка («В памятниках русской редакции...») характерно использование форм простого аориста 2-3-го л. ед .ч. глаголов, инфинитивная основа которых оканчивается на гласный, с окончанием -тъ «в противоположность 3 лицу

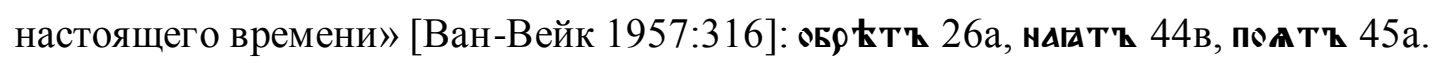

С другой стороны, в аористе глагола ААти происходит отпадение окончания -тh АА $89 \mathrm{a}$.

Спорадические отклонения от нормы наблюдаются: оүсъше (от оүсқ үнжтн) 63а,

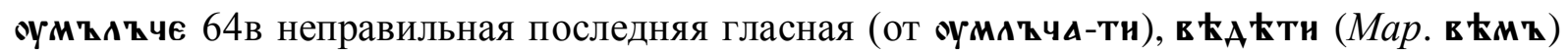
115a, они же оүмълқч4 119Г (Мар. оумлъчаша), запов $\mathbf{k} \mathbf{k}$ (правильная форма запов

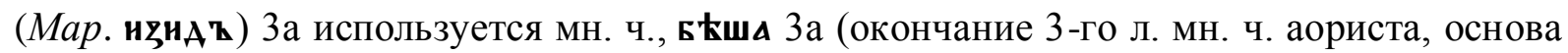
имперфекта). 
В рукописи отмечаются формы аориста дв. ч., где окончание -тА используется в 3-м

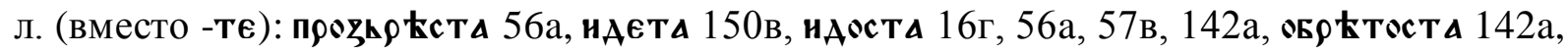
өтрћшнста 1426, рекоста 1426, 150в. Такие формы глагола наблюдаются и в старославянских рукописях.

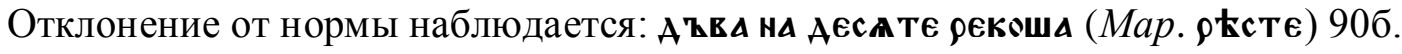

\section{IV.5.3 Имперфект}

В $M m E$ широко представлены формы имперфекта.

В глаголах прошедшего времени, в имперфекте, наблюдаются формы, которые характерны для древнерусского языка, относятся к первым русизмам, входящим в состав древнерусского извода (редакции), и стали частью норм церковно-книжного правописания. Ван-Вейк окончание -тъ («новообразование»), которое получают глаголы 3-го л. ед. и. мн. ч. имперфекта, относит к древнерусскому языку (Ван-Вейк 1957: 321). В рукописи действительно имеются глаголы с таким новообразованием, только предпочтение отдается -ти: 3-е л. ед. ч.: ..ААшеть а 82в, въпрашашети и 139в; 3-

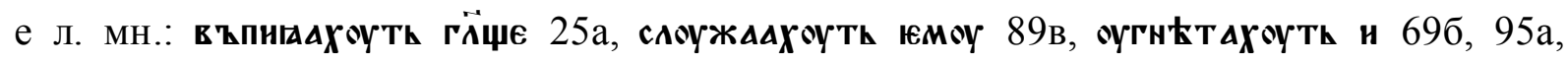

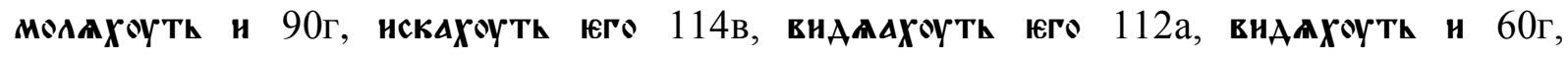

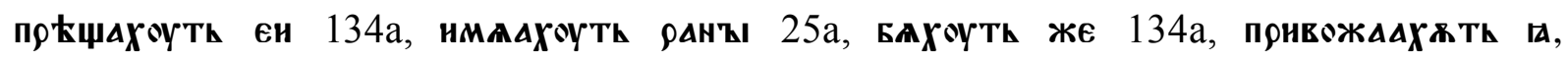

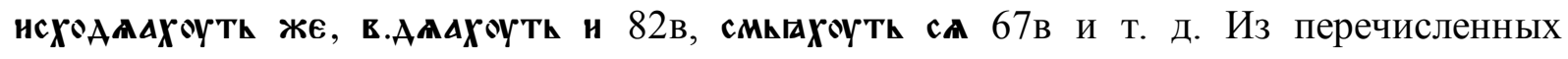
примеров видно, что большинство форм, получивших -ть, глаголы 3-го л. мн. ч. Проблемой -ть (аугмент) занимался Живов. Исследовав Гал. евангелие, разобрав примеры глаголов на -хжти (-хоүть), ученый пришел к выводу, что аугмент присущь только глаголам 3-го л. мн. ч. (Живов 20006: 210). Употребление аугмента только в 3-м л. мн. ч. Живов объясняет традиционным книжным чтением, «расчленявшего произносимую последовательность звуков на склады...» (Живов 2006: 211). Второй важный вывод, к которому подводят его наблюдения, это то, что «основной контекст, в котором появляется аугмент, - это положение перед энклитическим и» (Живов 2006: 203). Примеры $M m E$ лишь частично подтверждают предположения Живова.

О второй особенности имперфекта, принадлежащего к древнерусскому языку, у ВанВейка находим: «Распределение по аналогии ґ на глаголы, которые раньше имели $\mathbf{k}$, является русизмом...» (Ван-Вейк 1957: 320-321). С некоторым изменением, вместо ґ 
чаще пишется а (возможно, это особенность рукописи), именно такой формы глаголы, стоящие в имПерфекте используются в $M m E$ : ckдаше (Map. ck_taшє) 626, наАше 69б,

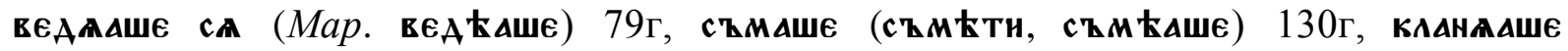

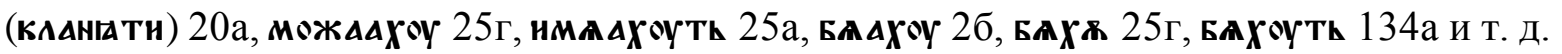

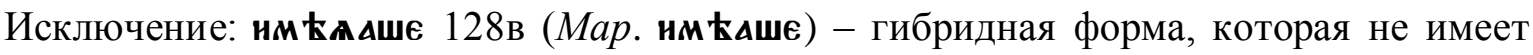
соответствующих аналогов ни в старославянском, ни в древнерусском языках. Вероятно, это просто ошибка переписчика.

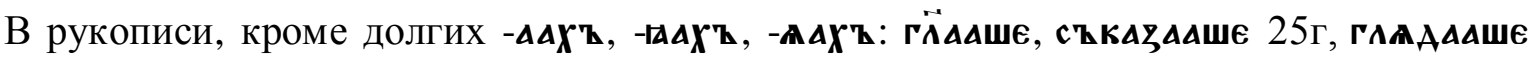
29а, творахше 24г, пю ұџахше 25а форм, используются стяженные (краткие) формы на -

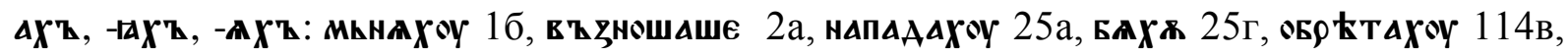

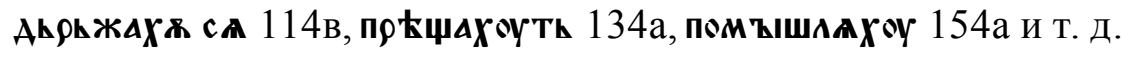

Образование имперфекта последовательно происходит от инфинитивной основы, отклонения не наблюдаются.

Отклонение от грамматической нормы наблюдается в 2-3-л. ед. ч.: оүчєшє $36 б$ (от

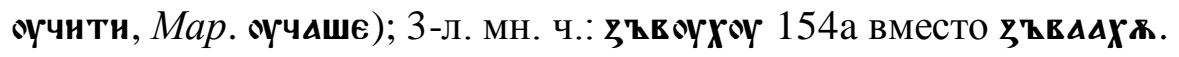

В дв. ч. использование окончаний соответствует грамматическим нормам старославянского языка: в кст А 16в.

\section{5.4 Перфект}

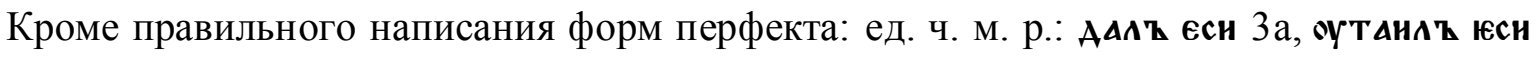

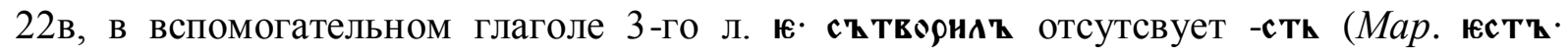
сътворнлт) 99в; мн. ч.: нћсте Ан чклн 153б, в двух случаях вспомогательный глагол

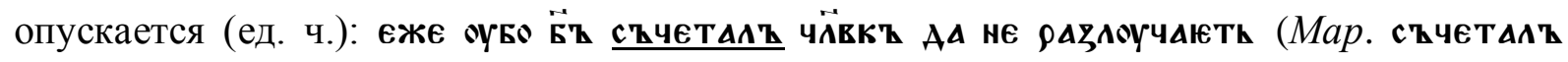
єстт), сқ твөрнха (Мар. твөрнтқ) 124в. По мнению Елкиной, в старославянском языке отсутствие вспомогательного глагола в форме перфекта наблюдается редко и только в 3-м л. ед. ч., и встречается такой пропуск лишь в Супрасльской рукописи (Елкина 1960: 191). Это определение полностью согласуется с характеристикой форм перфекта $M m E$. 


\section{IV.5.5 Плюсквамперфект}

Не наблюдаются отклонения от нормы в написании форм плюсквамперфекта, который состоит из $l$-причастия и имперфекта глагола Бытт: (ед. ч. м. p.): в $\mathbf{k}$ жє н єщє

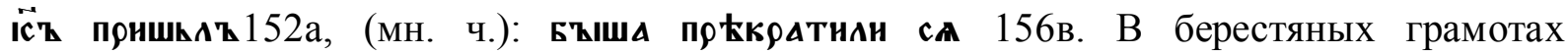
отмечается лишь один пример такой книжной формы. Зато в грамотах широко используется другая форма плюсквамперфекта, состоящая из $l$-причастия и перфекта

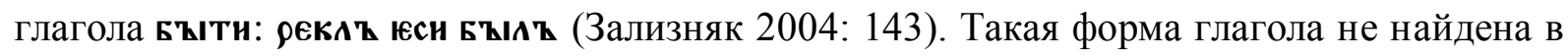
рукописи.

\section{IV.5.6 Будущее время}

В рукописи среди форм простого будущего времени нет каких либо отклонений от принятых форм старословянского языка. В значении будущего времени выступают перфективные глаголы с окончаниями настоящего времени: пост а тh с $\mathbf{A} 15$ г, ожнвє тh, прнкосноу с А 31б, пөємлють 726 и т. Д. А также в значении будущего времени выступают

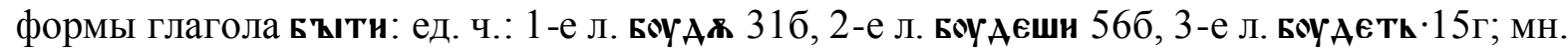

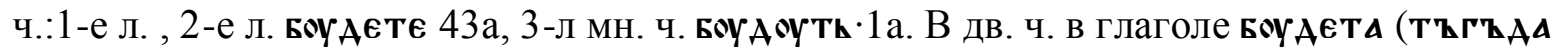
А

В соответствии со старославянской грамматикой используется и сложное будущее I: не нмАте вънити 46Г, начинетһ Бнти 55в. В рукописи находим пример замены описательной формы будущего времени на синтетическую форму (простое будущее):

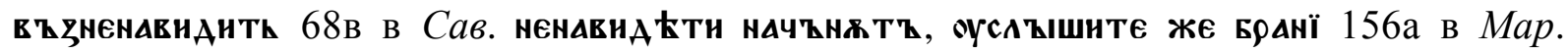
ОУсАҚШШАТИ ЖЕ ИМАТЕ Б९АнН.

В $M m E$ находим пример сложного будущего II (futurum exactum), которое состоит из причастия действительного залога прошедшего времени с суффиксом -l и глагола

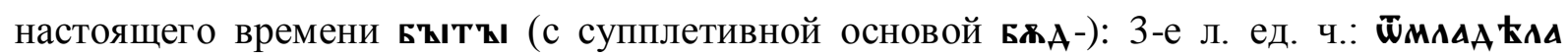
вOYAeth $55 \mathrm{a}$. 


\section{IV.5.7 Повелительное наклонение}

Повелительное наклонение иногда составлялось аналитическим путем с помощью

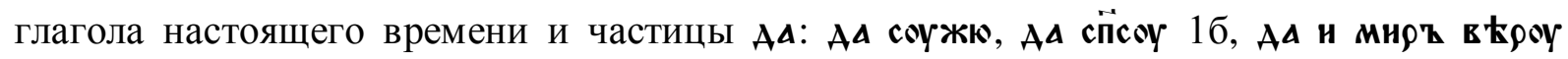

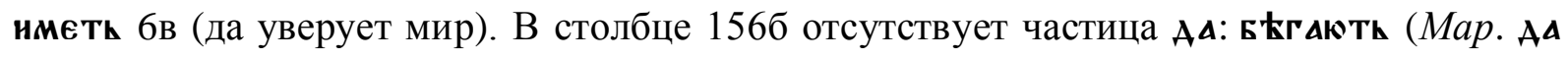

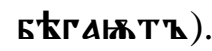

Второй формой, широко использованной в старославянском языке, выступала синтетическая форма повелительного наклонения. Среди примеров, найденных в рукописи, встречаются формы мн. ч. с «на $\mathbf{~ ґ , ~ ( 4 ) » ~ [ В а н - В е и ̆ к ~ 1 9 5 7 : ~ 3 0 6 ] : ~ 1 - е ~ л . ~}$

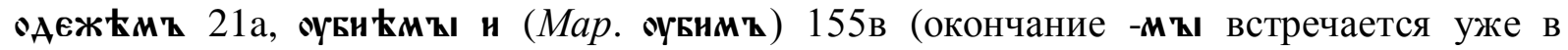
старославянских рукописях (особенно в Супр.) в формах глаголов настоящего времени 2-го л. мн. ч.. Образуется под действием последующего и [Елкина 1960: 159]); 2-е л.:

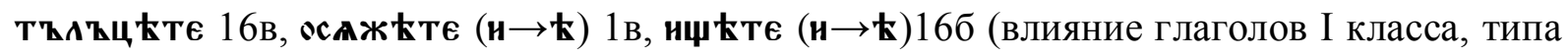
нести, несћте). Такие формы повелительного наклонения известны уже из первых старославянских кириллических рукописей (Ван-Вейк 1957: 306).

В форме глагола 2-го л. ед. ч. наблюдается неправильное личное окончание: гй

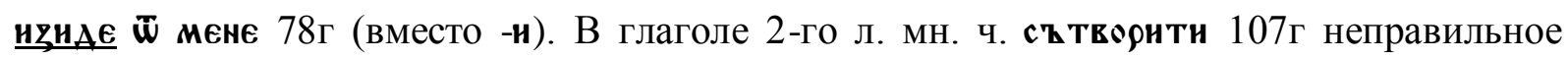
личное окончание. В рукописи отмечаются формы повелительного наклонения 2-го л. ед. ч. древнерусского языка: внжи 20а (5), не сқнћжи 127б-127в.

\section{IV.5.8 Условное наклонение}

Условное наклонение в $M m E$ состоит из вспомогательного глагола Быти, стоящего в

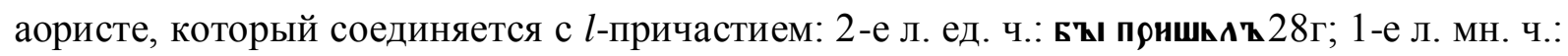

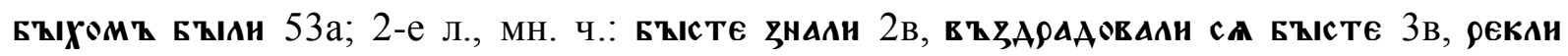

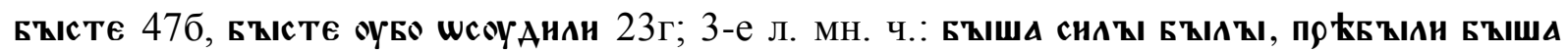

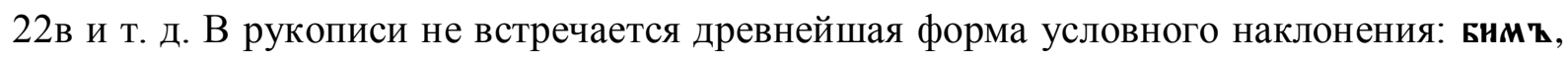
Бн, Бн, Бнмъ, Бнсте, Бж; Бнв 


\section{IV.5.9 Супин и инфинитив}

Приводится несколько примеров супина: ндоу оүгетөв Ати (вместо предполагаемого

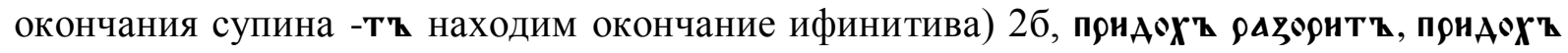

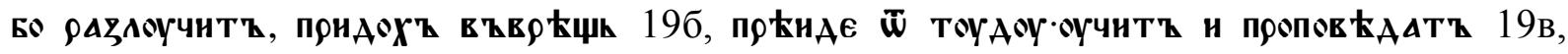

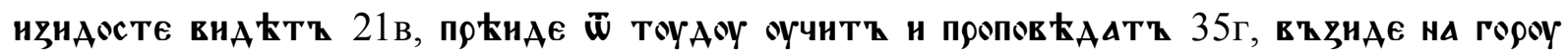

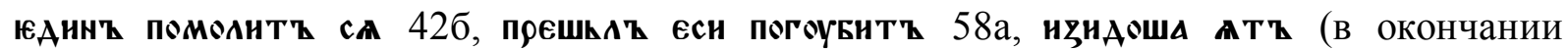
переписчик к букве қ приписывает еще штрих, который перечеркивается) 61в,

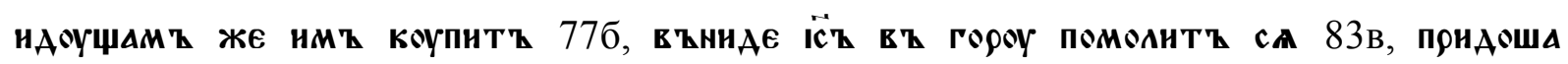

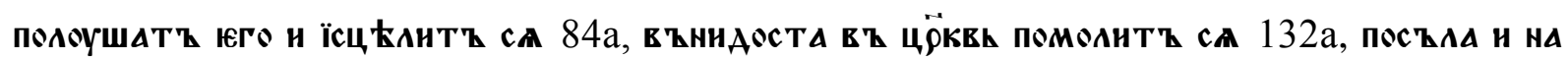
СЕАО своЮ ПАСТ Т Свнннн 134 Г-135а (49) И. Т. Д.

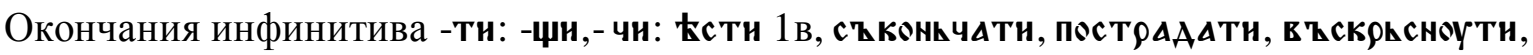
пюппв

\section{IV.5.10 Причастия}

\section{1. Причастие на $-l$}

Перфектное причастие относится к продуктивным частям речи. Причастие неотъемлемая составная условного наклонения (примеры м. р.): Бъы в $\mathbf{A} \mathbf{k} \mathbf{\mathbf { z }} 726$,

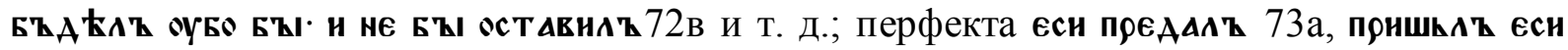

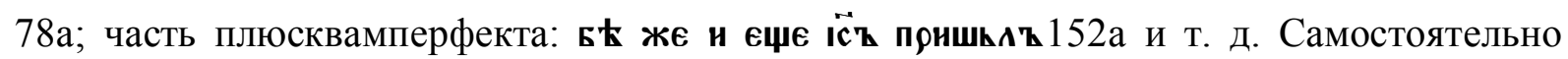
используется один раз в м. р. сқчеталқ 124в, один раз в ж. р.: съ твөрнла 124в (формы перфекта см. IV.5.4).

2. Причастия настоящего и прошедшего времени действительного и страдательного залога

В рукописи переписчиками используются все виды причастий. Среди причастий, использованных в $M m E$, наблюдаются краткие и полные формы.

\section{Единственное число}

В И. п. м. р. неправильно употребляются причастия настоящего времени

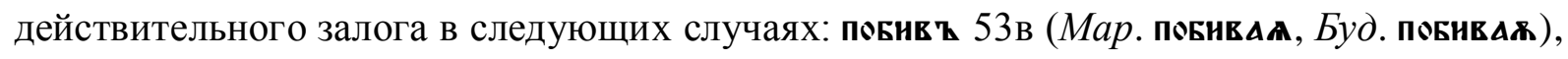




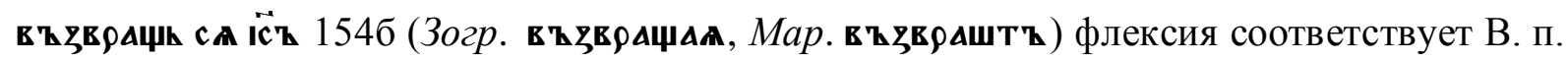
м. р. вместо И. П. Правильные формы полных причастии м. р.: пюосан, нщан 6в,1

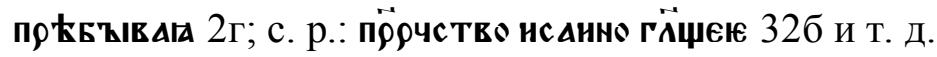

Несколько форм кратких причастий прошедшего времени действительного залога И.

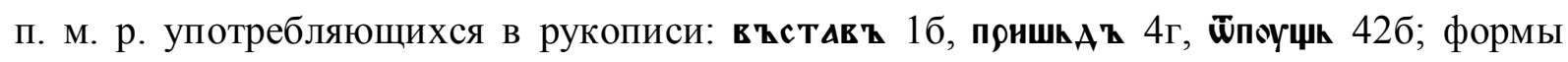

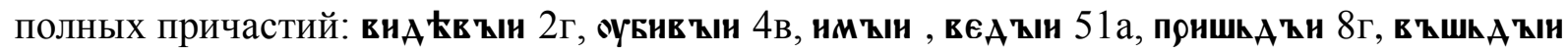

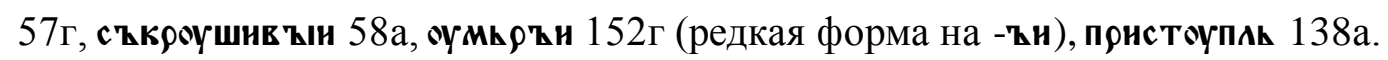

В рукописи выявлена краткая форма страдательного залога прошедшего времени с. р.: с. р.: пнсано 1г (краткая форма).

В рукописи отмечается краткая форма причастия настоящего времени действительного залога Р. п. м. р.: нмоуща 1в. В Р. П. м. и с. р. наблюдаются полустяженные формы полных причастий настоящего времени: Хотащахго 12г;

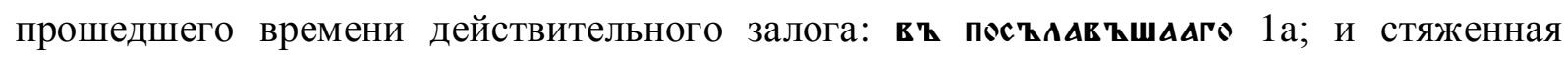
форма настоящего времени страдательного залога: грААА нАрнцАємаго 86Г, огна негАснмаго 123г. Отклонение от окончания старославянского языка в этой парадигме наблюдается в ж. р. причастий прошедшего времени действительного залога: ндє ти в қ

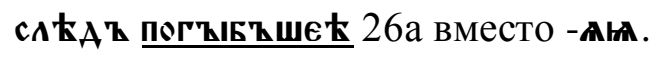

В Д. п. м. и с. р. зафиксирован стяженный вид полных причастий настоящего

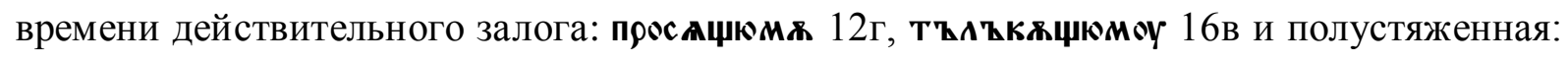

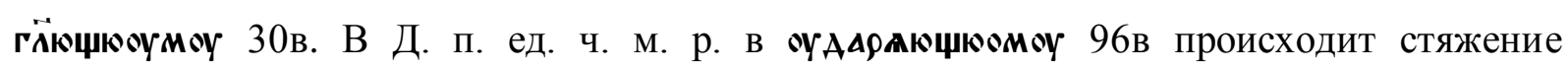
окончания, где є>о. Сходное явление наблюдается и в Будапештском ев.: ннщюомоу 101б. Неправильно употребляется краткая форма настоящего времени действительного залога м. р.: рєчн 81г (вместо рєщн 81 г).

В этой парадигме встречается пример краткой формы причастия прошедшего

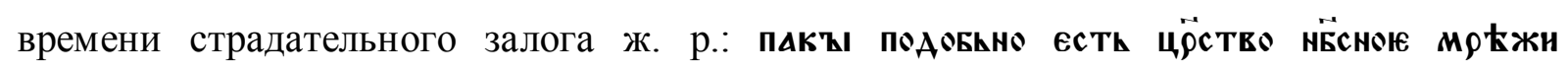

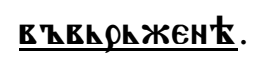

В В. п. м. р. правильно используется следующее краткое причастие настоящего времени действительного залога: нА өА९ АєжАџь 31в; в ж. р. в примере краткого 


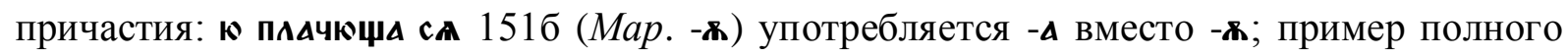
причастия ж. р.: нетворгащюю 4 а и т. д.

В парадигме правильно используется краткое причастие прошедшего времени

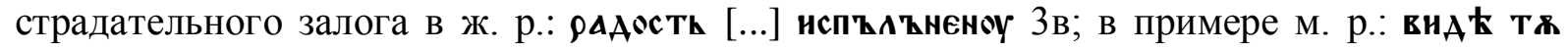
чӥвкА не оБлћчєна 646 (Мар. оБлъчєна) причастие прошедшего времени образовано от основы настоящего времени.

В Т. п. м. р. в краткой форме причастия настоящего времени действительного залога:

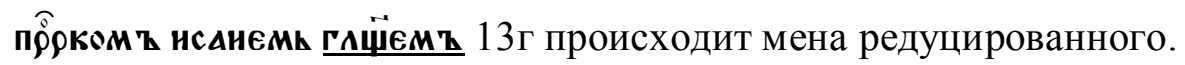

\section{Множественное число}

В И. п. м. р. краткие причастия настоящего времени действительного залога употребляются в основном правильно: ХвАлаще, вйгсловаше 2б; отмечается форма соушен $156 б$ (влияние протографа) и т. д.. В причастии гӥше и 18в (Мар. гёшен), вероятно, точка не нужна. Использование ненормированной формы зафиксировано в

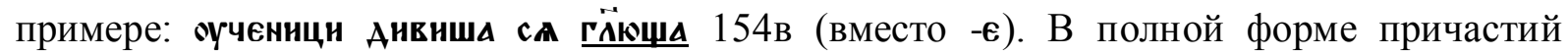

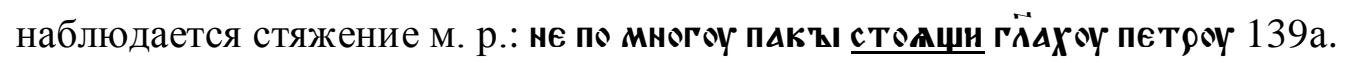

Приведем несколько примеров правильной формы краткого причастия прошедшего времени действительного залога И. п. м. р.: гавъше, бъвъшє 1б, нарядн же

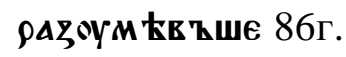

В рукописи представлены краткие формы причастия прошедшего времени

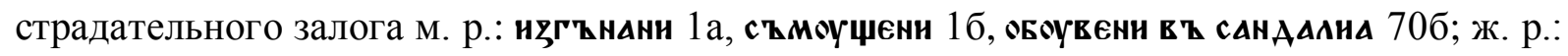
९ҚБ Қы печены 1в и т. Д.

Правильная форма краткого причастия Р. п. м. р. иллюстрируется примером: прнзыв мюшь 86г. В рукописи наблюдается также в нестяженном виде полная форма

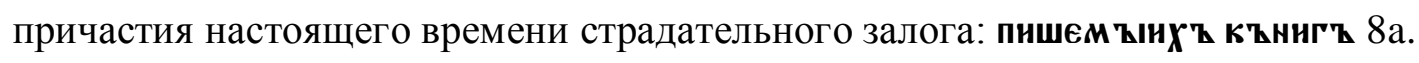

В Д. п. м. и с. р. в рукописи наблюдаются следующие формы кратких причастий настоящего времени действительного залога: в ћроүющємъ, чюАащємъ 1в и т. д. В этом падеже имеются примеры полных причастий: нєндвндацьнмт 12г (в окончании происходит смешение к<н), жнвоушннмъ 52б; а также стяженная форма өтроцищємъ

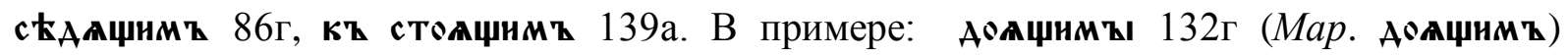


представлен стяженный вид полной формы причастия настоящего времени действительного залога с конечным -ұı. Полная флексия Д. п. причастия прошедшего

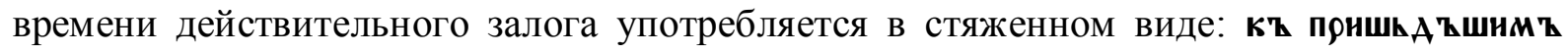
$48 \Gamma$.

В В. п. отмечается краткое причастие настоящего времени действительного залога м. р.: нмоушА 1в.

В Т. п. встречается полная форма прошедшего времени страдательного залога: висћмн зъванъммн 120а.

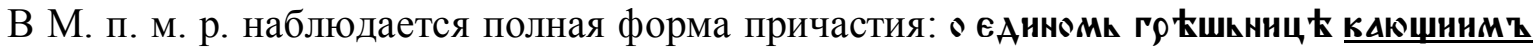
са 26б, где происходит мена конечного редуцированного.

\section{Двойственное число}

Старославянской грамматической норме соответствует форма причастия И. В. П., Зв.

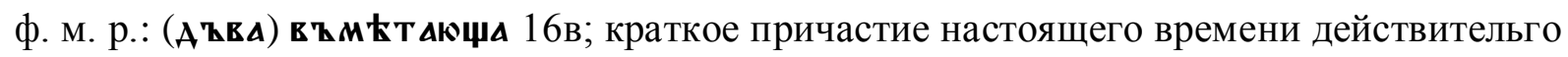

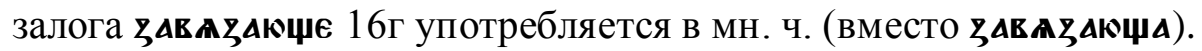

Среди форм прошедшего времени действительного залога тоже наблюдается форма И. В. П., ЗВ. Ф.: онА не АБињ ост АвАһшА 16Г.

В рукописи наблюдаются лишь очень незначительные изменения, происходящие в личных окончаниях глаголов. К такому измененнию относится окончание настоящего времени 3-го л. ед. ч. -тh, которое является установившейся книжной нормой правописания церковнославянского языка восточных славян. Сюда относится также

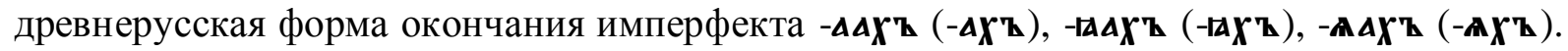
Перечисленные морфологические явления (и другие не столь важные, но отмеченные при изучении спряжения глагола) подтверждают древнерусскую редакцию рукописи.

В основном, причастия в рукописи употребляются соответственно со старославянскими нормами грамматики. В полных прилагательных наблюдается явление стяжения флексий. Отклонения, найденные в рукописи, имеют спорадический характер. 
Заключение

Милятино евангелие - полный апракос - не относится к знаменитым роскошным кириллическим (Остромирово евангелие 1056) рукописям древнерусского языка. Но с точки зрения исторической славистики это ни чуть не уменьшает ее бесценный вклад, ту важнейшую роль, которую рукопись выполняет, открывая нам культуру кириллического письма XII - XIII вв., давая возможность «услышать» элементы живой речи (древнерусской) восточных славян, «услышать» говор переписчиков (древненовгородский диалект). Основа языка $M m E$ - это старославянский язык, что для ретроспективного (ascendens) [H. Tóth 1996: 9] изучения является важным, незаменимым материалом, будь то изучение фонологических отношений или морфологических. В нашей работе принимается к изучению проспективное (descendens) [Н. Tóth 1996: 9] направление развития фонологии, морфологии.

«Церковнославянский язык до XVII в. употреблялся у русских в качестве одного из разновидностей русского литературного языка» (Елкина 1960: 6; Феринц 2011: 83). И только «со второй половины XVII в., особенно после присоединения к Московскому государству Украины [...]» начинает строится литературный язык на основе живой речи (Феринц 2011: 83). А «[...] старославянские элементы стали использоваться в качестве стилистического средства в поэзии и публицистике» (Елкина 1960: 6). Из процитированного раскрывается картина влияния старославянского языка и его высокая степень присутствия в современном русском. Поэтому изучение древних (древнерусских, древнеболгарских и т. д.) рукописей всегда будет актуальным.

Написание $M m E$ приходится на отрезок времени (X - XIV вв.), который является общим древнерусским (по мнению большинства славистов; оспаривают это предположение: Зализняк [2004: 7], Шевелев [2002: 47, 54-55]) в историческом развитии восточных славянских языков - это первая особенность отрезка этого времени. Вторая особенность - это частичное («осторожное») проникновение живой речи восточных писцов, связанное с особенностью литературного языка, орфографических традиций, а также с системой правописания вцелом [Шевелев 2002: 277] (идет речь об установлении норм церковно-книжного правописания). Поэтому рукописи принадлежащие XI - XIV вв., где отмечаются русизмы, - это только редакции или изводы древнерусского языка. В этом отрезке развития древнерусского языка рукописи разделяются на две группы: рукописи, где проникновение русизмов носит спорадический характер (Введение); рукописи, с установившимися церковно- 
книжными нормами правописания. $M m E$ относится ко второй группе рукописей. Эта информация дает возможность определить общее синхронное состояние языка $M m E$, установить его местонахождение в соотношении с другими рукописями древнерусского языка. Особенность, самобытность рукописи подчеркивается еще (несмотря на древность рукописи) элементами древненовгородского диалекта.

Фонетические явления древнерусского языка и древненовгородского диалекта в $M m E$.

- В рукописи носовые гласные отмечаются только графически.

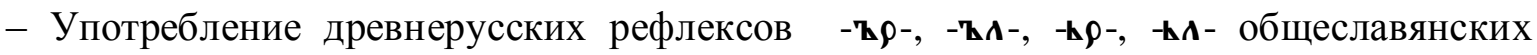
дифтонгоидов *tbrt,*tbrt, *tblt, *tblt. Такие древнерусские формы регулярно используются в рукописи и отображают произношение писцов. Это первый русизм, который стал нормой церковнославянского языка. Параллельно в рукописи

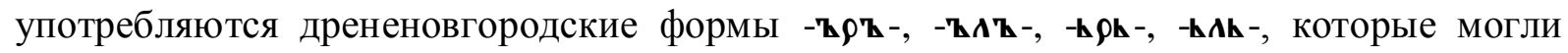
отображать живую речь.

В рукописи употребляются $\mathbf{h}$, $\mathbf{k}$ редуцированные. Редуцированные в сильной позиции не переходили в гласные полного образования. Редуцированные в слабой позиции в начале слова выпадают. Но слабые редуцированные, стоящие в середине слова, на границе соприкосновения морфем (принадлежащие суффиксам) не выпадают.

В Т. п. ед. ч. м. и с. р правильный конечный к часто подвергается замене (во всех частях речи). Напряженные редуцированные в рукописи употребляются правильно.

- Звук, обозначавшийся буквой $\mathbf{k}$ существовал, так как его находим во всех морфемах слова. Примеры, где имеет место мена $\mathbf{k} \mathbf{\epsilon}$ отображают закрытое $\hat{e}$ произношение этого звука в древнерусском языке (что расходилось с древнеболгарским произношением). Замена буквы $\mathbf{\epsilon}$ на $\mathbf{k}$ в рефлексах праславянских сочетаний *tert, *telt относится к нормам книжного правописания. Сюда же относится мена $\mathbf{k} \boldsymbol{\epsilon}$ в формах 2-го л. ед. ч. личного и возвратного местоимений в Д. и М. П.. В рукописи встречаются несколько рефлексов древнерусского языка (полногласие) праславянских сочетаний *tert, *telt.

К древнерусскому явлению относится $\mathbf{k} \sim \mathbf{A}(\mathbf{A})$ в формах имперфекта. Анализ звука, обозначаемого буквой $\mathbf{k}$, дает возможность определить черты новгородской школы в

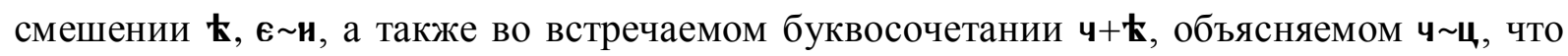


характерно для древненовгородского диалекта. Предполагается, что произношение $\mathbf{k}$ писцами приближалось к $i$.

- Незначительное число примеров отмечается в рукописи с древнерусскими рефлексами праславянских дифтонгоидов (звукосочетаний) *tort, *tolt и *ort, *olt.

- В написаниии рефлексов *dj норма еще не установилась. Наблюдается вариативность написания ж, жА.

- Из диалектических особенностей наблюдается, характерная для

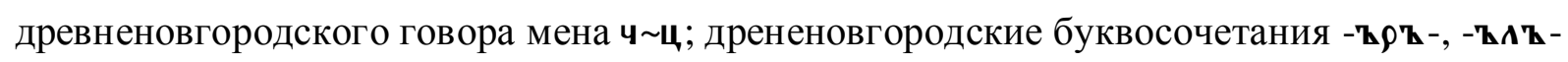

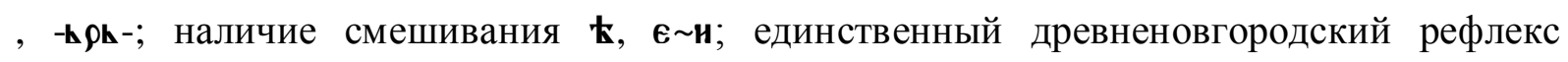
звукосочетания $* d+j>$ жг.

Анализ падежных окончаний существительных $M m E$ - безусловное доказательство общего процесса перераспределения окончаний у существительных с учетом родовой принадлежности.

К первым выработанным и установившимся нормам правописания церковнокнижного языка восточных славян относится окончание существительных с основой на

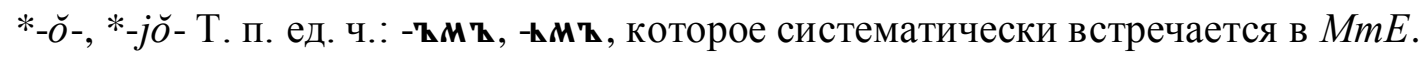

Древнерусское окончание -ł проявляет себя в существительных ж. p. мягкого варианта в Р. п. ед. ч., И. и В. п. мн. ч.. В этих же падежах в рукописи имеются примеры гибридного написания окончаний.

Местоимения сохраняют старославянские формы. В рукописи отмечаются формы древнерусского языка личного местоимения 2-го л. ед ч. Д. и М. п. и возвратного

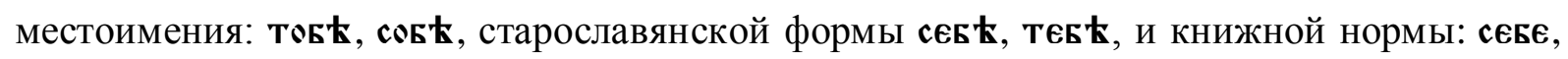
теБе.

В рукописи наблюдаются лишь очень незначительные изменения, происходящие в личных окончаниях глаголов. К такому измененнию относится окончание настоящего времени 3-го л. ед. ч. -тh, которое является установившейся книжной нормой правописания церковнославянского языка восточных славян. Сюда принадлежит также

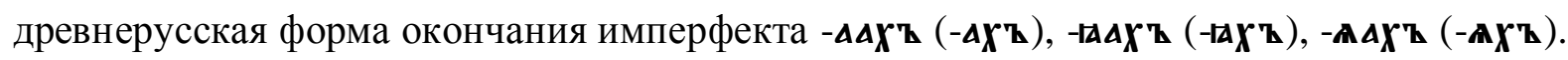

Стяженный вид наблюдается в полных формах прилагательных, причастиях.

Суммируя данные исследования рукописи, приходим к выводу, что полный апракос

Церковнославянские нормы правописания со временем расширили границы для большего проникновения новых русизмов. И уже с XIV в. имеем дело не с изводом 
древнерусского языка, а с тремя самостоятельными языками восточных славян, закрепившихся на письме.

Милятино евангелие - это древнерусская редакция старославянского языка с мощьной диалектической окраской древненовгородского говора. 
Церковный календарь с соответствующими чтениями Милятиного евангелия и их место в тексте

По содержанию и структуре Милятино евангелие - богослужебная книга, относящаяся к Евангелию-апракосу, а точнее - Евангелие-апракос полный. Содержание $M m E$ состоит из чтений или зачал, взятых из глав и стихов четырех евангелистов. Краткая опись содержания, взятая из Сводного каталога славяно-русских рукописных книг: «Чтения на весь год - л. 1а-159 г, начало со среды 6-й недели по Пасхе (начало И. XII 42); между листом 2 и 3 разрыв, лист 2г конец пятници 6-й недели по Пасхе (И. XIV 1-11), лист 3а начало воскресения 7-й недели по Пасхе (И. XVII 5); чтения обрываются на страстной пятници (Мт. XXVIII 34); утренние воскресные евангелия 10-е и 11-е лист 160а; евангелия на разные случаи (над больным бесноватым, на освящение церкви, об умерших) - лист 160б-г» (Шмидт 1984: 143).

Полный апракос - богословная книга, которая использовалась для чтений на каждый день (недельных чтений). Состоит из двух частей: синаксария и месяцеслова. В синаксарии чтения расположены соответственно подвижному церковному календарю (от Пасхи до Пасхи), а в месяцеслове относятся к неподвижному, гражданскому календарю, начинающемуся с 1 сентября. Синаксарий состоит из 5 циклов.

1. От Пасхи до Пятидесятницы (Духова дня) продолжительностью 50 дней.

2. От Пятидесятницы до Нового лета, приходящегося на начало сентября, продолжительностью 16-17 недель в зависимости от даты Пасхи.

3. От Нового лета до Великого поста, продолжительностью 16-17 недель в зависимости от начала поста (его начало на семь недель предшествует Пасхе).

4. Великий пост, продолжительностью 6 недель.

5. Страстная седмица (неделя) (Алексеев 1987).

$M m E$ выделяется из ряда других полных апракосов составом чтений, их последовательностью и местом в тексте рукописи. Изучению подлежит первая часть апракоса (синаксарий). После текстологического исследования приблизительно 500 рукописей до начала XV в., среди которых 200 единиц полного апракоса, Жуковская (1976) разделила их на две группы. К первой группе относится основная часть рукописей. Представителем этого типа служит древнейшая рукопись - Мстиславово евангелие 1115 - 1117 гг.. Широко известный сербский памятник Мирославово евангелие, написанное примерно в 1200 г., представитель второй группы. Разница 
небольшая, но историческая, будние чтения от Марка в Мирославовом евангелии во втором периоде (цикле) начинаются на неделю раньше.

Исследования содержания рукописей мстиславового типа от Пятидесятницы до Нового лета, на основе изучения дополнительных чтений, дало возможность выявить мстиславовский и милятинский классы рукописей. Имеются рукописи первичные, в которых отсутствуют чтения дополнительной недели, но основная часть содержит чтения дополнительной недели. Разница состоит в том, в котором месте и какого содержания чтения. В первую группу относим те рукописи полного апракоса, где имеются чтения дополнительной недели, расположенные после вс. 16-й нд. (возможны два или семь) - это так называемый мстиславовский класс. Во второй группе чтения расположены два после вс. 16-й нд. и пять - после вс. 4-й нд. Древнейшим представителем такого написания и является $M m E$, отсюда и название класса милятинский класс. Рукописи, относящиеся к милятинскому классу, составляют ограниченное число. Особенность $M m E$ состоит в том, что дополнительные чтения на пн., вт., ср., чт., пт. находятся после 4-й нд. (Таблица 7.), чтения следующих за ними сб., вс. соответствуют порядку остальным полным апракосам, что совпадает с чтениями сб., вс. соответствующих недель в кратких апракосах. Вследствие этого чтения на сб. и вс. предшествуют чтениям на будничные дни, происходит сдвиг на одну неделю вперед.

Еще одна особенность $M m E$ обнаруживается в III-м цикле. С начала Нового лета исчисление дней недели происходит не с понедельника, a $\mathrm{c}$ субботы. Последовательность такова: суббота, воскресенье и затем понедельник, вторник и т. д.

К особенностям $M m E$ относятся также несовпадение имен евангелистов с соответствующими библейскими главами и стихами. Такое явление объясняется недостаточностью знаний, образованностью переписчика или, изначально, в прототипе уже существовало такое несоответствие.

В начале зачал всегда имеются вступительные слова, среди них наиболее распространенные: въ оно вр̆

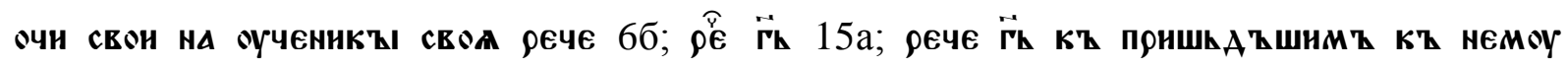
нюА 大емz 48 г.

К исследованию содержания рукописи, выполненную по циклам, прилагаются таблицы, в которых прослеживается разница между $M m E$ и современным изданием Библии в употреблении глав, стихов евангелистов на каждый день (Библия 1990: 641- 
647; Библия 2000: 1346-1355). Так, запись в рубрике: евангельские чтения церковные на каждый день (Ев.) $M m E$ - обозначает только ту главу и тот стих в рукописи, которые соответственно отсутствуют в Библии и наоборот.

Сокращения в таблицах: Д. - день недели; Н. - номер недели; Ев. - евангельские чтения церковные на каждый день; Матфей - Мф.; Марк - М.; Лука - Л.; Иоанн - И.; римскими цифрами обозначаются главы; обычными цифрами - стихи евангелистов.

I. Первый цикл $M m E$ состоит из 7 недель. Начало приходится на ср. 6-й недели по Пасхе И. XII: 42; между листом 2 и 3 разрыв, 2г конец пт. 6-й недели по Пасхе И. XIV: 1-11, 3а начало вс. 7-й недели по Пасхе И. XVII: 5.

Таблица 6. (І цикл)

\begin{tabular}{llllllll}
\hline \multicolumn{9}{c}{ Милятино евангелие } & \multicolumn{2}{c}{ Библия 2000 } \\
\hline $\begin{array}{l}\text { цик } \\
\text { лыст, }\end{array}$ & $\begin{array}{l}\text { столбец } \\
\text { I }\end{array}$ & Д. & Н. & Ев. & Д. & H. & Ев. \\
\cline { 2 - 7 } & ср. & 7 & - & & И. XVI: 17 \\
\hline
\end{tabular}

II. Второй цикл состоит из 17 недель. С пн. 5-й недели (по общему счету 12-й) находятся вставочные чтения (Таблица 7, подчеркнуто). 9а: пн. 1-й нд. из-за неразборчивости текста Мф. XVIII: 10-12 трудно читаемые; 73г пн. 17-й нд. слова стихов M. VI: 53 и 54 смешиваются. 
Таблица 7. (II цикл)

\begin{tabular}{|c|c|c|c|c|c|c|c|}
\hline \multicolumn{5}{|c|}{ Милятино евангелие } & \multicolumn{3}{|r|}{ Библия 2000} \\
\hline $\begin{array}{l}\text { цик } \\
\text { лы }\end{array}$ & $\begin{array}{l}\text { лист, } \\
\text { столбец }\end{array}$ & Д. & H. & Ев. & Д. & H. & Ев. \\
\hline \multirow[t]{19}{*}{ II } & $10 \mathrm{a}$ & BT. & 1 & Мф. IV: 23-24 & BT. & 1 & - \\
\hline & $14 \mathrm{a}$ & Пн. & 2 & $\begin{array}{l}\text { Mф. VI: 25-33, VII: } 13- \\
14\end{array}$ & пн. & 2 & Мф. VI: 31-34, VII: 9-11 \\
\hline & $24 \Gamma$ & Пн. & 5 & M. III: 6-12 & & & \\
\hline & $25 a$ & BT. & 5 & M. IV: 24-34 & & & \\
\hline & $25 \Gamma$ & cp. & 5 & Л. XV: $1-10$ & & & \\
\hline & $26 \mathrm{~B}$ & Чт. & 5 & M. VI: 30-39, 45 & & & \\
\hline & 276 & Пт. & 5 & M. XIII: 3-9 & & & \\
\hline & $29 a$ & BT. & 6 & - & BT. & 5 & Мф. XII: 16 \\
\hline & 306 & पT. & 6 & - & чт. & 5 & Мф. XIII: 1-3 \\
\hline & $30 \mathrm{~B}$ & Пт. & 6 & Мф. XIII: 3, 10-12 & ПТ. & 5 & - \\
\hline & $32 a$ & Пн. & 7 & Мф. XIII: 9 & Пн. & 6 & Мф. XIII: 12 \\
\hline & $43 \mathrm{~B}$ & BT. & 10 & - & BT. & 9 & Мф. XVIII: 20, XIX: 1-2 \\
\hline & $45 \Gamma$ & Пт. & 10 & - & Пт. & 9 & Мф. XXI: 17 \\
\hline & $53 \Gamma$ & ЧT. & 12 & Мф. XXIV: 29-33 & Чт. & 11 & Mф. XXIV: 13 \\
\hline & $55 \mathrm{a}$ & ПТ. & 12 & - & Пт. & 11 & Мф. XXIV: 27-33 \\
\hline & $61 \mathrm{a}$ & BT. & 14 & M. III: $20-21$ & BT. & 13 & - \\
\hline & $72 \mathrm{~B}$ & BC. & 16 & - & Bc. & 16 & Мф. XXV: 30 \\
\hline & $74 \mathrm{~B}$ & BT. & 17 & - & BT. & 16 & M. VII: 5-7 \\
\hline & $75 a$ & cp. & 17 & - & cp. & 16 & M. VII: 15 \\
\hline
\end{tabular}

III. «Следует иметь в виду, что согласно Уставу, чтение евангелия от Луки начинается с понедельника после недели по Воздвижению» (Библия 2000: 1351), в MmE с субботы. В сыропустную неделю в среду и пятницу литургии не бывает. В Библии в 20 -й нд. отсутствуют чтения на субботу. Поэтому в $M m E$ одной субботой больше: $134 \mathrm{a}$ 18-й нд. Л. ХІ: 5-13. 
Таблица 8. (III цикл)

\begin{tabular}{|c|c|c|c|c|c|c|c|}
\hline \multicolumn{5}{|c|}{ Милятино евангелие } & \multicolumn{3}{|r|}{ Библия 2000} \\
\hline $\begin{array}{l}\text { цик } \\
\text { лы }\end{array}$ & $\begin{array}{l}\text { лист, } \\
\text { столбец }\end{array}$ & Д. & H. & Ев. & Д. & H. & Ев. \\
\hline \multirow[t]{27}{*}{ III } & 826 & Пн. & 2 & - & Пн. & 2 & Л. IV: 37 \\
\hline & $86 \mathrm{~B}$ & पT. & 3 & Л. IX: 7-11 & पT. & 3 & Л. VII: $17-30$ \\
\hline & $90 \Gamma$ & сб. & 5 & Л. VII: 1 & сб. & 5 & - \\
\hline & $94 \Gamma$ & Bc. & 6 & - & Bc. & 7 & - \\
\hline & $98 \mathrm{a}$ & Bc. & 7 & - & BC. & 6 & Л. VIII: 36-37 \\
\hline & 1026 & Пн. & 8 & Л. XII: 22-31 & Пн. & 8 & Л. ХІІ: 16-21 \\
\hline & $107 \Gamma$ & ПТ. & 9 & Л.XVI: 19-31 & ПТ. & 9 & Л. XVII: $1-4$ \\
\hline & $110 \mathrm{a}$ & BT. & 10 & Л. XVIII: $1-8$ & BT. & 10 & Л. XVII: 37 \\
\hline & $111 \mathrm{a}$ & cp. & 10 & Л. XVIII: $18-25$ & cp. & 10 & Л. XVIII: 28-30 \\
\hline & $116 \mathrm{a}$ & сб. & 12 & - & сб. & 12 & Л. XIII: 18 \\
\hline & $118 \mathrm{a}$ & cp. & 12 & Л. ХXI: 8-9 & cp. & 12 & - \\
\hline & $119 \mathrm{a}$ & Пт. & 12 & - & Пт. & 12 & Л. XXII: 8 \\
\hline & $124 \mathrm{~B}$ & cp. & 14 & - & cp. & 14 & M. X: 12 \\
\hline & $125 \mathrm{~B}$ & Пт. & 14 & - & Пт. & 14 & M. X: 23 \\
\hline & 1276 & BT. & 15 & - & BT. & 15 & M. XI: 15-18 \\
\hline & $129 a$ & Bc. & 16 & - & Bc. & $\begin{array}{l}\text { (II) } \\
17\end{array}$ & - \\
\hline & $131 \Gamma$ & сб. & 17 & - & сб. & 17 & Л. XX: 45 \\
\hline & $132 \mathrm{a}$ & $\mathrm{BC}$. & 17 & - & $\mathrm{BC}$. & 16 & - \\
\hline & $134 \mathrm{a}$ & сб. & 18 & Л. XI: 5-13 & - & - & - \\
\hline & $134 \Gamma$ & BC. & 18 & - & BC. & 17 & - \\
\hline & 140в & сб. & 19 & - & сб. & 18 & - \\
\hline & $141 \mathrm{a}$ & BC. & 19 & - & Bc. & 18 & - \\
\hline & $142 \mathrm{a}$ & Пн. & 19 & M. XI: 12-14 & Пн. & 18 & - \\
\hline & 142в & BT. & 19 & Л. XXII: 43-44 & BT. & 19 & - \\
\hline & $144 a$ & Чт. & 19 & - & Чт. & 19 & Л. XXIII: 26-34, 44-56 \\
\hline & 1456 & сб. & 20 & - & сб. & 19 & - \\
\hline & $146 a$ & BC. & 20 & - & вс. & 19 & - \\
\hline
\end{tabular}


Таблица 9. (IV цикл)

\begin{tabular}{|c|c|c|c|c|c|c|c|c|}
\hline \multicolumn{6}{|c|}{ Милятино евангелие } & \multicolumn{3}{|r|}{ Библия 2000} \\
\hline $\begin{array}{l}\text { цик } \\
\text { лы }\end{array}$ & $\begin{array}{l}\text { лист, } \\
\text { столбец }\end{array}$ & Д. & $\mathrm{H}$. & & Ев. & Д. & H. & Ев. \\
\hline \multirow[t]{4}{*}{ IV } & $147 \mathrm{a}$ & BC. & 1 & - & & Bc. & 1 & И. I: 43, 45-51 \\
\hline & $148 \mathrm{a}$ & сб. & 3 & - & & сб. & 4 & - \\
\hline & $148 \Gamma$ & сб. & 4 & - & & сб. & 5 & - \\
\hline & $150 \mathrm{a}$ & сб. & 5 & - & & сб. & 3 & - \\
\hline
\end{tabular}

V. Результаты моего исследования V цикла $M m E$ не совпадают в двух случаях с данными находящимися в каталоге (Шмидт 1984: 143). Во-первых, чтения обрываются не на Страстной пятнице, как указано в каталоге, а на утрени страстного вторника: Мф. XXIII: 34, лист 159в-г. Во-вторых, в каталоге, где идет речь о принадлежности почерков стоит: «Два почерка: І-лист 1а-44г, 64а-71г, 77в-160б; II-лист 45а-63г, 72а77б». Лист 160в-г не упоминается, он упоминается лишь тогда, когда идет речь о содержании чтений: «евангелия на разные случаи - лист 160в-г». По данным моих исследований, последний лист 160а-б. Его содержание по столбцам: чтения на каждый день оканчиваются листом 159в-г, лист 160а содержит утренние воскресные евангелия 10-е и 11-е, в столбце 160а последняя строка - это начало чтений на разные случаи (над больным бесноватым, на освящение церкви, об умерших). Столбец 160а трудночитаемый, поэтому данные взяты из каталога. Окончание столбца $160 б$ содержит имя писца, его слова благодарности, имя заказчика рукописи.

Таблица 10. (V цикл)

\begin{tabular}{lllllllc}
\hline \multicolumn{9}{c}{ Милятино евангелие } \\
$\begin{array}{l}\text { цик } \\
\text { лыст, } \\
\text { столбец }\end{array}$ & Д. & Н. & Ев. & Д. & Н. & Ев. \\
\hline \hline V. & $157 \mathrm{a}$ & вт. & 6 & - & & & Мф. XXIII: 11 \\
\hline
\end{tabular}

При разделении текста $M m E$ на отдельные слова и определении глав и стихов зачал как ориентировочные работы - используются: Ягич 1960 и Kocsis 1994. 


\begin{tabular}{|c|c|c|c|c|c|}
\hline $\begin{array}{l}\text { цик } \\
\text { лы }\end{array}$ & $\begin{array}{l}\text { лист, } \\
\text { столб } \\
\text { ец }\end{array}$ & день недели & $\begin{array}{l}\text { номер } \\
\text { недели }\end{array}$ & название недели & $\begin{array}{l}\text { евангельские чтения } \\
\text { церковные на каждый } \\
\text { день }\end{array}$ \\
\hline \multirow[t]{11}{*}{ I. } & $1 \mathrm{a}$. & - & $-\quad(6)$ & & И. ХІІ: 42-47 \\
\hline & 16 & Чт. & $\overrightarrow{\mathbf{z}} \quad(6)$ & & Л. XXIV: 36-53 \\
\hline & 26 & пт. & $\overrightarrow{\mathbf{z}} \quad(6)$ & & И. XIV: 1-11 \\
\hline & $2 \Gamma$ & сб. & $\overrightarrow{\mathbf{z}} \quad(6)$ & & И. XVII: 5-13 \\
\hline & 3 в & пн. & $\vec{z} \quad(7)$ & & И. XIV: 27-31, XV: 1-7 \\
\hline & 4в & BT. & $\vec{\xi} \quad(7)$ & & И. XVI: 2-13 \\
\hline & $5 \mathrm{a}$ & cp. & $\vec{z} \quad(7)$ & & И. XVI: $15-16,18-23$ \\
\hline & $5 \Gamma$ & Чт. & $\vec{\xi} \quad(7)$ & & И. XVI: 23-33 \\
\hline & 66 & пт. & $\vec{z} \quad(7)$ & & И. XVII: $18-26$ \\
\hline & $7 \mathrm{a}$ & сб. & $\vec{z} \quad(7)$ & & И. ХХІ: $14-25$ \\
\hline & $8 \mathrm{a}$ & Bc. & $-\quad(7)$ & Пятидесятницы & И. VII: 37-52, VIII: 12 \\
\hline \multirow[t]{22}{*}{ II. } & $9 \mathrm{a}$ & пн. & $-\quad(1)$ & & Мф. XVIII: $13-20$ \\
\hline & $10 \mathrm{a}$ & BT. & $\vec{\Delta} \quad(1)$ & & Мф. IV: 23-25, V: 1-13 \\
\hline & $11 \mathrm{a}$ & cp. & $\vec{\Delta} \quad(1)$ & & Мф. V: 20-26 \\
\hline & $11 \mathrm{~B}$ & Чт. & $\vec{\Delta} \quad(1)$ & & Мф. V: 27-32 \\
\hline & 126 & пт. & $\vec{\Delta} \quad(1)$ & & Мф. V: 33-41 \\
\hline & $12 \Gamma$ & сб. & $\vec{\Delta} \quad(1)$ & & Мф. V: 42-48 \\
\hline & 136 & Bc. & $\vec{\Delta} \quad(1)$ & Всех Святых & $\begin{array}{l}\text { Мф. X: 32-33, 37-38, } \\
\text { XIX: } 27-30\end{array}$ \\
\hline & $14 \mathrm{a}$ & пн. & $\overrightarrow{\mathbf{B}} \quad(2)$ & & Мф. VI: 25-33, VII: 13-14 \\
\hline & $14 \Gamma$ & BT. & $\overrightarrow{\mathbf{E}} \quad(2)$ & & Мф. VII: 15-20 \\
\hline & $15 \mathrm{a}$ & cp. & $\overrightarrow{\mathbf{B}} \quad(2)$ & & Мф. VII: 21-23 \\
\hline & 156 & чт. & $\overrightarrow{\mathbf{B}} \quad(2)$ & & Мф. VIII: 23-27 \\
\hline & 15 в & пт. & $\overrightarrow{\mathbf{B}} \quad(2)$ & & Мф. IX: 14-17 \\
\hline & $16 \mathrm{a}$ & сб. & $\overrightarrow{\mathbf{B}} \quad(2)$ & & Мф. VII: 1-8 \\
\hline & $16 \mathrm{~B}$ & Bc. & $\overrightarrow{\mathbf{B}} \quad(2)$ & & Мф. IV: 18-23 \\
\hline & $17 \mathrm{a}$ & пн. & $\overrightarrow{\boldsymbol{\Gamma}} \quad(3)$ & & Мф. IX: 36-38, X: 1-8 \\
\hline & $17 \mathrm{~B}$ & BT. & $\overrightarrow{\boldsymbol{\Gamma}} \quad(3)$ & & Мф. X: 9-15 \\
\hline & 186 & cp. & $\overrightarrow{\boldsymbol{\Gamma}} \quad(3)$ & & Мф. X: 16-22 \\
\hline & 18 в & Чт. & $\overrightarrow{\vec{\Gamma}} \quad(3)$ & & Мф. X: 23-31 \\
\hline & 196 & Пт. & $\overrightarrow{\boldsymbol{\Gamma}} \quad(3)$ & & Мф. X: 32, 34-36, XI: 1 \\
\hline & 19 в & сб. & $\overrightarrow{\boldsymbol{\Gamma}} \quad(3)$ & & Мф. VII: 24-29, VIII: 1-4 \\
\hline & 206 & Bc. & $\vec{\Gamma} \quad(3)$ & & Мф. VI: 22-33 \\
\hline & $21 \mathrm{a}$ & пн. & $\vec{A} \quad$ (4) & & Мф.XI: 2-15 \\
\hline
\end{tabular}




\begin{tabular}{|c|c|c|c|}
\hline $21 \Gamma$ & BT. & $\vec{A} \quad(4)$ & Мф. XI: 16-20 \\
\hline $22 a$ & cp. & $\vec{A} \quad(4)$ & Мф. XI: 20-26 \\
\hline $22 \Gamma$ & ЧT. & $\vec{A} \quad(4)$ & Мф. XI: 27-30 \\
\hline $23 a$ & пт. & $\vec{A} \quad(4)$ & Мф. XII: $1-8$ \\
\hline 23 в & сб. & $\vec{A} \quad(4)$ & Мф. VIII: 14-23 \\
\hline $24 a$ & Bc. & $\vec{A} \quad(4)$ & Мф. VIII: 5-13 \\
\hline $24 \Gamma$ & пн. & $\overrightarrow{\mathrm{E}} \quad(5)$ & M. III: 6-12 \\
\hline $25 \mathrm{a}$ & Bт. & $\overrightarrow{\mathrm{E}} \quad$ (5) & M. IV: 24-34 \\
\hline $25 \Gamma$ & cp. & $\overrightarrow{\mathrm{E}} \quad(5)$ & Л. XV: 1-10 \\
\hline $26 \mathrm{~B}$ & чT. & $\vec{E} \quad$ (5) & M. VI: 30-39, 45 \\
\hline 276 & пт. & $\overrightarrow{\mathrm{E}} \quad(5)$ & M. XIII: 3-9 \\
\hline $27 \Gamma$ & сб. & $\vec{E} \quad$ (5) & Мф. IX: 9-13 \\
\hline $28 \mathrm{a}$ & Bc. & $\overrightarrow{\mathrm{E}} \quad(5)$ & Мф. VIII: 28-34, IX: 1 \\
\hline 28 в & пн. & $\overrightarrow{\mathrm{z}} \quad$ (6) & Мф. XII: 9-13 \\
\hline $29 \mathrm{a}$ & BT. & $\overrightarrow{\mathbf{z}} \quad(6)$ & Мф. XII: 14-15, 22-30 \\
\hline 29в & cp. & $\overrightarrow{\overrightarrow{\mathbf{z}}} \quad(6)$ & Мф. XII: 38-45 \\
\hline 306 & Чт. & $\overrightarrow{\mathrm{z}} \quad(6)$ & Мф. XII: 46-50 \\
\hline $30 \mathrm{~B}$ & пт. & $\overrightarrow{\mathbf{z}} \quad(6)$ & Мф. XIII: 3-12 \\
\hline $31 \mathrm{a}$ & сб. & $\overrightarrow{\mathbf{z}} \quad(6)$ & Мф. IX: 18-26 \\
\hline 31 в & вс. & $\overrightarrow{\mathbf{z}} \quad(6)$ & Мф. IX: 1-6, 8 \\
\hline $32 a$ & пн. & $\vec{\xi} \quad(7)$ & Мф. XIII: $10-11,13-23,9$ \\
\hline $33 a$ & BT. & $\vec{\xi} \quad(7)$ & Мф. XIII: 24-30 \\
\hline 33 в & cp. & $\vec{\xi} \quad(7)$ & Мф. XIII: 31-36 \\
\hline $34 a$ & чт. & $\vec{z} \quad(7)$ & Мф. XIII: 36-43 \\
\hline $34 \mathrm{~B}$ & пт. & $\vec{z} \quad(7)$ & Мф. XIII: 44-54 \\
\hline 356 & сб. & $\vec{\xi} \quad(7)$ & Мф. X: 37-42, XI: 1 \\
\hline $35 \Gamma$ & Bc. & $\vec{z} \quad(7)$ & Мф. IX: 27-35 \\
\hline 366 & пн. & $\overrightarrow{\text { и } \quad(8)}$ & Мф. XIII: 54-58 \\
\hline 36 в & BT. & $\overrightarrow{\text { H } \quad(8)}$ & Мф. XIV: 1-13 \\
\hline $37 \mathrm{a}$ & cp. & $\overrightarrow{\mathrm{H}} \quad(8)$ & $\begin{array}{l}\text { Mф. XIV: 35-36, XV: 1- } \\
11\end{array}$ \\
\hline $37 \Gamma$ & Чт. & $\overrightarrow{\text { H }} \quad(8)$ & Мф. XV: 12-21 \\
\hline 386 & пт. & $\overrightarrow{\text { ห } \quad(8)}$ & Мф. XV: 29-31 \\
\hline 38 в & сб. & $\overrightarrow{\text { H } \quad(8)}$ & Мф. XII: 30-37 \\
\hline $39 a$ & Bc. & $\overrightarrow{\text { и } \quad(8)}$ & Мф. XIV: 14-22 \\
\hline $39 \Gamma$ & Пн. & $\ddot{\theta} \quad(9)$ & Мф. XVI: 1-6 \\
\hline $40 \mathrm{a}$ & BT. & $\vec{\theta} \quad(9)$ & Мф. XVI: 6-12 \\
\hline
\end{tabular}




\begin{tabular}{|c|c|c|c|}
\hline 40в & cp. & $\vec{\theta} \quad(9)$ & Мф. XVI: 20-24 \\
\hline $40 \Gamma$ & Чт. & $\vec{\theta} \quad(9)$ & Мф. XVI: 24-28 \\
\hline 416 & пт. & $\vec{*} \quad(9)$ & Мф. XVII: 10-18. \\
\hline $41 \Gamma$ & сб. & $\vec{\theta} \quad(9)$ & Мф. XV: 32-39 \\
\hline 426 & BC. & $\ddot{\theta} \quad(9)$ & Mф. XIV: 22-34 \\
\hline $42 \Gamma$ & Пн. & $\overrightarrow{\mathbf{I}} \quad(10)$ & Мф. XVIII: 1-11 \\
\hline 43 в & BT. & $\vec{i} \quad(10)$ & $\begin{array}{l}\text { Мф. XVIII: 18-19, 21-22, } \\
\text { XIX: 13-15 }\end{array}$ \\
\hline $44 a$ & cp. & $\overrightarrow{\mathbf{I}} \quad(10)$ & Мф. XX: 1-16 \\
\hline $45 \mathrm{a}$ & Чт. & $\vec{i} \quad(10)$ & Мф. XX: 17-28 \\
\hline $45 \Gamma$ & пт. & $\ddot{i} \quad(10)$ & Мф. XXI: 12-14, 18-20 \\
\hline 466 & сб. & $\ddot{i} \quad(10)$ & $\begin{array}{l}\text { Мф. XVII: 24-27, XVIII: } \\
1-3\end{array}$ \\
\hline 46 & Bc. & $\ddot{i} \quad(10)$ & Мф. XVII: 14-23 \\
\hline 47 в & пн. & $\overrightarrow{\Delta i} \quad(11)$ & Мф. XXI: 18-22 \\
\hline $47 \Gamma$ & BT. & هï (11) & Мф. XXI: 23-27 \\
\hline 486 & cp. & $\overrightarrow{\Delta \vec{i}}(11)$ & Мф. XXI: 28-32 \\
\hline $48 \Gamma$ & чT. & هï (11) & Мф. XXI: 43-46 \\
\hline $49 \mathrm{a}$ & пт. & $\ddot{\Delta i \hat{i}} \quad(11)$ & Мф. XXII: 23-33 \\
\hline 49B & сб. & aî̀ (11) & Мф. XIX: 3-12 \\
\hline $50 \mathrm{~B}$ & BC. & $\overrightarrow{\Delta i \ddot{i}}(11)$ & Мф. XVIII: 23-35 \\
\hline 51 в & пн. & в & Мф. XXIII: 13-22 \\
\hline 526 & BT. & Вï (12) & Мф. XXIII: 23-28 \\
\hline $52 \Gamma$ & cp. & ह & Мф. XXIII: 29-39 \\
\hline $53 \Gamma$ & чт. & Вї (12) & Мф. XXIV: 13-33 \\
\hline $55 \mathrm{a}$ & пт. & в & Мф. XXIV: 42-51 \\
\hline $55 \Gamma$ & сб. & вї (12) & Мф. XX: 29-34 \\
\hline $56 a$ & Bc. & हिं & Мф. XIX: 16-26 \\
\hline $57 \mathrm{a}$ & пн. & гї (13) & M. I: 9-15 \\
\hline 576 & BT. & & \\
\hline 57 в & - & гї (13) & M. I: $16-22$ \\
\hline $57 \Gamma$ & cp. & гї (13) & M. I: 23-28 \\
\hline 586 & чт. & гї (13) & M. I: 29-35 \\
\hline $58 \Gamma$ & пт. & гї (13) & M. II: 18-22 \\
\hline 59 & сб. & гї (13) & Мф. XXII: 15-22 \\
\hline $59 \Gamma$ & Bc. & तें (13) & Мф. XXI: 33-42 \\
\hline 60в & пн. & $\vec{A} \quad(14)$ & M. III: 6-12 \\
\hline
\end{tabular}




\begin{tabular}{|c|c|c|c|c|}
\hline & $61 \mathrm{a}$ & BT. & $\vec{A} \quad(14)$ & M. III: $13-21$ \\
\hline & 61 в & cp. & $\vec{A} \quad(14)$ & M. III: 20-27 \\
\hline & $62 \mathrm{a}$ & чТ. & $\vec{A} \quad(14)$ & M. III: 28-35 \\
\hline & 62 в & Пт. & $\vec{A} \quad(14)$ & M. IV: 1-9 \\
\hline & $63 a$ & сб. & $\dot{A \ddot{I}}(14)$ & Мф. XXIII: 1-12 \\
\hline & $63 \Gamma$ & Bc. & $\vec{A} \quad(14)$ & Мф. XXII: 2-14 \\
\hline & $64 \mathrm{~B}$ & пн. & $\overrightarrow{\mathrm{EI}} \quad(15)$ & M. IV: $10-23$ \\
\hline & 65 в & BT. & $\overrightarrow{\mathbf{E}} \quad(15)$ & M. IV: 24-34 \\
\hline & $66 a$ & сp. & $\overrightarrow{\mathrm{EI}} \quad(15)$ & M. IV: 35-41 \\
\hline & 66в & чт. & $\overrightarrow{\mathrm{EI}} \quad(15)$ & M. V: 1-20 \\
\hline & 67 в & Пт. & $\overrightarrow{\mathrm{EI}} \quad(15)$ & M. V: 22-24, 35-43, VI: 1 \\
\hline & $68 \mathrm{a}$ & сб. & $\overrightarrow{\mathbf{E}} \quad(15)$ & Мф. XXIV: 1-13 \\
\hline & $68 \Gamma$ & BC. & $\overrightarrow{\mathbf{E I}} \quad(15)$ & Мф. XXII: 35-46 \\
\hline & 696 & пн. & $\overrightarrow{\text { aี } \quad(16)}$ & M. V: 24-34 \\
\hline & $69 \Gamma$ & BT. & $\overrightarrow{\text { | }} \quad(16)$ & M. VI: $1-7$ \\
\hline & $70 \mathrm{a}$ & cp. & 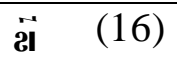 & M. VI: 7-13 \\
\hline & 70 в & ЧT. & $\overrightarrow{\text { aี } \quad(16)}$ & M. VI: $30-45$ \\
\hline & 71 в & пт. & $\overrightarrow{\text { a }} \quad$ (16) & M. VI: 45-53 \\
\hline & $72 \mathrm{a}$ & сб. & 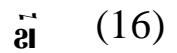 & Мф. XXIV: 34-44 \\
\hline & $72 \mathrm{~B}$ & $\mathrm{BC}$. & $\overrightarrow{\text { มี } \quad(16)}$ & Мф. XXV: 14-29 \\
\hline & $73 \Gamma$ & пн. & $\vec{\xi} \mathbf{i} \quad(17)$ & M. VI: $53,55-56$, VII: $1-8$ \\
\hline & $74 \mathrm{~B}$ & BT. & $\overrightarrow{y \mid} \quad(17)$ & M. VII: $8-16$ \\
\hline & $75 a$ & cp. & $\overrightarrow{y \mid} \quad(17)$ & M. VII: $14,17-23,16,24$ \\
\hline & $75 \Gamma$ & чт. & $\overrightarrow{z \mid} \quad(17)$ & M. VII: $24-30$ \\
\hline & $76 a$ & пт. & $\vec{\xi} \quad(17)$ & Мф. VIII: $1-10$ \\
\hline & $76 \Gamma$ & сб. & $\overrightarrow{\xi I} \quad(17)$ & Мф. XXV: 1-13 \\
\hline & 776 & Bc. & $\overrightarrow{\xi i} \quad(17)$ & Мф. XV: 21-28 \\
\hline III. & $77 \Gamma$ & сб. & $\vec{\Delta} \quad(1)$ & Л. IV: 31-36 \\
\hline & 786 & Bc. & $\vec{\Delta} \quad(1)$ & Л. V: 1-11 \\
\hline & $78 \Gamma$ & пн. & $\vec{\Delta} \quad(1)$ & Л. III: 19-22 \\
\hline & $79 a$ & BT. & $\vec{\Delta} \quad(1)$ & Л. III: 23-38, IV: 1 \\
\hline & $79 \Gamma$ & cp. & $\vec{\Delta} \quad(1)$ & Л. IV: $1-15$ \\
\hline & 806 & чт. & $\vec{\Delta} \quad(1)$ & Л. IV: 16-22 \\
\hline & $80 \Gamma$ & Пт. & $\vec{\Delta} \quad(1)$ & Л. IV: 22-30 \\
\hline & 816 & сб. & $\overrightarrow{\mathbf{E}} \quad(2)$ & Л. V: $17-26$ \\
\hline & $82 a$ & Bc. & $\overrightarrow{\mathbf{B}} \quad(2)$ & Л. VI: 31-36 \\
\hline
\end{tabular}




\begin{tabular}{|c|c|c|c|}
\hline 826 & Пн. & $\overrightarrow{\mathbf{B}} \quad(2)$ & Л. IV: 38-44 \\
\hline $82 \Gamma$ & BT. & $\overrightarrow{\mathbf{B}} \quad(2)$ & Л. V: 12-16 \\
\hline $83 a$ & cp. & $\overrightarrow{\mathbf{E}} \quad(2)$ & Л. V: 33-36 \\
\hline 83 в & чт. & $\overrightarrow{\mathbf{E}} \quad(2)$ & Л. VI: 12-19 \\
\hline $84 a$ & пт. & $\overrightarrow{\mathbf{E}} \quad(2)$ & Л. VI: 17-23 \\
\hline $84 \mathrm{~B}$ & сб. & $\overrightarrow{\boldsymbol{\Gamma}} \quad(3)$ & Л. V: 27-32 \\
\hline $84 \Gamma$ & BC. & $\overrightarrow{\boldsymbol{\Gamma}} \quad(3)$ & Л. VII: 11-16 \\
\hline $85 a$ & пн. & $\overrightarrow{\boldsymbol{\Gamma}} \quad(3)$ & Л. VI: 24-30 \\
\hline $85 \mathrm{~B}$ & BT. & $\overrightarrow{\vec{\Gamma}} \quad(3)$ & Л. VI: 37-45 \\
\hline $86 a$ & cp. & $\vec{\Gamma} \quad(3)$ & Л. VI: 46-49, VII: 1 \\
\hline $86 \mathrm{~B}$ & Чт. & $\vec{\Gamma} \quad(3)$ & Л. ІХ: 7-11 \\
\hline $86 \Gamma$ & пт. & $\vec{\Gamma} \quad(3)$ & Л. VII: 31-35 \\
\hline $87 \mathrm{a}$ & сб. & $\vec{A} \quad(4)$ & Л. VI: $1-10$ \\
\hline $87 \Gamma$ & Bc. & $\vec{A} \quad$ (4) & Л. VIII: 5-15 \\
\hline 88 в & пн. & $\vec{A} \quad$ (4) & Л. VII: 36-50 \\
\hline 896 & BT. & $\vec{A} \quad$ (4) & Л. VIII: $1-3$ \\
\hline 89в & cp. & $\vec{A} \quad$ (4) & Л. VIII: 22-25 \\
\hline $89 \Gamma$ & Чт. & $\vec{A} \quad$ (4) & Л. ІХ: 7-11 \\
\hline 906 & Пт. & $\vec{A} \quad$ (4) & Л. IX: 12-18 \\
\hline $90 \Gamma$ & сб. & $\vec{E} \quad(5)$ & Л. VII: 1 -10 \\
\hline 916 & Bc. & $\vec{E} \quad$ (5) & Л. XVI: 19-31 \\
\hline $92 \mathrm{a}$ & пн. & $\overrightarrow{\boldsymbol{E}} \quad(5)$ & Л. IX: 18-22 \\
\hline 926 & BT. & $\overrightarrow{\boldsymbol{E}} \quad(5)$ & Л. IX: 23-27 \\
\hline $92 \Gamma$ & cp. & $\overrightarrow{\mathrm{E}} \quad$ (5) & Л. ІХ: 44-50 \\
\hline $93 a$ & чт. & $\vec{E} \quad(5)$ & Л. IX: 49-56 \\
\hline 93 в & пт. & $\vec{E} \quad(5)$ & Л. Х: $1-15$ \\
\hline 946 & сб. & $\overrightarrow{\mathbf{a}} \quad(6)$ & Л. VIII: 16-21 \\
\hline $94 \Gamma$ & Bc. & $\overrightarrow{\mathbf{z}} \quad(6)$ & Л. VIII: 41-56 \\
\hline $95 \Gamma$ & пн. & $\begin{array}{ll}\overrightarrow{\mathbf{z}} \quad(6) \\
\end{array}$ & Л. X: 22-24 \\
\hline $96 a$ & BT. & $\overrightarrow{\mathbf{z}} \quad(6)$ & Л. XI: $1-10$ \\
\hline 96 в & cp. & $\overrightarrow{\mathrm{a}} \quad$ (6) & Л. ХІ: 9-13 \\
\hline $96 \Gamma$ & Чт. & $\overrightarrow{\mathbf{z}} \quad(6)$ & Л. ХІ: 14-23 \\
\hline 976 & пт. & $\overrightarrow{\mathbf{z}} \quad(6)$ & Л. XI: 23-26 \\
\hline $97 \mathrm{~B}$ & сб. & $\vec{\xi} \quad(7)$ & Л. IX: 1-6 \\
\hline $98 \mathrm{a}$ & Bc. & $\vec{\xi} \quad(7)$ & Л. VIII: 26-35, 38-39 \\
\hline $98 \Gamma$ & пн. & $\vec{\xi} \quad(7)$ & Л. ХІ: 29-33 \\
\hline
\end{tabular}




\begin{tabular}{|c|c|c|c|}
\hline $99 a$ & BT. & $\vec{\xi} \quad(7)$ & Л. XI: 34-41 \\
\hline 99 в & сp. & $\vec{\xi} \quad(7)$ & Л. XI: 42-46 \\
\hline $100 \mathrm{a}$ & Чт. & $\vec{\xi} \quad(7)$ & Л. XI: 47-54, XII: 1 \\
\hline 100в & Пт. & $\vec{\xi} \quad(7)$ & Л. XII: 2-12 \\
\hline $101 \mathrm{a}$ & сб. & $\overrightarrow{\mathbf{H}} \quad(8)$ & Л. IX: 37-43 \\
\hline $101 \mathrm{~B}$ & Bc. & $\overrightarrow{\mathbf{H}} \quad(8)$ & Л. X: 25-37 \\
\hline 1026 & пн. & $\overrightarrow{\mathbf{H}} \quad(8)$ & Л. XII: $13-21$ \\
\hline $102 \Gamma$ & BT. & $\overrightarrow{\text { H }} \quad(8)$ & Л. ХІІ: 42-48 \\
\hline 1036 & cp. & $\overrightarrow{\text { H }} \quad(8)$ & Л. XII: 48-59 \\
\hline $103 \Gamma$ & чт. & $\overrightarrow{\text { ห }} \quad(8)$ & Л. XIII: 1-9 \\
\hline $104 \mathrm{~B}$ & Пт. & $\overrightarrow{\mathbf{H}} \quad(8)$ & Л. ХІІІ: 31-35 \\
\hline $104 \Gamma$ & сб. & $\ddot{\theta} \quad(9)$ & Л. IX: 57-62 \\
\hline 1056 & BC. & $\vec{\theta} \quad(9)$ & Л. XII: 16-21 \\
\hline $105 \mathrm{~B}$ & пн. & $\vec{\theta} \quad(9)$ & Л. XIV: 1, 12-15 \\
\hline $105 \Gamma$ & BT. & $\vec{\theta} \quad(9)$ & Л. XIV: 25-35 \\
\hline $106 \mathrm{~B}$ & cp. & $\vec{\theta} \quad(9)$ & Л. XV: $1-10$ \\
\hline 1076 & чт. & $\ddot{\theta} \quad(9)$ & Л. XVI: $1-9$ \\
\hline $107 \Gamma$ & пт. & $\vec{\theta} \quad(9)$ & Л. XVI: 15-31 \\
\hline $109 \mathrm{a}$ & сб. & $\overrightarrow{\mathbf{i}} \quad(10)$ & Л. Х: 19-21 \\
\hline 1096 & BC. & $\overrightarrow{\mathbf{I}} \quad(10)$ & Л. XIII: 10-17 \\
\hline $109 \Gamma$ & пн. & $\overrightarrow{\mathbf{i}} \quad(10)$ & Л. XVII: 20-25 \\
\hline $110 \mathrm{a}$ & BT. & $\overrightarrow{\mathbf{i}} \quad(10)$ & $\begin{array}{l}\text { Л. XVII: 26-36, XVIII: 1- } \\
8\end{array}$ \\
\hline $111 \mathrm{a}$ & cp. & $\overrightarrow{\mathbf{i}} \quad(10)$ & Л. XVIII: $15-27$ \\
\hline $111 \Gamma$ & чт. & $\overrightarrow{\mathbf{i}} \quad(10)$ & Л. XVIII: 31-34 \\
\hline $112 \mathrm{a}$ & Пт. & $\overrightarrow{\mathbf{i}} \quad(10)$ & Л. XIX: 12-28 \\
\hline $112 \Gamma$ & сб. & $\overrightarrow{\Delta \mathbf{I}} \quad(11)$ & Л. XII: $32-40$ \\
\hline 1136 & Bc. & $\overrightarrow{\Delta \mathbf{l}} \quad(11)$ & Л. XIV: 16-24 \\
\hline $114 \mathrm{a}$ & пн. & $\overrightarrow{\Delta \mathbf{I}} \quad(11)$ & Л. XIX: 37-44 \\
\hline 1146 & BT. & $\overrightarrow{\Delta \mathbf{I}} \quad(11)$ & Л. ХІХ: 45-48 \\
\hline $114 \mathrm{~B}$ & cp. & $\overrightarrow{\Delta \mathbf{A}} \quad(11)$ & Л. XX: $1-8$ \\
\hline $115 \mathrm{a}$ & Чт. & $\overrightarrow{\Delta \mathrm{I}} \quad(11)$ & Л. XX: 9-18 \\
\hline $115 \mathrm{~B}$ & пт. & $\overrightarrow{\Delta \mathbf{A}} \quad(11)$ & Л. XX: 19-26 \\
\hline $116 a$ & сб. & $\overrightarrow{\text { BI }} \quad(12)$ & Л. XIII: 19-29 \\
\hline $116 \mathrm{~B}$ & Bc. & $\overrightarrow{\text { हI }} \quad(12)$ & Л. XVII: $12-19$ \\
\hline $117 \mathrm{a}$ & Пн. & $\overrightarrow{\text { BI }} \quad(12)$ & Л. XX: 27-44 \\
\hline $177 \Gamma$ & BT. & $\overrightarrow{\text { EI }} \quad(12)$ & Л. XXI: 12-19 \\
\hline
\end{tabular}




\begin{tabular}{|c|c|c|c|}
\hline $118 \mathrm{a}$ & cp. & $\overrightarrow{\text { Bi }} \quad(12)$ & Л. XXI: 5-11, 20-24 \\
\hline $118 \Gamma$ & Чт. & $\overrightarrow{\mathbf{E I}} \quad(12)$ & Л. ХХІ: 28-33 \\
\hline $119 a$ & пт. & $\overrightarrow{\mathbf{B}} \quad(12)$ & Л. XXI: 37-38, XII: $1-7$ \\
\hline $119 \mathrm{~B}$ & сб. & $\overrightarrow{\Gamma I} \quad(13)$ & Л. XIV: 1-11 \\
\hline $120 \mathrm{a}$ & Bc. & $\overrightarrow{\Gamma I} \quad(13)$ & Л. XVIII: 18-27 \\
\hline $120 \Gamma$ & Пн. & $\overrightarrow{\Gamma \mathbf{r}} \quad(13)$ & M. VIII: $11-21$ \\
\hline 1216 & BT. & $\overrightarrow{\Gamma I} \quad(13)$ & M. VIII: 22-26 \\
\hline 121в & cp. & $\vec{\Gamma} \quad(13)$ & M. VIII: 30-34 \\
\hline $122 \mathrm{a}$ & Чт. & $\begin{array}{ll}\vec{\Gamma} \mathbf{I} & (13)\end{array}$ & M. IX: 10-16 \\
\hline 1226 & пт. & $\overrightarrow{\Gamma \mathbf{I I}} \quad(13)$ & M. IX: 33-41 \\
\hline $122 \Gamma$ & сб. & $\vec{A} \quad(14)$ & Л. XVI: $10-15$ \\
\hline 1236 & BC. & $\vec{A} \quad(14)$ & Л. XVIII: $35-43$ \\
\hline 123 в & пн. & $\vec{A} \quad$ (14) & M. IX: 42-50, X 1 \\
\hline 1246 & BT. & $\vec{A} \quad(14)$ & M. X: 2-12 \\
\hline $124 \mathrm{~B}$ & cp. & $\vec{A} \quad$ (14) & M. X: 11, 13-16 \\
\hline $124 \Gamma$ & Чт. & $\vec{A} \quad(14)$ & M. X: 17-24, 26-27 \\
\hline $125 \mathrm{~B}$ & пт. & $\vec{A} \quad$ (14) & M. X: 24-32 \\
\hline $126 a$ & сб. & $\overrightarrow{\mathrm{EI}} \quad(15)$ & Л. XVII: 3-10 \\
\hline 1266 & Bc. & $\overrightarrow{\mathrm{EI}} \quad(15)$ & Л. XIX: 1-10 \\
\hline $126 \Gamma$ & пн. & $\overrightarrow{\mathrm{EI}} \quad(15)$ & M. X: 46-52 \\
\hline 1276 & BT. & $\overrightarrow{\mathrm{EI}} \quad(15)$ & M. XI: 11-14, 19-23 \\
\hline $127 \Gamma$ & cp. & $\overrightarrow{\mathrm{EI}} \quad(15)$ & M. XI: 23-26 \\
\hline $128 \mathrm{a}$ & чт. & $\overrightarrow{\mathrm{EI}} \quad(15)$ & M. XI: 27-33 \\
\hline 1286 & пт. & $\overrightarrow{\mathrm{EI}} \quad(15)$ & M. XII: 1-12 \\
\hline $128 \Gamma$ & сб. & $\overrightarrow{\text { à } \quad(16)}$ & Л. XVIII: 2-8 \\
\hline $129 a$ & Bc. & $\overrightarrow{\text { à } \quad(16)}$ & Mф. XV: 21-28 \\
\hline 129B & пн. & $\overrightarrow{\text { à } \quad(16)}$ & M. XII: 13-17 \\
\hline $129 \Gamma$ & BT. & $\overrightarrow{\text { aิ } \quad(16)}$ & M. XII: $18-27$ \\
\hline 1306 & cp. & - $\quad(16)$ & M. XII: 28-37 \\
\hline $130 \Gamma$ & чT. & $\overrightarrow{\text { aี } \quad(16)}$ & M. XII: 38-44 \\
\hline 1316 & пт. & $\overrightarrow{\text { aี } \quad(16)}$ & M. XIII: 1-8 \\
\hline $131 \Gamma$ & сб. & $\overrightarrow{\xi i} \quad(17)$ & Л. XX: 46-47, XXI: $1-4$ \\
\hline $132 \mathrm{a}$ & Bc. & $\vec{\xi} \quad$ (17) & Л. XVIII: 10-14 \\
\hline 1326 & пн. & $\overrightarrow{\xi I} \quad(17)$ & M. XIII: 9-13 \\
\hline 132 в & BT. & $\vec{\xi} \quad(17)$ & M. XIII: $14-23$ \\
\hline $133 a$ & cp. & $\overrightarrow{\eta \mathbf{I}} \quad(17)$ & M. XIII: 24-31 \\
\hline
\end{tabular}




\begin{tabular}{|c|c|c|c|c|c|}
\hline & 133в & ЧТ. & $\vec{\xi} \quad(17)$ & & M. XIII: 31-37, XIV: 1-2 \\
\hline & $133 \Gamma$ & пт. & $\overrightarrow{\xi i} \quad(17)$ & & M. XIV: 3-9 \\
\hline & $134 a$ & сб. & 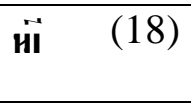 & $\begin{array}{l}\text { Неделя } \\
\text { мясопустная }\end{array}$ & Л. XI: 5-13 \\
\hline & $134 \Gamma$ & Bc. & & & Л. XV: $11-32$ \\
\hline & $135 \Gamma$ & пн. & & & M. XI: 1-11 \\
\hline & 1366 & BT. & & & M. XIV: $10-42$ \\
\hline & $137 \Gamma$ & cp. & & & M. XIV: 43-72, XV: 1 \\
\hline & 1396 & Чт. & & & M. XV: $1-15$ \\
\hline & $140 \mathrm{a}$ & пт. & & & M. XV: 16-32 \\
\hline & 140в & сб. & (19) & $\begin{array}{l}\text { Неделя } \\
\text { сыропустная }\end{array}$ & Л. XXI: 8-9, 25-27, 33-36 \\
\hline & $141 \mathrm{a}$ & Bc. & & & Мф. XXV: $31-46$ \\
\hline & $142 a$ & пн. & & & M. XI: $1-14$ \\
\hline & 142в & BT. & & & Л. XXII: 39-71, XXIII: 1 \\
\hline & $144 \mathrm{a}$ & Чт. & & & Л. XXIII: $1-25$ \\
\hline & 1456 & сб. & & & Мф. VI: 1-13 \\
\hline & $146 a$ & BC. & & & Мф. VI: $14-21$ \\
\hline IV. & 146в & $\begin{array}{l}\text { сб. первая } \\
\text { святого } \\
\text { великого } \\
\text { поста }\end{array}$ & (1) & & M. II: 23-28, III: $1-5$ \\
\hline & $147 \mathrm{a}$ & $\begin{array}{l}\text { вс. первое } \\
\text { святого } \\
\text { великого } \\
\text { поста }\end{array}$ & (1) & & И. I: 44 \\
\hline & 1476 & сб. - & (2) & & M. I: $35-44$ \\
\hline & 147 в & Bc. - & (2) & & M. II: $1-12$ \\
\hline & $148 \mathrm{a}$ & сб. - & (3) & & M. VII: 31-37 \\
\hline & 148 в & BC. - & (3) & & M. VIII: 34-38, IX: 1 \\
\hline & $148 \Gamma$ & сб. - & (4) & & M. VIII: 27-31 \\
\hline & $149 \mathrm{a}$ & BC. - & (4) & & M. IX: 17-31 \\
\hline & $150 \mathrm{a}$ & сб. - & $(5)$ & & M. II: $14-17$ \\
\hline & 1506 & Bc. - & (5) & & M. X: 32-45 \\
\hline & $151 \mathrm{a}$ & сб. - & (6) & & И. ХІ: 1-45 \\
\hline & $152 \Gamma$ & $\begin{array}{l}\text { вс. вербное } \\
\text { или } \\
\text { цветоносное }\end{array}$ & (6) & & $\begin{array}{l}\text { на утрени } \\
\text { Мф. XXI: } 1-11,15-17\end{array}$ \\
\hline & 153в & - & - & & $\begin{array}{l}\text { на литургии } \\
\text { И. XII: } 1-18\end{array}$ \\
\hline V & 1546 & Святой и & & Страстная & на утрени \\
\hline
\end{tabular}




\begin{tabular}{|l|l|l|l|l|l|}
\hline & великий пн. & & неделя & Мф. XXI: 18-43 \\
\hline & 155 - & - & & на литургии \\
& & & Мф. XXIV: 3-35 \\
\hline & 157 a & Святой и & & на утрени \\
& великий вт. & & Мф. XXII: 15- 46, XXIII: \\
& & & $1-10,12-34$ \\
\hline
\end{tabular}




\section{Литература}

Алексеев - Алексеев, А. А., Лихачева, О. П., Словарь книжников и книжности древней Руси. XI- первая половина XIV в. Л. 1987.

Антошків - Антошків, Г., Вставні та випадні о, е наприкінці слова // Hungaro-Ruthenica V, Szeged, 2011, 29-35.

Антошкив - Антошкив, Г., Церковный календарь с соответствующими чтениями Милятиного евангелия и их место в тексте // Acta Universitatis Szegediensis Dissertationes Slavicae Sectio Linguistica XXIX, 2011, 5-17.

Археографический ежегодник - Археографический ежегодник за 1965 год, Моска: «Наука», 1966.

Баймут - Баймут, Т. В., Бойчук, М. К., Волинський, М. К., Жовтобрюх, Т. П., Малина, Т. П., Самійленко, С. П., Порівняльна граматика украӥнської і російської мов, Київ: «Радянська школа», 1957.

Балаж - Г. Л. Балаж, Морфология Будапештского евангелия (Имена, местоимения, причастия) //Будапештское евангелие, под ред.: Й. Заимов, И. Х. Тот, Г.Л. Балаж; авторы и сотрудники: Е. Дограмаджиева, Х. Майорош, Г. Л. Балаж, М. Кочиш, И. Пожгаи, И. Х. Тот, Сегед: Szegedi Tudományegyetem Bölcsészettudományi Kar Szláv Intézete, 2003, 49-65.

Бевзенко - Бевзенко, С. П., Грищенко, А. П., Лукінова, Т. М., Німчук, В. В., Русанівський, В. М., Самійленко, С. П., Історія украӥнської мови, Київ: Наукова думка, 1978.

Библия, книги священного писания Ветхого и Нового Завета, Москва: Российское Библейское Общество, 2000.

Библия, 1990; Cinisello Balsamo (Milano).

Бодуэн де Куртенэ - Бодуэн де Куртенэ А. И., Заметки об изменяемости основ склонения // Сборник статей посвященных Ф. Ф. Фортунатову, Варшава, 1902, 234248.

Букатевич - Букатевич, Н. И., Савицкая, С. А., Усачева, Л. Я., Историческая грамматика русского языка, «Вища школа», 1974.

Вайан - Вайан А., Руководство по старославянскому языку, пер. В. В. Бородич, Москва: изд. Иностранной литературы, 1952/1948.

Ван-Вейк - Ван-Вейк Н., История старославянского языка, Москва: изд. Иностранной литературы, 1957.

Горшкова - Горшкова, К. В., Историческая диалектология русского языка, Москва: «Просвещение», 1972.

Горшкова - Горшкова, К. В., Хабургаев, Г. А., Историческая грамматика русского языка, Москва: «Высшая школа», 1981.

Грунський - Грунський, М. К., Вступ до слов'янського мовознавства, Київ-Львів: Радянська школа, 1946.

Дурново - Дурново, Н. Н., Введение в историю русского языка, Москва: Наука, 1969.

Елкина - Елкина, Н. М., Старославянский язык, Москва: Государственное учебнопедагогическое издательство министерства просвещения РСФСР, 1960. 
Живов - Живов, В. М., Автономность письменного узуса и проблема преемственности в восточнославянской средневековой письменности //Славянское языкознание, XII Международный съезд славистов, Краков, 1998 г. Доклады российской делегации /Отв. ред. О. Н. Трубачев, Москва, 1998, 212-247.

Живов - Живов, В. М., Норма, вариативность и орфографические правила в восточнославянском правописании XI - XIII века. Восточнославянское правописание XI - XIII века //Studia Philollogica, Москва: Языки славянской культуры, 2006, 9-75.

Живов - Живов, В. М., Проблемь формирования русской редакции церковнославянского языка на начальном этапе. Восточнославянское правописание XI - XIII века //Studia Philollogica, Москва: Языки славянской культуры, 2006, 225259.

Живов - Живов, В. М., Хоу-ть-н. Об идиосинкратических факторах при выборе морфологических вариантов. Восточнославянское правописание XI - XIII века //Studia Philologica, Москва: Языки славянской культуры, 2006, 220-224.

Жовтобрюх - Жовтобрюх, М. А.; Русанівський, В. М.; Скляренко В. Г., Iсторія української мови (Фонетика), Київ: Наукова думка, 1979.

Журавлев - Журавлев, В. К., Из истории вокализма в праславянском языке позднего периода // Вопросы языкознания №2, 1963, 8-19.

Жуковская - Жуковская, Л. П., Текстология и язык древнейших славянских памятников, Москва: Наука, 1976.

Зализняк - Зализняк, А. А., Древненовгородский диалект, 2-е изд., Москва: Языки славянской культуры, 2004.

Иванов - Иванов, В. В., Историческая грамматика русского языка, Москва: «Просвещение», 1964.

Иванова - Иванова, Т. А., Старославянский язык, 2-е изд., испр. и доп., СанкПетербург: из. С.-Петербурского университета, 1998.

Камчатнов - Хрестоматия по истории русского литературного языка. Памятники $\mathrm{X}-$ XIV веков по рукописям X-XVII веков, Москва, 2009, 459-492.

Карский - Карский, Е. Ф., Славянская кирилловская палеография, Москва: Наука, 1979.

Кульбакин - Кульбакин. С. М., Материаль для характеристики среднеболгарского языка, Выпуск первый. Боянское евангелие XII - XIII в., 1899.

Медведєв - Медведєв, Ф. П., Нариси з украӥнської історичної граматики, Харків: державний університет ім. О. М. Горького, 1964.

Мейе - Мейе А., Общеславянский язык, Москва: изд. Иностранной литературы, 1951.

Мещерский - Русская диалектология, под ред. проф. Мещерского, Н. А., Москва: «Высшая школа», 1972.

Петер - Петер, М., Историческая грамматика русского языка, Budapest: Tankönyvkiadó, 1976.

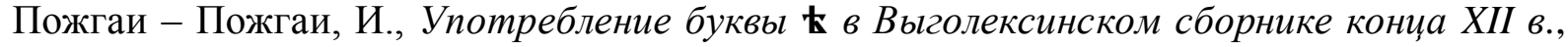
Hungaro-Ruthenica IV, Szeged: Kiadja a Szegedi Tudományegyetem Szláv Filológiai Tanszéke, 2008, 175-190. 
Преображенский - Преображенский, А., Словарь русского языка, т. 1: А-О, т. 2: П-С, Москва: Типография Г. Лисонера и Д. Совко, 1910-1914.

Семереньи - Семереньи, О, Введение в сравнительное языкознание, Москва: «Прогресс», 1980.

Селищев - Селищев, А. М., Старославянский язык, т. 1, Москва: Государственное учебно-педагогическое издательство министерства просвещения РСФСР, 1951.

Соболевский - Соболевский, А. Н., История русского литературного языка, Ленинград, 1980.

Соколова - Соколова, М. А., Очерки по исторической грамматике русского языка, Ленинград: Издательство Ленинградского университета, 1962.

Срезневский - Срезневский, И. И., Матеріаль для словаря древне-русскаго языка, т.1, Санктпетербургъ: Типографія императорской Академіи наук, 1893.

Стоянов - Стоянов, С., Янакиев, М., Старобългарски език. Текстове и речник, София: Наука и изкуство, 1972.

Толстой - Толстой, Н. И., $K$ вопросу о древнеславянском языке как общем литературном языке южных и восточных славян // Вопросы языкознания №1, 1961, $55-66$.

Успенский - Успенский, Б. А., История русского литературного языка (XI - XVII вв.), München, 1987.

Успенский - Успенский, Б. А., История русского литературного языка (XI - XVII вв.), 3-е изд. Москва: Аспект пресс, 2002.

Фасмер - Фасмер М., Этимологический словарь русского языка, т. 1-4. Пер. с нем. и доп. О. Н. Трубачева, Москва: «Прогресс», 1987.

Феринц - Феринц, И., Древнерусское и барочное понимание слов «книга» и «писатель» // Hungaro-Ruthenica V, Szeged, 2011, 83-91.

Филин - Филин, Ф. П., Происхождение русского, украинского и белорусского языков: Историко-диалектологический очерк, Москва: КомКнига, 2006.

X. Тот - Х. Тот, И., Древнейшая русская часть Саввиной книги, Сегед: JATEPress, 1995.

Х. Тот - Х. Тот, И., Житие Фекль //Studia Slavica Hung. XXII, Budapest: Akadémiai Kiadó, 1976, 233-270.

Х. Тот - Х. Тот, И., К изучению русской редакции древнеболгарского языка в конце XIв начале XII вв. //Studia Slavica Hung. XXXI, Budapest: Akadémiai Kiadó, 1985, 263272.

Х. Тот - Х. Тот, И., К истории праславянских звукосочетаний *tъrt, *tьrt в болгарском и русском языках //Hungaro-Ruthenica IV, Szeged. 2008, 223-228.

Х. Тот - Х. Тот, И., К истории склонения имен существительных в русском языке //Actа Universitatis Szegediensis de Attila József Nominatae (Материалы и сообщения по славяноведению), Szeged: 1962, 5-20.

Х. Тот - Х. Тот. И., Габор Л. Балаж, Иштван Пожгаи, Софийски евангелски фрагмент № 25 //Studia Paleoslavica V, Szeged. 2006, 89-112.

Хабургаев - Хабургаев, Г. А. Становление русского языка, Москва: «Высшая школа», 1980. 
Цейтлин - Старославянский словарь (по рукописям X - XI веков) под ред.: Цейтлин, Р. М., Вечерки, Р., Благовой Э., Москва: «Русский язык», 1994.

Шахматов - Шахматов, А. А., Исследование о языке новгородских грамот XIII и XIVвв. //Исследования по русскому языку, т. 1, 1885-1895.

Шахматов - Шахматов, А. А., Историческая морфология русского языка, Москва: Государственное учебно-педагогическое издательство министерства просвещения РСФСР, 1957.

Шевельов - Шевельов, Ю., Історична фонологія украйнської мови, Харків: АКТА, 2002.

Шмидт - Сводный каталог славяно-русских рукописных книг, хранящихся в СССР XIХІІІ вв., гл. редактор С. О. Шмидт, Москва: Наука, 1984.

Щепкин - Щепкин, В. Н., Русская палеография, Москва: Издательство «Наука», 1967.

Ягич - Ягич, И. В., Маріинское четвероевангеліе (Codex Marianus), Graz: Akademische Druck. U. Verlagsanstalt, 1960.

Antoskiv - Antoskiv, G., A második teljeshangzósság a Miljatyin-evangéliumban (XII. sz. vége - XIII. sz. eleje) //Bölcsészmühely 2009, Szeged: JATEPress, 2010, 9-14.

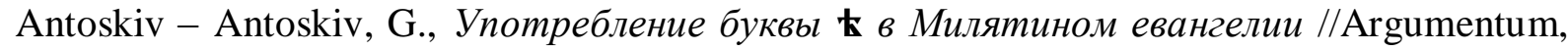
7, Debrecen: Debreceni Egyetemi Kiadó, 2011, 176-183.

Bakró-Nagy - Bakró-Nagy Marianne, Az adat a történeti nyelvészetben: megnilatkozás, forrás, megbizhatóság //Argumentum, 6, Debrecen: Debreceni Egyetemi Kiadó, 2010, 124-167.

Balázs - Balázs L. Gábor, A szláv fönévragozás történeti vizsgálatának metodológiai vonatkozásai, Szeged: JATEPress, 1999.

Baleczky - Baleczky Emil, Hollós, Attila, Ószláv nyelv, Budapest, 1968.

Brugmann - Brugmann, Károly, Kurze vergleichende Grammatik der indogermanischen Sprachen, Zu S. 399 (Übersichtstabelle zur nominalen Kasusbildung), Strassburg, 1904.

Kurz - Slovník Jazyka Staroslověnského, hlavní redaktor Kurz Josef, Praha, 1958.

H. Tóth - H. Tóth Imre, Bevezetés a szláv nyelvtudományba, Szeged: JATEPress, 1996.

H. Tóth H. - H. Tóth Imre, Cirill-Konstantin és Metód élete, működése, Szeged: Bába Kiadó, 2003.

H. Tóth - H. Tóth Imre, Balázs L. Gábor, Pozsgai István, Segédkönyv a bolgár nyelv történetének tanulmányozásához. Óbolgár (ószláv) korszak, Szeged, 2005.

Jagić - Jagić, V., Über einige Erscheinungen des slavischen Vokalismus //Arhiv für slavische Philologie, Berlin 1, 1876, 337-412.

Kocsis - Kocsis M., A Register of Initial Words in Gospel Verses, Szombathely. 1994.

Leskien - Leskien A., Grammatik der Altbulgarischen Sprache, Heidelberg. Carl Winter's Universitätsbuchhandlung, 1919. Август Лескин, Старобългарска грамматика (фототипно издание), София. Профиздат, 1981.

Miklosich - Miklosich, Franz von, Lexicon palaeoslovenico - graeco-latinum. Emendatum autum, Wien 1862-65/Scientia Verlag Aalen 1977; т. III. 
Текст Милятиного евангелия 
1a

CAABOY ЮГО.Н ГÄА

o nemh. ${ }^{42}$ ogaue oyEo

Иоанн

XII

$42-47$

5

10

H W̄ KHAZh MHOZH

в ЕровАША ЕТ Hh.

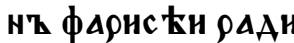

не нспев

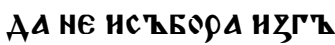

HANH БOYAOYTh -

43 вТЗАКБНША БО ПА

ЧЕ САABOY Чत̈Вपा०.

неЖЕ сААв оу БӜн

ю. ${ }^{44}$ ich

рече в в

Ма · не в К роуюТ

15 B' MA H' E' ПOC'

AAB ZW АATS MA

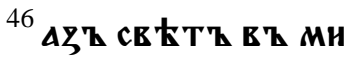

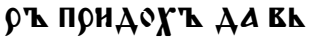

САK' в Е ९оYтан в '

20 MA в' ThME нE

БOYAETh $\cdot{ }^{47}$ и Аџе

КTо оүсАҚшить

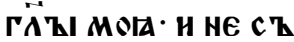

16

БAюAETh HX' $\triangle$

弓'Һ не соужю юмА

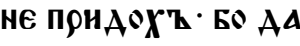

соужю мнооу $\mathrm{Hz}$

5 АА сп̈соу мнрт $: \because \cdot$

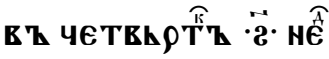

в ҚZнесенне $\vec{\Gamma} \Delta$ HA

Лука

XXIV

$36-53$

10

wero ... ev

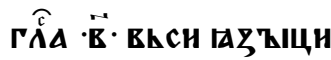

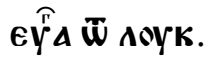

в ไ оно в

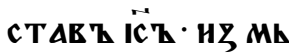

PTE'ZIX'Z Н СТА

no cepeat oy

15 ченнк' свон Х'

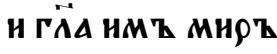

B $\triangle M \mathrm{~h} \cdot \Delta \mathbf{Z}^{\mathrm{Z}}$ ЮCMh

не Бонте сA ${ }^{37}$ оуБо

ТАВ ҚШЕ жЕ сА и при

20

с ТРАШКНН БҚIE $\mathrm{Z}$

WE MhHAXOY ÄX'h

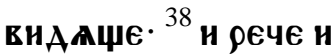

Mh 4h To c zMoYLE 
1в

нн юсте и по чh

ТО ПОМ ҚШШАЕни

IA E'ZX'AATK E'

С̈АЦА вАША. ${ }^{39}$ вНАї

5

ТЕ роуц К Мон и но

зћ мон гако сАMт

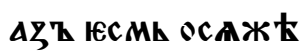

TE MA Н БНАНТЕ

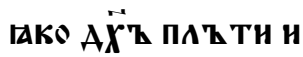

10 Костн не НМАТЬ

ГАКОЖЕ МА ВНАН

те нмоуща. ${ }^{40}$ н се ре

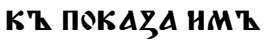

роүц к и ноз ${ }^{41}$ юще

15 жЕ не в К оуюше

MT HMT Ш̈ ОААОСТн

H YюAALEMT ca

PEЧE HMT HМАTE

Ан чh TO Ћстн сhАE

$20 \quad 42$ Они жЕ ААШШ ЮМЖ

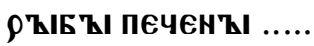

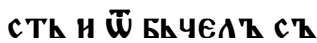

TZ.${ }^{43}$ н прннмт прt
$1 \Gamma$

АТ нимн tсть $\cdot{ }^{44}$ н

рече НМт - СЕ САО

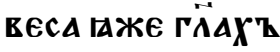

в $\triangle M \mathrm{~h}$ н Еще $\mathrm{chl} \mathrm{ch}$

5 вАМн' ГАКО ПОАО

БАЮTh C'ZKOHKYA

TH CA BһC太Mh Пн

CANZIHMT ET Z

KOH' MOЮC KOB $\mathrm{k}$.

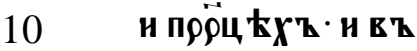

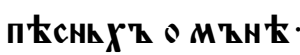

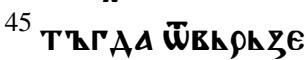

HMT OYMT AA PA

зоYм Кютh Пи

15 САнНІа. ${ }^{46}$ н рече н

Mh IAKO TAKO IE

CTh ПHCAHO H TA

kO пOAOEAWE Ẍ̈YY

ПОСТ ФАААТН ' И Е '

20 скрһсноути ш̈ мh

ФТЕ 'ҚIX' T

A से $^{47}$ н пропев $\mathrm{E}$

ААТИ СА ВТ НMA 
$2 \mathrm{a}$

ЕГО ПОКААННК в Т

ОстАВАЕнињ Г९ћ

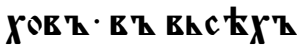

С TPAHAY' $\cdot$ HAYKH'

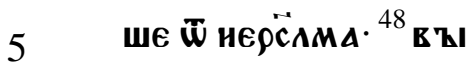

ЖЕ Юсте Послоусн

семоу. ${ }^{49}$ и се $\Delta$ З̧' по

C'ҚAW OEK TOKAHÏ

Іє оц̈ А Moюго на в ҚI

10

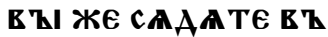

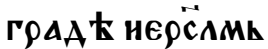

сц Е АОнъАЕЖЕ W

БАћपћTE сA снАО

ю ç в ҚIше $\cdot{ }^{50}$ H马RE

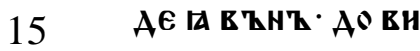

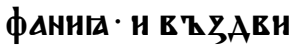

Г' ९ОУЦ Е СЕОН БАА

ГОСАОЕН ГА. ${ }^{51}$ Н Б२і

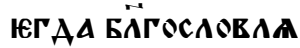

20 ше ґа ш̈стоупн

ш̈ них' и въ弓но

WAWE CA HA NË

52 Н Ти покАонншА
26

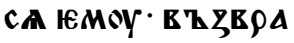

ТншА ЖЕ СА в И и

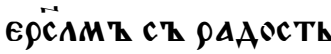

К вЕАНКОК. ${ }^{53}$ Н БА

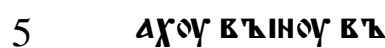

цр̈Квн· ХвАААџЕ

И БӒГСАОВАЧЕ Б̈А

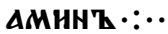

в ไ ПА Tे

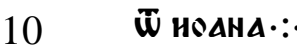

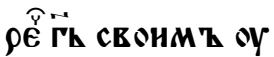

ченнкомт ${ }^{1}$ AA

Иоанн не съмоушањть

XIV

1-11

15

са срАце ваше ·

РОунте вһ Б̈һ · н в

MA в ЕоОНте ${ }^{2}$ в'

AOMOY оц̈А M०EГО

ОБНТЕАН МНОГ'ҚІ

соуть АџЕ Ан нн ·

20

рекоY оуБе в АM $\mathrm{z}$.

TAKO HAOY OYTOTO

вАTH MћсTO вАM Z

${ }^{3}$ ПАК'М ПФНАОУ и ПО 
2B

НМОУ в ҚI К'Қ СеБе

АА ндежЕ Юсми А

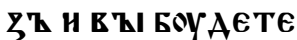

${ }^{4}$ н АМОЖе А弓' НА

5

в 太сте' н поYтh

в tсте ${ }^{5}$ гїА ๒мд

OOMA. Г̈н нE в 太

Mh КАMO HАEWH.

H KAKO ПOYTh MO

10 Жеми в

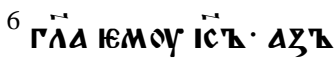

IEMh поYTh нстї

HА' Н ЖНВОТТ НИ

ктожЕ не прнаЕ

15

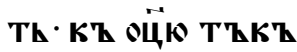

Mо минок. ${ }^{7}$ Аџе

MA БZIC TE ZHA

АН' Н оц̈А моего

ZHАAH БҚICTE OY

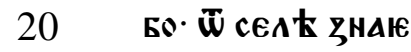

TE Н· Н внА ЕстЕ

н. ${ }^{8}$ гӒА ๒моу фи

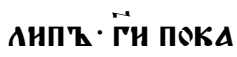

$2 \Gamma$

Жн намт оц̈А н А०

в ҚA KњTh HAMT

9 ГÄA ๒MOY $\overrightarrow{\text { ICे }}$. TO

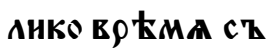

5 ВАМН ЮСМК Н НЕ

ПОЗНА АН МЕне

фнАнпе внА Ев ҚI

и МЕне внА Т оц̈А.

Н КАKอ TZI ГӒшН.

10 ПоКАЖн нАМт

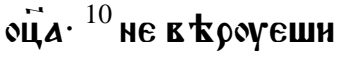

AH IAKO $\triangle$ Zु B B Z O

ц̈н н оц̈Һ вһ Мн

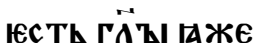

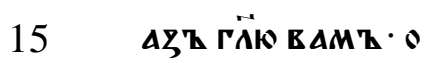

сеБћ не ГӒю งц̆

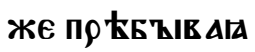

Н В' MZHE T'

TEO⿻HTh A सAO

20

11 в роу нмћте $\mathrm{MZ}$

HE IAKS $\triangle$ Zु B B T O

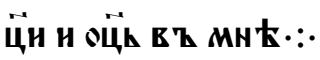

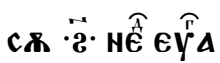


$3 a$

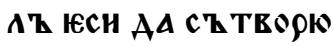

${ }^{5}$ H HWIN Е ПООСА АЕН

ИоанН MA оप̈е оY теБе сA

XVII

5-13

5

МоГО сААВоК южЕ

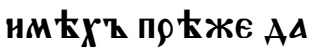

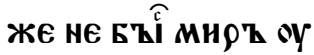

ТеБе ${ }^{6}$ ГАВнХ'Қ имА

TEOЮ Чล̈вКОМ $\mathrm{z}$.

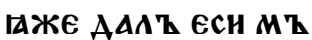

10 H太

Б太ША Н Мн太 ГА

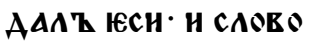

TESE C' ХОАНИША

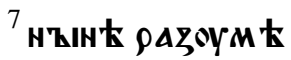

15 ША АЖЖЕ ААА' ЕСН

MH太 ОT' TEБE $\mathrm{ck}$

Th ${ }^{8}$ гаке гйЫ ґаже

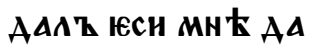

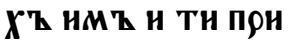

20 ГАША и ९АЗОУМ К

ША ВТ НСТНHОУ

TAKO $\tilde{W}$ TеБE н马Н

АОША' и в К ९ОвА
36

WA IAKS T ҚI MA

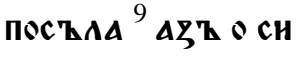

$X^{7}$ MOAN HE O MH

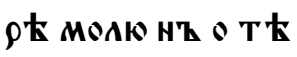

5 X'В МОль ГАЖЕ АА

$\triangle \mathrm{Z}$ ЮС МнҚ ФАКО

ТЕон соYть ${ }^{10}$ н Мо

A BCA TEOTA COY

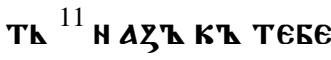

10

roAAOY oüe c T̈k

Н СТБАКАН А ВТ

HМА ТЕОЕ ІАЖЕ

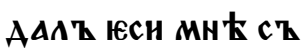

ХОАННХ'Z АА БOYАХ

15 ТИ ЮАннО ГаКОЖЕ

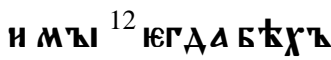

съ ннмн в' мно

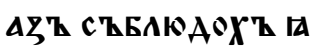

В'Қ НМА ТЕОЮ ГА

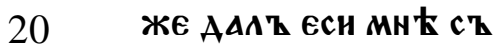

ХРАниХ'Һ н ни

ктоже $\widetilde{\mathrm{w}}$ ннХ' не

ПоГ'ҚIE TKKM० 


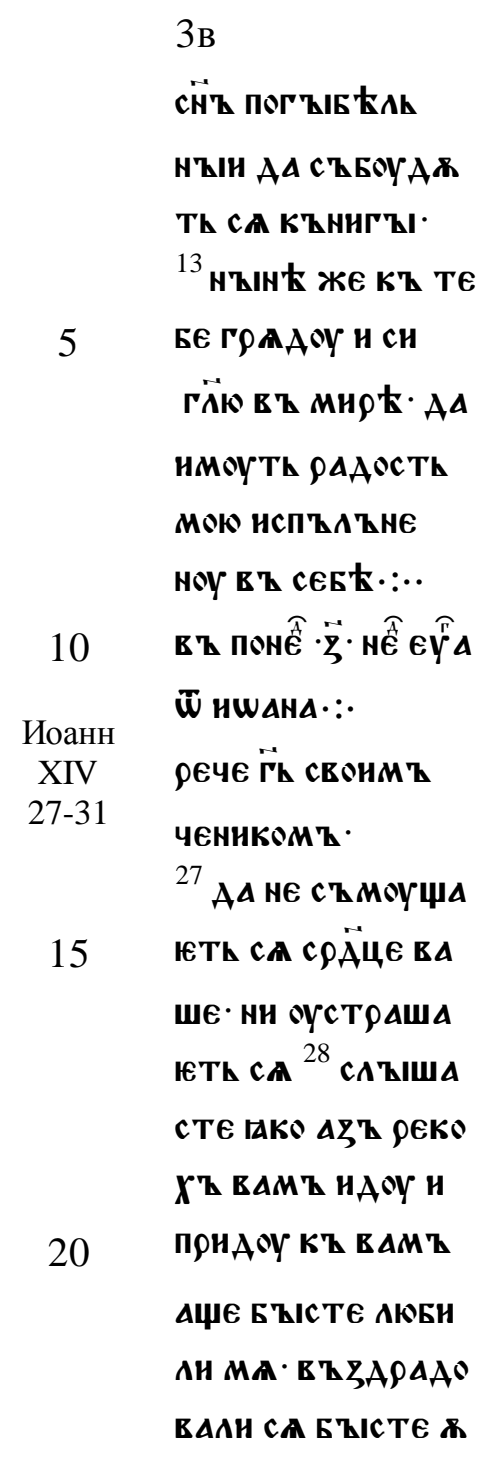

$3 \Gamma$

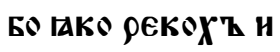

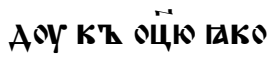

оц̈ Болни Мене

上ес Th. ${ }^{29}$ н HZIN

5 көх' вАMz' прt

жE ne вoYAE

Th A E ETAA EOYAE

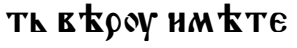

rako 4 z'

10 вАMт ${ }^{30}$ оуже не

MHOГО ГÄऽ С' ВА

MH. ГОAAETh БO

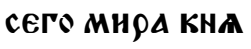

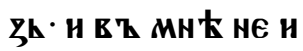

15 МАТЬ нНчьсоже

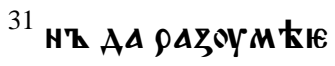

Th MHP' ch IAKO

АКБАК МЦ̈А И АКО

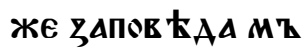

20 H太 оц̈ ТАKО TEO

Иоанн рюв вист Ан KTE

$\mathrm{XV}$

1-7

HA tMh Ẃ cOYA

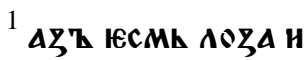


$4 \mathrm{a}$

с ТинКНАГА И ОД̈К

MOH А ЕААTEАh ๒

сти ${ }^{2}$ вhсAKoY go

ZTOY O MZHE HE

5

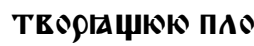

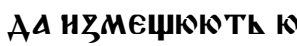

и вск творач8К

ПАОАҚ ОТ९ћБН

Th NO AA חAOAT EO

10 АНН СҚ ТЕорНТК

3 оуже в ҚI чнс те њ

стЕ' ЗА сАово ЕЖЕ

ГÄАХ' в АMт ${ }^{4}$ БоY

A tTE в' MZH太 и

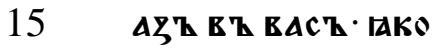

Бо А०३А не Може

Th חAOAA TEOPH

Ти о сеБћ· Аџе NE

EOYAETh HA AOZK

20 ТАКО н в'Ы АџЕ в Қ

MZHE HE ח९ KБOY

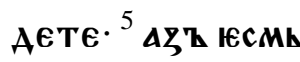

виногРААТ · в ҚI
46

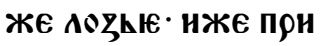

БOYAETE в' MHЕ

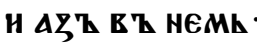

C'В TEорнти ПА⿱

5 АТ МнОГ' - ТКО

Без Мене не Mо

жЕТЕ Творнти нї

чисоже ${ }^{6}$ Аце кто

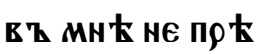

10 БОУАЕТИ Н нЪЕК

९hжетh сA в Zh'

TAKO AOZA HC $\mathrm{h} W \mathrm{E}$

Th Н СТБНРАКТК

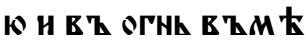

15 TAКTh К н С'ҚГ

palth ${ }^{7}$ aџе прt

БOYAETE вҚ MHЕ.

н ГӒн МОН вЪ вА

ch חоtБоYAOYTh.

20 ЮМОУЖе КОАн

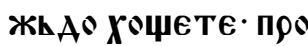

сHTE h AA БOYAE

Th BAM $\mathbf{z} \cdot: \cdot \cdot$ 
4B

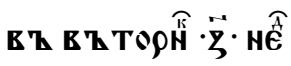

EY⿱乛⿻ $\Delta$ HWAHA.

Иоанн рече г̈h свонмқ

XVI

2-13

5

оученнкомт

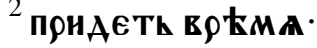

AА вһСАK'Қ OY

БHE ҚIH вАC' MhHï

Th сА споужИБоу

прнноснти Б̈оу.

10

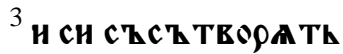

BAM'Z IAKO HE ПO

ЗНАША М̈̈А нН МЕ

не $\cdot{ }^{4}$ н' сн г̈лаX'

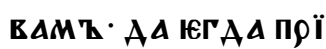

15 AETh ГОАнНА ПО

МHHАHTE CH IA

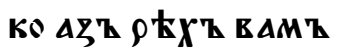

нспи

KOX'h вАM' IAKO

20 с' вАмн БҺХ'

5 HZIN'

ПOC'ҚАAB ไWW

МоУ МА н ннкТ О
$4 \Gamma$

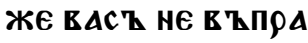

шАITh MENE KA

MO нАЕШН ${ }^{6}$ H' ГA

ко сн гїАX'Қ вА

5 Mh ск'

АНН С̈РАЦА вАША

7 H' $\triangle 7^{7}$ НСТнНОУ

вАMт ГӒю оуне

IEC Th BAMt A A A

10 Ђ' НАОУ АџЕ БО

HE HAOY $\triangle$ Z'Z ПА

рАКАнт' не прн

AETh K' вАMh 4

Ше Ан НАОУ Пос'

Аю н к' вАM ' ${ }^{8}$ и

ПОНШКАТ ОH'

БАНЧнТК Мн९А

- rotct н о coyat

и о пр АвһA ${ }^{9}$ o грt

20 ct OYБO IAKO HE

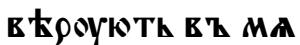

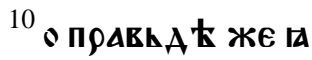

к० к' өщ̈ю нА०у н 
$5 \mathrm{a}$

K' тоMоY не ви

Анте мене ${ }^{11}$ O coY

A $\mathrm{t}$ жE IAKO KHAZh

мнра сего ос оуже

5

H' Бъi ${ }^{12}$ Еще много

HMAM Z E $\triangle M \mathrm{Z}$

ГААТТ нъ HE MO

жете носнти нъІ

н太. ${ }^{13}$ ЮГААЖЕ ПрН

10 АЕТИ онт $А \ddot{X}^{\prime}$ и

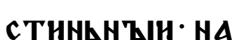

СТ АЕНТИ ЕҚІ НА

ВСАКОУ НС ТИНЖ : :.

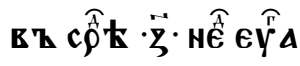

15 फั н०АнА $:$.

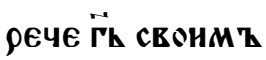

оученнкомт -

${ }^{15}$ вһCA ๒лHКО Н

MАTh व̈цh Mo

20 a coYth -cero ga

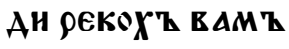

ТАКО MOњГО ПрН

HMETh HC'KE
56

стити вАMт ${ }^{16}$ в

MAN太 K TOMOY HE

вНАНTЕ МЕHЕ Н

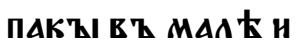

5 ОУЗू९нте MA

KO AZ'Z HAOY K' O

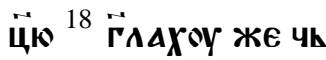

To ๒с Th юже Г̈八Th

вZ MAN K нE в ЕMh

10 पh TO $\tilde{\Gamma A T h}^{19}$ pAzoY

M

XОТ A XOYTh н в

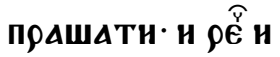

$M$ - O cEMh $A \mathrm{C} \mathrm{ch}$

15 TAZAlE TE CA ME

ЖК соБоК IAKO $\rho$ t

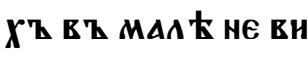

АНTЕ MENE И ПА

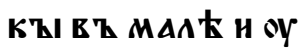

20

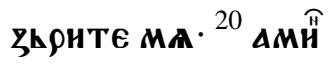

АМИี ГАК вАMТ .

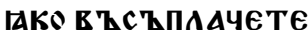

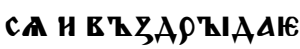


5 в

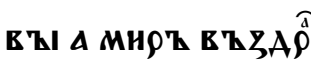

AOYЮTh CA в 'hI

ЖЕ ПЕЧААКнН БОУ

AETE' H' חEYAAh

5

BAWA E' PAAO

стh БоYAETh ${ }^{21}$ жE

HА ЮГАА ९АЖАIE

Th - пEчAAh HMA

Th זAKo прнаE Го

10

AT ЮIA ЮГАА жЕ

POAHTh OT POYA

Kh TOMOY ne no

MKHHTh сK'Қ $\rho \mathrm{Z}$

БН ZЗ ९АAOCTR

15

IAKO POAH СА पӒЕ

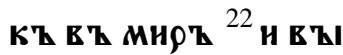

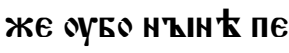

ЧААКHН БOYAETE

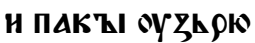

20 В'Ы И ЕТЗАРААОУ

IETh сA сРАЦЕ вA

Ше· Н ९ААОс Ти вА

ШегА НнкТожЕ нЕ
$5 \Gamma$

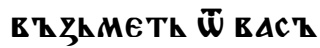

${ }^{23}$ и К Қ T' АН̈ MENE

не в ЋПроснте ни

чи тоже $\triangle$ Амй Амй

5 Г̈аю вам в Аџе

чhсо проснте $\overline{\mathbb{W}}$

ӧцА моюго в һ и

MA MOE AACTh

B $\triangle M \mathrm{~h} \cdot: \cdot \cdot$

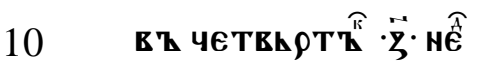

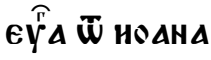
рече $\overrightarrow{\text { Th }}$ свонм $\mathrm{z}$

ОученНКОМ $\mathrm{z}$

${ }^{23}$ АМннт АМЙ

15 ГӒК вАMт АџЕ

чhсо проснте ш ӧцА Moero в h н

MA MOE AACTh

вAM7 ${ }^{24}$ AO cent HE

20 ПрОснте ничК

соже в Т нмА Мо

ю проснте и прн

HMETE' AA PAAO 
$6 a$

С Th ВАША HсПТА

HEHA EOYAETh $\cdot{ }^{25}$ сh

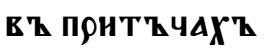

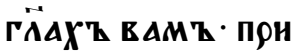

5

АЕТК ЖЕ ГОАНнА

ІеГАА в Z ПриТТ

4АX' ${ }^{26}$ Kh TOMOY

HE ГӒю в $\triangle M \mathrm{~h} \mathrm{IA}$

Ko $\triangle$ Zु' OYMOAN

10

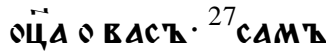

БО оц̈Һ АКБНТК

в ҚI Іако в ҚI ME

не вЋ ЗАюБнсте

н в ЕрOвАC TE IAKO

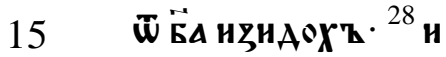

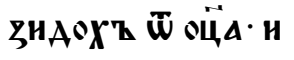

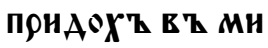

P' НАОУ К' оц̈ю

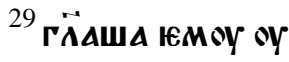

20 ченици юго - се

HZHस не оБнноу

ҐА СА ГӒШН· А ПрН

T३५А нHкงега
$6 б$

же не гӥшн. ${ }^{30} \mathrm{Hzl}$

H太 в 太Mһ IAKO в 太

СН ВСА· Н НЕ Т९Е

Боуюшн· АА КТО

5 TA в ҚПРАШАЕТИ.

- cemh в Ероуюмz

व

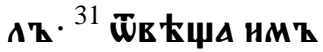

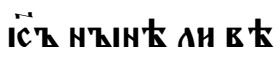

10 poyete. ${ }^{32}$ ce roaAe

Th ГOAHHA. H H'Z

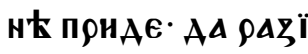

AETh сA KһжhAO

в Қ СвоГА '

15

ЮАННОГО ОС Т АЕИ

TE нЕСМК ЮАИнҚ

ТАКО оц̈Һ с' Мно

ю Есть ${ }^{33}$ сн ГӒ厶Хर

BAMT AА E' MHE

20

MHРТ НMАТЕ $\because$ -

Иоанн

XVII

18-26

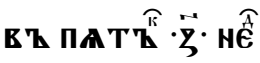

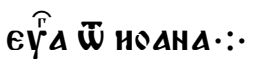

в Қ оно в 
6в

ZREAT Ï ОЧН СЕО

И нА оученик ҚI

своA рече ${ }^{18}$ гакоже

ThI MA oüe nock

5

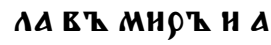

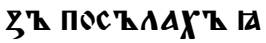

в 'Һ мнот ${ }^{19}$ н

$\triangle$ दु' CËயW CA CA

Mh AA EOYAOYTh

10

Н ТН СЁџенН. В Қ

нстиноу ${ }^{20}$ не О сн

$X$ 'h MOAN T

H' HO в E $\rho$ OY

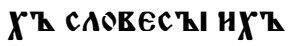

15 в' MA ${ }^{21}$ A $\triangle$ вC. E

AHHO COYTh IAKO

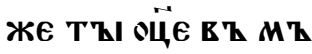

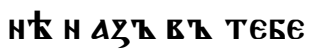

АА НTH В' HAC'

20 АННО БОУАОУТК

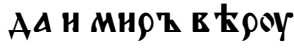

HMETh IAKO в '

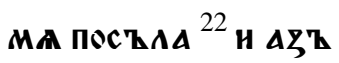

6г

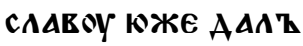

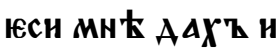

MT AA БOYAOYTh

ЮАНнО ${ }^{23}$ ГАКОЖЕ и

5 МИІ ЮАНHО $\triangle$ ЗҚ Е Қ

нНХ'В и Ти Е М

AА БOYAOYTh CZEK

ОКШЕНИ в Т ЕАНнО

H AА ९АZОYM КЕTh

10

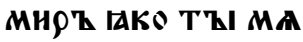

ПОСҚАА Н ЕҚZАN

БНА'

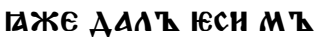

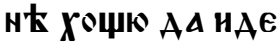

15 же њсми $\triangle$ दु и т ти

БOYAOYTh C'T MHO

1) AA вHAA Th cAA

воY MON КжE AA

IZ ЕСН М ҚH太 ґАКО

20

ВТЗАКБНАТ МА

юси пр Қже съА॰

женнга мнора ${ }^{25}$ 。

чё ПрАКһАКн'Қ! 
$7 \mathrm{a}$

мнрт тебе не по

ZHA. AZ' T TA חOZHA

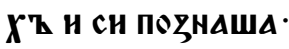

IAKO T'W MA חOC'

5

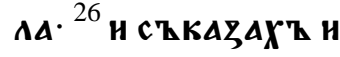

MZ HМА ТВОЮ И С'

КАЖК АА АЮБҚ $\mathrm{E}$

юЖЕ МА ЮСН в Қ

ЗАКБНАТ ЕТ НН

10

X'B EOYAETh H 4 Z'

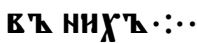

cov $\cdot \vec{H} \cdot$ HAIA EY

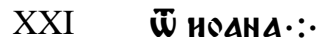

14-25 в он оно в

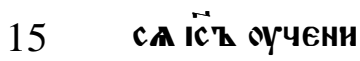

20
KOMth CEOÏMth

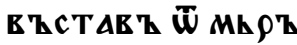

TE ҚX' ${ }^{15}$ Н ГӒА сн

моноу петроу сн

15

20

БНШН АН MA ПАЧЕ

СНX'Z ГÄА ЮMOY

єн г̈н ТЪІ в қсн
76

ТАКО АКБАК ТА

ГӒА EMOY ПАCH А

ГНhЦА MOA ${ }^{16}$ Гत̈А

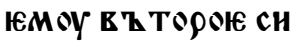

5 МонЕ Нонинт Аю

БНШН АН МА ГӒА

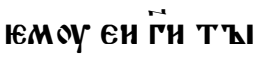

в 太СН ТАКО АКБАЕ

TA ГӒА ЮMOY ПА

10

СН ОБһЦА MOA ${ }^{17}$ ГÄА

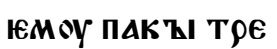

Тиюほ снМоне и

онинҚ АюБиши

АН МА оск' ९Б

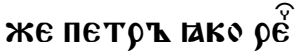

Іемоу ТрЕТнеЕ Аю

БНши Ан МА и ГӤА

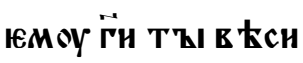

IAKO АКБАК TA ГЙА

IEMOY Ï' ПАСH O

ККЦА МОА ${ }^{18}$ АМЙ А

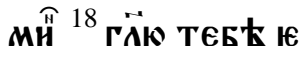

ГAA E К OYHZ ПOA 
7в

CAше CA САMт и

Xожаше raMo

же XОташе ' ІегАА

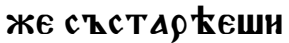

5

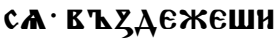

९оуц Е свон и нТ

TA חOAшETh и

BEAETh TA AMO

же не Хошеши. ${ }^{19}$ ce

10 жЕ рече ЗнАМЕнА

IAKO EN chMh $\rho$ Th

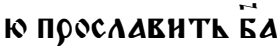

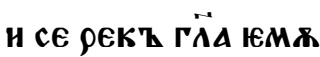

HАH ПO MZHE. ${ }^{20} \mathrm{~W}$

15 Б९цџи Же са пе

Т९Т внАТ ОУчени

КА ЮГОЖЕ АКБАА

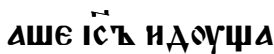

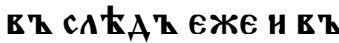

20 ЗАЕЖЕ нА вЕчерТ

и на пьрсн его и ९е̊

Г̈н кто юсть поћ

ААІАн ТА. ${ }^{21}$ сеГО вн
7Г

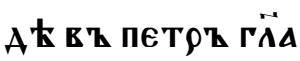

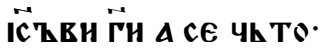

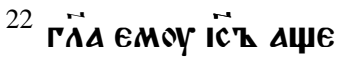

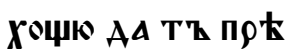

5 БZIRAITK AOH'

АЕЖЕ ПрНАОУ पh

To юc Th TEEk - no

MHE TZI ГОAAH.

${ }^{23}$ Н马НАЕ ЖЕ сАORO

10 СЕ вһ БФАТню' ГА

Ко оученик' T'

не оYми $\rho E$ Th · $\mathrm{HE}$

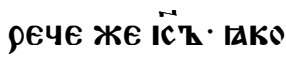

HE oYMh $\rho E T h \cdot H z$

15

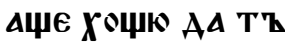

חPҚБKIEAETh AO

H'ВАEЖE ПрнАОУ

Yh TO E TEE t. ${ }^{24}$ ch £

cTh оученнк'

20

C々E 太A

ГАн о снХ' и женА

ПнсА сн и в 太мь

TAKO НС ТИНКНО 
$8 \mathrm{a}$

IETh chE kA kTE八h

ство IETO ${ }^{25}$ coYTh же

и нА мноГА' ГАЖЕ

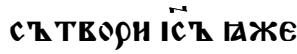

5

АЩЕ ПО ЮАННОМОУ

ПНСАHА БЪIB AK

Th ни самоMOY

MHN вһCEMOY MÏ

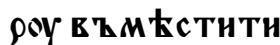

10

ПншемъІнХ' К'

ННГ' АМнн' $: \cdot$

HỂ IA ThAECA ThHA

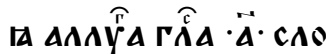

сеMh rïEMh .. $\cdot$ ê̛ं

15 元 HWAHA $\because$.

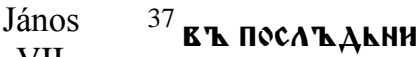

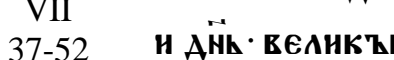

и ПФАЪАКнН

Kh c TOrawe

20

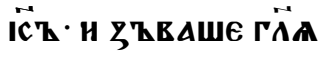

АџЕ КТО ЖАЖАЕ

Th A п्нАETh

Къ Мнћ и пнеТь
86

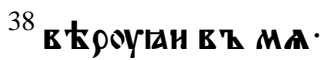

Іакоже книг'

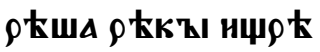

вА ЮГО нстекоY

5 Th вОА ҚІ Жнв Қl.

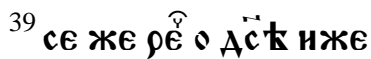

ХОт АХОУ пони

МАТИ в Е Ооуючн

в Z HегО не оY Бо БЕ

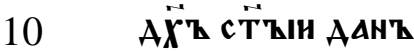

RAKO IC̈h HE OY $5 O$ Et

прослАвАEнъ. ${ }^{40} \mathrm{Mz}$

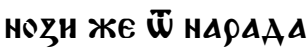

CATIWAR hWE CAO

15

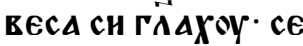

ЮС ТИ В Қ НС ТИнОУ

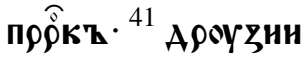

жE гÄAX oy ch EcTh

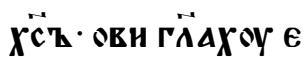

20

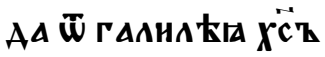

понАЕТт ${ }^{42}$ не Кни

ГҚІ Ан ९екошА' ГА

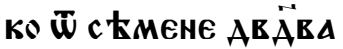


8в

н Ф̈ внфАЕМһскА

АГО ГРААА НАЕЖЕ

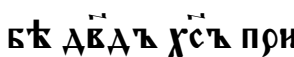

AєTh ${ }^{43}$ распира же

5

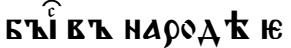

ГО ९ААН ${ }^{44}$ ЕТЕ९н ЖЕ

б̈ ннХ' ХОт АХОУ

ГАТИ И НЪ НИКТО

жЕ в Қ马АОжи нА Hh

10 роукоу. ${ }^{45}$ прнаошА

же слоугты к' $\Delta \rho{ }^{\prime}$

ереомт · н фарнс k

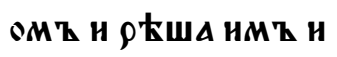

Ти пе чк Те не прн

15 веАосте Юго. ${ }^{46}$ шв 太

ЩАША САОУГҚ· НИ

КОАнже ТАКО ГӒА

AT ЮCTh Чत̈EK' IA

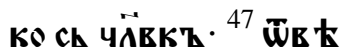

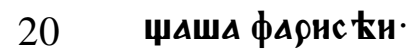

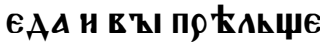

нН Ес TE ${ }^{48}$ ЮАА КTO

W̄ KHAZh E E $\rho O B A$
$8 \Gamma$

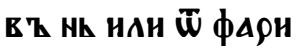

ckH. ${ }^{49}$ HT HAPOAT Ch

нже не в Ћсти ЗА

КОНА ПООКАА ТИ

5 соуть. ГӤА нНко

АНMЋ К' НнМт

ПоншһАТн К' не

MOY HOWh ' ЕАН

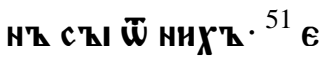

10 АА ЗАКОH' HАWh

COYAHTK पÄEKOY.

Аџе не сл ҚIшнтh

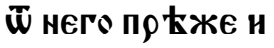

pAzoYm kith पh

15

20

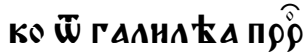

К' НЕ ПОНХ РАн

Иоанн

VIII

Тһ. ${ }^{12}$ ПАКҚ ЖЕ имҚ

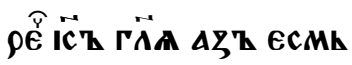


$9 \mathrm{a}$

св Етт мнроу. $x^{\circ}$

ААН ПО MH太

HMATK X'AHTH

BT ThME. H'Z H

5 MАTh жнвотА

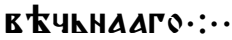

10

15

20

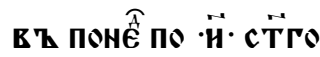

A $\vec{X} \Delta \Delta \hat{\hat{\Lambda}} \Delta$ Гरिष $\vec{H}$

ễ $\Delta \bar{W}$ MATh OEA

96

рEYE Th 


\begin{tabular}{|c|c|}
\hline & $9 \mathrm{~B}$ \\
\hline & ТИ ЗАБАОУЖИША \\
\hline & 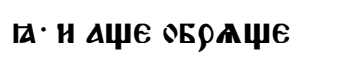 \\
\hline Матфей & 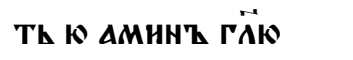 \\
\hline & BAM Z TAKO $\rho \triangle A O Y$ \\
\hline 5 & ЮТТ СА О нен ПАЧЕ \\
\hline & нЕ ЖЕ Р АEВА TH $А E$ \\
\hline & САТҚ И АЕКАТИ НЕ \\
\hline & зАБАоужишидъ. \\
\hline & ${ }^{14}$ TAKO HECTh BONA \\
\hline 10 & 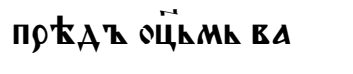 \\
\hline & ШНМ · НЁСКНҚIH \\
\hline & MҚ АА ПОГҚIБNE \\
\hline & 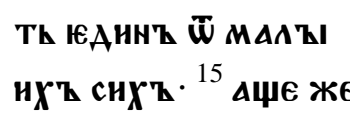 \\
\hline 15 & 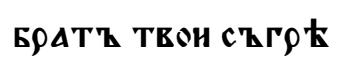 \\
\hline & ШНТЬ НАН Н ОБАН \\
\hline & Чн и мЕЖю сөБо \\
\hline & ю и Т КМИ ЮАНнћ \\
\hline & мh· $\Delta \Psi е$ послоушА \\
\hline 20 & ЮТИ ПрноБращЕ \\
\hline & 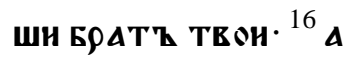 \\
\hline & ШАЮТК ПОНМн ПА \\
\hline
\end{tabular}

9г

К'ҚI С' СОБОК ЮАН

HOFO AH A ZEA AА

BZ OYCTKX'B AT

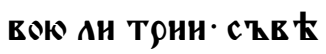

5 А

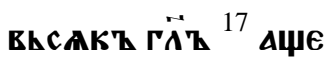

же послоушањть

иХ'Һ ९ьциї· цреквн

Аџє же и о цёквн

10 НЕ ९ОАНТИ НАЧКНА

Th ' AA EOYAETh TI

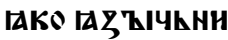

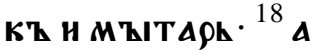

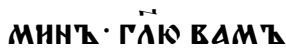

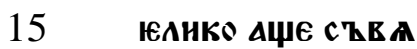

ЖЕТЕ нА ЗЕМАн БЖ

AETh cKBAZAH'

НА НЁСН· Н ЕАНКО

АџЕ ९А३А९ Кши

TE HA ZEMAH · БOY

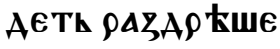

HZ HA HËСH. ${ }^{19}$ ПАKҚl

ПРАRO ГÄК вAMT 
$10 \mathrm{a}$

TAKO ALE ARBA

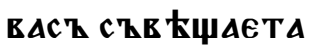

HA ZеMAH O BLCA

КОН веџн ЕАЖЕ КО

5

АнжиАО ПрОснтЕ

BOYAETh BAMT W

ОЦ̈А МОєГО нЖЕ Ю

сTh HA HËсEX' $\cdot{ }^{20}$ H

АЕЖе Бо EсT А АТRА

10 НАН Т९НЕ С ҚЕһ

НН Е ҚІ НMA MOЮ

ToY юс Mh $\Delta \mathbf{z}^{\mathrm{h}}$ no

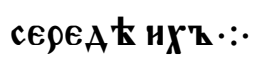

$3 \widehat{\AA}$

в Z в Z торН

15 ПантнКОстиї ЕУึА

Матфей

IV

23-25

W MAThOKA

в ไ оно во̆

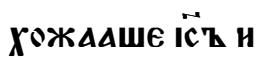

SYYAWE HA ch

20 нкмнцнх'

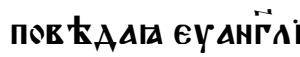

ю цр̈ствА· и ц КАА

IA KLCAK' HEAOY
106

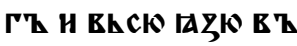

AюAhX'z. ${ }^{24}$ haE cANY

$X^{\text {th }}$ €ге по висен $\mathrm{c}$.

ОНн ' н ПОНвеАОША

5 ЮЕМУ ВСА БOAA

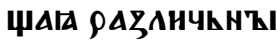

Мн неАОУГҚI - ї ст९А

стьМн РАКрКЖН

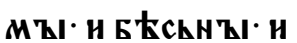

10

M С CAYKHZIA ZZ

A'Z HEAOYГZI HMA

ЩА Н ОСААБАЕНҚ

ЖнААМн · Ц Ц ЕАн

А. ${ }^{25}$ и ПО немh haо

15

ША НАРОАН МНО

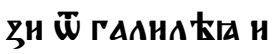

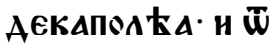

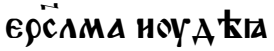

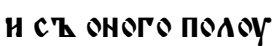

20 hopaAHa. ${ }^{1}$ OYzhot

Матфей в

1-13 ЗНАЕ нА ГОрОУ и А

Ko c kaE прнстоY 
$10 \mathrm{~B}$

ПНША K' HEMOY

Оученнци юго

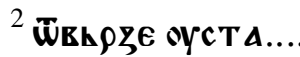

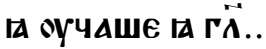

5

3 Бӥженнн ннци

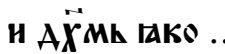

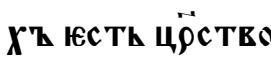

НБСКнОЕ $\cdot{ }^{4}$ БААЖЕ

НН ПААЧющщ

10 Гако ти оут КША

Th са. ${ }^{5}$ БӒЖни.

ТҚЦни гАКО

HACA ЕАATh ЗEMAH

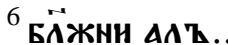

15 и жАжющн..

вһ A'Ы $\triangle A$ AH

TH HACZTT T' CA

7 Бӥжнн.

Гако Ти по.

20 ВАНH БОУАОУТК

8 Бӥжни чнс Ти

сОАЦМ т Дако

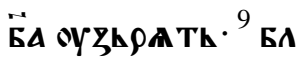

10 г

женн с 'Қмноаю

Щн ГАКО Ти СҚ

нове БӜнин наре

коути са. ${ }^{10}$ БӒже

5 НН НУГТНАННН

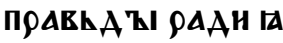

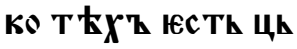

СА९Нс ТЕИЕ нЁск

ное ${ }^{11}$ БӒжнн Есте

10 ЮГАА ПОНОСА Th

ВАMТ · Н ЖАЕНОУ

Th в Қl н рекоYтh

BhCAKh ZुhAh Г̈̈h

нА в Қl $\mathbf{~ \mathbf { ~ }}$ Жюще

15 МЕНЕ ९ААН ${ }^{12}$ ९АА ОУ

ЮТТЕ СА Н весеАн

TE IAKO MhZAА вА

WA MHOГА ECTh

HA HECE X'Z $\cdot \because$ K

20 TAKO БO HYГRHA

шА пр̈९кЪ нже

Б КшА пр Кже вА

ch $\cdot{ }^{13}$ в hI юc Te conh 
$11 \mathrm{a}$

земАн - Аџе же

COAh овоYAETh

ЧнMh ОСОАНТЬ

СА· НнчемоУже

5

МожЕТИ К ТОMљ

TZKMO AА HCZI

ПIHA БOYAETh

Hһ и ПЕПнРАЕ

MA Чत̈ЕKҚI $\because \cdot \cdot$

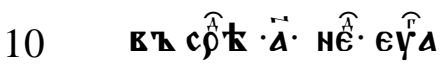

iv MAThoka

рече $\overrightarrow{\mathrm{Th}} \cdot$ свонми

Матфей оученнком $\mathbf{z}$

$\mathrm{V}$
$20-48 \quad 20$
15

15 ETh П९Авһ АA

вАША· ПАЧЕ Кнї

жиникъ и

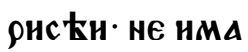

ТЕ в Ћнити в Қ

20 цёс ТЕИЕ нЁсь

ною. ${ }^{21}$ слтыш Асте

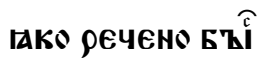

А९ Евһннми · не
116

ОУБНн · НЖЕ БО ОУБї

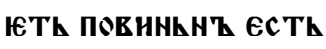

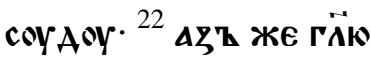

BAMT IAKO BLCAKT

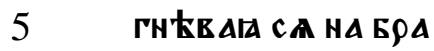

TA своETO EEZ OY

MА ПОВНHКН' Ю

с Th COYAOY. НЖЕ БО

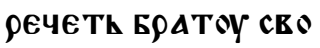

10

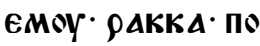

BHHLH' ECTh C'BEO

ОНџю - н нЖЕ ९ЕЧЕ

Тh Боую Повинь

HZ IECTh POAOY OГNh

15

ноумоу ${ }^{23}$ Аще оуБо

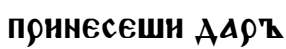

ТЕОН К' ОАТ А९ЕЕН

Н ТОY ПОМ АНЕШН

ТАKO БРАТТ ТЕОН

20

HMATK HEYK TO HA

TA. ${ }^{24}$ OCTABH TOY AA

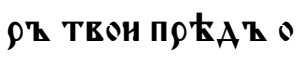

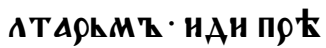


11в

ЖЕ съМнРН СА $\mathrm{ch}$

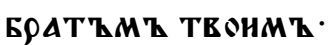

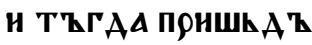

прннесешн АА९Т

5

ТЕОН. ${ }^{25}$ БоУАН Оүв Е

HABAIA CA C'z COY

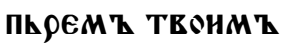

сKOPO AOH'A AEЖE

Іесн нА Поути с'

10 нHМh ' АА HE прК

AAHZ БOYAGWH COY

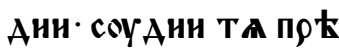

AACTh CAOY马 '

В Қ ТКМКницю в Қ

15

вирижети та. ${ }^{26} \Delta$

МЙ. ГӒю ТЕБ НЕ

H马НАЕшн $\tilde{\mathrm{W}}$ TOY

A t· АOH' АEЖE в '

ЗААСH ПOCA ЕАК

20 ННИ КОНАФАТТ $: \because$

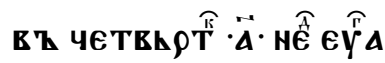

W MATh $* \Delta \cdot \therefore$.

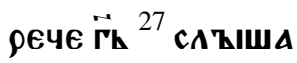

$11 \Gamma$

стЕ ІАKO РEЧENO

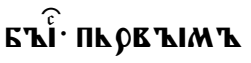

не ПрТАюБҚІ ст

твори. ${ }^{28} \Delta \xi \mathrm{h}$ жE

5 ГӒК ВАM ' AKO

ВИСАК'И НЖЕ в Қ

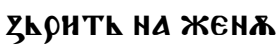

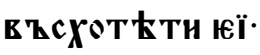

оуже АюБһ ст

10 Tворн с' нею

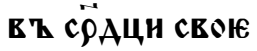

ми. ${ }^{29}$ АџЕ же око

TBOE АEсHOҢ

СҚБААЖНАЮТИ

15 ТА Н马КМН Н

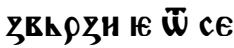

Бе - оүне Бо ти Ю

CTK AA EAHH' OY

A' TहOн ПОГ'Қl

20

БHETh · А нE все

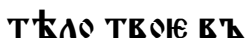

вь рьжено Боу

АЕТи в т геонж 
$12 \mathrm{a}$

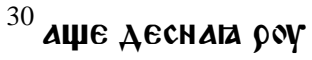
KА TEOA С'ВБАЖЖИ

HAETh TA oyc Kцї

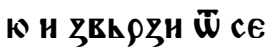

5

Бе - оуне Бо ти ести

АА ПОГ'ҚIБне ТИ Ю

АHН' OYAT TEOH

X'B $\triangle$ HE вCE TKAO

ТЕОЮ НАЕТИ Е Т

10 геоноу. ${ }^{31}$ ९Еิно жЕ

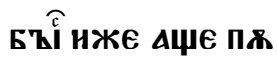

ститL женоу сво

ம. AА ААC Th н K'

Hнг'Қl ९Аспоусть

15 нไІа. ${ }^{32}$ Аदु' же ГӒ

BAMT IAKO KhCA

К'h поущ АाА же

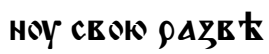

сAORECE БAOYAK

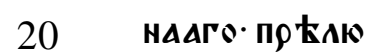

EҚI C' TEOPHTh .

нже ПотатГоу

понметь - оYже
126

ПОҚАКБҚІ С'Z ТЕО

рH C'Z HEN-:..

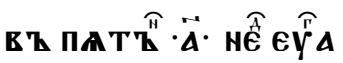

W MATh 0 kA

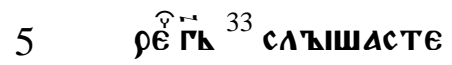

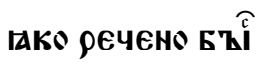

ПК Рв ZIM Z HE в Z

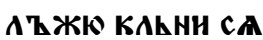

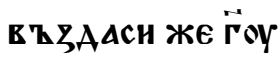

10 KAA TE'ҚI TEOA

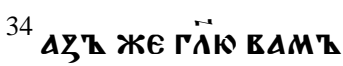

HE KAA TH CA ש̃

HюAK HH HËCEMh

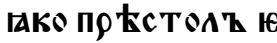

15 сти Бӝнн ${ }^{35}$ нн зе

MAEN IAKO MOAT

ножию юс Т人 но

ГАМА ЮГО Н НН ИЮ

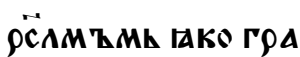

20 АТ ЮСТИ ВЕАНКА

АГО ц९्व $\cdot{ }^{36}$ нН ГАА

ВОЮ СЕОЮЮ КA

HН CA· ГAKO HE MO 
$12 \mathrm{~B}$

ЖЕШи ни ЮАНноГО

ВААCА Б ЕАА АН ЧК

९нА СС TहO९НTH

${ }^{37}$ БоУАН ЖЕ САОвО вА

5

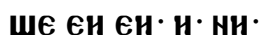

Hн. А АнX⿰冫е ceN $\bar{W}$

непрнІаУнН ЮС Th

38 и сАҢш АС TE IAKO

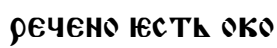

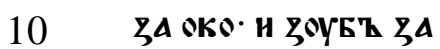

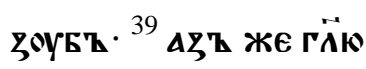

вАM' HE ПООТнЕ ї

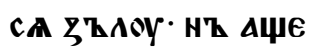

КTO TA OYAА९HTK

15 ВТ АЕСНоУю А АнН

ТОУ. ОБ९АТИ ЕМОУ

и ароугоук ${ }^{40}$ и Хет а

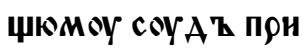

А ТИ с' ТОБОК И ९ї

20 ZОY ТЕОК вЪZа TH.

ш̈поустн ємоу и

с९Ачнцю ТЕ Ою. ${ }^{41}$ н

Аџе кто понметї
$12 \Gamma$

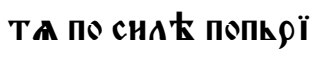

НЕ ЕАННО НАН С'

HHMK AZE $\mathbf{A} \cdot \because \cdot$

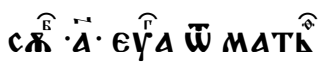

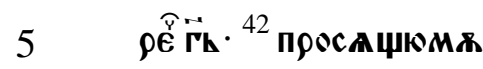

OY ТеБE ААн и X०

TALAATO W TEEE

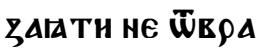

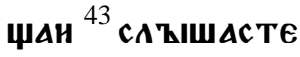

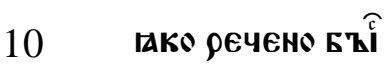

В ҚЗАКБНШН И

СКОLНА АГО СЕОЕ

ГО И В Қ ЗНЕНАВИ

АНШИ в९АГА ТЕО

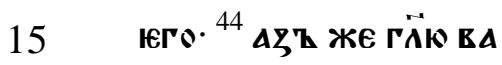

Мт АКБНТЕ в९А

TZI EAWA' БÄГOCAO

внте КАКноУџА

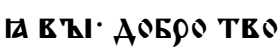

20 ОНТЕ ненАвнАА

Чнм В вАC' $\cdot$ H

MOAHTE CA Zа TEOPA

НАI В АM Z HAПA 
$13 \mathrm{a}$

СТИ НУГОНАЩА

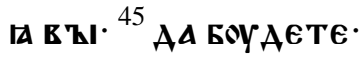

с̈н̈E ӧ̈а вашего

HжЕ IECTh HA HËCE

5

Х'

IE СHIAETh HA Z7h

ГА Н БӒГҚIA Н АТ

жанTh HA ПрАЕh

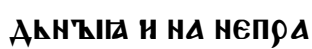

10

вһАһHҚIґ. ${ }^{46}$ Аџе

АКБНТЕ АКБАНА

IA E ҚI KOYК Mh

ЗАOY HМАTE ' HE

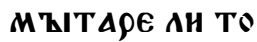

15 Же TBOpA Th ${ }^{47}$ H А

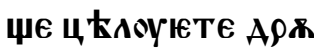

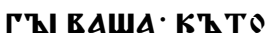

MoY. पh TO АHше

ТВорнте' не MЫ

20 TApE АH TAKO TBO

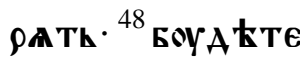

OYБO c'ZKh Qh WE

нН ГАКО оц̆ ВА
136

ШК HЁСНҚIH СҚEh

ршен' Юс Th $\because . \cdot$

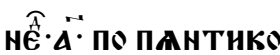

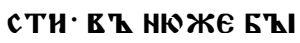

5 вАЕТИ. ПАМА

X'z с т̈т'

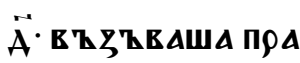

Матфей

$\mathrm{X}$

EY $A \cdot \bar{W}$ MATh OEA $\because$.

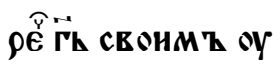

37-38

10

чеником ъ ${ }^{32}$ ви

САК' НЖЕ НСПО

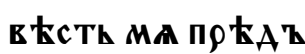

ЧӒЕКТ। भСПОВ

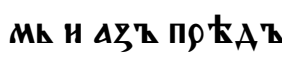

15

оц̈кMh Монмк н

ЖЕ ЮсTh HA нЁсе

${ }^{33}$ А нже ЙБи рижеть

са мене по Аа че

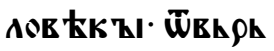

20 ГоY С А ЮГО и $\mathbf{4 Z \mathbf { Z }}$

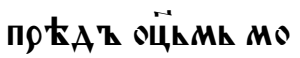

НMК нЖЕ Юс Th HA

нБ̈сеХদ $\cdot{ }^{37}$ нжЕ АюБї 


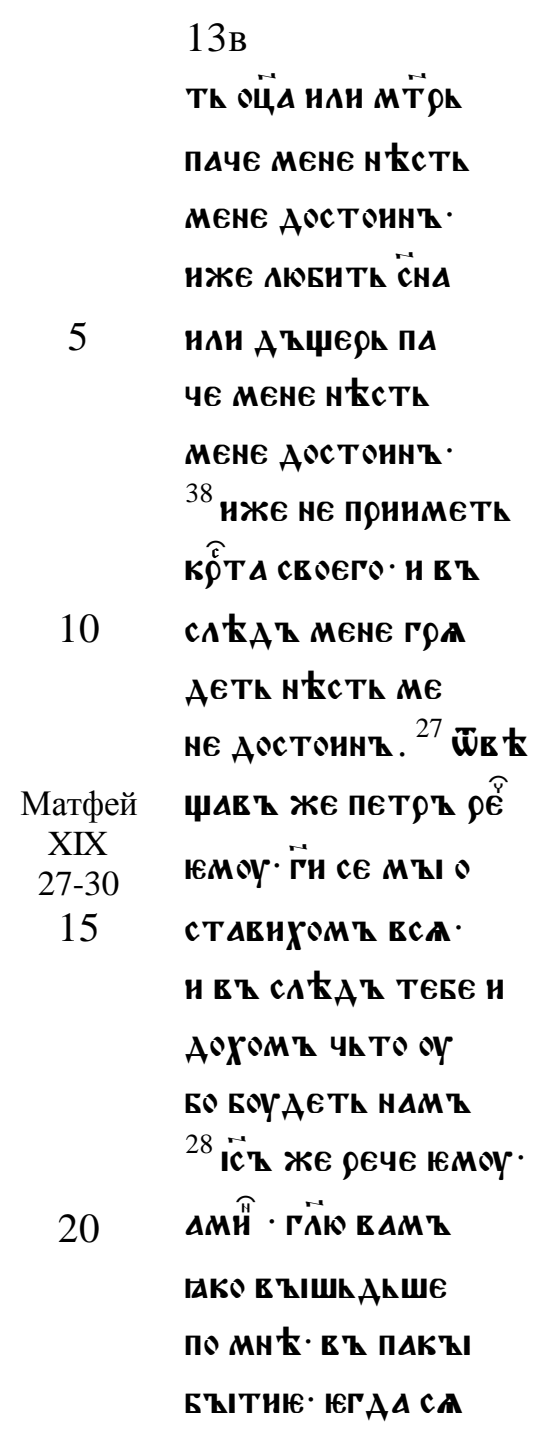

13в

Th оцА нАн МТ ९һ

мене Аостоннт

НЖЕ АКБНТК с̈нА

НАн АТще९һ ПА

YE MENE H KC Th

МЕNE АОСТ ТнH'

${ }^{38}$ нже не прннметь

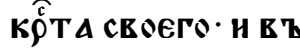

10

5

$13 \Gamma$

AETh CH'h पत̈вपh

ск'М на пю Есто

А С САAR ҚI CEOEA

САAETE И ВЫ HА

5 A'zBon ha aEcate

חоtcTonOY COYAA

WE SБЕMA HA AECA

TE KOA KHOMA HÄEO

MА. ${ }^{29}$ и БИСАК' ИЖЕ

0 ОстАKНTK АОM Z

АН БРАТИК· АН СЕ

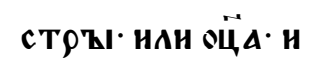

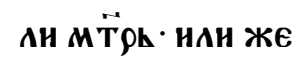

HOY· нАн А ТТн· Н

15 Ан СЕАА НАН ХОА

МЫ' Н МЕНЕ МОЮ

ГО ९ААН · с Т TO९H

цек прннмети

и жнвот в в ћчh

20

HҢH HACA

${ }^{30}$ MHOZH БO БOYAOY

Th - Пи ९внн посА $\mathrm{K}$

Аьнин· н послћ 
$14 \mathrm{a}$

АКнНнН ПК ОВНн $\because \cdot \cdot$

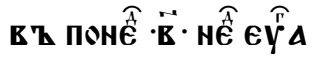

Матфей $\mathbb{\mathbf { W }}$ мАTh

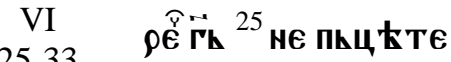

5 са гӥше. पи то

ЕМҺ ИАН Чһ ТО

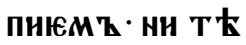

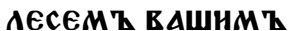

ह' पh TO оБ八 太पе

10 TE сA' HE АШ̈А Ан

БОАһшн ๒с ТА Пн

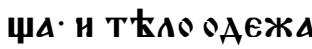

${ }^{26}$ въ३һ ९нтЕ нА Пти

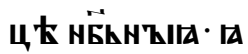

15 Kо не с Еютh нH

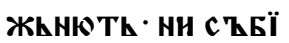

рАКть в Z жнтh

нНцА' Н оц̆ ЕА

ШК НЁСНZIH ПН

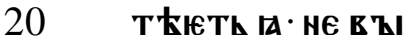

АН ПАЧE Юс ТЕ АOY

чhше ихтв ${ }^{27}$ кто

же $\overline{\mathrm{w}}$ васқ пекъин
146

сА МоЖЕТИ прн

АөжиТИ ТЕАЕсн

CBOEMh AAK' Th

ЕАНнъ $\cdot{ }^{28}$ н O WАEЖÏ

5

पh TO ПEYETE CA'ch

мотрнте цв ЕТИ

цКсЕАКн'Қ/ИТ'

KAKO PACT TYTh

HE TPOYжANTh CA

10

ни прААОУтh $\cdot{ }^{29}$ ГӒК

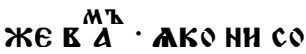

АОМОН' Вһ ВһСК

CAABOY CEON OБА

ЧЕ СA' IAKO EAHHT

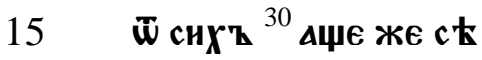

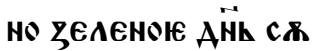

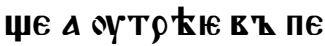

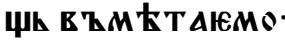

Ëh TAKO A kiTh $\cdot K O$

20

АКМН ПАЧЕ ВАС' МА

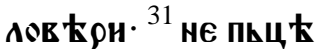

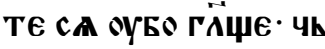

TO АM Н НАН पК TO 
$14 \mathrm{~B}$

ПНюМ АН ЧнМТ

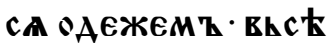

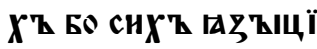

HщNTh в Вс Th Бо

5

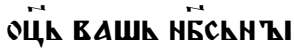

и ДАКО ТО КБоУњТЕ

вйсt X' снХ' $\cdot{ }^{33}$ нщ

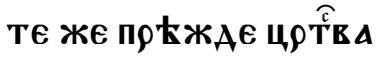

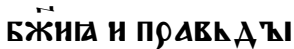

10

ІЕГО Н СН ВСА ПОН

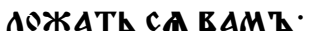

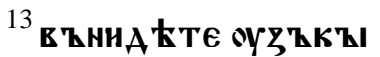

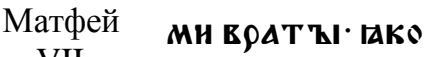

VII

15

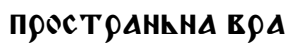

TА н шнрок' поY

TИ В'ҚEЯАA Н ЕТ ПА

ГОУБОУ' Н МHOZH

COYTh в ZX'АALї̈

HMZ $\cdot{ }^{14}$ KOAhMH OYZZ

20 КА в९АТА Н ТЕСНҚI

Н ПOYТК Е ҚЕOAА Н

в ' ЖнЕОТ' И МА

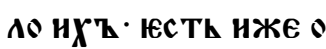

$14 \Gamma$

БрКТ АКТИ H $\because \cdot \cdot$

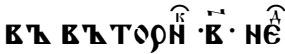

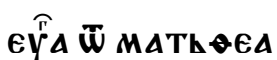

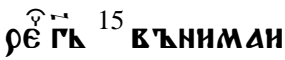

5 Те $\overline{\mathbf{w}} \Lambda \mathbf{z н и х и ~}$

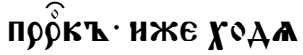

Th K'Z BAMZ · B '

вьцАХ'h оАєжАХ'h

в ZHOYT

10 же соути $X^{\prime \mathbf{L} щ к н и ~}$

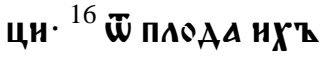

ПОZНАНTE IA. EAА

OELEMANTh $\overline{\mathrm{W}}$ Th

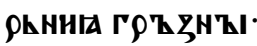

15 Ан $\overline{\mathbf{w}} \rho$ 太Пниг смо

КЂЕН. ${ }^{17}$ TAKO EhCE

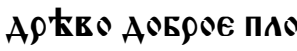

А АО АОБ९ҚІ ТЕО९н

TH.

20

ПАOAZI ZИАЫ TEO

рнти. ${ }^{18}$ не Можеть

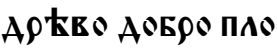

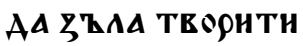


$15 \mathrm{a}$

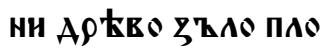

АА АОБ९А ТВОРНТИ

${ }^{19}$ висе А९Ћво ๒ЖЕ не

TEOPHTK ПAOAA AO

5

Бра' пос Ккањм॰

EZIEAЮTh H В 'Z W

FHh в ZMM ЕT АЮMO

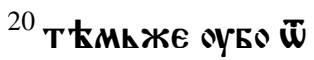

ПNOAА HX'Z ПOZHA

10 НТЕ ГА. ${ }^{21}$ HE ВИСАKТ

ГӒАН Мн Г̈ Гे $\overrightarrow{\text { मे }}$

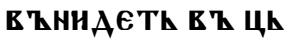

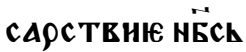

Hoほ H'Z TEOPAH

15

вОAю ОЦ̈А MOEГО.

нЖЕ ЮСТИ НА НЁС

$X^{\prime} \mathbf{z} \cdot \cdots \mathbf{k} \mathbf{z} \mathbf{c} \hat{\rho}^{\widehat{T}} \mathbf{k}$

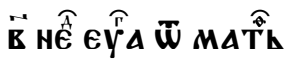

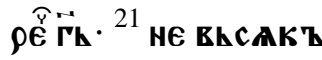

20 ГӒАН МН Г̈Н Г̈Н

В ZHHАETh В Қ ЦК

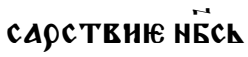

HOE' H' TEOPAH
156

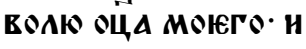

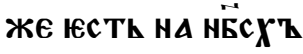

${ }^{22}$ мнезн рекоути мт

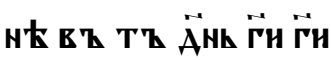

5 НЕ ЕТ ТЕऽЕ АН НМА

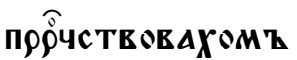

Н ТВонМК НMЕнК

М' СНАҚІ МноГ'ҚI

съ теори Хом ${ }^{23}$ и

10 ТИГАА НСПОВ ҚМh

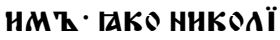

жE zHAY' вAC' $\cdot \tilde{w}$

HA

сн Твораџен БеZа

15

коннюе $: \cdot \cdot$ в Қ ч

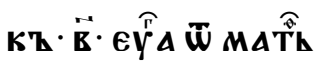

въ в

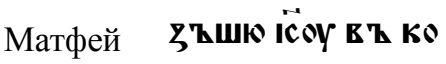

VIII

23-27

20

pAБAh - ПO HEMh

HAOUA OYYE

ници его. ${ }^{24}$ н се троу

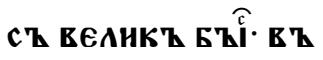

М०९H · IAKO ПOK $\rho \mathrm{ZI}$ 
15 в

ВАTH CA KOPAБAК

В ZАHАMH $\triangle \mathrm{TT} \mathrm{C} \mathrm{Ch}$

паше ${ }^{25}$ и прншкат

ше оученнци юго

5

в ไदБОУАНША н ГӒڤ

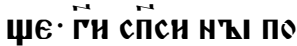

ГZIENE MZ $\cdot{ }^{26}$ Н ГӒА

HМт чh TO ст९Aшї

вН ЮСТЕ МААОВ 太

10

९НH TZГАА ВСCTA

в Z そапр К ти в

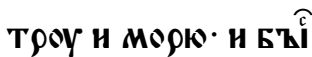

TИшннА веАнКА

${ }^{27}$ оученици же чю

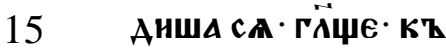

To ch IfC Th · raKo в E

трн и море· послоу

Матфей ШАютh юго $: .$.

IX

20

14-17

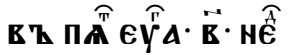

W MAThOEA $: \cdot \cdot$

в В в

пншА оученицї

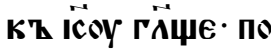

$15 \Gamma$

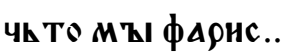

ПостнМт СА MHO

ГO. $\triangle$ ТВ ОН ОУЧенH

ЦИ HЕ ПOC TA Th СA

5

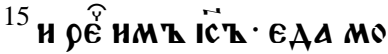

ГОУТИ сн̈Ове Б९А

ЧКнНн ПосТИТИ

CA· AOHAEЖE C' H ̈Ï

мн юсть жени Қ'

10 ПрНАОУТИ ЖЕ АН̈

IE ЮГАА ய̈нMETh

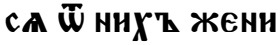

$X$ h Н ThГАA ПOCТА

Th са. ${ }^{16}$ ннктоже

15 БО НЕ ПОНСТ АВАГА

ЮТИ ПФНст ТВАE

HНIA - ПААT А HE Б太

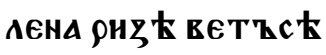

в'ZुhMETh EO Ko

20

Нhчнноу СвОК

рнб'Қl н горьши

АнрА БоYАЕТт. ${ }^{17}$ нH

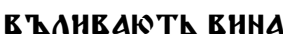


$16 a$

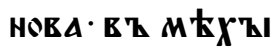

ветқХ'Ы- Аџе Ан

ЖЕ ни ПрОСАаОУ

Th CA М КСН· Н ЕН

5

No прол Қют人 CA

Н М АСН ПОГ'ҚIБНЖ

Th' HZ ЕНнО NOEO

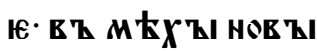

В ҚАНА ТН· Н ОБОЮ

10 с'ББКАЕТИ СА $\because \cdot \cdot$

CA ${ }^{\mathrm{E}} \cdot \overrightarrow{\mathrm{E}} \cdot \overline{\mathrm{W}}$ MAThoEA

Матфей $\rho \hat{\Upsilon} \vec{\Gamma}{ }^{1}$ не осоүжА

VII

$1-8$

15

HTE AA HE OCOY

женн Боуаете ${ }^{2}$ н

MhжE соYA $\mathrm{kmh}$ c及

AHTE COYAHTL CA

вАM ' $\cdot$ и в ' Нюже

мћроу м Крнте

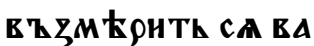

$20 \mathrm{Mz}^{3}{ }^{3}$ чh TO

ши соучьць В $\mathrm{B}$ :

ЦҺ Б९АТА Св ВеГО

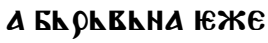

$16 б$

ЕСТИ вҚ оц Т TВоEMh

HE ЧюЮШН ${ }^{4}$ НАН КА

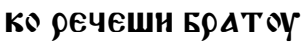

TEOEMOY· OCT ARH

5 AА H马ूMOY COYपh

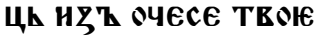

го. ${ }^{5}$ Анцем Ере нзһ

МH Пh $\rho$ В हOI Eh $\rho$ h

BИHO H马 OUECE TRO

10

EГO н TOГAA OYZh

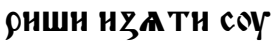

पhцК Н马 Очеса Б९А

TA TESEгO ${ }^{6}$ HE AA

Анте с

ни пом ћтАнте

15

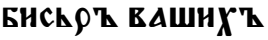

ПФҚАТ СвиннА

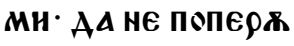

Th НХ' НОГАМн

20

СЕОНМН· Н ЕРА

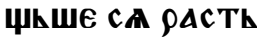

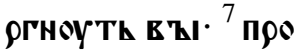

CHTE И AАCTh CA 
$16 \mathrm{~B}$

вАМт нщћTЕ н О

Брашете тһAт

ЦКТЕ н ОБРАџЕ

TE ${ }^{8}$ вLCAK' EO ПрO

5 САн ПрНюмАЕ

Th ищан овр

TAlTh и ThА ҚKळ

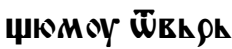

zaltTh ca $\cdot: \cdot \cdot$

$10 \mathrm{HE \hat {A }} \cdot \overrightarrow{\mathbf{E}} \cdot \overline{\mathbf{W}}$ MATR

Матфей в в в

IV

18-23 ї̈һ пон морн гА

АнАћнсц Қмь

вHA А АZEА Б९А

15 TA CHMOHA HA

рюц АњМАГО пе

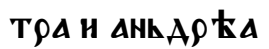

Б९АТА ЮГО в ҚM

ТАКџА м ЋжА

20 вһ Mope. БестА

Бо АовһцА. ${ }^{19}$ Н $\rho \widehat{\Upsilon ~}$

HMA HА ЕTА ПО

MZHE н C'..
$16 \Gamma$

ОЮ В ҚІ АОВИЦА

ЧӒЕКОМ द $\cdot{ }^{20}$ ОНА

HE АБНЮ ОСТ АВАК

шА м९ КжА По не

5 ми нАОстА. ${ }^{21}$ н прї

WHAT $\widetilde{W}$ TOYAOY

SY马LP太 HHA ATEA

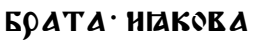

CHA ZEREA KORA.

10 HOAHА БФАТА EГО.

В Қ КОРАБАН С' Zе

вEA toMk оцймh

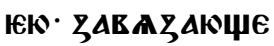

М९ћЖА Св ГА. н в Қ

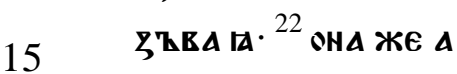

БНЮ ОСТ АВАКША

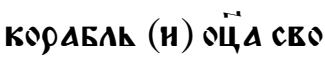

ETO ПT HEMh HAO

ста. ${ }^{23}$ н прохожаше

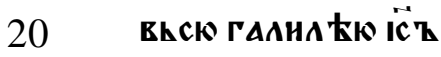

SYYA HA CZHKMH

ЧнХ'И нХ'

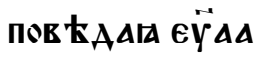


$17 \mathrm{a}$

нГӒнЕ цёст ТЕА.

Н Ц КАAГA ВНСAKK

HEAOYГT · H BhCA

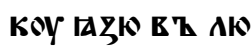

$5 \quad A^{\mathbf{k}} \boldsymbol{\gamma} \mathbf{h} \cdot \because \cdot$

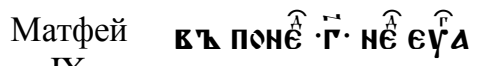

IX

36-38

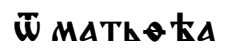

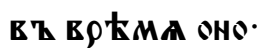

${ }^{36}$ вна th ї̈' Hapo

10 АТ многъ и мї

AOCPAORА О НH

X'B · TAKO БAXOY ch

Матенн и ш̈вцрh

ЖЕнн · ТКО овиц А

15 не нмоущА пАстТ।

PA. ${ }^{37}$ TZTAA ГÄA OY

ЧЕНHКОМ СЕ

Mh Ж ЖTE А OYБO

MHOГА. А А КАА

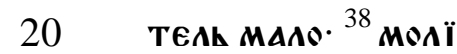

Te ca oyeo roy o

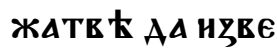

AETh A KAАTEAA
176

Матфей

$$
\mathrm{X}
$$

HA ЖATE OY CEON

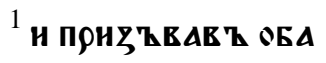

hA AEсA TE оYченї

КА СEOIA ААСТ Н

5 MZ ЕААСТК HА AC̈

X' HEपёThIX' AA

H马ГOHA Th IA. H

Ц ҚАA Th HEAOYГKI

H вCA IAZA ${ }^{2}$ OБK

10 МА ЖЕ НА ААСА TE.

AП ̊̊̊MA. HMEHA

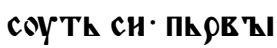

и снмент · нже

HАрHчањTL CA

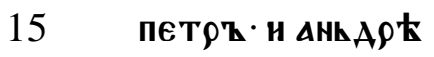

А Б९АТТ ЕГО Н НА

ков z зекеA Ћов $\mathrm{z}$

HOAHZ БРАT' EГO

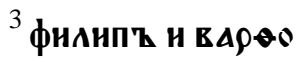

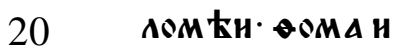

МАТфКн и М'ҚI

TAPh - HIAKOE h - $\triangle$

Афе०в ' ' и Келев Е 
17 B

Н НАРЕЧЕНҚН $\diamond \triangle$

A th ${ }^{4}$ снMOH' KA

HAN ЕН ИКАА СКА

ОНОТ А ТИнҚ НЖЕ

5 н поћААС Тһ. ${ }^{5}$ Сн о

EA HA AECATE nOCK

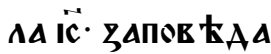

В И HMҚ ГÄA· HA ПЖ

Th IAZ'JK' NE HA

10 ТЕ И в Г ГРААТ СА

MАРАнҚ НЕ в ҚНї

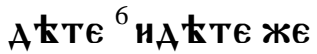

ПАЧЕ К' овһцАМ'

ПОГҚІБ Қ ШHМ Қ

15 АОМоУ нदӒЕА ${ }^{7} \mathrm{X}^{\circ}$

Ааше пропев $\mathrm{k}$

ААHTE ГӒше ' TAKO

ПОНБАНЖН СА ЦК

CAPLCTEO HËCHO

20 Ю. $^{8}$ БОлаџАІА Ц

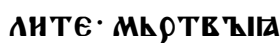

въско КшАнте

прок АЖЕн'ЫІа О
$17 \Gamma$

цнџАнте Б太сқы

нугоннте ' тоуне

прнасте ' тоуне

ЖЕ и АААнТЕ : :.

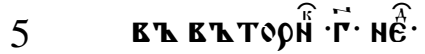

EỸ $\Delta \cdot \bar{W}$ MAThOEA

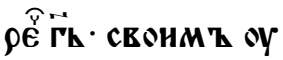

ченнкомт $\cdot{ }^{9}$ не ст

TAж太TE' उAATA

10 нн с

Ан пон пегас $\mathrm{X}$ '

вАшнХ' $\cdot{ }^{10}$ ни врћ

ТнщА нА поYТн

HН АТЕОN РH马OY.

15 ни сАПоГ'Қ ни жи

3АA. АOCTOHН'

БO њCTh A \$AATE

Аh ПНџА СвоЕА -

${ }^{11}$ в Т ньжЕ КоАнжь

20 AО Г९ААТ

Ch в ЂнHАETE' и

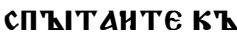

TO в TE HEML AOCTO 
$18 \mathrm{a}$

HнT ПОНАЕТК МнРҚ

BAWh HA Hh ' H TOY

прћвъIв Анте ${ }^{12}$ въ

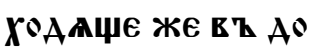

5

мъ ц ААуите $\cdot{ }^{13} \Delta$

LE OYБO БOYAETh AO

M Z АОстОHн' - П९ї

AETh MHрҚ вашh HA

Hh - Аџе Ан же не БоY

10 АЕТК АОстоннт Мн

P'h BAWh K' BAMT

вҚ马ЕРАТИТИ СA

${ }^{14}$ нже колнжи АО не

Прннметь вАС'

15 нН ПосАоушАЕТ

сАовеС' вАШнX'Z

HCX'AALE H马 AO

МОУ· НАН НЗ ГОА

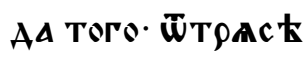

20 TE праX'k ש̈ ног'

вАшнX' ' НС 'АA

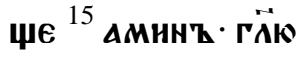

BAMZ $\cdot$ WOAALHK
186

Ю БOYАETh ЗЕМАН

соАомисц ' म земАÏ

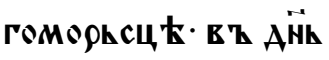

сOYАКНҚIH · нЕЖЕ

5 Ан ГОААОУ ТОМОУ : :.

Kh c cổ

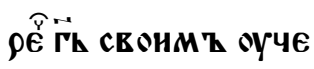

NнкOMz $\cdot{ }^{16}$ ce $\Delta \xi \mathrm{z}$

CҚAN E ҚI IAKO OKh

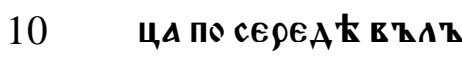

Kh БоYА Е TE жE M8

А९Н гаКО З Мнга.

Н ц КАН IAKO ГОA ОY

Бне. ${ }^{17}$ винемА Кте

15

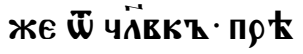

AAAATK EO ETH HA

CZHKMZI· H HA CZ

НКмнчнҮ'Қ вАшї

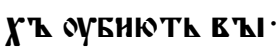

20

${ }^{18}$ н прћАТ в

же и цёа веАоми

БOYAETE MENE At

АA В'Z С'ZE 
18 в

Ю нМ Z Н ст ९АнАМ Z .

${ }^{19}$ ІегАА же прнвеАОУ

Th вҚ не ПКЦ Кте сA

KAKO АH पh TO

5

TE A ACTh БO CA BA

MZ EZ TZ 4ACZ 4 H

TO ГӒТЕ ${ }^{20}$ He в'Қl БO

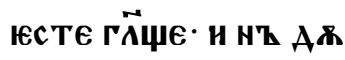

X'h оц̆А вашегО ГÃA

10 н в' вАСт. ${ }^{21}$ пр ЕАА

сти же Б९АТт Б९А

TA HA C'BMh $\rho$ Th' H

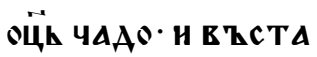

HOYTh YAAA HA PO

15 АНТЕАА Н ОУБНК

Th ז. ${ }^{22}$ н БоYаете

НЕНАВНАНМН Н

Мене МоюГО РА

AH' прt тhрhп

20 В Қ/H ЖЕ АО КОНh

ЦА спїен'Қ БOYAE

Th $\because \because \cdot$

в һ четв ${ }^{\widehat{F}} \cdot \vec{\Gamma} \cdot$ Hễ
$18 \Gamma$

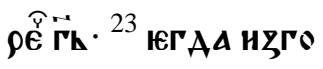

HATK E'ZI E' ГPA

A с семh - БћГАнте

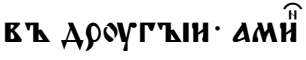

5

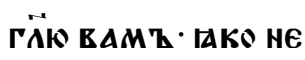

HMATE HСКOHКЧА

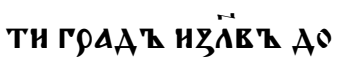

HZAEЖE ПОНАETh

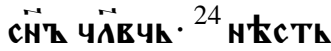

10 SYЧEसHK' HAAT OY

ЧнТЕАЕМ' - НH ९А

EK HAAZ FHZMML

СвонМh ${ }^{25}$ АОВ ҚА

IЕTИ БО оУченНК'

15 AА БOYAETh ТКO \&

ЧнТЕАК ЮГО - РАБЖ

TAKO ГH'Z IEГO АџE

БO ГHA AOMOY BEAh

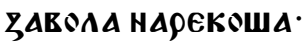

20

КОАһМH ПАЧE А०

MAWLHAIA ETO

${ }^{26}$ HE OYБонте CA OY

БO HX'B - HHYK TO 
$19 \mathrm{a}$

же Бо юс тh покриве

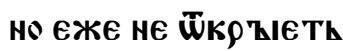

Са и ТАнноE ЮЖе не

оув

5

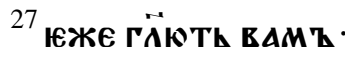

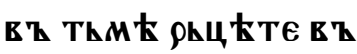
св kTt· н еже в '

Хосатышнте про

ПOВ 太АН TE HA сTЕ

10

HAX' $\cdot{ }^{28}$ н не оуБон

TE CA $\overline{\mathfrak{W}}$ оYБHE

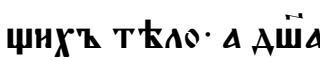

немогоYнमX'B oY

Бнти - оуБонте же

15 са ПАче НMоYџА

го и Аш̈оу и т ТА०

ПогоүБнти въ ГЕ

OH. ${ }^{29}$ HE A'ZE

ПЪ Тицн на соурн

20 Н МЕннМ Е ЮСТ А

и н. ЮАНHА ЖЕ $\overline{\mathbf{w}}$

HE. חAAETh HA

zeMA.
196

вашего ${ }^{30}$ н ваши же

Н ЕААСН ЕһСН Иџһ

TENH COYTh ${ }^{31}$ HE OY

БОНТЕ СА ОУБО Мно

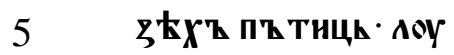

पhше ঋсте в ҚI $\cdot: \cdot$

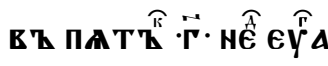

Wi MATh $0 E \Delta \cdot: \cdot \cdot$

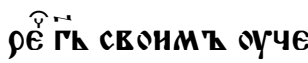

10

HHKOMZ $\cdot{ }^{32}$ BhCAK'

нже нспов Кс Тh

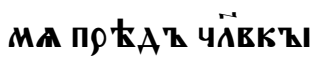

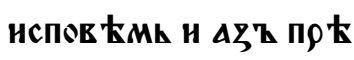

A h оц̈Мh Монми н

15 ЖЕ ঋсть нА НБсеХ'

Матфей ${ }^{34}$ не мннте гако прн

$\mathrm{X}$

34-36

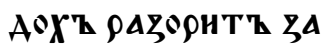

КОНА ' нН АКО ПОН

A॰X'Z в'ҚЕ

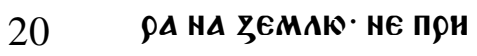

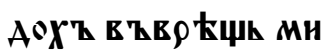

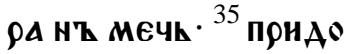

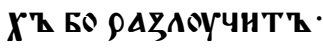


19в

CHA HA Ö̈А СЕOETO.

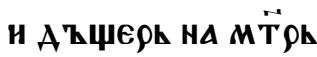

Свою. н нев tст ТY

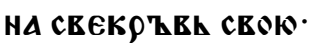

5

${ }^{36}$ Н ЕФАЗН ЧӒЕКОУ А०

МАШКННИ ЮМОУ.

Матфей

XI

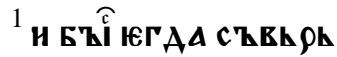

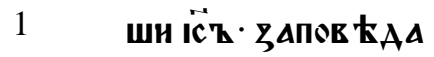

IA SE KMA HA AECA

10 ТЕ оУченикомА

свонМА' ПО КНАЕ

W TOYAOY ФУчнТ'

н пропев 太ААТ '

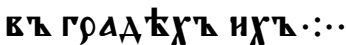

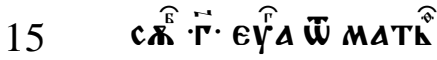

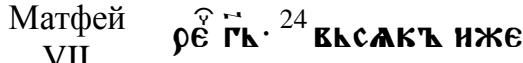

24-29

CA'ҚIUHTh CAORE

CA MOTA CH' H TEO

ОHTh IA. OYПTAO

20 БАю И МоУжК М8

Ароу. иже с $\mathrm{z} \zeta \mathrm{h} A \Delta$

ХОАМнноУ СвоК

HА КАMENH $\cdot{ }^{25}$ H C' 19г

НHАЕ АТЖАК И ПФН

А०ША $\rho$ КкҚ/ н в Қ

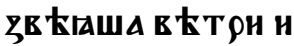

HATAA OUA HA XPA

5

МHHOY TOY H HE ПА

AE CA - OCHOB AHA EO

Б大 HА КАМЕнН $\cdot{ }^{26}$ H

BИCAK' CAҚIWAH

CAOEECА МОА СН И

nE TROPA HX'B OY

ПОАОБНТК СА М8

Жю БОУЮ मЖе $\mathrm{ch}$

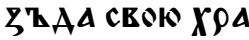

МнHOY HA ח EC'

15

ц $\mathbf{k} \cdot{ }^{27}$ и съннАЕ АТ

ЖАК' н П९НАОША

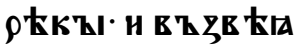

ША в 太трн и өпьро

ША СА ХОАМнНЕ

20

ТОН И ПААЕ СА' Н

Б太 ९АЪА९ОУШЕнї

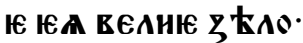

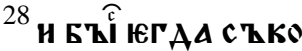


$20 \mathrm{a}$

HhЦА ÏC Kh EA CAO

BECA CH AHEAAX क

са оученнци его.

${ }^{29}$ Б K EO OYYA IAKO BA A

5 стТ нМЫ' н не IAKO

кннжиници и фА

Матфей

VIII

$1-4$

10

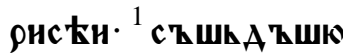

IEMOY ch rophl ह z

сA

нА९ОАН МноZН. ${ }^{2}$ Н

се прокаЖЕнһ прї

С TOYПН И КААНА

AWE CA ЮMOY ГÄA.

Гй АџЕ Хоџешн мо

15 ЖЕШН МА Очнсти

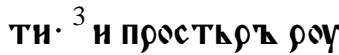

KOY Ï' $\mathrm{Z}$ КОСНОУ И ГӒА.

ХОНю ОЧнс TH СА

Н АБНЕ ВЧНС ТН СА

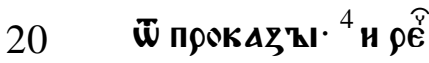

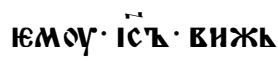

ннкомоуже не по

в 太жh· H' WhAth חо
$20 б$

КАЖн са не९ Ею и

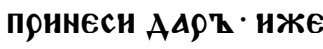

ПОвеА Қ Монсн· в Қ

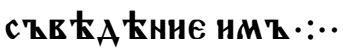

HÊ $\cdot \vec{\Gamma} \cdot \epsilon \hat{Y} \Delta \cdot \bar{w}$ MATh

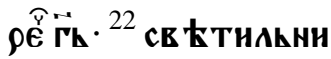

K' TkAsy EcTh W

Ko АLE OYБO БOYAE

Th oko TEबE просто

10

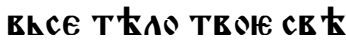

ThAO EoYaETh ${ }^{23}$ Al山E

AH OKO TEOE AOYKARO

БOYAETh всE TKAO

TROE ThMLHO БOY

15 АETh - АџЕ АH ОYБо

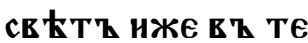

БE ThMA EcTh'Tt

Mh ThMA KOAh

мн. ${ }^{24}$ никъи

20

Бо можетһ А'द K

MA ГHAMAMA PAEO

ТАТИ· НАН ЕАНН

ro Аh $\rho$ жнти сA 


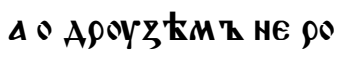
АНТИ НАЧИНЕТИ АН ЮАННОГО в Қ马НЕ НАВНАНTИ А А९ОУГА ГО вһЗАКБНТИ· HE

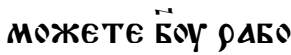
ТАТн· и БгАTИCTЕ $\boldsymbol{~}$. 25 сего ९ААН ГӒК вА Mh HE Пһц Һ TE сA

10 Аய̈ек вАшек- पh TO Һсте и чh ТО Пн

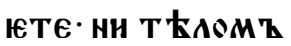
ВАШНM В В Қ ЧT० OБ八 KपETE CA HE

15 Аய̈ム Ан Больши ๒ сть пнщ ОАЕЖАн. ${ }^{26}$ в ҚЗһ९н TE нА Птнц Һ нБсе HZIIA IAKO HE C KN

в Қ жнТһннцА' и

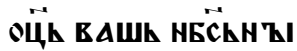

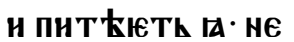

В 'ҚІ АН ПАЧЕ АОУЧһ ше юсте ${ }^{27}$ никтоже ї вАсһ ПеКһ/H СА Мо жЕти прильжнти

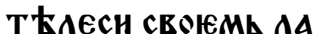
К'Қ ТИ ЮАНH' ${ }^{28}$ Н О W АєЖи чh Т० сA пеपе те сһмот Рнте цв

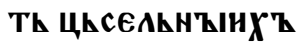
KAKO gACT TYTh ' HE

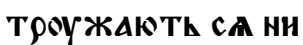
пранаути ${ }^{29}$ гйю же BAM Z ' ТАКО НH CONO MOH' в Қ ВһCEH CAA в СК ОЕН ФБА Қपе СА ГАКО EAHн' $\overline{\mathbf{w}}$ снХ' 30 АџЕ ЖЕ С Кно АН̈ С цењ· $\triangle$ оут $\rho$ в в ГHh вһM ŁT AEMO Бh TAKO A tETh'Ko АКМН ПАЧЕ ВАС ' МААОЕ К Пиц Т Те СА оуБо 
$21 \mathrm{a}$

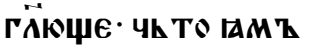

НАН ЧК ТО ПНњМ $\mathrm{z}$

АН ЧнМ Қ ОАЕЖћМ

CA. ${ }^{32}$ висkX'Z Бо сн

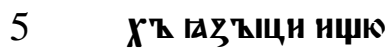

Th в 太стh Бо оц̈

BAWh HECLH'KH

IAKO T९ҚБоуюте

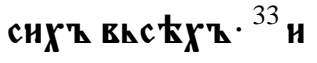

10 шћте же прћже

црёТтА Б̈̈нга н

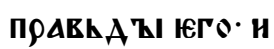

СН вһCA ПрНАงЖА

Th CA BAMZ $: \because \cdot$

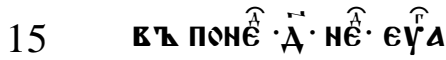

Матфей

XI

2-30

WU MATh OEA

ВZ ОНО в

WAE' HOAH' E'

оужьниц $\mathbf{~} \mathbf{A}$ t

20

В Қ оУченнК'Қ СЕ О

IA ${ }^{3}$ рече ґMOY. ThI

АН юсн ГОАА ҚІн

216

НАН ННОГО Ч АЮ М'Қ

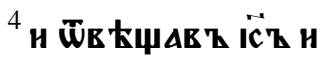

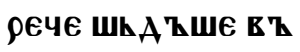

зЕ 太стите ноАнж

5 ГАЖе сАҚшнте и внанте $\cdot{ }^{5}$ сАћПни

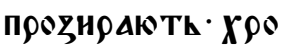

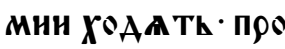

КАЖЕнНн - ОчнџА

10

NTh CA Н ГАОYСНH

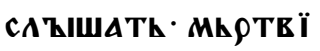

Н ВЪСТ АКТЬ ' Н НH

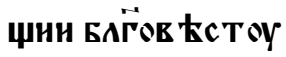

юTh ${ }^{6}$ Н БААЖЕНҚ

15

ЮС Th НЖЕ HE СТБАА

ZHHTh CA O MZHE

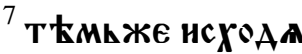

LEM ' HAYAT' IC̈h

ГӒАТИ НАРОАОМ

20

HOAN E YK TO H马H

АОстЕ вНА ТTZ в

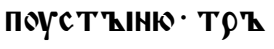

сTh Ан в ЕТ९ҚMh 
21в

KOА ББАЕМЫ: ${ }^{8}$ H'

ЧК TO H马НАОСТЕ вН

A ЋTҚ· ЧАЁКА АH Е Қ

MAK'KK' ९H马'

5

ОБАҚЧЕНА СЕ НЖЕ

MAK'KК AIA HOCIA

Th в' AOMOX' цео̆ї

$X^{7}$ coyTh ${ }^{9}$ Hz 4 co

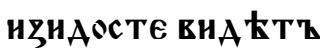

10 Пр९ेКА Ан· Ен ГӒю

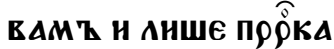

${ }^{10}$ ch Бо юc Th o HeMh

ЖЕ Пнс Ано Юс Тh.

cE $\triangle$ Zु' ПOC ZIA $\triangle \mathrm{W}$

15 АНГ̈А MOњEO прt

АТ АНЦКМК ТВОН

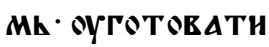

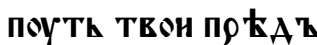

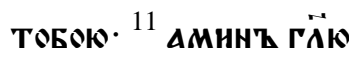

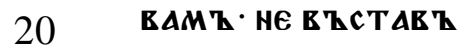

рожен'ҚIX' женА

МН· БОАН НОАНА

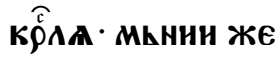

$21 \Gamma$

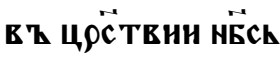

нћМh· БОАни ЕГО Ю

сти ${ }^{12} \widetilde{W}$ АНН ЖЕ н०А

HA KPCAAA AO cEnt.

5 цРС̈ТТЕ НЁСКНОЕ

HOYAHTL CA' H HOY

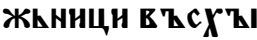

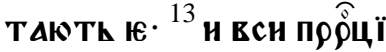

Н ЗАКОН' АО НОНА

10

прорекоша ${ }^{14}$ н Аџе

Хоџете прнгати.

TИ ЮсТИ НАНА $\boldsymbol{X}^{\circ}$

ТАН ПФнти ${ }^{15}$ нМ Е

ТАН ОУШH CAZIWA

15

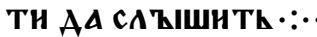

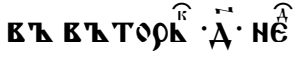

EY⿱乛⿻

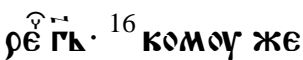

OYПOAOEAN gO

20

AT Ch - ПOAOELHT

Есть A Ктище

Mh ckAAџEMh

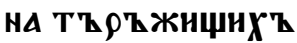


$22 \mathrm{a}$

нЖЕ в ҚУГААШАК

Th А९оугом' cвoї

Mh ${ }^{17}$ н гӥютh conoxo

Mh вАMһ' Н нE ПАА

5

сАCTE· ПААKАХОМ'

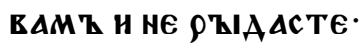

18 прНАЕ БО ноАН' НН

ҚАҚІи и ни пнга $* .{ }^{19}$ и Гйю

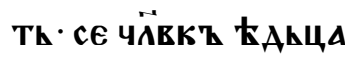

10 н винопннц А' М ҚІ

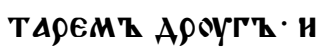

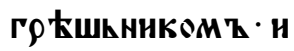

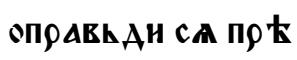

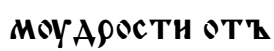

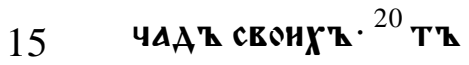

ГАА НАЧАT' ПОНO

СНТИ Г९ААОМ В В

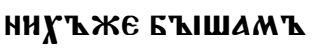

ножАншАГА СНА ҚI

20 ЮГО. ЗАНЕ нЕ ПОКА

Aய4 CA $: \because \cdot$

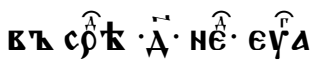

iu maThota
226

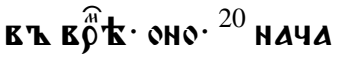

Th Iст поносити

ГОААОМ'

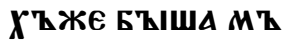

5 НоЖАНШАА СНАҚ

ЮГО 丂АНE HE ПОКА

AWA CA. ${ }^{21}$ ANT T TO

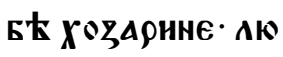

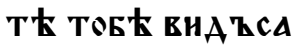

10 НАО. ГАКО АЩЕ БҚІ

в Т TOY९ Н С САОНЕ

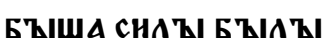

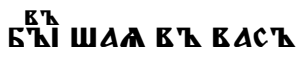

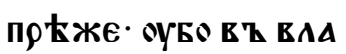

15 САННЦИ и ПОПЕА

ПОКАГАИН СА БҚ

ША. 22 ОБАЧЕ ГӒК вА

Mh T ТУ ОУ н СНAO

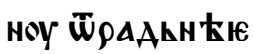

20

БOYAETh в' Aн̈h

COYALHҚIH · нEЖE

вАM А. ${ }^{23}$ H ThI KAПE

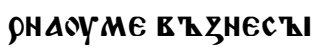

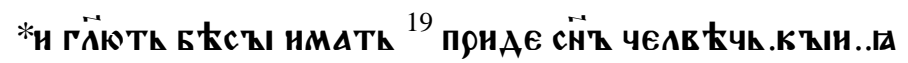




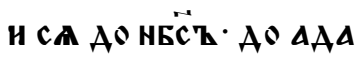

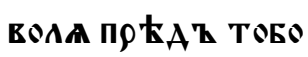

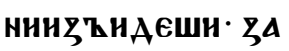

HE IAKO в h COAOM

X' БҚШША СНАЫ БҚI

ТЕБе ПрҚБЪАн БЪ

WA AO ANKHA Aн̈. ${ }^{24}$ ОБАЧE Гत̈К вА

Mh' IAKO ZEMAH CO

10 АОмксц Кн ш̈рААК

HЕほ БOYAETh · E ' ANh COYALH'WH HE же теке ${ }^{25}$ в т те вр

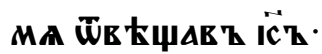

15 рече нспов स ААю

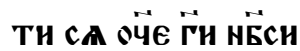

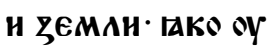

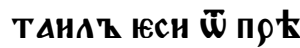
МоУА 'ҚІиХ' и $\rho А$

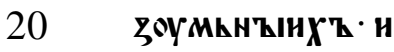
ГАВНАТ ЮСН MАA АЕнццеми ${ }^{26}$ Ен จӵย IAKO TAKO Б'ZICTh

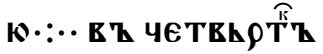
$\vec{A} \cdot$ Hể $\cdot \bar{W}$ MATh OE $\cdot:$

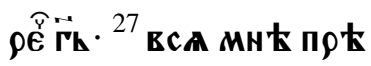
5 AАHА COYTh оц̈ Мh Монмь' н ни КТОЖЕ нЕ ЗНАЕТИ сН̈А TZKM० оц̈. нн оц्А КЪ Т० दूА

10 ЮTh TZKMO CḦ. и ЕМоУЖЕ вЕАнТ

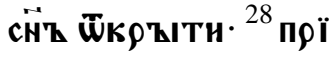

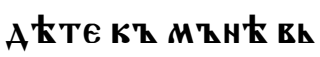
СН ТРОУЖАКџн

15 Н СА Н оБр ҚМене ни и $\triangle$ 'Z Покою

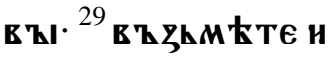
ГО MOЮ НА сеБ太- Н HAOYчHTE CA Ẅ ME 20 HE IAKO КрОTтK'

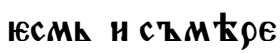
н' с९ӒЩимк н W БРАџЕТЕ ПоКОН 
$23 a$

АШ̈АMЋ вАшнм

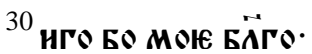

Матфей

XII

$1-8$

5

и вр Қма моң Аh

ThKo 1ECTh $\because \cdot \cdot$

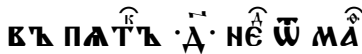

въ вө̆

ić в Z coysotoy

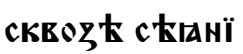

ГА. оученици

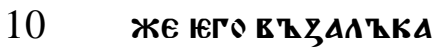

WА' H HАY АWА E '

стұ९ГАТн КААС'Қl

н Ћсти. ${ }^{2}$ фАрнс Łи

жЕ внА Ћв \ше и

15 рекоша юмоу. се

ОУЧЕННЦН ТВОН

TворатИ НГОЖе

HEAOCTOHTL TEO

Онти в' соуБотЖ

20

HЕсTE Ан ЧһАн

Yh TO C'Z TEOPH AA

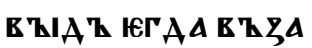

\section{6}

IZKA CA CAMh $\cdot H$ соуџни ст ннмь

${ }^{4}$ КАКО в'МНHАE в'

АОМт Бӝнн· н ХА太

5 БҚІ ПОАҚАОжЕни

A с'ZH सc Th' нХ'Zже

HEAOCTOHнO EMOY

БАше Кстн· ни соУ

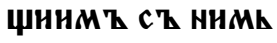

10

ThKMо жh ччеM '

ЮAHHЕMh ${ }^{5}$ AH HE

СТЕ ЧИАН в Z ZАKO

H. IAKO E ' C\$EO

Тоу' жирци соу

15 БОТТЫ СКЕһ РН А

Н НЕ ПОВННКНН $\mathbf{C} \boldsymbol{\Phi}$

Th ${ }^{6}$ ГӒю же вАM

ТАКО ц्р̈КЕ И БО

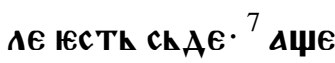

Ан БЪIсте в

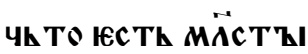

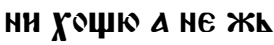

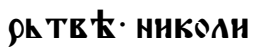


23 в

Же БҚIC TE оуБо W

соУАНАН нЕПови

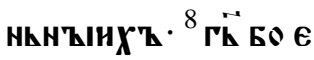

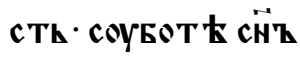

5 ЧАВ̈ЧКСКТЫН $\cdot$..

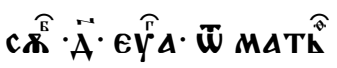

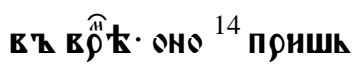

Матфей

VIII

14-23

10 A Т тhщоу юго $\boldsymbol{\Lambda E}$

жАџю orнh Mh

жигомоу. ${ }^{15}$ и прн

косноу Са ९н马'

ЮA И ОСТАЕН Ю W

15

ГHh' Н В ҚСТ А Н

сАоYжАше ЮМฎ

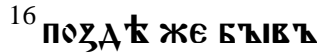

шю ПрнвеА०шА

K' HEMOY. Б Есh

20

ZГ'LHA СAOBOMK

А $\vec{X} \mathbf{X} \cdot$ и вһса не

AOYXhHZIA H

$23 \Gamma$

сц ҚАн. ${ }^{17}$ АА съБоY

AETh са реченое

пр९ेком и нсане

мh гАш̈ем т Th

5 HEАОYГИL HАWA

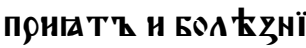

понес z. ${ }^{18}$ oузия tвz z

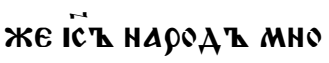

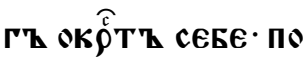

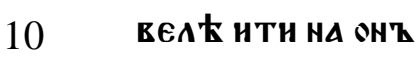

пол' ${ }^{19}$ н прнстоу

ПАК Кннжьни

КЂ ЮАНнҚ

MOY. ОYЧнТЕАК

15 HА ПО ТЕБЕ ГАМ०

жЕ КОАнжиАО и

АЕшн ${ }^{20}$ н ГӒА ЕМљ

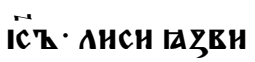

H'WL HMOYTR · H

20 Птиц НЕснҢ'

IA FHEZAA A $\overrightarrow{\mathrm{CH}}$

ЧӒВЧК HE НMАTК

K'hAE ГАAB ҚI ПO 
$24 \mathrm{a}$

Аъ кАоннти. ${ }^{21}$ А९оу

ГҚIн же $\widetilde{W}$ оученнк'

ıго рече юмоу. Гй

повелн мн прћже

5

ити и погрети оц̈А

монге. ${ }^{22}$ ich же гйA

IEMOY. ПО MHЕ НАН

Н ОСТАЕН МК РТЕЫЫ

Іа ПОГ९ЕТН СЕОГА МК

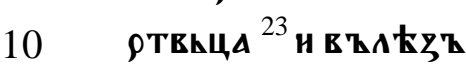

ш⿻ ๒⿴囗у в Z KopA

БАһ - ПO HEML HAO

Матфей шА оүченици юго -:

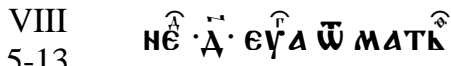

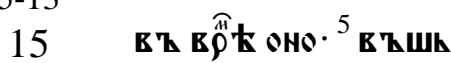

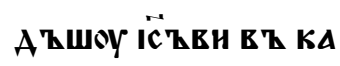

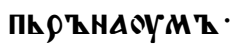

прнстоупи Къ не

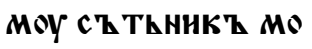

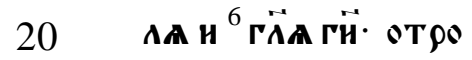

К' Мон АЕжнтһ :

СААБАENZ АКT Т IА

ко ст ОАЖА ${ }^{7}$ н ГӒА
246

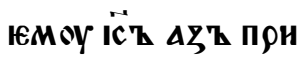

ШКАТ НСЦЕАК Н ${ }^{8}$ Н

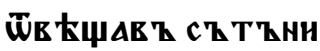

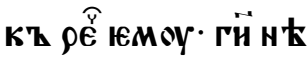

5 сMК АОСТОНнт АА

В Z АОМ' МОН въHї

АЕши н' TҚKM०

Фцци сАОвОМһ н

сц ЋА Қюти өт

10

К' Мон ${ }^{9}$ НБО $\triangle \zeta^{7}$

ЧАЁКҚ ЕСМh ПО

АТ ВӒАКОК нм ҚІ

ПОАТ СОБОК вОН

нъL и ГӒЕ семоY

15 НАН Н НАЕТЬ А А९Ж

ГоYмоY П९нАН

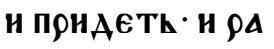

EOY MOEMOY C' TEO

ОH СЕ Н С' TEO९HTh

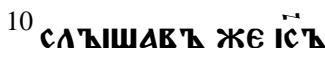

АНЕН СА ЮMOY'

ФЕЧЕ ГРАА ОҮШНН

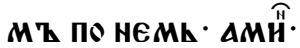


24B

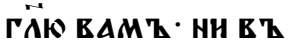

НЁАН ТОАНКҚ Е Е

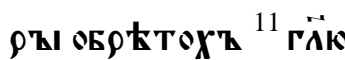

жE вAMT IAKO MHO

5

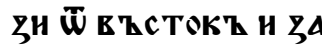

ПААТ ПФНАОУТ В В

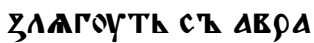

MZMh HCAKOMh.

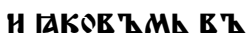

10

ЩрёТЕНН НЁсК

HЕMh ${ }^{12} \triangle$ С̈н̈ОВЕ ЦК

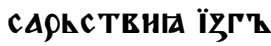

HAHH БOYAOYTh

B'h ThMOY крOMt

15

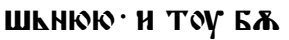

АETh ПААЧ ї скрh

жеть दоYБомт.

${ }^{13}$ н рече ї̀ сқ тhнї

КOY ИАН ІАКОЖЕ

20 в КРОВА. БОУАН

ТеБе нсц $\mathrm{k}$ 太 $\mathrm{W}$

трок' Юго в Қ Th

पAch $: \because \cdot$
$24 \Gamma$

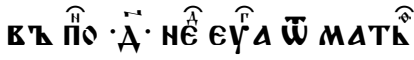

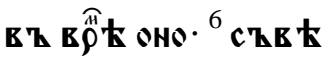

Марк Th с'z TворншА

III

6-12

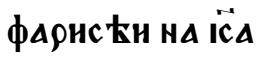

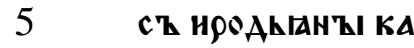

Кон Б'ШшА ПогоY

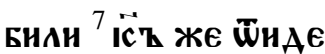

Ch оүченнк' СЕ

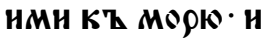

10

MHOГ'Қ HAPOAT

ГААНА КIA ПО HEMh

нАE' н $\overline{\text { W }}$ ЖнАОКh

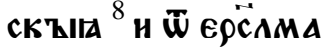

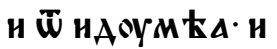

15 с' оного полоу н

OPAAHA. HЖE в Т

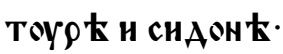

HAPOAT MHOF'

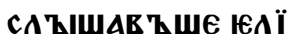

20

Ko TEOpA AUE h

прнаошА К' не

MoY. ${ }^{9}$ и рече оYче

HнКОМ Z свонМ $\mathrm{z}$ 
$25 \mathrm{a}$

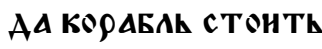

OY HERO- HAPOAA A

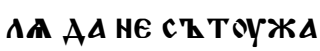

юTh ЮMOY. ${ }^{10}$ MHOГ'

5

Бо нсц КАн · ГКК НА

пАAАХОY ХОт Аџе пої

КосноуТИ СА ЮMh

нЖЕ нМААХОУТИ

९АнҚI. ${ }^{11}$ и ЮГАА вНАА

10 АХऽУти и Ас̈н не

чнстнн п९нПААА

АXOY к' HEMOY.

в ҚПнгАА ОУТ Th

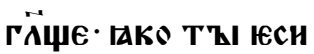

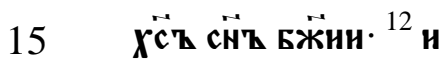

много пр КщАА

ше нмh АA не IA

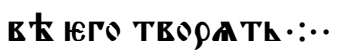

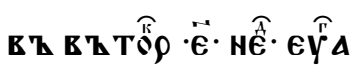

20 i் MAThota :

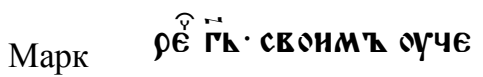

IV ннкOMz ${ }^{24}$ Б八юAt

24-34 TE са чh Tо слъшї
256

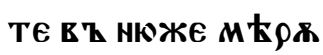

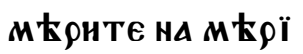

Th са вАMт н п пн

АОЖнTh СА вАM '

5 сАҚшАџннм Қ.

25 нже Бо АџЕ нмА

Th AАCTh CA вАMh

А нЖЕ NЕ ИМАТИ и

ЕЖЕ нмАТи б̈нме

10 Th ca î него. ${ }^{26}$ и гї厶

Аше • и т АK० юс Th

црс̈тко Бӝню

КОЖЕ АЩЕ чАЁк'

в ЋБһ

15

в' ZEMAN. ${ }^{27}$ To ch

ПнТһ Н вһСТАЮТИ

нощh н $\mathrm{AHh}^{\mathrm{H}} \cdot$ и ct

ма ПоОзАБАЕТИ.

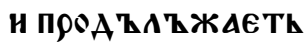

20

СА- ГАКОЖЕ нЕ в

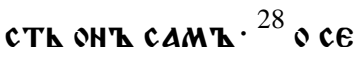

БҺ Бо そЕМАА ПА०

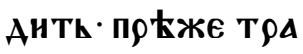


25в

воу по тОMи же кАА

с' · ТА жЕ нсп'М 'h

ннТК ПКШеницю

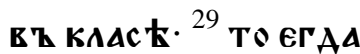

5

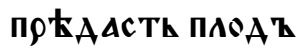

АБНЕ ПоустнТһ

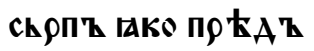

стонтИ

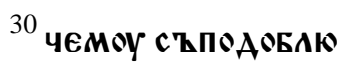

10 црётво Бӝню' н

к' Көен прнт'

чи прнложнмқ є

${ }^{31}$ к'h ropowh noy zh

ОИнОY • ЮЖЕ ЮГАА

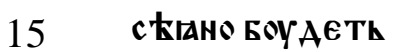

в Z ЗЕМАН МКнЕ

вhct X' c kM kn'

ести 弓ементї̈'

${ }^{32}$ н егАА в Қс ЕIAHS

20

БOYAETh - в'h ЗА A

стЕTh ' БОУАЕTh

БOAE вhckX'h $\zeta \epsilon$

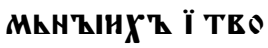

$25 \Gamma$

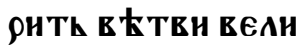

К'Ы гакожЕ Моџн

ПОАТ с 太Нню юГО

ПТНЦАМҚ НБС̈КН'Ы

5 HМт оYгнЕ马АНТн

СА. ${ }^{33}$ Н ТАЦ КМН ПФН

ТҚЧАМн мнОГА

Мн ГӒААШЕ НМ Қ

САОВО ГКОЖЕ МО

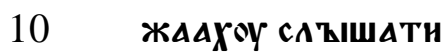

${ }^{34}$ Бес прнтъчА же

ничи ТОЖЕ нЕ ГЙА

АWE K' HHM $\mathrm{h} \cdot$ oco

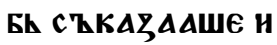

15 оученнкомт сво

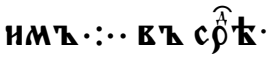

$\ddot{E} \cdot$ Hễ

Лука в в в

$\mathrm{XV}$

$1-10$

20

ПОНБАНЖАКЧЕ

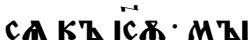

ТА९Е и Гр КШКни

ци ПосАоушАТ'

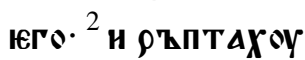


фарнс ки и кннжь

ницн Гӥџе · тако

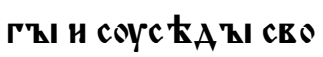

съго қшкникъы

IA. ГÄA HMZ ९AAOY

понемАети н с'

HTE CA C' MZHON

5 ннми $\mathrm{kcTh} \cdot{ }^{3} \rho \in \widehat{\Upsilon}$ же

ТАКО ОВИЦК MOЮ ПО

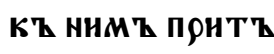

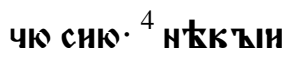

Чล̈ЕК' $\cdot \overline{\boldsymbol{W}}$ ВАСТ И

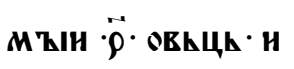

5

ГҚІ5һ шюе өБр

TOX' · ${ }^{7}$ ГӒю же вА

MT · IAKO T AKO PA

AOCTh БOYAETh HA

HËCH O EAHHOMh

10 ПоГОУБНТИ ЮАН

HоY $\widetilde{W}$ нHX'⿳亠 не 。

стАRHTh АH АERA

TH AECAT' H AERA

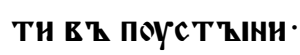

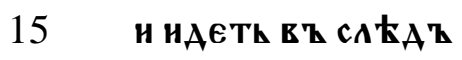

Пог'БҺ WE · AO

H'А АEЖЕ ОБ९АџЕ

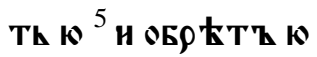

10

Г९ћшьннц К кА

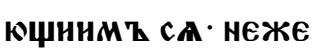

- aebath aecatth

Н АЕВАТИ ПФАВК

Аһник' - нже не

15 Т९ћБоують ПоКА

АНHIA ${ }^{8}$ HАH KAIA

ЖЕнА НМоУџн АE

Са Тh М Қаһниць

вไZАОжиTh N HA

Аџе погоуБнть

20 ९АМћ СВОН ९ААОУ

IA СA. ${ }^{6}$ н п९ншиАТ

20

М ЕАКнНци ЮАН

ноу. не в ҚжнЗА

ЮТИ АН св 太ТНАК

z'IBAlETh APOY

HНКА' Н ПОМЕТЕТК 
26в

ХФАМНнҚІ НщЕТК

Пона ћжьно АОнъ

АЕЖе оБрАџеТИ К

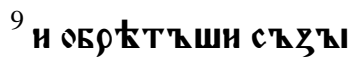

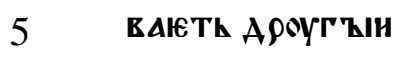

coyckA CEOL ГÄळ

Чн. РАAOYHTE СA

Ch MZHOW IAKO W

Бр kTOX'Z M kah

10 ницю кже погж

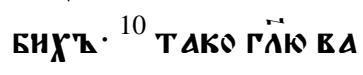

MZ - PAAOCTh EZI

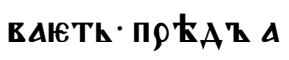

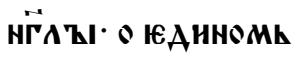

15 Г९ Кшкннц

юцнннмт сA $: \because$

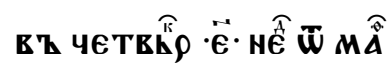

Марк въ в

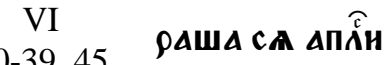

20 K' IC̈OY. H в '

ЗЕ 太стишА ๒МЖ

ВhсE ๒AHKO ch

ТВернША· Н ЕАН 26г

Ко нАөучншА. ${ }^{31}$ н

рече нМт $\overrightarrow{\mathrm{cc}} \mathrm{z} \cdot$ прн

А Ћте в' сАMн· в'

поусто M 太сто oco

5 Бһ ' н Почннте МА

AO БA XOY БO Пон

X゚Aашен '

Чен мнозн· НТн

не 8пражна а ХOY

10

CA. ${ }^{32}$ HA AOWA ET MOY

сте м kсте KopA

БАКМ Е ЕАННН. ${ }^{33}$ н вї

A 太WА IA HАОYWА

и ПOZHAWA IA MHO

15

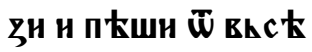

X' Г९АA' текошА

TАMO И ПОНАОША

K' HеMOY. ${ }^{34}$ H WhA'

İ̈h внА М МнОГ'

20

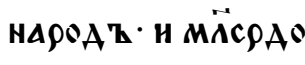

BА O HHX' ' IAKS БA

АХОY ТАКО ОвьцА

не нмоYщА ПА 
$27 \mathrm{a}$

cTOYXA. H HAYA OY ЧнТН ГА МногО. ${ }^{35}$ Н

МнноүЕ ҚШ丷 чА

соу· прнст тоупн

5

WA K' HEMOY. OY

ченнци юго ГӒџе

noyc To юc Th M

сто и оуже чАст

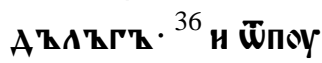

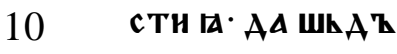

ше в' окрһстLHA

ІА ГРААКЦА Н ЕТ

cena koYmath co

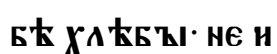

15 MoyTh 50 4hco $\mathrm{k}$

сти. ${ }^{37}$ онт же йв

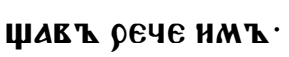

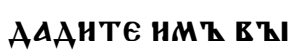

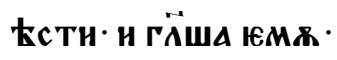

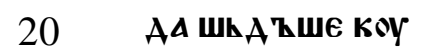

ПнMZ АZE ЕMA

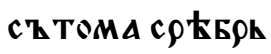

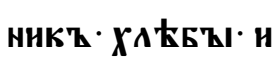

276

AААHMZ HMZ $\mathrm{k}$

сти. ${ }^{38}$ ОНъ жЕ ГӒА и

MZ К КОАНКО XА ЕБ'

HMАTE НА ТТЕ Н

5 внАНТЕ Н ९АZОУ

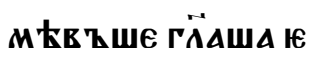

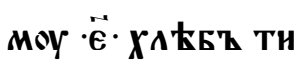

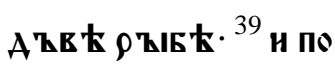

велћ нмт посАAї

10 Ти вса $\cdot{ }^{45}$ н ПФЕНАЕ

HA OH' ПOA' K' ह

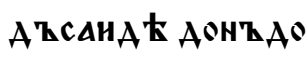

же ש̈поустить

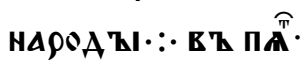

15 Eे Hễ

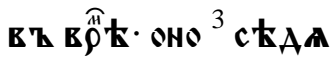

H' £MOY HA rO

Марк

XIII н пюА.. ц ९ёвн

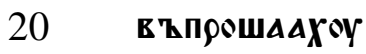

Th h EанHого пе

Т९' НाАКОК' Н

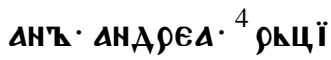


27в

HАM К'ГАА СH

БOYAOYTh · К КОЕ

БOYAETh ЗНАME

НнЮ ЮГАА НМОУ

5

Th KhСА СН ChKOHh

цАТн сА $\cdot{ }^{5} \ddot{\text { IC }} \mathrm{h}$ же

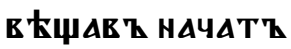

ГӒАТИ ИМЋ БАК

A KTE cA AA HEKTO

10 ПюҺАКстить вҚ.

${ }^{6}$ мнезн Бо Прнах

Th E'Қ HMA MOlE

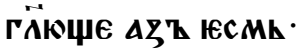

и мног' пр ЕАh

15 стАTИ ${ }^{7}$ ІеРАА ЖЕ

оусАҚІшнТЕ Б९А

НН и сАоУХ'ҚІ Б९А

Hн· HE оYжАCA

HTE CA' ПOAOEA

20

ITL БO БҚITH' H'

неоуКонКцинА

${ }^{8}$ в Zст TAHETh БO

IAZZIK'Z HA IA
$27 \Gamma$

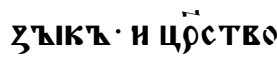

НА Цр̈ство. Н БоУ

AOYTh ГАААН H

МАТЕЖНН ${ }^{9}$ НАЧА

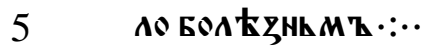

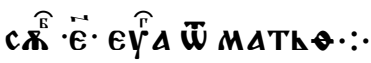

9 в в в

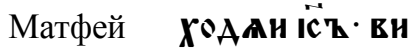

IX

9-12 А К ЧӒЕКА НА

10 НА МЫТКННЦН

c太AАША' HMENK

Mh MAT OEA' H

Гत̈A ๒MоY· По MT

н太 ГОћАН· н В'

15 СТАв 'И ПО нЕМК

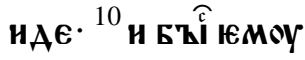

в Қ弓АЕЖАџю в Қ

AOMOY H CE MHO

зн гр Ешьннцн

20 и мҚт А९н прн

ШhА'Қше в Қ马АE

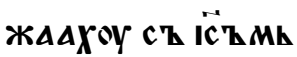

н с'Қ оученнк' £ 


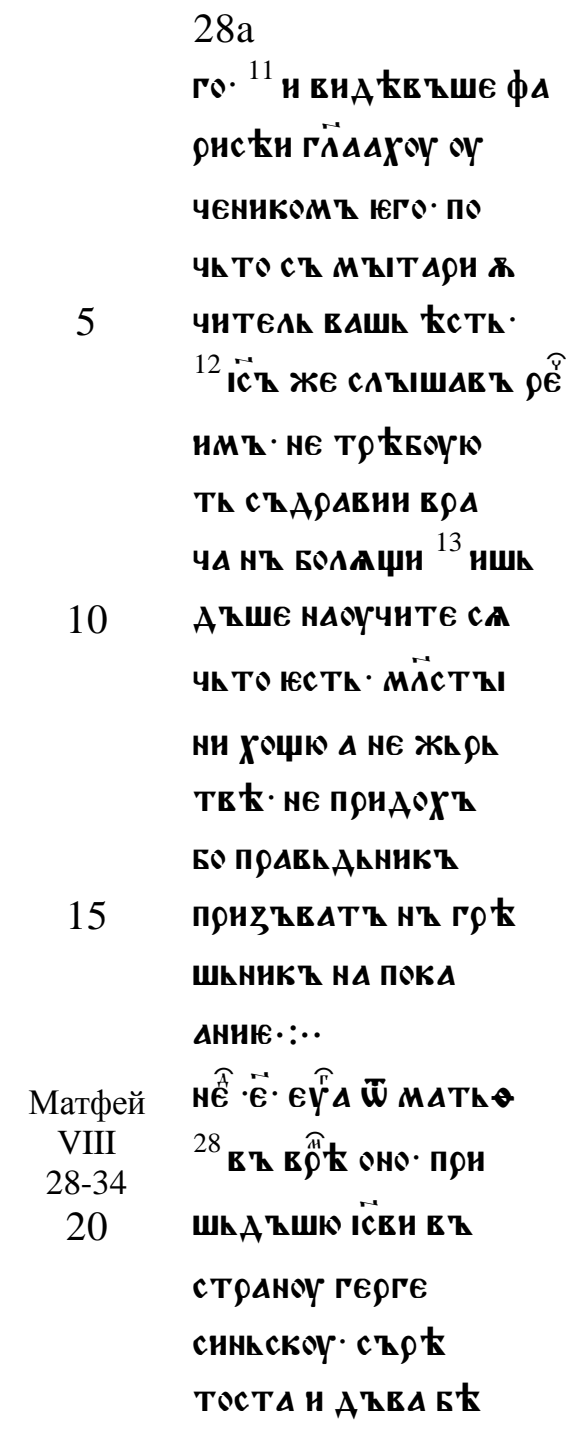

286

chHА $\overline{\mathbf{W}}$ гров' нс

ААџА АКтА दूล०.

TAKO HE MOЖАAWE

никТОЖЕ Мнноу

5 Тн поутим' тt

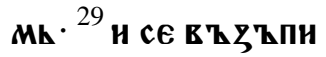

сТА ГӒщА Ч Ч ТО ほ

CTh HAM и н TEE

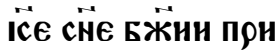

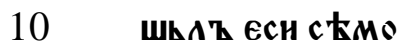

прђЖЕ в Һмене

Моучнт' HAch.

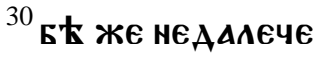

T̈ HEN СТ ТАО СвН

15 нни много пасо

мо. ${ }^{31}$ Бћси же Mona

Хоуть н гїще Аџе

нугониши нҚІ По

ВЕАН НАMҚ НТН

20

В 'h С TAAO СвHHOE

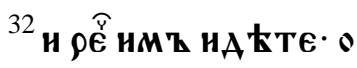

ни ЖЕ ншhА 'Һше

НАОША ЕТ СЕННH 


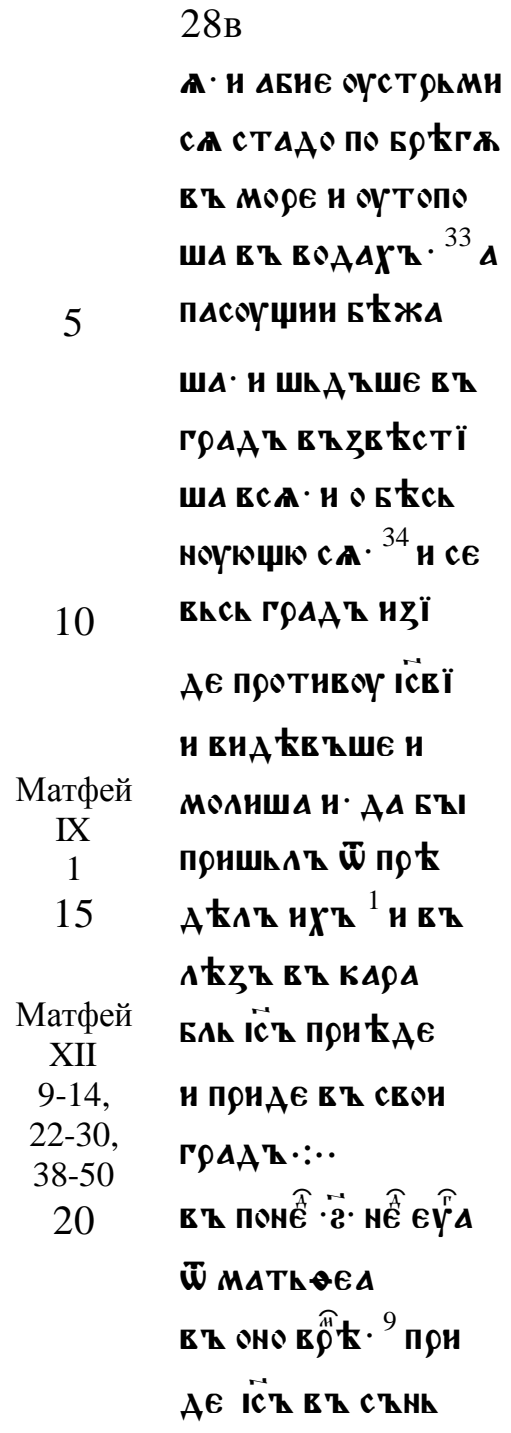

$28 \Gamma$

МНџЕ ЖНАОВИСКО

${ }^{10}$ и СЕ Чत̈ЕК' НМҚІ $\rho$

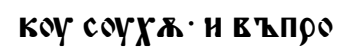

сншА и гїще· Аџе

5

Аостонти вт coy

Ботоу цҺАнти· АА

HA Hh B'ZГГАAГQAN

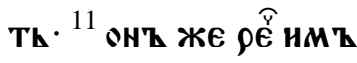

К'Т TO ECTИ Ч

10 т̈ вАст нже нмА

ТИ ОВһцю ЮАНнОУ

и Аџе в ЋПААЕТи

B'h COYEOT OY B'B IA

MOY HE H马һMETh

15 Ан њІа. ${ }^{12}$ КОАһМн оу

БО оуБО АоУчнн Ю

сти чล̈вкһ өвһц

TћMh жE АОстон

Th B' COYБOTOY

20

АОБ९О ТЕ О९нТи ·

13 Гत̈А Ч

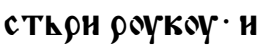

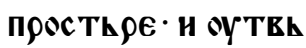


९АН СА ЩКАА ГАKО

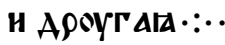

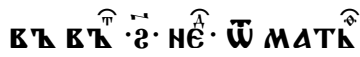

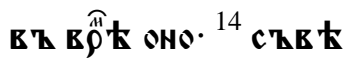

5

Th Ch TEорнша

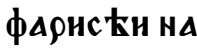

ICA IAKO AA ПOГOY

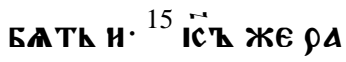

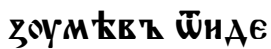

10 í TOYAOY. ${ }^{22}$ ThГАA

ПОНЕЕАОWА K'

нЕмоу. Б ЋсАщи

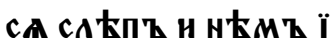

И ГӒШЕ И ГАААА

15 АШЕ ${ }^{23}$ Н АНКААА

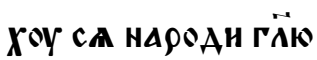

ще ЮАА ch Юс Th

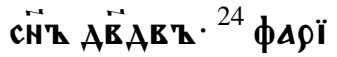

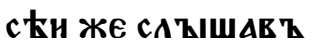

20 ше рекош с не

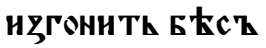

HT O REALZAROY

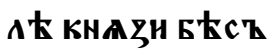

нугонити Б Бсқ

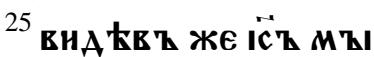

сАh нХ'

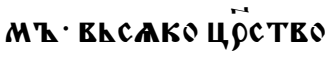

5 ९АЗА КАНЕ Т СА НА

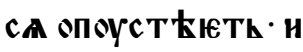

ВСАК' ГОААТ НАН

AOM

CA HA cA nE ct

10

Th ${ }^{26}$ и аџе cotona co

ТОНОУ ИУГОНИТИ

CAMh CA ECTh $\rho A$

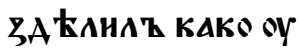

Бо ст АнЕ ТИ цёство

15 юго. ${ }^{27}$ н Аџе $\Delta \mathbf{Z}^{2}$ о ве

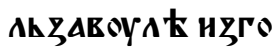

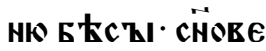

ВАШи ЧнМК Н̈ГО

натһ CEГO А ҚАA

20

Тн БOYAOYTh COY

АнाА вАMт ${ }^{28}$ Аџе

пи АР̈ми Бӝнемк

нзГОню БҺсқl 
CETO A ЕАA ТИ БOY AOYTh COYAHA EA

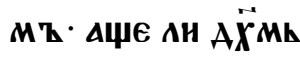
Бӝнемк нУгоню

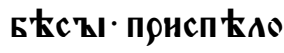

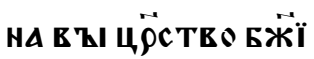

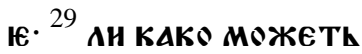
КТО вһ $\Lambda$ Һсти вһ А०

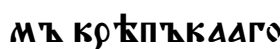

10 Ти СЪСОУАН ЮГО ९А ЗГРАБити ${ }^{30}$ нжЕ NЕ CTh C'Z MZHOW HA MA ЮCTh· HE C' БН АГА Н СҚ М ҚHO

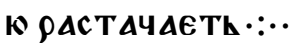
вZ cột в З оно в

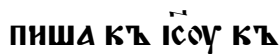
ннжиннци и

20 фАрнс ћи- оучн TE八N Хоџем' ï теБе zHAME нню виА АТн. ${ }^{39}$ 。
Hh же

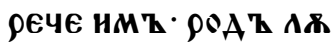
КАВ ҚIH АКБОА H. zHAMENHA про 5 снТА ' Н ЗнАМЕнї ほ HE AАCTh CA Ю MOY. HZ TZKMO ЗНАМЕнНЕ НОНҚI пр̈рка. ${ }^{40}$ TAKе Бо в

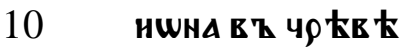
Кнтев · Т ТН Ан̈H ї Т९н ночн· ТАKО EOYAETh CḦ $4 E$

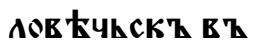
С̈ФАЦИ ЪЕМАА ТФї АН̈н· и ТОН ночн. 41 моужи нинев $\mathbf{z}$ ГнТАсциї в ҚстА HOYTh EO HA COY

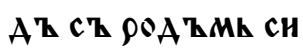
Mh h ocoYaATh H. IAKO ПOKAAB 'ZWE СА в Қ пропов ЕАА 
$30 \mathrm{a}$

нНЕ Ионнної се Бо

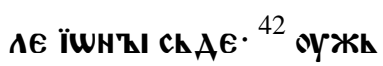

наГА ц ९̈Ца в ъстА

HETh HA COYATh ch

5 РОАТМК СвОНМһ Н

OCOYAA Th H· IAKO ПоÏ

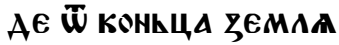

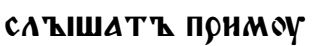

АРОС TИ СОАОМОHЕ

10

н се Боле соломона

ChAE ${ }^{43}$ ЕГАА ЖЕ нЕपї

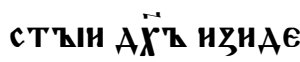

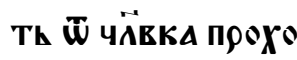

АНTh БEZROAKH'W

15

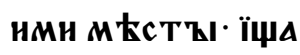

ПокоА и не овр ћ

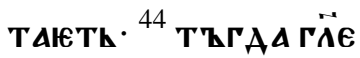

Th AА CA ОБрАџा

в $\mathrm{Z}$ AOMT ERO' H马 HE

20 ГОЖЕ нЗНА०Х'М и

ПоншһА' ОБ९АщЕ

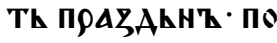

метент - оукоаше
306

Hh ${ }^{45}$ ThГAA haETh

и понмети ch co

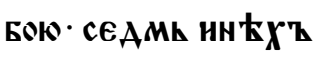

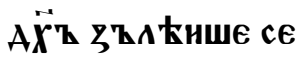

5 Бе и въшиА'Мше жї

BOYTh TOY' H БOYA及

Th nochtahHaIA

ЧӒЕКА TOГO ГOPh

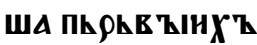

10 H POAOY CEMOY AOY

KAB oYoYMOY : :

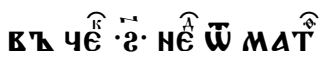

въ в

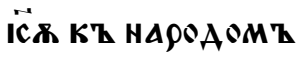

15

сЕ МТ̈н и Б९АТи

ГА ЕГО в ZHЕ СТ

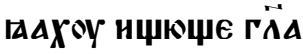

ти ємоу. ${ }^{47}$ рече же

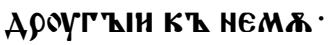

20

СЕ М Т̈И ТВО⿴囗 н Б९А

THIA TEOIA E'KH E

ctorath XOTALE

ГӒАТИ Кһ ТЕБ太 


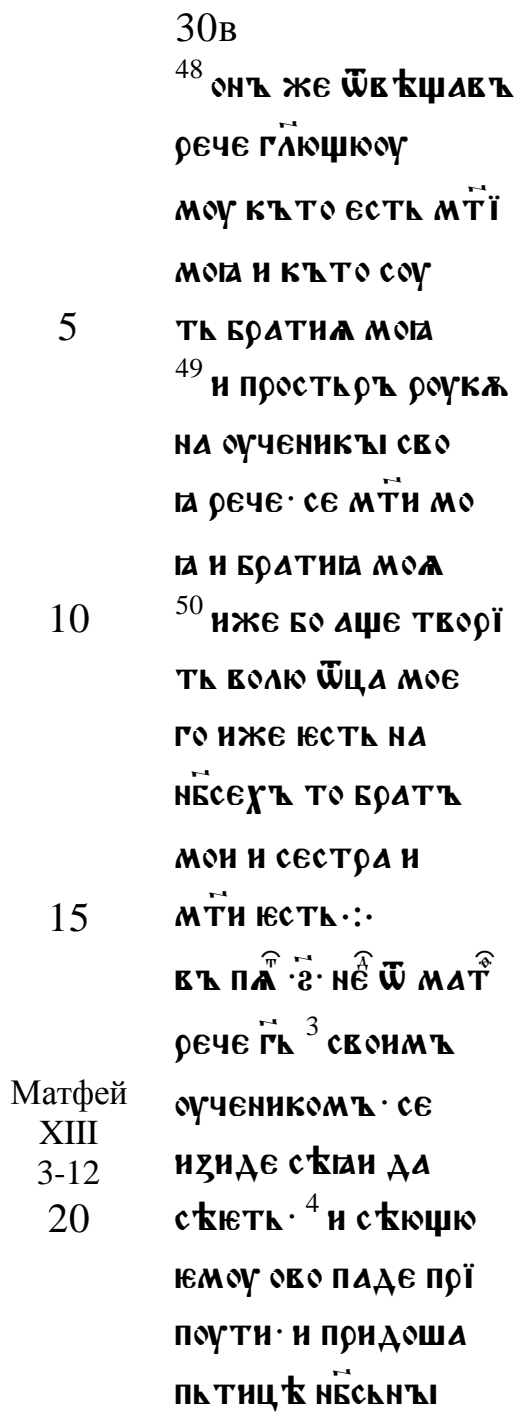

30г

IA ПОZАБАWA IA

5 AроYг

ША HA КАMEнH' ГА

же не нм Кше зе

5

МАА МнОГҚІ И А

БНЮ ПрО弓а БоША

Zане не им КША

ГАОУБИНЫ ЗЕМАА

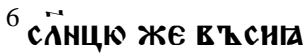

10 В ҚШК ПРНСМАA०

ША' ZанE HE ИМА

ХоY Коренна '

chme ${ }^{7}$ А АроугАाА

ПААE вТ ТК Рннн

15 Н в Қ马НАЕ ТИ РнНЕ

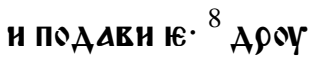

ГАIA ЖE ПАА ОWA

нА ЗЕМАН АОБ९

H A ARAAXOY חASAT

20 ОВО $\ddot{\rho} \cdot$ ०BO OK $\mathbf{h} \cdot \overrightarrow{\boldsymbol{\Lambda}}$.

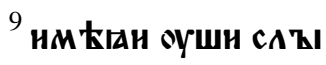

ШАТИ АА САҚШШH

Th. ${ }^{10}$ н прнстоупАь 
$31 \mathrm{a}$

ше оученнци юго

рекошА ๒MоY По

чh ТО прнтчАмї

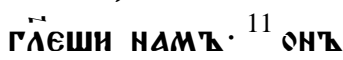

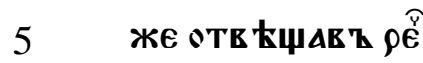

HMT IAKO AAHO Ю

CTh вАMT $\rho \Delta Z O Y$

MћTH ТАHнҚI ЦК

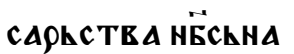

10 АГо о н Қмт же не

AАHO ๒сти. ${ }^{12}$ HMOY

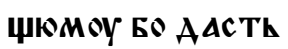

СА Н弓БОУАЕТИ Ю

MOY А НЖЕ HE НMА

15 Th· н юЖЕ нмАТһ

вһZhMETh CA O

Th него.:

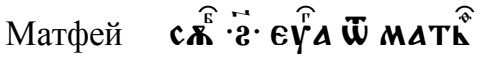

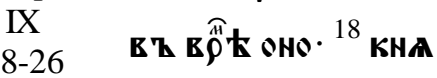

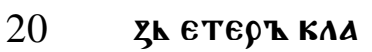

HAAUE CA İ̃

Гӥа· ГАКО АТџи

MOIA HZIN t OY
316

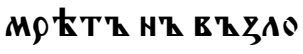

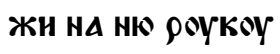

TЕою н ожнве Th

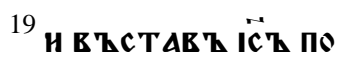

5 HEML нАE म ОУЧЕ

ннци юго. ${ }^{20}$ и се же

нА К९һЕ ОТ Фц

вA A ZB t HA AECA

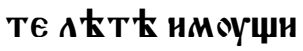

10 прнстоупльши

с' ЗААН· ПОНКО

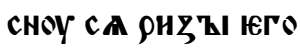

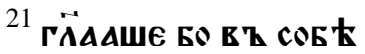

Аџе тһкмо прн

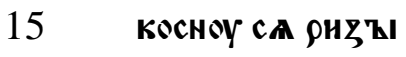

юГО сп̈сенА БOYАХ.

22 Ї丨

и виА Қв' к $\rho \in 4 е$.

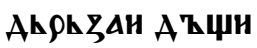

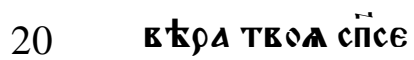

та и и сп̈сенА же

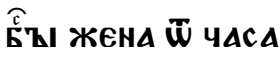

того. ${ }^{23}$ н прншиА 
31в

İC' · K АОMҚ КHA

Жи и внА Қв 'h conh

ЦА И НАРОАТ MTA

вАШИ ${ }^{24}$ Н ГӒА НМ Z

5

Ш̈нА

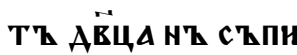

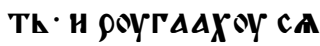

юеMOY. ${ }^{25}$ IЕГАА ЖЕ и

छГRHAHZ БKI $\mathrm{TA}$

10

POAT E BWWhAth IA

Th 10 zА poykoy. $\mathrm{H}$

В ЋС TA АЁцА. ${ }^{26}$ Hそї

AE в kс Th по вhсен

зеМАн $\because: 2$

15

Hể $\cdot \vec{z} \cdot \epsilon \hat{Y} \Delta \bar{W}$ MATh

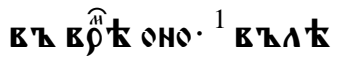

दE в Т КорАБАh

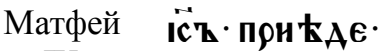

IX

1-8 Н ПФНАЕ вТ Свон ГОА

$20 \quad \mathrm{~A}^{\mathbf{h}} \cdot{ }^{2}$ н се прннесо

ША ЮMOY OCAAБАE

H' ЖнААМн· HА

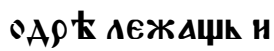

$31 \Gamma$

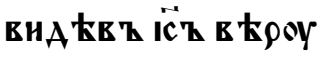

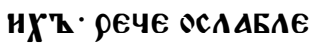

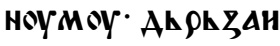

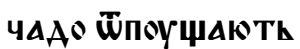

5 ТН СА ГОћСН ТВОН.

${ }^{3}$ н се њтерн $\overline{\boldsymbol{w}}$ кни

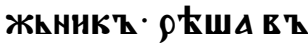

сеБ太· ch ВААСвHM 太

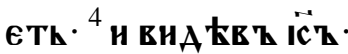

10 ПомъшАЕнию їХҚ

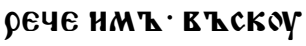

Ю ЕҚІ М ҚICAнTE вҚ

сРАЦиХ' вАшнХ'

5 4h TO EcTh OYAOEtE

15 рещн бипоущак

Th ca rP太ch TEo

Н АН ९ЕЩН В ҚСТАВ Қ

X゚AH ${ }^{6}$ H' AA OYв

стЕ ПАКО вААСТИ И

20

MATh С̈̈ Чत̈ЕपК

сКТА НА ЗЕМАН

ш̈поүщАТн грЕ

X'Қl ${ }^{7}$ T'ZГAA ГÄA W 
$32 \mathrm{a}$

CA АБАEHOYMOY

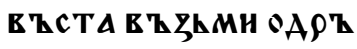

ТЕОН· НАН Е' АOM $\mathrm{Z}$

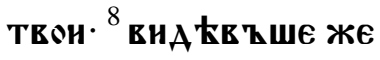

5 НАРОАН ЧЕАНША

СА· Н ПООСААВНША

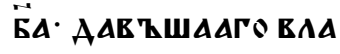

Матфей

XIII

10-23, 9 ,

24-54

10

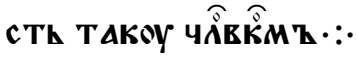

в т ПонЕึ

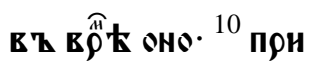

ст оупїв 'ъше oy

ЧЕннци Іс̈вн $\rho €$

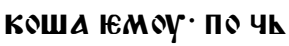

ТО прнТҚЧАмн ГӒ

15 Ши нмқ. ${ }^{11}$ онқ же

в ЋџАв

TAKO В АM 'h AАHO Ю

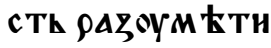

ТАннҚІ цёстЕА

20 НЁСНАГО НHЕ

Mh ЖE HE AAHO ECTh

${ }^{13}$ сеГО ९ААН ПОНТ'

чАМн ГӒК· ГА
326

КО виААџЕН не вї

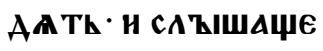

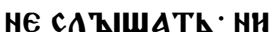

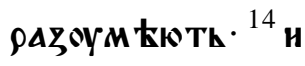

5 СҚБҚIВАETИ СА и

м ' п्̈९чство нсА

ннО ГӒџеЕ· н сАОУ

Хоми оусақшшнте

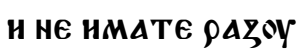

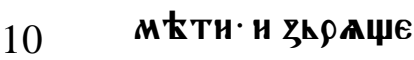

оУЗһ९нТЕ н не и

МАTE внА Е Тн. ${ }^{15}$ Оу

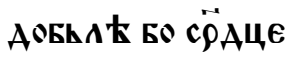

АКАНН СНХ'

15 ШимА тажико

CАҚІШАША И ОЧИ

свон С ММ ЋЖншА.

EAА КһГАА OYZh

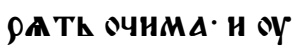

20

ШHMА SYCA ҚIшА

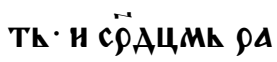

зоумћюти· н

Б९АТ А ТИ СА нц 
$32 \mathrm{~B}$

Аю А. ${ }^{16}$ вАШи ЖЕ БАА

Жени очн ГАКО ви

АнТЕ н оуши гАжЕ

сАҚIшнте ${ }^{17}$ ПрАв о

5

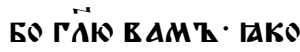

мнози поิ९ци ї прА

вһАһннци в ТЖАє

А ЋША ВНА КТН ґ

ЖЕ внАнТЕ и не вї

10 А ћША' и слҚшАтї

ГАЖЕ сАҚІшите и не

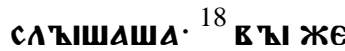

оусАҚшнте прнт'Қ

YIO C KIAB Z WAATO

15

19 висак' нже слҚl

ШиТИ САОВЕСА ЦК

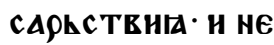

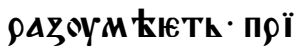

ХОАнтК не ПОнЕ

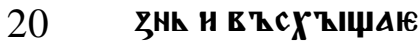

Th ckranol в h ch

РӒЩн югО СЕ Юсти

с Łганең прн поу
$32 \Gamma$

TH. ${ }^{20}$ A C KIAHOE HA KA

MENH T' ECTh CA'Қl

ША Н САОВО Н АБНЮ

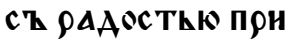

5 ЮМАГа Е ${ }^{21}$ н не нМА

Th же корене в h се

БЕ. Н'Z в БМЕнКно

IEc Th · БЪIв ҚШи же

ПЕЧААН И ГОНЕНИ

10 Г САОЕЕСЕ РААН СБН

І С ҚБ八 АЖНАЮ

Th ca. ${ }^{22}$ a c kande

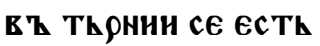

САҚІШАН САОВО И

15 ПечААһ св ҚТА се

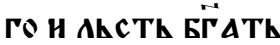

сTEA MOAABAAIE

Th Ю' И БЕС ПАРАА

БҚIRAETh ${ }^{23}$ A CKA

20 НОЮ НА ЗЕМАН А०

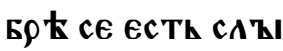

ШАН САОВО Н РА

zоYM kв AIA ЮГГО 
$33 a$

ПОНнОснТА ПАОАТ

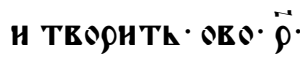

OBO шес ThAECA Th.

OBO $\cdot \vec{\Lambda} \cdot{ }^{9}$ HM tKAH OY

5

Ши САҚШШ АТ АА

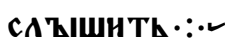

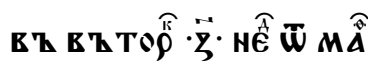

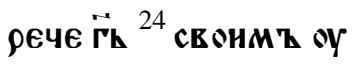

ченнкОМ $\mathrm{h} \cdot \Pi \rho \mathrm{H}$

10 ТВ

АОБН СА Цр्वे ТнЕ

HЁСКОН - पत̈ЕКОY

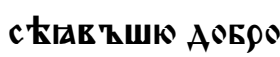

IE C KMA HA cEAt

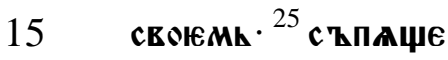

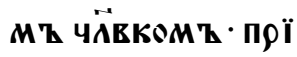

AE в९АГ' еГО и в '

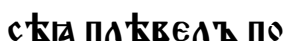

сере А П пшени

20 цћ и отнае ${ }^{26}$ ІеГАА

же преzane трA

ВА' Н ПАОА' C'Қ TEO

ОН· ThГАА ГАКН CA
336

и пА Евелъ $\cdot{ }^{27}$ прнши

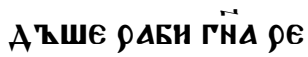

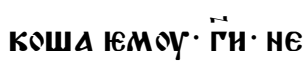

АОБро Ан с ҚMA ck

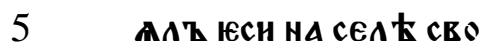

EMh $\cdot \bar{W}$ KOYAOY oY

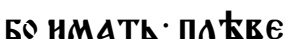

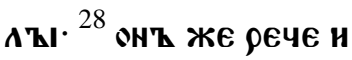

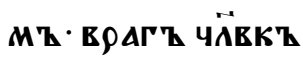

10

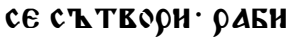

же рекоша юмоу.

Хощешн Ан оүБо

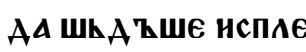

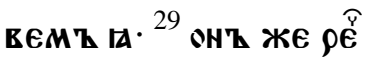

15 НМһ НH' ЮАА Е ҚСТ

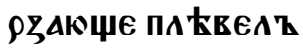

в ZCTLPRHETE KOY

ПКно с' НнмК н Пь

шеницю. ${ }^{30}$ ост Ави

20

TE Koупьно ९Асти

OYБO AO ЖАTE ҚI.

в' ГOA' ЖАTE ҚI

рекоY жАTENEMT 
33в

нсплев $\mathrm{k}$ те пр

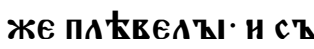

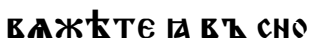

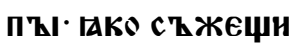

5

ґ. Пьшеницю же

съБерТте в Ж Жн

ТКницК мак-: •

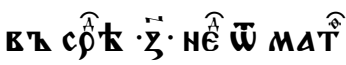

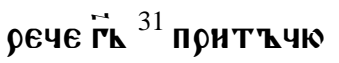

10 СНК ПОАОБКНО Ю

сти цёст твиє не

Бесьноң зирьноу

Горчнчкноу. еже

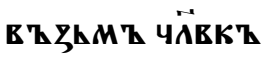

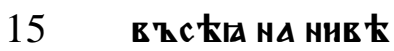

своен. ${ }^{32}$ юЖе Mhнt

ю вhct X'h ckMen'

ЮC Th ЮГАА ЖЕ в

ЂАРАС TETL БOAE

20

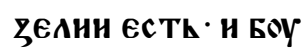

AETh AOYET - IAKO

же прнти пти

ЦАМ НЁСКнҚIY 33г

MZ H EZLHEZAH

TH CA в' в EIAX'Z 6

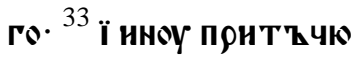

ГӒА НMZ · ПОАОБК

5 но ести цёство не

БесьнОЮ Кв АсоY н

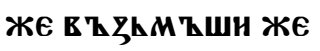

на погреве в т моY

YHAX'Z CATAX'Z

10

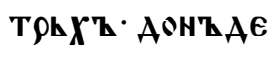

Же в Қскһice висе

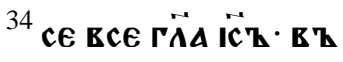

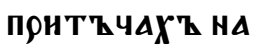

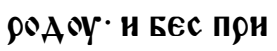

15 ТЋЧА ничК ТОЖЕ

нЕ ГӤАШЕ Кһ НH

Mz. ${ }^{35}$ A A ChEOYAE

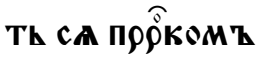

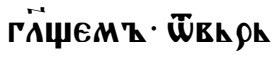

20

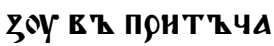

X'B OYс TA MOA.

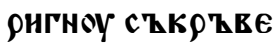

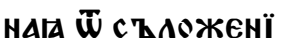


$34 \mathrm{a}$

Іа всего мнрА. ${ }^{36}$ T'

ГАА ОСТ АЕНE' $\mathrm{H}$ HА

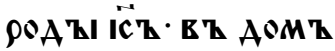

Свон ПрНАЕ $\because \cdot \cdot$

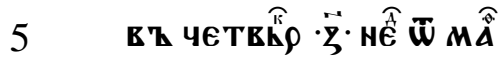

в Қ оно в

А '⿳一巛工

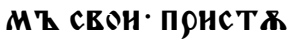

ПншА оученнци

10 ЕГО К' НEMOY ГӒळ

ще· съкажн на

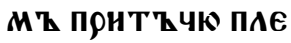

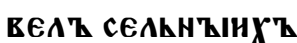

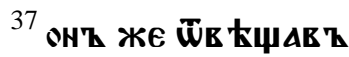

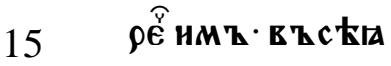

в ҚIн АоБрое с k

MA ECTh CḦZ पत̈B

पh ${ }^{38}$ HHEA $Ж E$ ECTh

हhсh мнот' AO $^{\circ}$

20 БроЮ Же сћмА

cE coYTh cHEE

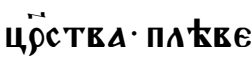

Ан же соYTh сн̈̈E
346

непригазнини ${ }^{39} \Delta$

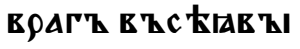

H IA ЮCTh ALIABOAT

$\triangle$ Ж $\triangle$ TEA ICTh KO

5 НКчАнне в ЕКА.

А ЖАТТАЕ АНГАН

coYTh $\cdot{ }^{40}$ TAKO OYEO

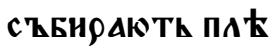

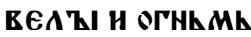

10 НЖHЗАКТК ТА

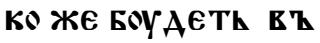

с'ҚКОНКЧАНИІ

в kка сеге ${ }^{41}$ noy

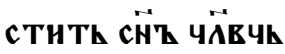

15 АНГАИЫ СЕОА·

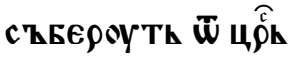

CTEA CETO RhCA C'

БААZH'Ы· H TEOPA

廿АГА БЕЗАКОНН

20 Ю. $^{42}$ н в ZЕК

म в Z пещh огнh

HOY. TOY EOYAE

Th плАчh и скрh 
34в

жеть 弓оуБом ${ }^{43}$ Th

ГАА ПОАЕЬАКННН

п९OCEL T A Th CA IA

ко сл̈нце в ц цёствї

5

и оц̈А нХ' · НМ ҚАН

Оүшн сАТІШАТИ

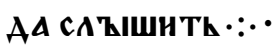

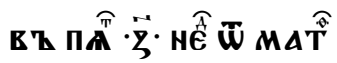

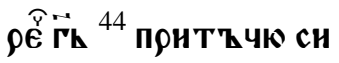

10 Ю ПОАОБКНО ЮС Th

Цр̈с ТЕНІе нЁсноЮ

съкровнще съкоз

веNOY на HHE $\mathbf{k} \cdot$ I

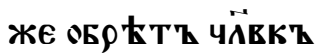

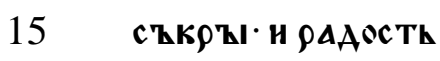

Ю ЮГО НАЕТИ И Все

ЮАНКО НMАTh ПрО

ААсть и коупн ни

BOY TOY $: \because \cdot$

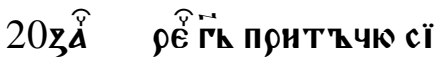

10 ${ }^{45}$ ПОАОБһHO ECTh

цёс ТЕО НЁСНОЕ

Чत̈вкоу коупьцю.
$34 \Gamma$

Нџюџю АОБРИ БН

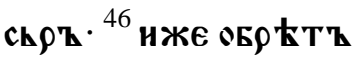

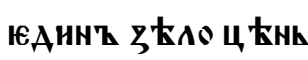

H' БHсh $\rho$ ' WhAT

5 ПФОАА вСЕ НМЕНИ

IE ๒АНКО НМА АШЕ

и коупн н. ${ }^{47}$ ПАК'

ПОАОБКНО ЕСТИ Цр̈ствО

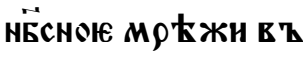

10 вириженћ в 'и мо

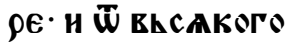

POAA C'ZEL PAE Z

Шн. ${ }^{48}$ АБНІе

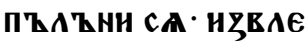

15 К'ZWE К нА К९АН

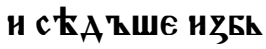

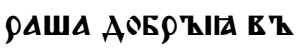

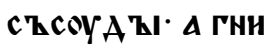

A ZIL H马EL

20

ША E Z HTh $: \cdots$

${ }^{49}$ TAKO EOYAETh

В'Z C'ZKOHL YAHH

Ю В太КА. H马HAOY 
$35 \mathrm{a}$

Th АнГАн и Ф̈лоYчА

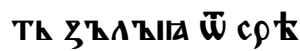

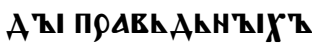

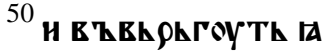

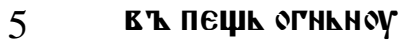

TOY EOYAETh חAAYh

и скрьжетһ ZоYБо

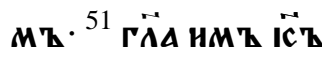

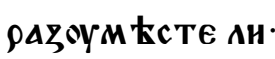

10

всE CE ГÄАША EMA

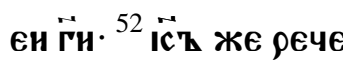

HMZ TORO A KAA

ВИСАKไ К'ҚH

ЖинHК' HAOY

15

पh сA ц्̈стЕНК

HËCHOYMOY. ПOAO

БКH' ECTh Чत̈ЕКОУ

Аомовнтоу. їже

H马HOCHTh $\bar{W} \mathrm{ch}$

20 КрОвнщА Св ЕГО

HOB АIA Н ВET'Z XА

व ${ }^{53}$ н Биर् егАА съко

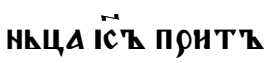

356

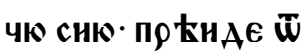

TOYAOY. ${ }^{54}$ н прншк

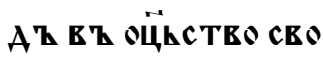

IE OYY AUEE HAC' 50

5 рнщнхт нхтв:०-

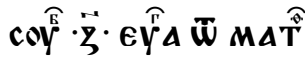

$\rho \widehat{\Gamma} \overrightarrow{\Gamma h} \cdot{ }^{37}$ иже АюБи

Матфей

$\mathrm{X}$

$37-42$

10 МЕне Аостоннъ

НЖЕ АюБНТИ СHA

АН А'Қџерһ ПАче

MENE нtсти Мене

Аостоннһ ${ }^{38}$ нже не

15

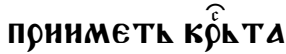

своего и в т сA kat

MENE HAETh ' HE

ст人 MEнЕ Аостон

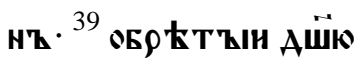

20 сво ПоГоУБНТК

ю. А нже погоүБи

Th Аш̈ю свою ме

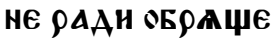


35 в

Th ${ }^{4} \cdot{ }^{40}$ нже в 'ы прне

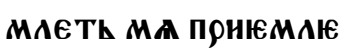

Th חOC h $A \Delta \mathrm{K}$ hWAA

ГО Ma ${ }^{41}$ ПрНюмАА

5

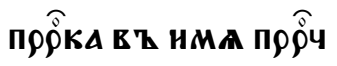

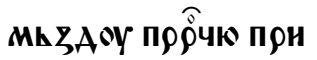

IЕМАETh · Ф ПРНЕМАA

ПРАККАКНHКА ЕT

НМА ПФАЕКАКНH

10

YE Mh

Аһннцю прннме

Th ${ }^{42}$ нже көлнжи

AO HAПOHTh EAHHO

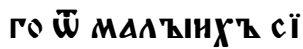

15 X'h YаWE c TOYAE

HZI BOAZI- TZKMO

ВТ НМА ОУЧЕННКА

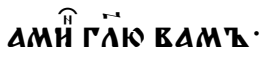

не ПогоуБить

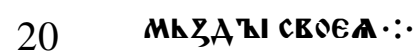

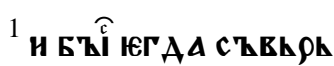

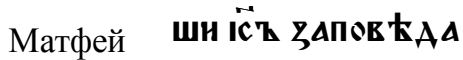

XI IA. оБ 1 MA HA AECA
35 г

ТЕ оYченнком А сво

HMA пр ЕHAE W TOY

Aоу оучнт и н пропо

в АA TTZ в' Г९AA

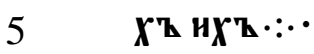

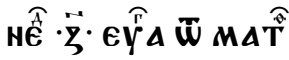

в Қ в

Матфей Х॰АAшю тоуА

IX

27-35

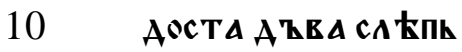

ЦА ЗОВ ОУША И ГӒЕ

ЩА ПОМнАОУН НҚІ

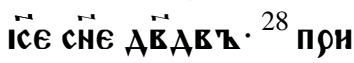

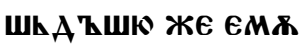

15 вт АОМ ' П९нстЖ

Пнсте К' HEMOY

сА ЋПьцА н ГӒА н

MA $\overrightarrow{\mathrm{C}} \mathrm{z} \cdot$ в t $\rho$ oYeTA

AH TAKO MOTOY CE

20

C々 TEOPHTH · ГÄА

стА EMOY Ен $\overrightarrow{\Gamma H} \cdot{ }^{29}$ TR

ГАА ПОНКОСНОY СА

очне EN· rÄa no 
$36 \mathrm{a}$

в КрҚ вАю БОУАН вА

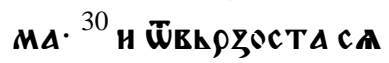

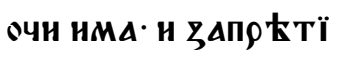

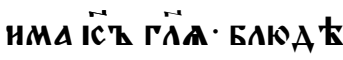

5 TА. АА НИКТОЖЕ НЕ

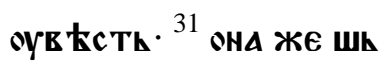

А'ШША ПрОслАвнстА

и ПО вһсен ЗЕМАн ТОї-

32 TЕМА ЖЕ ИсXРААЧЕ

10 MА. СE ПОHЕЕА

HEMOY Чत̈ЕК' H सMT

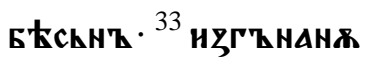

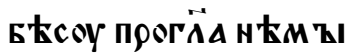

Н. Н ЧЕАНША СА HА

15 ९ОАН ГӒџЕ НHКОАН

ЖЕ Гавн са ТАКО в '

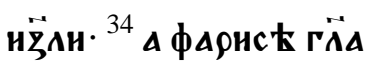

$\triangle$ ХरOY W KHAZH Б'

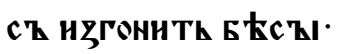

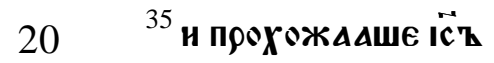

ГОААТЫ ВСА Н ВСН

ОУЧА НА СЪЕОРНџї

$X^{\prime} \mathbf{z}$ их' $\cdot$ н пропов
366

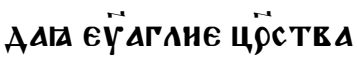

Н Ц КААД ВИСАKҚ

HEAOYГT - H ВСАK8

IAZN ET ANALX'Z $: \cdots$

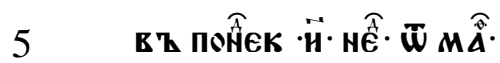

въ в९̈ћ оно ${ }^{54}$ прнае

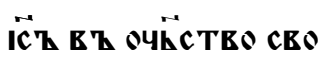

Матфей

XIII

54-58

10

Ю н оүчеше наро

А'Ы· HACZ HhMї

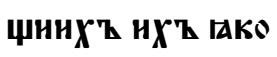

АНЕНТИ СА НМ Қ

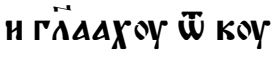

AOY cemoY ecth

прtмоударостh

15 ch. ${ }^{55}$ He ch Ан естh

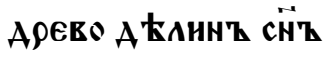

не се Ан мТ̈н его

HAPHYAETh CA MA

९НIA' Н Б९АТНІа $E$

20

ГO HIAKOE $\mathrm{z} \cdot \mathrm{HW}$

снфъ' Н снменъ

HoYAА ${ }^{56}$ и сест $\rho \mathbf{Z l}$

ІГГО НЕ ВСА АН В Қ 
36в

HACh COYTh - $\bar{W}$ KOY

AOY OYEO CEMOY BCA

си соYти $\cdot{ }^{57}$ и БААЖнА

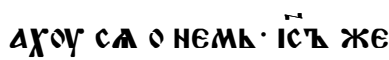

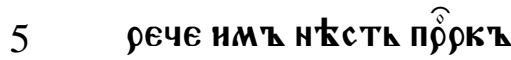

Бещьстн нҚ Т'ҚКме

В Қ СвОЕМh РЧКСТЕН

H. H ET AOMOY СEOEML

${ }^{58}$ H HE C'R TEO९H TOY $\mathrm{CH}$

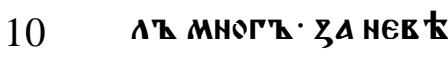

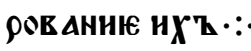

в Z в Z T

Матфей в қ в

XIV

1-13

15

WA HPOAR TETPA

$X$ 'h CAOYX'h IC̈E $\mathbf{z}$.

2 и рече отрокоми .

свонM Қ сE EсTh н

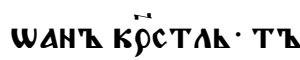

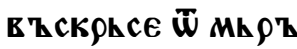

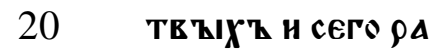

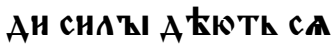

O NEML ${ }^{3}$ HPOAT EO

HMT HOAHA H C'ВEA
$36 \Gamma$

ЗА H· Н ЕТСАAH H В Қ Th

МБННЦЕ' НРОАНГАА ҚI

९ААН ЖЕнТІ фнАнПА

EPATA своEГO IAKO W

5

жени са Eк. ${ }^{4}$ ГÄ̆ШUE

БO IMOY HOAHZ · HE

Аостонти Ти нмЕ

Ти ега. ${ }^{5}$ и ХОта оуБн

TH OYEOTA CA HAPO

10

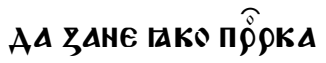

HMAXOYTh H. ${ }^{6}$ AнH

ЖE БҚIR Қ UN POAhC TEA

HPOAOBA. TAACA AT

ЧН Н९ОАНТААННА ПО

15

сереА Т пнц и оугеАї

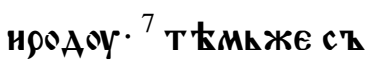

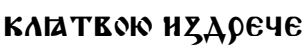

Іе - ААТИ ЕГОжЕ АџЕ

в Ђспроснти ${ }^{8}$ ОнА Же

20

HAR АЖENA MATE

९нК свОEN' ААЖК

Мн ९E̊ ChAE HA БANA

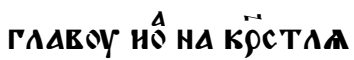


$37 \mathrm{a}$

9 и печААКнҚ Бे

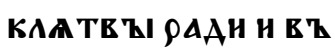

ЗАЕЖАџнХ' с' ни

Mh ПовеА А АТТИ Ен

5

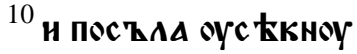

HOAHA ETh ThMhHї

цН ${ }^{11}$ и ПОНнЕсошА ГӒА

вOY ЮГО HА БАЕА

Н ААША А Евнци ї

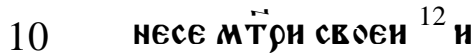

прнс тоYпакше oy

ЧенНци ЮГО В В Қ马А

шА т ҚАо его и погре

БОшА Ю· и ПрНшһА'

15

ше н въ弓в КстишА

IC̈OY. ${ }^{13}$ H CAKIWAR '

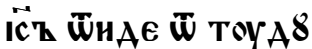

В Т КОРАБАН ВТ ПОУ

стО М ҚстО ЮАНнТ

20 Н САҚШШАВ ҚШЕ НА

POAH' ПО HEML НАO

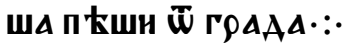

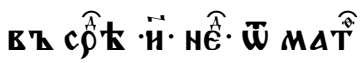

376

въ в

вЂше н Моужн $\mathrm{M} \mathrm{t}$

Матфей

XIV

35-36

5

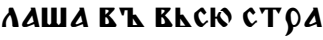

HOY TOY. Н ПОHЕЕАО

WA K' HEMOY BCA EO

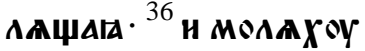

Th Н АА ТҚКМО ПрН

KOCHOYTh CA חOAPA

10

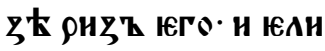

КО са ПонКосноуша.

юMh сп̈сенн БЪIшА

Матфей

XV

$1-21$

15

1 TZГАА прнстоYпї

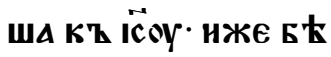

XоY въ нерслАм К к'

ннжьницн н ф фФї

сћи гӥше ${ }^{2}$ по чh то

оүченици Твон прї

стоYПАКTh ח९ सАA

20 Hнга с TА ९hцh - HE OY

MZIEAKTh EO POY

K' свонХ' ' ЮГАА

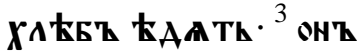


37 в

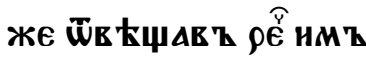

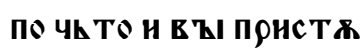

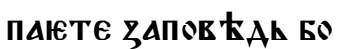

жию пр

5

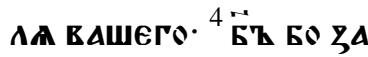

Пов 太АА ГӒА - पh TÏ

оц̈А и м Т̈९И и ГӒА и

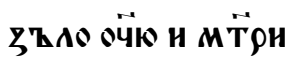

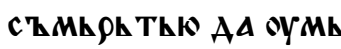

10 Оти в въ же гӥете.

нже Аџе речети о

цею нАн мТ̈рн АА

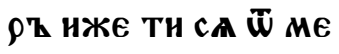

не oycn keTh ти сA

$15{ }^{6}$ не чhс твоуетh оц̆А

своего и мёте н и

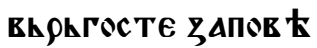

А Бёню. поћаА

HНIA А КАA в АШE

20 Го. ${ }^{7}$ АнцемЕ $\rho$.

Аовр $\mathbf{t}$ прорече

HCAHA O вACZ · ГÄA

${ }^{8}$ ПрНБАнЖАКТТ
$37 \Gamma$

CA MZHE АЮАH ЕСH

OYсTЫЫ СЕОНМН· H

oYcT Tl पh TOY Th MA

А С्̈АЦЕ НХ'Z OYAА

5 AAETh са ШU MEHE

${ }^{9}$ в' coyю же чh Toy Th

Ma' oYчАLE OYчEHÏ

1А ЗАПОЕ ҚАН Чत̈вЧ

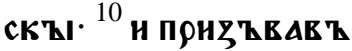

10

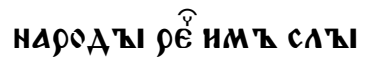

шити н ९АзоУм

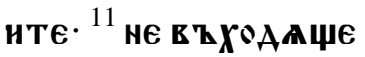

IE СКЕК РнНТИ ЧӒЕКА

HZ HсXРАAџЕほ И

15 ३ оуст' TO CKEh

९нНТК Чत̈ЕКА $\because \cdot$

в Z पе̂ $\cdot \vec{H} \cdot$ HÊ

12 в Т в

с тоупншА оуче

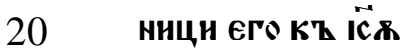

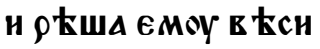

Ан ТКО фАрнс Кн

CAҚIUAR ҚUE CAO 
$38 \mathrm{a}$

ВО СҚБААЗННША СА

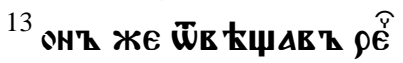

Bhch CAAT EROжE HE

НАСААН оц̆ Мон нЕ

5

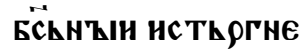

Th са нс корене $\cdot{ }^{14} \mathrm{w}$

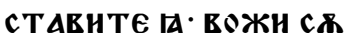

Th слћпнн слћпь

цемъ·слћпьци же

10 сАКПьцА АџЕ воАї

Th OБА E Z RAMOY E T

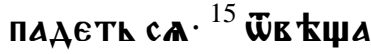

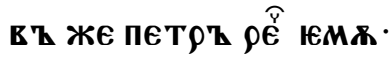

съкажн намъ пюї

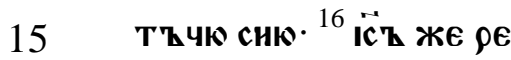

чE EMOY. EAHHAYE

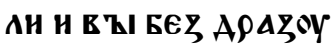

MA Есте ${ }^{17}$ He OY АH $\rho A$

zоYм kв $\triangle E T E \cdot$ IAKO

20
всE ЮЖЕ в Қ X'АНTИ

в' оYстА в प

вZM КџАETL СA· H

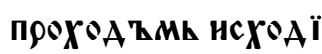

386

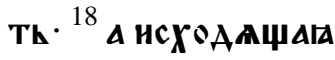

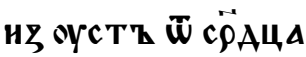

HCX'AATK H TA CKEL

OHA Th Чत̈вKA. ${ }^{19} \bar{W}$

5 С̈९АЦА БО HсXОAа

Th ПОМҚШШАЕна

Z'ZAA' TATKE'ҚI

А'ҚжhHAIA ПOYC TO

WhC TEA X XYYALHO

10 ГӥАнН $\cdot{ }^{20}$ сн соУть

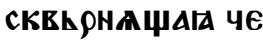

АОв ККА. А ЕЖЕ нЕ

OYMZRENAMA POY

KAMA ҚС Ти нЕ СКЕh

15 Оннтһ чӒвКА. ${ }^{21}$ НшК

Ath $\overline{\mathrm{w}}$ TOYAOY ičz.

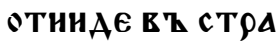

ноу турьскоу '

CHAOHh CKOY : :-

20

Матфей

XV

29-31

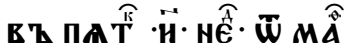

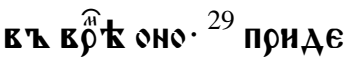

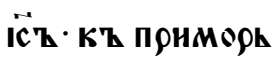

ю турьскоу н сн 
38в

Aonhckoy н в 'hшh

A' HA rOgOY ctaA

Аше т оу. ${ }^{30}$ и прнстоу

ПHWА K' HEMOY HA

5

РОАН МНОZН НМХ

це сқ собон хоOмh

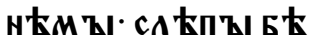

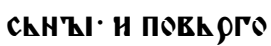

WA A ח९६Aт HOГА

10

MА Ї̈ЕАМА' Н нц Е

АH A. ${ }^{31}$ TAKO HAgOAOY

АНЕHTH СА' BHAA

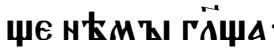

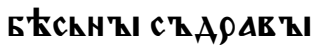

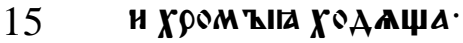

и CA 太ППҚIA вHАA

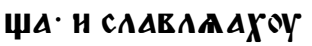

Матфей

XII

30-37

20
БА нचुАRА $: \because \cdot$

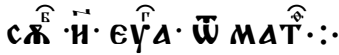

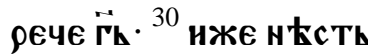

C' MҚHON HA MA

Іес Тh нжЕ не с'

БноАЕТИ С' Мно 38г

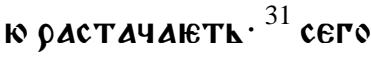

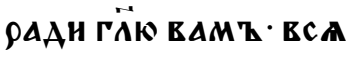

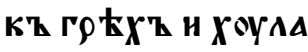

ש̈nоустить са чE

5 Аов Ккоми $\triangle$ Еже

HА $A \vec{X}^{\prime} \mathbf{z}$ ХОYАА

ש̈постить са чE

Аов ћком т $\cdot{ }^{32}$ н еже

КОАнЖКАО РЕЧЕТК

10

СAOBO HA СНА Ч

ש̈поустить са EMљ

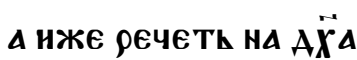

ст̈го не ய̈поусти

Th CA EMOY HH ET Ch

15 в ЕКТ ни в В ГОААОУ

ЧнН. ${ }^{33}$ НАн с С ТЕорН

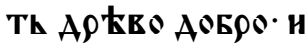

ПА⿱中⿰㇀丶㇀

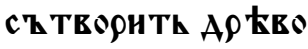

20

ZZАO И ПАOAT EГO ZZ

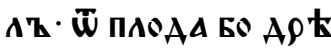

BO MOZHAHO EOYAE

Th ${ }^{34}$ нџААНІа Ю ХН 
$39 a$

АНнНHА' KАKО MO

ЖЕТЕ АОБ९О ГӒАТИ

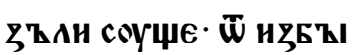

ТһКА БО с९̈АЦА Ост А

5

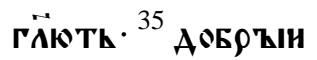

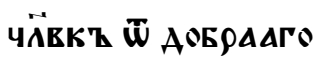

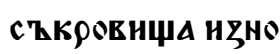

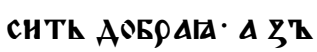

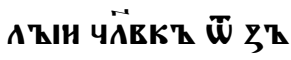

10 МАГО съК РовнцА

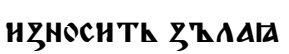

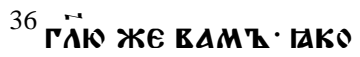

ВИСАКО САОВО ПЛА

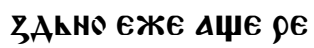

15 КОУТИ ЧӒЕЧн Е

BAAAATh O HEML

CAOEO BT AḦ COY

АКнҚ/н. ${ }^{37} \overline{\mathbf{w}}$ словест

БО Св ОНХ' ФП АЕ

20 АНШН СА· Н

вEC' СЕоHX' OCOY

Анши СА $: \therefore$ -

NÊ $\cdot \vec{H} \cdot E \widehat{Y} \Delta \cdot \bar{W}$ MAT $\cdot::$
396

вไ в९̈ћ оно. ${ }^{14}$ ншһАТ

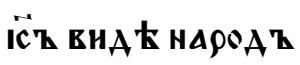

Матфей

XIV

14-22

5

МноГТ н МӤс९AO

вА О нЕМน ' НЦ КАН HE

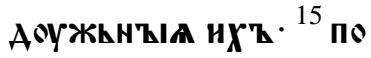

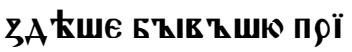

стоYпншА K' HEM МY

оүченнци юге гӒџе

поусто ести м ћсто

10

Н ГОАНHА ОУЖЕ МН

ноу - ш̈поусти наро

A'hl A4 WhA hWE в h

okphctthHala roa

АһцА KоYПа Th сов

15

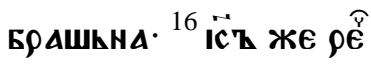

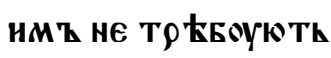

ОтнТИ · АААНTE нМТ

въ Łсте ${ }^{17}$ они же ГйА

WA EMOY HE HMAMT

20

chaе TZKMo $\ddot{E} \cdot$ Xat

БҚ Н АҚЕ

же

нес 太Tе мн ґ с Қмо 
39в

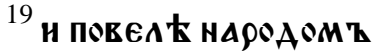
въЂАЕџн нА ТРАв 太

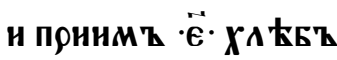

H AR

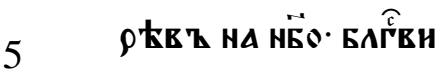

н ПрКАОМАh ААСТ

оученикомт үat

БҚ оученнци же

HAPOAOMz ${ }^{20}$ H raWA

10

Всн н НАC'ҚІТнША

CA· H В'ZаWA H马EҚI

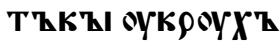

ATE K HA AECATE

Кошьници испт

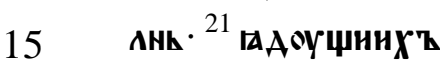

жE БА Аше MOYжh

ПаTh T'JCALh' 04

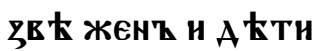

H. ${ }^{22}$ н АБне оүБ $\mathrm{E}_{\mathrm{AH}}$

20 ich оученнк' сहо

А вһА Ести вһ Ко

९АБАК ' Н ВАРНТИ

HА OHOMh ПOAOY. 39г

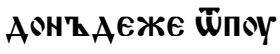

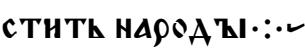

Матфей

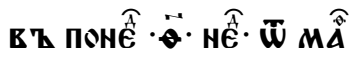

XVI

$1-12$

5

в В во̆

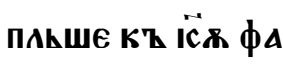

९Hс Кн н САAOYКE

Н нсКоуШАКџе Н.

просиша zнаме

HHA CZ HËE ПOКА

10

ЗАТн имт ${ }^{2}$ онһ же

от Қв 太щав Z $\rho E$

че HM R - вEчEPOY

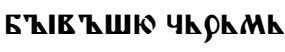

HOY HËऽ· Гत̈TE TH

15

ШHнА БOYAETh ${ }^{3}$ Zа

OYTSA Ä̈hCh ZHMA

पh Ph MhHOYE Th 50

CA HË OYHWZIE AIA.

Анце ОУБО Н НБС оу

20 мКете ९АсоужА

Ти· А ЗнАМЕннї

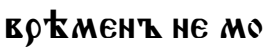

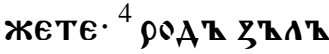


$40 \mathrm{a}$

АNБОА КН Е' · ZHAME

HHA HщеTh ' Н ZHA

MEHнIA HE AАCTh CA

HMT · H' T'KKMO ZHA

5

мению нонъ пр̈ркА

Н ОСТ АВHE Қ ВCA O

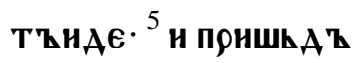

ше оүченици егО нА

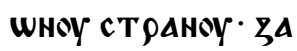

10

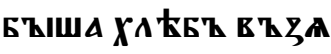

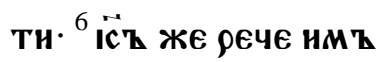

СҚMOT ФНТЕ И БАю

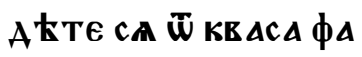

ОHс КНСКА. Н САAOY

15 Кћнска : :-

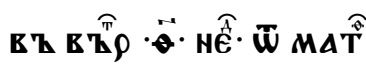

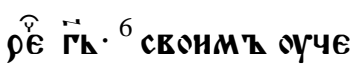

ннкоMЋ въне

MA ТTE И БАЮА

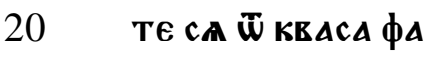

ОННСКА' Н СААОYКЕ

нскА ${ }^{7}$ Онн ЖЕ ПОМ ҚI

WAA A OY В'Z СEБ太
406

ГӒще КАKО ХА КБһ не

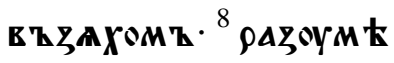

в h же ї́

МЫСАнТЕ в Қ СЕБЕ МА

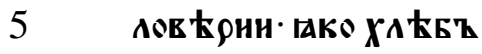

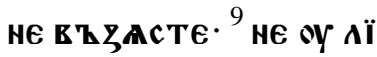

разоYм Квањте ни

ПОМКнНТЕ ПАТ ТИ

ХА ЕБ' И ПАТИ ТҚI

10 САШИ· Н КОАНКО КО

ШКниць ${ }^{10}$ Нн Ан се

Амн ХА ББъ- въ че

TZIPH TZICAЩА H

КОАНКО КОШКНH

15

ЦК въ弓Асте ${ }^{11}$ КАКО

не PAZоYете AKO не

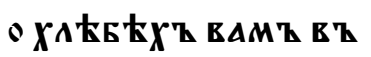

ннмАТн $\rho \mathbf{k X z} \cdot X \rho \Delta$

нHTE ЖЕ CA Ẅ KEA

20

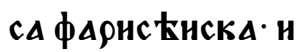

сААОук ЋнскА. ${ }^{12}$ Th

ГАA ९AZOYM KWA IA

ко рече Х९АнHте сA 
40в

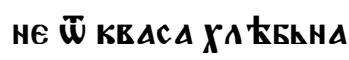

ATS H' $\bar{W}$ оученна

Матфей фарнс ћиска :..

XVI

20-28

5

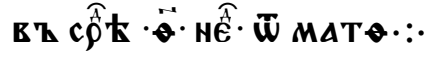

в Қ в

ič 'учченнкомт

Свонмт АА HїKO

Моуже не рекоути

IAKO Th ÆcTh ic $\overrightarrow{\text { Xck }}$

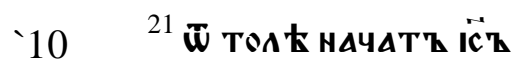

сЪКАZАТИ ОҮченН

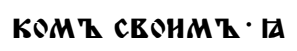

KO ПОАОБАETh Ю

МоУ нТН ЕТ нерёАM.

15 и много пострА

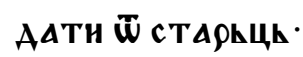

Н ОУБНЕНОУ БҚІТИ

и третин АН̈И вт

стАТн. ${ }^{22}$ Н ПО нМт и

20 пет९һ нАчАTZ стА

ВАА ТИ ГӤА МН

AOCTHE' T TZI Г̈H HE

НМАTh ТЕБе БҚITÏ
40 г

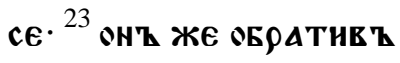

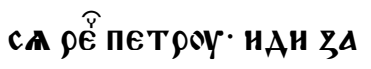

MA сOTOHO- CKEAA

ЗН'Қ МН ЮСН· ТАКО НE

5 сҚМҢшААЕши БӜн

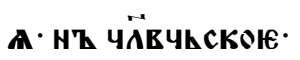

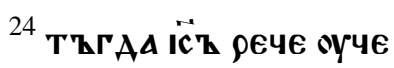

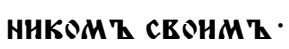

Аџе XОџете по $\mathrm{mz}$

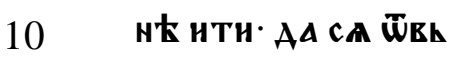

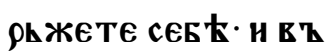

马һмете крьстт

СЕОН ' Н ПО М̈HЕ

ГPAAETE :..

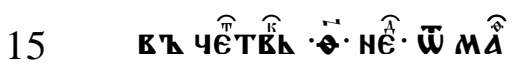

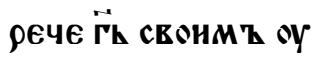

ченнком '

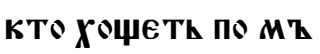

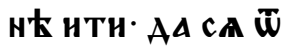

20 ви һһжети сеБе н в

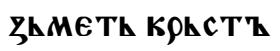

Свон· Н АА в ЋСА

IETh мн $\mathrm{k} \cdot{ }^{25}$ нже Бо 
$41 \mathrm{a}$

хочети A8

шю сहо сп̈с Ти по

ГОУБнТА К - А нжЕ

погоуБнти Аш̈оу

5 СвОК МЕнЕ А КАА

ов ранетh ${ }^{2} \cdot{ }^{26}$ 4h TO

oycnteTh Чत̈вк'

Аџе вись мнрт прї

овращеть $\triangle$ аш̈оу

10

Свою отҚщеТИТК

НАН ЧTS AАCTK ЧЕ

АОВ ККһ Н马М ЕНЖ

zА аш̈̈у свок. ${ }^{27}$ прї

Ти нМАTh С̈̈һ че

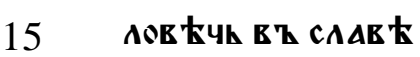

оц̈А своеГО с' $\triangle$ АH

ГҚАТЫ СвонМн· Н

TZГАА Е'ZЗАС Th

КOMOYжhAO ПO A

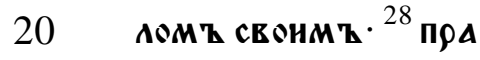

BO ГӒ̈ в АMZ · COY

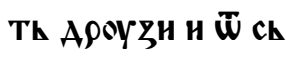

АЕ стОАџнНХ'
416

же не HMOYTh c'

Мрти въКоуснтї

АОН'ВАЕЖЕ ВНАA

Th CHA Yत̈BपА Г९A

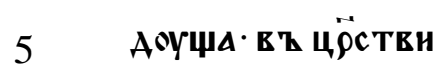

H CвOEMh $: \cdot$

Матфей

XVII

10-18

10

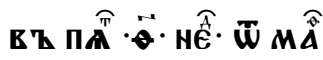

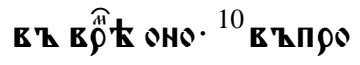

сншА І्ते оучени

ци его гӥще · чh

TO ОУБО КТНH

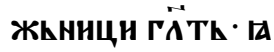

KO ПOAOEAITL H

Анн прћже прнтї.

15

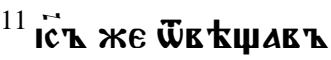

рече нМт ' НАнА

ОУБО понаеть пре

же и оүстронти все

12 ГӒю же вАMт · IAKo

20 НАНА ОҮЖЕ ПОНАЕ

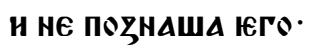

HT CC TEO

немһ - все ЮАнко 
41 в

BZCXOT KWA TAKS H

CḦ Чत̈вЧ НMАTh

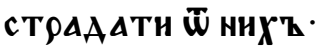

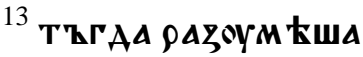

5 оУченнцН ГАКО Ш И

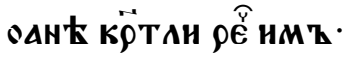

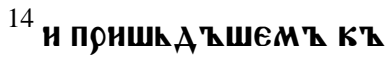

HAPOAOM ' ПОНСTOY

ПН K' HEMOY. Чत̈ЕКไ

10

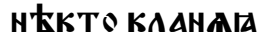

СА ЕМОУ ${ }^{15}$ и ГӒА Г ГЙ

ПОМнАОУН СН̈А МО

IETO - TAKO HA HOE T

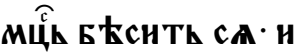

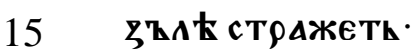

МНОГАШИАТI БO ET

OГHh E ZПIAAAIE

Th' Н мноГАШһ А'

въ воAOY. ${ }^{16}$ н прнве

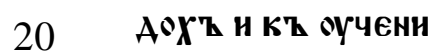

KOMZ TEOHMZ н

нЕ МогошА Юго и

сц КАнти. ${ }^{17}$ ш̈в 太
$41 \Gamma$

廿ав Же

- poаe нев Крнт и ра

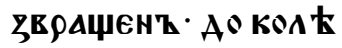

С' ВАМН БОУАOY AO

5 KOA Th ९LПAN вA

M ' ПонвеАнТЕ

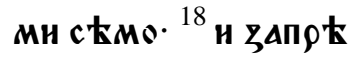

Тн ємоу іст' нзн

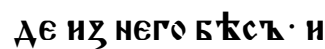

10

нсц $\mathrm{k}$ 太 етрокт

TOMh YAC $\mathrm{k} \cdot: \cdot$.

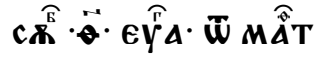

Матфей

$\mathrm{XV}$

32-39

15

в В во

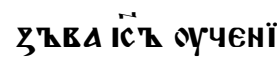

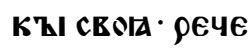

HMT MÁPAOYK O HA

pOA t cEMh - TAKO OY

же төн Ан̈н прнс

AATh MHE ' И HE И

20 MOYTh чhсо Астн

н ш̈поус тити ихт

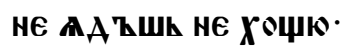

АА HE KAKO CAAE 
$42 \mathrm{a}$

NTh HA ПOYTH. ${ }^{33}$ ГÄA

шА ЮМоу оученицї

WU KOYAOY HAMZ E $\mathrm{z}$

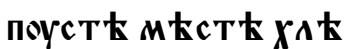

5

БҚ· HАC'ҚITHTH HA

POAА TOAHКА ${ }^{34}$ Н ГӒА

HMZ Ï̈Z · КОAHКО

ХАћБ' имАте· 'нї

же рекоша сеами.

10 и МААО ९ҚІБНЦи ${ }^{35}$ Н

ПовEAK HAPOAOY

в ҚЗАЕЧн нА ЗЕМАї

${ }^{36}$ н прннми се АMи

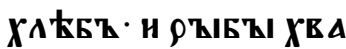

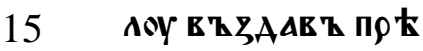

AOMH H AAC Th OY

ченикОМт СвОН

М $\mathrm{k} \cdot$ оученнци же

HА९OAOM Z $\cdot{ }^{37}$ H IAUUA

20 всн н НАС ҚІ ТнША

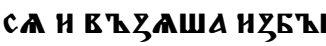

TZK'J' CEAMh Ko

ШКННЦК ИсПЪАКК.
426

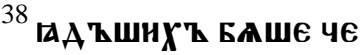

TZIPH TZICALA MЖ

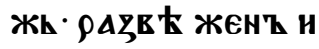

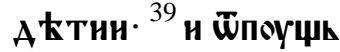

5 нАРОАТ в ВАEZE

В Қ КО९АБАК Н ПОН

АЕ в П ПюнА ЕАЫЫ МА

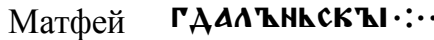

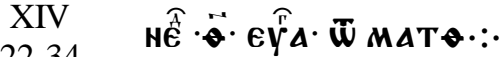

10 в В в

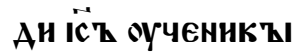

СВОА в ҚА ҚСТИ

BT KO९AEAh ' H

ВАРНТН НА ОНОMТ

15 Полоу АОнъАЕЖЕ

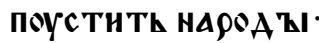

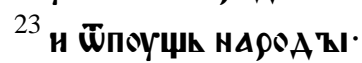

B'z ZHAE HA TOPOY IE

АНH' ПОМОАНТ ' $\mathrm{CA}$.

20 ПОЗА Ж

ЮАНнҚ БАше TOY ${ }^{24}$ KO

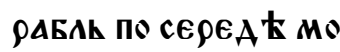

PA в'МАAIA CA E'ZHA 
42 в

МН БАШЕ БО П९ОТИ

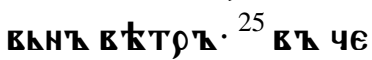

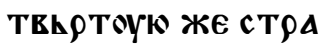

жю ноци нАЕ кһ нї

5

Mh חо MogN XOAA.

${ }^{26}$ н виА Қв 'аше и оу

ЧЕнНЦИ ХОААџА

ПO MO९К C'MMATO

шА са ГӒще· ТАKo

10 ПрнвнА ЋнНЮ ЕСТЬ.

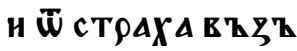

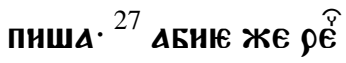

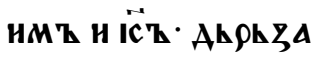

НTE $\triangle \zeta^{\prime}$ ЮСМh · HE БО

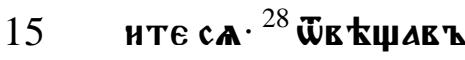

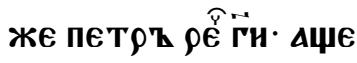

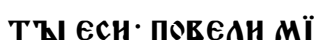

ПОНти К' ТЕБе По

вОААMи ${ }^{29}$ Он'

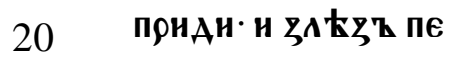

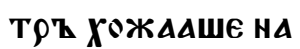

вөААХ' и ПОНАЕ К'

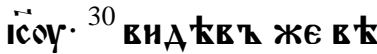

$42 \Gamma$

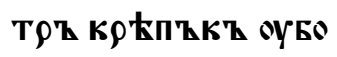

IA CA HАYАT' OYTA

ПАТн·н вһ弓'МПн

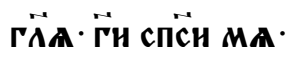

5

31 АБн юЖе іс 'h про

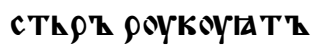

и и ГӒА ほмоУ МА

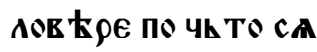

sycoymht. ${ }^{32}$ H в'hAt

10 द'ШемА нмА в '

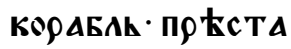

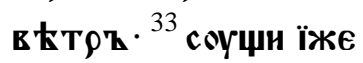

В' Кө९АБАН По

КАОНнША ЮМ ОУ

15 Гӥще в и нстиноу

сн̈Һ Бӝни юсн. ${ }^{34}$ и прн

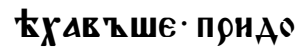

Матфей

ША HA ZEMAN ГE

XVIII

$1-9,11$

20

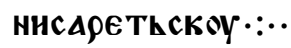

в Ћ понеึ

в' воҚма оно-

1 прнстоупншА

оученнци к'һ н 
$43 \mathrm{a}$

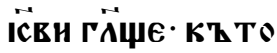

Бо Болнн Есть в $\mathrm{T}$

Цр̈сТЕНН НБ̈СКН

ми. ${ }^{2}$ н прнц'ҚвА.

5 іс̈ $\mathrm{A}$ 太тищь постА

ви и по сереА н нх'

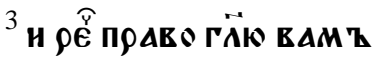

Аџе не оБрАтнте $\mathrm{CA}$

Н БOYAETE IAKO A.

10 ТН· нЕ НМАТЕ БЪН.

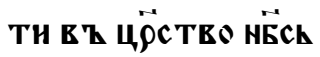

HOЮ. ${ }^{4}$ нжЕ БO $\mathrm{cA} \mathrm{ch}$

м Ернти ГАК'Ы А.

THщh ch· Th EcTh

15 Бөлнн в ц ц्̈ствнї

HЁскн ҚMһ $\cdot{ }^{5}$ нЖЕ А

че поннмети A $^{\text {t }}$

Тнщһ ТАКо в Қ $\Theta_{A H}$

HZ Е Қ НMA MOЮ $M$.

20 не прнемАЕть ${ }^{6} \boldsymbol{\Delta ~ н ~}$

ЖЕ съБААZНHTh Ю

AHHOГO $\tilde{W}$ MAA'ZIX.

снХ'В в Е оуюшнХ'Қ
436

В' МА •УНE ЮM ЮY Ю

CTh A АБ КCATh HA

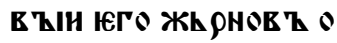

СКАН· Н ПОТОПАТК

Н Е П ПОУЧнसЕ MO

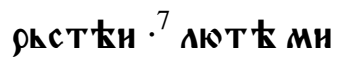

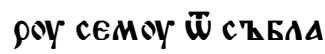

ZHT' HOYЖA БO ECTh

ПОНТИ СҚБААZНО

10

Mh - SБАYE ANT K YE

АОв kкоY ТоMоY.

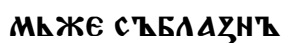

понХРАнть ${ }^{8}$ Аџе Аї

POYКА ТЕОА ' НАН HO

15 ГА ТЕ ОА СҚБААЖНА

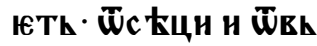

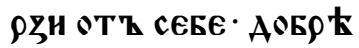

. ТИ ЮсТИ в ҚННТИ

в द жнзни Хромоу

20

нАн Б末аһноу. неже

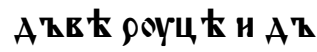

в 太 ноз нмоущь

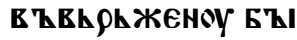


43 в

TH в Қ огHh в 太पh

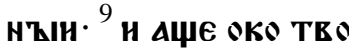

IE С'БААЖнАЕТИ

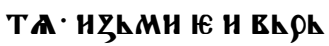

5

दु Ю

Ти юс Th $E_{\text {Aннћмh }}$

sKOMh в Z жHE TTh

в \НHТИ· нEжE A'

в Е очн нмоущоу

10

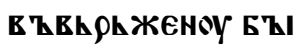

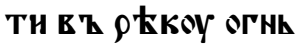

ноую. ${ }^{11}$ ПрНАЕ БО СН'

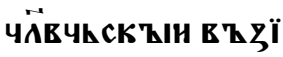

сКАTҚ и сп̈TҚ по

15

TZIEZ WAATS - :.

в ' в в

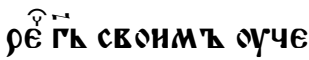

Матфей

XVIII

$18-19,21$

20 ннкомъ ${ }^{18}$ ЕАнко

АџЕ сһвАЖЕТЕ нА

弓EMAH' БOYAETh

CZEAЗАHZ HА НЁСН.

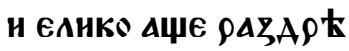

ШитЕ НА ЗЕМАН - Б8
$43 \Gamma$

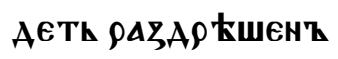

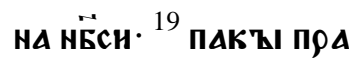

BO ГÄ० в АM Z · TAKO

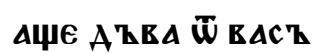

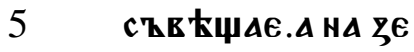

МАH O ВИСАKOH ВE

Чн и ๒АнКО ЖЕ КО

Анжи АепроснтА

БOYAETh HMA W

10 цेА моего нже естh

HA HEX' ${ }^{21}$ ThГAA

понс тоупАһ пет९'

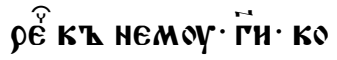

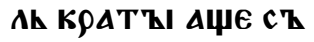

15

Г९ Ешить К' мнЕ

Б९АТТ МОН· Н ОСТА

ВАЮ ЮMOY CEAMh

KSATK ' HZ AOCEAMK

AECATZ K९ATZI.

20 .. АО СААМНЦЕК.

13 тһГАА ПФнАОША

Матфей

XIX

KT HEMOY A KTH.

13-15 АА ९оҮц Е въ弓А० 
$44 \mathrm{a}$

жиTh HA HIA и ПОМ

АНТИ СА - ОУченнцН

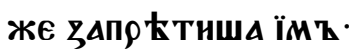

${ }^{14}$ ic $\mathrm{z}$ же рєче нмт -

5 станћте А Қти· їне

БФАните нМт п९н

TH K' MHE· TAKO

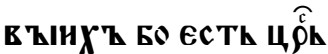

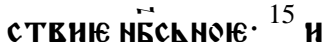

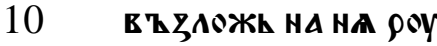

ц ' И ОТҚНАЕ ОТТ

TOYAOY::-

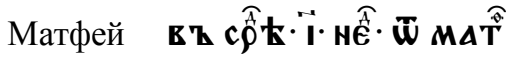

$\mathrm{XX}$

$1-28$

15

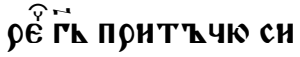

$\omega^{1}$ ПОА ББһHO EсTh

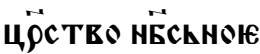

Чล̈ЕКОУ АОМОЕНТУ.

НЖЮ И弓НАЕ ЗА ПА

Th ZA OYT PA HAIA

20 T' А ҚААТЕАА ЕНнО

rOAAOY CBOEMOY. ${ }^{2} \mathrm{ch}$

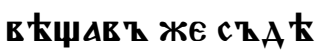

ААТЕАН ПО с९ КБ९h
446

HHKSY HA ÄHK ПO

С'МАА ГА ЕТ ЕИНОГОА

A' СЕOH. ${ }^{3}$ HWhA' ह'

ТОЕТИЮК ГОАННЖ.

5 внА ИнҚІ НА ТҚ ९Ъ

ЖH廿И СТОАџА ПРА

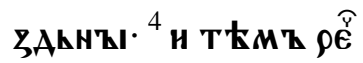

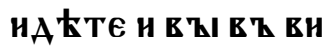

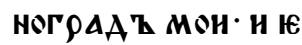

10 ЖЕ БОYАЕТИ ПФАВО

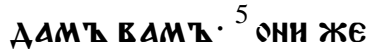

НАОША· ПАК'Қl ЖЕ и

WhAt ' B ' WECTOY

Ю и в ' AEв A TOYю

15

ГОАНHОУ СТ ТЕО९Н

ТАКОжАE ${ }^{6}$ в '

ноYК ЖE нА AECATE

ГОАНнОY HШКАТ.

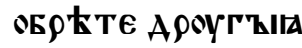

20

С TOAWА ГÄА HMT

Yh TO стоHтE ChAE

BhCh AḦh П९А३Ah

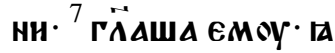


44 в

КО нНКТОЖЕ нАСТ

HE HAIATZ ГӒА ИMТ

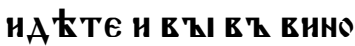

ГРААТ МОН и ЕЖЕ БЖ

5 АЕТИ ПРАВО ПрннмЕ

те $\cdot{ }^{8}$ вечероу же Бъ

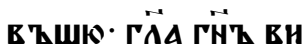

HогоАAА. К'Z ст

НТЕАК своEMOY Прї

10 ЗОВН А КААТЕАА Н

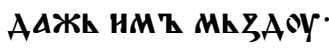

HAY.HZ W חOCA $\mathrm{k}_{A h}$

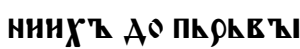

нХ'z ${ }^{9}$ прншидаше

15 жЕ нже в Қ Е Анноую

HA AECA TE ГOAHH及.

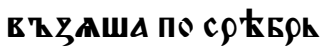

никоу. ${ }^{10}$ и ПоншКАТ

ШЕ ПК Вин ПФНАША

20 И Ти ПО с९ћБ९Кни

коу. ${ }^{11}$ прннмъше же

PZחZ T A OY HA FHA

12 гӥще · гко сн поса
$44 \Gamma$

AKHH ЮAHH' YACZ

TЕоРНША Н РАЕКНҚI

HAMZ C'Z TEO९HAT

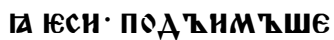

5 MZ TAгOTOY Aн̈ERh

ноУК и зНон. ${ }^{13}$ ОНТ ЖЕ

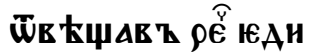

HOMOY HX'B APOY

жЕ не оБнжю теБе.

10 не по с९ћБрьникж

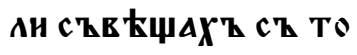

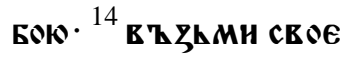

Н НАН Х ХОШК ЖЕ сЕ

MoY moca

15 МоУ ААТН ГАКО И ТЕ

Б太. ${ }^{15}$ НАН нЕсть МН

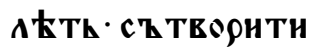

в ' свон Ү' Мн юже

XОџा० - АLE OKO TEO

20

E AOYKAKO ECTh IA

Ko $\triangle$ दु БÄГh EсMh

${ }^{16}$ TAKO EOYAOYTh ПO

сА ҚАКнНн ПК९Ен 
$45 \mathrm{a}$

Н· И ПК ФвнН ПОСА ААКнН

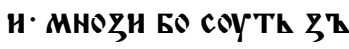

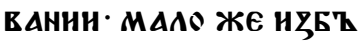

PAHzIX' $: \because \cdot \cdot$

5 в т че̂

в' врҚМа оно. ${ }^{17}$ в'

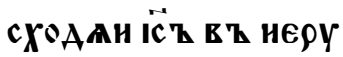

CAAHMZ ПOATZ W

БA HA AECA TE OYYE

10 НHКА ЕАННҚН НА

поуть ' н рече им'

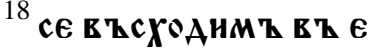

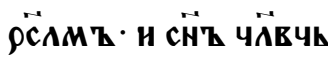

חоEAAH' БOYAETh

15 стА९ КишннАМ $\mathrm{z}$

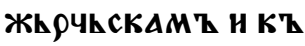

ннжьникоМ Қ

COYAA Th И HА C'ZMh

Оть ${ }^{19}$ и прнаАаA

20 Th Н HА ПороуГАнН

Е ст ФАНАМ' · Н БнЕ

нН ен пропатне

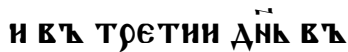

456

скриснети ${ }^{20}$ T'МГАА

понс ТоУПн К' нEMY

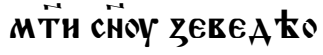

вOY. Ch СН̈ОMА СвОН

5 МА. КААНАКџн СА

Н ПрОсаџн нКЧсо

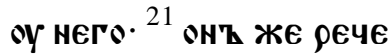

Ен· чсо ХОџешн ГӒА

EMOY. ОКчн AA CAAE

10 TA CHA WБА CHA MO

A. EAHH' O АECHOY

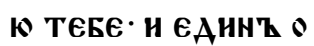

А Квоую теБе в

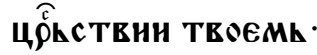

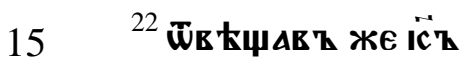

рече ' не в 太стА

CA Yco прOCALA

МожЕТА АИ Пи

ТН ЧАШОУ ЮЖЕ $\triangle$

20 उ' НМАMТ Пн

ти. нАн коцше

нне имьже $4 \zeta \mathrm{Z}$

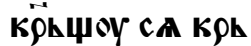


45 в

СТИТИ СА· ГӒАСТ ТА

EMOY MOжEв 太. ${ }^{23}$ гÄA

HMA. H YAWOY MOF

нспнетА' и коцше

5

ннемь имьже $\triangle$

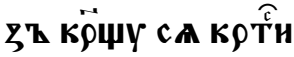

ТА сA. А ЕжЕ сћсти

- Aechoую мне и о

А Қвоую мне нћсть

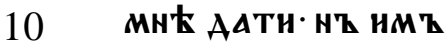

жE OYГОT Ов АHO $\mathrm{E}$

cTh оӵһMh Монмh.

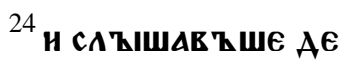

CA Th HAYAUA HE

15

ГОАОВ АTH W ОБО

n Братоу. ${ }^{25}$ и ї̈ъ же

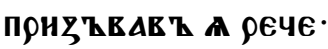

в 太CTE AKO KHAZH

СТ ९АНА НАMH ВАА

20 АОУТК нмн. ${ }^{26}$ HE TA

коже в h в $\mathbf{~ А c h} \cdot \mathbf{H h}$

нже Аџе Хощеть

БОАН БҚІТИ Е Қ ВА
$45 \Gamma$

C' ' AA EOYAETh BA

Wh слоугА ${ }^{27}$ и нже А

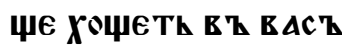

БZITH CT $\triangle \rho$ KH· AA

5 БOYAETh BAWh $\rho A$

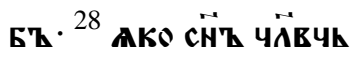

HE חонаE AA חOCAOY

\%ATh EMOY HT AA

посАоужнТи ' н АА

10 Ти Аш̈ऽу СЕОК Н弓БА

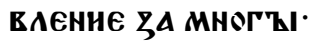

Матфей

XXI

12-14,

18-20

15

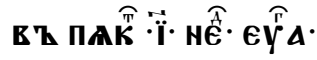

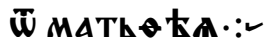

в В врема оно. ${ }^{12}$ вт

ннАе їст в ц цёк'

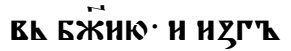

ha BCa mpoAaro

एАA и KOYПOYF

ЩАА в Ц Ц९̈КЕН· Н

20

АҚсKҚI T'Қ

КомтMт нспро

вирже' н с КАААн

ЩА ПФОААКШНХ' 
$46 a$

ГОАОуЕН. ${ }^{13}$ н ГЙА н

Mh ПнсAно EсTh.

ХОАМт Мон ХРАМт

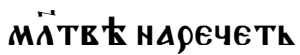

5

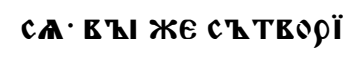

стЕ н пеце ОУУ $\rho \Delta$

ЂБОнникомт ${ }^{14}$ н

прес төупншА к'

немоУ ХООМни · н

10

сА Бпнн в ц цр̈кт

вн н н нप์

тро же в Қ马в

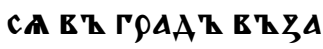

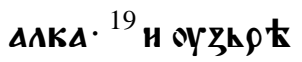

15 в' смок'hEh 6

Анноу пре Поути

ПрНАЕ Кһ нен ' н ни

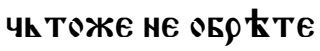

HА HEH· Hh ThKMO

20

АНСТЕНЕ ЕАНнО

ГӥА ЄH· АА никөлї

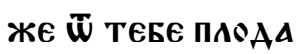

не БоуАети в' в
466

К'Қ· АБне и с'Қше

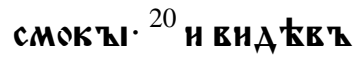

ШЕ ФУЧЕННЦН АНЕН

WА СА ГӒще· КАК०

5 АБне sус қше сMо

КҚЕКнНЦА $\because \cdot$ •

$\operatorname{cô} y \cdot \vec{i} \cdot \epsilon \widehat{y} \Delta \cdot \bar{w}$

Матфей

XVII

24-27

10

в Т воћма оно. ${ }^{24}$ пре

с тоупншА пре

ЕМАКџе ААни

к' пет Оовн· и

рекошА EMOY ' oY

ЧнтЕАh вАШИ HE

15 ААЕТК ААни. ${ }^{25} \rho \in$

पе ЕН म НГАА в

HнAE в' АОM'

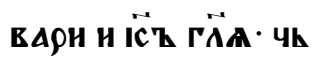

TO ТИ СА МнИТК

20

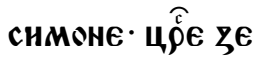

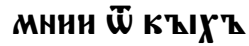

ПреЕМАКTh AА

нН· АН КннНс ' 
$46 \mathrm{~B}$

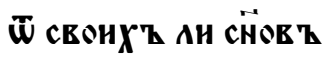

нАн $\overline{\mathrm{w}}$ чюжнхи $\cdot{ }^{26} \rho \mathrm{e}$

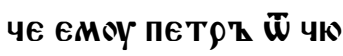

жнर' - $\rho$ ече емоу

5

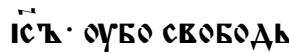

Hн АH COYTh С̈̈ОВЕ

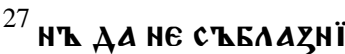

MZ HX'Z - WhA' E '

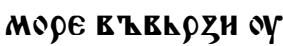

10 Анцк- н кже пре

ЖЕ имЕши ९ТІБоу.

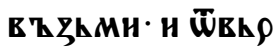

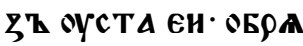

цешн стАтн $\rho$ '

15

Th EKZKMM AA

ЖАК НMT そА МА И

ZA CA. ${ }^{1}$ EK TZ YACK

Матфей

XVIII

$1-4$

20 прнс тоупншА оY

ченнчн КТ İ̈У ГАA

ГОАКце К' K० TO ОY

БО БОАН ЕС Th В T

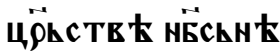

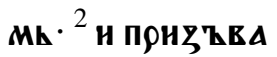

$46 \Gamma$

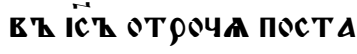

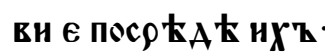

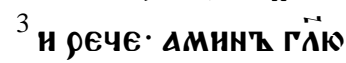

вАM '

5 ТИТЕ СА И БоУАЕТЕ

АКО А ТТИ не нМА

ТЕ вънитн въ це९

с TЕНЕ НЁсКнОE ${ }^{4}$ H

же Бо са стм к $\rho$ H

10 Th AKO отрочA cE.

Th ЕсТһ БОАнн· в '

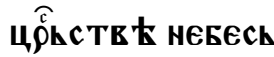

Матфей

XVII

14-23

15

нћMh $::$ :

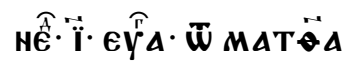

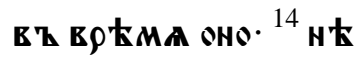

КไИ Чล̈ЕКТ ПРН

с тоупн Къ म̈су.

kadhaA ca emoy

${ }^{15}$ Н ГӒА ГЙ ПОМнАY

20 И CHA MOEГO - АKO

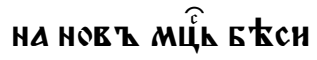

Th CA·H Z'BAt CT

рАЖETh ' MhHA 
$47 \mathrm{a}$

TAWhA BW EO MAAA

ETh HA WrHh H MT

HAT AWhA'ZI ET BOAY.

${ }^{16}$ н превеА०Х' и К'

5 ОУЧЕННКОМТ TЕО

НМ Н не MогошА

его нсц ЋАнти. ${ }^{17} \overline{\mathbf{w}}$

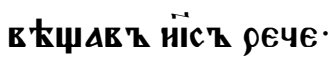

- poae nez kphнt.

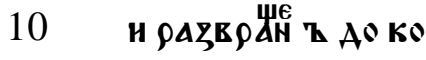

A С ch вАMH БOYAY.

AO KOA Е ThPחAN

в'Ы· ПОНве А ТТ

мн и с 太мо. ${ }^{18}$ н зА

15 прћтн емоу ї $\mathbf{z}$.

Н马НАЕ нж неГО БЕ

съ· н нсц КАн отро

Kh TOMh цACk. ${ }^{19}$ Th

ГАА прест тупаһ

20 ШЕ ОУЧЕННцН ЕАН

номоу मісу реко

WA. По чh TO MZI HE

в'zдмогехомт и
476

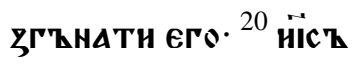

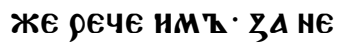

в кркстне ваше

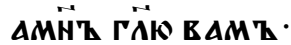

5 АџЕ имАте в Е९У.

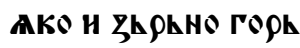

ЧнНКно- РЕКАН БҚ

сте горћ сен прн

HAH WU CNAOY TA

10

M०. и пренАETh

и нНЧһ ТОжЕ в Z马

МОжИно БоYAE

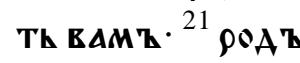

жЕ сь ничнмьже

15 HE HCXРАHTh T'

KZMO MÄTEOЮ

и поствми ${ }^{22}$ жн

воушемт же имт

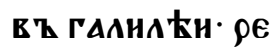

20

че имъ मіс $\mathrm{k} \cdot$ пре

AАH' БZITH HMA

Th CḦZ Чत̈हपh ह Z

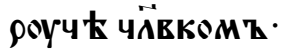




\begin{tabular}{|c|c|}
\hline $\begin{array}{c}\text { Матфей } \\
\text { XXI }\end{array}$ & 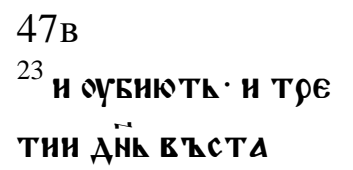 \\
\hline $\begin{array}{c}18-32 * \\
43-46\end{array}$ & 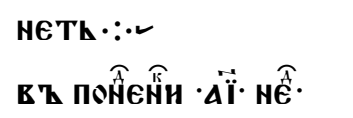 \\
\hline $5 *$ & 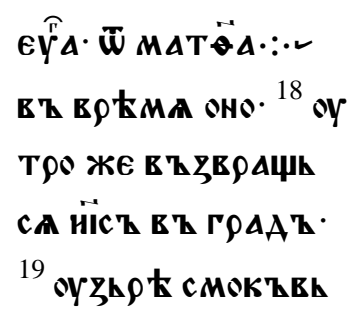 \\
\hline 10 & 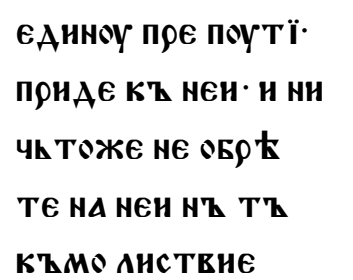 \\
\hline 15 & 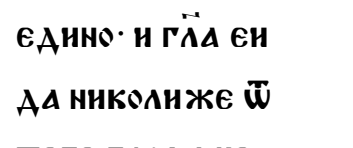 \\
\hline 20 & 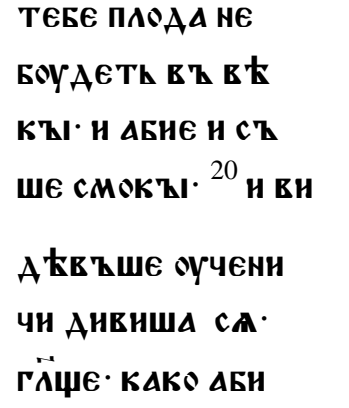 \\
\hline
\end{tabular}

$47 \Gamma$

є н сһше смокһ-

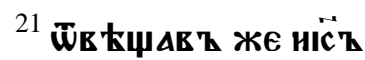

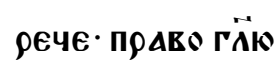

вАM Z - Аџе нмА

5 ТЕ в Кроу. Н не оу

COMLHнTE CA.

HE ThKһMO сMO

K'ҚKLHOE СZ TEO

рнте - Аџе н горt

10 сен ९еЧЕТЕ АЕИГ

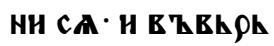

ZH CA R' MOpE. EOY

Aєти ${ }^{22}$ и все егоже

в Қпроснте вһ

15 мӥтв Е· в Еоу

юще прннмете $:$ -

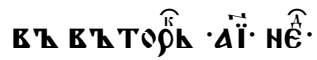

* $\quad \varepsilon \widehat{Y} \Delta \cdot \bar{w}$ mat $\vec{\theta} \Delta$

*. вт врtвма оно.

2023 прншиатышоу

EMOY в Қ цёквК.

прнс тоупншА

Kh HEMOY OYчA 
$48 \mathrm{a}$

щоу. сторқиши

H'Zl жh $\rho$ чhск'ҚI

н стА९цн АюАКсти

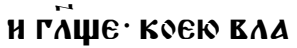

5

с ThN сE TRорншн -

H К' TO TH AАCTh

вААС Th сню. ${ }^{24}$ ше 太

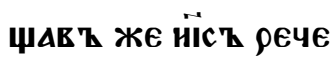

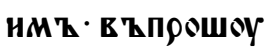

10

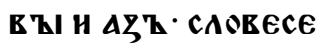

ЕАНного ЕЖЕ А

це речете мнћ

н А弓' вАM ' реку

KOEN вАACThN

15

ce Tворю. ${ }^{25}$ кёце

HнE HE WAHOBO

Ẅ KoYAOY Et'ch

нЁсе Ан † речетh

HAMT - חOYh TO oY

20 Бо емоу не Асте в

$\rho \mathbf{z l} \cdot{ }^{26}$ Аџе Ан рече

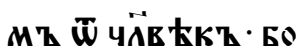

HMT CA HAPOAA.

† .ЧӒЕКТ - РнН жЕ

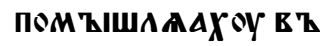

сеБе ГӒше - Аџе oY

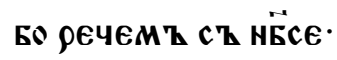

486

всн Бо ако пр९КА

HMOYTh HWAHA.

${ }^{27}$ шв ћџав Ђше же

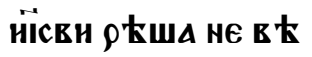

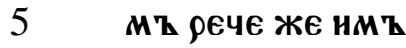

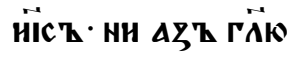

BAM Z ' KOEL BAA

c ThN ce TEOpNo:-

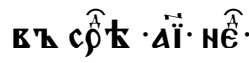

10 Eर्भि.

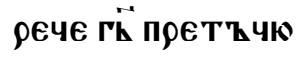

сию. ${ }^{28}$ Чत̈вК' ЕТЕ

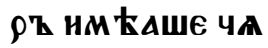

A $\mathbf{A}$ АвE $\mathbf{k} \cdot$ и пюн

15 ШhАт К' ПирвУ

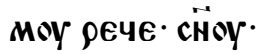

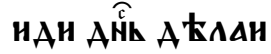

в Ђ внногоАА

MoEMh ${ }^{29}$ онт же

20

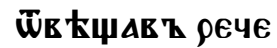

не Xощоу. nocat

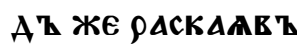

са нае ${ }^{30}$ н престу 
48 в

חAh K' Apoyroyoy

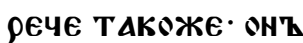

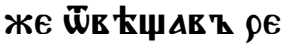

$4 \mathrm{E} \cdot \Delta \mathrm{Z}^{\mathrm{B}} \mathrm{HAOY} \mathrm{rH} \cdot \mathrm{H}$

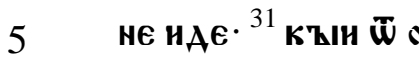

БOF C' TEOQH ВOAK

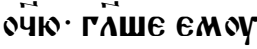

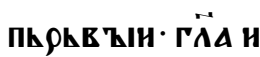

Mh HIC' $\mathrm{h} \cdot$ п९ABo

10 ГӒю вАMZ - A

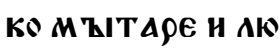

Бод ћнца вА९A

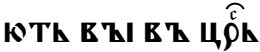

ств 太 Бённ. ${ }^{32}$ прє

15 AE БO HWAH' K९h

стнTEAh K' вА

MT חOYTLM'

ПОАЕКАКН'ҚIY

Mh' н не Асте E

20 Mоу в $\mathbf{k \rho \mathbf { Z l }} \cdot \mathbf{M} \mathbf{z l}$

TAPE и АКБОА

НЦА АÜ EMOY

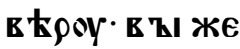

$48 \Gamma$

внА Ев ЂШен не

PACKAACTE CA חO

CAKAh - ATH EMY

в

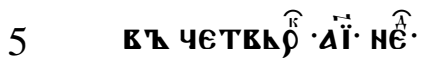

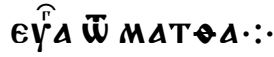

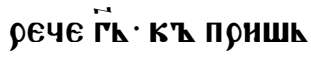

Аһшнм' к' не

MOY Hю् АEMT.

10

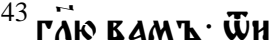

METh ca ש̄ вach

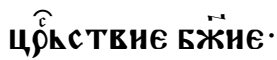

H AАCTh CA CTPA

нЕ ТворАџнН

15 ПАОАТ ЕГО. ${ }^{44}$ н ПА

АТЫH HА КАMENH

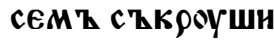

Th CA A HA HEMh

жe חaAe c 'zKosy

20

шнтһ н. ${ }^{45}$ Н СА'

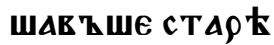

ншинҚI жh $\rho$ पh

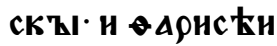


$49 \mathrm{a}$

н прнт Қ че его

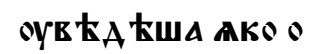

них'Қ ГӒЕ Th $\cdot{ }^{46}$ нщу

Ш. А ТИ Н ОYБОА

5

UA CA HAPOAA.

ПОНЕЖЕ АKO Пр९̈КА

HMA..Th H $: \because$.

Матфей

XXII

23-33

10

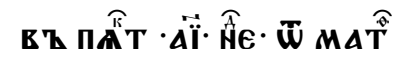

вт воЋма оно.

${ }^{23}$ прес тоупншА

KT HEMOY CAAY

кћн· ГӒше не

БҚттн въскр Е

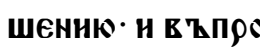

15 сишА и ${ }^{24}$ гӥще - оу

ЧнТЕАК Монсн

че. Аџе K' To oy

миреть не имы

YAAА AА ПОHМE

20 Th Б९АTZ ЕГОЖЕ

HOY EMOY' म $\mathrm{KT}$

сTАRHTh ПАEMA

БPATOY свOEMOY
496

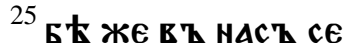

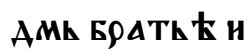

ПК ОВ Қ/Н оЖЕнһ

ca oymhре не н

5 МЫи ...мене -

С ТАВН ЖЕНОY СвО

م) БРАT ОY СвоEM

оу. ${ }^{26}$ т.коже и в $\mathbf{~}$

тордин и трети

10 Н Aо сE....

${ }^{27}$ поса Ћжае же оY мире жена ${ }^{28}$ AА

на въck kшенн

E KoTe $\Delta \Delta$ ATS oY

15 Бо БоYAETh W cE

АМн женА. всн

Бо им КША юже

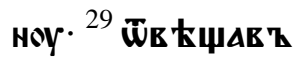

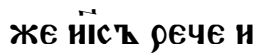

20

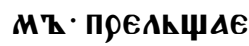

те са нев

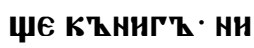

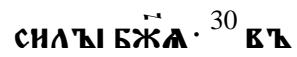




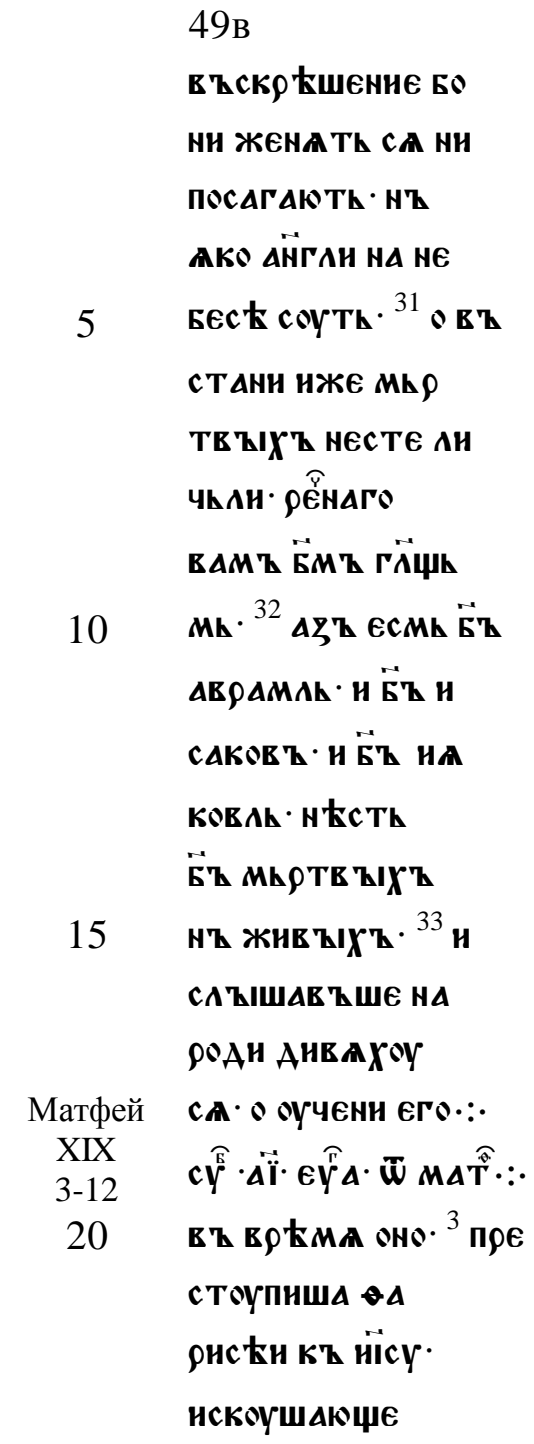

49г

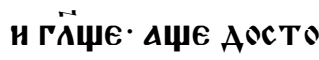

НTh पत̈вкоY ПОY

с ТИТИ ЖЕНОУ Сво

Ю ПО вСАКОН ЕНН Е.

54 онт же бив tцА

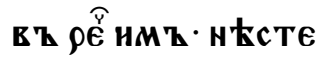

АН цьАН' АКО С'

ТВоРн нсКОнН -

Моужиск' ПОА

10 H Женhск' с ' T

ворнат есть ${ }^{5}$ и

рече - cero pa

AH OCT АEHTh

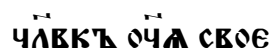

15 Го н мт̈ри'н пре

А ћпити са же

HЕ СвОен· Н БОY

АETA ОБА Е ПҚ ПАҚ

Th EАнноу. ${ }^{6}$ Tt

20 Миже оуже нћ

CTA A KEA H' ПN'

Th ЕАннА ажЕ оY

Бо Б̈Қ съКоYПить 
$50 \mathrm{a}$

Чล̈ЕК' АА HE $\rho \triangle$

ZNOYЧAETh ${ }^{7}$ ГÄA

WA EMOY. पh TO

ОУБО МонсН ЗА

5 ПОв ААА ААТИ

КнНГ'Қl PACחOY

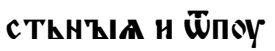

стнтн $\mathscr{N}^{8}{ }^{8}$ ГӒА Н

MZ' АKO МОHCH

10 По Жестосирак

o rawemoy no

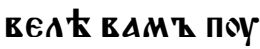

ститн жен'ҚI

ВАША' НСКОНН

15

Же не Бरі таKo.

9 ГйА же вАм.

АKo нже Аџе пY

стить женоY

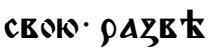

20 сАОвесе АКБО

A 太инаго. TEO

९HTh \& ANEеA

АнНЕ ТЕорити.
$50 б$

и ЖЕНАИ СА ПОТИ

Б太ГОW. ANEOA

HCTEO TEOPHTL

${ }^{10}$ н Гत̈АША EMOY OY

5 ченнци его. Аџе

TAKO EC Th BHHA

Чत̈вкоY С̆ ЖЕНО

م- OYHE ECTh HE

женити са. ${ }^{11}$ онт

10 ЖЕ рЕче нмт - нE

всн вһMKCTA

Th сAORECH CEГO.

HZ ИМТЖE ААНO

EcTh ${ }^{12}$ coyTh 50

15 КАЖеници нже

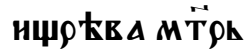

hapoahWA CA TA

KO- H COYTh KAЖE

ннци Аже нскА

20

ЗНША Чล̈ЕцН· Н

соYТИ КАЖЕнН

ци ижЕ кАЖЕ

Ннцн БЪIША CA 
50в

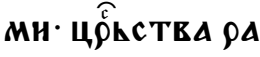

АН HËLHALTO

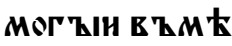

ЩАTH AА E K

5 мћстить $\because$ -

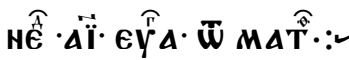

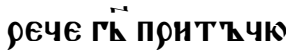

Матфей

XVIII

23-35

10

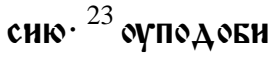

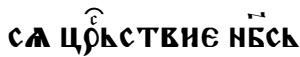

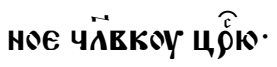

нже ХОть сһ тA

ЗАТИ СА О САOEЕ

c太 C'

НМН. ${ }^{24}$ НАЧКН'

15

woY жe EMOY

C'T TAZATH CA

- сАовесн· н ПОе

BEAOWA EMOY

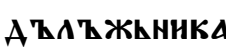

20 ЕАнНОГО ThMO

N TANAHZ T'Z

25 не нмоушоу

же EMOY पh To
50 г

в Қ३ААТИ・ По

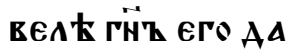

IDOA AAATh H.

и ЖеноУ ЕГО и ЧА

5 АА И ВСЕ ЕАНКО

HMAWE $\cdot$ H $\overline{\mathbf{W}}_{A \Delta}$

Ти н. ${ }^{26}$ ПАA' OYБО

PAE' T'Z KAA

Hawe ca emoY

ГӒА Гӥ Потирh

ПН HA MТH太 H

все Тн в ҚЗАА

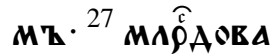

в Z ЖE ГḦh ९AEA

5 того поусти н.

Н АТАГО ОС Т АВН

EMOY. ${ }^{28}$ Hшh AT

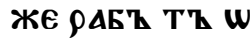

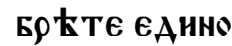

20

ro $\bar{w}$ кAER $\rho$ t

Th свонX' $\cdot$ '

же Б大 EMOY AT

$\triangle$ hжhн' с'ZTh 
$51 \mathrm{a}$

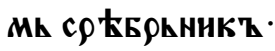

НМЫИ И ААВАAШE

ГӒА· ААЖИ Мн и

Миже мн есн $\mathrm{AT}$

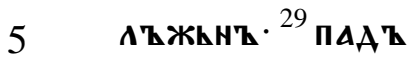

SYEO gAE' TZ ERO

oу ногоY ero. mo

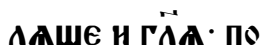

Th ९Пн HА M ZHE

10 Н Все Тн в ҚАА

Mь. ${ }^{30}$ онт ЖЕ нЕ Х०

TAWE' H' REATh

ВZCАAH Н ЕT Th

МКнНЦК АОНТ

15 АЕЖЕ въ弓ААсть

EMOY BCh ATAГ'

${ }^{31}$ внд Ав ъше же oY

Бо кАев $\rho$ Кти БҺ

В ҚШАA · С ЖААH

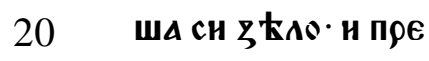

WhA ZWEE c'zKA

ZAWA ГḦOY CBOE

MOY BCA ETIE T
516

WAA ${ }^{32}$ TZTAA

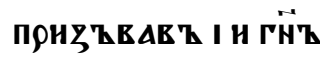

Гत̈А EMOY PALE AY

KAB ZIH BCh ATAT

5 ГҚ ТЕОН ОС ТАЕН

X'Z теБе Понеже

оумоли Ма. ${ }^{33}$ He

ПОАОБАUЕ АН TE

Б Е ПОМНАОВА

10 Ти кАев

TEOEГO АKO Н

АЗ'Т ТА ПОМНАО

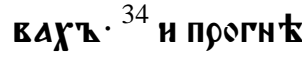

BAB Z CA F̈HZ EГO.

15 прєАА н мчТ̈АЕ

MЋ AOHzAEЖE

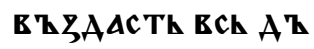

$\Lambda \mathbf{Z}$ Гh Св

КО Н Оप्प М०Н НЁС

20 н'ҚІн с'Z TЕорнть

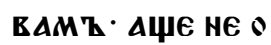

сTABAAETE K' 
51в

ЖАО Б९АТ8 СहО

EMоY. $\ddot{\mathbf{w}}$ срци

в АшнХ' $\cdot$ пре

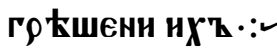

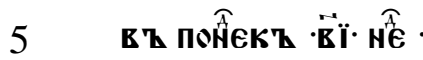

Eर्भि$\Delta \cdot \bar{w} M \Delta T \cdot \vec{\theta} \Delta \cdot:-$

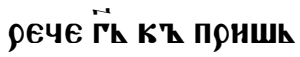

Матфей

XXIII

13-39

10

Атшнми неА

WMz $\cdot{ }^{13}$ rege вAM

КҚННГҚЧНА Н ОА

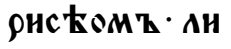

цем Крнн Ако

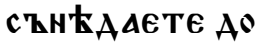

МЫ ЕКАОВИЦА

15 Н вНHON ААЛЕЧЕ

MOAA Th CA·CE

ГО ९ААН ПОНнМЕ

те Анше осоуже

нне. ${ }^{14}$ горе в Ам т

20 КТАНГ'ҚЦНА Н

- Арнс Ки Анце

мЕрни' АK० Zа
$51 \Gamma$

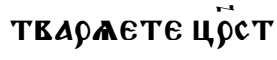

вHE HБ̈сLHOE Пре

A' Чत̈вКҚ/ ह ҚІ БО

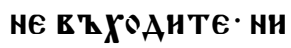

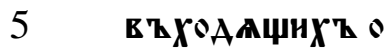

сTARAAETE

в Вннтн. ${ }^{15}$ Горе вА

МЋ КЂнигъци

А и ОА९нс Ен Ан

10

цемКрн· АKo

ПонXРАнTE MOQE

H coYwoY. c' TEO

рнте ЕАнного

ПрЕШКАКЦА $\cdot$ H

15 еГАА БОУАЕТЬ.

TRорнте сHА AK

БОH SГHLHE COY

Гоув КншА в АC'

${ }^{16}$ горе вАMZ вОЖАН

20 слћПнн ГӒџнн.

нже АџЕ кАннете

сА цр̈КЕКК ницК

тоже ести $\triangle 4$ и 
$52 \mathrm{a}$

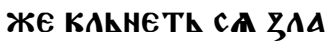

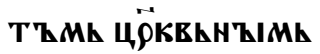

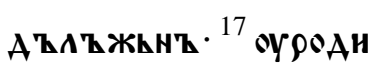

вИ и САћПН Ч Ч० БО

5

АН ECTh ЗААTO АH И

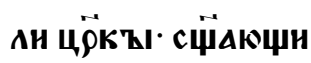

А ЗиАТ०. ${ }^{18}$ нже Аџе

Kльнеть сA трt

БКнНКҚМК нНЧһ

10

Тоже Есть А нже

KALHETh CA AAPT

Мh нже естh вһ $\rho$

ХOY ЕГО АТАЖинт.

${ }^{19}$ ОУ९оАнЕн и СА ЕПн.

15 Чһ T० БОле Есть.

АА९Қ Ан нАн Т

ББНнКЂ СЇААН

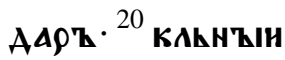

сА оуБо жирТЕИ

20 HНКҚML $\cdot$ КАКHE

HETh CA н вChCt

ми нже ви РXY

ЕГО. ${ }^{21}$ Н КАКНZIH СА
526

цр̈квкК кАһнеть

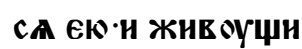

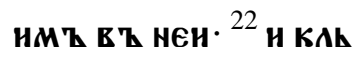

HZIH CA HËсKMh.

5 КАннети са пре

с толъми Бёне

Мh' Н с АААџнН

Mh HA HEMh $\because:$ -

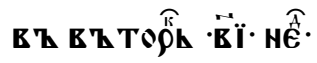

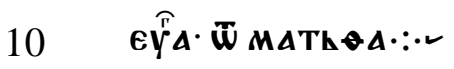

рече г̈h к' прншь

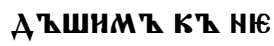

MOY HOA $\mathrm{kW}$

Mh ${ }^{23}$ rope ваM Z

15 КҺНнГҚЦНА Н ОА

९HC太H' AKo oAE

CATOYETE MATY

н копри ' н кумн

H' ' Н ОСТ АВНС ТЕ

20

TAXLUAA ZAKO

HA' COYAT' H MH

AOC Th' H В Е POY'

сн ЖЕ ПОАОБАШЕ 
52 в

СК ТЕО९НТН ·

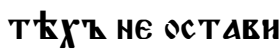

ти. ${ }^{24}$ вожи слћпи

н· 'ц Қщающен

5

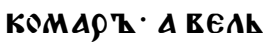

БоYАТ ПОЖноА

кще ${ }^{25}$ горе в АMт

кннжкници จ.

рнс Кн· Анцем Қ

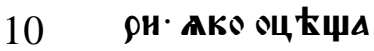

Ете вЂнћшине

Е СТККААЦИ И

БАКАО Н ОYТ

ЮAOY жE חZA'

15 ни соYти Г९А

БАенНА ' и Бес

прАRhAKA. ${ }^{26} \bullet 4$

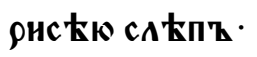

Рчнстн пһрв 太

20 Е оутрине есть

КААННЦН· Н

EANAOY. AA

БOYAETh и в'
$52 \Gamma$

нћШКнеЕ нМА Чн

сто. ${ }^{27}$ гере в АMт

КННГҚЧнАН ОАРН

с 太Н· АнцЕМ Е Рни

5 АКО ПОАОБНТЕ СА

ГРОБОМт ПОВА

ПАЕноМ ' нЖЕ в Қ

HKWAOY OYEO ABA

ALTh CA K९ACh

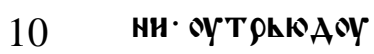

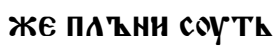

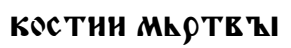

X' Н вCAKOA HE

ПРАЕКАТ НЕЧНСТО

15 TZI. ${ }^{28}$ ТАКО и в ҚI

BZHसWAOY ARAA

ETE CA पत̈вKOMT

ПОАВһ ALHH · OY

TPLNAOY жE חर

20 Анн соусүше Ан

цемћрна' и Бе

ЗАКОнНА $:$ :

B Z cộ̂ 
$53 \mathrm{a}$

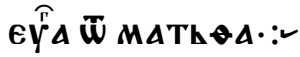

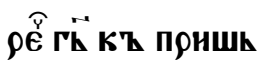

АТшнмт к немY

HoA АOMz ${ }^{29}$ rope

5 вАМТ Кннжьни

ци н ОА९нс Ен оу

Пекрнти -АКО зи

Жете Гробты про

роциск'Қla' h оY

10 TВА९AETE ९АКҚ

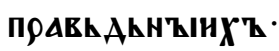

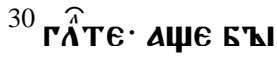

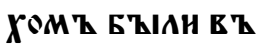

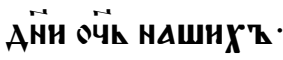

15 не БЪд

Бо оБһщьници

БҚІАН КРҚЕН

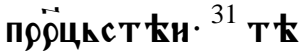

Мh же посnoy

20 Whс TR8ETE $\cdot$ сEБE

Ако сн̈ове есте

H马 БHЕ \ WHX'

пёркты. ${ }^{32}$ н в ҚІ нА
536

КОНһчАETE M

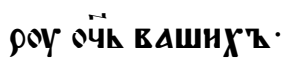

${ }^{33}$ ZМна - б̈родне

ХНАКсцнН· КАКО

5 оуБ Кжнте шٓ coY

AА OГHA АLE९h

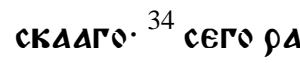

AH. ce $\Delta Z^{\prime} \mathbf{h}$ nock

AN K' BAMZ חро

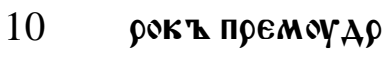

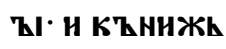

ннк'· म

оуБнете и РАспь

нете. н $\overline{\mathrm{W}}$ ннхт

15 оуБнете на сқ

БорнчнХ' вА

шнх' · н ш̈же

нете $\widetilde{w}$ roAaA

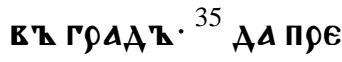

20 АЕТИ нА вЫ вһ

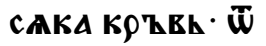

KPZBE AREAA .

ПОАKLALHATO 
53 в

АО К९ТЕН З ЗАХА९H

HZI CHA E $\Delta \rho \Delta$ X H $^{2}$

нА. ЕГОже оУБн

сте межоу цёкт

5

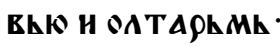

${ }^{36}$ ПрАВО ГӒК вАM

AKO П९нAETh Eh

ce tona gOAt ch.

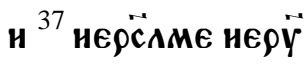

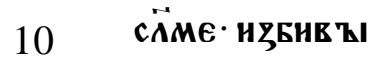

и пр̈ркъ- и каме

нНЕМК ПОБНЕ $\mathrm{h}$

ПOC'Z AAH'ZIA KT

ТЕБе КОАнШИ

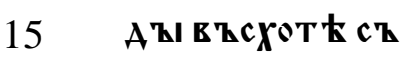

БКРАTH YAAA

TBOA· $\triangle$ Ц ЕMh

ОБРАЗ'ҚМh СТБИ

рАETh Кокошh

20 ПЪ ТЕнһЦА Сво

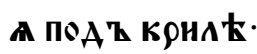

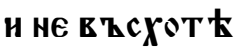

сте ${ }^{38}$ ce ост АвлA
$53 \Gamma$

ETh CA AOMT BA

Wh noyct' ${ }^{39}$ гÄळ

БO в АMт ' HE HMA

TE MHE вНА КТН.

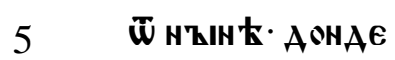

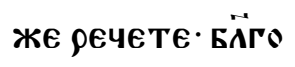

Матфей

XXIV

13-33,

42-51

10

САОВАEN' ГОAАТ

и въ hмA ГN̈E $:$.

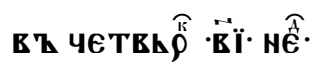

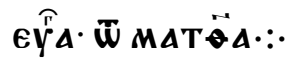

рече Г̈̈ свонмъ

оученнкомт -

${ }^{13}$ претирп Қв Қин

ЖE А० коHhца спїE

15 Th сA. ${ }^{14}$ н пропо

в 太CTh CA EYAг̈t

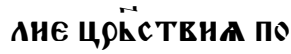

всен вселен Кн

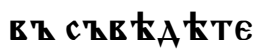

20

AhCTEO вC KM

с TPАHАMZ · TH

TZГАА ПОНАЕТК

КОньчннА. ${ }^{15}$ егАА 
$54 \mathrm{a}$

жe oYzhphte Mh

ghzoc Th zanoyc

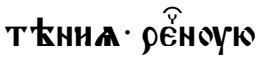

ПрӦК' Мh ААнН

5 АТМК СТОАШОY..

HA M KCT $\mathrm{E}$ с T̈t

Мh нже чh TETh

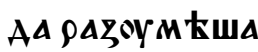

ETh. ${ }^{16}$ ThraA coY

10 щн въ нюА КН.

АА Б ЕГАWTh HA

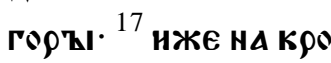

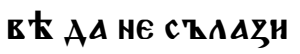

Th в ҚろА Тн· ЕЖЕ

15 в' Х९АМнан его.

${ }^{18}$ нже HA CENt A4

СА HE в ҚZE९A

廿АETh вЪCПА

Th BZZА Th

20 दु свонХ' ${ }^{19}$ горе

ЖЕ непрАЗАКнҚІ

MZ Н АОАџнНМ.

в Th TҚI АН̈H. ${ }^{20}$ MO
546

АHTE ЖE CA HE БOAE

Th БKCTEO вAшE

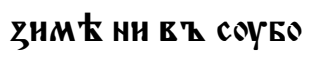

ToY. ${ }^{21}$ EOYAETh EO

5 ТИГАА ПЕЧАAК ВE

АHКА AKO HЕCTh

EKIAA WU HAYANA

ВСЕГО МН РА ААЖЕ

Н АО Н'ҚIN

10 МАТИ БҚITH. ${ }^{22}$ Н А

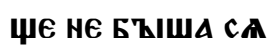

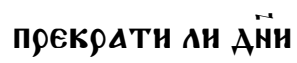

Е ТН· ТО Не БҚI сп̈с

AА CA RCAKA ПAT

15 Th НУБК ОАНҚІН

$X^{\text {'h } \rho а А н ~ п \rho е к \rho А ~}$

TATK CA AHKE TH.

${ }^{23}$ ThгA АџE Kh

To peчe Th ' chAE

20

र्रे НАн сһАE не

в Боуунте ${ }^{24}$ в т

с TANOYTh EO

Аъжн ХОнстосн. 
54 в

и $\mathbf{\Lambda}$ жн проци· н

AAAATK ЗНАMENH

A ВEАHКА Н पЮАECA

АКО ПрЕАКс ТиТИ

5

АЩЕ БҚІ МОЩКНО

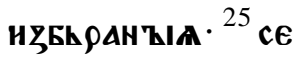

прорекеX'h ваM z

${ }^{26}$ Аџе рекоути вА

$M \mathbf{h} \cdot \mathbf{c E}$ в hחоуст ThI

10

Hн ECTh HE H马HА

те· се в и скр ...

X' HE нM КT. в

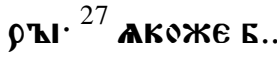

МИАННН ' НС ${ }^{\circ}$

15 Анти ש̈ в Қсто

K' $\cdot$ H ABAAET.

CA AO ZAחAA..

TAKO EOYAE..

Н прHшhс TE..

20

CHА Чत̈EЧК СКА

АГО. ${ }^{28}$ НАЕЖЕ БО А

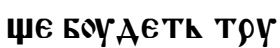

חh- TOY ch EEPOY
$54 \Gamma$

Th СА ОрһАн. ${ }^{29}$ АБН

ЕЖЕ ПО ПЕЧААН АН̈н

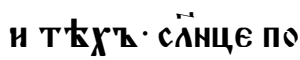

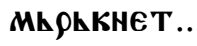

5 МоунА не А..

CE 太.. CEO.TO' H

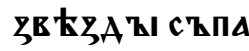

AOYTh C'B HËE

СНАЫ HËChHZIA

10 ПОАЕНГНОУ..

CA. ${ }^{30}$ Н T'ҚГАА АЕН

Th CA ЗН.MENH

Е С̈Н Чत̈..A HЁСН

H T'ZГАA .ZCחAA

15 Чผт . СA ПАE

MENA ZEM.ALHA

A. H OYgh $\rho$ ATh

СНА Чล̈ЕЦА ГРА

AOYWА HA OEAA

20

Ц ҚХҚ НБ̈СКНҚIH

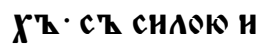

САARON МНОГО

ю. ${ }^{31}$ н постлеть 
$55 \mathrm{a}$

АН̈ГА СКОА С'

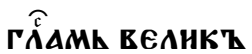

Mh TPOYБLH'ҚH

Mh' Н СZEE ९OYTh

5

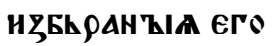

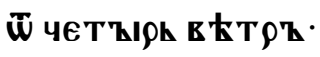

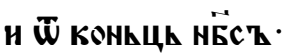

АО конкци нХт. ${ }^{32} \overline{\mathbf{W}}$

CMOK'ZE HАOYЧH

10 те са претъчн.

ГАА ОYЖE в КАEA

ẄMAAA EAA БOY

AETh' H AHC TELE

ПрозаБнеть В в

15

стЕ АКО БАн马' $E$

с Th ЖАTEA. ${ }^{33}$ TAKO

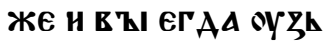

рнте все се в Бан

TE' AKO Б八н弓' $E$

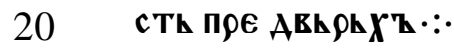

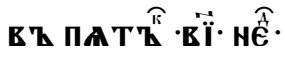

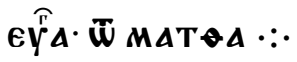

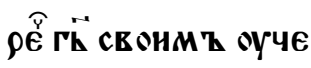

556

HнКОМъ ${ }^{42}$ БһАНTE

ОУБO ГОТОВН - AKO

не в Есте въ коY



5 ши прндети. ${ }^{43}$ то

жЕ в Ванте ' ако

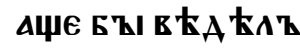

IH'z AOMOY в Z KY

ю стражоY TАTИ

10 ПФНАЕТА. БЪА

$\triangle$ Th OYБО БҚІ म $\mathrm{HE}$

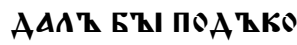

ПАТН КА ҚТИ СЕО

ЕА. ${ }^{44}$ сеГО РААН и

15 вЫ БOYА КTE ГO

ТОВН' AKO в ' T'

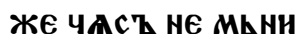

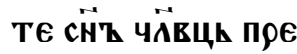

AETh ${ }^{45}$ K' To oyБo

20

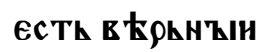

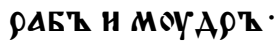

ЕГОЖЕ ПОСТ АВИ

Th F̈h HAA h AOMth 
55 в

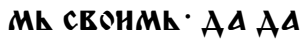

с Тһ ПнщоУ нМТ

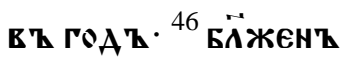

рАБh Th - EжE пре

5 ШhA' Гh̆ ОБРАще

Th TAKO TBOpALA.

${ }^{47}$ ПФАВО ГӒК вАMТ

AKO HAAT BC EMh

НМ ҚннЕМһ Свон

10 МК ПОСТАЕНТН-Н.

${ }^{48}$ Аџе Ан речетһ Zु

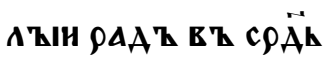

цн свОемһ ' MOY

Анти Г̈ мон прн

15 ТИ Тн ${ }^{49}$ нАЧКне

Тh Бнти КАевре

TZI СвOA· АСТИ

ЖЕ и ПиТИ С' ПНА

нНЦАМн. ${ }^{50}$ пеєАЕ

20

Th же rh ९АБА Т०

TO' E T AḦ E K HK

жE NE чає Th '

в \ чAC' в' HhжE
$55 \Gamma$

не в ксти ${ }^{51}$ н полте

шети и ПолтмА

h чACTh EГO c' AH

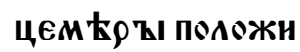

5 Th ' TOY БOYAETh

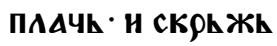

Th ZOYБOMT : :

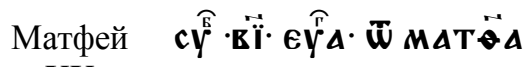

$\mathrm{XX}$

29-34

10

въ во Қма оно. ${ }^{29}$ ç

ХОААџОУН ІС̈ОБИ

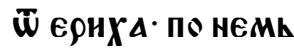

haE HAPOAT MHO

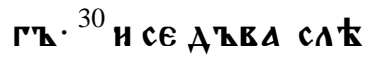

ПКЦА С ЕААџА

15

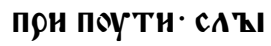

WAB TWA AKO

HIC'Z MHMO HAE

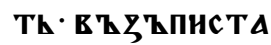

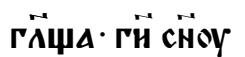

20

A $\overrightarrow{\mathbf{E}}$ AOR 'Z ПОМнАу

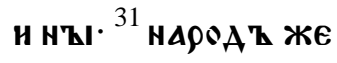

उАПФЕТн НМА АА

OYM ҚАЧнТА. WHA 
$56 \mathrm{a}$

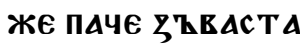

Гӥџа' ПомнАоу

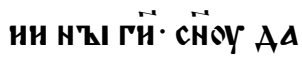

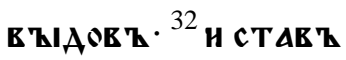

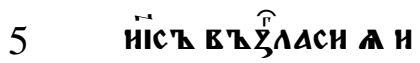

peчe yh To Xoue

TA AA C' TEO९N в А

MA. ${ }^{33}$ ГӒАCTA EMOY

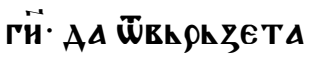

10

СА ОЧн НАК ${ }^{34}$ МнА

СूРАОВАВ $\mathrm{h}$ ЖЕ Н

IC' ' ПонкосноУ

СА ОЧНК ИМА. Н

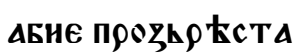

15 НМА Очн' Н ПО НЕ

MK HAOCTA : :-

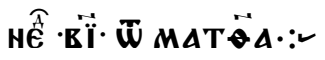

Матфей

XIX

$16-26$

20 в7 врt MA оно ${ }^{16}$ oY HOWА HЋKҚIH

престоYПаһ K'

HIсу рече EMY

ОҮЧнТЕАК БАА

TKIH' पh TO AO
566

Бро с С TEOPN AA

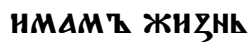

в 太Чһноую. ${ }^{17}$ OH'

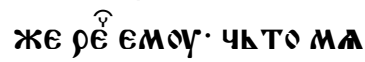

5 ГӒши Бล̈ГА ни

КТОже БӒГ' H'

ThKMO Ëh EAH

нъ Аџе Ан ХФџе

шн въА Łсти

10 в ' жнвет'

БАЮАН ЗАПОВ

АН. ${ }^{18}$ ГӒА EMOY

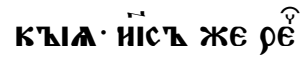

EMOY. EжE HE OY

15 Бнешн· не пре

АКБ' С Z TEO

рншн· не оүкоА

Аєши' не Аһжни

nOCAOYX'h БOYAE

20

н м $\ddot{\text { Tे }} \cdot$ н в $\mathbf{z}$

ЗАЮБНШН БАН

\%hHATO севего. 
56 в

AKO CAMT CA ${ }^{20}$ ГÄA

EMOY оYноша' вh

CA СH C'Қ ХОАНH

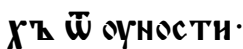

5

4h To ecMh eщe

HE AOKоHLYA

$\mathbf{\Lambda} \mathbf{h} \cdot{ }^{21} \mathbf{\Gamma \Lambda \Delta}$ EMOY ić

Аџе Хошешн сқ

ви ршен' БҚIти

10 НАН ПФОААЖК

нМ Кние ТЕоє

и ААЖһ оуБоГ'ҚI

MZ' Н HМ КTH

НМАШИ НМ 太

15 HHE HA HËС X'

Н ПОНАН в Z СА

АТ МнE ${ }^{22}$ сA $\mathbf{Z l}$

ШАВ '⿳ ЖЕ оYно

ША САOEO $\cdot \overline{\mathrm{WH}}$

20 АЕ ПЕЧАAКН'

БАше БО нМ

a прета

жАHнA MHА
$56 \Gamma$

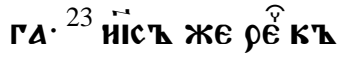

оүченнкОМҚ сво

HM Z ПФАEO ГÄ०

BAMT' AKO HE OY

5 АОБК в ҚНHАЕТК

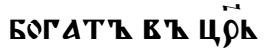

с TEO NEБС̈һHEE

${ }^{24}$ ПАКТ ГӒю в А

MT' AKO OYAO

10 Бh Естh вENh

BOYAOY ckozt

ИГЕАНЕ ОУШи

пронти' неже

БогАTOY в Z щh

15 СА९һCTEO HЁСК

HOE в ҚНH TH

${ }^{25}$ CATIWAR kWE

же оученнци

ETO AHEAAXOY

20

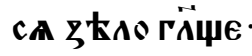

Kh TO OYEO MO

жeth cincenth

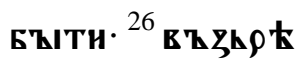


$57 \mathrm{a}$

къ же иіс

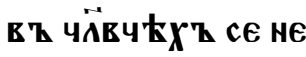

в Қ弓Можино. $\Delta \bar{w}$

БА всА вһЗМожи

5 HA $\because \cdot$ 冫

в и понек и

Eर्भे

Марк вт вотма оно

I $9-35$ пре AE Hich Ẅ на

10 ЗА९Е А ГАА

А КнсКАГО ' H

Крьстн сA W

HA ET HWPZAA

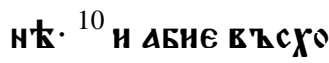

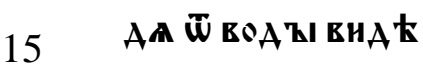

PAZBOAALA CA

HЁ $\Delta \cdot$ и $A \vec{X} \mathbf{z} \Delta K \mathbf{Z l}$

TOAOYEK C'zXOAA

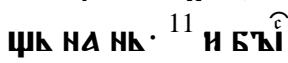

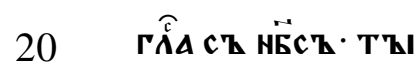

Есн СН̈々 МОН в Қ

ЗАюБАЕнТЫН •

ТеБе Блг̈овониһ
576

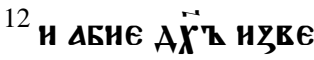

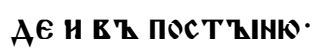

${ }^{13}$ н БЕ тоY в' поY

с TЪINH АН̈НH $\cdot \vec{M}$.

5

Н $\cdot \vec{M} \cdot$ нощнн · НскУ

ШАEMT С' сотоно

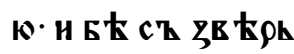

Мн· Н АН̈ГАН САОУ

жayoyTh EMoY.

${ }^{14}$ по преА Аннн же

hWAHOB $\mathrm{k} \cdot$ пре

AE Hick в Z ГА

Ани $\mathrm{kw}$ пропо

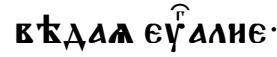

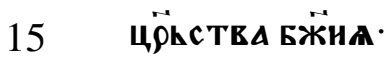

15 ГӒА AKO HAПМT

HН СА в९ ЕМА' Н

ПрЕБАНЖН СА

црйствне Бӝн

20

E. ПоКАHтE CA

в Кроунте в'

еशिАлне: :-

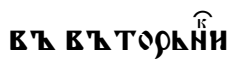


57 в

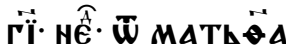

въ врҚма оно. ${ }^{16}$ пре

X'AA Híc' п९H

Морн ГААНА ЕН

5 стКМн. внА

СНMOHA Н АНAО

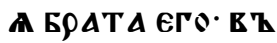

мещоүщА в КЖжА

в' Mope- Б大ст A

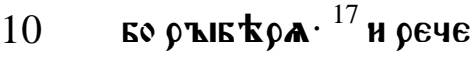

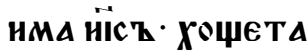

Ан в С сА ЕАТ МнE

H C'Z TEOPN BA AA

БOYАЕТА АОВКЦА

15

Чत̈ЕКОМ द $\cdot{ }^{18}$ Н АБН

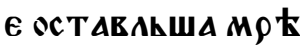

жA сBOA ПO HEMh

HAOC TA. ${ }^{19}$ н преши

A ThEE TO TOYAOY

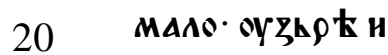

AKORA ZеREA

ВА' Н НWАHА БРА

TA EГO' H TA ET
$57 \Gamma$

РАБАН ГОTOEA

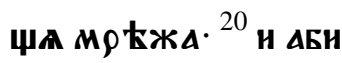

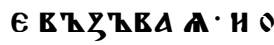

с TABAKWA О्प̈A

5 своего zевеА

B' КО९АБАH' C' HA

НМКнНКҚІ ПО НЕ

Mh HАOC TA ${ }^{21}$ В ZНH

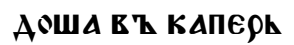

10 HАOYM ' Н АБНЕ

E' COYEOT'Z/ ET

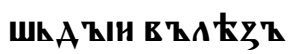

BT KOPAБA OYЧA

ше ${ }^{22}$ н оужАс $\Delta$ оу

15 СА о оүченнн его.

БAше EO OYYA A' A

KO вАACTh HM KA

$\triangle$ НЕ АКО КЪННЖһ

НнцН нХһ $\because:$ -

20

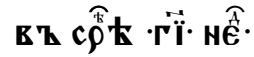

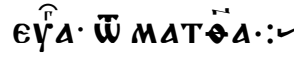

вт воТМа оно-

23 Чत̈ЕКТ НЕКТО 
$58 \mathrm{a}$

Б大 нА СЪнһмнџн

HоуА Енсц ЕМh

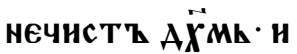

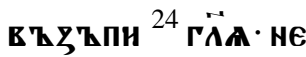

5

A Łнте и что естh

наMһ и ТеБе иісе

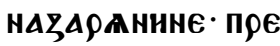

шhA' Есн погоY

БНT'Z HACZ · E

10 МИ ТА КТО Есн

с Т̈Қи Бӝни ${ }^{25}$ и зА

ПреТн ЕМоУ ГӒА.

оуМАТКнН н马Н

АН н马 неге ${ }^{26}$ н $\mathrm{ch}$

15 кроушнв Қи $A \overrightarrow{\boldsymbol{X}^{\prime}}$

нЕчнс Т'ҚН ·

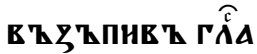

Mh ВЕАНКЂMh .

НH马НАЕ нж неГО

$20 \quad{ }^{27}$ Н оYЖАсошА $\mathrm{cA}$

всH· AKO в ZПП A

ШАТИ СА К' СEБE

ГӒ山E पh TO EC Th
586

се पh TO SYченHE

HORSE CE. AKO RAA

с Thю и $A \vec{X} \mathbf{h} M h$

нEЧнс ThIMh вE

5 Анть' н послоу

WANTh ETO. ${ }^{28}$ H马H

Ає же слоYX' его

АБне В В вск ст $९ \triangle$

HOY ГААНА ЕНСКУ

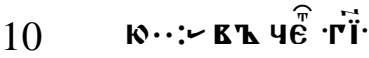

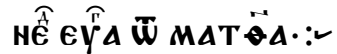

в' воТма оно.

${ }^{29}$ преАЕ Иіс К к' А०

$M \mathrm{~h}$ СHMOHOE $\mathrm{h}$.

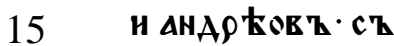

HAKOB ZMM HAO

HZMh $\cdot{ }^{30}$ Th山А

же снмона · $\Lambda \mathrm{E}$

жAше огнhMh

20

ЖИГОМА Н АБНЕ

ГÄAWA EMOY O HE

н. ${ }^{31}$ н прнстоупак

в \ЗАЕнжЕ ю и 
58 в

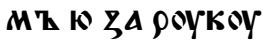

ЕА Н ОСТ ТАН Ю А

БНЕ ОГНh ' Н САСY

жеше emoy. ${ }^{32}$ no

5 ЗА ЖЕ БҚIв ҚШШ

еГАА ЗАНАЕ сӒнце

преношаX

HEMOY BCA HEAOY

жинҚIA. ${ }^{33}$ н БЕ всь

10 Г९ААТ С'ZБК ФАA'

CA K' A ARһ

${ }^{34}$ нсЦ ТАН МноГҚ।

HEAOYЖLHZIA.

EKALHZIA HE

15 Аоуг' Аьржи

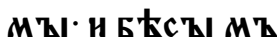

HOГ' H马ГTHA.

И HEOCT АRAA А

ШЕ ГӒТИ БћсOM々.

20 AKO

H. ${ }^{35}$ H ЗА оYT

соYM९АЧКно

उ太AO- в ZCTA
$58 \Gamma$

В ' HZHАE ' Н НАE

HIC' E' поYсто

M KcTO. Н TOY

MAT̈воY A ŁawE : :

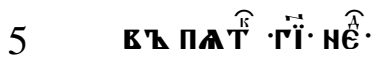

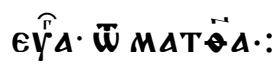

въ врҚМа оно

${ }^{18}$ Ea axoy oyчe

II Н-22 ННЦн нАновн.

10 н А.рнс Кн по

сташе са' ПрН

AОША И ГӒША $E$

MoY. חO पh To

оученнци иш

15 нови н

с ћи ст̈ни $\triangle$

AT YNT Th $\triangle A T$

вон оученици

NE ANT पNTh

${ }^{19}$ н рече нми मіс'

EAA Moroyth

сН̈ОвЕ Б९АЦК

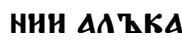


$59 \mathrm{a}$

TИ· AOHAEЖE ch

нНМН ЖЕНАН СА

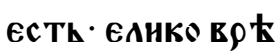

MA ch сОБоК HM

5

ютh женащАГо

CA' HE MOTOYTh

ААъКАТт. ${ }^{20}$ пре

АоYTh же Ан̈не $E$

ГAА ẄHMETh CA

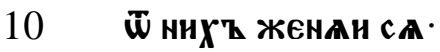

Н ТZГАА АА ҚЧЕ

Th EK T'ZI A HHH $^{21}$ H

кто же прес ТА

ВАЕННА・ ПЛАТА

15 не БҺАенА не пре

сT ARAAETh ' $\rho$ H

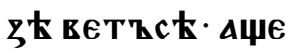

Ан то въдһметь

н nocstathk' ש

20 нEA- HOROE

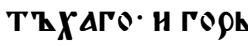

ШH аноА БоYае

Th ${ }^{22}$ и ник' тОже
596

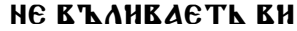

HA HOE $\triangle$ Eh $M$ tX'

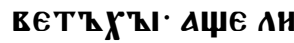

ЖЕ ни П९осААНТЬ

5 ВНнО НОВеЕ М Е

Х'Қl· И внНО ПрО

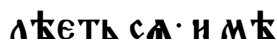
СН Пог'ҚINOYTh

H' RHAO HOB OE:

10

в M M X'hl HOB

В ไАНА ТИ : :

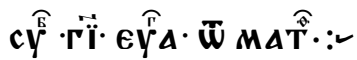

Матфей

XXII

$15-22$

15

в М М९ҚМА Оно.

15 chEtTh ch TEO

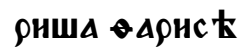

и нА HІсА' АКоже

Н ОБАИСТИТН Н САО

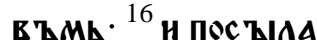

WTh K'T HEMOY OY

20

पENHKҚI CROA C C

ноОАНАНҚI Гйџе.

OYЧнТЕАК в

МҚ АКО нстинК 
59 в

нъ есн· и поути Б̈̈ь

К ПО Нс Тин Е ОУчн

Ши' И НЕ РОАНШИ

ни о коми же $\cdot$ не зh

5 ОНШН БО НА АНЦА

ЧӒвкОМ һ ${ }^{17}$ ПОв

Жh OYБO HAM $\mathrm{z} \cdot \mathrm{4h}$

TO ТИ СА МКHНTИ.

АОС ТОHнO АН ЕСТИ

10 ААТИ Кнньсъ КЕ

сА९ЕвН НАН НН -

${ }^{18}$ рАзоум кв т же

Hick понн'

во нX'

15 MA нсКоУШАE

те Анцем ћри ${ }^{19}$ н.

ПокАЖнтЕ Мн

ЗААТИцю Кнни

сьноую - ОНн жЕ

20 ПренесошА ЕМY

ЦАт ТУ. ${ }^{20}$ и ГӤА и

MZ - чнн ECTh o

Б९Аद' И нАПи
59 Г

с АннЕ ${ }^{21}$ ГӒАША Е

MoY Kec $\Delta \rho E \mathrm{~K}$.

Th ГÄА HMZ $\cdot \bar{W}$

АААНТЕ оУБО ЕЖЕ

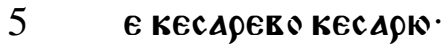

и еже $е$ Бӝне то Б̈оу

${ }^{22}$ н САҚIU АR ҚШE АН

BHWA CA $\cdot$ H OCTA

ВАКШЕ Н ӤНАО

10 யА $: \because \cdot$ แ

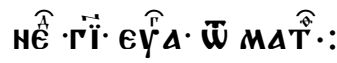

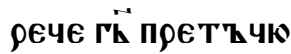

Матфей

XXI

33-42

15

СНК. ${ }^{33}$ पत्सКК БК

етерТ Аомови

Th · HЖE HАCАAH

виногРАА '

ПАОТТММ Н ОГОА

АН' Н НСКОПА Е $\mathrm{Z}$

HEMК ТОЧнА० $\mathrm{H}$

20

CZZhAA CTZA'

Пт· и прєАА и А

ААТЕАЕМ' Н О

тиАE ${ }^{34}$ егАА же 
$60 \mathrm{a}$

ПрЕБАНЖН СА ГО

OAT INOAOMT

ПОУс ТИ РАБҚI

CBOA K' A ҚA

5

АЕМ ' ПОНА Ти

ПАОАТ ЕГО. ${ }^{35}$ Н НМ 'Қ

we A tАATEAE

ОАБҚ ЕГО АВоГО

БНША. ОВого жЕ

10 ОУБНША. ОВОГО

же каменнеми

ПоБншА. ${ }^{36}$ ПАК'

ПОСҚАА ИнҚІ ९А

БҚ' МнАЖАНША

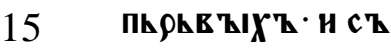

ТВорншА нМт

Tакоже $\cdot{ }^{37}$ noch t

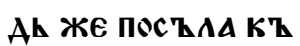

нHMТ СН̈Қ СЕОH.

20 ГӒА оус९амАA

nth ca cHa moe

го. ${ }^{38}$ a KAATEAE

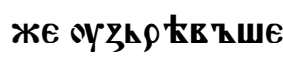

$60 б$

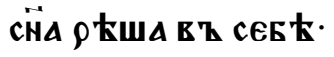

сE EсTh HACA ҚаһнH

Кһ ПреА Ате оуБн

НМ Қ I Н· н поннМ Е

5 Mh аOсT TANHE $E$

го. ${ }^{39}$ нм Ћше нұве

АОША Н ЕТН' НЗ ЕН

НОГРААА Н ОУБН

ша н ${ }^{40}$ EГAА OYБO

10 ПрНАЕТТ вИН

ГPAAA. पh TO C'B

TВорнт人 A ЕАA

TE八EM TћMh

41 гÄUA EMoY· Z7h

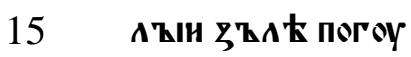
БНТК А ' Н внноГОА

AT ח९EАACTK HNE

Mh A KАATEAEMh.

нжE 而AAAATh $E$

20

MOY חAOATI ET

ГOAТ СЕОН ${ }^{42}$ Гत̈А

НМ Қ $\ddot{\text { ICे }}$ - HНКО

АнжЕ ПочнтА 
60 в

сте в ' кннгАХ'

кАMENh ЕГОЖе не

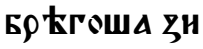

жоущен сһ БҚIсть

5 В ГА ГАВ оу оYГ'

AOY. ש̈ EWICTh cE.

Н EсTh АнЕһно в Қ

Марк оүчк нашек ::-2

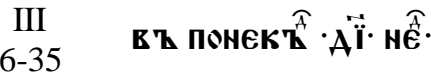

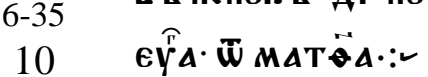

въ во Бма оно. ${ }^{6} \mathrm{cz}$

в KT' CZ TRO९н

ША А९нс KH HA

HICA.C' HPOAHA

15 НҚ/ КАКОН БҚI

ША ПОГОУБНАн

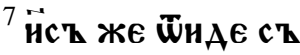

оученнк'Қl

СЕОНМН К' $\mathrm{MO}$

20 ОК. Н МнОГ' НА

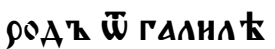

A по неMh нае

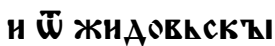

$60 \Gamma$

A. ${ }^{8}$ н $\overline{\mathrm{W}}$ не ОоусААн

MA. H OTR HAOY

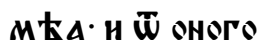

mOAOY HOPAAHA.

5 нже в $\mathrm{z}$ тоурћ и си

AOHE HAPOAT MT

HOF' · CA WIWAB h

Ше ЕАнКО TворА

ше ПонАОША K'

10

немоу. ${ }^{9}$ н рече оYче

HHKOMT СEOHM $\mathrm{h}$.

АА КО९АБАК СТ ОH

Th oy nere napo

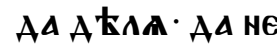

15 c'B TOYжANTh $E$

MOY. ${ }^{10}$ MHOГ'ZL 50

Hсц ЕАН· AKO HA

nAAAXOY EMh ' $X^{\circ}$

Tаце прекосноу

20

TH СА ЕМh • нЖе

HM KAX OY PAH'J'

${ }^{11}$ н егАA вHAAXOY

Th и всн нечнс ТИ 
$61 \mathrm{a}$

н прнпАА

K' HEMOY. и в'

ПHA XOY ГӒШе.

AKO ThI EсH

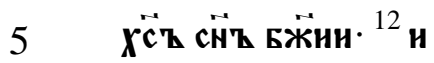

многе пр кща

WE HMT ' A $\triangle$ HE A

в 太 ETO TEOPA Th $\because$ :

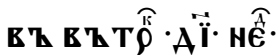

10

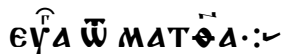

в' врҚма оно-

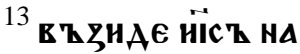

гороу н п прнз'

вА Аже сАMт ${ }^{\circ}$

15 TAWE HAOWA

Kh HEMOY. ${ }^{14}$ H Ch

TEOPH ATE A HA

AECA TE AA EOY

AOYTh c' HHMh.

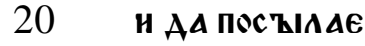

Th a nponoz taA

Ти ${ }^{15}$ Н нМЕТи вАА

сть ц ЋАнти не
616

АОугЪІ нугонити

в қсқ. ${ }^{16}$ и полежн

СНМОНОВИ ИМА

Пет९һ $\cdot{ }^{17}$ НАКОВА

5 ЗевеАЕнНА. HWА

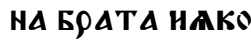

ВАА' И ПОАОЖН и

МЕНH' в Қ АHE९E

гесқ • ЕЖЕ Естh

CHА ГООМ ОЕА. ${ }^{18}$ H

АНАО ЕА Н ОНАН

ПА. H ВА९Z OОAO

MKA' H MATh

- ta mbit apa.

15 H OOMOY. HAKO

BA AAT OEOBA 'H

OAA KA. H CHMO

ha KAHAN Ka

${ }^{19}$ H OYAOY HсKА९H

20 डThсКААГО нже

и пре Аас Ти н. ${ }^{20}$ н

ПОНАОША в Қ А०

Mh' H C'ZEh $\rho A$ 
61 в

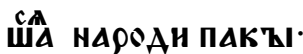

АКО не Моцн НМт

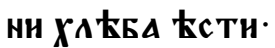

${ }^{21}$ H CA'ZIWAR ZWWE H

5 ЖЕ БАX ОY оY него.

H马HAOWA ATZ(I)

И ГӒАХOY БO AKO

HEHC TOK 'Z ECTh $:-$

в h cô̂́t

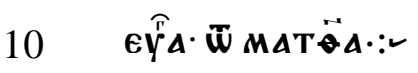

в во вома оно

${ }^{20}$ преАE HIC' $\mathrm{z}$ '

$M \mathrm{~h} \cdot$ H CKEh $\rho A$

WA CA HAPOAH.

15 АКО НЕ Моџн и

Мъ ни ХА ББА $\mathrm{k}$

стн. ${ }^{21}$ H сAтIسA

в Қше нЖЕ БА XоY

OY HETO. H马HAO

20 ША АТИ И· И ГӒА

XОY АКО ненсто

в т ес Th ${ }^{22}$ и кни

жьници иже ш 61г

epc̈sMA ckWhAT

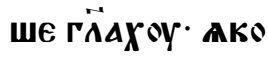

BEAhZAOYAT

HMATh AKO

5 вйАКОю Б Есо

вһскЫМ нदго

нить Б大сқ! ${ }^{23}$ н

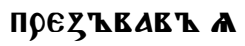

ПОНТ'Қ ЧАМн

ГӒше нмт ' КА

10

Ко Може Th сото

на сотеноу нуго

нитн. ${ }^{24}$ н Аџе ци

cAphCTEOHA CA

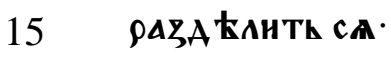

нE Можетh стА

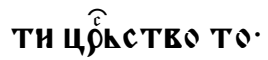

${ }^{25}$ н Аџе АОMт сA

MT CA ९AßA KAH

20 Th' HE МОжЕTh

сTАTИ АОM $\mathrm{z}$

Th. ${ }^{26}$ н $\Delta \mu E$ сото

HA B'LCTAA' $E$ 
$62 \mathrm{a}$

CTh HA CA· H

उA ЕАHAT CA

нE МожЕTh сTА

Ти· нҚ Конhць

5

HMATh $\cdot{ }^{27}$ HнK

ТОжЕ не можЕТи

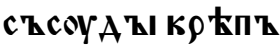

KATS B ZWWA AT E T

AOMh ERO ९AZTPA

10 БНтн· Аџе не ПК

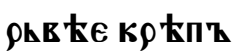

КАГО С'ВАЖЕТИ

и TZГAА AOMZ $E$

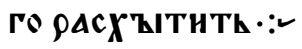

15 в четки Tे $\cdot A \ddot{i}$

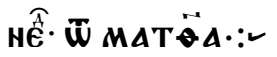

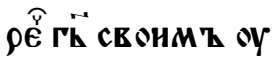

ченикомт

${ }^{28} \triangle M \overrightarrow{H T} \cdot \triangle M \overrightarrow{H Z} \cdot$

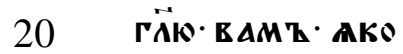

всA ÜпоYста Th

СА СН̈ОМ Ч ЧӒЕЦК

cKOMh ' H XOY
626

МЕнНА - ЕАНКО

${ }^{29}$ Аџе Хоулити в т

с Tेhй $A \vec{X} \mathbf{h}$ не и

MATh OCTABAE

5 нНА вไ В ҚКҚ!

H' ПОВНнhН' $E$

сти в Кциноу оу

moY COYAOY. ${ }^{30}$ zA

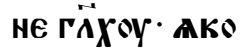

10 Ӓ̈' нечнсть и

мАти ${ }^{31}$ прнАЕ ЖЕ

м Н̈н его н БрА

Тна его. Н в '

НҺ с ТОАџЕ

15 Посһ ААША К'

немоу гӥще н

32 ctaame oy nero

HASOA'

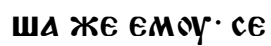

20

MT̈н TEOA и

Б९АТНА Н СЕСТ

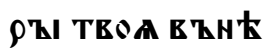

нщоути ТеБе 
$62 \mathrm{~B}$

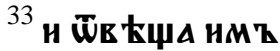

ГÄA'Kh TO ECTh

МТ̈Н МОА И Б९А

THA MOA ${ }^{34}$ H CK

5

TAAAAR' OKOAO

нжЕ O NEML C kAA

XоY. Гत̈厶 сE MTH

MOA Н БОАТНА

M०A ${ }^{35}$ нЖЕ БО АџЕ

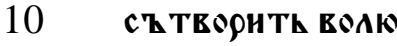

Бӝню· съБрАТ Қ

Мон· н сест ТА

MOA · М М̈H ECTh :-

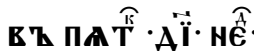

15

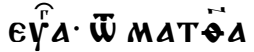

в Қ вотма оно.

ЧATR HIC' ОYЧн

Марк

IV

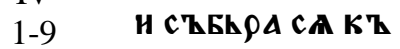

20 HEMOY HAPOAT

MHOГ' - AKO CA

MOMOY EZA E

z'hwoY B' Kopa
$62 \Gamma$

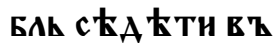

MO९H' H ВCL HA

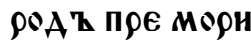

БAUE HA ZEMAH.

2 и оYчаше А в' Пре

ThYAX' MHOГO.

н ГӒше НMЋ в२

оученни своеМһ

слҚIшите 'ce

10 H马HАE CКAH

c 太мне $\cdot{ }^{4}$ н БъIс Th

с 太ющоуемоу

OBO חAAE' HA חOY

Ти н П९нАОША

15

Птиц Е и пОзоБА

ma E. ${ }^{5}$ a apoyro

E חAAE HA KA

MENh ЕЖЕ HE БА

ШE ZEMAA MHO

20

Г'Ы· Н АБне прО

ZАБЕ НЕ ИМ КНН

a ataA एaOY

БНH'Қl ZеМАн 


\begin{tabular}{|c|c|c|c|}
\hline & $63 \mathrm{a}$ & & 636 \\
\hline & 6 СӒНЦК ЖЕ в ҚСНА & & СЕОНМ' ${ }^{2}$ ГӒА HА \\
\hline & 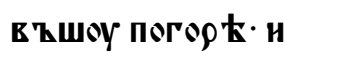 & & Mocker tmk \\
\hline & не им Қнна А & & 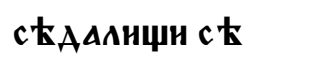 \\
\hline & АА Кө९енН оУС'Қ & & АошА къннжь \\
\hline 5 & we $\cdot{ }^{7}$ а ароугое па & 5 & ннци и ө Арнс 太 \\
\hline & АЕ в Қ Тирнин· и & & Н. ${ }^{3}$ ВСА ОУБО ЕАН \\
\hline & ЗНАЕ Тирнне и & & ко Аџе рекоути \\
\hline & ПФААВН Е· Н ПАО & & 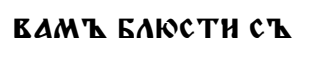 \\
\hline & АА нЕ ААСТи ${ }^{8}$ и & & БАЮААНТЕ И ТВО \\
\hline 10 & А९oуг⿴е пАAE & 10 & \\
\hline & нА そЕМАн АОБ९ $\mathbf{k}$ & & ми жЕ иХ' не тво \\
\hline & И АААШЕ ПАО & & 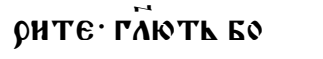 \\
\hline & 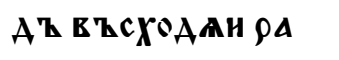 & & 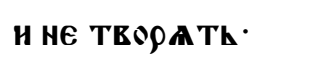 \\
\hline & ст'ҚН · И ПреПАө & & ${ }^{4}$ C'RBAZАWTh ЖE \\
\hline 15 & АН ТК̆MH АЕСA & 15 & БременА ТА \\
\hline & Thl' H C'T T'MMh & & ЖиКА н нEOYАO \\
\hline & ${ }^{9}$ и ГйАше нм КА & & БҺ носнмА' н \\
\hline & и оуши слҚшшА & & B ZCKÁ AАK \\
\hline & 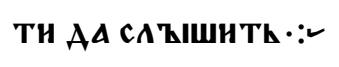 & & Th нА плEщА. \\
\hline 20 & 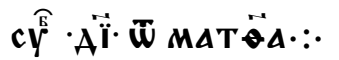 & 20 & पล̈вкOM Қ $\cdot \Delta$ Пh \\
\hline Матфей & вТ вреМА оно. & & ९сТТМК СЕОН \\
\hline $\begin{array}{c}\text { XXIII } \\
1-12\end{array}$ & 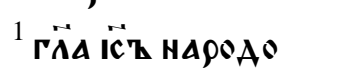 & & ML NE Х०TA \\
\hline & Мт и оучеником & & Th Авигноу \\
\hline
\end{tabular}


63 в

ти ну' .5 вса же

A KAA CEOA TEO

९ATK АА ВНАНMН

EOYAOYTh पत̈ЕKЫ.

5 рашноакти ЖЕ

ХРАННАНЧА СЕО

А' Н ВЕАНЦАКТК

CA ПOAOA $\mathbf{k K} \mathbf{Z l}$

В ҚсконАна Он

10 З' СЕОНХ' ${ }^{6}$ АЮБА

Th же преже в һ̧А

ГАнНА HA вEчE९A

$\boldsymbol{X}^{\mathbf{z}} \cdot$ и преже $\mathbf{c t}$

ААНHA НА С'ҚБО

15 рнщнхи $\cdot{ }^{7}$ н ц

АOB АHНA HA TT

$\rho \mathrm{h} ж н ц и х \mathbf{~} \cdot$ и

ЗЪЕАТИ СА Чत̈ЕКЫ

ОУЧнТЕАН. ${ }^{8}$ В ҚI

20 ЖЕ НЕ НАРНЦА

ите са оучнте

АН.

Естh оучнте
$63 \Gamma$

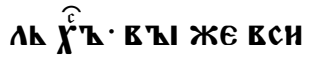

Братна есте ${ }^{9}$ Н ०

оӵа He zов Кте ce

БE HА ZEMAH '

5 H' БО EсTh вАШh

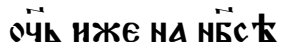

$\chi \mathbf{z} \cdot{ }^{10}$ в Қl же не на

рнцанте СA HA

СТАЕБННЦН ЕАН

10 H' БO ECTh HАCTA

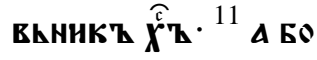

АH ВАC' БOYАH ВА

MZ сАOYГА. ${ }^{12}$ А НЖЕ

BZICHTh CA'CA

15 М СА ОБннЖАЕ

Th · и нЖЕ ОБни

Матфей

ZHTh CA CAMT E Z

XXII

2-14

20

ZE ZICHTh CA :

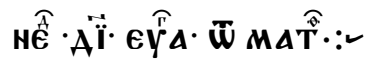

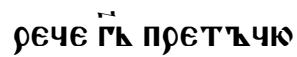

СНК. ${ }^{2}$ ОУПОАОБН

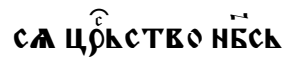

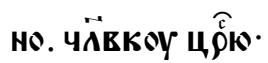


$64 \mathrm{a}$

НЖЕ С' ТВ ТОН БФАК'

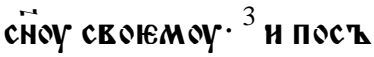

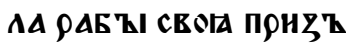

ВАТИ З'ҚЕАН'IIA HA

Б९АК' Н HE XОTAА

ХОУ понтн. ${ }^{4}$ ПаК Қl по

СЪАА ИНЫ ОАБЫ ГӒА

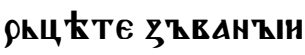

Mz- OБҚAт МоH OY

10 Гетев АХ'

Мон· Н оүПнТ АнО Ю

И НСКОАЕнО И все ОУ

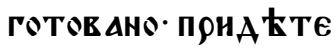

нА БрАК' ${ }^{5}$ Онн же не

15 Бр КГҚше ОТнАОША.

OK' ' HA CENO CROH. W

в Қ ЖE HА KOYПAю

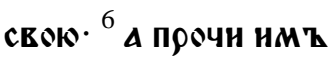

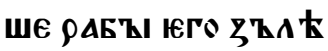

20 оуКО ९ншА и ОУБН

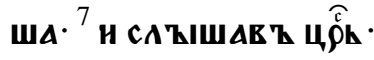

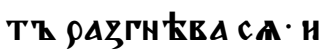

ПOC'Z $\triangle A E$ ' BOA CEOA
646

ПоГоУБн оУБнїцА

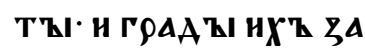

жиже ${ }^{8}$ ThгАА ГӒ厶

PАБOMZ СЕОНM

5 БОАКТ ОУБО ГОТТЕ Қ

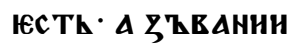

HE БKWА ААС TOH

Hн. ${ }^{9}$ HA $\mathrm{KTE} \mathrm{OYБO} \mathrm{HA}$

HсXРAHLA ПOYTh

10 HAIA H EAHKS АџЕ

оврацете прнзо

в КТЕ нА Б९АКъ $\cdot{ }^{10}$ Н

ШhA WШE ९АБH TH

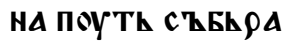

15 ША ВСА ЮАНКО ЖЕ

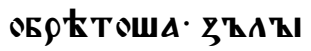

ГА ЖЕ и АОБР ҚIIA

СПТАнИША Б९АК'

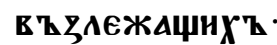

20

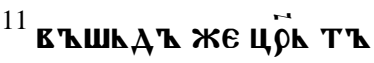

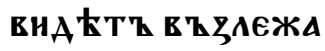

щнНХ' ВНА Т ТЖ

Чล̈ЕКА НЕ ОБА КЧЕ 
64в

HА ОАЕЖЕК БОАЧКнО

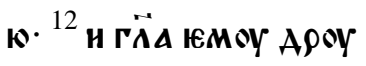

ЖE КАКО в Қ HНAE

с太Мо. нЕ НМЫИ РАЕ

5

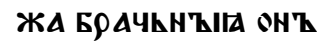

же оүмъдтче ${ }^{13} \mathrm{Tz}$

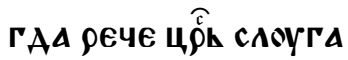

Mh' ChBAZАR'LWE

юMоY роYц Т и но

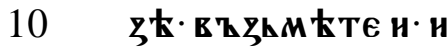

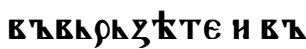

ThMoу кром 太шь

HNE- TOY БOYAETh

ПААЧи и ск९һЖе

15 Th दоYБOMz ${ }^{14}$ mz

HOgH EO COYTh $\mathrm{zh}$

вАнН и МААО ЖЕ

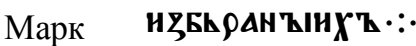

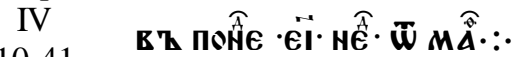

$10-41$

20 64г

CHWA H· Ch OE ҚMA HA

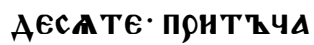

MH ${ }^{11}$ Н ГӒА НM Z ह ВА

MZ IECTh AAHO E E

5 А

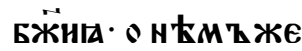

в ZнЕШКнинмҚ

ПОНТТ ЧАМн все Се

EOYAETh. ${ }^{12}$ AА EHAA

10 МЕ И внАА ТИ И НЕ

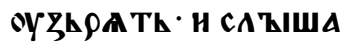

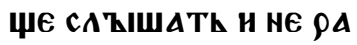

ZOYM kюTh • ЮAA

KAKO ОБрАT A Th CA

15 H остАKA Th CA ÏMT

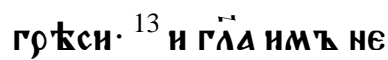

в ЕСТЕ АН ПОНТҚЧА

${ }^{14}$ ceIA c KIAH сAOBO C

Юти ${ }^{15}$ сни же соути

20

HА ПОУТН ' Н ЕГАА

АБHE SYCA ҚIWATh

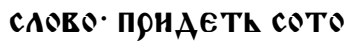

HA вZCX'ZTHTh CAO 
$65 \mathrm{a}$

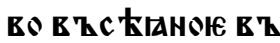

срӒЦиХһ нХһ $\cdot{ }^{16}$ сни

жE соYтh такожАє

нЖЕ НА КАМЕни с 太

5

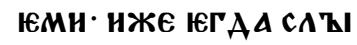

ШиТИ САОЕО АБИІ

C' PAAOCThK E ZZG

MOYTh Ю ${ }^{17}$ и не нМ Е

КTh корени в Z се

10 EЕ. HZ AO ROAA COY

Th по томи же Б'

в ҚШН сКҚ ФБН нАї

Н马ГТНАНHЕ СAO

ВА А ЋАА · АБНЕ $\mathrm{CZ}$

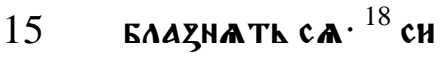

нжЕ сOYTh с 太ाA

ннн· в Т Ти Рннн н

сА'ҚIШАLE сАОво

${ }^{19}$ и печААн в ЋКА се

20 Го Н Аһсти Бг̈АTh

СТЕА' Н ПФОчннХ'В

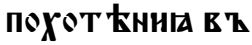

XoaALE moaAkAa
656

NTh СAOEO H БEC ПAO

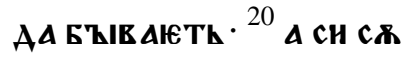

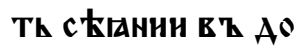

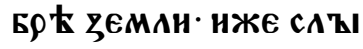

5 ШАТТ САОвО Н ПОН

๒МАюТИ Ю И ПАОАТ

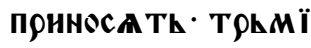

AєсатһL н шести [ю]

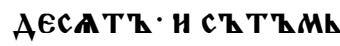

10

${ }^{21}$ и ГӒАШЕ НM '

ПОНХФАНТИ СЕ ЕТИ

АКНHК' И АА ПОА'

сПОУАТMh ПОАО

ЖEN' БOYAETh '

15 Ан ПОАТ ОАФҚМК

$\triangle$ НE НА СЕ ҚТнАћ

оУтО вһ弓А०жнть

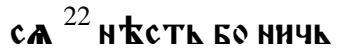

ТОжЕ Т АНнО юЖЕ

20 НЕ ГАВИТИ СА $\cdot$ HH

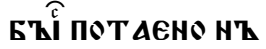

AА ПрHАETK HA A

вАЕнне ${ }^{23}$ нже нМА 
65 в

Th оушн сАҚIшАTИ

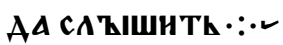

в в в '⿳⺈⿴囗十一

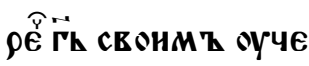

5

HHKOMZ $\cdot{ }^{24}$ БAКА АTE

cA पh TO ca'blшнте

в ' нюже мероу м

рнте нам К рнтL CA

вАМ Қ ' и прНАожи

10 Th вАM' сА

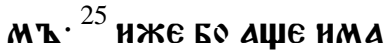

Th AACTh CA EMOY.

А нЖЕ нЕ нМАТИ н $е$

жЕ нмАTh Ш̈нMETh

15 са 元 него. ${ }^{26}$ н ГӒАА

ше TAKo юc Th цер̆

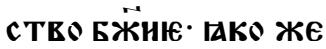

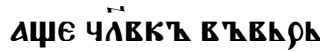

жETh ckмa в

20

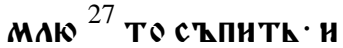

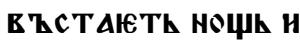

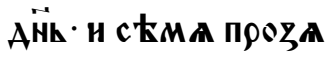

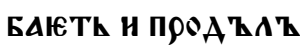

$65 \Gamma$

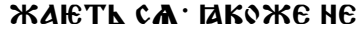
в KCTh OH' CAM h. ${ }^{28}$ o ce

БК БO ZEMAA ПNOAH

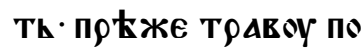

5

томи же глАсһ ' ТА жЕ

HсПЪАнНTh ПКШе

ннцю в Қ КААс $\mathbf{k} \cdot$ Tї

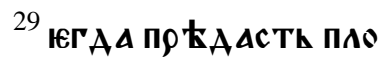

АТ АБнњ поустить

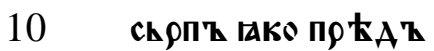

с Tентh ЖАTЕА ${ }^{30}$ н

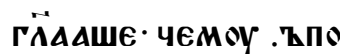

АОБАю цёст ТЕ Бён

І и К' КАен прнТТ

15 чн прнложнмт єє

Kh ropowhноу zh

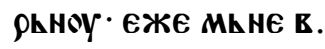

c kX'Z c KMEн' EсTh

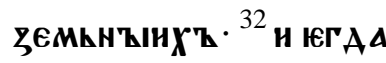

20

в ZC KIANO GOYAETh

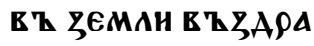

стЕТИ И БOYAETh БO

$\Lambda \in$ вhckX'h ZEMh.. 
$66 a$

HX' $\cdot$ H TEO९HTh в 太

ТВН ВЕАНК'· ГАКО

жЕ Мочн ПеА द с Łнї

ю юге птицамъ не

БескнҚнм' гнt

ЗАНТИ СА ${ }^{33}$ Н ТА

ц ЋМн прнТЋчАМї

МноГАМН ГӒАШЕ И

MZ САОВ О. ГКОЖЕ MO

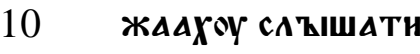

${ }^{34}$ Бес прнтТчА Же не

ГӤАШЕ ИМИ САОвО.

Гакоже можАА

сАЫШАТн Бес прн

15 ТЋЧА жЕ не ГӤАше

НM ' ОсОБh ЖЕ ch

KAZAWE HMT OYपE

ннкомҚ свонм $\mathbf{2} \cdot: \cdot$ -

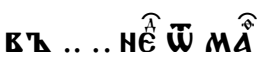

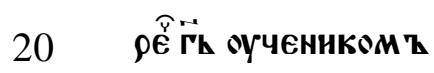

свонми ${ }^{35}$ пр Ена

MT HA OHZ חOAZ ${ }^{36}$ H

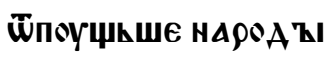

ПОАША и ГАКОЖЕ БЕ
666

ВТ КО९АБАН ' НННН

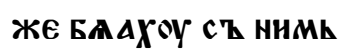

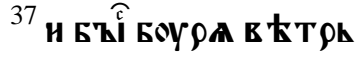

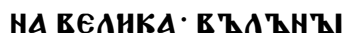

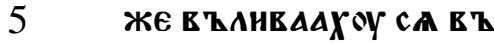

КОРАБА · ТАКО оYЖЕ

ПОГРАЗноУТН ХОТА

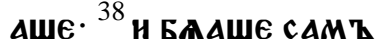

HA KT $\rho M$ K HA B

10

ЗГААВНН С ҚПАН В Т

ЗБОУАНША И И ГӒА

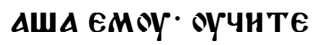

Аю не БрћЖЕШи Ан

АКО ПОГ'ҚIEAEM $\mathrm{Z}$.

15

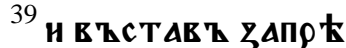

Тн в Е троу. н рече

Mорю м ҚА Қцн оY

с ТАнн ' и оүлеже в 太

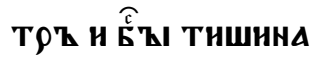

20

веАнКА ${ }^{40}$ Н ९ЕЧЕ НМТ

Чк TO TAKO ст९Aшї

вн Юс ТЕ КАКО не и

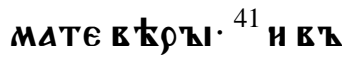

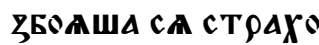


66в

Mh ЕЕАНКЪМК Н ГӒА

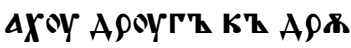

roY Kh TO EO ch ECTh

гако в ћтри и море

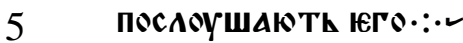

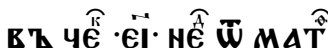

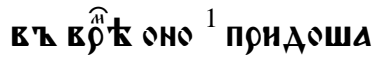

Мap

V

$1-24$,

$35-43$

10

15

HA OH' ПONT MOPA

в Z ст ОАноY ГА

ААрннкскоу ${ }^{2}$ н

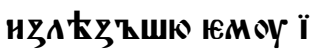

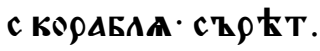

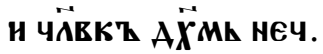

ст ҚIM $\cdot{ }^{3}$ нже жит

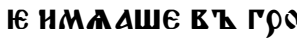

БћX'h • н нн ве९нГА

Мн никТОже нЕ Мо

\%АAWE çB AZАTÏ

${ }^{4}$ По неже мног АШи

20

А'Ы поут й верн

ГАМИ С'ВЕАZАHOY

соушоу' прtт Th

zaAX OY CA Ü HerO

вернг'Ы и поутА сқ 66г

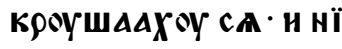
ктоже не можАше Ю го оүтемнтн. ${ }^{5}$ н прї

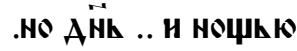

5 в т гов Аү' и въ го

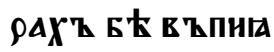
Н БНІа СА КАМЕнН

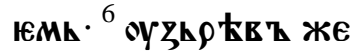
ICA H马 AAAEYA TEYE И

10 ПОКАОНН CA ЮMOY.

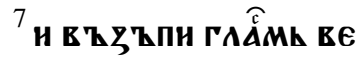
АНКҚML ГÄA प पू TO MZHE म TEE ICE CHE

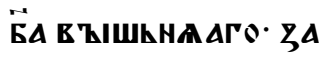

15 КАНнАК ТА БМ̈һ НЕ MOYЧH MENE ${ }^{8}$ ГÄA WE БO EMOY H马HAH Аш̈ нечнст Тн $\bar{w}$

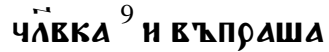

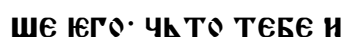

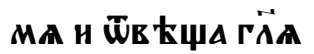
АЕГеОН' НMA MO I ІаКО мноZН ЕСМh .

${ }^{10}$ h MONAWE h MHOTO 
$67 \mathrm{a}$

АА нХ' не поустнть

в Қ IнҚI ст

ше же тоY пеат repo

Ю СТААО СЕНнНН ВЕ

5

АНКО ПАСОM०. ${ }^{12}$ Н МО

АНША Н ЕСН Б ЕСН ГӒऽ

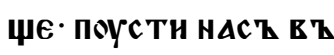

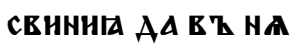

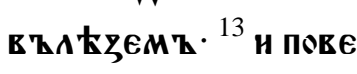

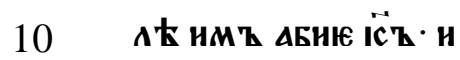

HWhA ZWE А ӒH HEपї

стнї· в ҚА Łzоше в Қ

СЕннига Н оустрК

Мн СА СТАAO CZ Б९ Е

15 ГА ВТ Mоре БЕ ЖЕ и

X'

廿и и оYт Аח АХOY в $\mathrm{z}$

Морн ${ }^{14}$ н ПАс Оучнн

Свини Б Б ЕжАША· Ï

20

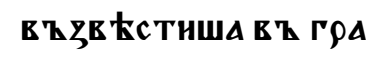

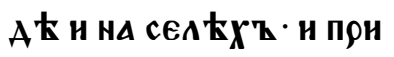

АОША вHА ТT' БKIET

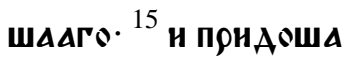

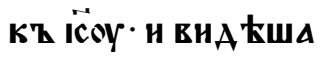

676

Б 太COBAR Z WAATO CA

с ҚААШАН ОБҚАҚЧЕ

HА Н С'ҚMZICAAWА

HM KE ҚWA ATO AEГE

5 OHА Н OYБОАША СА.

${ }^{16}$ H пов 太 А АWU HM

БҚIR ҚWEほ

Б大сСHOYMOY. H ОСЕн

HhTA ' ${ }^{17}$ H HАЧ АША

10 МөАнТИ Н· Н Ф̈ИТн

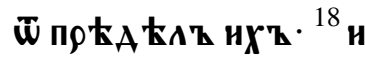

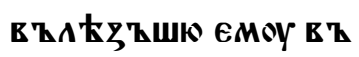

KOPАБАh MOAAWE H

Б ЕС ОвАR ҚIH CA

15 Б' C' HHMh БҚIA

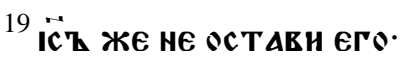

HZ ГÄА EMOY НАН Е'

АОM С СЕН С' СвоїM

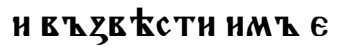

20

AHKO TEE

ОН И ПОМНАОВА ТА

${ }^{20}$ н ӤнАE н нАЧА ПрО

ПОв ҚААТИ ЕТ АЕКА

ПОАН· ЕАНКО С'Z TEO 
67 в

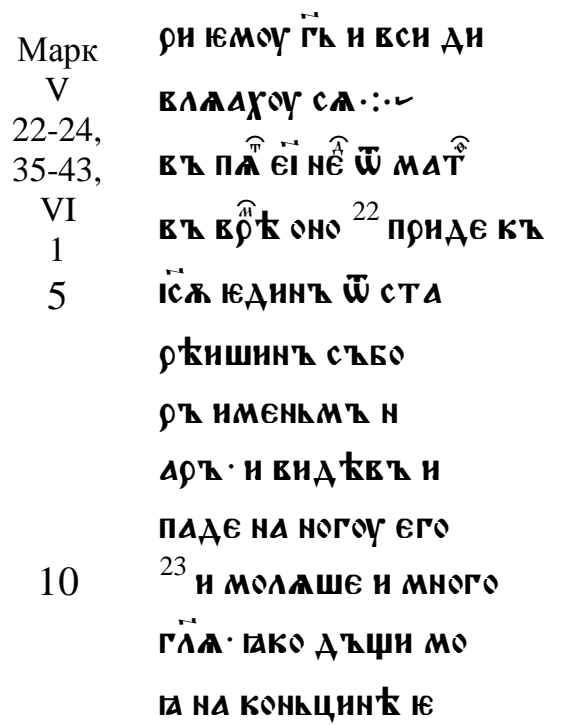

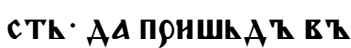

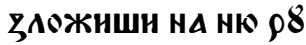

15 ц $\mathbf{k}$ ґкоже иц ЕА

ЮТИ и ЖнЕА БОУАЕ

Th. ${ }^{24}$ нае съ нимь и по

HEMh haAAUE HA

POAT MHOГҚ ${ }^{35}$ ПОНАО

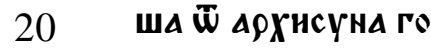

ГА ГАКО АТЕН ТЕО

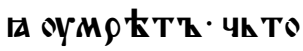

юще троужАюши

оучнтела ${ }^{36}$ ich же
$67 \Gamma$

OYCA'ZIWAB T CAOBO

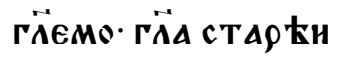

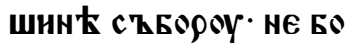

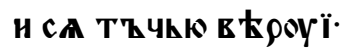

${ }^{37}$ Н НЕ ОСТ АЕН НН ЕАННО

ГО ЖЕ ПО нЕМи нти

HZ T३ पhю пет $\rho$ Th

HАКОВА ${ }^{38}$ Н ПОНАОША

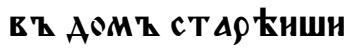

10 HOY с'ҚEOPOY. Н ВHА

ПлНџн - ПААЧюџҢ

СА И ЕЪПНКЩА Мно

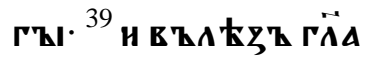

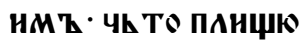

15 ЮТЕ чтА ПААЧЕТЕ СА

отрковнцА нЕсть

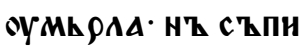

Th ${ }^{40}$ H CMhIAXOYTh

са ґемоу сh же нбгт

20 НАЕ Т ВСА ПОНА ОЦА

өтрөкөвнци ї мт̈рк

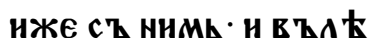

ЗЕ ИАЕЖЕ РТ РОКови

цА АежАше ${ }^{41}$ и А зА ९оY 
$68 \mathrm{a}$

коу отроковнцю гйА

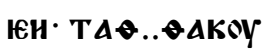

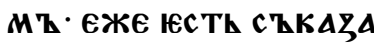

юмо отроковице ТЕ

5

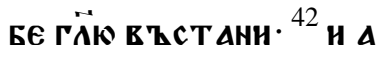

Бне вһстА отроковї

ЦА и Х०ЖААШЕ БАше

жe $\hat{\mathrm{i}} \mathrm{k} \cdot \overrightarrow{\mathrm{k}} \cdot \mathrm{Te}$

ША СА ОУЖАСТИК вЕ

10 АнКею ${ }^{43}$ Н ЗАПФ ЕТН

НМ Қ МнОГО АА НИ

КТОжЕ не оүв Ћсть

сего. Н ९Eче АААнТЕ

Ен Ћсти. ${ }^{1}$ H马нАE ОтТ

15 ТОУАОУ и ПОНАЕ в

ОТИЦИС ТЕО СЕОЮ' Н

ПO HEMh HAOWA OY

Матфей

XXIV

$1-13$

20

ченнци ІеГО $: \because$ -

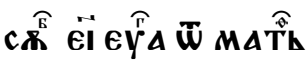

в в в

ПншА оученнци

Къ І्СЕН ПОКА३А

ТИ ЮМОУ З'ҚААННА

цёвьната. ${ }^{2}$ онт же

25
686

НЕ вНАНТЕ АН СНХ'

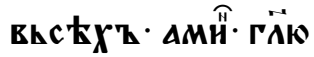

BAM $\mathrm{h}$ - HE HMATh W

с TАTИ КАMEHL HA

5 КАМЕнн нже не ९А३О

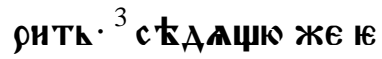

MOY HA TOPҚ ЕАEOHн.

прнс тоупнша к' HE

моу оученицн его ю

10

Анномоу гӥще пов

Жh HАM K К' ГАА CH

BOYAOYTh · H पh TO I

с Th ЗНАМЕNHЕ TEO

еГО п९ншкс Твна

15 н конһчАнне в ЋКА.

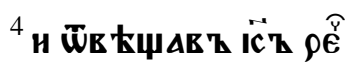

HMT - ENWA KTE CA

АА НнкоГОжЕ вА

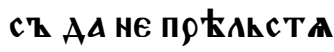

Th. ${ }^{5}$ мнези Бе прн

AOYTh в' HMA MOE

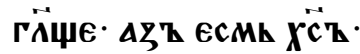

и мног'Қ пр ЕАh

стать ${ }^{6}$ oycazima 
68 в

Тн нже їмАте Б९Анї

И САҚІШАНHIA Б९анї

И ВНАНТЕ И НЕ ОУЖА

САHTE сA- ПOAOБАETh

5

Бо вһс КMһ БҚITH.

HK HE TKГAA ECTh

КОнһчинА. ${ }^{7}$ вЪСТА

HETh БO IAZ'WIK' HA

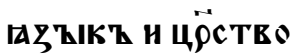

10 НА Цр̈ствО н БоУАА

Th ГАAАH И ПАГOY

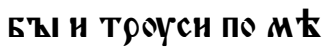

стА ${ }^{8}$ всА ЖЕ си нАЧА

AO БOA ŁzHн ${ }^{9}$ ThГАA

15

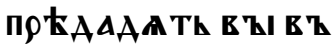

СК З РБИ · Н ОУБНКТТ

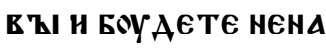

вНАНМн вһс ЕМн ґА

З'ҚІК' НМЕне МоE

20

ГО РААН. ${ }^{10}$ Н TИГАА

C'ZEA AZHA Th CA

МнеZН И АРОУГК

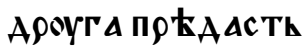

Н ЕҚЗНЕНАВНАНTК

25
$68 \Gamma$

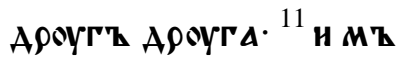

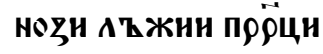

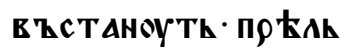

с TA Th МнOГZ! ${ }^{12}$ Н Zа

5 оумножениє БезА

КОННА НСАКнЕТЬ Аю

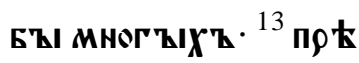

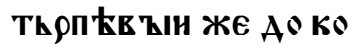

* Hhца. Th спїеть сA $\because$ -

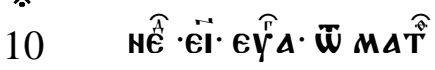

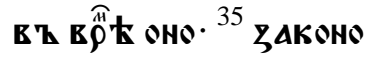

оучнтЕАК HЕКҚI

Матфей н прнстоупль

XXII

$35-46$

15

к' IC Ö рече' н

скоYшаґа и ГӒа.

${ }^{36}$ ОYчнTEAN KAA ZА

Пов 太аһ веАнКА

въ ЗАКонt. ${ }^{37} \overrightarrow{\text { ich }}$ же

рече EMOY. АА АКБН

20

Ши Г̈厶 Б̈ С своEГО вh

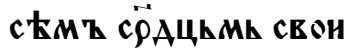

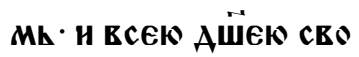

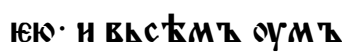

МИ СвонМһ ${ }^{38}$ сн юе ТИ

25 ПК ФЕАГА Н ВЕАНКАГА 
$69 \mathrm{a}$

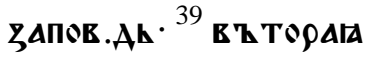

ЖЕ ПОАОБНА ЕН· в Қ

ЗАКБНШН БАНЖКНА

ATO CEETO IAKO C $\triangle M \mathrm{Z}$

5

CA $\cdot{ }^{40}$ Eh CN WEON zano

в 太АKN вLCh ZаKOH'

и пр९ิцнн $\mathbf{c A T h} \cdot{ }^{41} \mathrm{ck}$

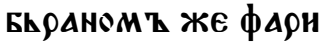

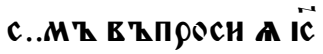

42 ГÄA. YTO CA в $\triangle M Z$

10

МКнит. o $\ddot{\gamma} \hbar$ чнн Есть

CH' · ГÄUA EMOY AA

в'ҚIA.. ${ }^{43}$ ГӒА HMт

KAKO OБO AËATh $A \overrightarrow{X^{\prime}} \mathbf{h}$

15 ми ..рнцАЕТК н

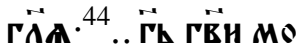

ЮMOY .АAH O АECHOY

ю M.H. .он'АEЖE

ПОАож. в९АГ'ҚІ ТЕО

20 А ПОАТнОЖню Но

ГАMА TEонма ${ }^{45}$ Аџе

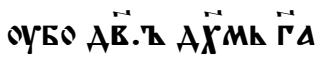

НАРНЦА.ТК ' Н ТОКА

Ko IfC.. CH' EM OY. ${ }^{46}$ H
696

никтоже не можА

Аше ш̈в ћџАтн ємж

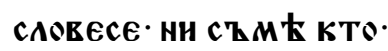

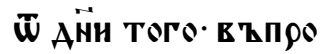

5 снтн его К томоY : :

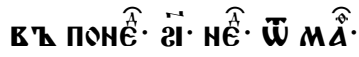

в Қ в

Марк Aame napOAT MHO

$\mathrm{V}$ Г' $\cdot$ H OYFH太TA

24-34

10

Xоути н. ${ }^{25}$ н се же

нА ЕТеРА соушн въ

Точенни КрТЕЕ $\Lambda$ 太

. $\mathbf{E} \cdot \overrightarrow{\mathbf{I}} \cdot \cdot \mathbf{T E} \cdot{ }^{26}$ и многе по

с ТРАААВ ҚШИ $\overline{\mathrm{w}}$ мно

15

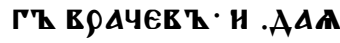

в Қшн ш̈ сеБе все и

ннчк төже оY. त t

В ҚШH· H' ПАЧ. HA

rophwe ПоншкA'

20

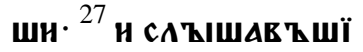

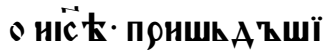

в' HAPOA $\mathbf{c k} 34$

жAA прнкесHOY ca

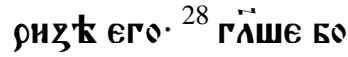


69 в

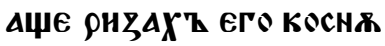

сА нсц ҚА Қю. ${ }^{29}$ Н АБнЕ

HC' $X$ НОУ НС ТОЧБHН

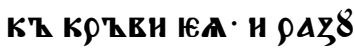

5

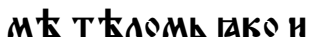

сц ҚА 太

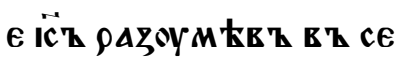

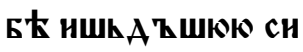

АOY Н马 НеГО ОБРАТИ

10

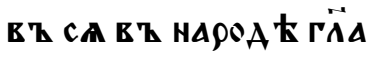

Аше ' нЕкTо п९нко

сHOY CA PHZAX'Z MO

иХи · ${ }^{31}$ и ГӒАША ЮMOY

оученнци ЕГО' ви

15 Анши нА९्Aт Гне

ТоYШИ ТА· Н ГӒЕши

нЕкТО прнкосноу

са мн. ${ }^{32}$ н озноАше

CA вHA KTH СE CZTEO

20

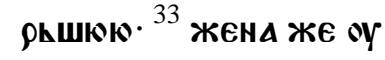

БOIAR Қ ШИ СА И Т

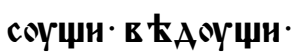

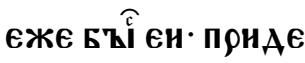

Н ПрНПААЕ КТ НЕ
$69 \Gamma$

MOY. H H马A९EपE EMOY

всу истиноу. ${ }^{34}$ ič же

юН АТџн в Е $\rho \triangle$ ТВо

A CIICE TA· HАH БТ MH

5

९Ъ Н БОУАН С 'ҚА९АВА

W̄ PAHZI TBOEA $: \because \cdot$

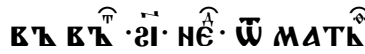

Марк

VI

1-13

10

1 в Қ в

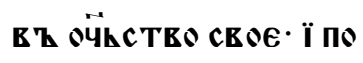

HEMh HAOWA OYYE

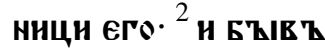

ШH COYEST K - HAYA

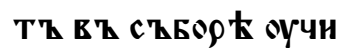

ТН· И мнези САҚІшА

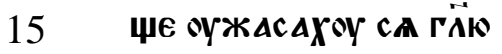

LE W KOYAOY ce ecth ce

MOY. H KAA חр EMOY

APOCTh AAHA ÆMOY H

CHAҚI KAKOB ҚI POYKA

20

MA EГO БҚIEANTh ${ }^{3}$ HE

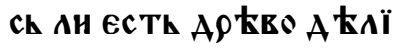

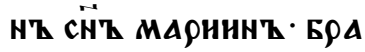

Th ЖЕ иाАКевАh ' Н осн

HH' · HOYАНH' · H СH 
$70 \mathrm{a}$

МОНОВ Қ ' И НЕ СЕ АН СЕ

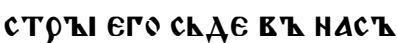

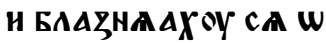

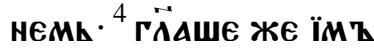

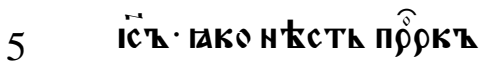

БещКстинҚ ТZКОМо

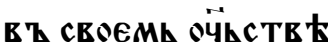

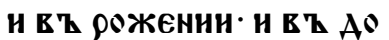

MOY СЕОеMR ${ }^{5}$ H HE MO

10 ЖАAWE TOY нH ЕАН

HOIA СHA ҚI C'Z TEOPH

TH· HZ TZKMO MA

AO HEAOYжин'LI'?

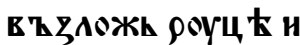

15 сц ЋАн. ${ }^{6}$ н чюжААше

са нев Қ рованию и

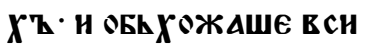

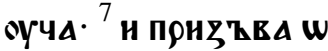

БА HA AECATE' H HAYA

20 ПоУЧАТН АТЕА АТ

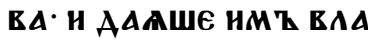

сTh HA Ä̈kX' неपн

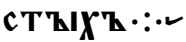

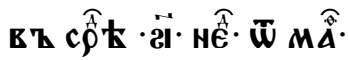

706

в в в

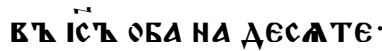

Н НАЧ АТТ СТААТИ

H AAIAWE HMT BAA

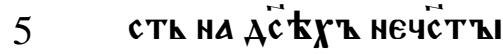

$\boldsymbol{X}^{7} \cdot{ }^{8}$ Н ЗАПОВ

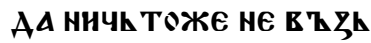

MOYTh HA חOYTh - HT

TZЧКК ЖhZАh EAH

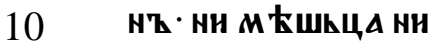

ХА ҚБА ни Пон Пога

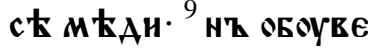

HH E' ' CAHAАAHA. H

НЕ ОБААЧНТИ СА ВТ

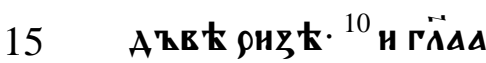

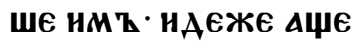

въAkzETE в АOMh

тоу понБоуа

AOH'AEЖE H马А

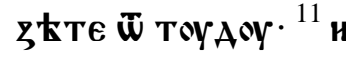

АЕЖЕ ЮАнко АџЕ не

ПрннмоУТһ вАсъ · ̈̈

cXoaAlHE $\bar{W}$ TOYAOY

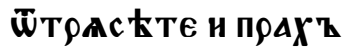


70в

нЖЕ ЮС Th ПОА' НОГА

MА ВАШНM В С CKE

A $\mathrm{kTE \Lambda hство} \mathrm{нми} \triangle$

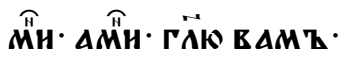

5

Ẅ АALH KЕ БOYAETh

СОАОМААНОМТ Н ГО

MOPAHOMT ET AḦ

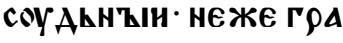

AOY TOMOY ${ }^{12}$ h WhAT

10

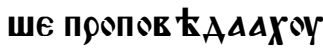

AA ПOKALTh CA. ${ }^{13}$ ï Бt

C'Қl MHOГ'Қl H马ГОHA

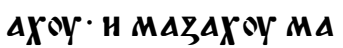

САҚML А९ ҚЕАНҚIH

15 м'

жhн'ҚIа нсц ЕА

BAAX OY $\because$.

Марк

VI

30-53

20

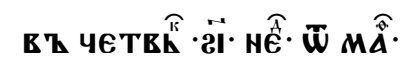

въ в

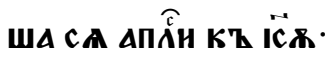

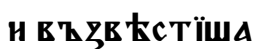

ВСЕ ЮАНКО СТ ТВО

ОНША Н ЕАНКО НА

оүчншА ${ }^{31}$ Н ९ॄ НМт 70г

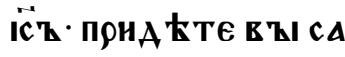

Мн вһ поус ТО М Есто

ОСОБ · Н ПОчннТЕ MA

AO. БA XOY БO ПонXO

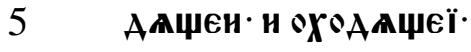

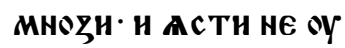

ПОАЖНА АХОУ СА ${ }^{32}$ и

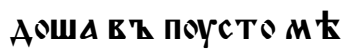

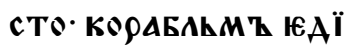

10

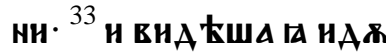

廿а H ПOZHAWA IA MT

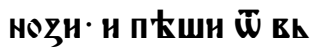

с қХ' Г९АА текошА

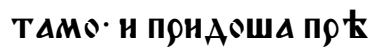

15 ЖЕ иХ' • и вЪНнАОША

K' HeMoy. ${ }^{34}$ и whA'

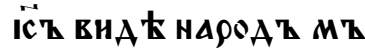

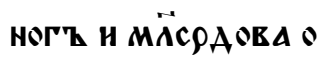

HHX' · TAKO БA XOY

20

TAKO ОЕһцА HE HMOY

ЩА ПАС TOYХА• Н НА

ЧА ОУчнТИ ІА МноГО.

${ }^{35}$ и мнноуе Ђ шоу 44

coy прнс тоупАьше 
$71 \mathrm{a}$

К' немоу оученнци

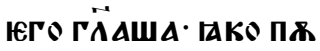

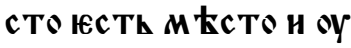

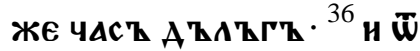

Поус Th IA. AA WhA'B

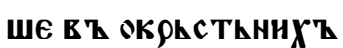

centX'z KoYmath co

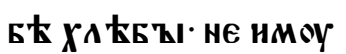

Th Бо чco Łс Th. ${ }^{37}$ oнt

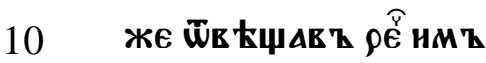

АААНТЕ ИМт вҚІ Ћстї

и ГАÄயA EMOY AА Wh

Aтше коупнмт Aт

в 太MA ck TOMA c९t

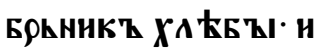

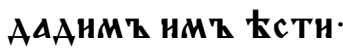

${ }^{38}$ онт же ГӤА НMТ Ко

АнКО ХА ҚБһ НМАТЕ

НА

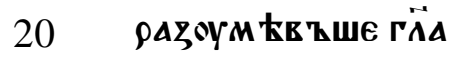

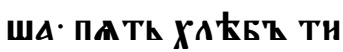

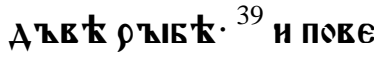

А Н НМ ПОСААНТН

BCA HA CחOA'Қl HA MAA
716

A

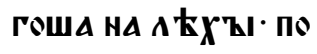

С' TOY И ПО ПА ТИ АE

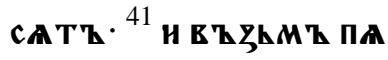

5 Ти ХАћви и Аһв

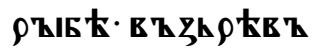

HА HË БลิГГВН · Ï П९H

АОМн ХА КБҚІ Н АА

гаше оүченикомт

10 СвонМт АА ПОААГА

NTh ПФҚат нHмH.

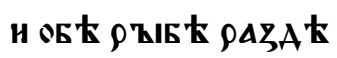

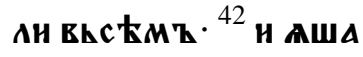

ВСН Н НАСҚITHША СА -

15

${ }^{43}$ H В Қ马АШША HZБҚIT T

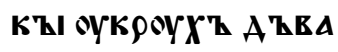

HA AECATE KOWA H

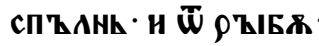

${ }^{44}$ и БАше ФААТШиХ'

20

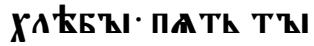

сащи моужи. ${ }^{45}$ н А

БНЕ ПОНнОУАН ОУ

ЧЕНHК ҚI СЕОА В $\mathrm{Z}$

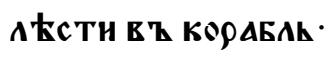


71 в

и прТЖЕ итн нА ОНТ ПОА' КҚ ЕНА ҚССНА АОнъАЕже $\tilde{W}$ поуст ї

Th HAPOA $\mathbf{Z l} \cdot \because \cdot 2$

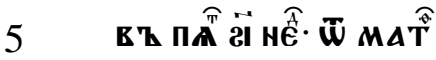

в ъ в

АН иІс' оученнк Қ।

СвОГ в ҚА СТ

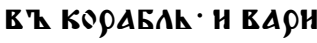

10 Тн НА ОнОМ' ПОАОУ

Kh вHАТСАHА

ш̈поустнть наро

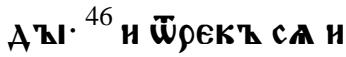

АE в' ropoy помеsї

15 Th CA. ${ }^{47}$ н вече९оY Б'

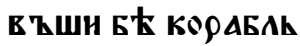

no cepeat mopa $\triangle 4$ ch

EАннһ HA coyct ${ }^{48}$ н

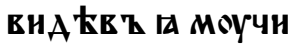

20 МЫ .ГААГре

БAAXOY БAшE БO

в 太т $\rho$ с соупроти

BhH' E $\mathrm{Z}$ че TKL $\rho \mathrm{K}$

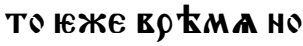

71г

Чн ПОНАЕ КТ ННМ Қ

XOAA חO MOgN H XOTA

ше га миноути ${ }^{49}$ они

ЖЕ внА Қвһше и XОАA

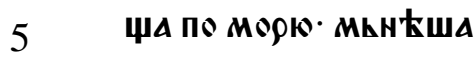

ПОҚАТ ОЧнМА вНАА

ЧЕ ОБРАЪ' АВААКџИ

СА и вһ弓ҚПишА. ${ }^{50}$ всн

БО и вНА КША Ї вһ马МА

10 TOWА CA $\cdot$ OHZ ЖE ГÄА

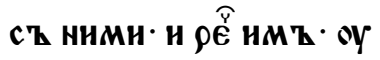

ПЋвАНТЕ нЕ БОНТЕ

са. ${ }^{51}$ н вһА ЕZе Кһ ни

MZ E' KO९АБАh Ï СTA

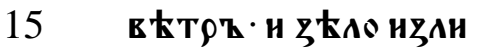

XА В Т СЕБТ САMH ОУЖА

CAXOY CA И पाЖАAA

XOY CA. ${ }^{52}$ HE PAZOYM

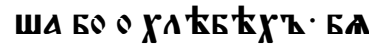

ше БО сРАЦЕ нХ' оКА

МЕNENO ${ }^{53}$ и ПОНШКАТ

WE ПОНАОША HА ZЕMAК

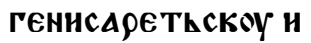

прнс т АшА $: \because$ - 
$72 \mathrm{a}$

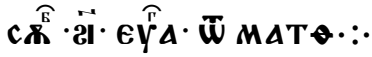

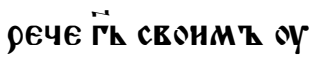

Матфей

ченHКОМт $\cdot{ }^{34} \triangle \ddot{M H}$

XXIV

$34-44$

5

ГӒК вАMТ · HE МH

MO haETh POAth ch.

АОНАЕЖЕ вСА БОY

AOYTh ${ }^{35}$ HЁ H ZEMAA

MHMO HAETh А CAO

हECА MOA HE MHMO

10 HАOYTh ${ }^{36} \triangle$ O АН̈H TO

ML H O ГOAHA Т TOH

НHКЋ ТОЖЕ нЕ в

СТК · НН АНГГАН НЁС

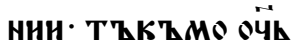

15 ЕАннъ. ${ }^{37}$ Акоже Б

в Қ Ан̈н ноEв Қl TA

KO БоYАЕТИ н в

АНН С̈НА Чล̈вЧ ${ }^{38}$ A

Коже Бо БАХ Уу пре

20 жЕ ПОтОПА АAОY

це и пиюще · же

наџе са и ПОСАГА

юще मо негоже

АН̈н вънНАЕ нОН
726

в ковһчегт. ${ }^{39}$ н

HE ऽчктншА. A०

HZAEжE ПонАE

ПОTOП' • Н ZА T'

5

BhCA. TAKO EOY

АЕТИ' н Прнжис ТЕИ

E CHА Чล̈вЧА ${ }^{40}$ TT

rhaA A' EA EOYAETA

HA cEA K EAHнT

10 ПоEмAКTh $\triangle$ А९Y

ГKIH OCT АEAAF

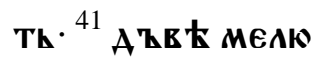

чин в' жирқни

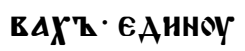

15 ПоЕМАюТһ' Н

АНHOY OCT АВАA

NTh ${ }^{42}$ БhAHTE OY

БO AKO NE в Есте

B'Z KOYK ГOAH

20

HoY $\overrightarrow{\text { Th B }}$ в

Аети ${ }^{43}$ се же в t

Анте АKо Аџе

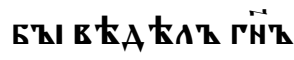

XPAMA ER KOY 
72 в

ю ст९АЖоY TATh

понаETh' EkA

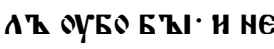

БҚІ ОСТ АЕНАҚ ПО

5

АВКөПАТИ ХОА

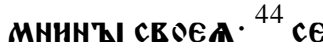

ГО ९ААН Н ВЫЫ БОY

А

KO в 'h HhжE чAc'

10

не МнHнте $\cdot \overrightarrow{\text { CHK }}$

Чล̈вЧКсКЪН ПрЕ

AETh $:: 2$

Матфей

XXV

$14-29$

15

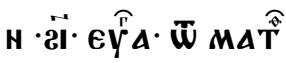

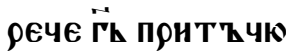

СНю. ${ }^{14}$ ОУПОАОБН

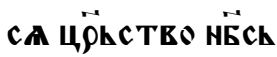

HOE - पत̈вKOY.

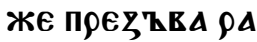

БҚI СEOA. H ААСТИ

20 НМТ НМ ЕннЕ

CBOE. ${ }^{15}$ H OBOMOY

AACTh $\cdot \vec{E} \cdot$ TANA

HZTT ' OBOMOY

ЖЕ АТЕА' ИнО
$72 \Gamma$

MoY жE EAHH' .

КОMOYЖAO ПрО

THEOY CHA

H. О итнАE

5 АБне ${ }^{16}$ ШhA'

пренм ҚIн $\vec{E} \cdot$ ТА

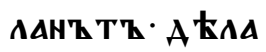

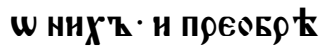

те ароугоук $\overrightarrow{\mathrm{e}}$.

10 TAMAHZ TZ $\cdot{ }^{17}$ T AKO

жЕ иже АТВА' пре

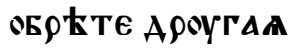

АҚЕА ${ }^{18}$ А ПрннмҚІ

H EAHH' • WhA'Z $\rho A$

15

скоПА ZемАК'

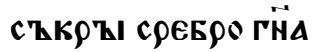

своего. ${ }^{19}$ НЕ ПО Мно

зъ же времени

ПФНАE ГН̈Ъ ९АE Қ

20

TKX' • н C' TAZA

СА СТ ННМН О САО

весн. ${ }^{20}$ н прес тоу

Паһ пренмъи $\ddot{\bullet}$.

TANAHZ TZ $\cdot \overrightarrow{\text { TAA. }}$ 
$73 a$

$\overrightarrow{\Gamma H} \cdot \vec{E} \cdot$ TAN ANTT

Мн Есн ПреААAт

ce apoyroye $\cdot \overrightarrow{\mathrm{e}}$.

TAAAH' TZ ח९EO

5 БөћтоХ' имн.

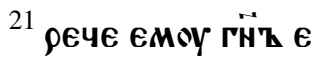

ГО. АОБ९ҚІ ОАБЕ

БАГГЫн в Е $\rho$ не •

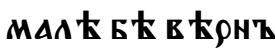

10 НААТ МНОГҚIMH

TA ПOCTAKAN.

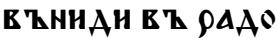

ст人 $\vec{\Gamma}$ А св оего. ${ }^{22}$ пре

стоупАь же прен

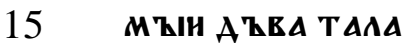

HZ TA PEYE $\overrightarrow{\Gamma H} \cdot A T$

BA TANANTA MH

Есн преАAAт·

APSYTAA ATEA

20 ПреоБр КтоХи и

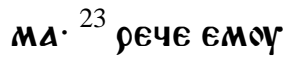

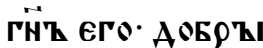

и РАБЕ БАГГҚН в 太

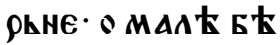

736

в K $\rho$ hH HAAT

МHOГ'ҚIMH TA

ПОСТ АВАЮ · В ҚНН

АН в Қ ९AAOCTh Г̈А

5 своего. ${ }^{24}$ престоу

ПАһ же пренмЫ

Н EAHH' TANAN'

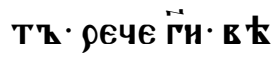

AAX' TA "⿴囗 коже

10 СТОК' ЕСК Чत̈ЕКТ

Жинеши оYАOY

HE C太AR '

ОАЕШИ ОYАОУ ЖЕ

нE РАСТ ТОЧнЕ $\mathrm{h}$.

15

${ }^{25}$ H OYEOAET CA

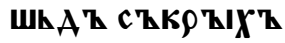

TANAN' TZ TEO

Н В'Қ ЗЕМАН· Н Се

НМАШН СвоE. ${ }^{26} \bar{W}$

20

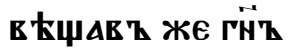

его рече $\mathrm{E}$

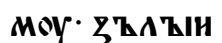

PAБE AOYКАВ ҚI

h. в 太 Aame a 
73 в

KOЖKHN OYAOY

ЖE нE c 太AR '

C'BEHPAK OYAOY

ЖE NE ९AC TOYAR Z .

5

${ }^{27}$ ПОАОв АШЕ Ти ОY

БО в ҚААТИ с९ЕБ९О

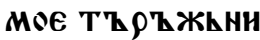

коMz' н прешh

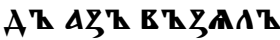

10 оуБе БҚIX' своE

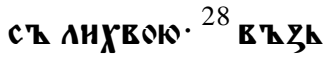

м 太те оүБо ш̃ не

FO TANANZ TZ $\cdot$ H

АААНTE HMOY

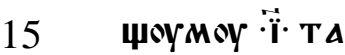

AAH' T T $\cdot{ }^{29}$ HMOY

LоYMoY БO всь

AE AAHO БOYAE

Th · $\triangle \mathbb{W}$ не нмоY

20 щаго и еже Аџе

MKHHTh CA H

MЋA. в'ZZATO

Матфей

XIII

9 boyaeth ש̈ he

ro. ${ }^{9}$ ce ГÃA в
$73 \Gamma$

З ААCH· HM KA OY

Марк

ШH САҚІШАТИ

VI

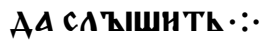

54,53 ,

55,56

5

в Z ПонЕึ

в Ђ во ЕМа оно. ${ }^{54}$ и

WhAthwOY HICOY

HC Kog AEAA - IO

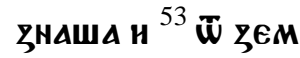

AA renhCA Sh Th

10

ск'Қla ${ }^{55}$ претеко

WA E' СТ РАHOY

TOY. H HAYAWA

HA OAP KX' БOAA

ЩАА П९НнОСНТИ

15 НАЕЖЕ САҚIUА

XOYTh H AKO TOY

ести ${ }^{56}$ и Аможе

КОАНЖК АО в Қ XO

жАше в Қ всн.

20

НАН В Т Г९ААҚI Н

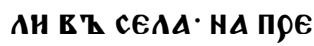

ПоYТи нХ' ПОАА

ГAAXOY HEAOYXh

H'LIA. H MOAAXOY 
$74 \mathrm{a}$

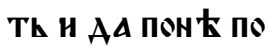

AOAkKOY PHZु' E

ro прекосноуть

СА· Н ЕАНКО ..Е $\mathrm{H}$.

5 ПрНКосноуШАСА

Марк

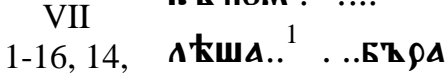

Кһ нем . ....

17-23, ША СА К' немоу

$16,24-$

30

10

фАрнс Ен· н нЕ

цнн $\widetilde{\tilde{w}}$ кннжьни

K' $\cdot$ ПрешһA'

Ш нероус ААнмА.

${ }^{2}$ н внА..В Қше н Е

K'ҚIA $\overline{\mathbb{W}}$ оYчеNH

15 Къ ЕГО ' нЕЧнстА

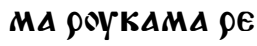

КоY廿е HE OYMЋEE

HAMA AAOYLE

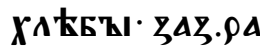

20 XоY ${ }^{3}$ фАрнс है оу

БО и всн ЖнА ОВе

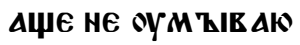

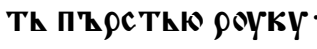

TO ne aAath ah
746

ОhжАџЕ ПреААнн

А ст $\triangle \rho ч к \mathrm{cK \Delta} \cdot{ }^{4}$ н $\overline{\mathrm{w}}$

Т Қ ожищА Аџе не oga knth ca he a

5

АА Th ' Н ИНО Мно

Го Ести ЕЖе прна

ША' АК९ЖАТН О

MZIEAHHA YAWA

M T H YhBAHOM $\mathrm{h}$.

10

H KOTLAOMZ · Н

Аромт .5 по том..

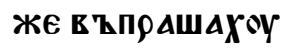

Th ero фарнс th.

И КҚННГҚЧНА П ПО

15 чь то оүченици

TEOH HE XOAATh

ПО ПрЕААНнЕ СТА

phчhскоу. H'h HE

OYM ZRENAMA

20 роYкаM

Th $\gamma^{\wedge} \mathrm{kEz} \cdot \mathrm{ch}$ жE

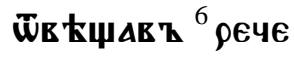

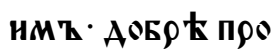

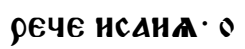


74 в

вАС' Анцем Е рнн -

Акоже пишети са

CH ANALE OYC Th

HAMH पh TOYTh

5

МА· А С̈РАЕ НХ'

oYAANAETh CA Ü

мнE. ${ }^{7}$ coYe $\%$ पh

TOYTh MA OYYA

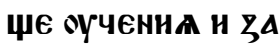

10

ПОВ ЕАН Чล̈ЕЦК

сK Қl ${ }^{8}$ OC T АВHE '

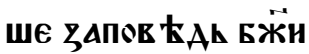

ю. Аһрижнте

ПрЕААННА Чล̈ЕЧК

15 cKa $\because \cdot 2$

B Z E Z

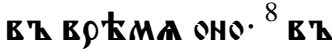

прашаX оуть н

фарнс Кн н к'

20 ннжкннцн · $\omega$

OM ҚIE АНHН ЧК

BАHOM Қ H ЧAWh

Н HНА МHАГА

ПОАОБLHA TAKO
$74 \Gamma$

вА ТЕорите $\cdot{ }^{9}$ и

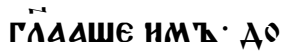

вр К Хоулнте ЗА

ПОВ ЕАН БӜНА

5 АовроА Бание

OBOE chБANAETE

${ }^{10}$ Монсн Бо рече पh

ТИ ОӴа СвоеГО И

М Т̈рһ свою' нже

10 उЪА ЕсАовнтһ оц̈А

и мт̈рh ${ }^{11}$ в Қl же

ГӒ те Аџе рече

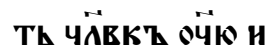

Ан мТ̈рн ков $\triangle \rho н$

15 Hz - Єже EсTh AА

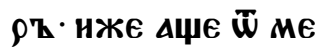

не поспћешн

${ }^{12}$ кh тоMoY же He o

с ТАЕнтЕ ЕГО ни

20

पh соже ch TRoph

Ти ойе своемоу.

нн МТ̈рн своен

${ }^{13}$ БEZ'Z OYс T ARA

TEоpa 
$75 \mathrm{a}$

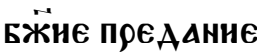

ми вАшнми ЄЖЕ

ПрЕААСТЕ. Н ПОА०

БКНА СНЦА МнО

5

ГА Тв орнте $\cdot{ }^{14}$ н пре

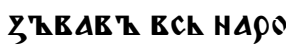

АТ Гӥше нм द $\cdot$ по

сАоушАнте мне

всн и ОАЗОҮМ Кн

10 TE ${ }^{15}$ ннчhсоже Eс Th

EжE в ZHसюAOY.

ЧӒЕКА Е Т XОAА

в ' Hh ' HE Може Th

оск९̆ Книтн· НҚ

15 hсXРaALAa Ũ he

TO T AKO COYTh

скекрнацаА чE

АОВКА ${ }^{16}$ АЧЕ KT

TO нмАТИ оушн

20 САҚШШАТИ АА САҚ

шитh $:$ :

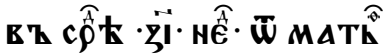

в' в९ЕМа оно. ${ }^{14}$ пре

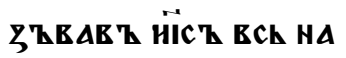

756

POAт ГÄШE нMт

ПослоYшАнТЕ

МЕНЕ ВсН И ९АЗУ

м Ките $\cdot{ }^{17}$ в ҚпрА

5 шахоути оучени

чн его о прнтТчн

${ }^{18}$ Н ГӒА НМт ' Т АКО

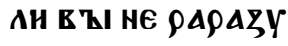

МКни ЕстЕ' не ९А

10 zоум Еете Ан А

КО все ЕЖе нЗ в $\mathrm{z}$

HOY E $\mathbf{Z}$ X'AHTh

в И Чत̈ЕКА НЕ M०

жETh 6 oскви $\rho$ h

15 нити. ${ }^{19}$ АКО не в Қ

XOAHTh EMOY.

вт СРАКце нZ чр太

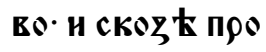

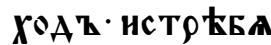

20 ВСА Б९АШКНА.

${ }^{20}$ Гก̈AWE жE · AKo

HсX'AALEE

पÄEKA TO CKEK

ОКНHTh Чत̈ЕКА. 
75 в

${ }^{21}$ ну' oут 9 Бо с९ӒЦА ТО сКЕК९И HНTh Чล̈ЕКА ПО MZICAH ЭҚАН Н

croaAth - mpe ANA АanHa БAOY

ЖЕнНА ОУБон.

22 TATKB'ZI AOYKo

вАнНА' AhCTh

10 АНХОНМАННЕ

OKO AOYKABO $X$ OY

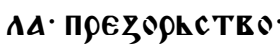

Безоумне ${ }^{23}$ все

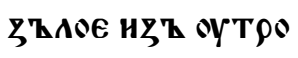

15 БZ HCX'AHTh.

Н ТО сКЕК РнН ТК

ЧลีЕКА ${ }^{16}$ НЖЕ и

MАTh оYшн сA'Қl

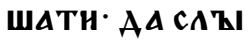

20 шнть ${ }^{24}$ н $\overline{\boldsymbol{W}}$ тоY

AOY в ZCT АE'

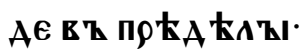

TOYPhск'Қl И СH

AOHhсK'Қl·:•-
75 г

в h ч $\overparen{\widehat{T}} \cdot \overrightarrow{\zeta I} \cdot \mathbf{H E \hat { E }} \cdot \overline{\mathbf{w}}$ MATh

в' врҚма оно.

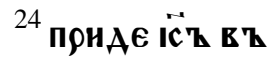

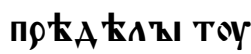

5 ९КСКҚІ И СНАО

HhCKҚl· H E ZW.

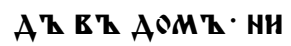

когоже нE XОTA

ше АА и оув $\mathrm{k.Th}$

10 Н нЕ Може оутА

HТн СА ${ }^{25}$ CAMIUA

в \ши же женА

- нЕMh - EAЖE AT

Чн имаше $A \vec{X} \mathbf{z}$ не

15 чнсть Ппнши А Тшн

ПААЕ ПрЕАТ НОГАMА

его. ${ }^{26}$ женА

AHHhCKA. сY POQY

ННЦКСКА РОАТМh

20

Н MOAAWE Н АА Н

жE Th Б太сһ H马 А'

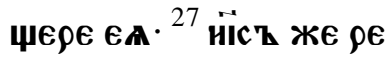

чE EH· OCT АHH' AА

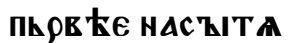


$76 a$

Th CA YAAA HECTh

БO АОБрО ОТ А TH

XАЕБА ЧААОMТ Н

Пhсом' пове $е ц и$.

5

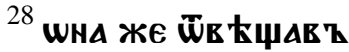

ши рече емоу. Еи

$\overrightarrow{\Gamma H} \cdot$ и Пһсн БO ПOA'

трапеzоn kaA

Th $\overline{\boldsymbol{w}}$ коуннци А

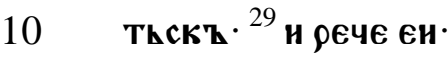

СЕГО РААН САОвЕСЕ

НАН HZHAE БҺсҚ

HЗ АҚщЕРН ТЕОеА

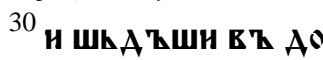

15 М СЕงн- ФБрћТЕ

Ртроковнцк АЕ

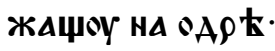

Марк

VIII

1-9

20

H БЕсҚ HWhA'ZWh $\because$.

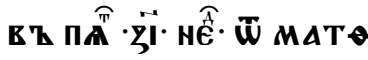

в Қ воЕМА Оно. MT

HOTOY COYWOY HA

POAOY. Н HE HMOY

шоу чксо Łстн· пре

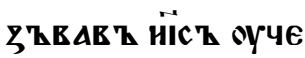

НHКЫ СЕОА ГӒА

HМ Қ ${ }^{2}$ МHАҚ МН $E$

c Th HAPOAT Ch A

ко оуже Т९н Ан̈н

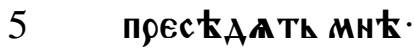

H HE HMOYTh 4hCO

Łстн. ${ }^{3}$ н Аџе ш̈пy

HOY a He katzuA

B' AOMZI CEOA O

CAAE KWTT HA חOY

Тн· АроУ马ни Бо

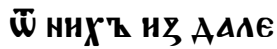

YA COYTh ПоH

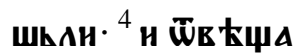

15 ША ЕМоу. Оучени

ци его ш̃ кOYAOY

СНА КTO МОЖE

Th HAC'ZTTHTH

XА KБъ HA поY

20

с ТҚАНН ${ }^{5}$ И Е ҚПФО

сн А КОАНКО XА太

Б' НМАТЕ - ОНИ

же рекоша сеами.

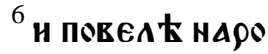


$76 \mathrm{~B}$

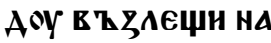

ЗемАн' и прннмт

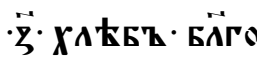

САОвНЕ Т ПРЕАО

5

MH' H ALAWE OY

ЧЕННКОМТ СвОН

Mh АА ПФEА

ГАЮТ' ' Н ПОАОЖН

WA прEATZ HAPO

10 АТМน ${ }^{7}$ Н НMAХY

PZIETZ MAAO H

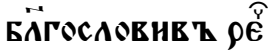

ПреАТА АжнтЕ

и ТҢI. ${ }^{8}$ АША ЖЕ И

15 HАC'THШАс

Н ВҚЗАWА HZБҚI

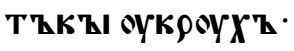

·े. кошиници

9 Бћ же АА' ши Хर

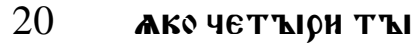

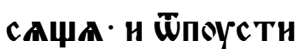

А. Н АБнЕ в ҚА

zE в 'h KogAБ八h ch

оученнкт сво
$76 \Gamma$

НМн· Н ПреАЕ в Т

с TPАNZI AАAMA

Матфей тиск'ы·:-

XXV

1-13

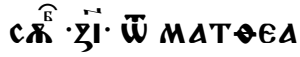

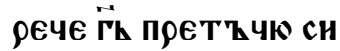

6. ${ }^{1}$ ПОАОБһHO ECTh

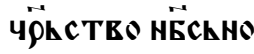

e. AEcA TH A tв h' A

ЖЕ Пренм ЋшА св 太

10 ТНАКННКҚ СВОА Н

ZНАОWА ПООТнЕОУ

женнхоу. н нев

стt. ${ }^{2}$ ПA Th ЖE БAА

ше $\overline{\mathbf{w}}$ ннХ' Боун· н

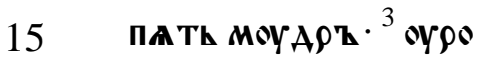

АһHZIA Же прен

M ҚША СЕ К ТНАКHН

KҚI CBOA· HE в Қ马а

WА CZ СОБON MACAA

20

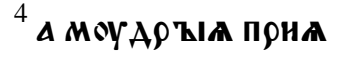

ША C' СОБОК MАCAS.

в' chcoyatX'h ch cEt

ТНАКНHКҚІ СЕОН

мн. 5 MOYAAщоY 
$77 \mathrm{a}$

же женн XоY в $\mathrm{z}$

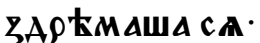

вса н съпаXоY. ${ }^{6}$ по

Аоу ноцн же в ЂПАь

5

БzIc Th се женнX'

ГPAАETh HCX'AH

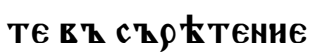

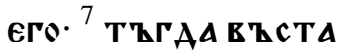

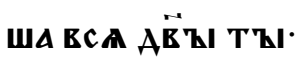

10 Н оүКРАСНША Св Е

ТИАКННКҚI СЕОА -

${ }^{8}$ a oypoanhtza ge

КошА МоYА९ZH

Mh АААНTЕ И НА

15

MT W MACAA BA

ШеГО АКО СЕ К ТИ

АКННЦН НАШН ОУ

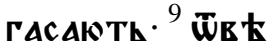

ЧАША ЖE MOYА९'Қl

20

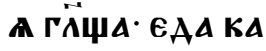

KO HE AOCTAHETh

BAM ' Н HАM '

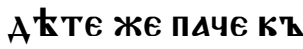

ПрОААКчнимт
776

и коупнте сеБ太

${ }^{10}$ нАОуџАМт жЕ и

мъ коупнт' пре

АE женнХ' म гето

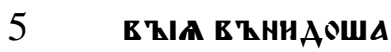

C' HHML HA Б९АK'

Н ZАТЕоренसI БҚI

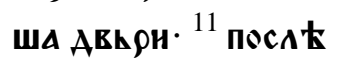

АК ЖЕ ПрнАОША и

10

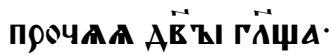

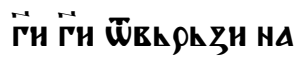

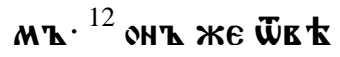

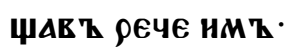

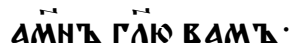

15 не в вА в вАсқ ${ }^{13}$ Би

АНTE оYБо АКО не

в КстЕ АН̈Е НH ЧА

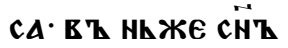

Чล̈БЧксКТИН ПрЕ

$20 \quad$ AETh $\because \cdot 2$

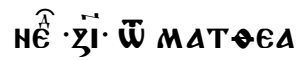

вт врТМа оно-

Матфей

XV

21-28
${ }^{21}$ H马НАЕ Иіс' в '

стрАноу тоу⿰ь 
77 в

сКоY н снаOHh скоY. ${ }^{22}$ н

се женА ХАнААнҚІни

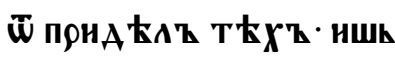

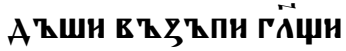

5 ПОМНАОУН МА Г̈Н СН̈У

$A \vec{E} A \mathbf{A} \cdot A \mathbf{Z} \psi \mathbf{H}$ MOA $\mathbf{Z h}$

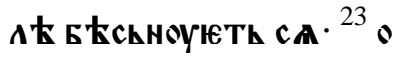

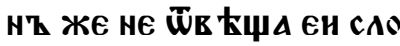

весе· и прћст тупльше

10 ОУЧЕННЦИ ЕГО МолА

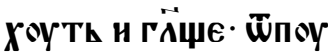

стн Ю гаКО в ЋПнеть

B Z CA ZA Z HAC' ${ }^{24}$ OH'

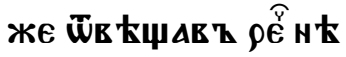

CMK ПOCZAAH' T'KKMO

15

К' өБһЦАМ'h ПОГ'

БЪшHM7 AOMOY

उत̈воу. 25 онА ЖЕ прншь

АТШН ПОКАОНИ СА Ю

20

MOY ГӒџн Г̈Н ПОМ०

зи мн. ${ }^{26}$ онт же ш̈в

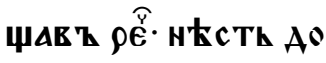

Б९О ОТ А ТИ ХА КБА ЧА

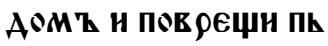

77Г

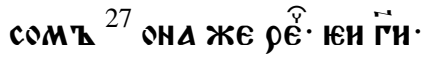

HБО и Псн

ПнцК ПАААКщнїХर

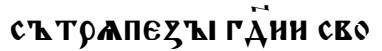

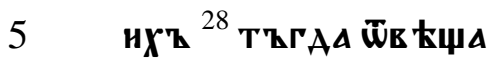

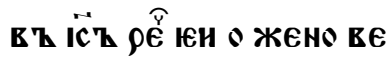

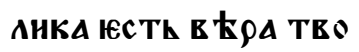

ПА. БОУАН ТЕБЕ IAKO

же Хощешн· н иц

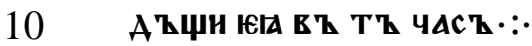

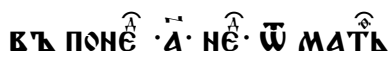

Yh TH. AO cEA cX TE

SHh YACA C̈TZH ERA

HKГKAHCTZ MATO.

† |l|cs||les|l|es|l|cs

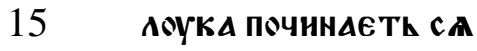

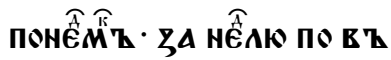

ЗАЕнЖЕНнН · сн соY'ТА

H HỄAA W חATh חOCA

† ЧНСТН ОБААZНА БҚIАА

20 ТАКОжЕ н ..АऽҮКА ЧА

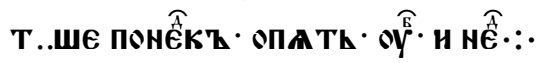

Y⿳⺈. ПOCA

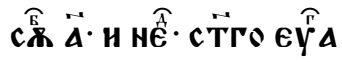

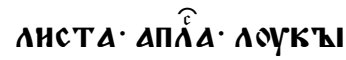

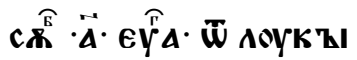


$78 \mathrm{a}$

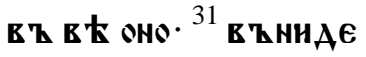

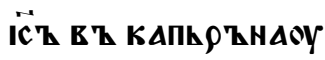

Лука

IV

MZ ET ГОАA' ГАAH

31-36

5

10

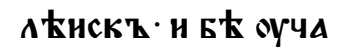

в Z coysetoy. ${ }^{32}$ H oY

\%Ac AXOY CA O OYYENH

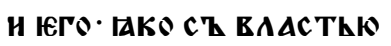

БЕ САОво ЕГО ${ }^{33}$ Н Е Қ СЪБО

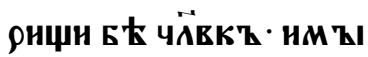

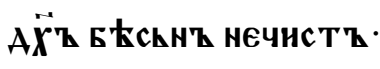

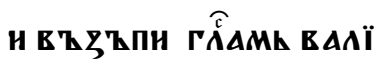

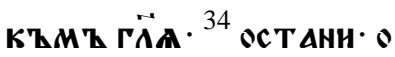

CTAHH - Yh TO ECTK HAMT

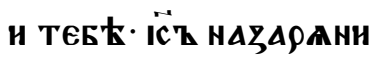

15 не' прншиАт есн прt

же вр Емене погоуБн

Th HACZ · E KMh TA K'

То есн с Т̈Ън и Бённ.

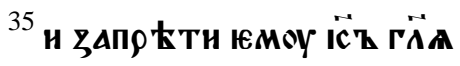

20 ПФҚМ ҚАҚЧн ИУНАН И

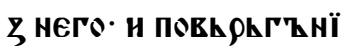

пе сереа А нъ него ни

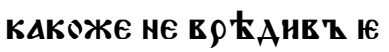

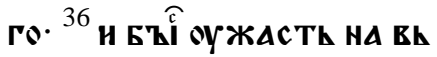

786

ckX' и с' TAZAAX OY

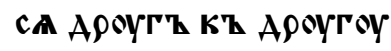

ГӒше पh TO Eс Th сAOEO

CE. IAKO вA AC ThO н

5 СНАОК вЕАНТЬ ' НЕЧн

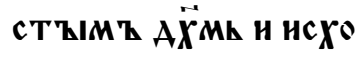

AATh $: \because \cdot$

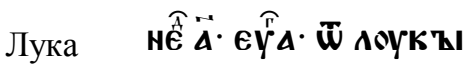

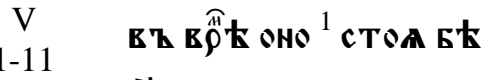

10

ich пон еzерt ге

нHсАре Тһсцен

${ }^{2}$ H внА А А ҚЕА

KOPAБ八A С T OALA

прн езерt.

15

же sшh A hше $\tilde{w}$ Hew

ПОвА АКАХ УY моТЖА

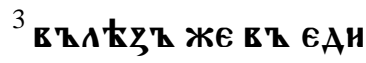

HZ $\widetilde{W}$ корАБАнци ' Н

же Ба аше снмоно

20

в ' MOAн И Ш̈ ZEMAA

ш̈стоупнти маАо.

H c太A' оYчаAше H

с KOPAБAA HAPOATI.

${ }^{4}$ гакоже пр ТстА ГӒA. 
78 в

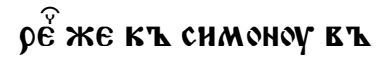

ННАН ВТ ГАОУБННОУ

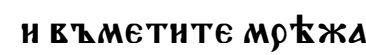

ВАША Е И АОЕНТЕОУ -

5

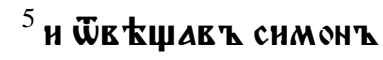

PEYE ЕMOY HACT ARh

нице - ОБ ноџһ всоу

троужише са не aXo

мъ ничhсоже· По гйоY

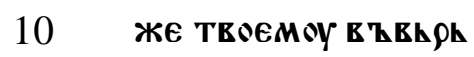

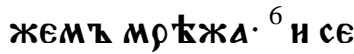

C' TRорнв ZWE IAWA

множис ТЕО ९ҚIБ'

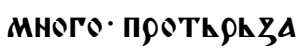

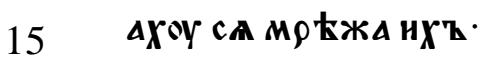

${ }^{7}$ н поманоуша прн

ЧАС TLHHKOMZ ' H

Же БаAXOY вт арOY

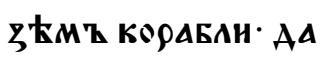

20

поншка Қше помо

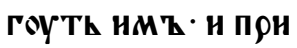

АОША. H HАПТА ҚНH

WA ATKEA KOPAEAA

ТАКО ПОГроУЖАТИ
$78 \Gamma$

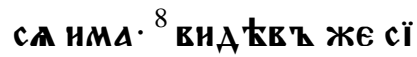

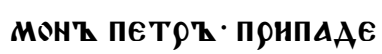

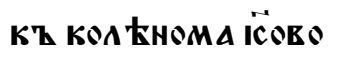

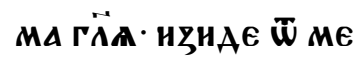

HE IAKS MоYжh ГPtwh

HZ юсмh $\overrightarrow{\Gamma H} \cdot{ }^{9}$ и оужАс'

Бо оАһ ९һЖаше и и вһ

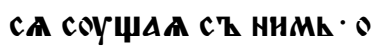

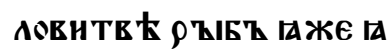

10 ША. ${ }^{10}$ Т АКОЖАЕ ЖЕ и АКО

ВТ HOAHT CHA ZEREA

ОВА. ГАЖЕ БА АСТА ОБИ

Щһ HНКА СНМОНОВН ' Н

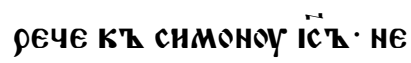

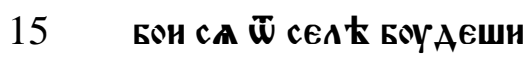

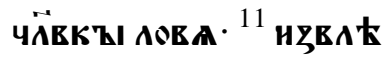

KhШE KOPAБAA HA COY

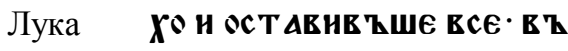

III

20

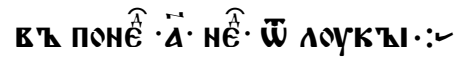

в В в

ТВЕРТОВААСТКНИ

К' ОБАНЧАЕМ' $\bar{W}$ H

oAHA. O H POAHAA 
$79 \mathrm{a}$

женћ Б९АT А своEГO

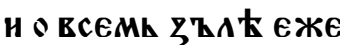

съ тверн ноеАт. ${ }^{20}$ прн

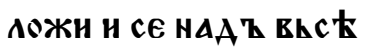

5

МН' Н ЗАТЕО९Н НОА

НА ВТ ТКМКнНци ${ }^{21}$ н

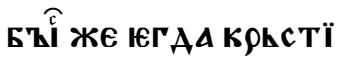

ША СА ВСН АЕАНЕ · Ï OY

K९hC THE 'ZWL CA Ï Mo

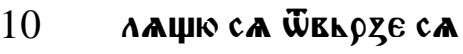

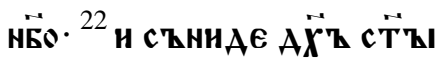

H. TKAEChH'ZIMZ $3 \rho \Delta$

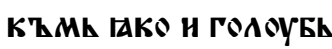

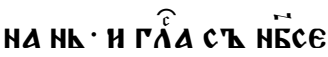

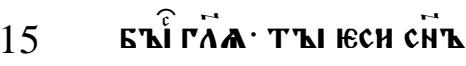

МОН В ҚЗАКБАЕНҚ/Н

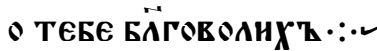

в Z в Z

в в в

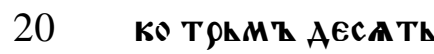

МҚ А ТTҚ НАЧнНА

IA CH'Zl ç TAKo Mh

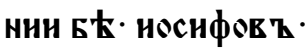

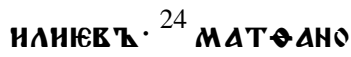

796

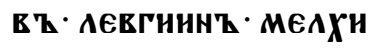

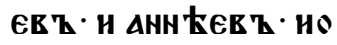
снфов ' $\cdot 25$ MАTАOHE B h - $\triangle M O C O E$ h $\cdot$ HAOY

5 МЕК' ЕСАНТОЕ ' НА

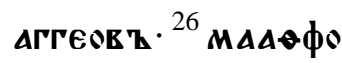
E ' $\cdot$ MAATT $\triangle O$ OE h . MAT AOHER ' CEME ннОЕ $\mathrm{h}$ - НОснфов $\mathrm{h}$. НОУАНнТ $\cdot{ }^{27}$ HОАННА

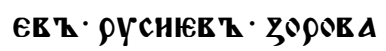

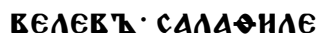
в ' ' ннонев Қ ${ }^{28}$ мелХи ER h · ААНАHER ' $\cdot$ К

15 САMOR Z EAMOHAMO в ' $\cdot$ н EAHEZOPOK Z HOAPA MOE ' ' MAT OATOE h АЕУГннт $\cdot{ }^{30}$ снМЕОНО B Z ' HOYАОВ Z - EAHAKÏ

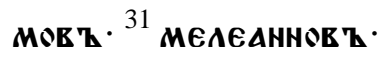
MAHHAHOE ' $\cdot$ MAT - AHOE h ' HAOAHO

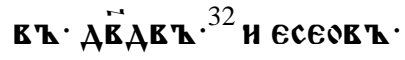


79в

ОВНАОВ $\mathbf{~} \cdot$ BOOZOE Z

СААMOHOR Қ ' HAACA

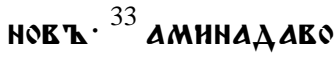

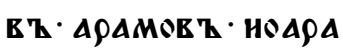

5

MOR h $\cdot$ Eс $\rho$ MOE h $\cdot$ фA

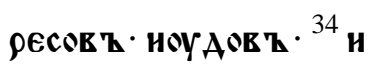

САKOBOR $\mathbf{h} \cdot \triangle \mathrm{AB} \rho \triangle M O$

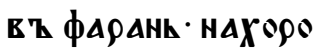

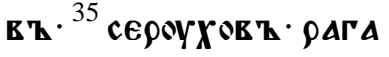

10

вов $\mathbf{~} \cdot$ фелеков $\mathbf{~} \cdot \mathrm{e}$

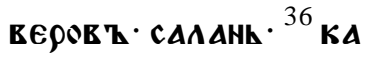

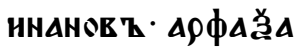

AOE h ' CHMOE ' ' HO

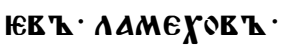

15

${ }^{37}$ MAOYCANh EHOX:

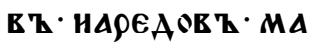

АЕАЕНАҢЕ Қ $\cdot$ КАН

Лука

HAHOE Z $\cdot{ }^{38}$ ENOCOE Z

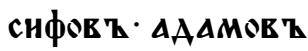

Бӝнн. ${ }^{1}$ І $\overrightarrow{\mathrm{c}} \mathrm{h}$ же испт

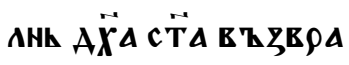

TH CA Ü HOPAAHA.

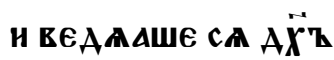

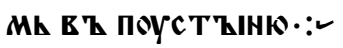

79г

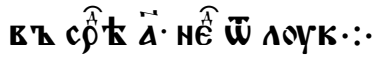

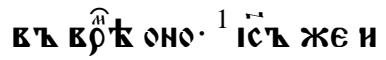

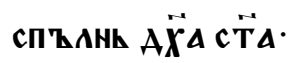

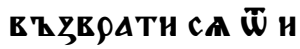

5 E९Aана н веАA

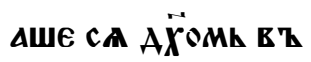

Поуст TЫसњ ${ }^{2} \cdot \vec{M} \cdot A \overrightarrow{H H}$

HCKOYW AIEMT ALIA

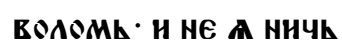

10

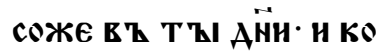

НКЦАR ҚШEMЋ СА H

MZ ПOCA ЕАH EZZАA

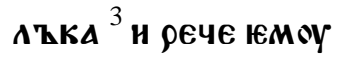

ALARONZ

15 сн Бӝнн· ९һцн кАМЕ

HHN CEMOY AA БOYAX

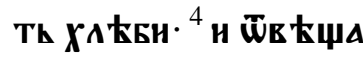

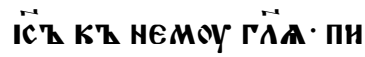

c ANO ECTR - TAKO HE W

20 ХА КБ ЕАНнОМһ ЖН

в БОУАЕTh - पӒ̈K'

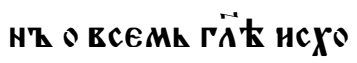

ААџнМ $\mathrm{Z}$ Н马 оүстТ

Бӝнн ${ }^{5}$ н в Қ马ЕеАЕ и 
$80 \mathrm{a}$

ALABOAT HA TOPOY B ZICO

KOY. ПOK $\triangle$ ZА EMOY BCA

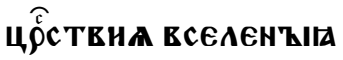

въ цАс Қ врћменьнћ ${ }^{6}$ н

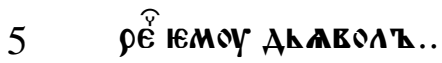

.. ААM Z вААCTh ... Eh

CN н СAAB OY HX'Z .KO

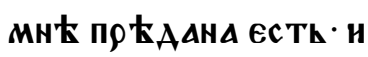

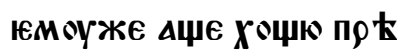

10 AАMт ${ }^{7}$ ThI оYБо Аџе

ПААТ ПОКАонНШИ СА

ПОҚАТ M ҚHOW. БOY

AOYTh TEБE всA $\cdot{ }^{8}$ H ОтТ

в Kщ

15 НАН ЗА МНОК СОТОНО

ПнсАHO БO Eс Th Г̈ОY

Б̈оY TहSEMOY ПОКА

нишн СА и ТОМоY Ю

АнНОMOY ПОСАОУжї

ши ${ }^{9}$ и веАЕ и вт нероу

СААНM ' H ПОС ТАЕН

Н НА К ФНА Ц ЦёКЕНН Е

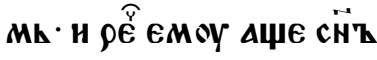

есн Бӝнн вирьзн са
$80 б$

WU COYAOY AOAOY.

${ }^{10}$ ПнсАнО БО ЕСТһ $\cdot$ Ан

IAKO АНГГАОМ Қ СЕОН

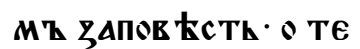

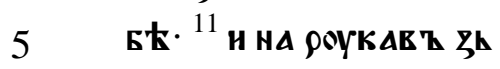

MoYTh TA AA HE KT

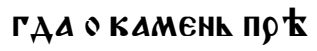

ТҚКнЕши ноГ'ҚІ ТЕО

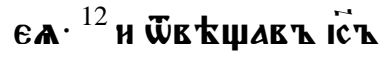

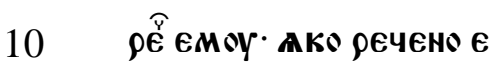

сTh ' не нскоусншн $\overrightarrow{\Gamma \Delta}$

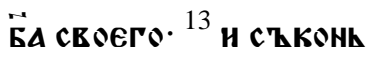

ЦАВ Z ВСAKO HCKOY

шенHE ALAROAh W

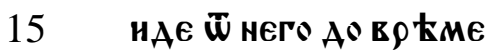

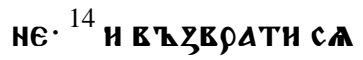

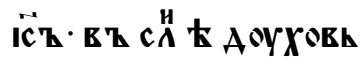

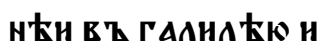

в 太сти H马нАЕ По все

20

н ст९AHK O HEMh $\cdot{ }^{15}$ H

Th oYYAWE HA C'BEO

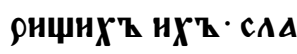

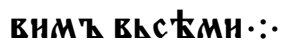

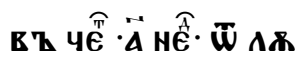

K'zl $:$ : 
80в

вไ в

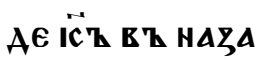

$\rho \in \phi \mathbf{h}$ в h немh

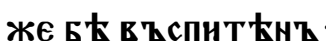

5

Н В ҚHНAE ПО WEҚIYA

N E' AN̈h coYEOTh

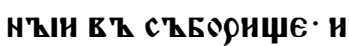

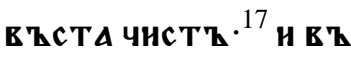

ААША ЕМоУ К'ВНнГ'ҚI

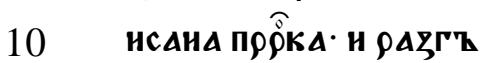

ноув Қ К' ниг'Қl $W$

Брћте м ћсто наєже

Бћ напнс Ано ${ }^{18} A \overrightarrow{X^{7}} \mathbf{Z}$

ГḦ HA MH太 EГOжE

15 ९ААН ПОМАЗА МА

БӒГОВ ҚС ТНТҚ НH

ЧнНMТ ПОСТАА MA

нсц ЕАнТи съкоОу

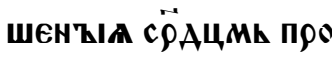

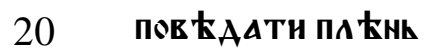

никомъ шัпоуще

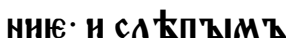

повзир Ение $\cdot$ ш̈поу

стити съкож 80г

WEn'আa в

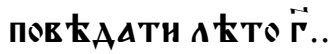

ПОНА ThHO ${ }^{20}$ H CZTKHOY

В К КҚННГ'Ы В ҚАА СА.

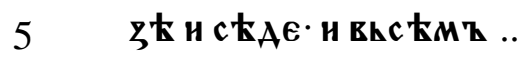

С ҚБОРНЧН ШЧН БА.СТА

Зһ ОААЧн НА Нh ${ }^{21}$ НАЧһ

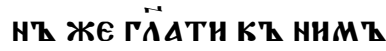

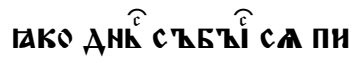

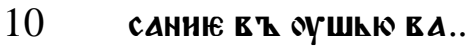

ю. ${ }^{22}$ Н всн ПосAоYшh. TEO

BAAX OY IEMOY. H AHEA

AXOY CA O CAOBECEX'

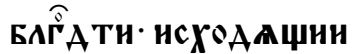

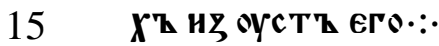

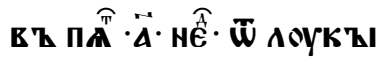

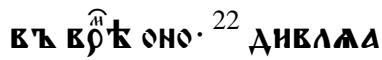

XOY CA HAPOAH OCAO

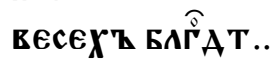

20 сХОААџнНХИ Н

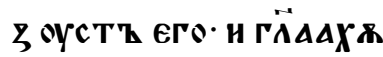

HE Ch АH ECTh CH' HO.

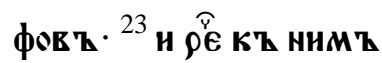

ВСАКО РЕЧЕТЕ МН ПФН 
$81 \mathrm{a}$

ТҚ पाN СНК- В РАЧЕ Н

СЦ ҚАН СА САM - EAH

KO сAтIWAXOMZ БҚI

в ҚШНнХ' в Қ КАПК $\rho$

5

HAOYM 太 сZ TEOPH ..

АЕ В Қ ОЧИс ТЕНн СЕОЕ

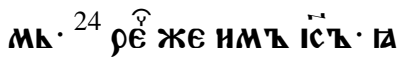

ко ннкоторҚынже

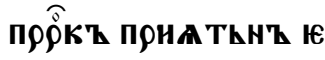

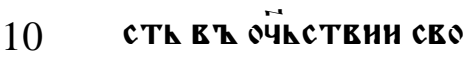

EМи. ${ }^{25}$ в т ис тиноу же

ГӒК вАМТ ТАКО МнО

ГҚІ ЕЪАОЕНЦ Е Б КША

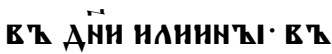

15 НН̈АН ЕГАА ЗАТЕО९Н

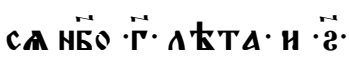

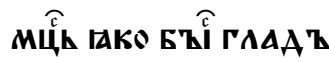

велнк' пе вһсен зе

МАН ${ }^{26}$ Н нН К' ЕАНно

20 Н ЖЕ нХ'И ПОСТААН'

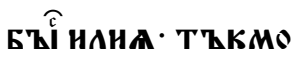

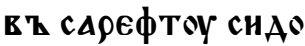

нискоук к' женt

в ҚАОБНЦН $\cdot{ }^{27}$ Н Мно
816

ЗН БААХОУ ПООКАЖЕ

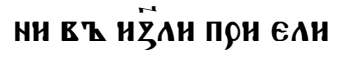

сћн пр९цн· н нн ЕАн

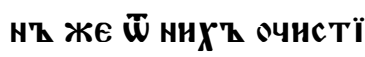

5

СA. HZ TZKMO HEO

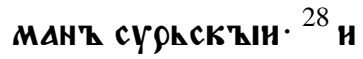

СПЪАННШАСА ВСН

ГАРОСТИ НА СТЕОРН

щн сА ҚІшАџн. ${ }^{29}$ н Е Қ

10

с TAR ZWE HZГ'ZHA

ША И ЕТНТ Н马 ГОААА

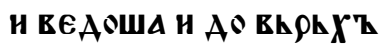

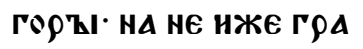

AT HX'Z CZ弓ZZAAH'

15 БААШЕ АА БҚIША

Н ННЭ'Қ РНнОУАН -

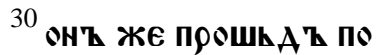

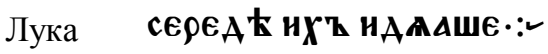

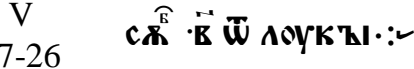

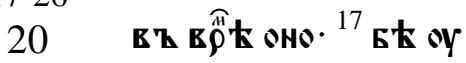

YA IC̈k EA AXOY ck

AAще фарнс $\mathrm{K}$

Н ЗаКоноОучнте

Ан· нЖе БА АХУУ прї 
81 в

ШhAH ש̈ BhCAKOTA

всН ГААНА ҚНСКЫ

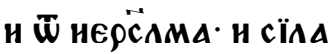

ГН̈A Б大 ЦЕАНТИ А.

5

${ }^{18}$ и се Моужи носаще

HA OAP Е Чत̈ЕКА НЖЕ

БҚ ОСААБАENZ ' Н СКА

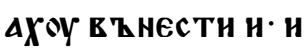
положнти ї пр $\mathrm{kAT}$

нНМк ${ }^{19}$ Н не оБрћT/

WE KOYAOY в ҚHECTÏ

HA

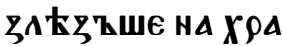

$M \mathbf{~} \cdot$ cKEOZ $\mathbf{~ c K O Y A ~}$

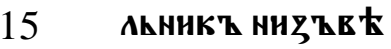

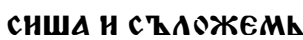

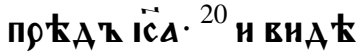

в Z в К

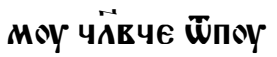

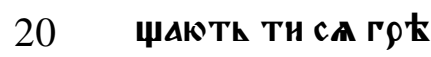

СН ТВOH. ${ }^{21}$ H HАYAWА

ПОМ ҚІША А Ти

К'ъннжьници· и

фАрнс Кн гйџе
$81 \Gamma$

КTO EсTh СH· НЖЕ ГӒTh

ВААСЕНМНК' КТО МО

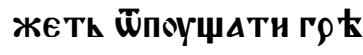

X'Ы TZKMO ЕАHнZ Б̈Z.

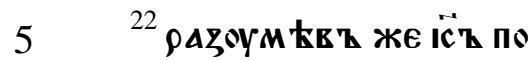

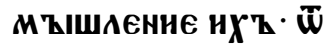

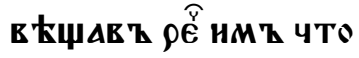

ПОМ ҚIША АЕТЕ в h

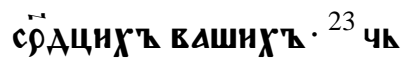

10 ТО ОУАОБ КЮ ९ЕЩи О

СААБАEHOYMOY $\bar{W}$

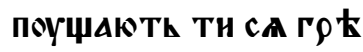

СН ТЕОН НАН ФЕЧН ЕТ

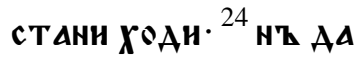

15 в 太стЕ ПАКО вААС Th

HMATK СН'Z ЧÄЕЧК

скҚин нА ЗемАн च̈

поушатн го $\mathbf{X} \mathbf{Z}$.

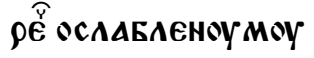

20

ТЕБе ГӒК в Қст АНH

в ЗИМН АОЖЕ СЕОЕ

HАН Е Т АОМ Т ТहOH. ${ }^{25}$ H

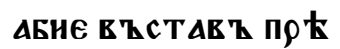

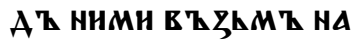


$82 \mathrm{a}$

немиже леЖАше їАЕ

В' АОMТ СЕОН СААВ А

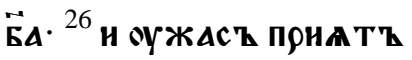

ВCA' Н CADEAAAX OY

5

Б̈ НСПҚАНHША $\mathrm{CA}$

ст९АХОМК АНЕКНО

A Ḧhch $: \because \cdot 2$

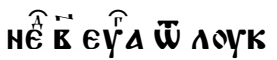

Лука

VI

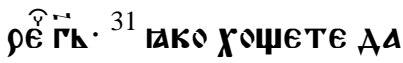

10 ТЕорА Th вА ЧӒЕЦН

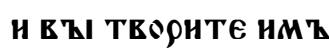

TАКОжАє ${ }^{32}$ и АџЕ Аю

БНТЕ АЮБАШАГА Е ҚI

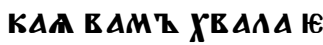

15

сТК НБО и ГО АШКнН

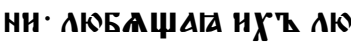

БАТТ. ${ }^{33}$ Н АџЕ БӤГОТТО

ОНТЕ БӒГОТТВоАџн

M Z BAM Z ' KAIA E $\triangle M \mathrm{z}$

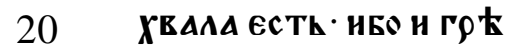

ШКници ТоЖЕ ТВоРА

Th ${ }^{34}$ н Аџе в Қ ЗАнм

ААEтЕ $\bar{W}$ ниХһЖЕ чА

ЮТЕ вЪСПрНА ТН· КА
826

IA BAMZ XEAAA ECTh

нБо н гОћШиннци

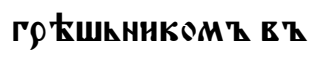

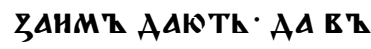

5 спрннмоуть ९АЕ

HO. ${ }^{35}$ WEAYE ANEHTE

в९АГ'Ы в АШША Н АO

Бро творнтЕ ненА

ВНААШНM В ВССҚ

10

Н ЕТ ЗАНM ААНTE.

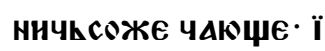

БOYAETh MhZAA вA

ША МнОГА' И БОYАЕ

TE cḦEE в ҚIULHA

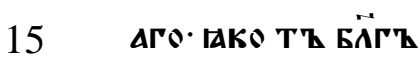

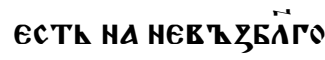

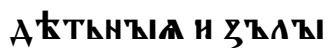

га. ${ }^{36}$ Боуа Ете оуБо мї

АОСКРАН АКОЖЕ ОЦ̆

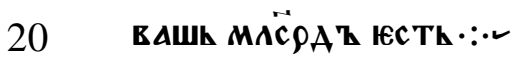

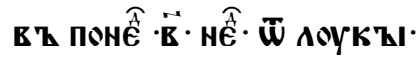

в Ћ во̆

Лука

IC̈Z EZ АОМТ СНMO

IV

38-44

нОв ' 
82 в

СНМОНА Б С ОАК ९КЖИ

MA OГHК MT ВEAHK'

Мh Н МОАНША Н О НЕ

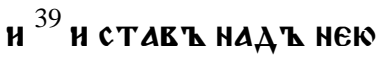

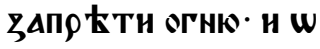

СТ АВИ Ю АБНЮ В ҚСТ Т

.hши жЕ слоужАА

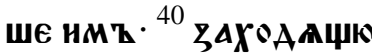

жЕ сАН̈цю всн ЕА ̈̈ко

10 HMAМXOY БONALA

IA HEAOYГTL ९AZAH

чКнҚI· прнвожААХळ

Th IA K' HEMOY. OH'

ЖE нА КогоЖАО иХ'

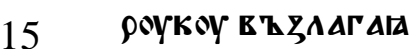

..AAwETh a $\cdot{ }^{41}$ HeXo

АAДXоYтh же в Есн.

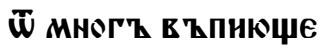

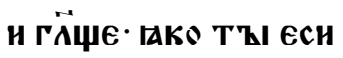

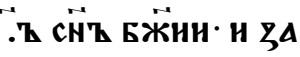

20

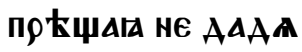

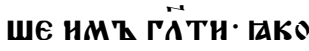

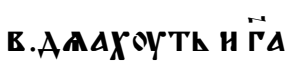

сАM
$82 \Gamma$

в Қшю жЕ АН̈н ишһ

AT HAE в П חоYсто M Е

СТО. Н НАРОАН НСКАА

XОY ЕГО и ПОНАОША АО

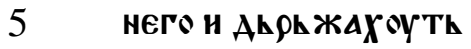

H. AA E'W HE OWh A' W

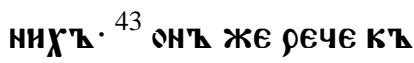

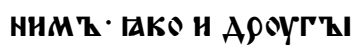

MT ГОААОМ' ПОАОБА

10

ЕТИ МН БӒГОв ЋстНТї

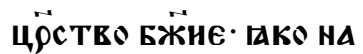

се посъААн' ЕсMь. ${ }^{44}$ H

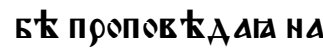

С'ВЕОНщНХ' ГААН

15 А

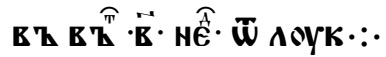

в冖 в

Лука ЮАнноми Ё ГОААА

$\mathrm{V}$ н семоужи нспт

12-16

20

Ани прокаже

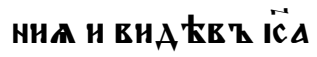

ПААЕ ННЦК MOАA СА

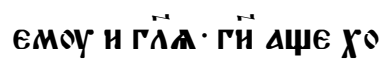

ЧЕши Можеши МА О 
$83 \mathrm{a}$

чнститн ${ }^{13}$ н прости

ръ роукоукосноу и

ректын

СА· Н АБИЮ ПроКАЖЕ

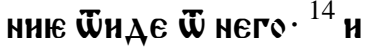

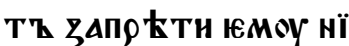

комоYже не ГӒТН· H'

ШhАТ ПоКАЖН СА Жһ

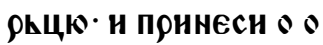

10 цнщеннн моемк

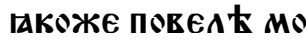

нсн в \ оцнщению

нм ъ. ${ }^{15}$ прохожааше

ПАЧЕ САОВО O HEML

15

H C'ББһ $\triangle A$ XYY CA HA

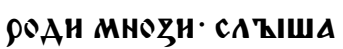

ТН НСЦ ҚАНТН СА О

Th HEAOYГT СвонX'Z

${ }^{16}$ Th Же Б

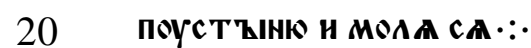

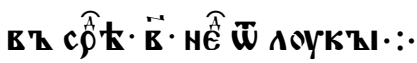

в в в

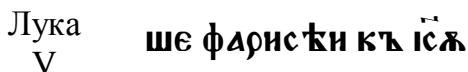

33-39 рекошА емоу. по
836

ЧТ० оҮченНцН НОА

HOEH ПOCT Т TИ СА YА

С TO. H MÄTE ҚI TEO

раTh TАKOжаE и

5 фА९нс Кнсц

и ЋАати и Пиють $\cdot{ }^{34}$ 。

н' же рєче кh ннм द

ЕАА МожеТЕ сн̈' Б९А

YKH'ZIIA AOHZAEЖE

10 ЖЕНАН СА ЕС ТИ СҚ НИ

МН СЪТЕОРНТИ ААКА

ти ${ }^{35}$ прнауУтL же Ан̈н

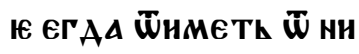

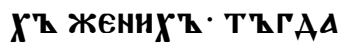

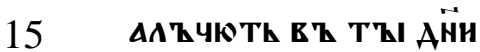

${ }^{36}$ ГӒАШЕ ЖЕ и ПрНТТ

प15 K' HHM $\mathrm{Z} \cdot$ IAKS

НнКТОже прн..А

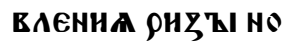

20

ВҚI HE ПОHс TАВАA

IETh HA PHzOY вE

T' ХоY. Аџе Ан же

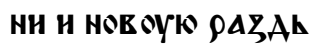

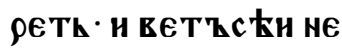


83 в

ПрНАСУчнТА СA

ПОНС Т АВАЕнНЮЕ Ю

же не ше новаго ${ }^{37}$ и

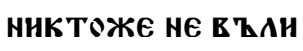

5

BAIETh ВHNA HOEA

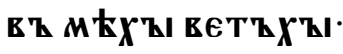

Аџе Ан Же ни· прос А

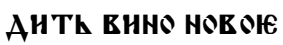

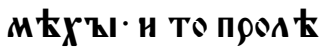

10 ЮТИ СА Н М ЕСН По

ГЪIEHOYTh ${ }^{38}$ H' в в̈̈

HO HOBO ETh M ЕX'W

HOR ҚI Е ҚАНIА ТИ

И ОБОЕ СТБАЮААТК

15

СА. ${ }^{39}$ Н ННКТОЖЕ ПН

в Қ вет ' $\boldsymbol{X}$ А АБHE

XонеTh HOBOYOY

MoY· Гत̈Th Бо вE

Th Xol $\Lambda$ oyчe

20 cTh $:$ :

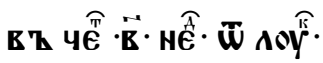

въ в

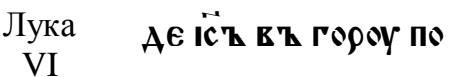

12-19 МолНТ' СА· К Е
$83 \Gamma$

ОБ ноџһ Еไ Мล̈ТЕ К

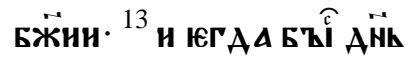

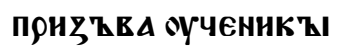

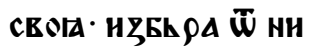

5 X'Z A'ZRA HA AECA TE

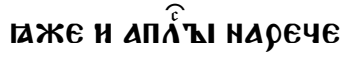

${ }^{14}$ снмона ЕГОЖе и Ме

HOBA ПETPA' H АHK

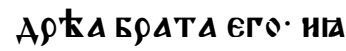

10 КовА н ÏОАНА ' фНАн

ПА н· вА९фолОМ КА.

15 H MАT O КА. H OOMX

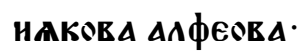

Н СНMOHА НАРНЦАЕ

15

MAГO ZHAOTA. ${ }^{16}$ Hю

AOY HIAKOBAA - HК

AOY HсKАPHOThCKA

Аго нже и Бъі пр

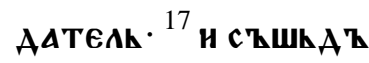

20

.. HНMH СТА HА M Е

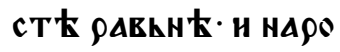

A' оYченнк' его.

МножИс ТЕО МноГО

АюАНИ Ш̈ ВсеЕА ЖНАО 
$84 \mathrm{a}$

KИСKҚIA HEPC̈AMA

ПOMOghA TOYghCKA

и снАОньска. ${ }^{18}$ нже

ПФНАОША ПОСАОУША

5

ТҚ юге· и їсц ҚАнтһ

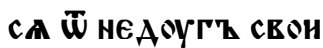

X'h म с ст९Ажюще от'

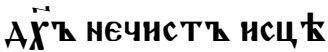

AA XoY CA ${ }^{19}$ H вCh HAPO

10 АТ НскААШE ПрНКА

САТИ СА ЮMh • ПАКО СН

АА Н马 HEГО НСXОЖА

АШЕ НСЦ ҚАААШЕ всА :

в Z ПА

в Қ в

HA M KCT T PARLH K

H HAPOAT OYЧENH

К'

МноГО АЕАНН - ש̈ все

20

и поморнга түрКскА

и сндониска. ${ }^{18}$ нже прї

AошА Пос

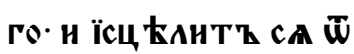

846

HEAOYГ' СЕ ОНX'Z

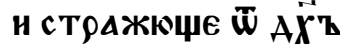

нЕчнс Т ' म Ӥсц ЕАА

АXOYTh CA. ${ }^{19}$ H ECh HA

5 ९ОАТ НСКААХОY ПФН

КАСАTH CA EMh IA

KO СНАА H马 HEГО Н

с Үожаше нсц КАА

АШE вСА ${ }^{20}$ Н Th в $\mathbf{~}$.

10 АТ ОЧн СВОН НА ОY

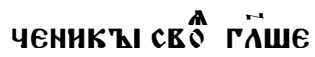

Бӥжнн нищнї $A \overrightarrow{x^{\prime}} \mathbf{z}$

Mh IAKO T kX'h ECTh

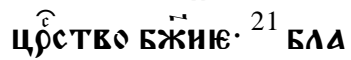

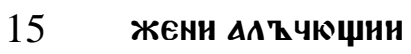

HZIN K IAKO E ҚI HA

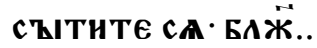

ПААЧКШН СА НҚI

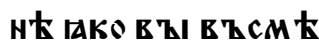

20

Ете са. ${ }^{22}$ БӒжни Б8

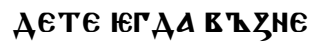

HARHAATK E'ZI

ЧӒвцН· Н ЕГАА ९А

उАОУЧАТТ ЕЫ' Н ПО 
84 в

HOCA Th ' Н ПрOHEC

Th HMA вAWE זAKO

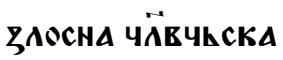

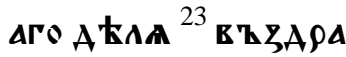

5 AоYнTE CA Bh Th

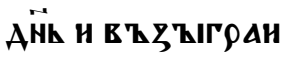

TE cA· cE MhZAA вA

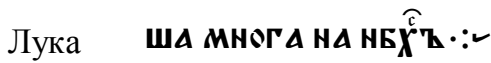

$\mathrm{V}$

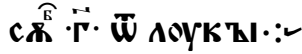

въ в

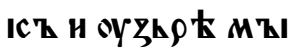

TА९A HMENh

Mһ Аевгию с 太

AАџА HА MZTTKHÏ

15

цН· Н ९ЕЧЕ ІЕМУ ПО

MZHE HAH ${ }^{28}$ H OCTA

вAh вCA в Z CA

егО нае ${ }^{29}$ н ст Творн

чрТЖЖЕнНЕ ВЕАн

20 КО АЕОУГн в Т АОМ

CBOEMh И БAшE HA

POA' МнOГ'

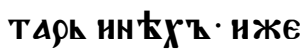

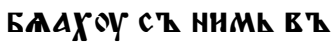

$84 \Gamma$

ЗАежАџе ${ }^{30}$ и рҺптАХж

КЂннжьннци нХ'Қ н

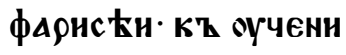

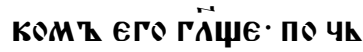

5 Тосъ мытА९н игећ

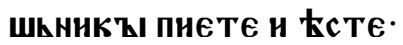

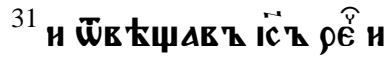

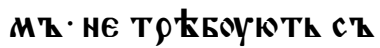

АРАЕНН БФАЧА НҚ БО

10

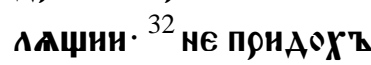

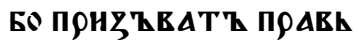

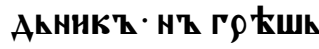

Лука

VII

11-16

15

НHКЂ НА ПОК АІАНHЕ $: \because$

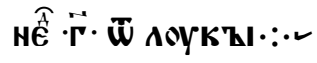

въ во̆

В Қ Г९ААТ НА९НЦАЕМҚI

Н HАHн' · Н С' HHMh

ОУченНци ЮГО. Н НА

POAт Мног' ${ }^{12}$ ГАКОЖе

20 ПРНБАНЖН СА КТ Е९А

TOMZ ГОААА Н СЕ Н马 HO

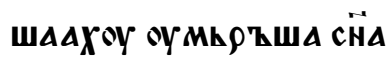

ЮАННОЧААА М Т̈ОН СЕО

EH· Н ТА БА АШЕ ह'ҚА० 
$85 \mathrm{a}$

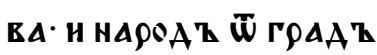

MHOГ'Қ БААШЕ сһ HE

w. ${ }^{13}$ Н внA АE'

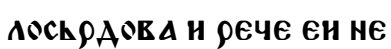

5

ПААЧн СА $\cdot{ }^{14}$ Н ПОНСТ ТУ

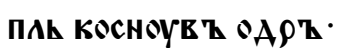

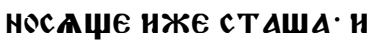

рече оуношА ТеБе ГӒю

в Ћст АнH ${ }^{15}$ н с ҚАE Mh

10 ОТЕҚІ Н НАЧАТТ ГӒТї

н ААстL н м Т̈рн своE

h. ${ }^{16}$ н понатт же стра

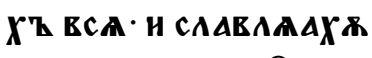

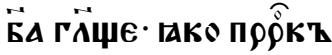

15 ВЕАНК' Е ҚСТА

E'h HAC' ' TAKO

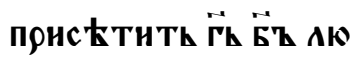

Лука Анн свонхт: $\because \cdot$ -

VI

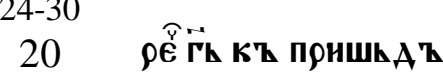

шнми К' немоу ню

A tom z. ${ }^{24}$ roge в АMт हо

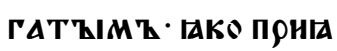

стE oYTt XoY в AWL.
856

${ }^{25}$ rope ваMт настLеE

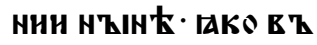

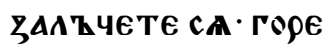

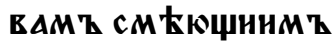

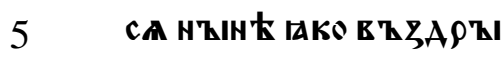

ААЮте и в ҚсппАЧE

TE ca. ${ }^{26}$ ropE ierAa AO

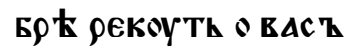

Чล̈вцН П По сEMOY TEO

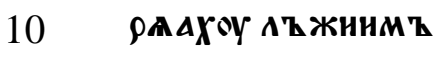

прӧкөмт оц̈н ихт

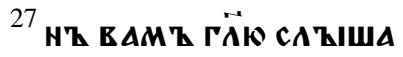

ЧНМТ - АюБНТЕ в९А

Г'Қl ВАША АОБ९О ТहO

15 ОНТЕ НЕНАВНААЧН

MЋ вАсъ ${ }^{28}$ БАГ̃

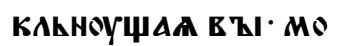

АHTE СA ЗА TEOPALA

IА ВАMZ ОБНАОY. ${ }^{29}$ БН

20

NщNMOY TA B' AE

сноуК ААнНТ ТУ ПО

ААН и Ароугоую' Н ०

ТЕМАКцюмоу оу

ТЕБе ९нदОУ И с९Аपн 
85 в

Цћ нЕ БрАни ${ }^{30}$ всако

MOY ЖE ПрОсаџ"

MoY oY TEEE AAH · H

WEMANщATO TBO

A HE HCTAZAH $\because:-$

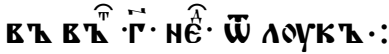

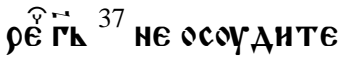

Лука

VI

37-49

10

АА нЕ осоужЕни БОУ

Аете ш̈пучцанте

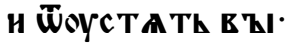

${ }^{38}$ АААНTE И ААС Th СА

вAMT M K

HATKKAHOY ПOT $\rho$ Ж

CLHOY' И ПОЕАНВ АК

15 UN CA AAAATh HA

АОHO ваше ' TOF OY

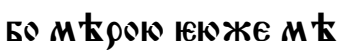

рHTE HAM K

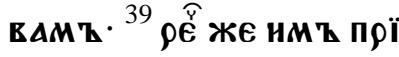

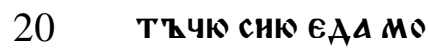

жЕтh слћпьци слћ

ПКЦА ВОАНТН· НЕ О

БА АН Е' А АMOY В'

ПAAETA CA $\cdot{ }^{40}$ H ECTK
$85 \Gamma$

оYченHК' HAA'Z OYЧї

TEАEM $\mathrm{h}$ свонм $\mathrm{z} \mathrm{ch}$

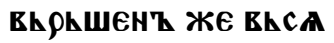

K' БOYAETh IAKO OYЧї

5 ТЕль его. ${ }^{41}$ чь то же вн

Анши соучкК' нже

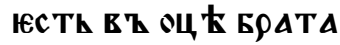

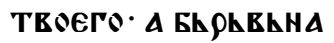

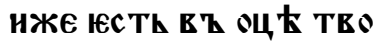

10

EMһ не чюеши ${ }^{42}$ НАн

КАКО МоЖЕшн рещн

БОАTOY TEOEMOY

ОсТ АЕн соук'И нжЕ Ю

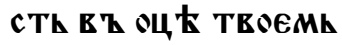

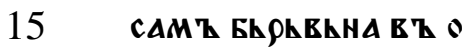

Ц Т СЕОЕМК НЕ вНАА

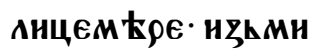

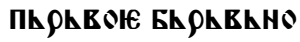

H马O SUECE TBSEГO H TT

20

ГАА Прози рншн нУА

Ти соүк' нже $\mathrm{e}$ в h 0

ц Е Б९АТ А твоєГО $\cdot{ }^{43}$ H太

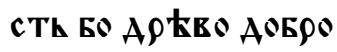

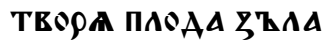


$86 a$

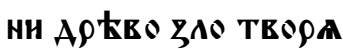

ПNOAА АОБРА ${ }^{44}$ हhCAKO

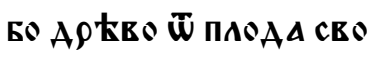

EГO ПOZHAHO БOYAETh

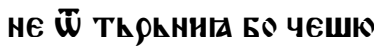

Th смокһен· нн $\overline{\boldsymbol{w}}$ КоY

ПНнҚІ Г९ОЗнНА ОБК

ЕМАКТТ ${ }^{45}$ БАГГТН БО

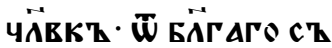

10 КФОВНЧА СРАЦА СЕОЕ

ГО Н马НОСНТК БӒГ АIА.

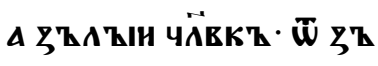

ААГО СЪКООКННА С્ФАЦА

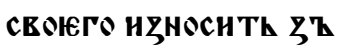

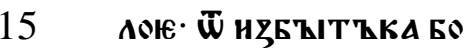

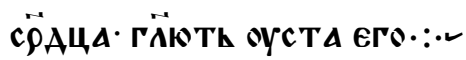

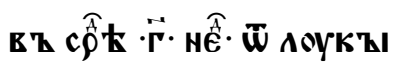

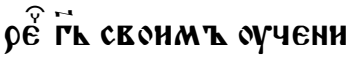

KOMz - ${ }^{46}$ पh TO MA ZOBE

20 ТЕ Г̈н Г̈н А не тв орн

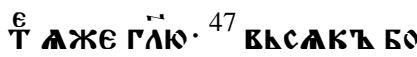

ГФААҚИ КҚ МНҚ И САҚІ

WAH CAOEECA MOIA · İ TEO

PA IА СҚКАЖю в АMҚ
866

KOMOY ECTh ПОАОБL

H' ${ }^{48}$ ПOАOБLH' ECTh

ЧӒвкоУ ЗНЖющ

МоУ ХОАМнноу и н

5 ЖЕ нскөПА' н ОугАљ

БН· И ПОАОЖИ ОСНО

ВАНHЮ HА КАМЕHН ·

НАВОАКНЕНHК ЖЕ

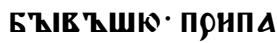

10

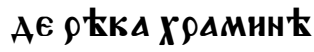

ТОН НЕ МОЖе АЕН

ГНОУТИ ЕА - ОСНО

BAHA EO EK HA KA

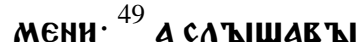

15

H HE C'Z TEOPL MOAO

БКH'Қ ЮСТИ Чत̈ЕКЖ

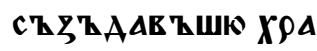

MHнOY CEON HA ZE

МАН БEZ' ОСНОВА

ННА - ЕНЖЕ ПРНПА

АА ९ЋКА Н АБНЕ ९А

Z०९н СА Н БҚі $\rho \Delta$

ЗАРОУШЕННЕ ХОА

МHнҚI TOІ ВЕАH 
86 в

ко. ${ }^{1}$ юГАА ЖЕ съконh

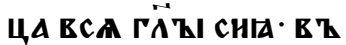

Лука

VII

1

5

в Қ ЖЕ нРОАТ четви

ОтовААC ThHї

Лука

IX

7-11

10 AОM ҚIША АШE $\mathrm{CA}$

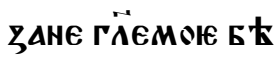

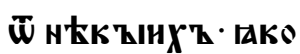

HOAH' E K CTA $\bar{W}$ Mh

ОТв ZIHX' ${ }^{8} \overline{\text { W Hнt }}$

15 Х'Z ЖЕ ГАКО нАнІа

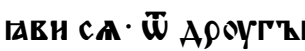

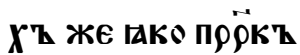

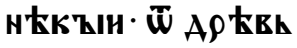

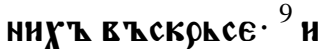

20 рЕЧЕ нРОАТ ' НОАНА

Aदh oус kкHоYX'

ктоже њстh ch w

немhже 4 Zु с $\triangle \mathrm{hl}$

WW T AKOE AIA $\cdot$ '
$86 \Gamma$

скАШЕ ВНА КТн Н. ${ }^{10}$ Н

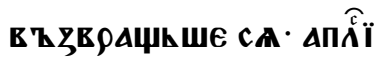
Пов \$ААША ЮMOY ЕАН

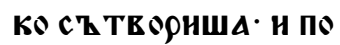

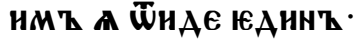

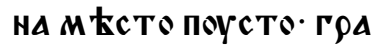
АА НАРНЦАЕМАГО вН А ТССнаА. ${ }^{11}$ нА९ОАн жЕ

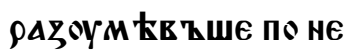
Mh НАОША' н ПонїМТ Ф ГӒАШЕ Кһ нНмъ • цёс твин Бӝни· н трt БоующАГА Ц ҚАЕнНга ц КАА АШЕ $\because:$ レ

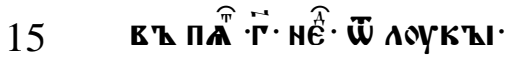

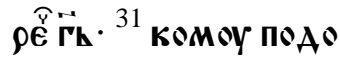
БАК ЧӒЕКЫ POAА СЕ ГO. H KOMOY COYTh חо АОБһнн. ${ }^{32}$ ПОАОБИнН СЖ Th - өтроцнщемk ck ААџнМ К НА ТҚ $९$ ҚЖ

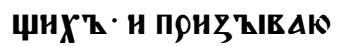

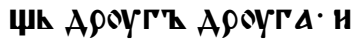
ГӒютh сопохомт вА 
$87 \mathrm{a}$

МИ И НЕ ПААСАСТЕ

ПЛАКАХОMТ ВАMТ

и не ९ЪААСте ${ }^{33}$ понаЕ

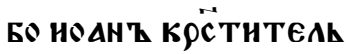

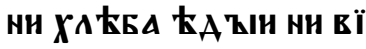

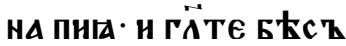

HMATh ${ }^{34}$ ПрНАE СН'

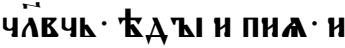

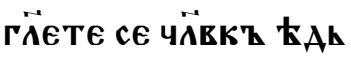

10 ЦА и вннопннцА.

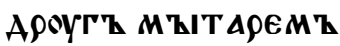

и гр Ешьником ъ

${ }^{35}$ H OIPARLAH CA ПОН

MOYАРОСТН ОT' Eh

c太Х' ЧАА' СЕОНХ' $\cdot: \cdot$

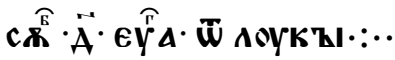

вт в

Лука

VI

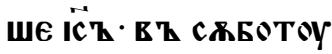

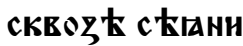

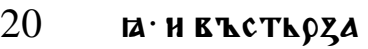

Хоу. оүченици

Іего кА Асъ. н

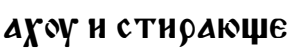

роукамА. ${ }^{2}$ Етерн же
876

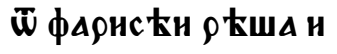

M · 4 T TO TE

ГОЖЕ нЕ АОстонт人

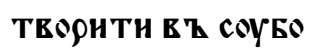

5 TоY. ${ }^{3}$ н ш̈ в

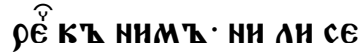

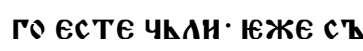

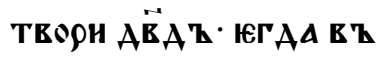

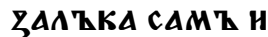

10

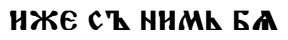

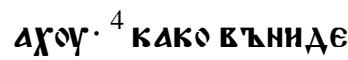

в ' АОМт Бӝнн н

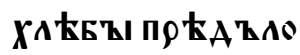

жению прннм т $\mathrm{k}$

15

с Th' H АACTh соYщн

HMT с' нHмh' HX'

же не Аостолаше A

с TH. TҚKмо иерt

OMZ EAHн 太Mт. ${ }^{5}$ H

20

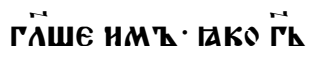

Юс Th С̈̈һ ЦӒЕЦК

ск'и соуБот t. ${ }^{6}$ Бъі

же и в һ А९оYгоYю

СОУБОТОУ - В ZННТИ 
87 в

EMоY вт ст нһ Мнще

Н ОУЧнТН· Н БЕ ТОУ

ЧӒЕК' · Н РОYКА Е MOY

АECHAIA COYXА ${ }^{7}$ H HA

5 उноААХОУТК н К'

нижьници и фА

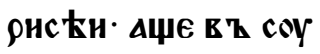

Ботоу нсц КАнти

Н АА ОБ९А џाNTh

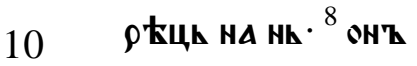

жe в БаAаше по

мъшлению их'

и рече моуже

вн нмоучюмоу

15 coyxoy poykoy. в $\mathrm{z}$

СТАНИ И ХРАН' ПО

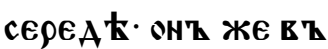

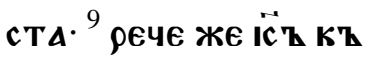

НHMҚ Е'ҚПрОшю

20 в МІ АџЕ Аостонти

В Т СЖБОТ ОУ АОБРО

ТЕОРНТИ НАН ЗАО

Творити· Аш̈ю

спётн нАн погоу
87Г

Бити. ${ }^{10}$ н възир..

HA BCA ९EYE ЮMOY.

прости рн роукоY

TEON ОН' же прост

5 ТИ И ОУТЕК९АН СА

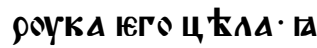

KO и ароYгата

Лука н

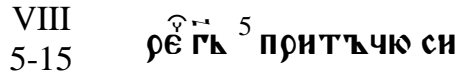

10 ю н马НАE н с Еган

с KIAT' с Қмене сво

его. и ЮГАА с KIA

ШЕ ово ПААE ПрН ПЖ

Ти и попьрано Б'

15 Н ПтицА НЁСКНЫ

a поzоваше ю. ${ }^{6}$ a ароу

rol ПAAE Ha KaME

нн и прозАБ' оY

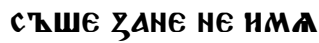

20

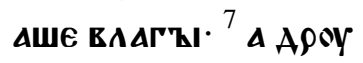

roe naAe no cepeAt

ТИ РнНIA И ПОААЕН

If ${ }^{8}$ a A

НА ЗЕМАН АОБ९ Н 
$88 \mathrm{a}$

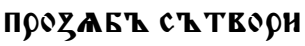

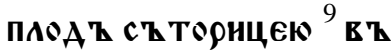

прашАаХОУ же оученї

ци юге гӒџе - чь то ес Тh

5

прнТЋчА сн. ${ }^{10}$ Онъ ЖЕ

९EपE HMT ВАMT AA

но юс Th в

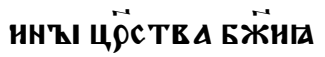

$\triangle$ Прочннм В в В ПрН

10

TZYАX'Z AА ВHАALE

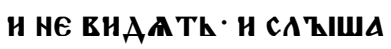

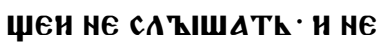

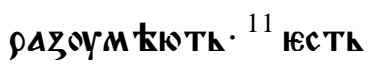

ЖЕ прнтчА сн· с Ема

15 ๒сти слово Бӝню ${ }^{12} \Delta$

нже прн поути соу

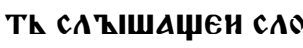

во. По тоM' ЖЕ ПрН

AETh ALIABOA'

20 ЂКМЕТИ САОЕО Ш̈ С̈АЦК

иХ' А А не в Е $\rho \mathbf{~ и ~}$

Мъше сп̈сени Боу

АОYTh ${ }^{13}$ А нжЕ нА КА

МЕнн· нжЕ ЮГАА оY
886

CAkIWATh C'h PAAOCTh

К ПОНЕМАКТ СА СА

во и сн Корене не и

моути нже в в в

5 MA в

и вҚ в९ћМа нАПАстї

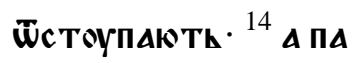

А ҚШин в Қ Тһ Рннн

сH COYTh CATIWAB $\mathrm{h}$

10 Шен шँ печААн и Бо

ГАTLCTEА Н СА АСТ Th

ми житинскҚІМн

Xотаце пOAARAa

NTh СA' Н HE AO Rh

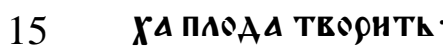

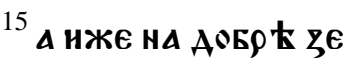

MA 太 сн соYтh' нже

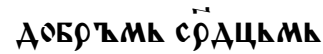

И БӒГОМИ САЪШША

20 एЕ сАЕвО Аһ ЮһЖА

Th ' H INOAT TEOPA

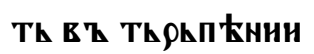

сЕ ГӒА вЪ ҚГААСН ·

MЋАН ОУШH САЫША 
88 в

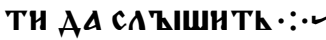

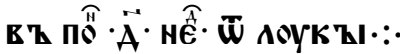

Лука

VII

$36-50$

5

$$
\text { в' в }
$$

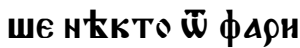

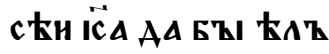

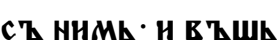

AT ET АОMт фА९ї

сћовт в һһАеже ${ }^{37}$ и

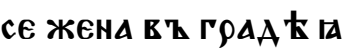

10 жЕ Бћ г९ћшьницА

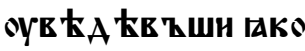

в ҚЗАЕЖЕ в Қ Х९АМн

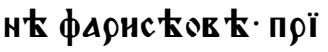

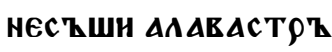

15 Х

उААН ПОН HOГОY Ю

ГО- ПА АЧюџИ СА НА

ЧА МочнТн нO马末 Ю

ГО САК弓АМН Н К ВАА

20 C'ZI ГАAВ ҚI СЕОEA O

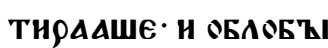

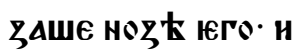

Mazawe ХOHzMо

w. ${ }^{39}$ вна Ав Ђ ЖЕ фА
$88 \Gamma$

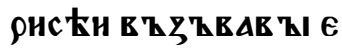

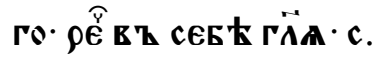

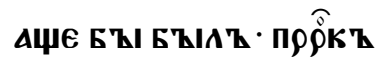

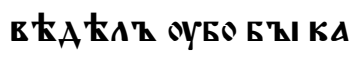

5

КОВА ЖЕНА ПОНКАСА

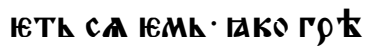

ШьницА юсть $\cdot{ }^{40}$ н ш̈в 太

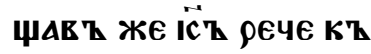

немоу. снМОне иМА

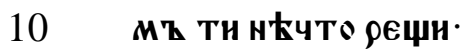

онт же ९ече оүчнте

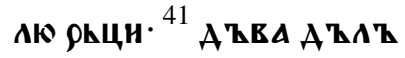

ЖһннкА БЕсТА ЗА

HМОААЕКЦК нЕКО

15 ЮМОУ ЮАНH' АТА Z

жhH' Б

C'BT' АНH

ГҚH Па THК АECA

Th. ${ }^{42}$ не нмоушемА

20 ЖЕ нМА вһ弓ААТн

OБ太MA $\tilde{w}_{A A} \cdot$ KOTO

ОВН ОУБО ПАЧЕ हТ

ЗАюБНТһ и ${ }^{43}$ ш̈в

ЩАВ Қ ЖЕ снМОн' 
$89 \mathrm{a}$

рече емоу' непьџю

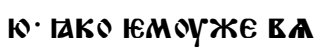

ШЕ онт жЕ рЕЧЕ ЮМА.

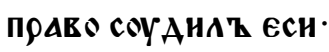

5

${ }^{44}$ H ОБРАТИЕ Қ СА K'

нен - рече снМоноУ

вНАНШН АН СНК ЖЕ

HOY' ПОНАОХ' Е Z TEO

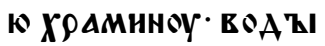

10 HA HOZ Т МОH HE AА.

сН ЖЕ сАһЗАМн ОМ०

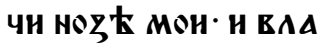

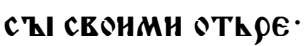

45 АОБЪЪАННАМН нЕ

15 ААсть '

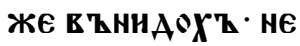

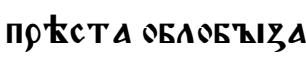

ющн ногоу моек.

${ }^{46}$ MАCA

20

Mh ГАAR 'ҚI MOE A HE

ПОМАЗА СН ЖЕ ХОН

उMON ПOMAZA HO

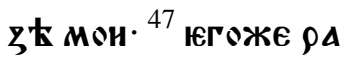

Ан гӒю ти
896

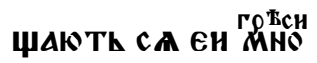

ЗН· ГАКО в ҚЗ ЗАКБН

многе - $\triangle$ Емоуже

Mhне ẄпоушаIETh

5 СА МһньшнМт Аю

Бити н. ${ }^{48}$ рече ЖЕ Юн.

Ẅпоушаютh са TE

Бе ГО Қсн ТЕОН. ${ }^{49}$ н нА

YАWА вһЗАЕЖАџн

10 с' ННMһ ГӒАТН Е

ceEt· KTO ch EcTh

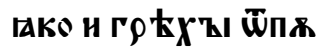

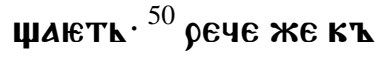

жEN Е - в

15

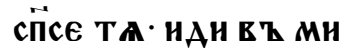

$\rho \mathbf{h} \cdot: \cdot 2$

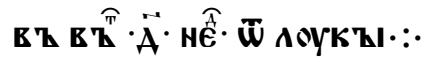

в в в

жАWE ic $\mathrm{z}$ с $\mathrm{kg}$

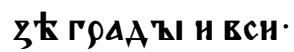

пропев Е ААІа н

БӒГОв Ћс Тв оYта ЦК

сАрһс тво Бёне' и

oga ha Aecate ch hH 
89в

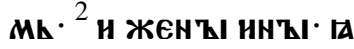

ЖЕ БА ХоY исц ЕАЕ

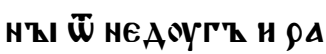

н' Н н $A \vec{\gamma}$ '

5

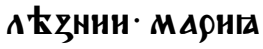

нАрНЦАЕМ АIА МА

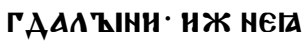

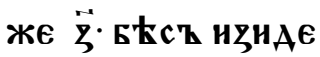

${ }^{3}$ HWAHHA. XENA XOY

10 ЗАНА ПФНСТ ТЕКНН

КА НООАОВА. Н COY

CAHA' HНTI MHOГ'ҚI

ГАЖЕ сАоYЖАА ОУ

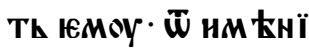

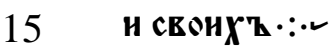

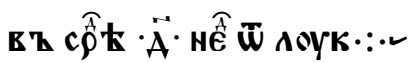

въ в

Лука

VIII

22-25

20

и оученнци его

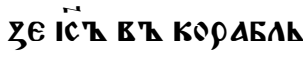

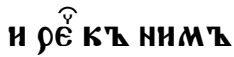

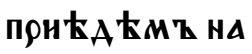

OHOY стPAHOY EZE

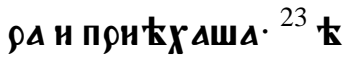

Аоушеми же нмт
89 Г

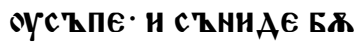

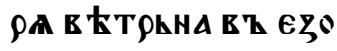

PO И C'ZKOHKYARAA

XOY СA· H В' БЕА Е БҚI

5 вААХОY. ${ }^{24}$ прнстоупн

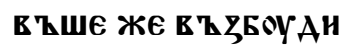

ША и ГӒџЕ нАСТА

ВһННЦЕ ПОГҚIБНЕ

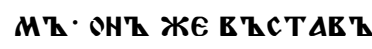

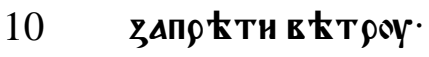

Н в ҚАҚНЕНHК Морь

скоумоу. н оулеже

н Бъі тншнна ${ }^{25}$ н ре

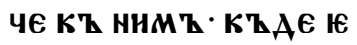

15

с Th в К

Aв ZWE ЖE CA पाNAH

WA CA K' CEEE ГÄLE

Kh TO OYEO ch ICTh.

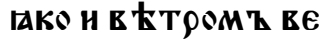

20

АНTИ Н ВОАЕ И ПО

c COYWAKTh IER -:

в Z Ч

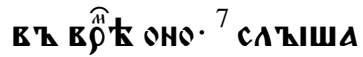

IX

7-18

в Ж ЖЕ ноОА' четЕE 
$90 \mathrm{a}$

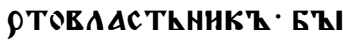

вАющАI

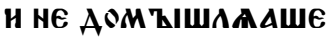

ZанE ГÄE MOЮ Б大

H太KҚIX' · IAKO HOAH'

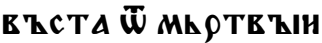

$\boldsymbol{X}^{\mathbf{z}} \cdot{ }^{8} \overline{\mathrm{w}}$ ин $\mathrm{k} \boldsymbol{X} \mathbf{\mathbf { z }}$ ЖЕ Гако

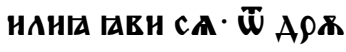

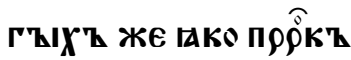

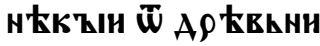

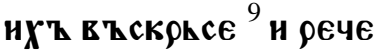

HPOAT ' HOAHA AZ' OY

сћкноуХһ · Ктоже ๒

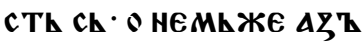

15 СА'ЫШК Т АКОВАГА

скаше внА Т Ти н. ${ }^{10}$ и

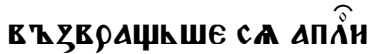

Пов Е ААWА ЮMOY ЮАн

ке с 'z TE

20 Ш̈нАЕ ЮАНH' НА МЕ

стО поYс TO ГPAAA HA

९нЦАЕМА ГО вНАСАН

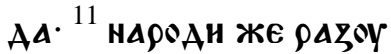

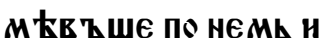

906

AОША' Н ПФНнМ' ГА

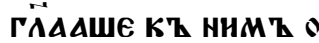

цёс твнн Бӝни· и т $\rho$ 太

Боующага ц ЋАЕни

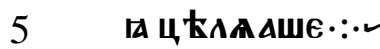

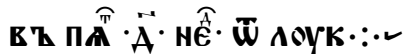

вт вӧћ оно. ${ }^{12}$ прнши

Atwe Kh icoy $A$ h

BA hA AECATE pE

10 KошА юмоу $\bar{W}$

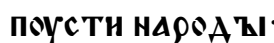

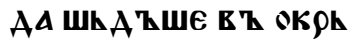

С ThHAД вСН Н СENA

НАОYТК Н ОБРАШЮ

15 Th Брашино 'аKо ch

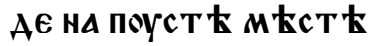

юсми. ${ }^{13}$ рече же кһ ни

$M \mathrm{~h} \cdot$ АААHTE HMh

в Қы Łстн· онн же $е$

20

KошА ЮMоY. HE HMA

Mh ChAE ВАџЕ ПАТИ

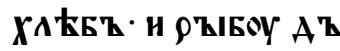

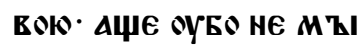

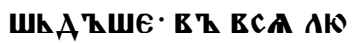


90в

АН CHIA KOYПHМ'

Б९ашина ${ }^{14}$ Баше Бо

MOYЖK IAKO ПA Th

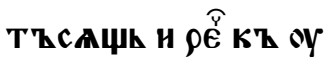

5

ченнкоMт СвонМт

ПОСААНTE ГА НА ОКОАҚІ

ПO ПАTH AECATZ ${ }^{15}$ H

C' TEорHША Т АKO H

ПОСААНША ВСА ${ }^{16}$ ОН

10 .. же $\cdot \overrightarrow{\mathrm{e}} \cdot$ ХА

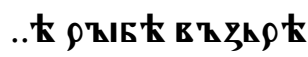

В Қ HА HËО БӒГОCAO

ви ГА. н ПрТАОМн и

AАAше оученико

15 М свонм

Аожити нарОАОУ ${ }^{17}$ Н

КША всн и нАСҚIти

.. СА· Н вҚ马ашА Н

..в7шеほ нMт оY

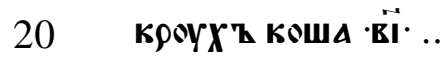

18 ..ЕГАА MONAUI..

..ЕАНнҚ И С' НИ

M. EAAXOYTh OYYE

нНцН єеГО : $:$ -
90Г

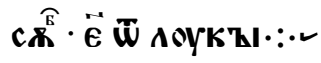

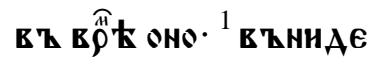

Лука

VII

$1-10$

5

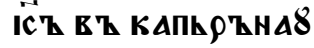

M th ${ }^{2}$ ch ThHнK ОY

жe ntKoemoy pA

БT БOAA 马 KAO OYMH

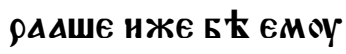

YhCThH' ${ }^{3}$ CATIUAB '

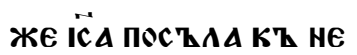

10 Моу ст А९һЦА ЖНАОВ.

CKA MOAA H· AA WhAT

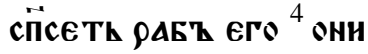

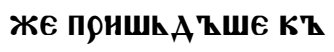

IC̈ЕН MOAAXОYТИ Н

15

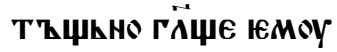

IAKO АОстоHн' ECTK

ІеЖЕ АџЕ ААСн ЕМоY

${ }^{5}$ АюБнтһ БО газ'К'

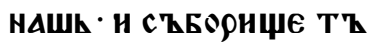

20

ch弓hAA HAMZ ich ..

haAwE ch HHMh IE

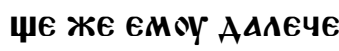

CoYwoY $\bar{W}$ AomoY no

chAA ...... AP APOY 
$91 \mathrm{a}$

ГZIA CZ TLHНKҚI

ГӒА ๒MOY Г̈Н· не АЕН

жH сA HKCMh БO Ao

с TOHнT АА ПОА. К९O

5

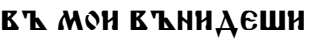

${ }^{7}$ т ҚМи ЖЕ нН сеБе А०

с ТОНнА С' ТЕО९нХ'В

ПрнТи Кһ СеБЕ· H'

Оьци словоМк нсц

10

А Еютh отрокт мо

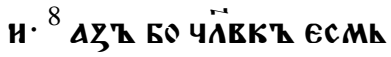

ПОАТ ВААСТЕАН ОУ

ЧнНЕнТ · НМ ЕГА ПО

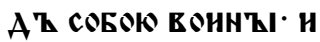

15

ГӒК СЕMOY НАН Н И

АETh ' н Ароугоумж

ПФНАН И ПФНАЕТЬ

Н РАБОУ MOEMOY $\mathrm{ch}$

TEери се н сһ TE

20 Th ${ }^{9}$ Н САҚIWAR 'Z СE

ic'z АHEH CA ЮMOY

Н ОБ९АТНЕ ' СA ПО

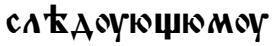

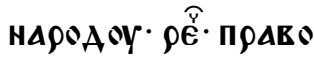

916

ГӒऽ ВАМҚ НН Е Қ И

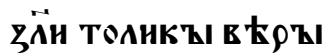

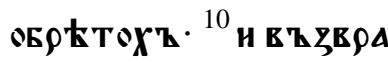

THE ZWE CA B'Z AOMT

5 ПОСҚААННИ ОБ९ћ

TOWА БӒАШААГО

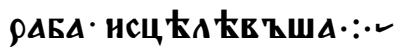

Лука

HÊ⿱乛龰 $\cdot \vec{E} \cdot W$ БоГАT KMh

XVI

19-31

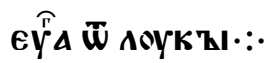

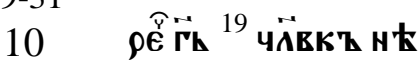

КЪН БҚ Бг̈АTZ

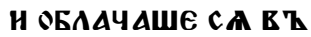

БАГРАНИЦК ЧК

рвеноу весеќA HA

15 вСА АН̈H Сह КThА

${ }^{20}$ нищни жЕ БК н ККТО

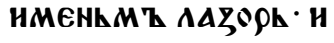

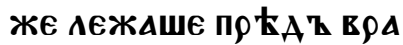

ТҚ юГО гноннъ $\cdot{ }^{21}$ и по

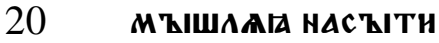

ТИ СА·

ПАААКЧнНХ' С'

Т९AПЕ马Ы БОГАТ АГО

Hһ И Пси ПрНХОАА 
91в

ЧЕ ОБАН马АХ ОY ГНОН

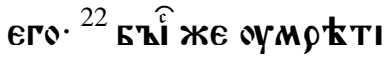

ннцюм оу н несе

HOY БҚITH АН̈ГА'ҚI

5

HА АОHS АВ АМАE.

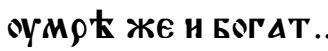

н. н погревоша. ${ }^{23}$..

АA И КТ ЗЕЕАТ ОЧн

СЕОН СҚH ЕТ МоуКА

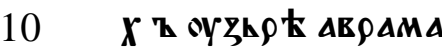

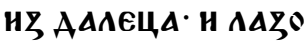

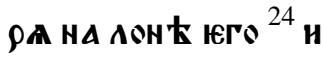

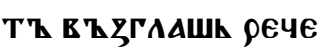

จӵе АврАме помн

15 МОУН МА' Н ПОСҚАН

АAZОРА АА ОМОУЧнТТ

КОНьци ПК РСТА СЕО

EГO в В веA Н ОУсTЖ

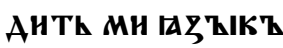

20 Мон ГАКО ст ФАЖю

в Қ ПААМЕнн семи

${ }^{25}$ рече же АВрАM · पА

АО ПОМАНИ ТАКО

ПрНГААҚ ЕСН БӒГА
$91 \Gamma$

IA TEOA в Ж ЖHEOT 太

TROEMh $\triangle A$ A 4 OOPh

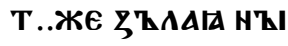

нћ жE chAE OYT kWA

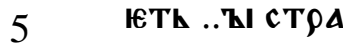

жЕшн. ${ }^{26}$ н HAAт вhct

Мн снмн МЕЖю вА

МН Н НАМН ПрОПА

с Th ВEAHKA OYTEK

10

PAH CA TAKO AA XO

ТАџн МннОУТИ

Wु COYAOY KT BAMT

HE в'Z ZMAT ANTh ·

ни нже W TOYAOY

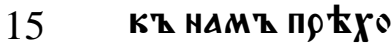

Aа Th ${ }^{27}$ рече

AN TA OYБO WÜE AA

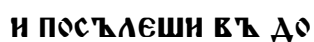

м т оц̈А моего ${ }^{28}$ нмА

20 МИ БО ПАТТ Б९АТИ

E. IAKO AА.O в Есть н

MТ АА НЕ И ТИ П९Н

AOYTh HA M Естосе

моученою. ${ }^{29}$ ГӒА ЕМ及 
$92 \mathrm{a}$

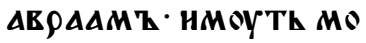

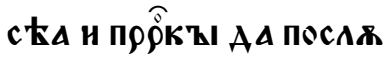

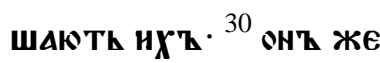

ОЕЧЕ ни РӵЕ АВ РАMЕ

5

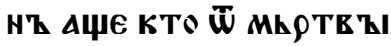

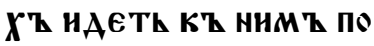

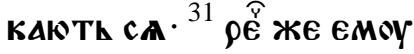

Аџе мосеА н прёк

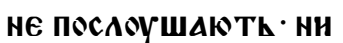

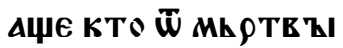

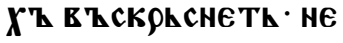

нмоуть в Е $\rho \mathbf{Z l} \cdot \because \cdot$ -

Лука

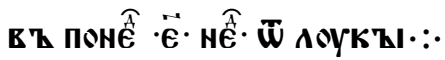

IX

в Z в

ić moname ca eah

HҚ· СҚ Ннмн БАХЖ

оученнци юго. н

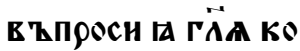

ГО MA MhHнTh HA

20

POAҚ БҚІти. ${ }^{19}$ Они ЖЕ

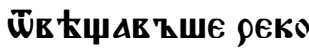

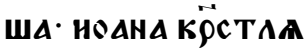

и инн ЖЕ иАню ..Ви

нЖе гако пр९्... .Ан
926

н'

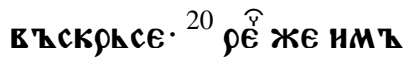

в же кого гӥете

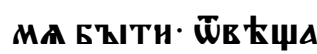

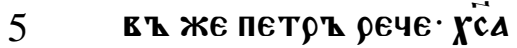
Бӝнга ${ }^{21}$ онт же запр

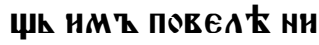
комоуже не ГӒАТИ сего. ${ }^{22}$ реK' IAKO TOAO

10 БАЮТИ СН̈ОY Чत̈ЕЧК скоумоу много по

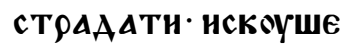

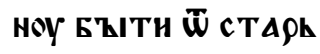
ци ' н жирьци ' н кни жникъ' н оуБненоу

БЪІтн· н вЪ ТрЕТи

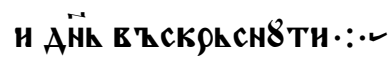

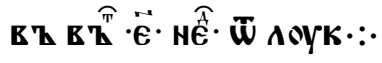

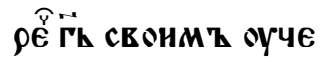
никомz $\cdot{ }^{23}$ Аще кTо Xо山еть По мzнЕ и

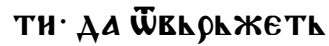

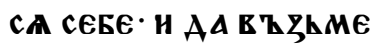

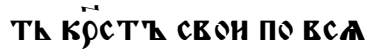


92 в

АН̈Н ХОАНTL ПО МHЕ.

${ }^{24}$ нже БО АџЕ ХОџеТК

Аш̈ю свою съпАстї

ПоГОУБНТА $\mathrm{N} \cdot \triangle \mathrm{A}$

5

же Аще погоуБить

o Aய̈̈ свок мене

९АAH TZ cIICETh

o ${ }^{25}$ Kaाa Eo nosh za

Чล̈вкоУ АџЕ ПрНо

10 Брашеть всь мнрт

$\triangle$ СеБЕ ПОГОУБИТК

Ан отъщетить ${ }^{26}$ н

же Бо Аџе пост Қl

АНTL СА MENE И MO

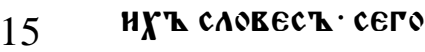

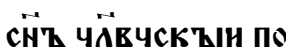

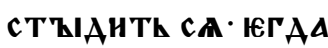

ПОНАETИ в' САAB $\mathrm{K}$

своен н шӴн म с $\overrightarrow{\text { TXर }}$

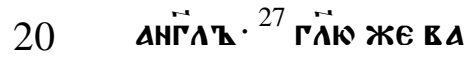

MТ ЕТ НС ТИноУ $\mathrm{CX}$

Th А९оузни ше сто

Аџннх'В сhAE' Н

He

Же нмоYти в \KоY
$92 \Gamma$

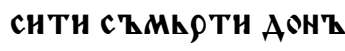

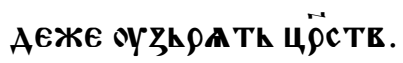

Лука є Бӝню::-

IX

$44-56$

в Қ cộ

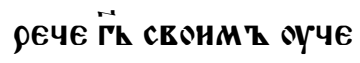

ннкомъ - ${ }^{44}$ в ҚАОжн

TE в ВІ в Қ оүшн вА

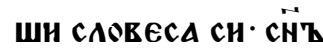

БО Чล̈БЧсКҚИ НМА

10 Th ПФ АААТН С А Е

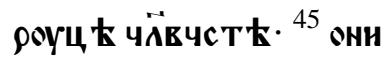

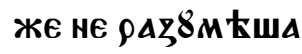

ГӒА сего. Бћ Бо прн

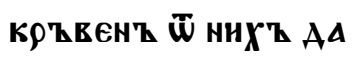

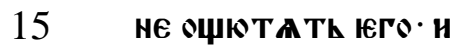

БOAXOY CA EZMOOCH

TH EГO W ГÄ

${ }^{46}$ в ҚнНАЕ ЖЕ ПОМЫ

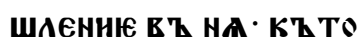

20

БОАНН БҚІ БҚІМ $\cdot{ }^{47}$ Н

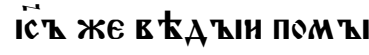

ШАЕнНА С̈РАЦА ИХҚ

ПОНнМ Т ОТ ООчА ПО

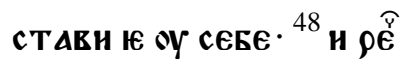


$93 \mathrm{a}$

нм ' нЖе Аџе прнї

METh WT Poua ce в'

НMA MOE MA ПрНЕ

МАЕТИ НЖЕ АЩЕ МА

5

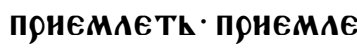

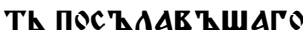

МА НЖЕ БО МИНН ІЕ

cTh вhct X'h вAch ch

Ести велни. ${ }^{49}$ ய̈в КџА

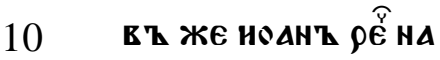

ст АВКнHче ' ВНА

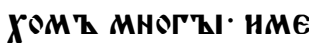

HLMT TEOHML $H$

马ГОНАџА Б Қсһ и

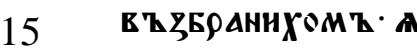

KO в' сA

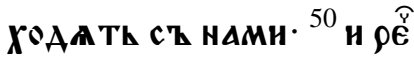

Kh HEMOY IC $\mathrm{r} \cdot \mathrm{HE}$

Браните $\cdot$ нћсти

20 Бо нА в ҚІ НЖЕ Бо нЕ

С Th HА в ҚI ПO в AC'Z

IECTh $\because:$.

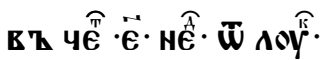

въ врћма оно ${ }^{50}$ прї
936

стоупль Kh icoy $\mathrm{E}$

Анн' $\overline{\mathfrak{w}}$ оученнк'

ERO gÊ EMOY. HACTA

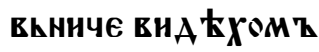

5 НноГО НМЕнКМ Т

TEOHML Н马ГОНАША

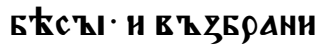

XOMZ EMOY. AKO $\mathrm{B} \mathrm{K}$

CA ЕАТ HE ХОАнTL

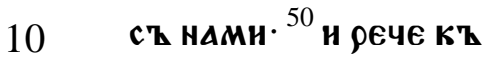

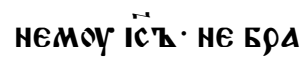

нHTE њMOY' HЕсTh

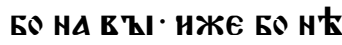

C Th HA E ZI ПO BACK

15 Ести Б1 биі же егАА ст

KOHh YAR AX YY СA Аस̈H

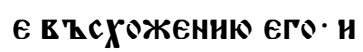

TҚ ФУТЕК ААН АнцЕ

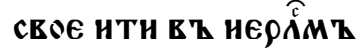

20

52 ї постАА в Кс ТКни

КТЫ ПФ ААТ АнцК Сво

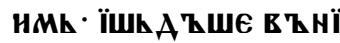

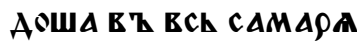

HhCKOY AA OYГOTOBATh

EMOY ${ }^{53}$ H HE ПОHAWA EГO 
93в

АКо Анце ЕГо Б К Г९А

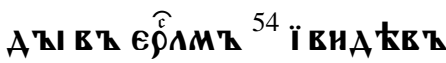

WА УЧEHIKA ЮГО· НАKOE T

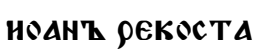

5 Г̈н ХОџешн АА $\rho е$

чев $\mathrm{t}$ A $\triangle$ огнh $\mathrm{ch}$

HНАETИ C' HЁЕ И

ПОАСТИ А' ДКОЖЕ

.. ca ç troph. ${ }^{55}$ 。

10 БФАТНЕ Қ ЖЕ СА ЗА

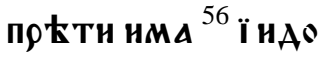

WА ETh INOY BCh $: \because$ -

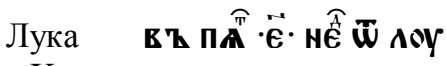

$\mathrm{X}$

1-15

15

в' воЋ Ма оно ${ }^{1}$ a

ви инसX' $\overrightarrow{0}$ oYче

ннк' $\cdot$ и пос'

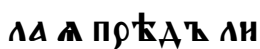

ЦКМИ СЕОНМh - $\mathrm{Z}$

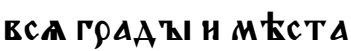

20 НАЕЖЕ сАM

Аше итн ${ }^{2}$ ГӒАше

K HHM $\mathrm{Z}$ ЖАTE $\triangle$ OY

Бо многА. А А ҚААTE

Ah MANO MOAHTE
$93 \Gamma$

..

CA OYEO FHOY XA T

в А А H૬вEAETh $A$ t

5

МАTE八A HА ЖATE 8

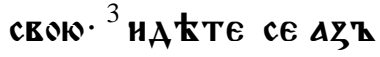

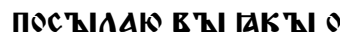

вцА По сеРА Е вАҚК'

${ }^{4}$ HE HOCHTE В ҚААГААH

10 ША· нН М ЕШКцА нН СА

пог' и ннкогоже нА

поути не ц ЋАоунт.

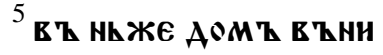

АETE КОАнЖһ AO- Пh

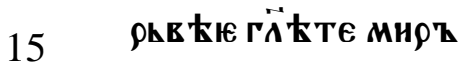

AOMOY семоу ${ }^{6}$ н Аџе

BOYAETh TOY CH' MÏ

९А Почнњ Th HА нH

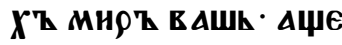

20

АH HH K' ВАM Z E $\mathrm{Z}$

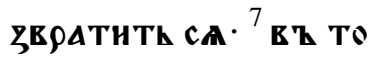

мh жE AOMOY прt

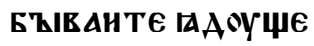

и пиюще паже соуть 
$94 \mathrm{a}$

HA HHX' $\cdot$ AOC TOHH' EO

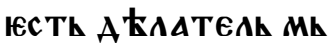

ЗАТЫ СвоEA - HE ПОнХ०

АНТЕ Н马 АOMOY Е' $\mathrm{Z}$ AO

MOY. ${ }^{8}$ н в В НLЖE ГPAA'

КОАНЖИАО в Т ХОАН

ТЕ ПрнемАюти в ҚI

ААНTE ПОКАТААГА

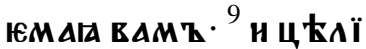

10 ТЕ нЕ АОУЖинҚІІа н

же coYTh в ' немh ' н

ГӒТЕ имъ ПрнБАн

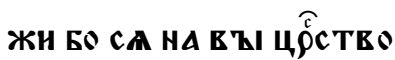

Бӝню. ${ }^{10}$ в һ ниже грА

15 АТ КОАнжиАО в Қ ${ }^{\circ}$

АНТЕ н не ПрНЕМАю

Th вАC' · HшhА 'hше

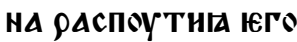

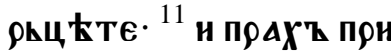

20 АКПЋШин насъ

AА вАшего в Қ ногА

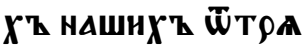

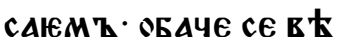

АНТЕ ГКК ПФНБАН
946

жн са HА в цІ цёство

БӜню. ${ }^{12}$ ГӒю же в АМт

IAKO COAOMAAHOMT

B T TZ ANH ẄPAAh

5 нКЮ БоУАЕТИ неже

гоAAOY TOMOY. ${ }^{13}$ rope

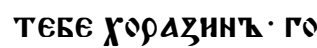

DE ТЕБе вносАнАO

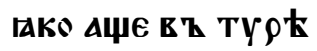

10 Н СНАОН Е БҚIWА СН

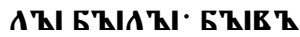

WAIA B' B BAW חо K

ЖE OYБO в Т вАACA

ннци н попелt $\mathrm{ct}$

15

ААШЕ ПОКАГАИН СА

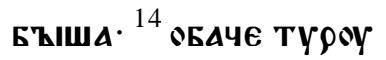

н сHAOHOY ẄPAALH

I EOYAETh в'Z COYA $\mathrm{K}$

нежЕ вАМА ${ }^{15}$ Н Т'Қ КА

20 ПеренАоYMе АО нЁсе

B ZZHEEC ' CA AO AAA

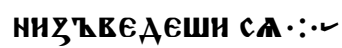

Лука

VIII

16-21

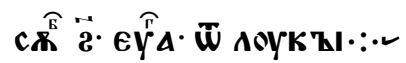

рече $\overrightarrow{\text { rh }}{ }^{16}$ ннктоже 
94 в

CE 太 ТНАКННКА Е '

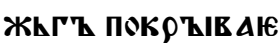

Th ero chcoyathmh.

НАН ПОАТ ОАРZ ПОАТ

5

МАГ АIETh H' HА СB Қ

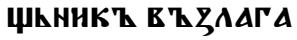

IETh АА В ZX РААШH

H EHAIATh CE ETT

${ }^{17}$ HECTh БO TAHHOE

10 ЖЕ НE ТАВАENO БOY

АETh · НH ОУТАНHO

ІеЖЕ не Боуаети по

ZHAHO- И В T TABAE

Ннњ ПОНАЕТЬ ${ }^{18}$ БАК

15

A tтE CA OYБO KAKO

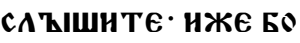

HMATh AACTh CA

IEMOY. А НЖЕ БО HE

нMATh ' н ЕЖE Mh

20

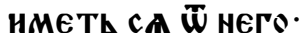

${ }^{19}$ н ПрНАОША ЖЕ К нЕ

Моу· МТ̈н и Б९АТи

IA юго и не МожАХж

$94 \Gamma$

БесћАОвАТн К' не

MOY HAPOAOMZ $\cdot{ }^{20}$ и в Z

छв 太стишА ๒моУ ГӒю

це' мТ̈н твог и БрА

5 THIA TEOA вZH太 стO

IATh вHАЕТИ TA XОTA

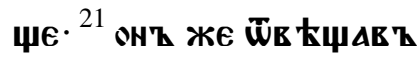

рече Кһ ннмт - МТ̈н мо

ПА Н БОАТНІА МОА · СН

10 соYTh -

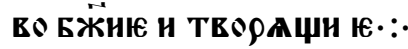

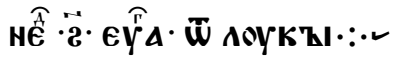

Лука

VIII

41-56

15

в В вӗ

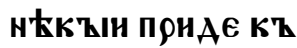

Іски · МоУжЕ Б

HМа НАН९' · Н

Th KHAZh C'ZHKMH

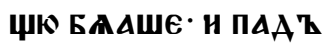

ПОН ногоY ICEOY MO

20

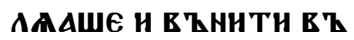

AOM' Свон. ${ }^{42}$ IAKO A'

ЩН ЮАННОЧААА БЕ

IEMOY. TAKO ATEON HA

AECATE А TTOY'H TA 
$95 \mathrm{a}$

ОYМнРАШЕ ЮГАА ЖЕ и

AAWE HAPOAH OYГHE

TАXоYти и ${ }^{43}$ н жена соY

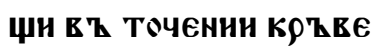

5

W ATEON HA AECATE A

ТОУ ГАжЕ в АчЕМ' и

ЗААГАВ ҚШН все НМ

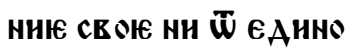

го же може нсц ћА

10 ти. ${ }^{44}$ прнстоупльшн

C'ЗаАН И КОСноУ СА

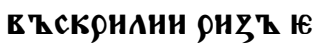

ГО. И АБНЕ с ТА ТоКҚ

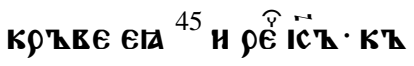

15 Tө есть косноув 'Ы

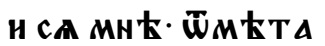

ючеми же сA вhct

ми ' ९ече петри н и

ЖЕ Ба ХОY ст ннми.

20

НАС ТАКНHчE HA

DOAH OYT КШUHAK

Th TA' н гHETOYTh

и ГӒЕшн кто Ести ко

сноув ҚIн СА Мнt. ${ }^{46} \ddot{\text { IC }}$
956

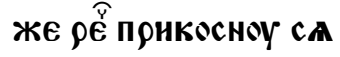

MHE K'TS $\cdot 4 \zeta$ Z 50 पा

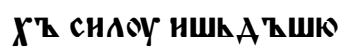

нУ Мене ${ }^{47}$ н внА ЕЕ '

5 ши женА тако не оу

ТАН са трепЕщющн

ПрнПААЕ ' И ПрнПА

АТшн п९ћат нимь

उА нюже внноу КО

10 сноу са ЮMи Пов $\mathrm{K}$

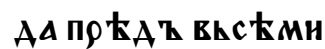

АКАКМН Н НАКО Н

сц ҚА АБнЕ. ${ }^{48}$ нс̈з

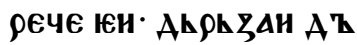

15 Шн в

ТА нАН в' мноһ ${ }^{49}$ IE

廿е же џмоу гӒџю

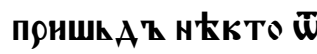

А९ХисунаГоГА ГӒА

20 IEMOY TAKO оYMP

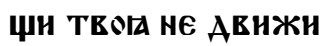

оүчнтела ${ }^{50} \overrightarrow{\text { IC' }}$ же

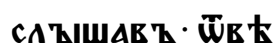

廿А ЮMOY ГӒА. НE БО 
95в

Н СА TZKMO в KоOY

и cïcena boYaеth

51 прншеАт же в $\mathbf{7}$ А०

MZ' HE AА HHKOMOY

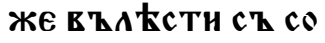

Бок- тъкмо петроу

H IWAHOY H АKOBOY.

и оц̈оу отроковнцА

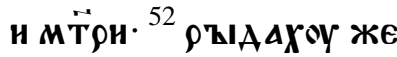

10

BCH ПNAKAXOY CA

ІЕА - он' жЕ рече нЕ

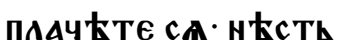

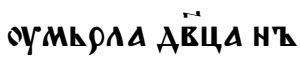

съпнти. ${ }^{53}$ и роугахоу

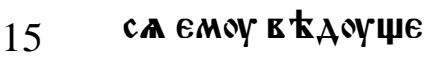

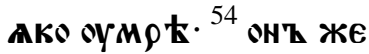

HZГ'ZHAE Z RCA ET

HZ HMT E ZA POYKOY

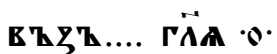

20 Троковнце втстА

ни. ${ }^{55}$ и в ҚЭв ФАТн СА

$A \vec{X} \mathbf{h}$ EA· и в Қскёрсе $\triangle$

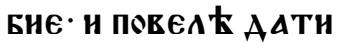

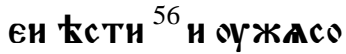

$95 \Gamma$

CTA CA POAHTEAH

EA. OH'

ТИ НМА' HE ПОВ

ААТН нНКОМОУЖЕ

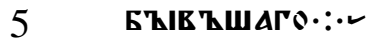

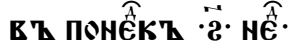

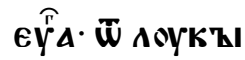

Лука $\rho \in \mathbf{\epsilon} \overrightarrow{\mathbf{r}} \cdot{ }^{22}$ вса мн

$\mathrm{X}$

$22-24$

10

nokAAHA COYTh

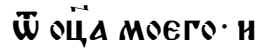

нНКТОжЕ не в

с Th KTO ÆсTh сн̈'

ТҚКмо оц̈һ и К.Т०

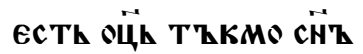

15 и юмоуже Аџе Хоще

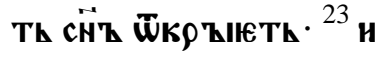

OБPATHE'Z CA K' OY

ченнкоМт рече БАА

ЖЕНН ОЧн вНААџн

20 и аЖЕ внАнте ${ }^{24}$ ГӒю Бо

BAM Z I IAKO MHOZH

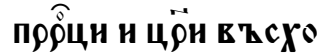

ТКША внА АТн· ГА

жЕ вЪ внА ЕТи и не 
$96 \mathrm{a}$

внА ЕША' И САҚШША

Ти гАЕ сАЪшите

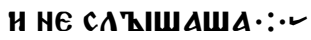

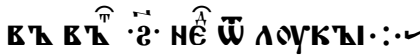

E' W WHื.

ÏСУ ЮАНнОМОY· HA

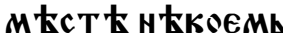

MOAALК СА Н

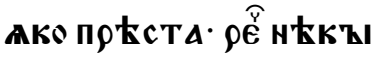

10 н $\overline{\mathbf{w}}$ оученик' юго

K' немоу. Г̈ нАOY

ЧН H'ҚI MOAHTH CA

ГАКOЖE HWAH' · HA

оүчн оученнкъ

15 свог ${ }^{2}$ н ९єче нМҚ Ю

ГAА MOAHTE CA. ГÄt

TE - Wप̈ нашh нже Ю

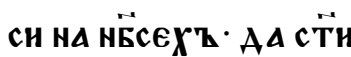

Th ca hma troe. aA

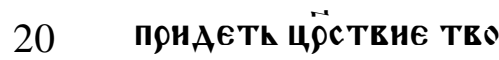

Ю· AА БOYAETh BOAA

TEOI. АКА НА НЕС̈ И

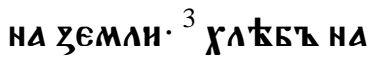

Wh БҚITKH'ҚI · ААЖК
966

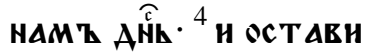

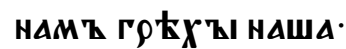

ДАКОЖЕ И М ҚІ ОСТ АВАА

IEMT BhCAKOMOY AT

5

АТ ЖИНHКОУ НАШЕМฎ

Н HE В ҚBEAH HACҚ В Қ

НскоуШЕнињ н' И

ЗБАЕН Н'Ы $\widetilde{W}$ АOYКАЕА

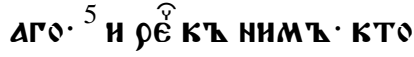

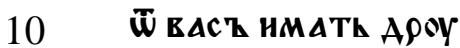

ГА' Н HАETИ К' HEMOY

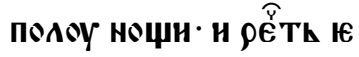

моу Ароуже ААжи мї

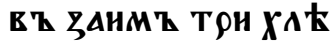

15

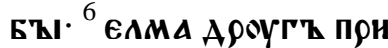

АЕ К' МнҚ· И НЕ НМА

М Ч Что Положити

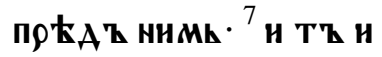

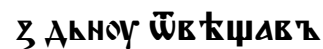

20

рєчеть - не творн мї

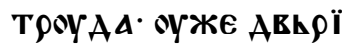

ZАTBOPENZI COYTK

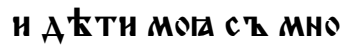

ю HА АऽЖH COYTh · HE 
96в

MOГOY В ҚСТ АE' ААTÏ

TEБ $\cdot{ }^{8}$ ГӒК ЖE вАMт

АџЕ И не ААСТИ ЮмМУ

в ҚCTAR' ZAHE ECTh

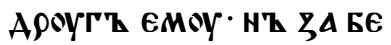

ZOULC TEO ЮГО в ҚСТА

B' ААС ТИ ЕMOY ЮАH

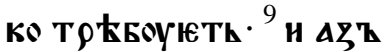

ГӒю вАMZ - ПрОснте

10 Н ААС Th СА вАM ' H

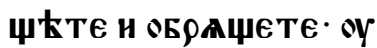

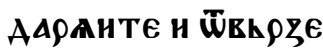

Th CA вAMt ${ }^{10}$ BhCh БO

ПООСАН ПОНЕМАЕТК

15 НџАН ОБРАџеТТ '

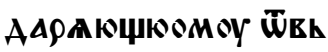

ghzeTh ca $\because \cdot 2$

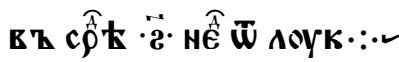

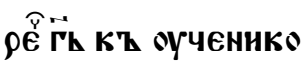

20 МҺ свонмъ ${ }^{9}$ просн

TE H AАCTL CA вAMT

НџћТЕ И оБрАџеТЕ

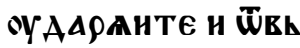

ghZETh CA вAMth kh
$96 \Gamma$

СК БО ПрОС Ан ПОНЕМАЕ

Th · НШАН ОБРАџЕТК

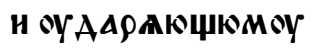

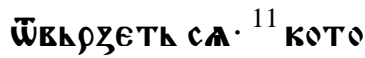

5 рАГО жЕ вАС' оу оц्य

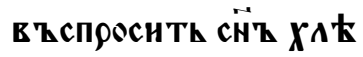

БА EAA KAMEHL ПOAA

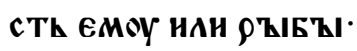

EАА ЕТ ФҚББЫ М КСТО

10 ЗМНК ПОААСТИ ЮМА.

${ }^{12}$ НАН АЧЕ ПроснТт - АН

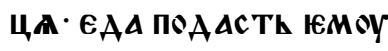

скА९Пню. ${ }^{13}$ Аџе оуБо

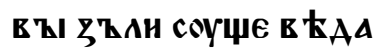

15 IЕTE АААНHА БӒГАГА

AАГАТИ ЧААOMT ВАШÏ

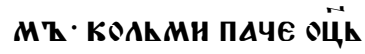

BAWh · C ' HËсE AACTh

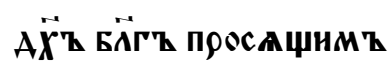

20

oy него.:-

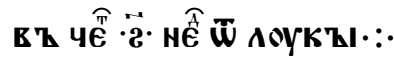

в з оно в

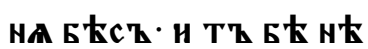

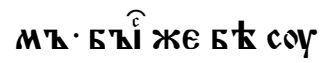


$97 \mathrm{a}$

ḦГКНАHOY ПООГӒА

N太М \IH И АHЕАAА

XОY СА НАРОАН ${ }^{15}$ НКЦН

и же $\overline{\mathrm{w}}$ ннхһ рекошА

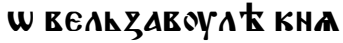

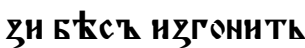

Б大сқl. ${ }^{16}$ и Ароузин же

HскоушАКще 'ुHA

МЕнита нсКААХ УY

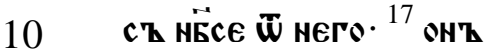

же в Қаты их' помы

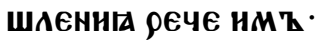

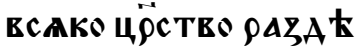

AATA CA CAMO HA C..

15 oпоүст Тети и А०

Mh HA AOMZ ПAAETh

СА. ${ }^{18}$ АџЕ ЖЕ и сотонА

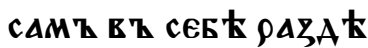

АH CA' KAKO CTAHE

20 Th церство юге. ${ }^{19}$ таKo

ГӒТЕ MA О веАһ३А

воУА Қ нбГОне Б

C'Zl C CHEE в АUH O KO

Mh H马ГOHA Th - cETO
976

A КАA TH ВАMZ БOYAЖ

Th coYAHI ${ }^{20}$ Аџе Ан же

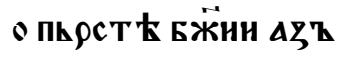

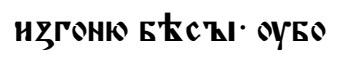

5 Постнже нА вАСт ци

сА९нс твнњ БӝнњЕ ${ }^{21}$

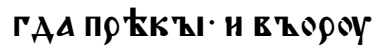
жHE ' CA ХРАнHTh AO

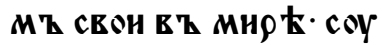

10 Th нмЕннга Eго. ${ }^{22} \Delta$ по

неже кр КПлин юго

HAWhАТ ПОБ太АН

Th И И ВСА ороУЖН

IA OThMETh ' HA HE

15 же оүпЋвАше и па

HTh IEO PAZAAETh h

HOMOY. ${ }^{23}$ нже нЕсTh

c' MHON na Ma ECTh

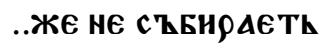

20

c'h MтHOW PAC'ZIIIA

IETh $\because: \bullet$

в Z ПА⿱⺈

peपe $\overrightarrow{\Gamma h} \cdot{ }^{23}$ нже н सс Th

C' MZHOW HA MA I 
97 в

с Th · НЖЕ НЕ сһБН

ETh ch M ZHOW ПАЕТЬ · ${ }^{24}$ ІЕГАА НЕЧн

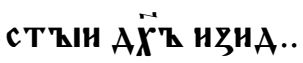

5

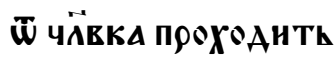

сКвOZ̈ БEZROALH.

\А М Кст А нщА ПоК.

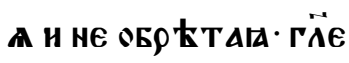

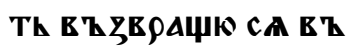

10 АОМт МОН Ш̈ НюАЖ

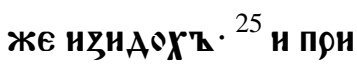

ШhA' оБ९ ҚтАETh

ПометЕнт · Н оүкРА

WENh ${ }^{26}$ TZГАА HАETh

15 н понметh А९оY.

X'h rophwh cese $\cdot \vec{z}$.

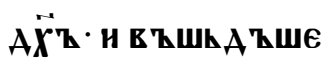

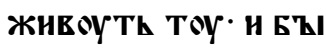

вANTh חOCA $\mathbf{K}_{\text {Ah }}$

20 HАIА पล̈ЕКOY TO

MoY roghwa nh ph

в Қ/нX'h $\cdot \because \cdot$ -

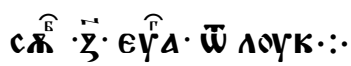

Лука въ вё $\mathbf{~}$

1-6

97Г

BAB Z IC̈h A 'ZEA HA

...... оученик $\mathrm{z}$

HX' ' ААCTh HMT сH

AOY H BAACTK HA..

5 сkX' вtсkX'h не

Аоугы и нсц ЕА..

${ }^{2}$ н постАA זA

..ААТИ Ц९्̈ТЕО Б

..Н Ц КАНТН БОАА

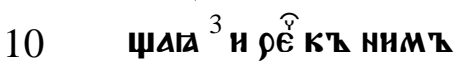

нНчксОже не в..

MA KT. HA חOY..

..Жи.. ни пнр

ни .... $\triangle$ ни ...

15 ........ КЕОК $9 .$.

нмћти н вһ..

..В.NHA.ET.

....КАнте и й

...... Х०АНТЕ И

20 EMАю

.......

... пр4

X'В $\overline{\boldsymbol{U}}$ н... вАших'

ш̈трA..TE в .. 
$98 \mathrm{a}$

БЪА Ћнне нА на $\cdot{ }^{6}$ н

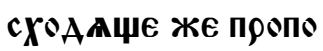

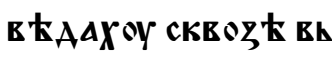

СН· БӒГОв Қс Тоүюще

5 и ц ҚААџЕ ВһСКАОУ-:-

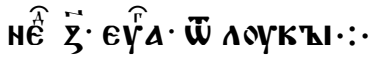

Лука

VIII

26-35,

38-39

10

в Ђ в

AE İCh E K EhCh ГA

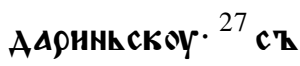

рҺте и моужи

ЮАHн'

АА нже им Б Б $\mathrm{kch}$

..A KT' MHOГ'

.Т PHZOY HE ОБАA

15

. Аше са и в Қ XPA

.Һ не жив а Аше

.7 в z гров k X' ${ }^{28}$ оузh

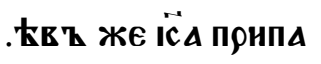

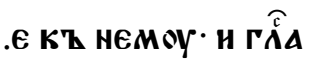

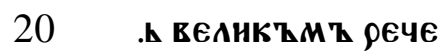

पh TO ECTh MHE H

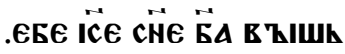

HALTO MOAN TH CA

не Моучн мене. ${ }^{29}$ пр
986

廿аше Бо аґ̈ви нечн

с тоумоу. н६нти

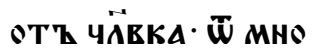

Fh EO A ЕTZ вZCX'Ы

5 ШАШЕ Н. И ВАЗАХОУ

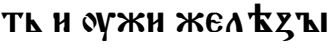

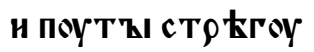

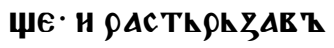

ОУ马'Ы· ГОННМ' БА

10

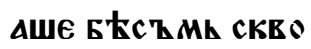

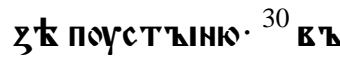

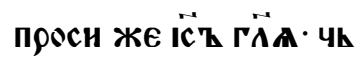

Tо ти нма Eсти •

нһ же рече легеон' .

15 Гако Бћсн мнозн

B ZHHAOWA E Z Hh .

${ }^{31}$ Н MOAАXОYТК И АА

HE ПOEEAHTh HMT

в Б БЕЗАКноу нти.

20

${ }^{32}$ БЋ ЖE TOY С ТАAO СвH

ННн много ПАСО

MO В Қ ГOPҚ Н МОAH

ША Н АА ПОЕЕАНТК

НМҚ ЕҚ ТҚІ ЕҚННТї 
98в

н повелt нми $\cdot{ }^{33}$ н шh

А Ћше же к қсн $\overline{\mathrm{w}}$ че

АОВ ККА Е ҚННАО

ША ВТ СЕНHНIA $\cdot$ Н OY

5

СТОКМH СA CTAAO

пе вр kгоу в в еzеро

и оутепе ${ }^{34}$ вна Ев

ше же пАсоушен Бты

в Ћшеほ БћЖАША н

10

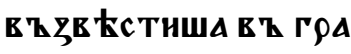

A

ЗНАОША ВНА КT'

БҚIE ZW

АОША К' ІС̈ЕН· Н ОБ९

15 TOWA С सАAЩА Чล̈КА

Н马 НЕГОЖЕ Б Есн Н马Н

AOWA. SEҚA ҚYENA H

СҚM ҚICAAџА ПОН

Horoy IC̈OY. म OYБO

20

raWA ca. ${ }^{38}$ moname

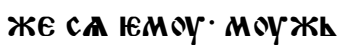

H马 HEГOЖE H马HAO

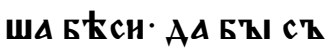

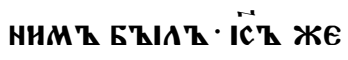

$98 \Gamma$

Ш̈поусти и ГӒа ${ }^{39}$ въ

ЗЕРАТИ СА ВТ АОМТ

СвОН· Н ПОВ Е ААН ЕАН

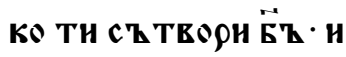

5

hАE ПO вLCEMOY ГОA

AоY пропов

ЮАНКО С' TE ОРН Ю

MoY $\overrightarrow{\mathbf{c}} \mathbf{z}$.

XI

29-54

10

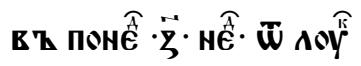

въ в

ющемт же са наро

AOM R HAYAT Z

IC̈ ГӒАTH' POAT

Ch AOYKAR h ECTh

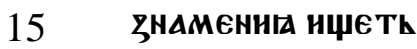

Н ЗНАМЕнHЮ HE AА

c Th CA EMOY' H' Th

КМО ZНАМЕНHЕ И

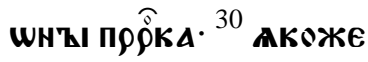

20

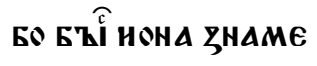

ниЕ ниневГИТОМ

TAKO БOYAETh Н СН'

पत̈вपh ९OAOY TOMOY

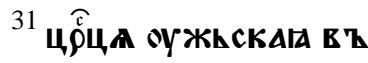

с TANETh HA 
$99 \mathrm{a}$

сOYAт·c' МоYжн פO

AА cETO h OCOYAHTh IA

ГАКО ПОНАЕ Шٓ КОНКЦК

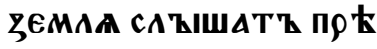

5

MOYА ООсти СОNOMO

HA. И СE MHOXAЮ CONO

MOHА СһAE ${ }^{32}$ Моужн ни

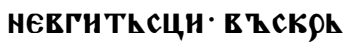

cHOYTh HA COYAT $\mathrm{ch}$

10

POA'BMh CHMh' H OCOY

AA Th H' IAKO HE ПOKA

IAWA CA E' ПрОПОв $\mathrm{K}$

АК НШНнноу. Н Се $\mathrm{MT}$

HOжАIE HOHZI ChAE.

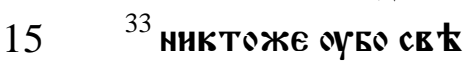

ТНАКННКА в ҚЖКГ'Қ

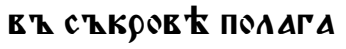

ЮТ · HН ПОА' сПОУА'

Mh' H' HA СE 太THA太

20 АА В ҚХРААНЕН БИ

AATh сEKTh $\because \because 2$

в Қ в '⿳⺈

$\rho \widehat{乛} \overrightarrow{\Gamma h}{ }^{34}$ св

TtKAoY EcTh oko. IE
996

rAA OYEO WKO TEOE

поОсто БоYАЕТИ Н

всE T ҚAS TR

AO БOYAETh - $\triangle$ ПO HE

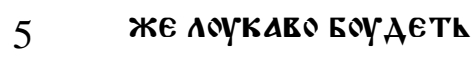

H T太AO TEOҢ ThMh

HO БOYAETh ${ }^{35}$ БАКАН

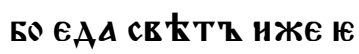

с Th в 'h TEБE ThMA I

10

с Th. ${ }^{36}$ ALE OYБO TKAo

TEOE все св Е ThAO БOY

АETh ' HE HMҚH ЧАСТ

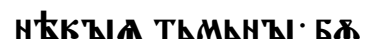

AETh cE $\mathrm{EThAO} \mathrm{RhCE.}$

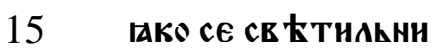

КТ БАНСЦАнНЕМК

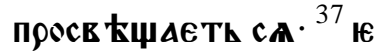

ГААЖЕ ГӒААШЕ

aAwE ca EMOY фарH

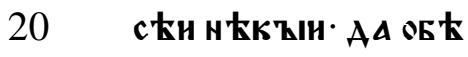
Aoye Th oy nero. в z wh

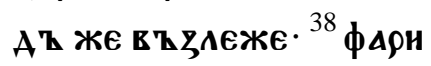

с 太и жЕ Анки са · ви

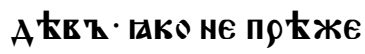


99в

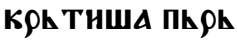

в te oв АA.${ }^{39}$ рече

же г̈h к' немоу н'ы

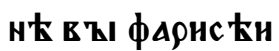

в ZH太WWHEほ С Th

КААННЦН Н БАЮАО

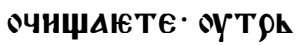

HAIA BAWA ПTh $\mathrm{K}$

HA COYTh Г९AБAE

10 НИга И ЗЪМАЕБҚ. ${ }^{40}$ БЕ

Зоумкнин ' не нже

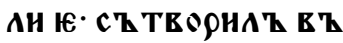

нћшьнењ· и оут

HEE C' TR OPH. ${ }^{41}$ WEA

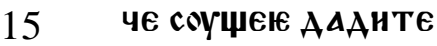

МАС̈ТЫЫHЕ Н СЕ Все

ЧнС TO ВАM В БOYAE

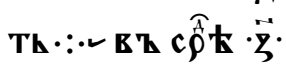

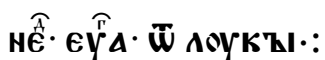

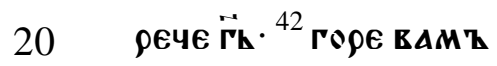

фАрHC KOMZ · raKo

oaeca toyiete ma

ТОУ Н ПнГАн' И КY

Мнн' • Н висеге zе
$99 \Gamma$

AHIA H Y $\rho E C \mathrm{C}$ COYAT

Х॰АнтЕ БӜнн СН Же

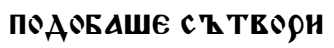

TH· И ONЕX'Z HE OCTA

5 вААтИ ${ }^{43}$ АюТ Е вАMТ

фарнс Еом' - raKo AL

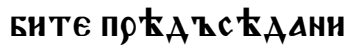

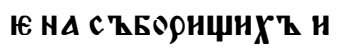

Ц ЕАОВ АНHIA НА ТZ $\rho \mathrm{Z}$

10

жнцнХ' $\cdot{ }^{44}$ Ают Е вАMт

кннжьникомъ и

фАрнс Комт Анцем Е

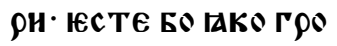

БН НЕ в ААОМН И ЧӒЕ Е

15 Чн ХОААЧЕН вһ ОһХЖ

н не в

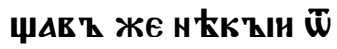

книжьникъ и ГӒА

ЮМОУ· ОУЧнТЕАК

сЕ ГӒА и нҚ корн

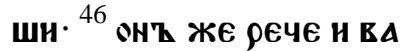

М К КнНжьннко

M A ANT E IAKO HA

KADAAETE HA YEAO 
$100 \mathrm{a}$

в ҚКҚI Б९ ҚМЕнА ТА

ЖhКА Н HE OYAOБL HO СНMА А САMH нН $\epsilon_{A}$ Ï

нћмh же пьрһст'

Mh П९нкАC

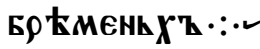

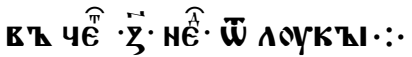

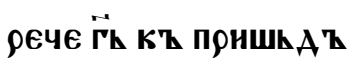

шнмт Кт немоу ноу

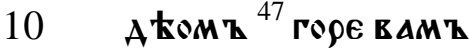

кннжьници и фАрї

с太Н· ГАКО КОАснте

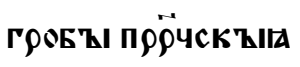

งц्н вАШи нछБншА

15 ॠ ${ }^{48}$ с'ав

Ете Бо A ћломи оци

ВАШИХ' И воАнТЕ

C' НHМн· ГАКО ТН ОY

Бо нЗБишА ІА в ҚІ Же

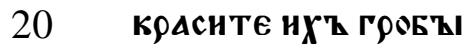

${ }^{49}$ сеГО ФААН и ПО ВМоY

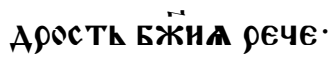

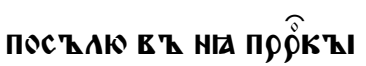

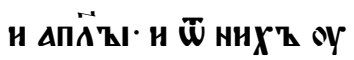

1006

БНКТИ НЖАЕнОУТК

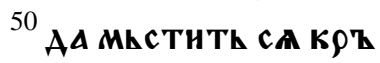

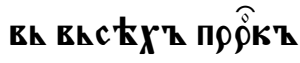

ПрОАнв АEMAIA Ẅ HA

5 чААА вһсеГО мнРА

w poAa cero ${ }^{51} \bar{w}$ крtzeE

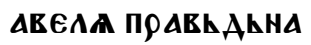

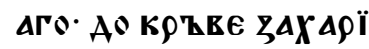

А ПОГҚIБҚ WA

10

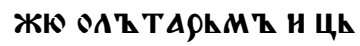

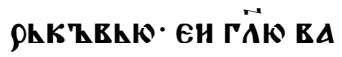

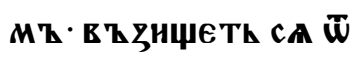

POAA сEГO 52 ANTE вA

MҚ КҚННГҚЧНАМ Қ

15 АКО Вһ马АСТЕ КАЮ

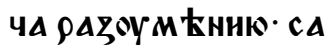

Мн НЕ В Қ Х०АНТЕ' Н

В Қ ХОААННM В В Қ

зБраннсте ${ }^{53}$ ГӒџе

20 жЕ юМоу КҺ ннмт сн

ЦЕ ' НАЦ АША КнНЖЬ

ницн и фарнс Ен Аю

TЕ Гн Қв АТн СА· н пре

С ТОАТИ И О MHOZ 


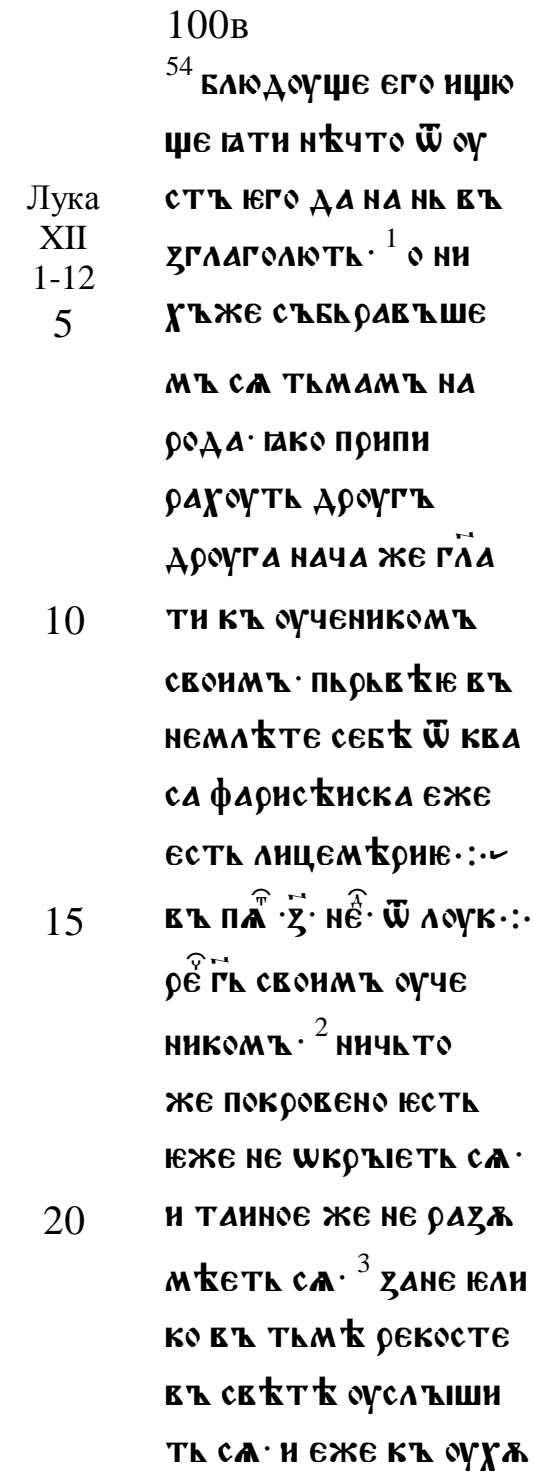

100в

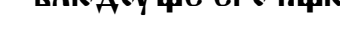

Лука

CTh IETO AA HA HK ET

छГААГОАКTh. ${ }^{1}$ O нH

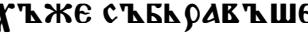

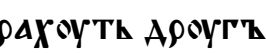

АРОYГА НАYА Же Гत̈А

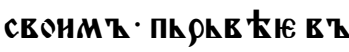

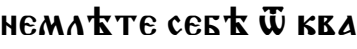

сА фАрнс КнскА Еже

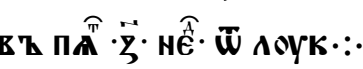

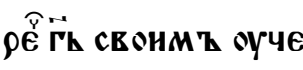

никомъ ${ }^{2}$ ннчи TO

ЖЕ Покровено юсть

H TaHoe

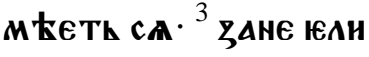

ko kT ThMt pekocte

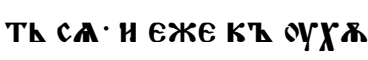

100 г

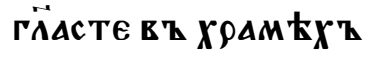

пропов 太C Th CA HA

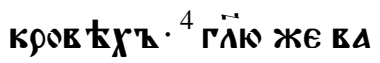

MZ АРОУГОМТ СЕОН

5 МZ нЕ оУБонтЕ са W

ОуБНвАКщнХ' T太

AO' H ПО TOMh HE HMOY

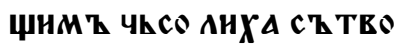

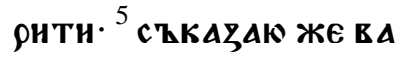

10 МҺ Кого СА ОУБОНТЕ

ОУБОНТЕ СА НМОУША

ГO вАACTh ПO OYБLЮ

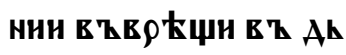

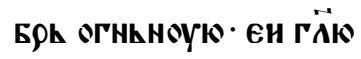

15 вАMZ - ТОГО оуБонтЕ

Са. ${ }^{6}$ не ПатИ Ан ПТИ

ЦК Ц КнHтL CA HA ПА

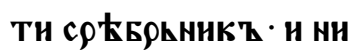

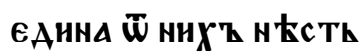

20

ЗАБҚЕенА ПО ААҚ БМ̈

${ }^{7}$ HҚ Н ВААСН ГААЕ ҚI ВА

шегА всн ищи ТенH соY

Th - HE БонтE CA OYБO

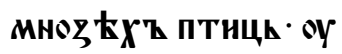


$101 \mathrm{a}$

Hhше юсте в ҚI ${ }^{8}$ гй

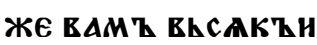

ЖЕ нспев Қсть MA прҚ

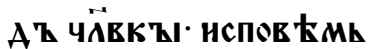

5

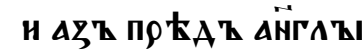

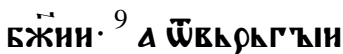

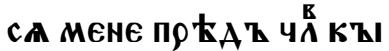

ш̈вирьжент Боуае

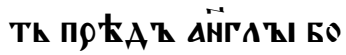

10 ЖнН. ${ }^{10}$ н ВСАКТ нЖЕ

९EपE Th CAOEO HA CḦ

Чล̈Вपh OC TABHTh CA

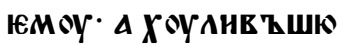

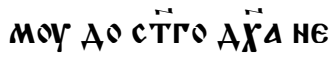

15 остАвнтL СА ЮМоY

${ }^{11}$ ІеГААЖЕ ПОНвеАОУТК

в Қl нас' БорнщА нE Пт

Ц ҚТЕ СА КАКО АН ЦКТО

ПОМЫІСАНТ · НАН ЧК

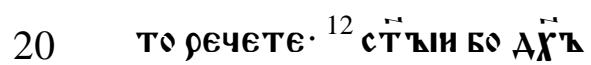

HАОYЧнTh ВZI EZ TZ

ЧАС' ГАКОЖЕ ПОАОБА

๒ТИ ГӒАТН •: :

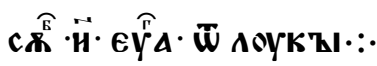

1016

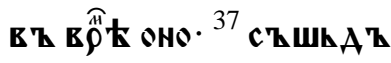

ww ïㅇ ch rophl chot

Лука те н нАродт мно

IX

$37-43$

rh. ${ }^{38}$ н се моужи и

5

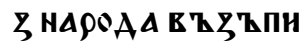

ГӒА- ОУЧИТЕАК ПЮН

Зू ९н HA CHA MOETO.

IAKO ИHOYAAT МН Ю

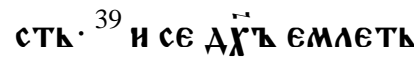

10 Н· и в Внезапоу в ВПї

ЮТ и проYЖ $А E$ Th сA

С' ПЕНАМн и ЕАВА

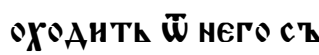

кроушАга н. ${ }^{40}$ и моли

15

X'7 са оYченикоMт

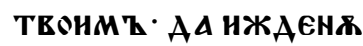

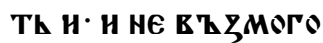

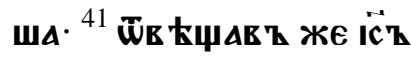

речE - W pOAE neB $\mathrm{\rho h}$

20

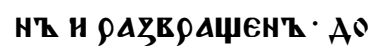

KOAK EOYAOY E' BACZ

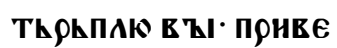

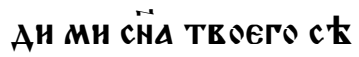

Mо. ${ }^{42}$ Еще жЕ ЮMOY ГОА 
101в

Аоушоу' Пови рһже н

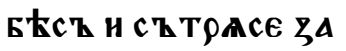

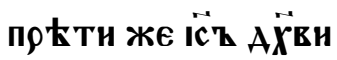

НЕЧнс ТоYMOY н Н

5 сц КАн От роКА н в Т

АА и оц̈ю ЕГО. ${ }^{43}$ АНвАА

АХОУ ЖЕ СА всн О велї

Лука чни Бӝни $::$ -

$\mathrm{X}$

25-37

10

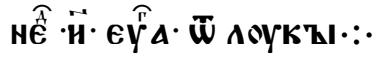

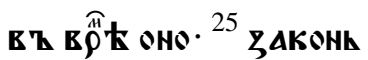

никъ н Ккте прї

стоупн к' іс̈ оу· н

скоYUAA и ГӒА.

ОУЧНTEAК पK

15 To ç Tворh жнво

Т' в ЕЧКнҚІн Прн

чАџю. ${ }^{26}$ онт же рече Ю

MOY ET ZаKOHE पh

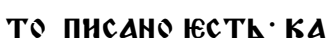

20 ко чи тешн. ${ }^{27}$ он' же

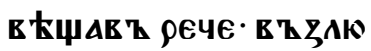

БНшН Г̈ $\overrightarrow{\text { Б}} \Delta$ св

Ẅ вһсеГО с̈РАЦА ТЕО

его. и всек аш̈ек. и
$101 \Gamma$

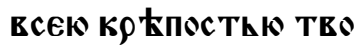

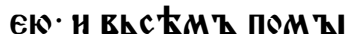

ШАЕннЕМh ТЕонми

Н БАНЖКНАГО ТВО

5

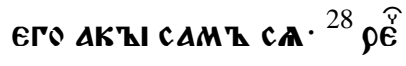

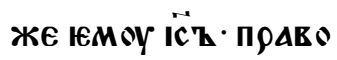

ГӒЕшн· се съ творн

и жив қ Боуаешн. ${ }^{29}$ 。

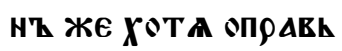

10

АнтH CA·CAMT PEYE

КҚ Ï̈ЕН· Н КTO ECTh

БАнжьнни мон. ${ }^{30} \overline{\boldsymbol{W}}$

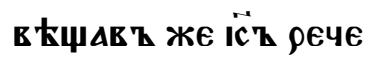

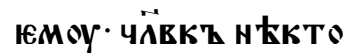

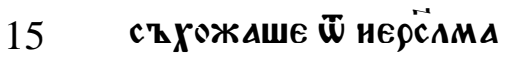

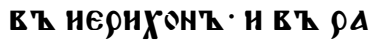

ЗБонннкҚ в ҚПААЕ

НжЕ и СҚЕ ҚАҚК'Ше и

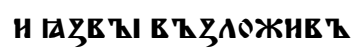

20 ШЕ ОТТИНАОША- Ост АВН

в Ћше и А Кжив А соУ

ща. ${ }^{31}$ по прнкаюча木

же жирици ХожаА

ше поутhMт TkMz 
$102 \mathrm{a}$

И внА ЕЕТ И МнМО нАЕ

32 тАКоже и АЕвГИТ' БҚ

E' HA TOMh M KcT T

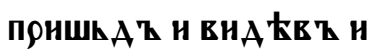

МнMO HАE ${ }^{33}$ CAMAPA

нннъ же нћкЪи г९А

АТЫИ ПрНАЕ HААТ HК.. мӒср..вА ${ }^{34}$ н прнстоу ПHE Z .EAZAB Z С TPOY

ПҚІ ЕГО в Z ЗАНRА. MA

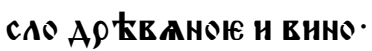

В ҚСААНЕ Қ ЖЕ И НА СЕО

и скотҚ ПрнвеАЕ н в Қ

ГостинКнНце и пре

15

АЕЖА Юми ${ }^{35}$ н нА оут ९һ

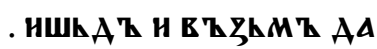

CTK АТЕА с९КБ९КHн

КА ГОс ТиньннКОУ' Н

рече Емоу прнАежн

20

ЕМн · н Еже АџЕ нЗАА

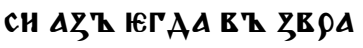

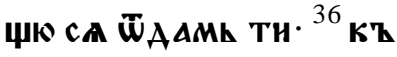

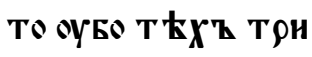

Н БАнЖьнНн Мнн
1026

Th СА БҚITH ВZПАAZ

WISMOY ET $\rho A Z 5 O$

нннкъ! ${ }^{37}$ онъ же рече

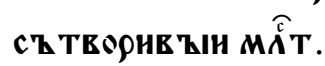

5 с нимь рєче же њ

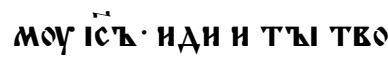

рн такоже::-レ

Лука в пи понеึ

XII

13-21

10

в Т в

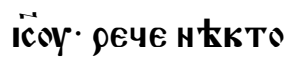

IEMOY Ẅ HAPOAA OY

ЧнТЕАК ФһЩн Б९А

TOY MOEMOY AA PA

ЗА ҚАНTL C'Z MHOW

15

прнчас тие. ${ }^{14}$ онт

же рече емоу че

пов Еपе К КT MA

ПОСТ ТЕН COYAHЮ

HАH A KАATEAA HA

20

Ат вАМн. ${ }^{15}$ рече же

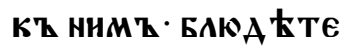

са и ХоАните са Ẅ

BhCAKOГO AHXOHMA

HHIA IAKO HE Wु HYEW 
102в

ThKА КОM OY\%A०

жнвот' юго юст人

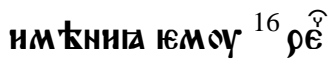

жЕ прнтТ чю КҺ ни

5

MZ ГӒА Чล̈ЕКОY NЕ

KOEMOY БÄTOY. OY

Множи СА НHЕА. ${ }^{17}$ и

MҚIшАAше в Қ сеБE

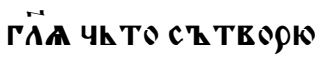

10 Гаке не им АМ К К'

АЕ съББрАТн ПАО

Аъ монуъ. ${ }^{18}$ н рече ${ }^{\text {ce }}$ ch

Творю рАзорю жн

ТКННЦН МОН · Б БО

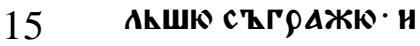

c'kEegoy ToY вh

са жнтА мо

IА Н БААГ АIA

MoA ${ }^{19}$ н рекоY

20 Аш̈н моєн Аш̈е

НМАШН МНОГО

АоБро пежАџе

HА А ҚТА МноГА.

ПОЧнЕАН· ГАЖАК
$102 \Gamma$

и Пни н весЕАн СА. ${ }^{20} \rho$ Є̊

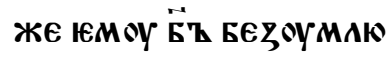

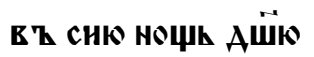

TEON HCTAZAN W

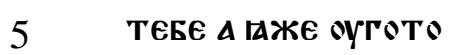

BA KOMOY БOYAOYTh

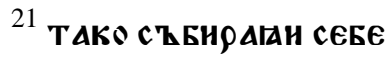

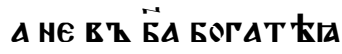

СН ГӒА в Қ ЭГААСН И

10 М ҚІаН ОҮШН САҚШША

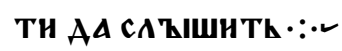

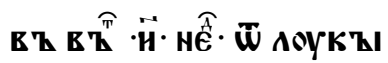

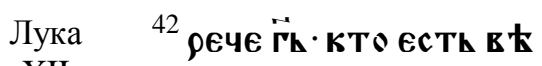

XII

42-59

ОНҚН ПОНСТ АВИНН

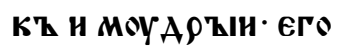

ЖЕ ПОст АвнTh Г̈h HA

AT YEAAAHL CBOEN

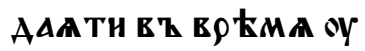

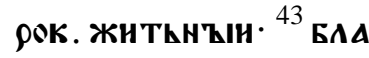

20

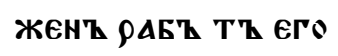

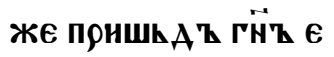

ro wE

ОАНА Т АКО $\cdot{ }^{44}$ В Т ИС ТИ

HOY ГÄ́ вАM ' TAKO 
$103 a$

HAAZ ЕИС ЕMZ HME

ннЕМh Свонмь ПостА

вити н. ${ }^{45}$ Аџе Ан рече

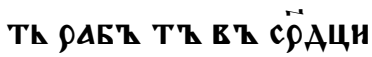

5

СЕОЕМh MOYAHTh ГH'

МОН ПОНТН· Н НАЧК

НЕТИ БНТН ९АБҚІ И ९А

БҚІни ГАСТИ ЖЕ и Пи

ТИ И ОУПИЕАТИ СА .

10

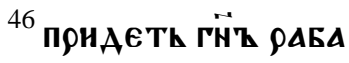

Tого в \ нһже Ан̈ не

YАITИ И ВТ ГОАНHЖ

в \ нюже не в 太сти' и про

тешетһ н· н чАсти ю

15 Госъ не в Арнънмї

положнти. ${ }^{47}$ рАБт же

OHZ в 太А ҚEҚIH вO

AN ГӒ СвOEГO Н HE ОY

ГОTOВ АЕ Қ Н HE C'

20 ТЕО९Нв ҚЫН ПО вОАН

IEГO- БИEH' БOYAE

Th много. ${ }^{48}$ не в ваt

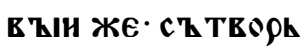

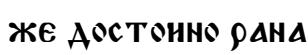

1036

Mh БhEH' БOYAETh

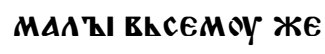

ЮМоУжЕ ААHO БОУ

AETh много много

5 нунцнти са Ф̄ него

и юмоуже пр ҚаАшА

многе - Аншиша про

cath W HerO $: \because$.

B h c cốt $\mathbf{t} \cdot \vec{H} \cdot$ Hễ.

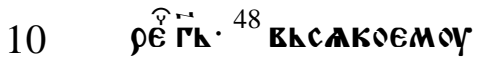

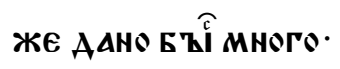

много нбнџеТА сA

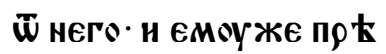

ААША многе Анши

15 Wa поOса Th Ẅ Hero.

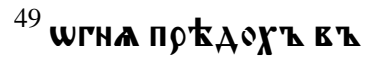

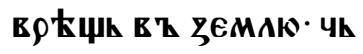

То Ан Хоџю Аџе Ан

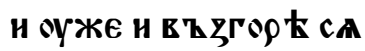

20

${ }^{50}$ крКџеннњ • ЮЖЕ нМА

МZ Крһстнти СА. Н

KAKo oYah phжH ca.

АОНЪАЕЖЕ КОНКцА

IETh CA. ${ }^{51}$ MHHTE AH· IA 
103в

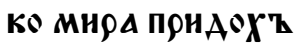

ААТН нА ZЕМАК ни

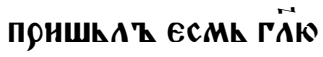

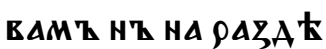

5

АЕнНाа. ${ }^{52}$ БоYАЕTh БO

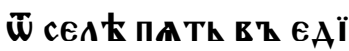

HOMT AOMOY PAZA E

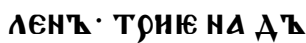

вА. Н АТЕА НА Т $\rho{ }^{53} \rho \Delta$

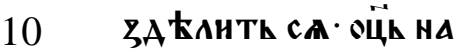

сHА. И С̈Н' НА ОЦ̈А.

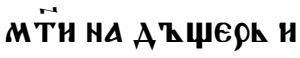

АТщн на мТ̈ри све

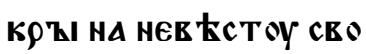

15 ю. н нев \$стА на све

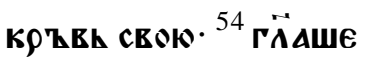

EO HAPOAOY. ETAA

马ирнте WБААК'

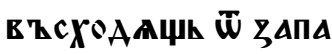

20 АА' Н АБНЕ ГӒЕТЕ ГАКО

TOYYA HAETh Н БҚI

BAETh TAKO ${ }^{55}$ H IEГAА

оугъ в Кющ · ГӒТЕ

ЗНОН БOYАETh ' Н БҚI
$103 \Gamma$

ваюти ${ }^{56}$ Анцем Ћрню

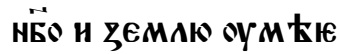

ТЕ нскоушАти А в $\mathrm{K}$

МЕне сеГО КАКО не и

5 скоушаюте ${ }^{57}$ чь то же

н о сеБ К не соYанте прА

ВИА ҚI. ${ }^{58}$ ЮГАА БО НАЕ

ши с'z соYПь ९ннк'

MZ СЕОНМ' KҚ KHA

10 ЗК' НА ПОУТИ ААЖАК

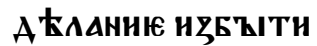

ш̈ него АА не поЋвле

ЧETh TEБE К' СОУАНH

h COYAHн TA ח९६AA

15

c Th cAOYZK· H cAOYTA

TA EZCAAHTh E' Th

МКнНцК. ${ }^{59}$ ГӒК ЖЕ ТЕ

БЕ не ИМАШи йНТн

W TOYA $\mathbf{t}$ АOHAEЖE и

20

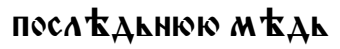

НнцК в Қ马ААСН $\because: 2$

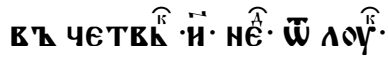

Лука

XIII

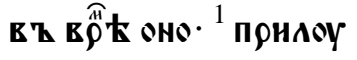

ЧнША СА НКЦНн В 
$104 a$

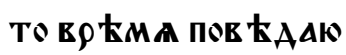

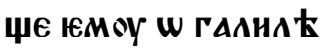

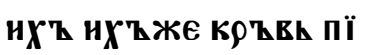

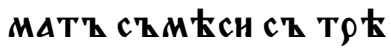

5

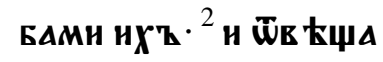

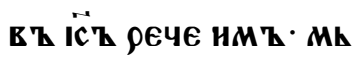

нНТЕ АН ГААНА ҚАН

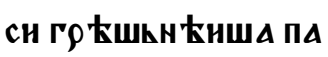

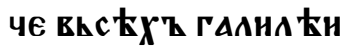

10 H' Б КWА IAKO TAKO

пост ТАААWА ${ }^{3}$ НH ГӒळ

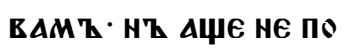

кАETE са'всH TAKO

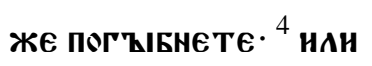

15 OHH OCMh HA AECATE

HА НEЖE ПАAE С ThAT

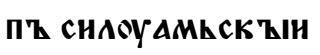

ПОБН А МһнНТЕ АН

TAKO TH АТАTZ\%hH

20 Нше БЋША ПАчЕ вh

c太ХҚ чӒвкъ жнвоу

щнХ' в Қ нерёлМ

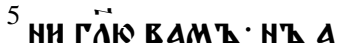

ШЕ не ПоКАЕТЕ СА всн
1046

ТАКОже ПоГ'ҚІБне

те ${ }^{6}$ ГӒю же сню прн

Th पा० ' CMOKOEh H

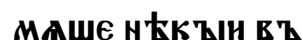

5 внНОГОАА Т СвОЕМh

в ВСАЖЕНОУ. И ПОНАЕ

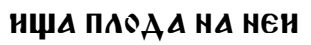

и не оБр К те ${ }^{7}$

Кһ виног АААрЕви.

10 се третнеЕ А

нЕА Е же прихожю

НщА ПАРАА Н НЕ ОБР Е

TAW HA С MOKEH СEH.

Пос Кци ю оУБО. в

15 скоую н земан оу

ПоАЖНАЮТһ ${ }^{8}$ онт

же

IЕМУ Г̈н Ост АЕн

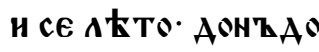

20 же окоп

C Th · H OCҚIПAN

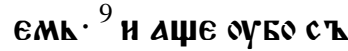

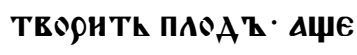

Ан же нH· в Қ Г९AAOY 
104в

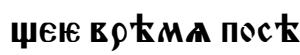

чеши к० : :-2

Лука

XIII

31-35

5

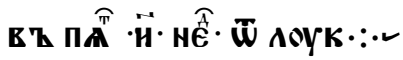

в Қ в

нћцин фАрнс Łн

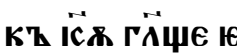

MOY H马НАН НАН Ш

COYAOY IAKO HPOAT

ХоџЕтК та оуБнти.

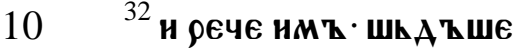

рьц Вте Ансоу то

моу. се ндгень Б

СЫ ИСЦ БАЕнНА ТЕО

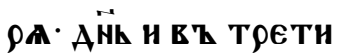

15 Н КОНКЧАК. ${ }^{33}$ ОБАЧЕ

ПOAOБАITL MH ANh

и оүтро. н в В он'

ANh ИТн· IAKO HE в '

Зможино юсти про

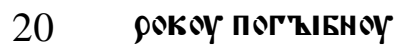

Ти кром нерёслн

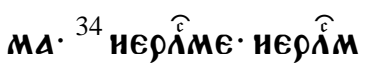

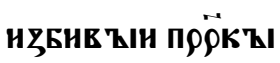

н каменнњми по
$104 \Gamma$

БHE AIA ПOC Z $\triangle A \mathrm{H} \mathrm{ZI}$

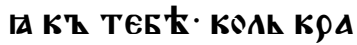

ThI в ZCXOT kX'h ch

БКРАТН YАA TEOIA.

5

TAKO KOKOWh с'Қ БH९A

ЮТИ ПТЕНКЦА СвОА

ПОАТ К९нА Қ свон и

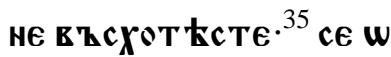

cTABAAETh CA AO

10 Mh BAWh ПOYсT' ГÄऽ

Же вАMт - TAKS не и

MATE MENE вHA

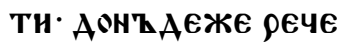

ТЕ БӒГНҚ Г९ААЫИ

15 в Н НMA ГHе $: \because$ -

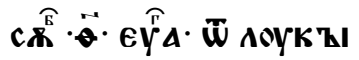

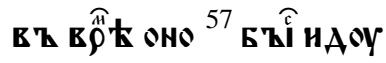

Лука

IX

57-62

20

H K HEMOY. HAOY

Kh TEEK памо

ЖЕ КОАнЖиАО наE

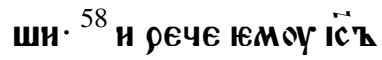

АНСН ГАҚКБНҚI НМЖ

Тһ · И ПТИЦА НЁСК 
$105 \mathrm{a}$

HZIA THKZ,A A CḦZ

Чล̈ВЧСКҚIH HE HMA

Th K'АAE ГАAR ҚI ПO

АТкАонити. ${ }^{59}$ рече же

5

ADOYГOYMOY X'AH

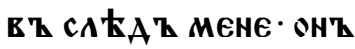

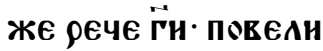

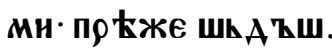

погрети оц̈А моего.

10

${ }^{60}$ рече же ємоу $\overrightarrow{i c z} \cdot w$

СТ АЕН ML९L TE ҚIIA

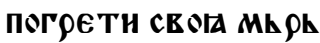

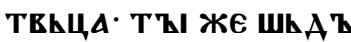

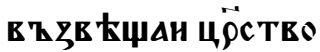

15 Бӝне ${ }^{61}$ рече же н Ароу

ГИи нАОУ ПО ТеБе $\vec{\Gamma}$

АревАЕ ЖЕ ПовеАн Мї-

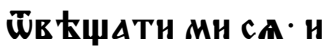

жE coYTh в h AOMOY Mo

20 ґми ${ }^{62}$ рєче ЖЕ кһ не

MоY ï $\mathrm{z} \cdot$ нHкТОжh

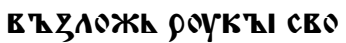

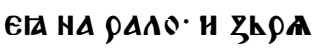

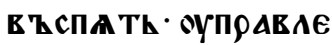

1056

HZ ЮCTh в ц

Бӝнเе $:$ :

Лука неึ.

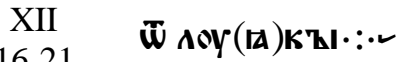

16-21

5 рєче $\overrightarrow{\text { rh }}{ }^{16}$ прнтт

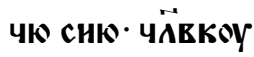

HसKOEMOY हैA

ТоУ оУмножн СА

HНEA. ${ }^{17}$ H MҚIUАA

10

ШE вһ сеБE ГÄA - पh

TO C' TEOPN IAKO

HE HMAMT KhAE ch

БКОАТИ ПАОАТ MO

HXZ. ${ }^{18}$ H PEYE cE ç TRO

15 คю.

ННЦА МОГА Н БОАК

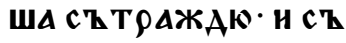

Бероу ТоY вһсA Жн

TA MOA' Н БӒГ АIA

20

MOA. ${ }^{19}$ и рекOY АШ̈н

MоEн· АШ̈Е ИМАШи

МнОГО АОБРО АЕЖА

廿е NA А Т TА МнOГА.

ПОчнЕ АН · ГАЖАК' 
105в

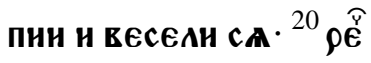

же юмоу Б̈h Беzoy

MAF' H E T С СК

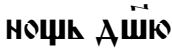

5

TEON HСТАЗА

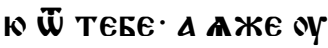

ГOTOEA KOMOY EOY

AOYTh ${ }^{21}$ TAKO C'B EH

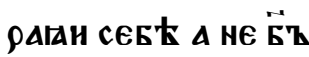

10 БоГАТ 太IА. СН ГӒА

в ҚУГААСН · НМ КБА

Лука

XIV

$1,12-15$,

25-35

15

Н ОYШН САҚIШАТИ

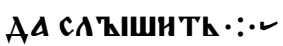

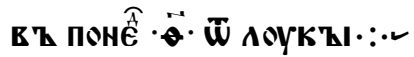

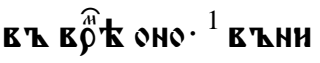

AE IC̈h ET AOMT HE

KoEro kHaza

фарнс КнскА.

Һсти ХА ЕБһ ${ }^{12}$ н ГӒА

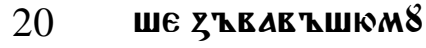

Н · ЮГАА ТЕе९Нши

ов ҚАТ иАн вечерю

нЕ ЗОВН АРОУГ'Қ

ТЕОНХ' · НH БРАТИ
$105 \Gamma$

. ТВоега ' НH ООЖенН

A Твоего ни соYс $\mathrm{t}$

AT БГАTTh EAA KOAH

и ТИ ТАКऽЖАЕ ТА в

5 ZОВоYТК н БOYАETh

Ти въ弓ААнне ${ }^{13}$ нъ Ю

ГАА ТВорншн Пн९Қ

В Қ ЗОВН ННџАГА МА

АОМочн Х ХOМ ҚIIA.

10

сА БПЪІа. ${ }^{14}$ и БА АЖЕ

HZ БOYAEWH - TAKO HE

HMOYTh ТИ чсO в $\mathrm{K}$

ЗААTH В ҚЗААC Th

БO TH CA EZ в Z

15

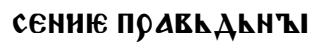

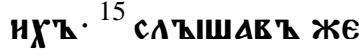

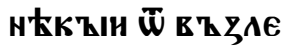

ЖАџнХһ с ' нимь

рече ЕМОУ. БААЖЕН'

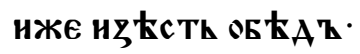

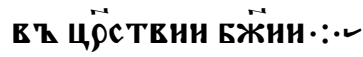

в Z в В

в Z в

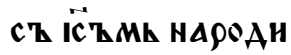


$106 a$

МнеदН ' Н ОБРАТИ СА

рече нм т. ${ }^{26}$ Аџе кто

ГРААЕТИ К' МнЕ и

HE ВҚ ЗНЕНАKНАН

5

Th оц̈А своеГО ' И MА

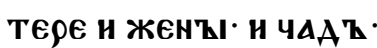

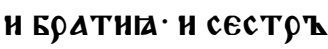

юще жЕ и своеА Аш̈А

не МожетИ Мон оу

10 ченнк' БЪІтн. ${ }^{27}$ нже

не носнти К९์T А

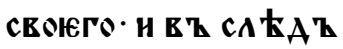

MË HE HAETL HE MO

жеть БҚIти Мон оу

15 ченикт. ${ }^{28}$ Кто Бо $\overline{\mathrm{W}}$

вАCZ XОTA стTAחZ

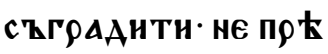

же Ан сқат

Th нмЕние - Аџе Ан

20 нМАTh ЕЖЕ Юсть

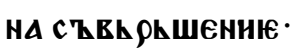

${ }^{29}$ АА не юГАА Положї

Th WCHOEAHн!E '

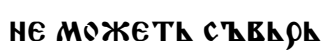

$106 б$

Шити $(\diamond)$ всн ви

ААШЕН HАYLHOY

Th POYГАTH CA EMOY

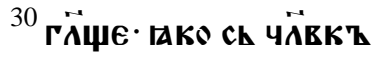

5 НАЧА ГРААНТИ Н

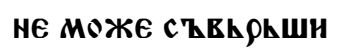

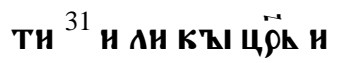

АТЫH К' НномоУ

ц

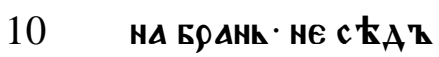

Ан прћже сһв КщА

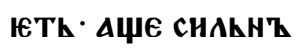

юс Th ch AEсA THS ThI

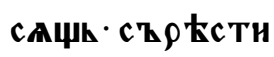

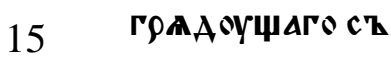

Azв kMA AEcate

THICALEMA HA Hh .

32 АџЕ Ан Же нН - ТО Е

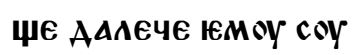

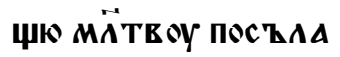

В Z MOAHTh СA O МH

p. ${ }^{33}$ TAKO OYEO BCA

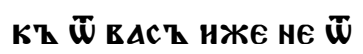

peyeth ca khcero cko 
106в

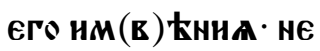

Можетһ Мон БЪІтї

оученнкт $\cdot{ }^{34}$ АоБро ю

стh соль АщЕ же со

5

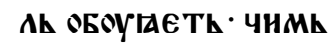

оYБО осолHTL СA. ${ }^{35}$ Hн

вЪ ӘЕМАН нН в Қ

ГНОН T९ҚЕ Ес Th

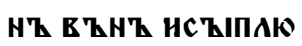

10 Th א. Hм Еґан оүшї

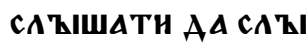

шитһ $\because \cdot$ ข

Лука

XV

$1-10$

15

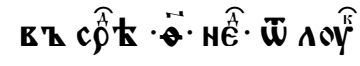

в ъ в

ПОНБАнЖАКЧЕ

ca K'h ićoy m $\mathbf{z l}$

ТА९н и г९ћшКни

ци ПосАоУШАТТ Ю

ro. ${ }^{2}$ и $\rho \mathbf{Z n T} \Delta$ Хर०Y $\phi \Delta$

20 рнс Łи кннжкни

ци ГӒџе ако съго

ШКник'М ПрнемАЕ

Th' н с' ннмн tстh

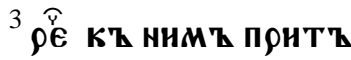

106г

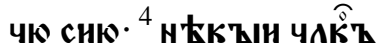

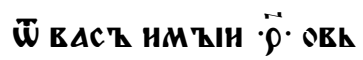

ЦК Н ПОГОУБНЕ Қ ЮАН

HOY Wु нHX' · HE OCTA

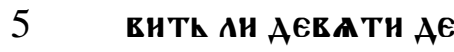

САТ'Z И АЕВАТИ в'

ПОУСТ ҚINH ' НАЕТК

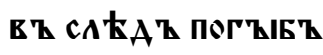

WAIA AOH'A

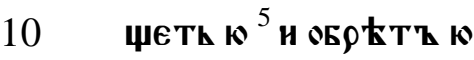

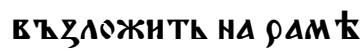

Свон ९АAОYа Са ${ }^{6}$ н прї

WhAT ET АOMT СЕOH

PAAOYA CA.CZZZZIEA

15

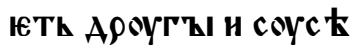

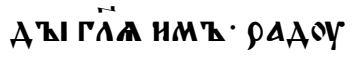

HTE CA Ch MZHON - RAKO

овр АТ ТХһ овьцк Мо

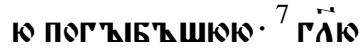

20

BAM $\mathrm{Z}$ - IAKO TAKA PA

AOC Th EOYAETh HA

НЕСН О ЕАННОМИ ГОћ

ШКнНЦИ КАЮШН

Mh CA HEЖE O AERA 
$107 \mathrm{a}$

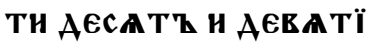

П९АКһ АКнНК' · нЖЕ

не т९ ББоуть По

КАГАНИІа ${ }^{8}$ НАН КАА

жЕнА нм оуџн АЕСА

5

Th м末АКннци

ПогоуБНтһ M

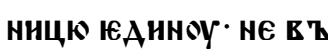

жнзањТ Ан св Е тї

10

АКННКА' Н ПОМЕТЕ

Th ХоАMz - нщеть

прнА Кжино АO

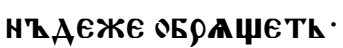

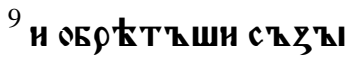

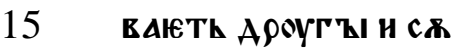

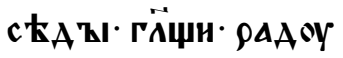

HTE CA C' MHON' IA

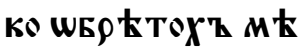
АһнНЦю КЖЕ ПОГж

20 БнХһ $\cdot{ }^{10}$ Т АKО ГӒЕ вА MT PAAOCTh EZIEA

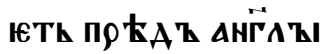
БӜни Р ЕАнномк Г९ КШКницН КАЮ
1076

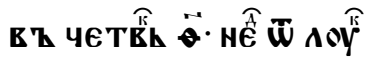

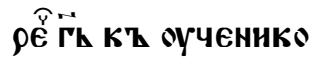

Лука XVI

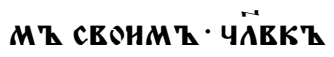

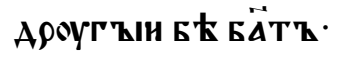

нже нм Қаше стро

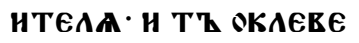

TAHZ БZIE' K' HE

MOY IAKO ९ACTAYA

Іа нМ Енига ЕГО. ${ }^{2}$ и

10

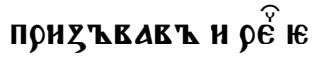

MOY. पh TO ce cA'ZIWL

- теБе въ弓аAжи

в KTh O Пр Қс TABAE

ННн АОМОвьн Емh -

15 не въ弓Можешн Бо

K' TOMoy Aomoy стро

нти. ${ }^{3}$ рече же кт не

MOY стPOHTEAK AO

MoY. Yh TO c ' TEOpN.

20

ТКО Г̈h МОH ОТЕМАE

Th строюннњ АОМж

$\overline{\mathbf{w}}$ мене· КөПАТи

не MoroY просн

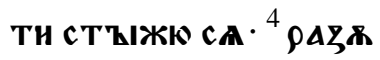


107в

M kX'Z 4h TO C' TEO

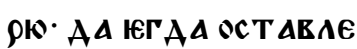

H' БOYAOY. ст ९OH

нию АОМоу' Прни

5

MOYTh MA E' AOMh

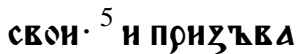

вไ ЮАНнОГО КОГО

ЖАО АТАТЖКИН

КЫ Г̈нА своEГO ГÄА

10 Аше же пи phвоу⿰у丨

моу. колнц Ем т

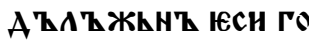

СПОАНнОУ СЕОЕМА.

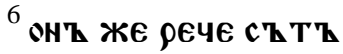

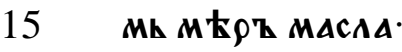

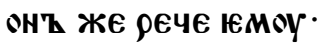

прннмт Кънигъ

TEOA н с ЕАТ сKоро

нАПншн $\overrightarrow{\mathrm{H}} \cdot{ }^{7}$ По TO

20

мh же ароугоyмоу

рече ' ТЫ жЕ колн

ц Ћм А

юсн· онт же рече сқ

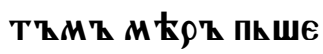

107Г

ннц Е · ГӒА ๒моу

ПФНнМн КТАНГ'ҚІ

TEОА ' Н НАПНШН $\cdot \vec{n}$.

${ }^{8}$ н поХЕААн ГḦ̌ А०

5 моу стронтела не

ПОАВһАLHATO · IA

Ko MOYAPt ch TEO

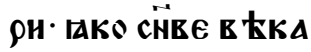

сего MOYар Кнше

10 ПАЧE cḦE 'Z CE KTA

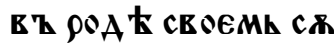

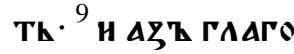

AN в $\triangle M \mathrm{Z} \cdot \mathrm{C} \mathrm{Z}$ TEOPH

ти сев ароуг'Қl

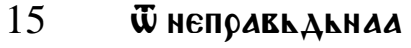

TO EÄThC TEA IEГAA

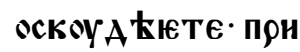

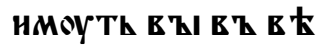

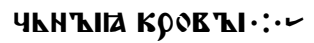

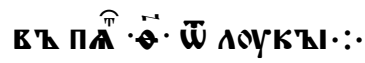

рече Г̈h к' прншк

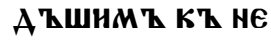

MOY HюA tomh $\cdot{ }^{15}$ ह hl

IECTE OПPARhAAL 
$108 \mathrm{a}$

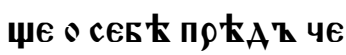
А०в Кк'

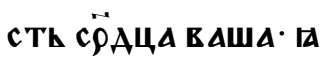
КО ๒ЖЕ ЮСТИ в И ЧӒв

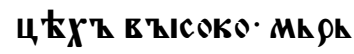

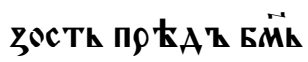
Iес Th. ${ }^{16}$ зАКОНЫЫ и про роцн AO HWAHA $\cdot \bar{W}$ TOA ц церт ТЕ Бёние

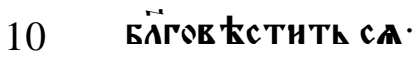
Н ВһСAK' в ҚHEHOY AETh Ca. ${ }^{17}$ OYAOEte же Есть неБоу и зе МАН МННОУТН ' НЕ

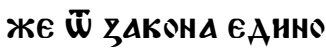

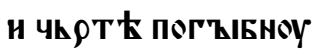
TH. ${ }^{18}$ вһсAK' ПоYщА ТАН ЖЕНОУ свОК и прї BOAA HнOY АЕБҚI A

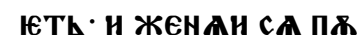

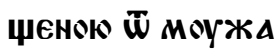

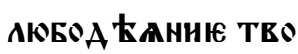

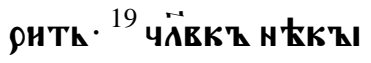
Н БК БӒТТ · Н ОБААЧА
1086

WE СА В БА БАГРАНН

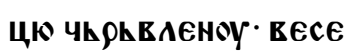
ПА СА НА ВСА АН̈н

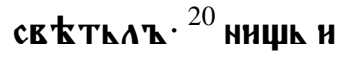
5 ЖЕ Бћ нћкто име HhMh $\Lambda 4 Z \odot \rho / \cdot$ нже

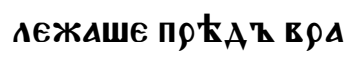
ТҚІ юГО ГнОНн' ${ }^{21}$ н

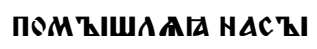
10 Тнти са $\bar{W}$ кроупн Цк ПАААКцнХ'В $\overline{\mathbf{w}}$

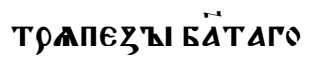
H' Н ПСН ПОНХЕАALE ОБАН马АХОУ ГНОН Ю 15 го. ${ }^{22}$ Б' ницюмоу н несен8 БҚITH АНГА ҚI HA AO

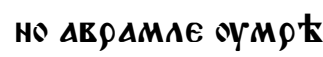
ЖЕ и БАГАТ ҚН и по 20 Г९еБошА ${ }^{23}$ н в 'Z АА ЗВEAТ ОЧн СЕОН С'Қl

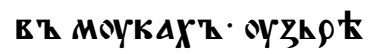

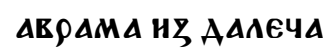

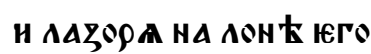


108в

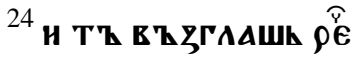
จप̈е АврАME Помн АОYН MA' Н ПОСТАÏ

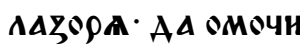
Th Конhци Пи

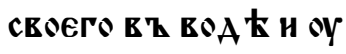
сTOYAHTh IAZ'ZIK'

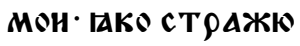
В Т ПААМЕнН СЕМИ.

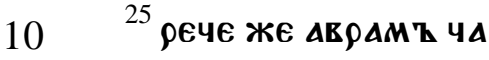
АО ПОМ АНИ ГАКО ПОї

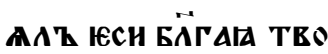
А вһ жнвот t TEO ほMh $\triangle \Lambda \triangle Z O \rho h$ T $A$

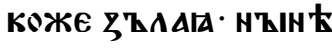
ЖE chAE oYt tயAETh СА· А ТЫ СТ АЖЕШи ${ }^{26}$ н нАА' вис Қми Сн Мн· МЕЖК вАМн и нА КА OYTЕК ОАН СА· ТАKO АА ХОт АџЕ Мнноу

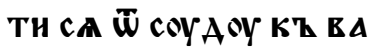
Mh HE в ZMMATANTh

$108 \Gamma$

ни нже $\mathbf{\mathbf { w }}$ TOYAOY кh

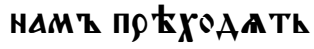
27 речE жE MONК TA गуह० Wप̈Е ААН П०

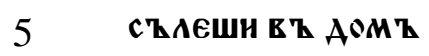
оц̈А моего. ${ }^{28}$ нмамт

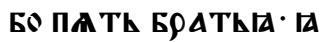
KO АА СһЕ Қстити и Мъ· АА нЕ и ТИ прН 10 AOYTh HA M Қстосе мӵниг ${ }^{29}$ гйАше же

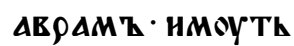

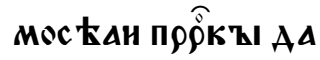
ПослоYШАКТ НХ'

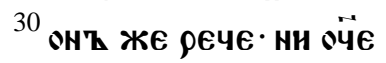

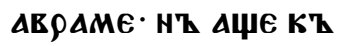

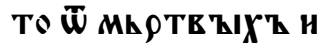
АETh к' ннм' покА nTh ca. ${ }^{31}$ peYe ЖE ЮM ЮY Аџе мосеА и по९ेк' не ПослоушАКТИ нН А

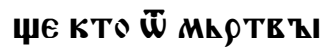

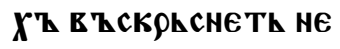
нмоути в 


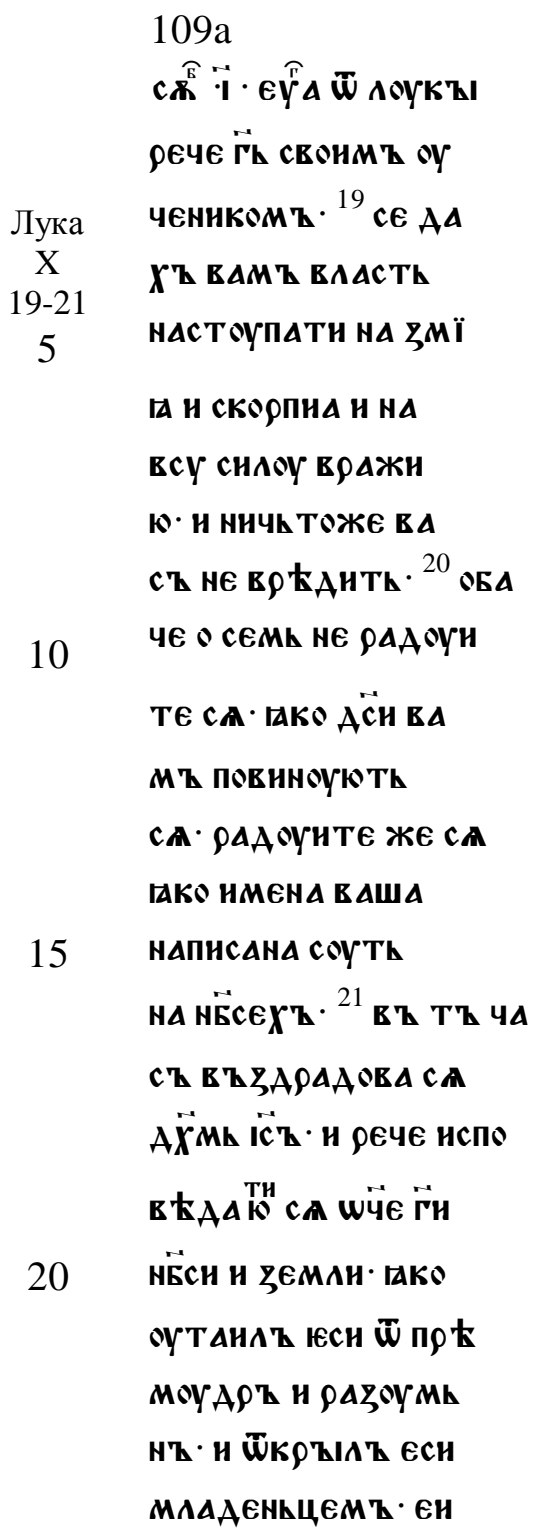

1096

Wप̈E IAKo TAKo EKर्

БлГ̈Оволеннє прћ

Лука

A' TOE०к::.2

XIII

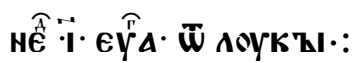

10-17

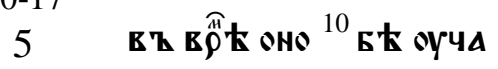

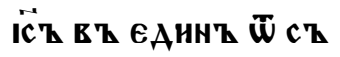

нһмнци в 'h соY

БотһI ${ }^{11}$ и се жена

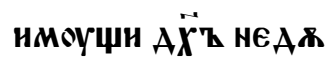

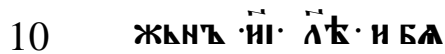

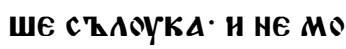

ГОУџн в ҚскАОни

Ти са тин8 $\mathbf{8}_{A h}$.

12 oyzh $\rho$ tв h

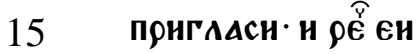

жено - т̈поущена Ю

CH OT' HEAOYTA TEO

Eго. ${ }^{13}$ н вһ ЗА०жн нА

ню ९оуц Қ и АБнЕ

прост

20

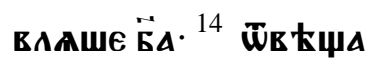

в т ЖЕ А९ХнсунАГО

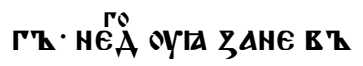

соуБотоу нсц ЕАн ю 
109в

и ९ече $\cdot \overrightarrow{\mathfrak{2}} \cdot$ АнНН Ести

В\ НАЖЕ АОстОНТИ

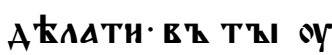

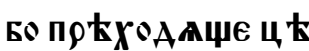

5

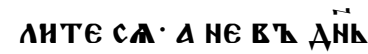

соуБотһH'L/ ${ }^{15} \overline{\mathbf{w}}$

в 太щАв

немоу и ९е · АнцемЕ

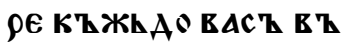

10

соYБотоY не от९Е

ШАETh АН СвВеГО во

ASY. AH OChA $\bar{W}$ A

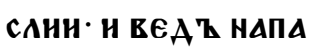

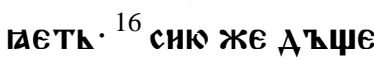

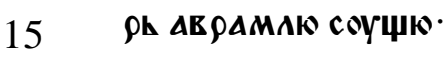

NЖE ChEAZA COTO

ha CE OCMUE HA AECA

TE A tTo. HE AOCTO

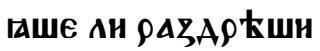

20

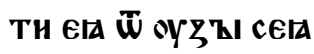

в Z AN̈ соYБOThH'ҚI

H. ${ }^{17}$ H ce EMoY ГÄ廿lo

стЫAA XOYTh CA

вСН ПРО THEAAF 109г

Чн СА ЮМоУ н ВСН

ANAHIE РААОВ АХOY

Th CA O EhC kX'h CAA

BLHZIX' EZIE $\triangle 10$

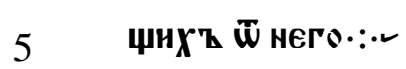

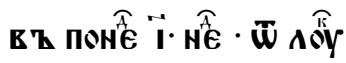

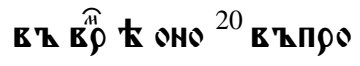

Лука

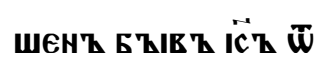

XVII

20-36

фАрнс kн· $K \mathrm{~h}$

10 ГАА ПФнАЕТК Цёство

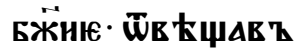

жЕ ими и рєче не прї

АЕТи церство Бӝню

СТБАюАЕНнЕ ${ }^{21}$ н

15 рекоути се chAE н

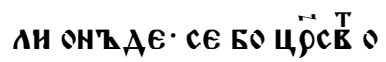

Бӝню оут ҺьюАОУ

в' васт ести. ${ }^{22} \rho \in \kappa \AA$

же кh оученикомт

20

понАОУТИ Ан̈не

ГАА вЪЖAEАAЮTE

EAHнOГO АНE · CHA

Чล̈ЕЧА. ВНА КТИ И

не оузирите ${ }^{23}$ н $\rho е$ 
$110 \mathrm{a}$

KoYTh BAMT - cE chAE

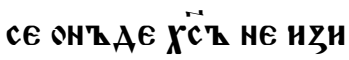

А $\mathbf{k}$ те

${ }^{24}$ ГАКО МЪАнНН БАН

5 СЦАКщн СА·

АТNЁСLHZIIA. HA ПO

А ВНЁСН ҚН СЕК TH

Th CA. TAKO BOYAE

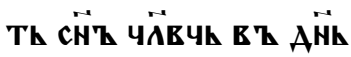

10 свон. ${ }^{25}$ прtже же по

AOБLETh EMOY MHO

ГО ПОСТ ТАААТН· Н

сКоYшеноY БҚITH

STK POAA cERO-:.

15 в В в

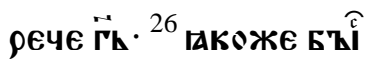

в Қ Ан̈и ноEв Қ! TA

КО БОУТК И ЕТ АН̈H

CHA Чत̈BपА ${ }^{27}$ IAAAA

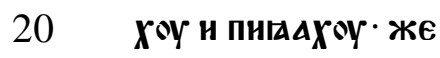

HAAXOY CA H HOCA

ГAAXOY. AO HETOFE

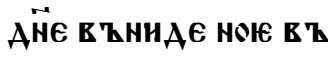

КөБһчеГ' · म прнАE
1106

ПОТОПҚ И ВҚЗАТТ

всA. ${ }^{28}$ ТАКОЖЕ ЖE ГА

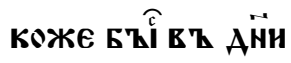

AOTOE 'J AAA $\triangle$ X

5 н пнгаAX

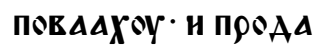

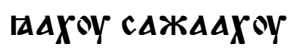

ГРАЖАААХOY. ${ }^{29}$ в $\mathbf{z}$

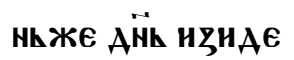

10

nOTK ש̃ COAOMAA

Hh OA Z ЖГИ КАM ҚI

ropalt ' H OrHh c'

НБ̈Е И ПОГОУБН Вh

са. ${ }^{30}$ по томh же Боу

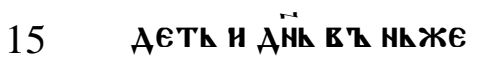

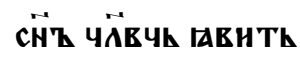

СА. ${ }^{31}$ в Т TZ Aн̈h нжЕ

БOYAETh HA KOOB $\mathrm{k}$.

H CBCOYAH ET AO

20

MOY. AA HE ÇA kzE

Th в'ZATZ HX' · H

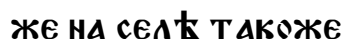

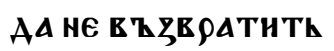

са втспа ти ${ }^{32}$ Помї 
110в

HAHTE ЖENOY АO

товоу. ${ }^{33}$ нже Аџе в $\mathbf{~}$

знщетh Аш̈ю сво

ю спї ти погоуБн

5 Th ผ. нже погоувї

Th жнвить ю ${ }^{34}$ гй

жE вАMZ в $\mathrm{h}$ TOY но

Wh BOYAE TA ATEA

НА АОЖН ЕАННОМК

10 ЕАНН' ПОЮМАЕТИ

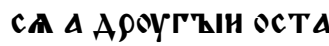

BAALTh CA ${ }^{35}$ goYAe

TA AZE K в' KOYП

К МЕАОУЩн· ЮАН

15 HA ПоEMAETh CA

$\triangle$ APOYГAA WCTABAA ETh са $\cdot{ }^{36}$ н йи 太џА

в һше ГӒАшА EMOY

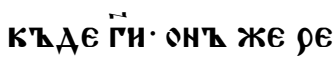

20 чЕ нмт НАЕЖЕ ТЕ

Лука Ао и тоY и ९̊ иАн съБе

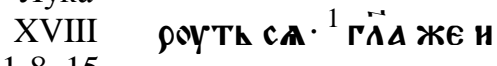

$1-8,15-$

$27,31-$

34

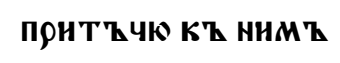

KAKO ПOAOEAETK 110г

BИCEГАА MOAHTH CA

и не с тоужАТн · си

ю ПрНТҚЧю ${ }^{2}$ ГӒА С

АНН Бћ нћКТО. В'

5 HћКоEMh Г९АА Е Б̈

HE БOA СA HH Чत̈ЕK'

с९AMAAIA CA. ${ }^{3}$ ह'

внцА ЖЕ Б Е вһ ГРАА

томи ' и прнхожАше

10 К' немоу ГӒшн ·

с тн MENE $\bar{W}$ соYпh

рьннкА моего $\cdot{ }^{4}$ н не

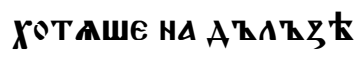

врћменн· поса

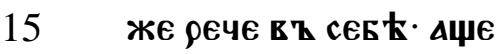

И БӒ НЕ БОК СА ' И Ч ̈ЕК'

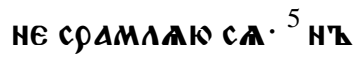

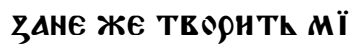

TPOУАТ Е ҚАОвНЦА СН

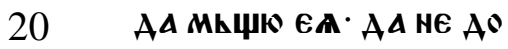

КОнКцА ПрНХОАА

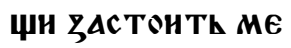

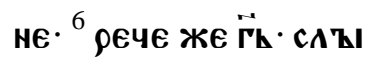

ШиТЕ чтО СОУАНН 
$111 \mathrm{a}$

неПрАККАКН'ҚH ГӒЕ

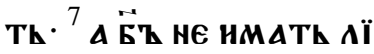

сЪ ТЕорНТИ Мһсти

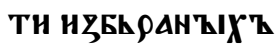

5

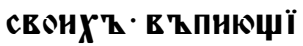

X' K' HEMOY A $\overrightarrow{\text { Hh }}$ и

ночh · Н Ти РПнТн

о ниХһ ${ }^{8}$ ГӒК жЕ вА

$M \mathrm{~h}$ IAKO $\mathrm{c} \mathrm{Z}$ TEOPH

10 Th Mhсть HX'Z в

ckopt $::-2$

в Z c cốt

въ вӗ

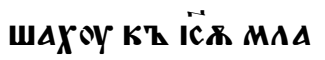

15 АЕнһщА АА БҚІ

СА нХ'В прнко

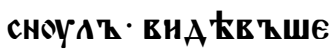

же оученнци пр $\mathbf{t}$

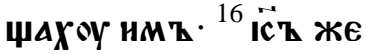

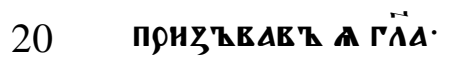

не А ћите А ћтнн прї

ХОАнТИ К' MHЕ.

И не БОАннтЕ нМ Қ

TAKOE 'Ы/X'Z EO EcTh
1116

цёс тво Бӥне ${ }^{17}$ пюА

во ГӒю в АM Қ · нже

Аџе не прнемлеть

цр̈с ТвА БӜНА АКҚІ

5 ОТРочА нЕ нмАТК

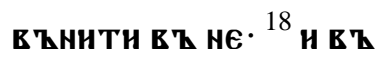

просн и нћкъи че

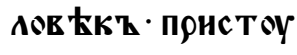

חAh K' ÏCYY ГÄA - OY

10

ЧНТЕАК БАГ̈ЫН Ч

To ç Tहорь жив

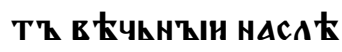

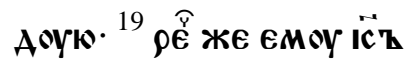

पh TO MA ГӒயH БАГ̃А.

15 ннктоже нtсть

БАГ̈' HZ TZKMO Б̈

ЮАНнт $\cdot{ }^{20}$ ЗАПОв ЕАЇ

в ЕсН· НЕ ОүБНн· Аю

Бо А Қганита не $\mathrm{ct}$

20

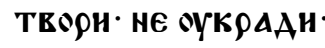

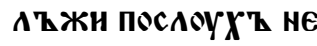

БОУАН - ЧК ТИ ОД̈А ТЕО

ЕГО и мт̈рh ${ }^{21}$ онт же

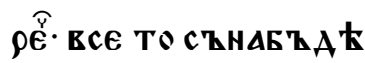


111в

X' HzоУ оунос Тн

MoEra. ${ }^{22}$ CATIULAK

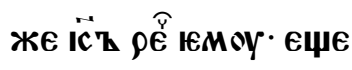

Eанноге не АоКо

5 HҺчАA' ЮСН· Все Ю

АНКО НМАШН ПрО

ААЖАК И ९АЗААЖК

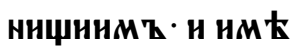

ТН нмАШи нм $\mathrm{E}$

10

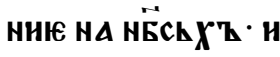

Ан по мн. ${ }^{23}$ онт же

CA hIWAR h CE חEYA

AKH' БK' БAWE GO

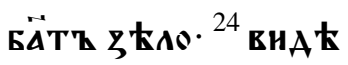

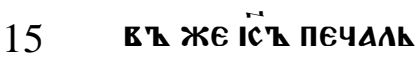

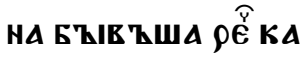

KO HE OYAOБL HMOY

ЩЕн БӒТИСТЕО в Қ

црество Бӝнє в т

20 HнАОУТА ${ }^{25}$ ОУАОБЕ

E EO ECTh BEALEOY

AOY сквоз А иГАн

нЕ оүшн пронтн.

неже БӒТоY в ц ци
$111 \Gamma$

сА९һс Твнњ БӜнњ в

нитн. ${ }^{26}$ рекоша же

MOY CA ZIWAR ZWEH.

кто можети спёент

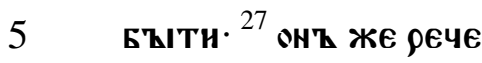

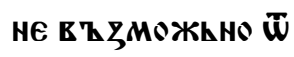

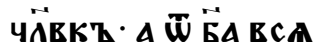

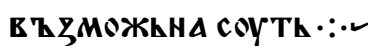

в Z чеึ :

10

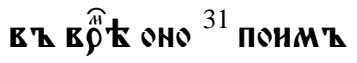

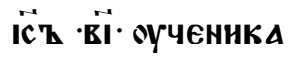

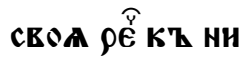

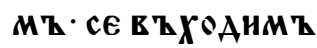

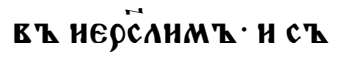

15 KOHһ ЧАКTh СA ВСA

ПнСАнНाа ПӦ९ЧК

CKA O CHE पÄBपh

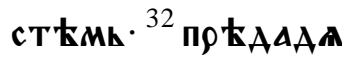

Th Бо н ст

20 h пероугаютh CA

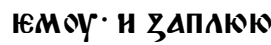

Th H. ${ }^{33}$ н Бнв 'ъше OY

БНюТА Н· И Т९ЕТн

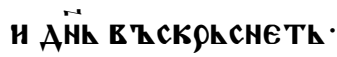


$112 \mathrm{a}$

${ }^{34}$ и ти ннчисоже $\overline{\boldsymbol{W}}$ сн

$X^{7}$ HE PAZOYMAXOY

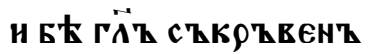

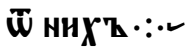

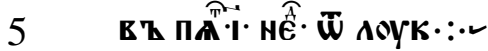

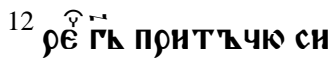

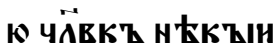

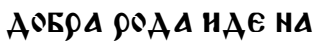

стрАноY АААЕче ПрН

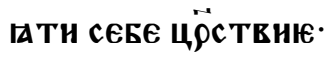

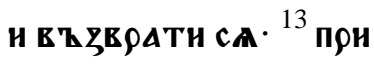

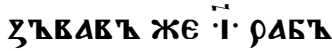

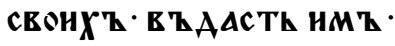

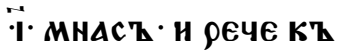

15 ннмт К КоупАю А Кн

TE АОН'МАEЖE ПОНАЖ

${ }^{14}$ А ГОАЖАANE' HENA

вHАA $\triangle$ XOYTh ЮГО '

ПOC'ҚАШША MӒTEOY.

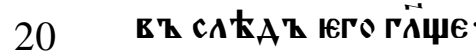

не Xочем z семоу.

АА цреств оуе Th HА

АТ НАMH $\cdot{ }^{15}$ Н БъI IEГАА

ВЪЗЕРАТН СА · Н ПФН

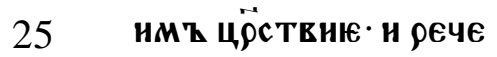

1126

АА ПОНГААСА Th Ю

MOY РАБҚ' нМ Қже

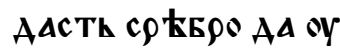

B tcTh KaKoY KOY

5

ПAN БOYAOYTh c'B

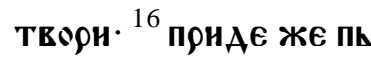

ОКВ ҚIH ГӒА Г̈Н

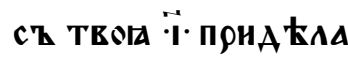

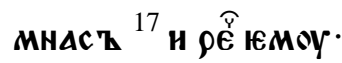

10

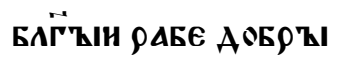

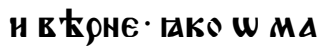

А Е в

АН OБАACTK HAAT

АЕСА THЕ ГОААТ.

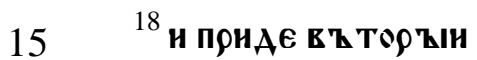

ГӒA EMOY MHAC'

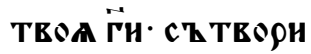

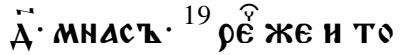

MOY. БOYAH HAAT MA

20 ТнК ГФААт. ${ }^{20}$ Н А९ОУ

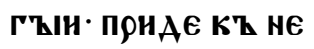

MOY ГӒА · Г̈H CE MHA

C' TEOA КЖE ИМ

X'h ПОАОженоу в' оY

25

Epoyct. ${ }^{21}$ goray'h go ca 
112B

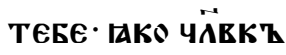

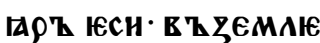

Ши югоже не Поло

жи - и женеши его

5 же не с trak $\mathbf{2} \cdot{ }^{22}$ гй

IEMOY $\tilde{w}$ oYcTth TEO

их'z соужю ти' 3 '

АТИ ९АБЕ А ҚННЕ Қ।

H. в ҚАAшE IAKo

10 Чล̈ЕКИ ТА९ ЕСMh.

в һろЕМАК югоже

не положи · н жинь

Іегоже нE ckIAX'

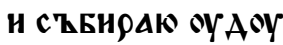

15 ЖЕ не РАС точнХ'

${ }^{23}$ H ПО ЧК TO HE в ZAA

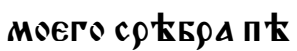

НАЖКнНКОМ冖 ·

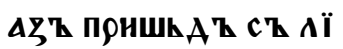

20

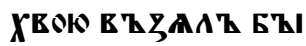

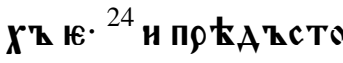

Ацнмт $\rho \in 4 е \cdot$ в $\mathrm{kg}$

M KTE Ẅ нEГO MHA

CZ' Н АААНТЕ НМВ

25 шюмоу $\overrightarrow{\mathrm{l}} \cdot$ MHAC
$112 \Gamma$

${ }^{25}$ н рекошА ๒моу г̈н.

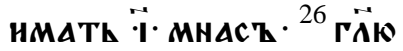

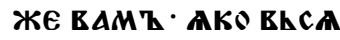

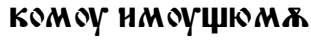

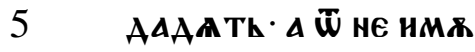

ЩАГО н ЕЖЕ нмАТһ

ш̈нмоуть $\bar{w}$ неге. ${ }^{27} \mathrm{w}$

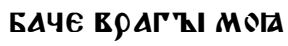

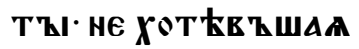

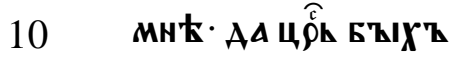

БҚIA' HAAT НHMH.

ПОНЕеАНТЕ ГА СКМО

нс ћц Кте п прћАТ

Мнок. ${ }^{28}$ и се ९ект и

15 AawE По

АА въ иерсолми $\because \because$ -

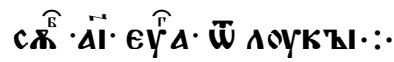

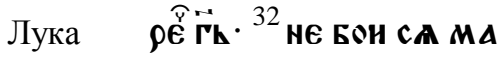

XII

$32-40$

ASE C TAAO IAKO EAA

20

ГОНรЕОАН оц̈Һ в АШК ·

ААТИ ВАМТ ЦретТЕН

IE. ${ }^{33}$ ПрОаААНTE HМЕ

HнЮ ВАШЕ • И АААН

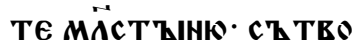

25 рнте сеБ大 в һААГААї 
$113 a$

џЕ не ветһШАКџе

сткоовнце не оскоу

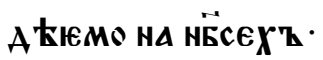

иАЕЖЕ ТА Тнњ не Пої

БАНЖАКТИ CA- НH

ThAA ThAHTh' HH पh

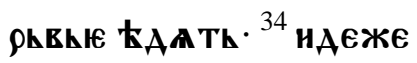

Бо ести сһкровнце

вАше тоу и сРАце вА

we вoyAETh ${ }^{35}$ goyad

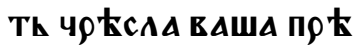
ПOІАСАНА· Н СЕ КТИ

Аһннци ГО९аце. ${ }^{36}$ и

ВҚІ ПОАОБКНИ Чत̈ЕКО

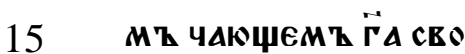

ЮГО К'КГАА вҚگЕ

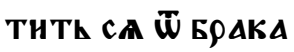

АА П९ншкА Қшк н

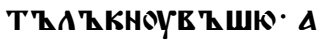

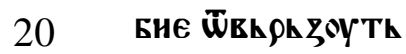

СА Юмоу. ${ }^{37}$ БА АЖЕнї

९АБН Ти ГАЖЕ $\overrightarrow{\Gamma h}$ 。

БОАџЕТИ Б'АААША.

АМннҚ ГӒК вАM Қ
1136

СА Н ПОСААНТИ ГА И

мнноуе т послоужї

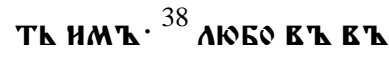

ТороуК АКБО в Т Т $\rho E$

5 тиюе ст Аж8 при

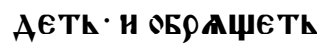

ТАКО- БААЖЕнН СоY

Ти ९АБи Тн. ${ }^{39}$ сE ЖЕ в

АНТЕ ГАКО АџЕ БҚI

10

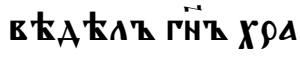

МНнҚІ В Қ КҚІИ

YАC' TATh ПОHАE

Th Б'А ҚА' оуБо

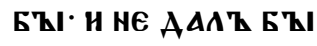

15

ПОАҚКОПАТИ Х९А

МНHҚІ СЕО.А. ${ }^{40}$ Н В ҚI

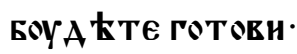

IAKO в 'h нһЖE чАс'

не мннте $\cdot \overrightarrow{C H h}$ че

Аөв Ћчискъи прн

AETh ::-

HÊ $\cdot \overrightarrow{\Delta l} \cdot E \hat{Y} \Delta \cdot \vec{w} \Lambda$ syк $\cdot:$

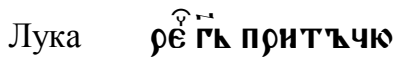

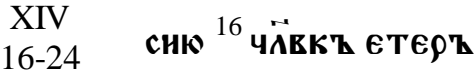

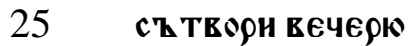


113в

ВеАНКОУ Н Z'ҚЕА

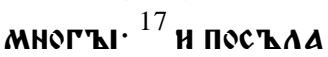

PAE'L в' rOA' REYE

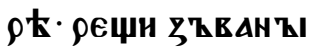

5

Mh HA

TOBA OYЖE COYTh

BCA. ${ }^{18}$ H HАYАШШ ET

коупћ їрнцАТн

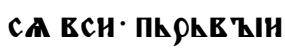

10

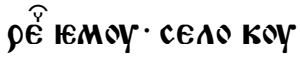

ПнX'Қ ' HMAMZ HOY

ЖАК НЗНТН ' Н ЕН

А КТН Е' MOAN TA

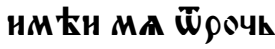

15

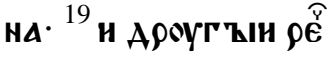

ґ̈му coyngoyrt

BOAOELHZIX' KOY

ПнХ' $\vec{\bullet} \cdot$ HАОУ НСКж

CHTh HX'Z MOAN TA

20 Hм太Н Ma Ẅрочh

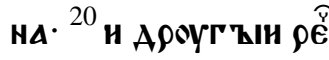

ЖеноY ПOAX'Z и се

ГO PAAH HE MOГOY

прнтн. ${ }^{21}$ н прншһАТ

25 Пов ЕАА ГН̈ОУ Сво
$113 \Gamma$

IEMOY СH T'BTAA PA

ZHEBA CA FH' AO

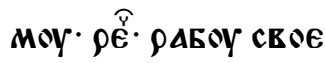

MOY. HAH CKOPO HA

5 ९АспоҮТНІа. Н СТК

ГНҚI Г९ААА Н НH

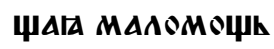

н'IIA. H X

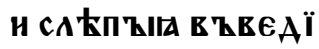

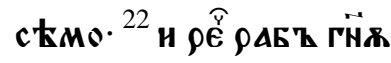

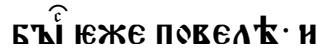

еще MЋсто юсть

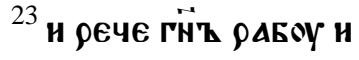

ЗНАН НА ПОУТИ И

15 ХААОУГ̈L н оүЕ

АН ЕҚННТН АА HА

ПZАZHНTИ CA AO

MТ MOH. ${ }^{24}$ ГӒК हO вА

M ' ГАKO Hн ЕАH

20 нт же моужи т $\mathbf{k} \boldsymbol{X}_{\mathbf{T}}$

Z'ZEAH'ZIX' HE E'

кoychTh Moera вE

чера ' мнози Бо

COYTh 弓'ZЕАНHН

25

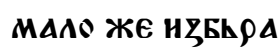




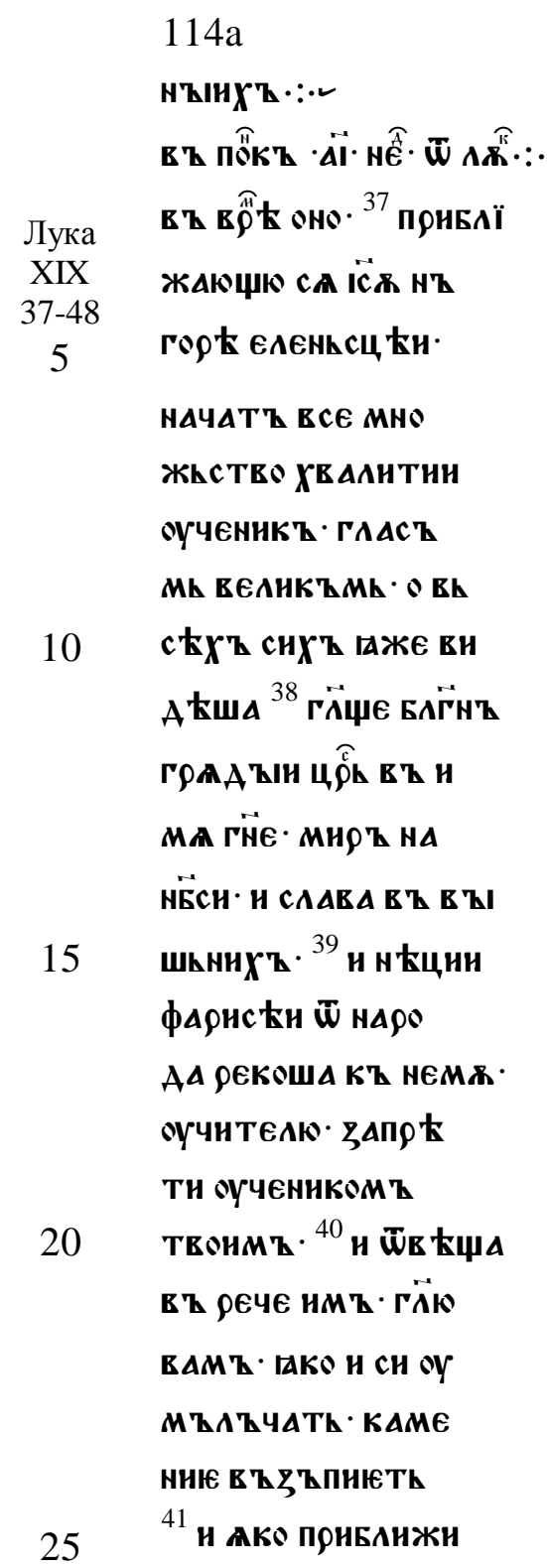

1146

СА внА Кв ' Г९АA'

Н ПААКА СА О HEMh

ГӤА. ${ }^{42}$ ГАКО АџЕ БЪ

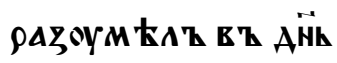

5

сһ ТҚІ и АЖЕ К' Ми

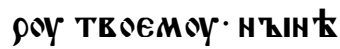

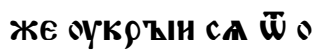

чнК TKOEN. ${ }^{43}$ TAKO прH

AOYTh АН̈HE HА TA.

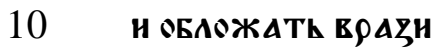

TEOH WCT

TEБ'· н ОБНАОУТ'

ТА· и өкрочАTh ТА

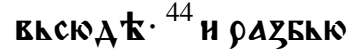

15

Th Т А И YAAА TEO

ГА В Т ТЕБЕ Н НЕ W

CTARATh КАMENH

нА КАМЕнН в Т ТE

Б'· Понеже не $\rho \Delta$

20 зоум в

Пос ћченнгА TRо

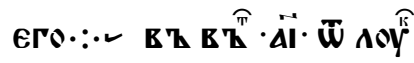

в т в

іст в' цёквк

25 н нАЧАТТ НУГО 
114B

НИТИ ПРОААКЧАГА

ГОАОУБН. ${ }^{46}$ ГӒА НМъ.

ПHCAHO ECTh - H БOY

AETh Х९АMт Мон

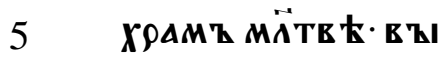

же съ творнсте и

вһ

HнКОМт $\cdot{ }^{47}$ Н БАШЕ

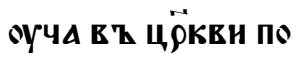

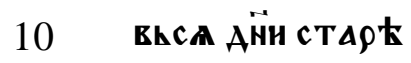

ишинҚІ же жирь

чиск'Ы и кннжь

ннцн нскАХОУТК

Іеге погоуьити

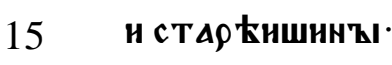

АюАНН. ${ }^{48}$ не ОБрКТА

XoY 4h To cz TE opa

Th ЕMOY. АNAHIE

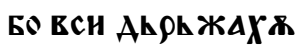

20

CA ЮГО ПосAоYшА

кще юго $: \because 2$

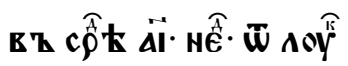

Лука

$\mathrm{XX}$

$1-26$

25

в Z в

WN ICOY ANAH ET

цёквн БАГ̈०
$114 \Gamma$

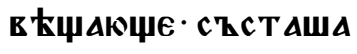

са стА९ КншинҚ Жи

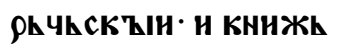

ннцн съ с Т Арьцн · н

5 рекоша 2 гӥџе Кһ не

МоY. ОБци нАMт Ко

ЕК ОБА АС ТНК СН ТЕО

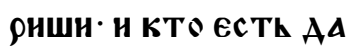

В ҚIИ ТЕБЕ оБААСТ

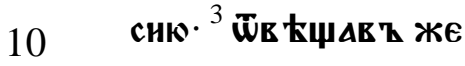

рече К' ннмт - в'

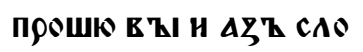

весе н Оһц КТЕ мн

${ }^{4}$ коцченне ноаново

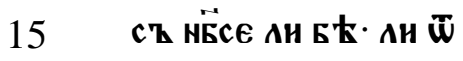
Чล̈ЕКт. ${ }^{5}$ ОНн ЖЕ ПО

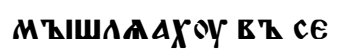

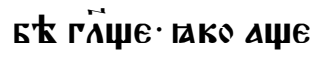

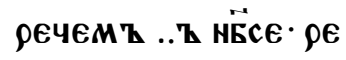

20

чеTh HaMth no yh

TO OYБO HE в Қ

с те юмоу. ${ }^{6}$ Аџе лн ре

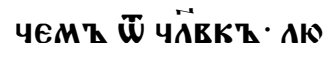

АНЕ ВКСН КАMENH

25

EMh ПОБНюТИ NҚI 
$115 \mathrm{a}$

нбе Кщени Бо соу

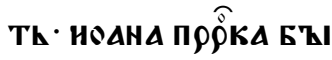

Ти. ${ }^{7}$ н йв ћиаша не

в

5

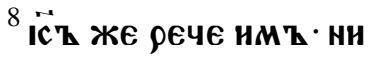

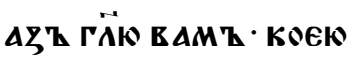

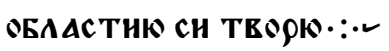

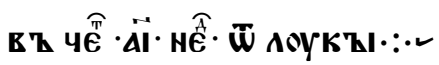

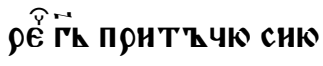

10

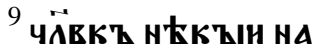

СААН ВННОГРААТ · Н

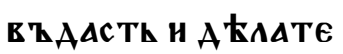

АЕМ ' Н 'ТнАЕ HА А

TА мнегА ${ }^{10}$ н в' в९Е

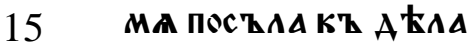

TEAEMT PAEA. AA W

ПАОАА вИНОГРААА

ADAAAATh EMOY. At

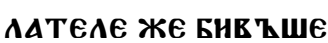

20 поустншА н тҚщА.

${ }^{11}$ н прнАежн А९оугА

ГO ПOCҚ ААTH РАБА.

Онн ЖЕ и ТОГО Бив '

ше и досажиже ем8

25 ш̈поустиша н ти
1156

щА. ${ }^{12}$ и прнлงжн тре

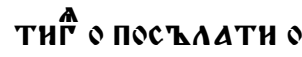

ни ЖЕ и сеГО БнЕ $\mathrm{h}$

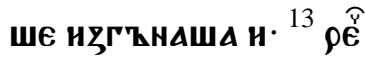

5 же $\overrightarrow{\mathbf{\Gamma h}} \cdot$ внногоААА

पh To ch TEOpN no

С ҚAN CHA MOETO в '

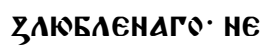

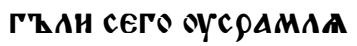

10

NTh CA. ${ }^{14}$ BHA tEk

ШЕ ЖЕ н ' А ЕААТЕАН

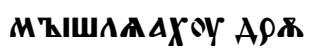

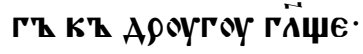

ce tecth HAcA $\mathrm{k}_{A h}$

15 ннк' - оуБннМт н

h AA HAWE EOYAETh

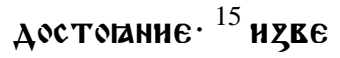

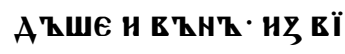

НОГРААА ОУБНША

20 H. पL TO OYБO CZ TEO

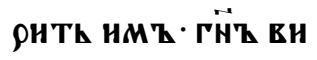

ногрААА. ${ }^{16}$ прнАЕТь

н ПогоуБнти А

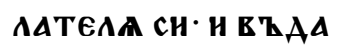

25 с ТИ вИноГРААТ И 
115в

H太M ' CA ҚIWAK '

ше же ९екошА АА не

БоуАети. ${ }^{17}$ он' Же в Қ

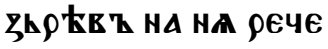

5

Yh TO oYEO IECTh nï

CAHO сE KAMEHK Н

же ш̈вирьгоша зи

жющен сь Бъर् в द нА

YANO SYT'ZASY. ${ }^{18}$ EhCA

10 КЪ ПАА ҚI нА КА

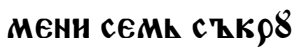

WHTh CA· $\triangle$ HA HE

МhжЕ ПААETh c'z

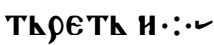

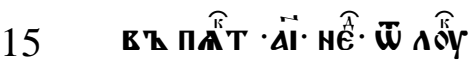

въ в

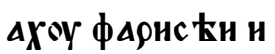

кннжьници

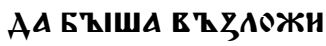

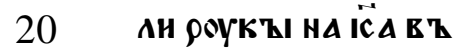

Th YAC' H OYEOTA

WA CA АNАHН' PA

马OYM KWA БO IAKO

Кһ ннм' рече прн
$115 \Gamma$

A AB hWE חOCh $\mathrm{hAWA}$

A KАATE八A TEOpa

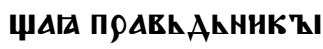

БZITH' АА HMOYTL Н

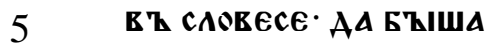

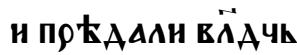

С ТЕОУ Н ОБААСТН ВО

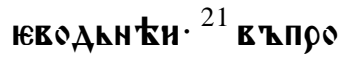

СНША н ГӒயЕ - ОҮЧн

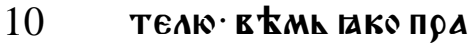

во ГӒШН· Н ОҮчншн

Н НЕ НА АНЦА Зһ

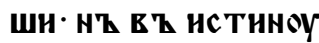

поути Бӝню оүчн

15 шн. ${ }^{22}$ Аостонтһ Ан нА

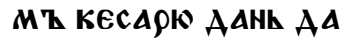

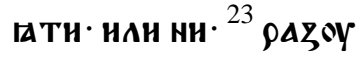

м Łв h

рече $к$ ннмт ${ }^{24}$ покА

20

жћте мн пАтоY. чКї

HМАTh ОБРА马' Н НА

ПнсАниюе Рнн же $е$

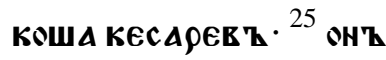

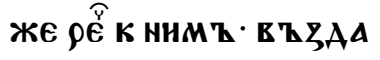

25 АнТЕ оуБО гажЕ соY 
$116 a$

Th Kec $\Delta \rho \in \mathrm{\Delta} \Delta$ Kec $\Delta \rho \mathrm{N}$

$\triangle$ БӜНга Б̈Ен ${ }^{26}$ н не Мо

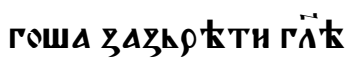

IEГO' ПоҚАТ АюАһMH

5 Н АНЕАКШЕ са ${ }^{\circ}$ Ш̈в

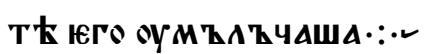

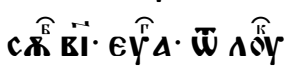

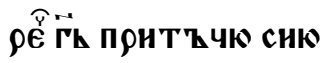

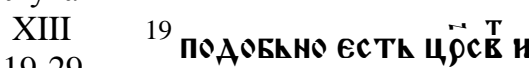

19-29

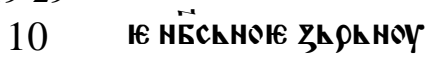

героушнноу. єже прї

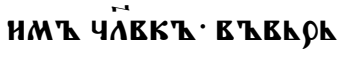

Же в द вһ

Свон· н вһЗААСТЕ н

15 БЋі в А९ Аво велнњ

Н ПТНЦА НЁСКНҚIIA

В ҚСЕАНША СА Е'Қ Е Е

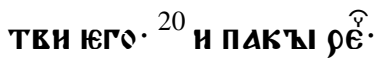

KOMOY OYПOAOEAN

20

црество Бӝнњ ${ }^{21}$ поАО

БКHO ECTh KEACOY.

жЕ прннм Тши женА

сткр' в' моуц

T९н сїт A. AOH' AE

25 же в ъскъисе все ${ }^{22}$ и про
1166

Хожаше сквоз

ГОААЫ И ВСН ОУЧА

Н Шhс ТВHЕ ТВе९A

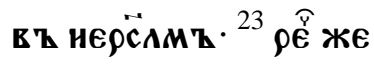

5 Юте९̆ к' немоу. $\overrightarrow{\text { гे }}$

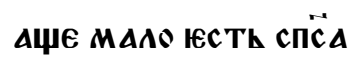

КщнХҚ СА - Онъ жЕ

рече К' немоY.

${ }^{24}$ ПОАЕНЗАНТЕ СА

10

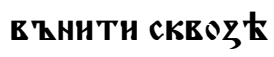

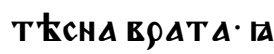

КО МнозН ГӒК вАM Қ.

В ҚННТИ И НЕ ВЪЗМО

гоуть ${ }^{25} \overline{\mathrm{w}}$ нелћже в

15 с тAHETh $\overrightarrow{\text { Th }}$. AOMOY.

Н ZАTEOQHTh АЕК

Н НАЧЬHETE в ҚH太

с тОАТн· и ТА Еџн

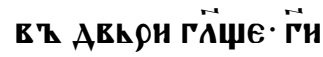

20

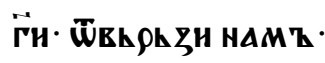

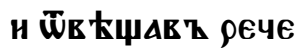

Th вАMh - не в 太Mһ

BAc'z W KOYAOY EcTE.

${ }^{26}$ TZГАA HАYLHETE

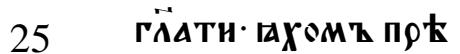


116в

АТ ТОБОК. Н ПНХО

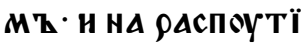

HX'B HАWHX' оYчї

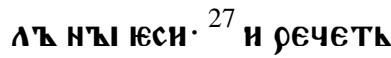

5

ГӒю вАMЋ не в ЋМh

вAch W KoYAOY Ecte.

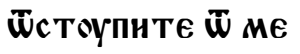

не висн А ЋААТЕАЕ

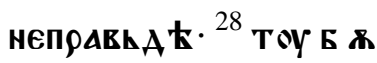

10 АЕТИ ПлАчһ н скрһ

жеTh ZоYБOMz - IE

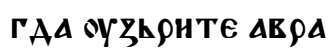

MA HC АKА HIAKOE А.

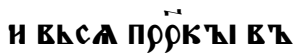

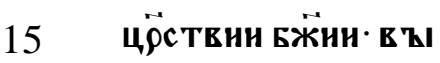

же нугеннм ҚІ вт

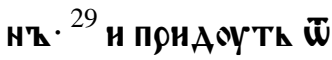

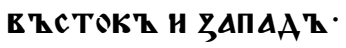

н сћве А н оүГА. н

20 ВZZАAГOYTh E'

црествни Бӝнин $::$ -

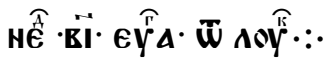

Лука

XVII

12-18

25 в в в

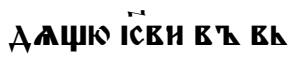

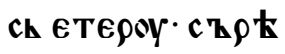

$116 \Gamma$

TE H· AECA Th חрOKA

жен' Моужи - нже

CTAWA H马 AANEYA.

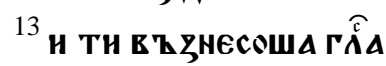

5 ГӒळщh

ННче ПОМнАоун нҚІ

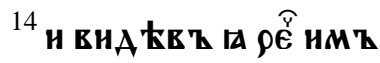

шhАтше покажћте

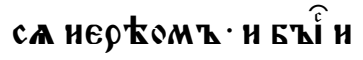

10 АОУЩЕМт НM ' цистншА СА. ${ }^{15}$ ЕАн Nh $\tilde{W}$ HнX' вHA

гако нсц ЕА КША в

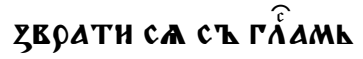

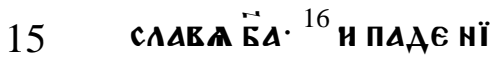

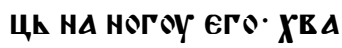

AOY EMOY EZ3ALA

и * тов Е с АМА९Анн

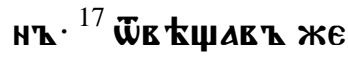

20

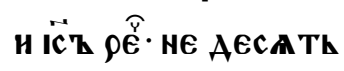

АН Нџнс ТишА СА

А АЕвати ${ }^{18}$ KАKO HE O

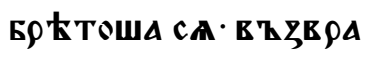

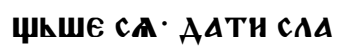

вOY Б̈ОГ. ТТКМО ИнО 
$117 \mathrm{a}$

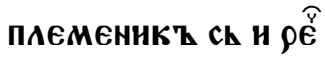

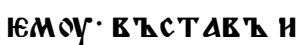

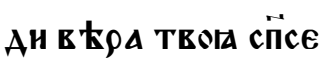

TA $\because: \cdot$ -

5

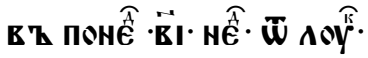

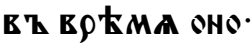

${ }^{27}$ прнс тоупншА

Лука нћцин к' $\overrightarrow{\mathbf{c}} \boldsymbol{\mathbf { k }}$

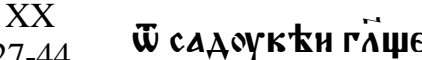

10 в Ћскр Ћшенню не

БҚІтн· в ҚПФАША

Хоуть и ${ }^{28}$ ГӒЕше - Оучн

ТЕАК МОНсн нАПÏ

CAAT IEC Th HAMT

15 АџЕ комоу Б९АT'

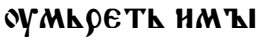

и женоу' и тһ БещА

AT EOYAETh A A חO

нмеТИ БРАТ' жЕ

20 ноу его н в Ђско

СНТИ ПАEMA БРА

TA cBoero. ${ }^{29}$ ceAmh

БрАТИІа БАШе· Н

ПК ९К В ҚIH ПОНМ'

25 женоу оумире Бе
1176

HAAZ ${ }^{30}$ H ПOATK в

тор'Ын женоу и Т'

оумире БещАAт ${ }^{31}$ н

Т९ЕТИН ПОА ТҚ К. ТА

5

Коже и всA сеАMh.

HE ОС Т АRИША पАA'

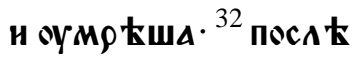
жЕ же $\mathrm{khct}$ ' $\mathbf{h}$ и же

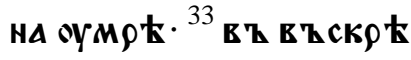

10

шенню оүБо кото

PATO БOYAETh нX'

жEHA ' CEAMh БO HM Е

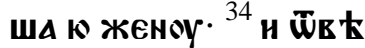

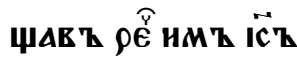

сHEE в ККА сегО же

HATh CA' H ПOCATA

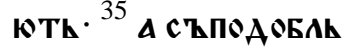

шен сA в kK' Th oy

АОУчнТИ· Н Е Вско Е

20 шению єже $\overline{\mathbf{w}}$ мь

РЪ Tв ҚIX' • НH ЖЕНА

Th CA HH ПOCAГ AK

Ть ${ }^{36}$ ни оумо Етн Бо

חо TOMh MoroYTh

РАЕКНН БО АНГГМ 
117в

COYTh · C CHEE COYTh

Бённ· в ъскр ћше

нию же соуще $\cdot{ }^{37}$ А IAK०

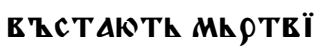

5

H. Н МОСН С'ҚКА३А

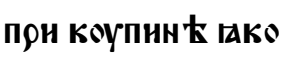

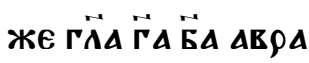

МАА Н ЁА НС АКОВА

и Б̈А HIAKOKАA ${ }^{38} \overrightarrow{\text { ETh }}$

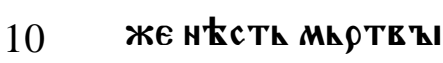

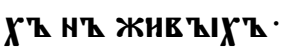

вһсн Бо томоу жн

ви соуть ${ }^{39}$ шек ЋшА

въше же н Кцин

15 ш фарнс Łи реко

ША оУчнТЕАю А०

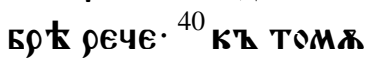

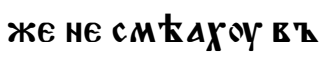

ПоАШАТИ ЮГО нН

20

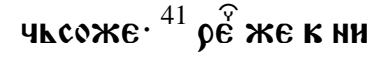

Мт КАКО ГӒТИ КHї

Жиннци

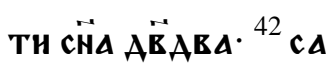

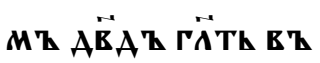

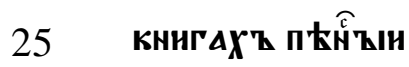

117 Г

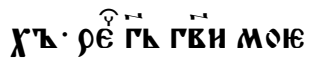

MOY. САAH O АEСH及

o мене ${ }^{43}$ AOH' АEжE

ПОАОжК в АГГ'Қl TEO

5 А ПОАТНОЖИЕ НО

ГAMA TEOHMA.

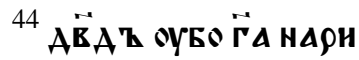

ЦАЮТК И КАКО С̈H

IEMOY ECTh $: \because \cdot$

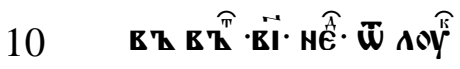

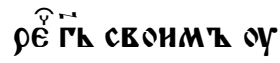

ченнкОМт $\cdot{ }^{12}$ в

Лука

XXI

12-19

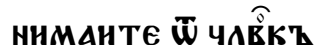

В ZЗАОЖАTh БO HA

15

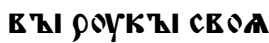

НЖАЕноУТА в ҚI

по ААКще нA ck

БорнщА н ТһMh

ННЦА' вЕАОМ ҚI

20

К' цеॄЕМт · н вАӒКА

MТ НMENE MOE

ГО ९ААН. ${ }^{13}$ ПрнКАК

чнТИ ЖЕ сA вАMт

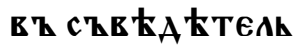

25

ство. ${ }^{14}$ ПОложнте 
$118 \mathrm{a}$

оУБО нА СРАЦИХ'К ЕА

шиХ' · не прқже по

оүчАти са ӥв ћщА

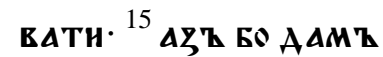

5 вАMт оустА н прТ

MоYарости ' енже

HE в Қ马MOГOYTh ПрО

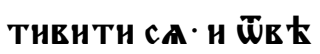

ЩАТИ ЕһСН ПрОТИ

10 ВАЧНН СА вАМ $\cdot{ }^{16}$ пр Қ

ААни же БоYаете ро

АНТЕАН И БОАТНЕ

Ю Н РОАТМК Н А९ОY

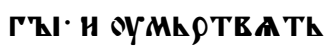

15

ш̈ вАсъ $\cdot{ }^{17}$ и БOYAETE

нЕнАВНАНМн вһCt

МН НМЕНЕ MOEГО

PАAH. ${ }^{18}$ Н вААC'

ГААВ ҚІ в АШЕІа нЕ

пог'ҚIEнE Th ${ }^{19}$ в Z Th

рПћнн вашем $\mathrm{k} \mathrm{ck}$

Лука

XXI

5-11,

20-24,

28-32

25

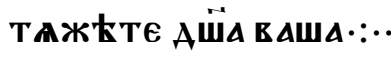

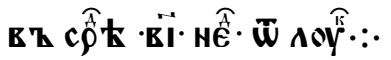

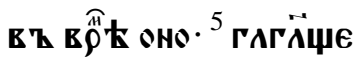

MZ・ H太KҚIMZ K'
1186

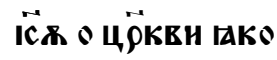

кАMEннеми А०

Брқым н стсоуаты

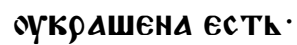

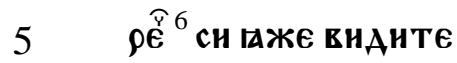

ПонАОУТК Ан̈нाЕ

в h HAЖE NE OCTA

HETh KAMENh HA

КАМЕни сһАE ижЕ

10 HE ९АZорнтL CA

${ }^{7}$ в ҚПросншА Же и

ГӒџЕ ОүЧнтЕАК

КТГAА СH БOYA

Th' H YTO ECTh ZHA

15 менне ЮГАА Сн

ХОTА ТИ БZITH. ${ }^{8}$ 。

Hh же рече БАКА

TE CA. MHOZH БO

ПонАОYТЬ В' НMA

20

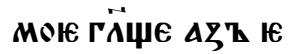

сми' и вр Қма пюї

БАнЖН СА- НE и

A $\mathbf{T E}$ вһ сA

$\boldsymbol{X}^{\mathbf{z}} \cdot{ }^{9}$ ІеГАА ЖЕ оусаты

Шите Б९Ани и не 
118 в

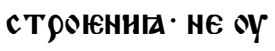
БОНТЕ СА· ПОАОБА

IETh БO CHMT EZI

ТИ· Н' HE ОY АБНЕ

5

КОнК чинА. ${ }^{10}$ TъГАА

Гӥше в Қст TAнETh

EO IAZ'WK' HA IA

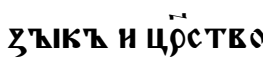

нА цёство. ${ }^{11}$ т $\rho у с \mathrm{̈}$

10 ЖЕ велнцн· н По Мћ

СТА ГАААН И МОРН

БOYAOYTh - сT९A

ХОВАнНІа ЖЕ И ZНА

Меннга. сқ нЁсе ве

15 АНКА БОYАОУТА

${ }^{20}$ ІеГАА ЖЕ оУЗһ९нтЕ

ОБһСТОНМ В ВОН· НЕ

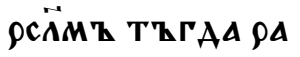

zoYmkete rako nрї

20 БАНЖИ СA ЗАПОУ

ст ЋнHEMh ${ }^{21}$ TZГАA

соушен в' нюА Еи

АА Б КГАКTh в' ГO

р'Ы· нже по сере А
$118 \Gamma$

Th · нЖЕ в

X'Z AА HE в

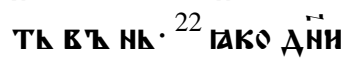

Iе МКщенню сн соY

5 Th A А HCПТАТHA

Th CA RCA HAחHCA

HAIA. ${ }^{23}$ АюT K

ЗАКНZIHMТ Н AOA

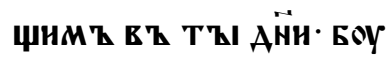

10 АЕТК БО БА АА вЕАН

КА НА ЗЕМАН· Н ГН̈太

B Z HA AWAKX'h CHX'B

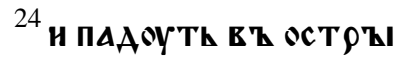

МЕЧА' И ПА ЕНЕнН

15 БOYAOYTh в' A

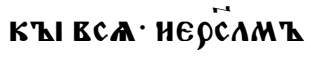

БOYАETh ПоПноАЕ

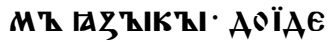

жE çKonhYANTh

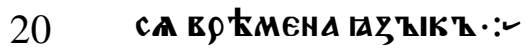

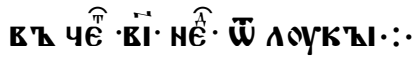

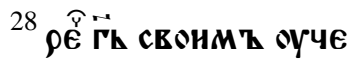

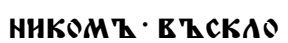

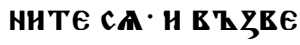

25 А Ћ TE ГААв ҚI вАША 
$119 \mathrm{a}$

ЗАНЕ ПОНБАНЖН

СА НЗБАВАЕнНЮЕ

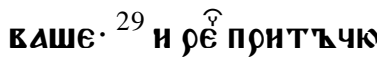

HMЋ ' ВНАНTE СMO

5

КОБһнНЦК Н ВһСА

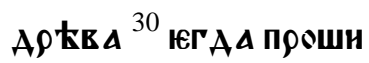

БАNTK CA BHAALE

- сев · в kс TE IAKO

БАН弓马 ЖАTЕА ЕСТИ

10 TAKO н в' EГAА OY

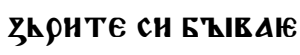

MA в 太анTE IAKO

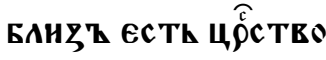

БӜ̈н ${ }^{32}$ ПрАв ГӤЕ вА

15 Mh ' IAKO HE HMATh

Пюћити ९OAт ch AO

HAEЖE KhCA БOYAX

Th. ${ }^{32}$ нЁО и ZеMАA МН

MO haETh - А сAOBE

20 CA MOIA HE HMOYTh

прћити :-

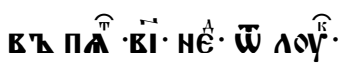

Лука

XXI

37-38

25 вт в

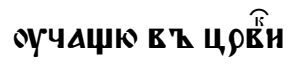

$\triangle$ в В НОџн нс РО
1196

aA B

в Т ГорҚ нАрнцАњ

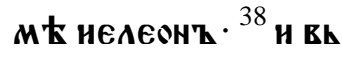

СН ANAHIE H马' OY

5 Т९А п९нх॰жААХऽу

K' HeMOY в цёКЕ

ПослоYшАT' ЮГО.

Лука

XXII

$1-7$

${ }^{1}$ н ПрнБАнжАше СА

ПОАЪАКННК' W

10 П९ ЕСН'ҚК' $\cdot$ НА९н

ЦАЕМ ҚІн ПАС ХА.

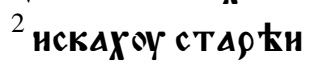

шинты жh $\rho$ чh

СК'Ы и КннЖһнн

15

ЦН· КАКО Н БЪШША

ОYБНАН- БOAXOY

БО СА АЕАНН. ${ }^{3}$ в $\mathrm{Z}$

HнAE ЖE COTOHA

ВТ НОУАОУ НАРНЦА

20

ЮMATS сKАPHOTA

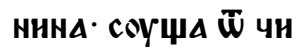

CAA ОБОN HA AECA

TE $\cdot{ }^{4}$ H WhAt ГӤА CTA

рћишннамқ жh

25

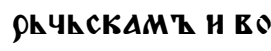


119в

ЮEВААM Қ КАКО И

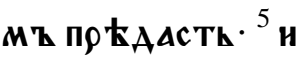

ह Қ ЗА АА ОВ АWА

СА· И СҚВ ҚџАША Ю

5

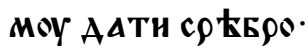

${ }^{6}$ ї нспев

WE ПОАОБһHА в९ Қ

MENE АА и ПО ҚАА

CTh HMT БEZ HAPO

10 АА. ${ }^{7}$ прнАЕ

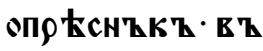

НКЖЕ ПОАОБКНО

БААше ж९ћТИ ПА

cxoy::-2

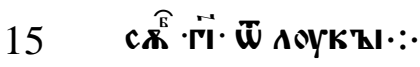

въ в

ННТИ Ї्ЕН ЕҚ АO

Лука

XIV

1-11

20

MZ ETE९А КнA

ЗА фАрнс КнсКА

в Z соYвотоY Xat

БА Ћс Тһ· И ТИ БАА

XОY нE ZHАКше H.

${ }^{2}$ и се чйккһ Ете९һ

HM ZI BOALHZIH

25

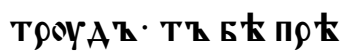

119 Г

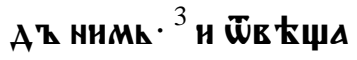

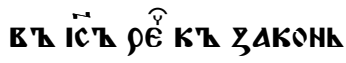

ннкомт н фА९нс $\mathrm{k}$

OMZ ГӒAАџE AOCTO

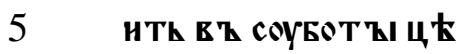

Анти. ${ }^{4}$ онн же оумт

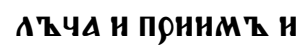

сцћАн н ' и ш̈поусти

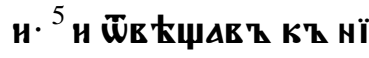

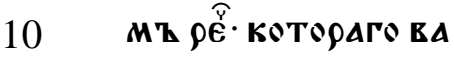

C'h OChA' HAH EOA'

вЪ сТОУАЕнКцК в Қ

ПААЕТИ · Н НЕ АБНЮ

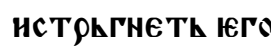

15 в Z AḦ СОYБOThHZI

и. ${ }^{6}$ н не въ弓мМгошА

б̈в ЕџАти юмоу

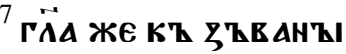

MT ПОHTYК WAK

20

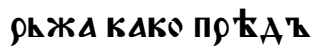

c 太ААНHIA НЭБНОА

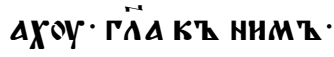

${ }^{8}$ IЕГАА Z'ZBAH' БOY

АЕШН НА Б९АК' НЕ

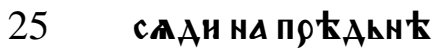


$120 \mathrm{a}$

Mh M KcTK'

YhCThH太Н TEБE БOY

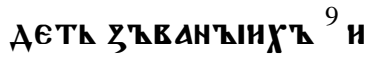

ПОНШКАТ Э'ҚЕАВ ҚIH

5

ТА и оного-

ААЖһ семоY м Есто. н

TZГАА НАЧИНЕШН $\mathrm{CZ}$

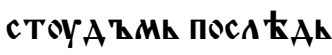

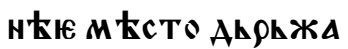

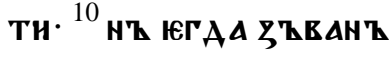

БOYАЕШH· ШhA' ck

АH HA ПOCA ҚAKH KMh

М ҚСТ Е АА ЮГАА П९Н

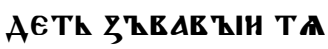

15 речети ти. Ароуже

ПOCAAH CA в ҚIWE

TҚГАА БОYАЕТИ ТИ

CAARA CZ KLC太МH

ZҚЕАНҚIMH C'Z TO

20

EOW. ${ }^{11}$ IAKO в ZZZHOCA

H CA BИCAK' C'MME

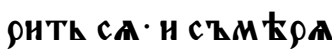

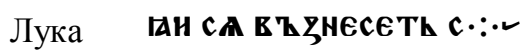

XVIII

18-27

25

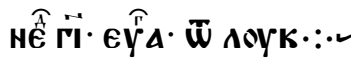

в' в

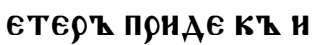

1206

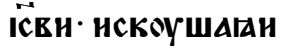

ГӒА ОУЧНТЕАК БАА

ГZIH' पL TO CZ TEOPh

ЖHЕОТТ в ЕपКНҚI

5 h насл Еаһствоук.

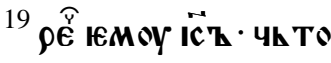

МА ГӒЕШИ БАГ̈А· НИ

КТОЖЕ БӒГZ · HZ TZ

KMO ËZ $\epsilon_{A H H Z} \cdot{ }^{20}$ ZА

10 Пов ҚАн в Ксн ' не

ОуБНн· НИ ПФНАК

БҚI c'Z TEQPH· HE OY

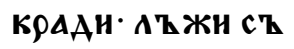

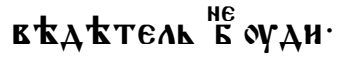

15 ЧК ТИ оц̈А ТЕงеГО

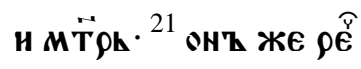

IEMOY вһсA сн съXРА

нНХ'

MOEA ${ }^{22}$ CA ZIWAR' WE

20

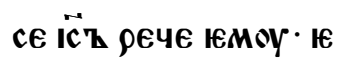

ШЕ ЕАНнОГО НЕ А०

KOHh YAA' ECH· हh

СА ЮАНКО НМ АШї

ПрОААЖК Н ९А३АА

25 
120в

ТН НМАШИ С'КК

вHщЕ NА HЁСХZ

И ГОААН ПО МНЕ

${ }^{23}$ OH'

5

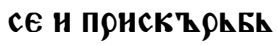

HZ БҚ/ Б大 БО БӒTZ

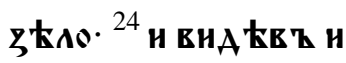

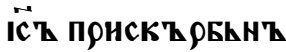

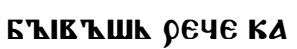

10

KO HEOYAOEL - HMOY

廿НMҚ БА Т̈Ис ТЕО

в церст тво Бӝню

в Қнити. ${ }^{25}$ ОУАОБЕ

Ю БO ECTh ВEALБЖ

15 AOY СКве马 Н иГАн

нћ оушн пронти

неже Ан БӒтоу в

цёст тво Бӝне в

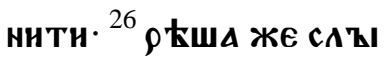

20 ШАВ ҚШЕн· TO КTO

Можети спїенһ

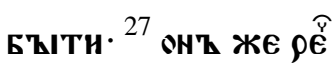

нев Қ马MOжино

प

25 120г

в \ понё

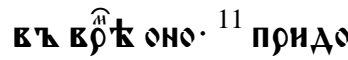

Марк шА фАрнс Ен К'

VIII

11-27

IC̈OY H HAYAWA CK

5 ТАЗАТИ СА С' НH

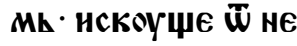

го zнАMENHIA $\mathrm{c} \mathrm{z}$

НБСЕ НСКоүшАюче

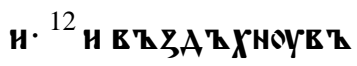

10

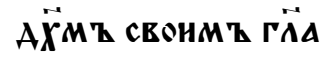

पh TO POAT ch zHAME

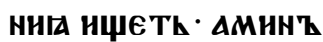

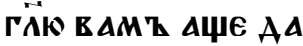

c Th ca pOAOY cem8

15

зНАМЕнию. ${ }^{13}$ Н остА

BAh IA E'Z KOPAEAh

HАE ПАK'J. ${ }^{14}$ H ЗАБҚI

ША ЕҚ弓А ТИ ХАћБҚ

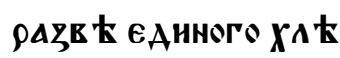

20

БA HE hMAXOY c'z

СОБоК в Қ КО९АБАН

${ }^{15}$ н прћџаше нмт

ГӒА- ВНАНТЕ БАЮ

A tTE ca $\bar{W}$ KR $\Delta c \Delta \phi \Delta$

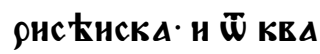

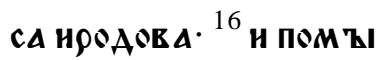


$121 \mathrm{a}$

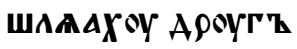

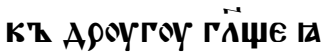

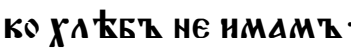

${ }^{17}$ не оу Ан чююте и рА

5

zoym Łほте • окАME

HЕАО АН С̈РАЦЕ КА

ше ${ }^{18}$ нмАТЕ Очн їмж

ЩЕН нЕ вНАНТЕ И ОУ

ши имоушен не слы

10 Шитн· не Помьнї

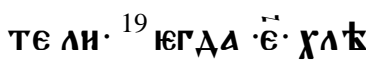

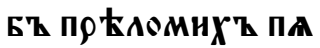

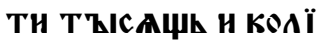

ко кошьниць оу

15 КроУХ' Пнасте

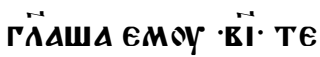

${ }^{20}$ и югАА же $\vec{z} \cdot$ чет Қ

pemz TZICALEMz.

КОАНКО КОШКНН

20 ци нсптА'ҚHh OY

KоOYX' вZZACTE.

онн же рекоша се

АMи ${ }^{21}$ н ГӒА нМт не

oY Aн PAzоYM KeтE

||cs||cs||cs|||cs|||cs|||
1216

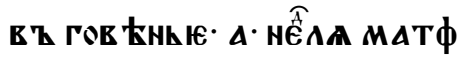

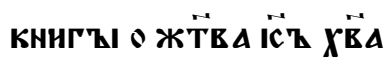

. HÊึ土A MAPKO HA .. HÊึลH

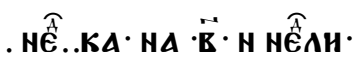

5 HWAHZHA $\overrightarrow{\mathrm{B}} \cdot$ HÊิAH

Марк

VIII

22-26,

30-34

10

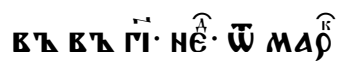

въ в

15

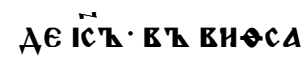

HAOY H ПОHЕEAO

WA KT HEMOY

сА 太ПА Н МОАн

ША Н АА И КОСнЕТТ .

20

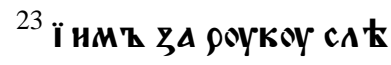

ПАГО НУБЕАЕ И Е ҚHТ

Н马 ЕАСН· Н ПАННОУ

В Қ НА ОЧн ЮГО в Қ马А०

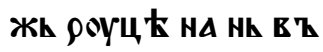

прашаше ' н аще чh 
121в

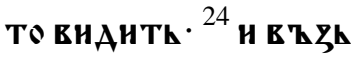

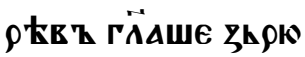

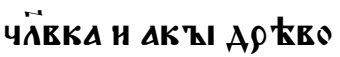

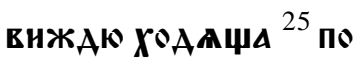

5 ТОМh $Ж Е$ ПАКҚ в Қ

ЗАОжн ९ОУц Е нА О

чн его н съ твори

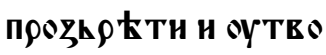

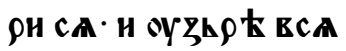

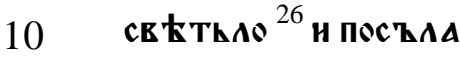

Н В' АОМ ЮГО ГӒА

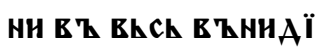

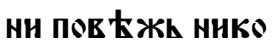

Моуже в Қ висн $: \because$ -

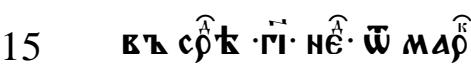

ви в $\rho$ ๘

Тн їъ оүченнко

MZ СЕОНМТ НH

КомоУже ГӤАТИ

20 О нЕМн ${ }^{31}$ н нАЧАTИ

ОУЧнТИ ГА. ГАКО ПО

АОБАETK СН̈ОY Чत̈Вपा

МноГО ПОС TPAАА

Тн нскоушеноу

25
$121 \Gamma$

и ст А९ Łишинъ жь

९һчhсК' и Кннжьни

К' и ОУБКеноУ Б ҚITї̈

и по т $\rho$ Х'

5 скрисноути. ${ }^{32}$ н не оБн

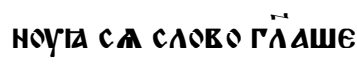

и прћнмты н петрт

НАЧАTҚ ПОЕТНТИ

юмму. ${ }^{33}$ онт же оБрА

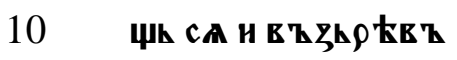

HА ОУЧЕНHКҚI СЕОА

ZАПрКти петроУ

ГӒА hАН ЗА MHON CO

TOHO TAKO HE M $\mathrm{Zl}$

15 слншн ґаже соуть

БӜнА нไ ТАЖ че

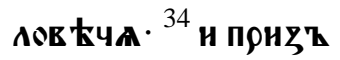

BAR T HAPOATI C'K OY

ченнкҚІ свонми

20 рече нмт нже Хоче

Th По МнЕ ити АА

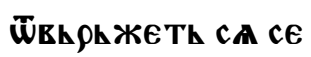

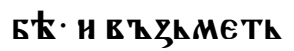

Крьст'Қ свон н ПО

25 MЋнћ НАЕТК $: \because$ - 
$122 \mathrm{a}$

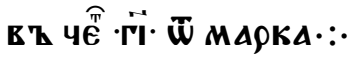

въ вёћ оно. ${ }^{10}$ прна

Марк

IX

10-16

5

ША ОУЧЕНИЦН САО

BO HIC̈EO - पh TO IE

сти ґЖЕ и马 Мh

ОТЕ ҚIX' Е ҚсКОһсHЖ

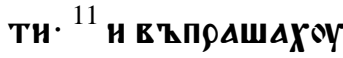

Th и ГӒше · ТKS ГÄळ

Тһ кннЖьннци ґА

10 КО НАН ПОАОБАЕТК

прнти прћже ${ }^{12}$ он'

же $\widetilde{\mathrm{w}} \mathrm{k}$

HMT ' HAHA OYБO

прнши А П пюћже ж

15

стронт人 са и КА

KO ECTh ПHСАHO W

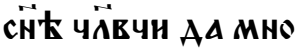

Го пост९АжETh Ï пo

XoYAaTh h. ${ }^{13}$ HZ ГÄ

20 ВАМ ' ГКО НАНА

ПОНАЕ И СЪ ТВо९н

WA EMOY EAHKO в T

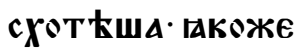

ICCTh ПHCAHO W HE

25
1226

ОУЧЕННКОМТ ЕНА

HAPOAT MHOF' O HH

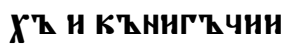

Ch TAZАN山E cA ch

5

ННМН. ${ }^{15}$ Н АБНЕ ВСН НА

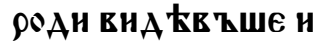

оужАсошА са. н прн

рнцюще ц КА०вА

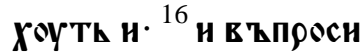

10 Кънижьникъ! чh

TO ch TAZAETE cA

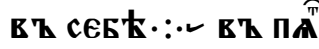

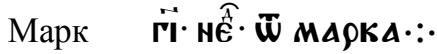

IX

33-41

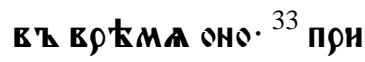

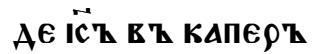

HAOYMZ H E' AO

MOY EZIE Th ח९A

WAWE A- पh TO HA

ПоУТИ в С СеБе По

20

MҚIшАA АС TE. ${ }^{34}$ Они

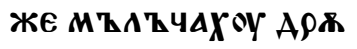

Th K' А९OYГOY ГӒще

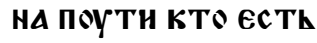

БОАнн ${ }^{35}$ н с ЕАТ Прн

25 
122в

и ГӒА нм В АџЕ КТО

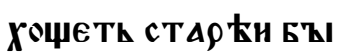

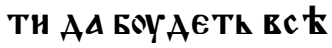

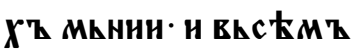

5 слоуга. ${ }^{36}$ и прннмт

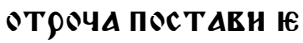

по сереА К ихт н ш

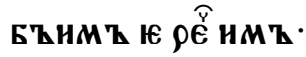

${ }^{37}$ нже АџЕ ๒АнН'О ТА

10 Кок'М' отрочА

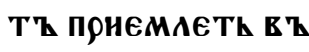

hMa MoE Ma прh

ЕМлети ' нже

Аџе ма прнемле

15 Th' не Ma ПрнемАE

Th HZ חOC $\mathrm{ZAAB} \mathrm{Z}$

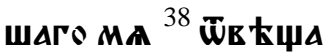

IEMOY HOAHT ГÄA.

ОУЧнТЕАЮ вНА

20 Хоми нћкогон

MENhM' TEOHMh

НУГОНАџА БКс'ҚI

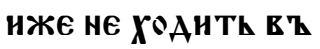

CA 太A'Z HACZ ' И в'

25 ЗБРАннХОМт ЕМА.
$122 \Gamma$

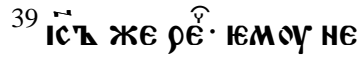

БрАннте ґМоу ' ни

Ктоже Бо ести и

жЕ съ творнти си

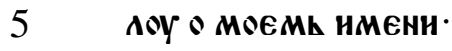

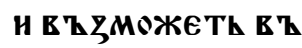

скорТ 弓'МАОсАОвн

ТИ МА $\cdot{ }^{40}$ нЖе БО н太

С Th HА в ҚI ПO в AC'

10

Iес Th ${ }^{41}$ нже Бо Аџе

HAПOHTh E ҚI Y AWL

BOAZI· B' HMA' IA

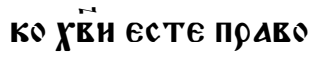

ГӒК вАM Һ

15 ГОУБНТИ МhЗАТЫ

cBsera $: \because \cdot 2$

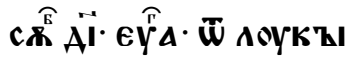

Лука $\rho \widehat{\complement} \overrightarrow{\Gamma h} \cdot{ }^{10}$ в

XVI

10-15

20

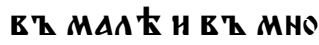

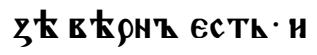

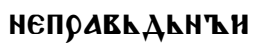

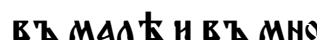

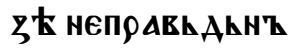

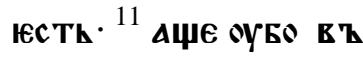

25 
$123 a$

жнтин не Бъі в крь

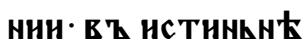

Mh KTO в АC' в E $\rho$ OY

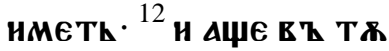

5 ЖАЕМт в ЕРнн не Бъі

BAWE BAMT K'Z TO

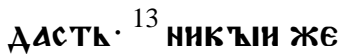

РАБҚ Можетh ATE K

MА ГӒННОМА РАБО

10 ТАТИ АН ЕАННОГО

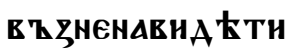

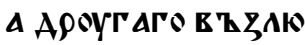

БНТК' НАН ЕАНнОГО

Ahрhжнтh сA· $\Delta$ W

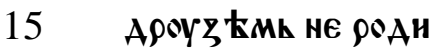

ТИ HАчhHETh ' HE MO

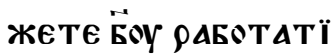

и БӒтLс TहOY. ${ }^{14}$ сAтا

шАА ㅇ ЖЕ сн всA

20 фарнс ћи с

Бици соүше ' н ПОАРА

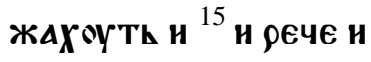

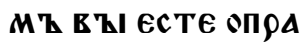

вһААКщен СЕБ

25
1236

вћсти С̈̈АЦА вАШШ

IAKO ЄЖE Естh в'

ЧӒвц КХИ вЪІсеко

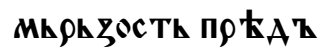

5

ГӒhMh Естh $\because$.

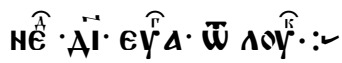

въ в

Лука

XVIII

$35-43$

БАНЖАЮчЮ $\mathrm{cA}$

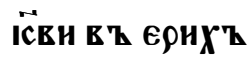

10 слћпьць Етеръ

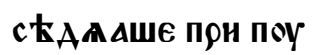

ти пооса $\cdot{ }^{36}$ сAтышА

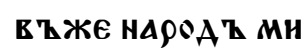

MO X'AALh - в ZПIPA

15 WAWE पh To oYbo ce

ести ${ }^{37}$ пов ћ Аашы же

IEMOY IAKO ICेh HAZA

РАнинТ МнМО ${ }^{\circ}$

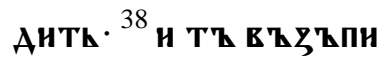

20

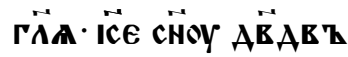

ПОМнАОУИ МА $\cdot{ }^{39}$ Н

поқАТ НАОУџен

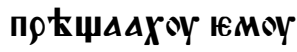

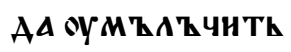

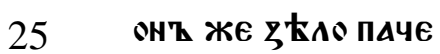


123 B

в ЋПнНАше CHOY AА

В ҚА АОЕ Қ ПОМнА8Н

MA. ${ }^{40}$ стАB h

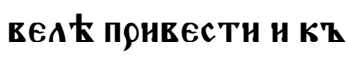

5

сЕБ П ИнБАнжьшю

жE сA K' HEMOY в $\mathrm{h}$

просн и ГӒА. ${ }^{*}$ 4h TO X゚

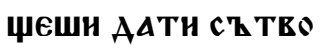

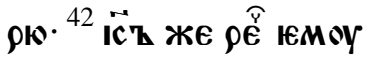

10 Прози

Іа спїе ТА $\cdot{ }^{43}$ и АБне

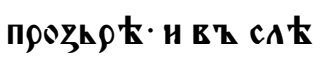

ath iero roaaAame

СААВА Б̈А. И ВСН Аю

15 АНЮ вНА ЕвЋше

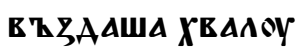

БЁн $\because \because$ в Қ ПOHÊ⿱乛龰

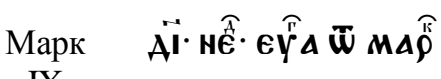

IX

20 БААЗнHтL СА

- EaHнOML MAATl

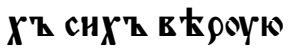

ЧнХ' в '⿳ МА. AO

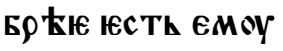

25

ПАЧЕ АџЕ ОБАОЖА
$123 \Gamma$

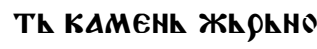

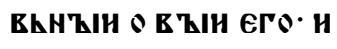

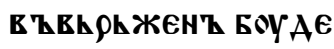

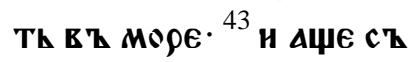

5 БлАжнањТК ТА $\rho 8$

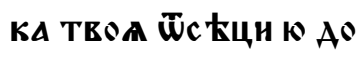

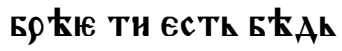

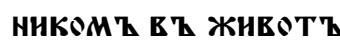

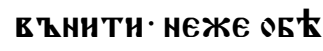

10

роуц К имоуше нти

В Т РОАТ ОГНА НЕ ГАСН

MAГО. ${ }^{44}$ НАEЖE पh ९ूЕh

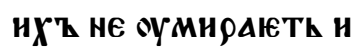

orHh He oyrále Th ${ }^{45}$ H

15 Аџе ногА TBOA C'

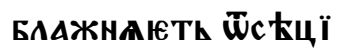

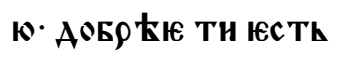

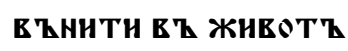

ХромоY. неже A TR K

Hogk нмоYще в $\mathrm{K}$

вһ ९һженоу БҚІти в Қ

POAT OГHA HE ГACOY

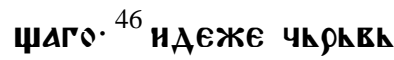

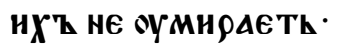

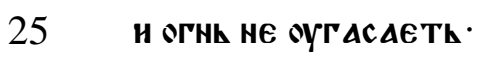

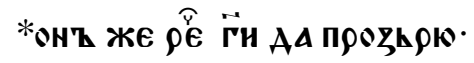


$124 \mathrm{a}$

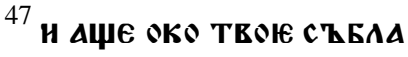

ЖHAほTh ТА ИстТKнї

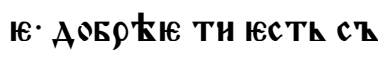

EAHнtKM WKOMZ R'

5

нити в ц церте те Бӝн

Ю· нЕЖЕ оБТ оци им8

ЩК ИТИ В РОАТСТЕО

огнКнOЮ. ${ }^{48}$ НАЕЖЕ पh

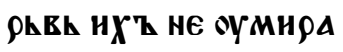

10

ETh H OГHh HX'B HE $\boldsymbol{X}$

ГACAlTh ${ }^{49}$ BhCAK'

EO STHKMK OCOAHTh

CA' H BLCAKA TPARA

COALK OCOAHTh CA.

$15{ }^{50}$ Аовро ести соль Аџе

Ан жЕ соль нЕ сААнА

БOYAETh - ЧнM ' $\mathrm{W}$

Марк солнте·нмћнте соль

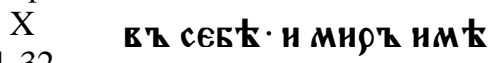

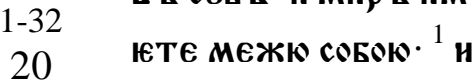

W' TOYAOY R ZCT AR Z .

ПОНАE ПО WHOMOY ПO

АOY HW९AAHA. H ПОН

АОША ПАК'Қ HАРОАH

25

K' HEMOY. H IAKO OE'
1246

ЧАН НMAАWЕ ПАКҚI

SYчАAWE IA :

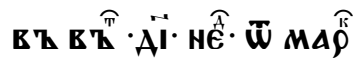

в В в

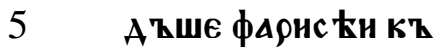

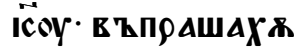

Th H· АОстонТА Ан

моужю женА поустї

Ти нскоушАюще и.

10

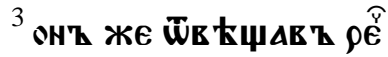

HM ' Yh TO BAMT ZА

Пов ҚАА Монсн. ${ }^{4}$ Они

же рекоша повеић Mo

НСН К КННГҚІ РАСПОУ

15 С ThH'II' НАПНСАТИ

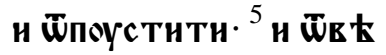

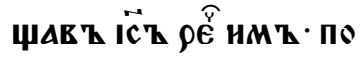

жectoch pahe вame

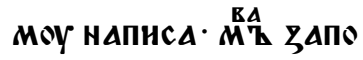

20

в 太АК CHI. ${ }^{6}$ A W HAYA

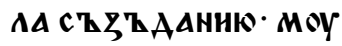

ЖА и ЖеноY с'Z ТЕO९н

AT IA ECTh Ëh. ${ }^{7}$ cerO A t

АA ОСТ АЕНTK - पӒЕКТ

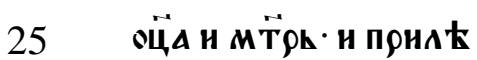


124в

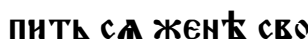

Ен ${ }^{8}$ н БоYАЕТА ОБА в $\mathrm{Z}$

ПАТ Th ЮАНнОУ TЕ

Mh жE оYже н 太стА

5

A ZBA HZ ПAT Th ЮAH

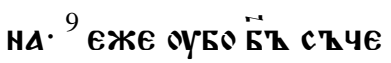

TAAZ ЧӒЕKҚ AА HE

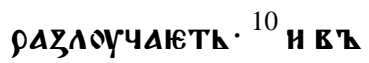

AOMOY חАK'ҚI OYपE

10 Ннцн о семь в ВПрА

шАХ Оуть Н ${ }^{11}$ Н ГӒА Н

ми · нже Аџе поустї

Th женоу свою н

женнть СА нною

15

ПоКАКБҚI ТЕерН

Th на ню. ${ }^{12}$ и Аџе же

HA поYс THTh MOY

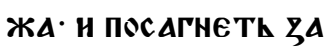

инт - оуже По ҚАюБҚ

20 C'Z TहорнАА ::-

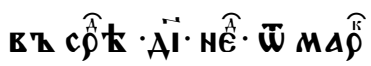

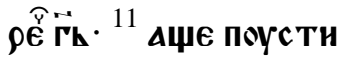

Th женоу свок с '

БАОУАНТИ С'В НнОю.
$124 \Gamma$

Th. ${ }^{13}$ н принош АХОу

K' HEMOY A tTh AA

HX' прнкоснеть $\mathrm{CA}$

оученнцн же пр

5 щаАХоути прнноса

цнмъ $\cdot{ }^{14}$ вна ћв ъ же

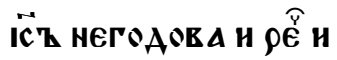

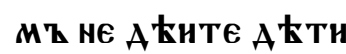

Н ПонХУАНТИ К' М'

10 нЕ не Б९Аннте нм

тац Łүт Бо ести цё

с тво Бӝню. ${ }^{15}$ АМннт

ГӒю в $А M \cdot$ нже Аџе

не прннметһ цр̈стЕА

15 БӝнгА ґако отрочА

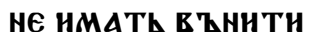

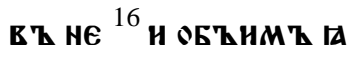

Б八г̈ословаше в '

ZNAT AIA POYЦ К HA ${ }^{\text {HA }}$

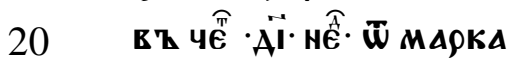

в Ђ в

AA廿N ICX HA חOY

ТИ ПонтЕче ЮАн

HZ K HeMoy· ï по

25

КАОНH CA EMOY HA 
$125 \mathrm{a}$

Kол Еноу и въППА

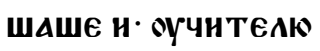

БААГ'ҚlH - पh TO C'

TEOPЮ АА ЖНЕОТ'

5

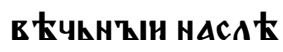

AOYю. ${ }^{18}$ Hट̈'

Чh TO МА ГӒЕШН БАА

ГА. ННКТОЖЕ БАГГЪ

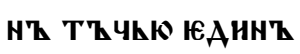

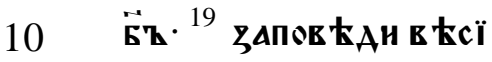

не АNE' A $\mathrm{kH} \cdot$ HE OY

Би и не оүкоААн

не Аъжи съв

Аһс тоун чь Тн 0

15 цेА твоего и м т̈рк

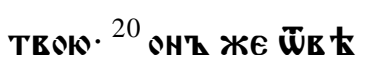

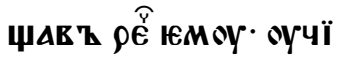

TEAN всA сн с' XРА

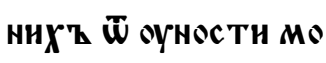

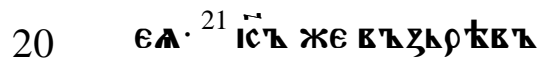

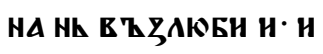

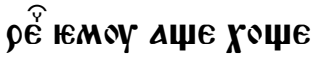

ши сһвһ Фшен' БҚI

ТН· ЕАННОГО ЕСН НЕ

25 АОКОНКЧАА' НАН
1256

АНКО НМАШн про

ААЖи и ААЖи нищї

HMЋ HМЕТН НMА

Ши съкоовнще нА

5

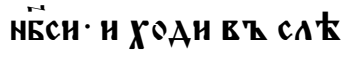

АТ Mене въ ЗूMт

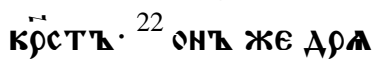

XА' БҚІ6 О словесн

ОТҚНАE сК'Қ९Ба. БA

10

ше Бо нм Кг стT

ЖАннга многА. ${ }^{23}$ н

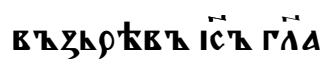

ОУЧЕнНКОМт СЕОН

MZ ' KAKO HE OYAOEh

15

нмоүџнмт Бг̈АTh

с ТЕо в ц ц्рстЕо БӜн

ю вънити. ${ }^{24}$ оученн

ци же оужАс АүоY са

- cAozeceX' ero. $\overrightarrow{\mathrm{c} z}$.

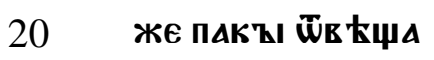

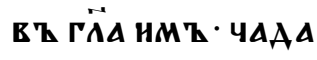

KAKO HE OYAOEL ECTK

ОYПҚЕ АКШНMT HA

БӒThCTEO в Ц Цёс TEO

25 Бӝню в ъ ннтн. ${ }^{26}$ онї 
125 в

ЖЕ нУАнХА АнЕАА

aroY ca ГÄще K'h ce

Б太- TO KTO MожETh

сп̈̈ЕнҚ БҚІти ${ }^{27}$ н вҚ马һ

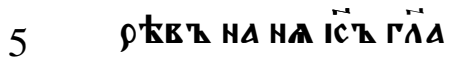

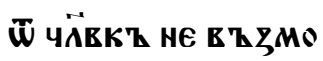

Жино А

उMOжнHA coYTh $\because: 2$

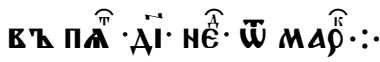

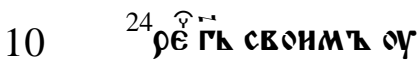

ченHКОMТ · KAKO

HE OYAОБLHO ECTh

HAA ЕКщнмт CA

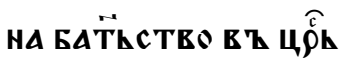

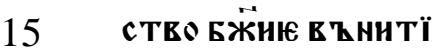

25 OYАОБ Е EсTh вEAh

БАOYAOY сквоз ИГА

нЕ оушн Пронти не

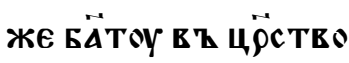

20 НБ̈сьноњ ЕЪННТН.

${ }^{26}$ ОнН ЖЕ НУАНХА АН

вАA АXУY Са ГӒше

Kh сеБ К кTO Може

Th сп्̈ент БъITH. ${ }^{27}$ H

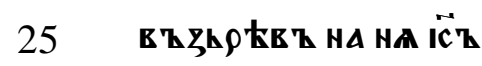

125 Г

ГӒА

ЖhHO. HZ

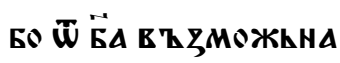

coYTh ${ }^{28}$ HAYATZ חETPZ

5 ГӒАТИ ЮмОУ СЕ МҚІ

ОСТ АЕНХОМТ ВСА Н ЕТ

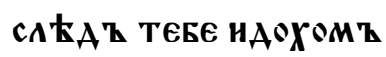

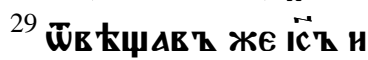

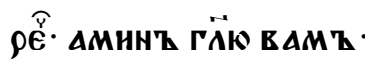

10

НнКТОжЕ Юсть нжЕ

ОСТАЕНTИ АОМ' И

АН БФАТИК $А$ АН

сестрҚl Ан बц्य Ан

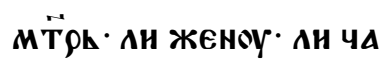

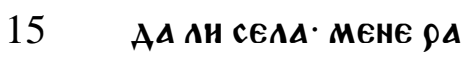

АН и БлГ̈в КџеннА

${ }^{30}$ Аџе не нмАти прига

Ти сһ торнцек н'ы

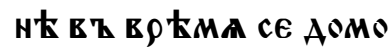

20 в $\mathbf{Z} \cdot$ н Б९АТнга н сест $\rho \mathbf{Z}$

и оц̈А и м т̈ре и чА

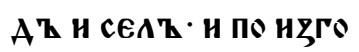

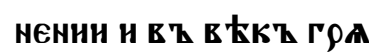

АоУчнн жнвотТ в

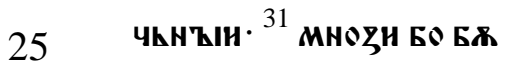


$126 a$

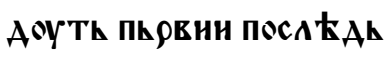

Нни и ПоСА ҚАКнин ПК

ОЕнн. ${ }^{32}$ БААХ ОУ ЖЕ нА ПЖ

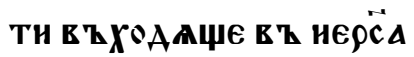

5 АНМ И БААШЕ ВА९АТ

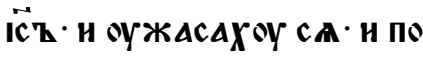

catah HAOYџE GOAXOY

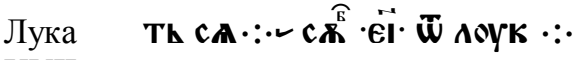

XVII

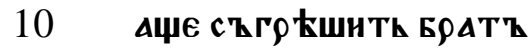

ТВон ЗАПо ЕТн Емоу н

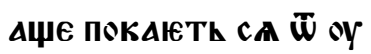

стн емоу. ${ }^{4}$ н Аџе сеАMе

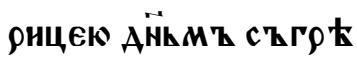

15 шити ти·сеАмернцею

К' ТЕБЕ оБРАТнТИ СА

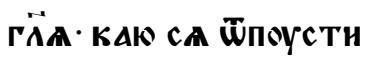

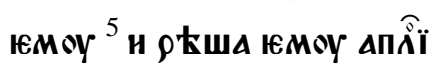

Г̈н прнложи намъ в 太

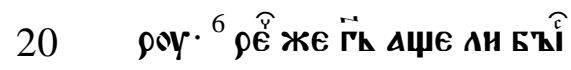

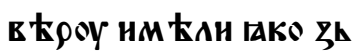

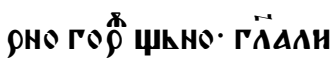

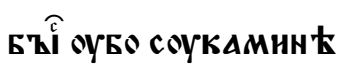

СЕН· В Қ ЗूМН СА Н Е ҚСА

25 АН СА в'Қ MODE Н ПОСАОУ
1266

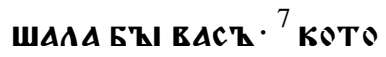

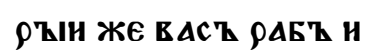

М 太га ө९оушь иАн пА

соущк म нже прнши

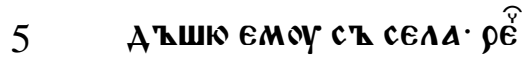

Th ЮMOY АБHЕ' МH

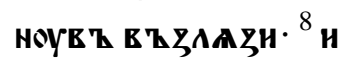

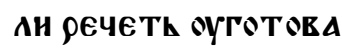

Н ЧК ТО вече९АК' H

10

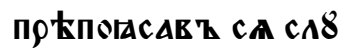

Жн мн· АонаеЖе $\mathbf{~}$

М И и Пию и по томь

Асн и пнњши Т'Қ. ${ }^{9} \mathbf{E}$

AА HMATK XEAAOY $\rho \Delta$

15 БOY CвOEMOY TAKO $\mathrm{ch}$

Творн Повел ћнА

Іа. нЕ Мню ${ }^{10}$ ТА. Н в Қ】

негА с'Қ творнте по

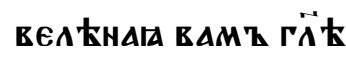

20

TE ГАКО РАБИ НЕАО

с Тонни њс Мұ $\cdot$ и ๒

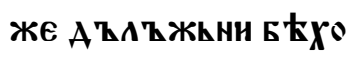

MZ с'Z TEорнтн· $\mathrm{ch}$

TEорнхомт $\because: 2$

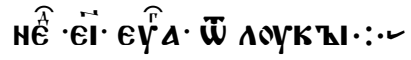


126в

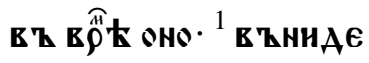

ič в' ерндонт. ${ }^{2}$ н

Лука

XIX

$1-10$

5

се моужи име

HһMT НАРНЦА

юМЫН ЗАКХен· н ск

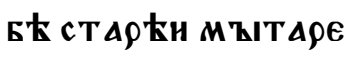

MZ И TZ БЕ БӒTZ ${ }^{3}$ H

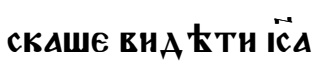

КТО ести' н не Може

10 внА Етн нАРОАТМт.

IAKO T KAOMh MAAT

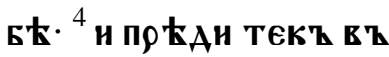

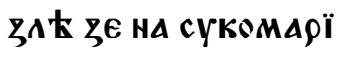

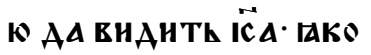

15

TOYA X XOTAWE MH

HOYTH. ${ }^{5}$ AKO ПОHАE HA

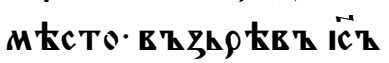

внА К и ФЕче К нЕ

MoY ZаKX EE חоTh

20

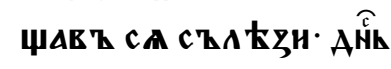

БО ПОАОБАЕТИ МН ЕТ

AOMOY TBOEML Б'

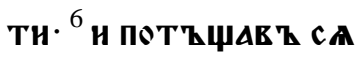

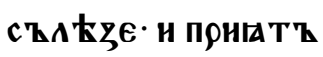

25
$126 \Gamma$

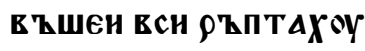

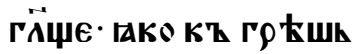

ноу Моужю в ТннАЕ

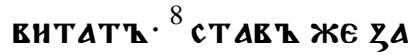

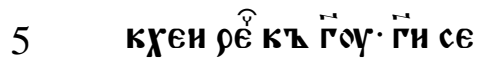

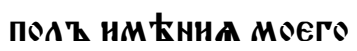

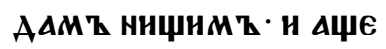

КОГО ЕсМК ЧнМТ оБИ

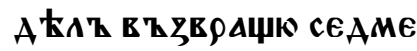

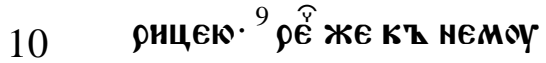

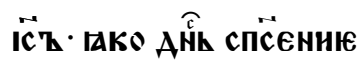

AOMOY CEMOY БZi - ZANE

H Ch CH' АR

${ }^{10}$ ПФНАЕ БО СН̈Ъ ЧӒЕЧКСКТ

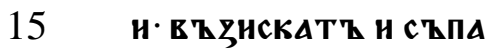

С Th ПОГҚIE'W WL

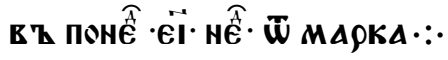

Марк въ в

$\mathrm{X}$

46-52

20

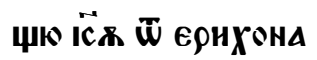

н оүченикомт $\mathrm{E}$

ГО Н НАPOAOY МHOГОY.

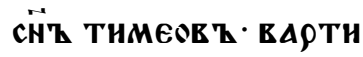

мен· catn' ckAAA

ше при поути проса -

25 
$127 \mathrm{a}$

HAZА९ANHнT ECTh

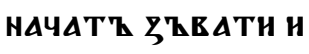

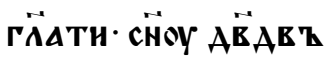

ПОМнАоуИ МА ${ }^{48}$ и Поћ

5

цаXоYTh EMOY MHO

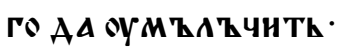

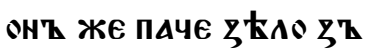

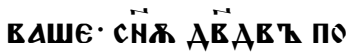

МНАОУН МА. ${ }^{49}$ СТАВ '

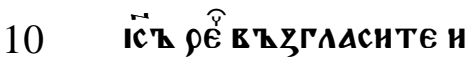

Н ГААWAWTh CA KחL

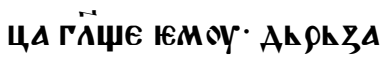

Н В ҚСТ ТНH ГӤАШАЕ

Th та. ${ }^{50}$ онт же ש̈вирь

15 Г' ९НЪЫ СвОА в ҚСТА

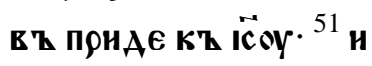

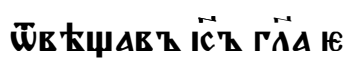

MOY. पh T० Х०४Еши

AА ch TEорю TEE $\mathrm{k} \cdot \mathrm{cAt}$

20 ПЪН же ГӒА ЕмоY. оY

ЧнтЕАК АА ПрОзКрю.

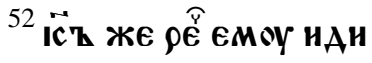

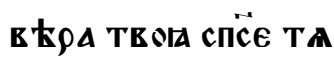

н АБне прози
1276

в7 поYтh $\because: 2$

Марк

XI

11-14,

19-33

5

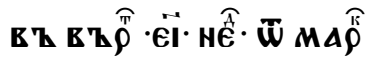

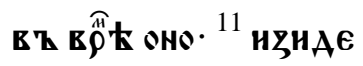

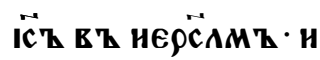

в Ц цёквн С ҚГАА

AАB Z BCA' ПOZA K OY

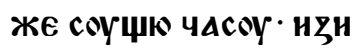

АЕ в Қ внфАнню съ :

Б大MA HA AECATE ${ }^{12}$ H

10

Къ оут ९һннн ишь

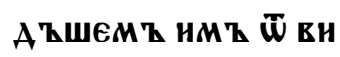

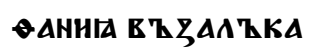

13 и вна

LOY H马 ААAEบА HMOY

15 Чн Анс ТЕнє прнАЕ

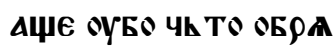

це ТИ НА нен ' н прн

ШhА' К нен ннчьсо

же не оБр Қте нт T'

20

ЧИК АНC TEHIE' HE БA

ше во вотма смо

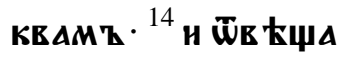

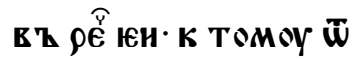

теБе въ в БкҚ никт

25

ТОЖЕ ПАОАА HE с 
127B

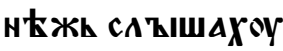

же оученнци его. ${ }^{19}$ и

AKo noz,

Жаше в ҚH' H马 ГРА

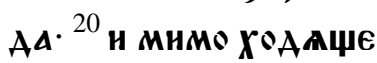

5

ОYТ РО вНА ЕША СMO

КОвһннцю оустХ'

шю нс кореннга. ${ }^{21}$ н

в ҚспОМАнОУв Қ

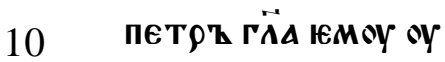

ЧнтЕАК внЖһ сМо

ковьннцю южЕ

прокла оусъше. ${ }^{22}$ н

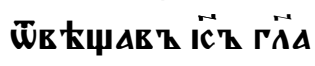

15 Емоу' нм Қите в

роу Бӝню. ${ }^{23}$ АМннт

ГӒК вАМ ТАКОЖЕ

речете ropt ceh aвï

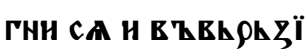

20 СА в' MOpE. H Hе OY СОУМнH CA ET Ch

РӒЦИ СвоЕМК H'

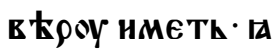

коже речети Боу

25 AєTh $: \because 2$
127 Г

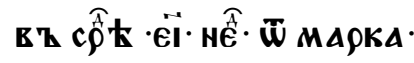

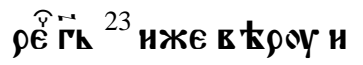

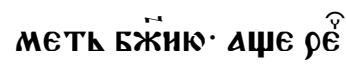

Th ropt сен АвигнH

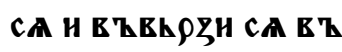

5

Море ' н не оусоумнн

Th СА в Қ СРАЦН СЕОЕ

Mh' H' в K

Гакоже речеTh БоY

10

АETh ${ }^{24}$ сего ९АAH ГӒК

вАM Z · CA EAHKO АLE

MOAa

ТЕ в Броунте ' AKo

ПрннмеТЕ и БОУАЕ

15 Th вАM $\cdot{ }^{25}$ н егАА сто

hте MosaLE CA.

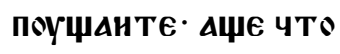

HMATE HA KOTO AA

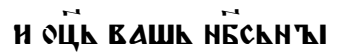

20

и ш̈пуус тить вА

Mz По ЕШенна вА

ША. ${ }^{26}$ Аџе Ан в ҚІ не $\overline{\mathbf{W}}$

поуџАете · ни оци

ваши ш̈пугстить

25

н вАшнн Х' $\cdot: \cdot$ 冫 
$128 \mathrm{a}$

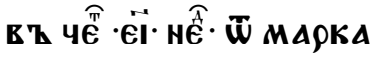

в В в

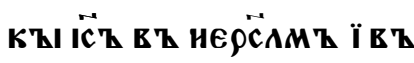

цёквн ХвАААџж 6

5 моу п९нАОшА к'В не

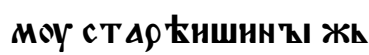

рьчьскҚا Кннжьницї

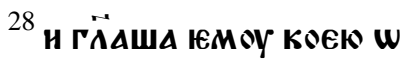

ВААС ThE СН ТВорнши

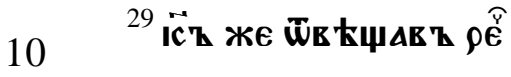

НМ Қ Е ҚПРошю в ҚІ Н

А马' ЕАНнОГО саовесе.

н Ш̈в 太щанте Мн н $\rho$ Е

KoY K' в $\triangle A M \mathbf{h} \cdot$ KOEN :

15 БААС Тню сн ТЕорю

${ }^{30}$ Крьшение но Ане $\overline{\mathbf{W}}$

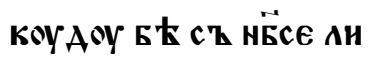

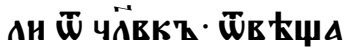

нте ми. ${ }^{31}$ и помъIшАА

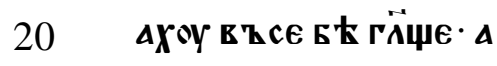

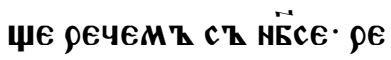

YETh HAMT ПI YTS

оуБо не в Кровасте

Iемоу. ${ }^{32}$ Аџе Ан рече

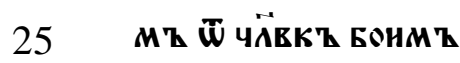

1286

СА АКАНИ · ВИСН БО Н

MAAXOY HOAHA IAKO

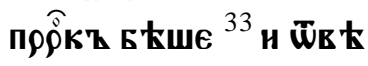

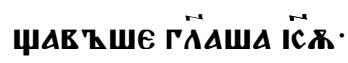

не в вми · $\overrightarrow{\mathrm{IC}}$ ' же

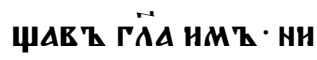

$\triangle \zeta 7$ ГӒю в $\triangle M \mathrm{Z} \cdot$ KOE

N .вA

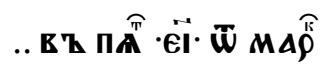

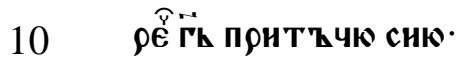

1 виног ААА' HАCA

АН Чत̈ЕК $\cdot$ Н ОГРААН

Марк и оплотемт иске

XII

1-12

ПА ТОЧНАО Н СҚ弓'ҚАА

15

С TZAПZ म В ВААСТИ

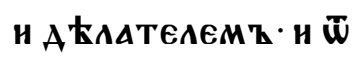

HAE ${ }^{2}$ н пOCZ $A \Delta$ Kh A

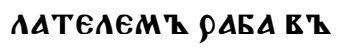

врћма· АА ẄTAжА

20

TEAh Прннметь :

T' ПАОАТ ЕННОГОА

AА ${ }^{3}$ нмЋше и БншА

Н ПосһААША Н ТҚЩА

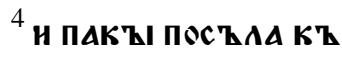

25

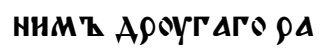


128 в

БА Н ТОГО КАМЕННЮ

МИ БНВҚШе П ОБНША

ЮMOY ГААВOY· Н Пос'

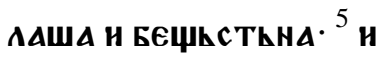

ПАКҚІ иноГО ПосҚАА

Н ТОГО ОУБНША' Н МНО

Г'Қ ИнҚІ ОВ ҚІ БНющЕ

ОВ ҚI ЖЕ оүБнв Ающе -

${ }^{6}$ еще же нм Қа аше ๒

10 АНноГО СН̈А в ҚZАN

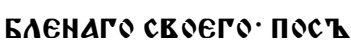

АА И ТОГО в Қ СА А Қ К'

НHMT ГÄA IAKO OYC९A

MATh CA CHA MOETO.

15

${ }^{7}$ онн же А ҚААТЕАН ви

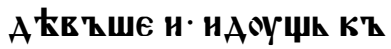

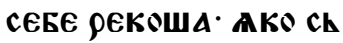

IECTh HACA ҚАКHИK'

П९нА

20 h HaWE БоYаETh A०

стОАнИЕ ${ }^{8}$ НМЪШе И

ОүБНША НЗЕК ОБГошА

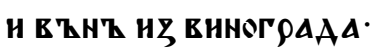

${ }^{9}$ прнАЕТК и ПогоуБН
$128 \Gamma$

С ТИ ВИнОГРААТ ИН ЕМТ ${ }^{10}$ ни снХ' Ан Книг' Чк Ан есте· КАMEнh нже $\bar{W}$ ви ргошА ЗАЖющен · ch БZI E'Z ГAAB oY OYThAOY.

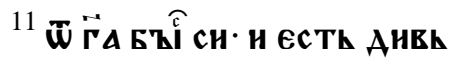

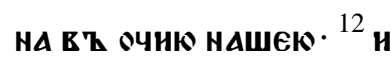
cКАXОYТК АТИ И ОУБО AULA CA HAPOAA. PAZOY 10 MћWА БО АKO K HНM Т

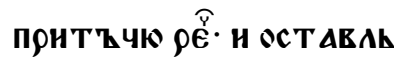
ше и ЁнАошА $: \because$ -

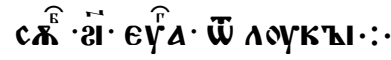

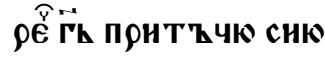

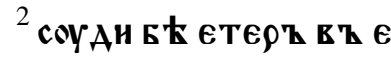

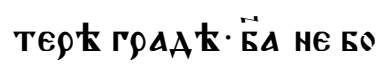

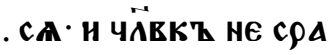
MAAIA CA ${ }^{3}$ в ҚАOEA ЖE Б太 в' Г९АA Т TOMh 20 н прн ХожАше к томж ГӒџн· Мһс Ти Мене $\overline{\boldsymbol{W}}$ coympa моего ${ }^{4}$ н не Xo

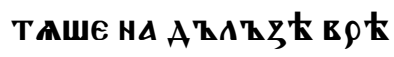

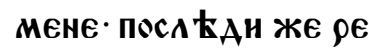


$129 a$

БON СА Н Н ЧӒЕК' HE C९A

MAAN CA. ${ }^{5}$ ZAHE TEOPH

Th МH T९OYAТ ЕҚАОвH

ЦА СН АА МКџК EA· AА

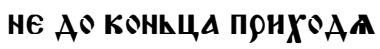

шн зАстонтһ мн. ${ }^{6}$ рече

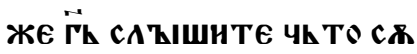

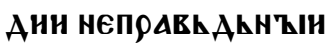

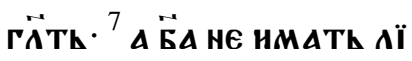

10 СҚ Творнти Мһстн· н

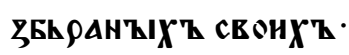

в ҚПнющнХ'Қ К' нЕМЖ

A $\overrightarrow{\text { Nh и н нощь } ~}$

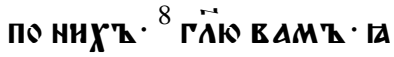

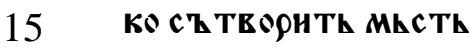

HX' ह Z ckopt $:$ :

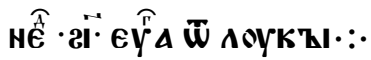

Матфей

$\mathrm{XV}$

21-28

20

в В в

в Z стрAнOY TOY

н снаOH, скOY. ${ }^{22}$ H се

жENA XАHAHZINE

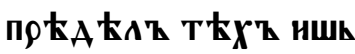

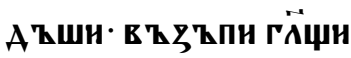

ПОМнАОУН МА Г̈Н С̈̈ฎ

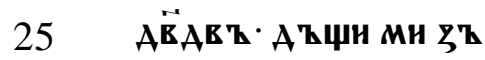

1296

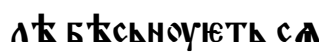

${ }^{23}$ онт же не ш̈в tй

н словесе ' н прнст8

Пльше оүченици $е$

5

ГО MOлаХОУТИ и ГӒще

Ш̈Поусти К АKО вт

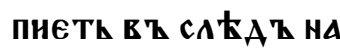

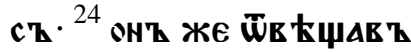

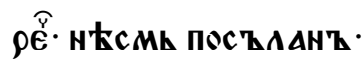

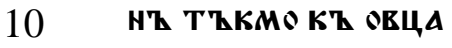

Mh ПОГ ҚIE' ШHM

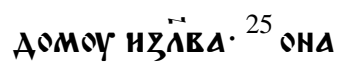

ЖЕ ПрншһА ТШН По

КАОНИ САЮMOY ГӒळ

15 чн Г̈н помози мн.

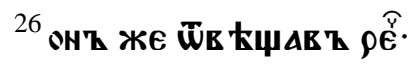

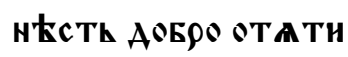

XАКБА ЧААОМ' И ПО

в९ещн ПисОМт $\cdot 27$ ОНА

20

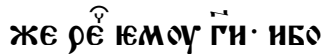

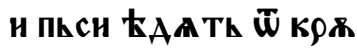

ПнцК ПАААКШНХ'В

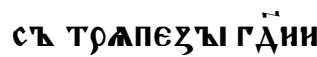

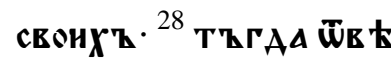

25

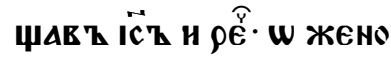


129B

велнкА Ести в

TEOA- БOYАН ТЕБЕ

ГАК०ЖЕ ХОщЕшн '

сц ЋА А А

5

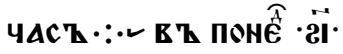

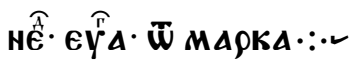

в т в

Марк ША кннжиници и

XII

13-44

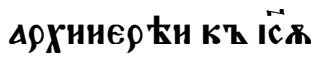

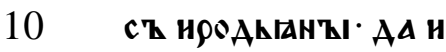

БҚШША ОБАКС ТНАН САО

воми. ${ }^{14}$ Онн же прнши

А Қше ГйАшА EмоY.

ОУчнтЕАК в 太Мһ IAKO

15

нс THнһH' Есн· н не

РОАНШИ НН О КОМК

ЖЕ не Зһ Рнши Бо нА

АНЦА ЧӒЕКОМ' · H'

В Қ нс Тнноу Поути

20 Бӝню оучншн · ९ьцї

OYБO HAMZ ' АОСТ TH

Th АH AAHh ААTH КE

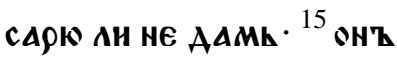

жЕ в ЕАТЫ нХ'Қ Анце

25 M
129 Г

Ма нскоушАЕТЕ П Пине

с Ђте мн цАТОУ АА внЖю.

16 онн Же прннес ОшА Н ГЙА

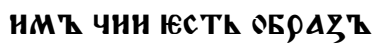

5 сь н нАПнсАнне РНн ЖЕ

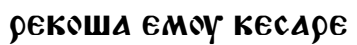

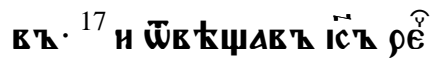

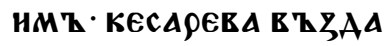

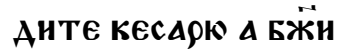

10 А БЁН· И ЧКАНША СА

o ceMh $\cdot: \cdot$ -

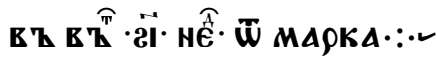

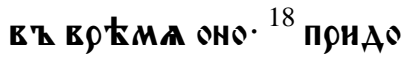

ША CАA ОУКEH K' ІС̈ВH

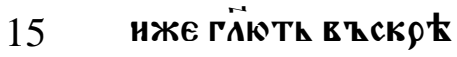

ШЕННК НЕ БҚІТИ· И БҚ

прАшАХ оуть н гӥще.

19 оучнтелю не Мосн Ан

HАПНСА HAM'Қ IAKO A

20 џе комоу Б९АТ' оумh

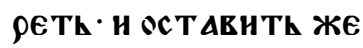

HOY H YAAT HE OCTA

вити' АА Понмети Б९А

Th EM8 женоу его и в

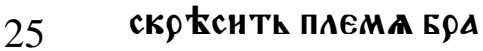

TA CBOEro ${ }^{20}$ CEMh 
130a

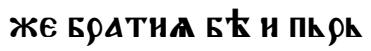

в ҚИ ПОАТТ ЖЕНОY И

МНРАГА НЕ ОСТ АВН ПАЕ

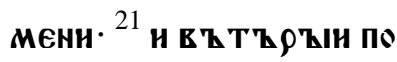

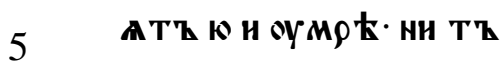

Ос ТАВИ ПАЕМЕнЕ ' И

третиї тАКоже $\cdot{ }^{22}$ и поА

WA ю сеАMh H HE OсTA

вншА ПАЕМЕне· ПосА

10

же же вис kX'z oүмhpe

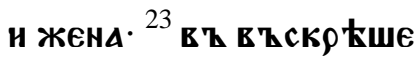

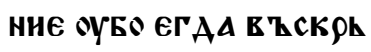

сHOYTh ' KOT OPOYMOY

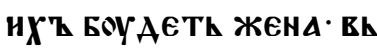

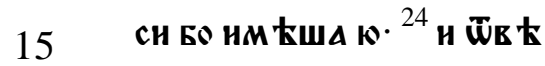

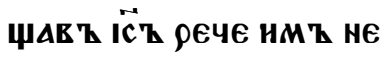

СЕГО АН РААН ' БАОУАН

ТЕ не в ВАОУщЕ Книг' -

ни снАҚ БӜна ${ }^{25}$ ЕГАА

20 БО нУ МИРТЕЫХ'В Е

скоцсноуть ' ни Жена

Th СА ни ПоС АГ АютL

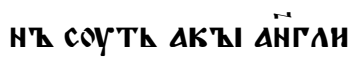

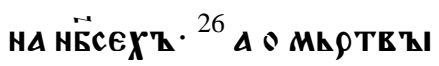

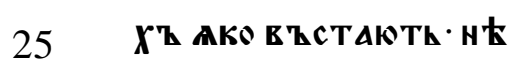

1306

с ТЕ АН ЦКАН Е Қ КННГА

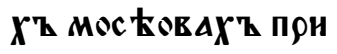

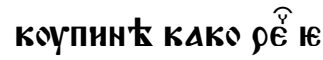

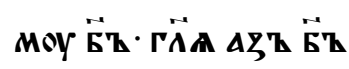

5 АВРАВАК Н Б̈Қ НС АКО

ВТ Н Б̈Қ НाАКОВАh $\cdot{ }^{27}$ HЕ

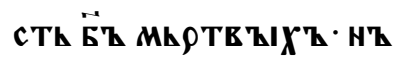

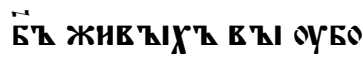

МНОВН С СБААЖНА

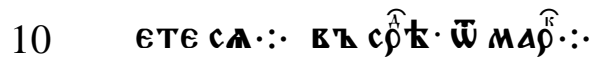

в т в

Пи $\Theta_{\text {Аннъ }} \overline{\mathscr{W}}$ Кни

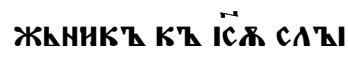

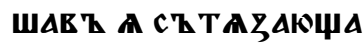

15 CA'BHA KE' AKO AO

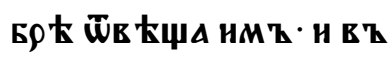

просн кАA ECTh ZапO

в 太аһ ПК

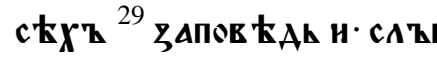

20

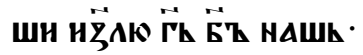

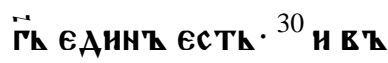

ЗАКБН Г̈А Б̈А ТВОЕГО

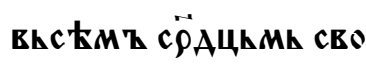

нМк и всею Аш̈̈ю

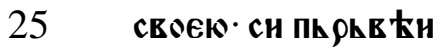


130в

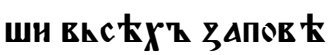

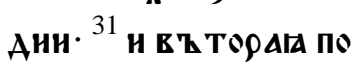

АОБКНА ЕН в ҚZАК

БНШН БАНЖИНАГО

5

CEOETO IAKO CAMZ CA

БОЛЬШИ СЕК ИНОА ZА

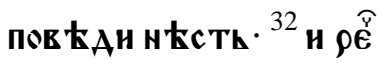

๒МоУ Кннжиникъ

АОБР К оУчнТЕАК вТ

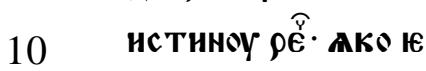

АннҚ Есть и нћсть

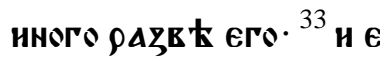

же АюБнти вис Емт

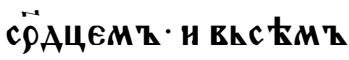

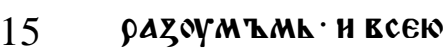

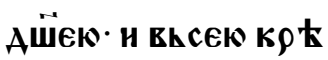

Постью· и ЕЖЕ АюБи

ТИ БАНЖИНАГО ГАКО

сEБ大 БOлE EcTh KhCt

20 X'⿳ сқжижени и жи

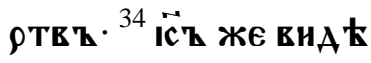

в И и АКО съMҚICAh

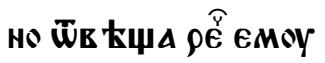

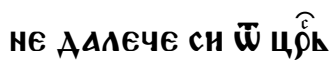

25 ствА БӜнА·н ник'
130 г

Тоже юго не сһ MAше

К томоу' въпооснти

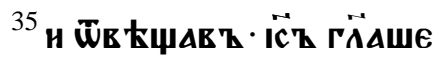

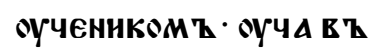

5 цёКЕН КАКО ГӒТИ КнН

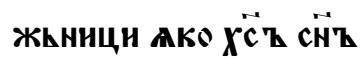

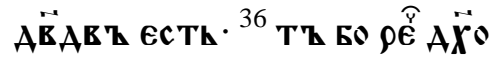

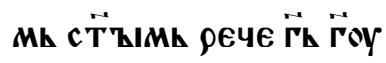

MOEMOY СAAH O AE

10 сноую МЕне АОнтаеже

ПОАОЖЕ вРАГ'ҚІ ТЕОА

ПОАТнОЖНЕ НОГАMА

TвонMA. ${ }^{37}$ с АMZ оYБо

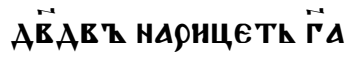

15 и $\bar{W}$ KOYAOY CH' EMOY $E$

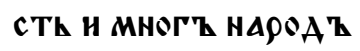

ПослоY WAWE EГO в

cAACTh $\because:-$.

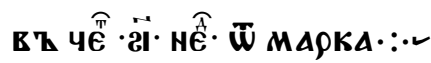

20 р€че г̈h свонмқ оүче

НнКОМъ ${ }^{38}$ БАКАНТЕ

СА оУБО Фี КннжКни

K' ХОТАЧнХ'Z Х०АНTÏ

В ТА ОА ЕННН АЮБАШН

25

X' Ц КАОв АнИІА ' НА T' 
$131 \mathrm{a}$

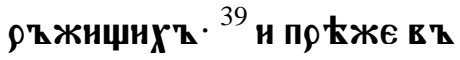

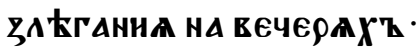

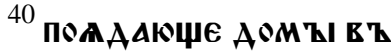

АОвици ' и виною АААЕ

ЦЕ MOAAџе $\mathrm{CA} \cdot \mathrm{ch}$ Приї

МоYТЬ Анше ссоужени

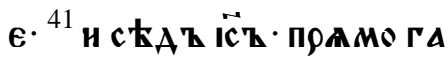

ЗАФУААКНН ВНААШЕ

KAKO HAPOAT MEщETh

10

M

КИН· И Мнози Б̈АТИ

H E ҚM ZT TX OY MHO

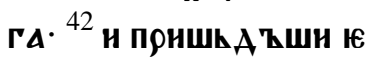

АННА В ҚАОВНЦА ОУ

15 БоГА в ҚЕһ ९һжЕ А

в 太 чАТ Қ ЕЖЕ Е КОН'

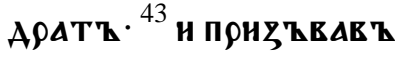

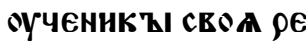

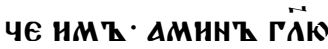

20 ВАM ' АКО В ҚАОЕН

ЦА СН OУБOГАА ' МHO

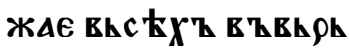

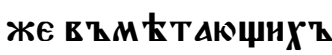

ВТ ГАЗАФУААКНК

25
1316

в ҚЕК РГОША · $\triangle$ CH $\bar{W}$ АншенHА своEГО вһ сЕ ЮАНКО НМАШЕ

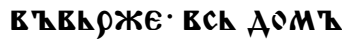

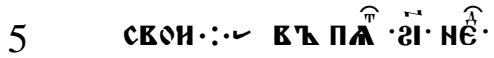

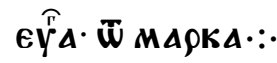

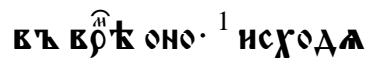
Марк XIII

1-8 рEчE EMOY EAHH'

10 отт оученнкт его. оУЧнТЕАК внЖһ КА КОво КАМЕнHЕ и КА

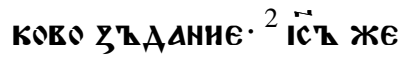

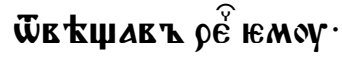

15 ВНАНШН ВЕАНКА

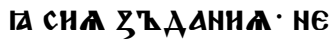
HMATh OCTATH ChAE KAMEHh HA KAMEHH HЖЕ HE HMАTh ९AZO ОНТи са. ${ }^{3}$ и с ҚАаџю EMOY HA ropt EAEHK сц А И ПФАМО цр̈КЕн

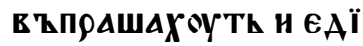
HOГО ПET९Z HAKOE' 25 
131в

Ци НАMҚ ' КһГАА СН

БOYАOYTh Н КОE БЖ

АETh 弓нАMEнHE

ГАА СН HMOYTh BhCA

5

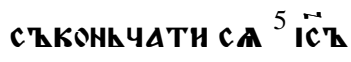

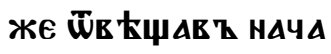

Th ГӤАТи нМ' БАю

A tTE ca AA nE KTO

прђАһстить въ. ${ }^{6} \mathrm{Mz}$

10 неदн БО ПонАОУТЬ

в' има MoE ГӒџе А

弓' есми ' и мног'ы

прҚАһст TA Th ${ }^{7}$ EГAA

жЕ оуса ҚIшнте БрА

15 ни и слоуХҚы Бо Анһ

HZI HE оYжАCAHTE

CA· ПOAOEAETh БO

БZITH' H' HE OY KO

нһчнна. ${ }^{8}$ в Тст Ане

20 Th БO IAZTIK' HA IA

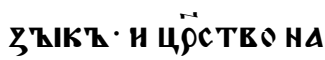

ЦР̈с ТЕО Н БОУАОУТК

Т ФОУсн ПО М КсТА'

БOYAOYTh ГАААН Н

25 МАТЕЖН' И НАЧАА
$131 \Gamma$

EOA kुHhM h $\because: 2$

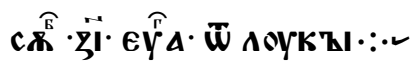

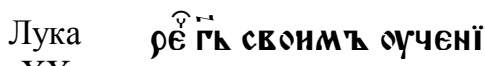

$\mathrm{XX}$

46-47

5

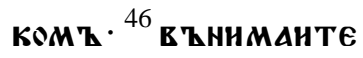

сеБ太 $\overline{\mathrm{W}}$ кннжьникъ

ХОТАЧнХИ в В ОАЕЖА

X'Z ХОАНТН' И АЮБАЧН

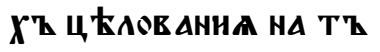

ржичнХ'

10

ААнна нА СЪНКминцї

$X^{\prime} \mathbf{h} \cdot$ и по Łжес

HA ов $\mathbf{A} \mathbf{A} \mathbf{k} \mathbf{\gamma} \cdot{ }^{47}$ нже с '

HЕААЮT' АOM ZI E'

АОЕНЦһ ' Н ВНнОЮ АА

15 АЕЦЕ MOAA Th СА' СH

прнмоути осоуже

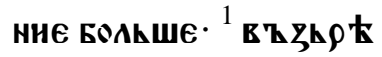

Лука

XXI

$1-4$

20

в Ћ жЕ внА

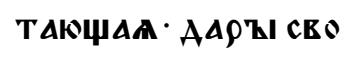

A БӒТЫА ${ }^{2}$ внА

९ОУ В ВАОЕНЦК ОУБО

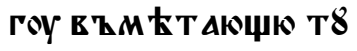

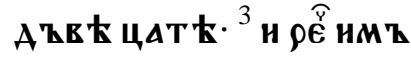

в Қ нс ТнноУ ГӒю вА

25

Mh ГАКО в 'ААЕННЦА 
$132 \mathrm{a}$

СH OYБOГАA БOAE BhCKX'

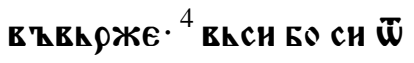

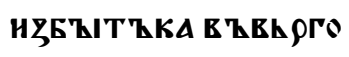

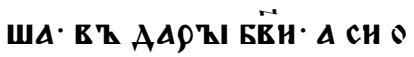

Th Аншенна своего вһ

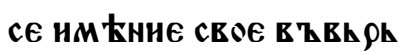

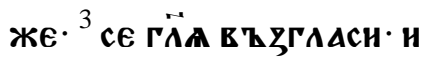

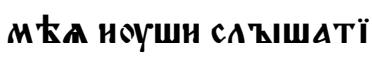

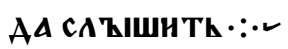

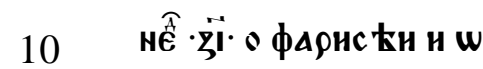

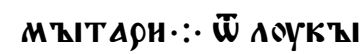

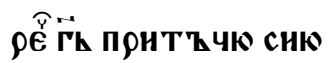

Лука

XVIII

10-14

15

10 Чล̈ЕКА АТЕА Е ҚНН

АОс ТА в' Ц९̈КЕК ПОМ०

АНТТ СА· ЮАНH'

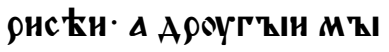

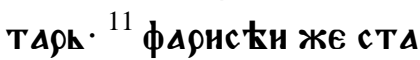

B' B' CEE KONAWE CA

ГÄA БË X'АANYY TEE

20

B'Z BAAN- AKO HECMh

АКО И ПФОЦНН ЧӒЕЦН

Х'Қџџннци по ЕАю

БOA 太Н· HАH AKO Ch MҚI

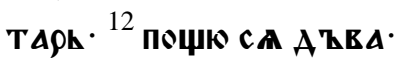

1326

AECA THнOY AAIA вCE

ГО ЮАНКО ПОНТ АЖАК

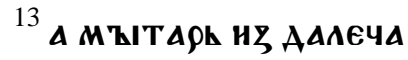

с TOA. HE XOT AшE HH

5 ОЧнК своек вһ ЗЕЕстї

HA HË NZ БHAWE ET

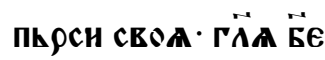

МӒс ТНE Қ БОУАН MҚ

нћ Г९ ЖШКнНКОУ ${ }^{14}$ ГӒळ

10 вАM $\mathbf{z} \cdot \mathbf{c h H H} A \mathrm{C}$ ch W

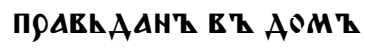

СВОН ПАЧЕ ОНОГО АКО

BИCAKT EZZHOCAH

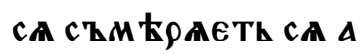

15

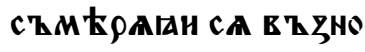

CHTh CA $: \because$ -

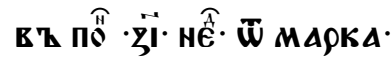

Марк

XIII

9-37

20

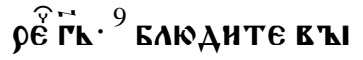

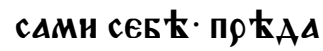

AATh EO E'ZI HA C'ZHK

МНџА Н НА СЪHКМH

ШНХ'Қ БНЕнИ БоУАЕТЕ -

и ПОћАТ вОЕвоААМн

и цорн ст тнете мене 
132B

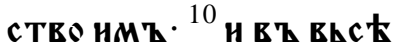

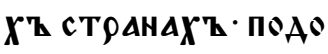

БАЕти пр Кже пропо

вћААТИ СА БАГ̈ОЕ

5

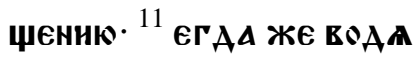

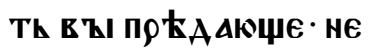

прћже пооучанте

CA· पL TO вһ ZГКАГОAE

TE Hh EжE АџE ААСTh

10 CA вАMZ E Z TZ YACZ

се ГӤТЕ не в ҚI БOYAE

те гӥющен н' $A \overrightarrow{X^{7}}$

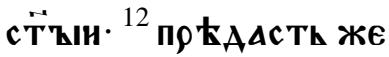

Б९АT' Б९АTА HА $\mathrm{Ch}$

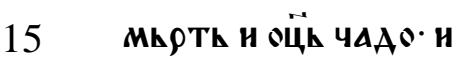

B'ZCT AHOYTh YAAA

HА POAHTEAA Н ОYБH

NTh ॠ. ${ }^{13}$ h БоYAETE HE

НАЕНАНMH ЕһсЕМї

20 НМЕНЕ МОEГО РААН.

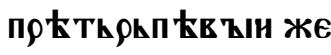

А० коньцА спёент 58

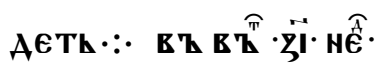

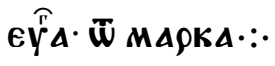

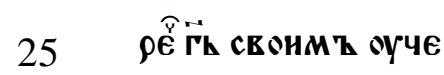

$132 \Gamma$

никомт ${ }^{14}$ егаА оузирн

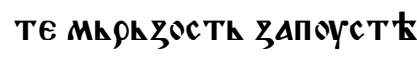

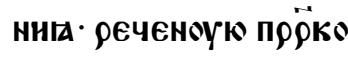

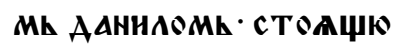

5 Тн нА М Ест К НАЕЖЕ не

ПОАОБАЮТК - ЧК T'ҚIH АA

PAZOYM KETh THГAA H

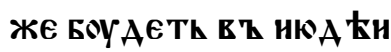

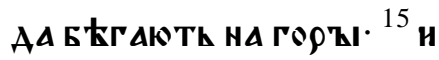

10 Же нА кров Е АА не съАА दн

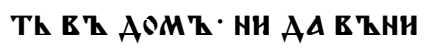

AETh B'ZGATh YCO

MoY своего ${ }^{16}$ и съLи на се

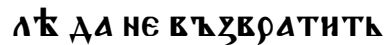

15

CA EZCПIATh EҚZATT

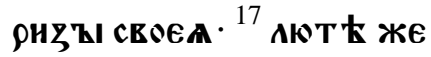

непРАЗАТнҚIM и

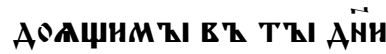

${ }^{18}$ Молнте ЖЕ СА АА НЕ БЖ

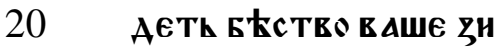

М А ни вһ соYБетоY

${ }^{19}$ БOYAOYTh БO Aн̈не TÏ

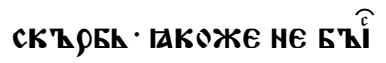

TAKOKA Ẅ HAYANA

25

弓'ААнНК ЕЖЕ сһ弓' 
$133 \mathrm{a}$

AА Б̈Z AO HWIH太 HE БOYAE

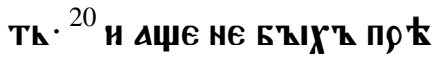

К९АТнАҚ АН̈нН не БҚІ

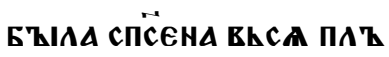

5

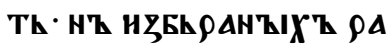

Ан гаЖе нъБи РА прекрА

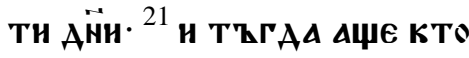

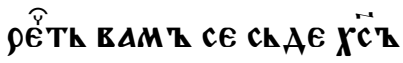

сE онаE не им Қте в К $\rho \mathbf{~}$

10

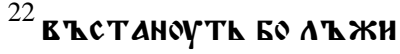

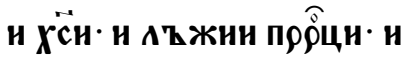

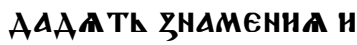

YNAECA. AA ח९ KAhCTA

Th - Аџе в Қ ЗМожино н

15 ЗБһРАн'Ыа ${ }^{23}$ в ҚІ ЖЕ БАю

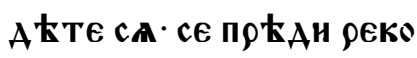

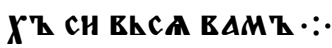

в Z с

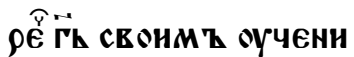

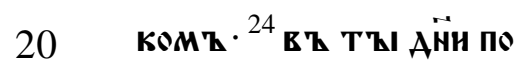

сКһ९БН ТОН· СӒнцЕ ПО

МһркнеТИ и АОУна не

ААСтh св KT А своEГ⿸ ${ }^{25}$ H

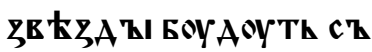

25 НЕСЕ ПАААКЩА и СНАЫ
1336

АжЕ COYTh HA HËCEX'

ПОАЕНЖАТИ СА. ${ }^{26}$ и T'Қ

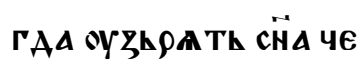

АOB КЧА НАОУША HA O

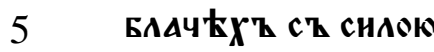

MHOГOК Н САABOH.

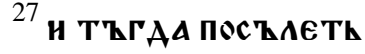

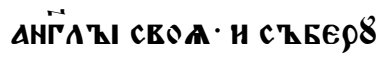

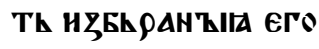

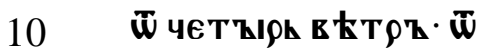

КОНЬЦИ ZеМАA АО КО

HhЦА НЁсн ${ }^{28} \ddot{\mathbf{w}}$ сMоко

вьницА ЖЕ нАОУЧн

ТЕ са ПрНтЋчн ЕГАА

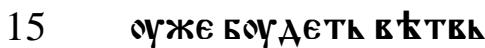

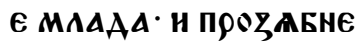

Th АНС ТहHE' вНАНТЕ

АКО БАн马' Ести ЖА

TEA. ${ }^{29}$ T АKO н вҚL EГAА

20

оУ马НРНТЕ СН БҚIE AN

ЩА в 太АНТЕ ГАКО БАН

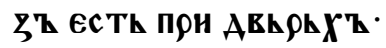

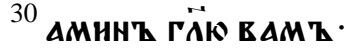

IAKO HE HMATh прE

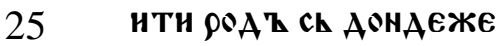


133в

вһСА Си Б.АОУТ' ${ }^{31}$ не

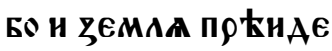

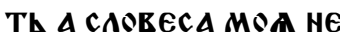

прtнAOYTh

5

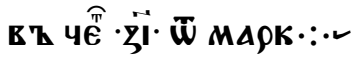

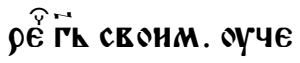

нНКОМт ${ }^{31}$ НЁО и दE

MAA МHМО НАETK

$\triangle$ CAOEEC $\triangle$ MOA HE ПO

HАОYTh ${ }^{32} \triangle$ В АН̈Н TO

Mh AH O YAC Е HHKT:

жЕ не в Ксть ни гӒ̈

нжЕ COYTh HA HËсE

ХZ · HH CḦZ HZ TZYK

15 К МЦ̈. ${ }^{33}$ БАюА ТТЕ СА И

Молнте не в БстЕ Бо

К'ГаА воТма БоYаE

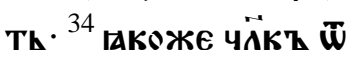

X'AA OC TABAAETh

20 АОМТ СЕОН Н ААВТ РА

БОMТ СЕОНМ. ВАА

СТh' Н КОM ОYжА०

А ЕАО своE И в९АTА

ОЮ ПОВЕАНТ Қ АА БҚ

25
$133 \Gamma$

не вћсте Бо кһгАА $\overrightarrow{\text { h }}$

AOMOY ПОНАETh ' вEपE

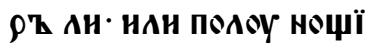

АН ЕТ КОУ९ОГААШЕнНЕ

5 Ан оутро. ${ }^{36}$ АА нЕ Прнши АТ

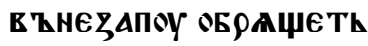

вЪ СЪПАџА ${ }^{37}$ А ЕЖЕ вА

Марк

XIV

$1-9$

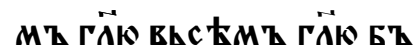

Анте ${ }^{1}$ Баше Же Пас ХА

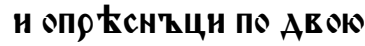

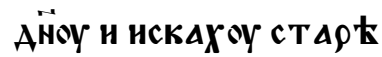

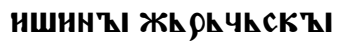

и кннжьници КАКон

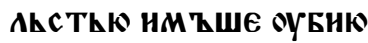

15

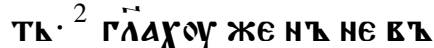

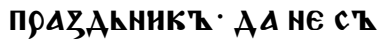

МОУЩЕнНЕ АюАКMТ БОY

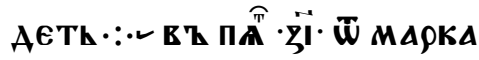

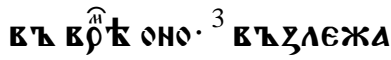

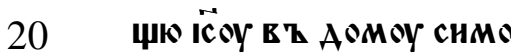

на прокаженат̈

ПОНАЕ ЖЕНА НМОУЧн

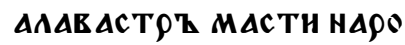

А ПЫ Пис ТнКНА А९АГҚ।

25

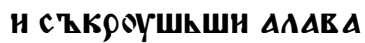


$134 \mathrm{a}$

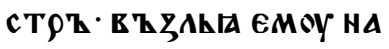

ГААВ OY. ${ }^{4}$ БА XOYTh ЖE нЕ

цин неге Аоующе в з се

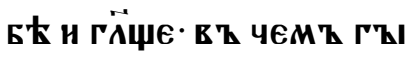

5 БЕАК СН МАСТКНАБҚ.

5 MожАше БО СН МАСТ

ПФОААНА БЪТТН В ВАЧЕ

Т९Н СZ ТҚ ЦАТТ Н ААТИ

СА ннцнмъ ' н пр

10 шаX

octantTE EA - पh To EH

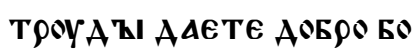

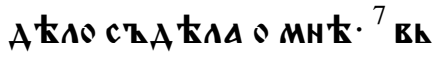

сеГАА БО нНџАГА НМА

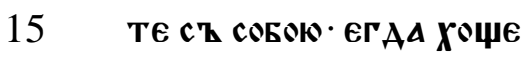

те можете АоБро творї

Ти имт - $\triangle$ МЕне не все

ГАА нмАТЕ ${ }^{8}$ ЕЖЕ нм С сн

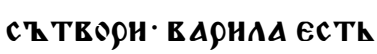

20 ПОМАЗАТИ ТЕА॰ МऽЕ

нА ПоГреБенне МА OY

строн. ${ }^{9}$ АМннҚ ГӒю вА

МИ НАЕЖЕ КОАНЖАО

пропов Е АанO БоYаE

25 Ти Бйгов 太щенне се
1346

в ми м. н Еже сһ тво

ОН сн· ГӒАнО БOYAETh

Лука вт ПАMA Th $E$ A

XI

5-13

5

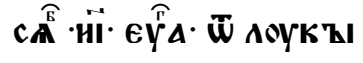

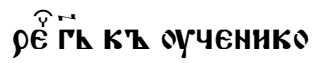

MZ· СЕонМт ${ }^{5}$ KTO $\bar{W}$

BAC' HMATh APOYГA

HАETK K' HEMOY חO

Аоу ночн· н ९е̊̆Th ЕMА

10 А९оуже в द ЗАнм т АА

жи мн төн ХА ЕБы. ${ }^{6}$ А

ко Ароугт съ поути

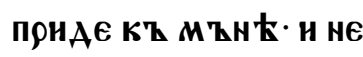

нмАM々 ЕжЕ полงжю

15 поқат ннми. ${ }^{7}$ и Тт и

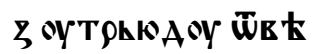

НАR '

рн мн троYАА оYже

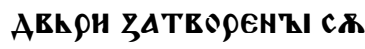

20

Th· Н А ЕТН MOA ch Mh

HOК нА АОЖн СоYTh .

HE MOTOY В ZCTAK'Z AA

ТН TEБЕ ${ }^{8}$ ГӒК в АMT

АџЕ н не ААСТ ЕMж

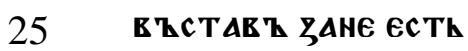


134B

A POYFT EMOY' HT ZA

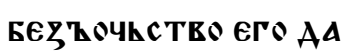

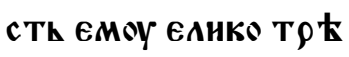

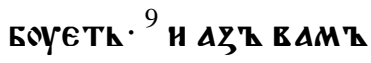

5

ГӒК пооснтЕ н ААСТИ

СА вАМЋнщКТЕ н О

Б९АџеТЕ ТһАҚц

TE н ОT.вh ९h Th CA вA

M Z. ${ }^{10}$ BhCAK' EO прO

10

САН ПОНЕМАЕТЬ' Н Н

ЩАн оБрћт АЮТ И

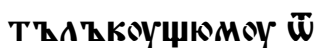

BhozoYTh CA. ${ }^{11}$ Koto

paro же $\overline{\mathrm{W}}$ васт оц̆А

15 сн̈һ свон въспроснть

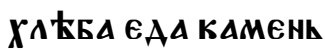

ПOAАCTh EMOY АH ९ZI

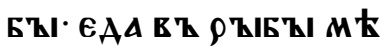

СТО ЗМНК ПОААСТК

20 юмоу. ${ }^{12}$ нАн Аџе просї

Th ТАНА ЕАА ПОАА

стh Eмоу скорпню.

${ }^{13}$ Аџе оуБо в Қl зһАн с8

ше оум Еете ААA

25 MHА БӒГА ААІАТН
$134 \Gamma$

YAAOMZ B АWHM Z ' KOAh

МН ПАЧЕ ОЦ̈Һ ВАШК НЁсh

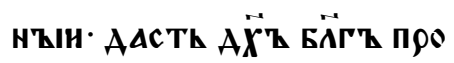

сАџннмт .. него.:.

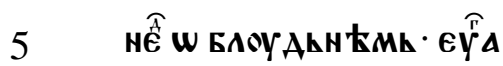

wi soYк'

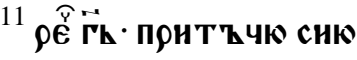

Лука

$\mathrm{XV}$

11-32

10

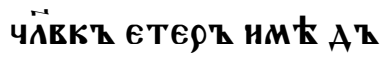

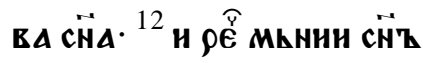

จц̈ю จЧЕ ААЖи Мн А०

с ТОНнОУК ЧАСТК НМ Е

ННІа. Н ९АЗА ЕАН НМА Н

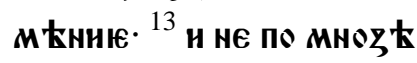

X' A

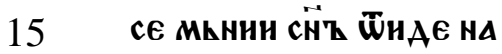

с TPАнOY АААEчE И TOY ОА

с Тоци нМ Кнню св ое жи

В ҚIH БАОУАННО ${ }^{14}$ НЖАН

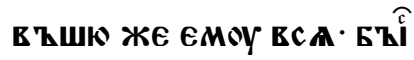

20

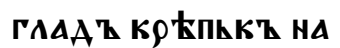

с Т९АНЕ ТОН И TZ НАЧА

Т' АНШАТИ СА. ${ }^{15}$ и П९н

ШКАТ П९нА ЕПН СА $E_{A H}$

HOMh $\bar{W}$ ЖHTEAh TOA с TPA

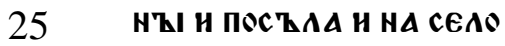


$135 \mathrm{a}$

СвоE ПАСТТ Свинин. ${ }^{16}$ Н

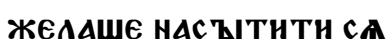

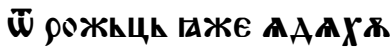

СЕннНА Н ниКТОЖЕ

5

ne aAaAme emoy. ${ }^{17}$ в h ce

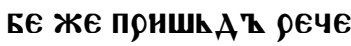

КОАНКО НАНМИНHК'

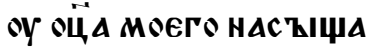

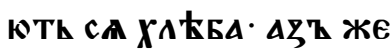

10 ChAE ГAАA'MMh ПOГ'ҚI

БАК. ${ }^{18}$ В ТC T АB ' HAOY K'

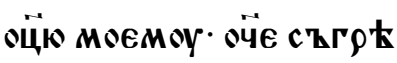

ШиХ' НА нЁО и п९ А Қ

TОБою. ${ }^{19}$ оУже H KCMh AO

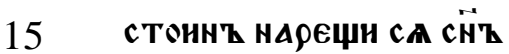

TEOH C'Z TEOQH MA A

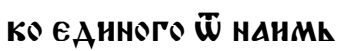

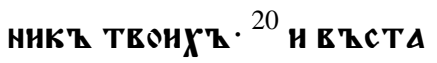

в И НАЕ Кһ оц̈ю своЕМฎ

20 еце же емоY ААлEче coY

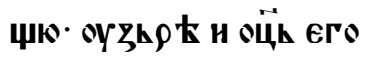

H MHAT EMOY Б ZIC Th

И ТЕК' HАПААE НА в Қ

К ЕГО Н ОБАОБҚIZА Н.
1356

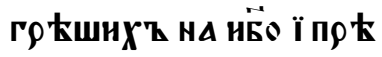

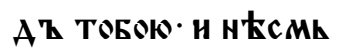

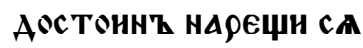

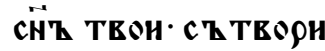

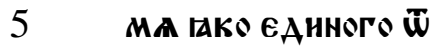
HАHMLHНК' TEOH

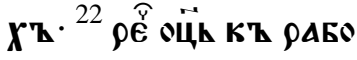
M7 свонмт - скоро н

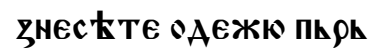

10 воую н оБл Ћц Қте н Н АААНТЕ ПК ९һстЕнК HA poykoy EГO н с Aח

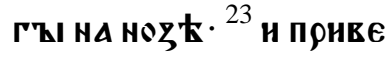
АТше ТЕАьци оупнтА H'ҚH ZАKOA ЕTE И AAT

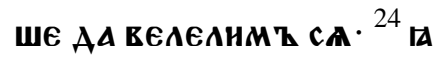
KO CḦh MOH Ch MLPTE'h

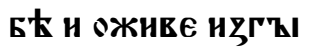
БАһ Бћ и оБрћте са. Н НАЧ АША ВЕСЕАНТН CA. ${ }^{25}$ Б大 же CH' EГO стA

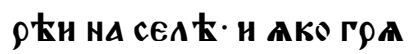
А ҚІ Н ПФНБАНЖН СА КТ АОМоY И САҚШША ПЕнН 25 
135в

в Z EАнного

हhIрашаше पh TO $\mathrm{X}$

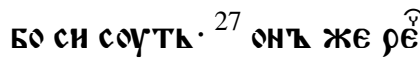

EMOY. БФАTZ TEOH

5

ПОНАЕ ' Н ЗАКААА ОЦ̈

ТЕон ТЕАһЦК оУПнТА

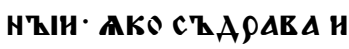

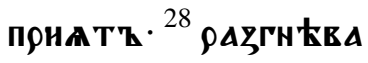

в Ж ЖЕ СА. и не Х०ТА

10 ШЕ въннтн - оц̆ ЖЕ

TO HWhATh MOAAWE Ï.

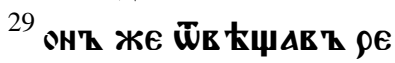

पе оц̈ю своE MоY Се К०

KHKO A KT' ९АБOTA

15

ю ТЕБе и николнжЕ

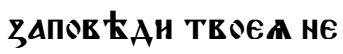

прТст оүпнх' н ми

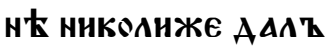

ECH KOZAATE· AА ch

20 А९ОУГЪІ СвОНМн в

ZБECEAHA CA БZZX'

${ }^{30}$ EГАА

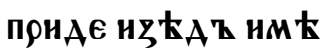

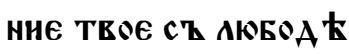

25 нцн· зАКАА ЕмоУ ТЕ
$135 \Gamma$

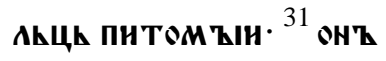

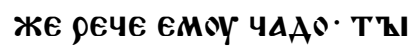

ВhсегАА съ М. НON Есн H BhCA MOA TEOA COY

5 Th ${ }^{32}$ в Қ Қвеселити ЖЕ са

Н вЪЪА९ААОВАТН СА ПO AOБАWE IAKS Б९АT Z

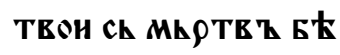

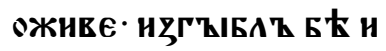

10 өБрћте сA $: \cdot$ -

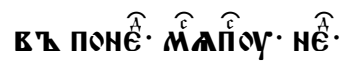

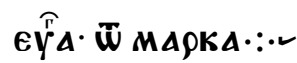

Марк в в в

XI

1-11

15

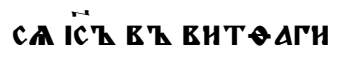

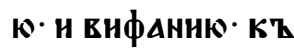

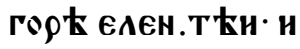

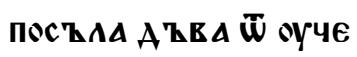

HHK' свонX' ${ }^{2}$ H ГӒА

HMA' HA ЕTA ET EhCh

20 аже Ести п९

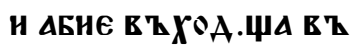

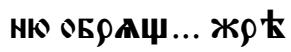

БКЦК ПФНЕАЗ.. НА

нhже н ŁcTh.. нHкTе

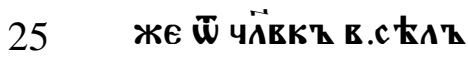


$136 a$

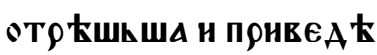

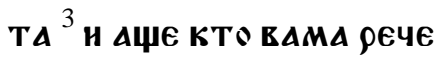

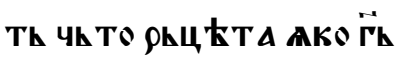

ТрћБоуњ Тһ ЕГО АБне

5

же ПАК' посъАETh н с

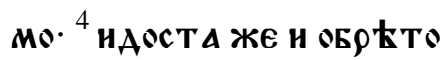

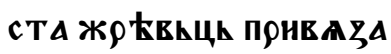

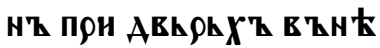

нА ९Аспоутнн н отрЕ

10

ШАСТ А И ${ }^{5}$ Н нћцин ОТТ

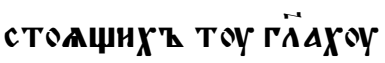

Th HMA чh TO A kETA W

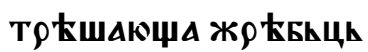

${ }^{6}$ онА же рекостА нмт А

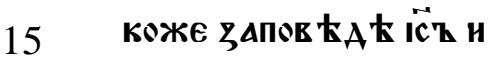

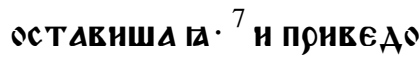

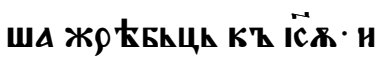

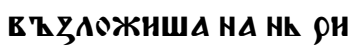

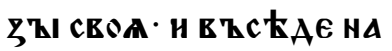

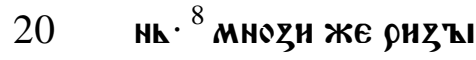

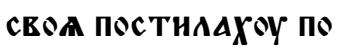
ПоуТн· А А९оУ马ни в

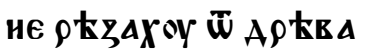
постнлах оу по поY

и вЪПнА XОY ГӒще О

Марк

XIV

$10-72$

15

\section{0}

10

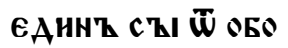

N HA AECATE. HAE

КҺ стА९ Қишнно

Mh жh $\rho$ чhскАMt

АА н по ААССТ нмт .

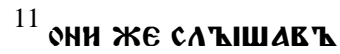

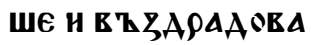

ША СА· Н ОБ ҚШАША

CA EMOY с९ ЕБрКнH

25

ШЕ КАКО н БҚІ в Z П० 
136в

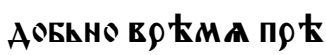

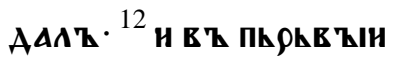

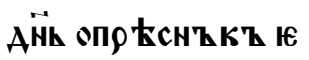

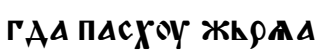

5 XоY ГӒАWA EMOY OY

ЧЕнНци свон КҚАЕ

Хошешн шhА'Мше оу

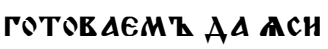

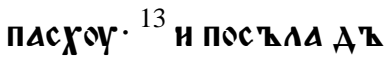

10 вА $\tilde{W}$ оученнк' сво

нХ'И Н ГӒА НМА НА Е

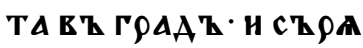

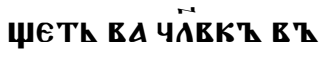

сКОУА ТАһннци во

15 AOY HOCA П ПО HEMh H A tта. ${ }^{14}$ и Аможе Аџе вънHАЕТИ ९һцћтА ГḦУ АОМоY оучнте

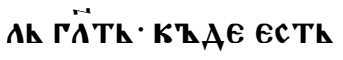

20 ОБнтћАһ' НАЕЖЕ ПА с хуоу сқ оученик'ы свонмн сън Еми. ${ }^{15}$ н

TZ вАMА ПОКАЖЕТИ ГОРАнНЦК вЕАНю

Boy TOY oyrotokA

$136 \Gamma$

HTA HАMZ ${ }^{16}$ HZHAOCTA

ОYЧЕНHКА Н ПОНАОСТА

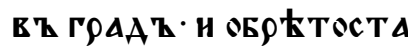

ГАКоже ९ЕЧе имА и оуго

5

товАстА ПАс ХळY. ${ }^{17}$ н вече

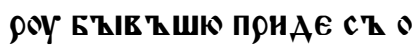

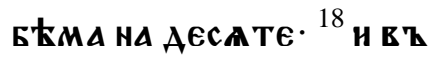

उАЕЖАџЕМт нМ и и А

АоушеMz · $\rho ч е ~ i \overrightarrow{c h} \cdot \Delta M і ̈$

10

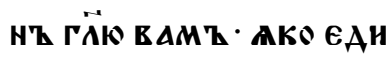

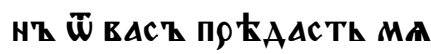

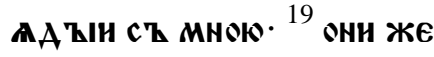

НАЧАША СК' $О Б$ ЕТИ И

ГӒАТИ ЕМОУ. ЕАНH' ПО

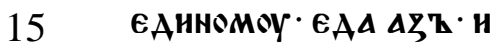

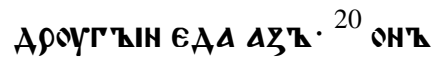

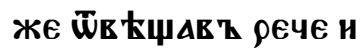

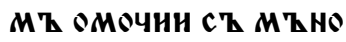

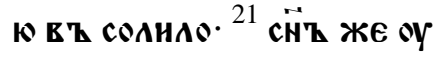

БО Чล̈ЕЦК НАЕТИ АКО

ЖЕ Есть Пнсано W HEMh

АюTЕ ЖЕ ЧӒЕКОУ TO

MоY. н МһжЕ СН̈ पत̈вपh

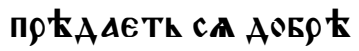

25

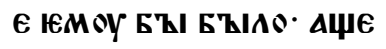

БҚI HE РОАНАҚ СА Чत̈ЕКТ 
$137 \mathrm{a}$

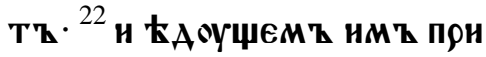

нMz ї̈z

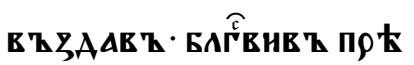

АОМн И ААСТ НМТ И

5 че прннм Қте се ести т Ao moe. ${ }^{23}$ и прннм' Yашю

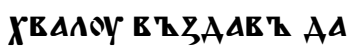

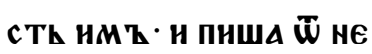

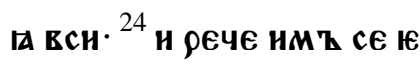

10 CTh K९̈ZEh MOA HOEA

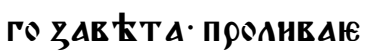

MА ЗА МнОГҚ. ${ }^{25}$ АМНHҚ

ГӒю вАM Қ ТКО оYже

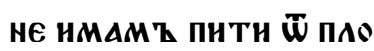

15 AА cETO AOzhHATO AO

TOГO AN̈E EГAA Пию

нно въ цёс Твн Бӝн

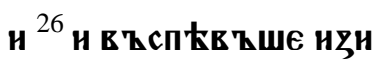

A

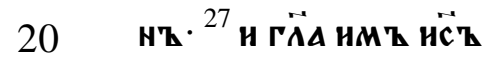

ТАКО вСН СТБААЗНH

TE CA O МнҚ В Қ СНК но

Нh ПHСAHO БO ECTh

поражю Паст'Қlра

25 Н ОВКЦА ९АЪБ КГНОУ

Th Ca. ${ }^{28}$ H' no Tomh ๒
1376

ГАА Е ВСКОКСНОУ ВА

ОК Е ҚІ ЕТ ГААНА.Н.

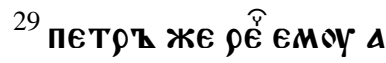

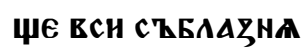

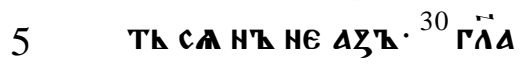

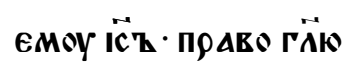

TH AKO TZI AḦ ET

сню ноџь Пр Кже АА

же в $\mathrm{z} \mathrm{тө \rho нцею} \mathrm{коурт}$

10 не в Ћспоети трнши

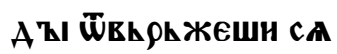

мене ${ }^{31}$ перти же и

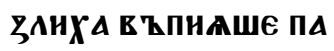

че АџЕ Мн СА АОУчн

15 Th ch товек оумоt

TH· HE OTZKL

теБе Т Ткоже Же и

всн ГӒАХОУ. ${ }^{32}$ и прНАО

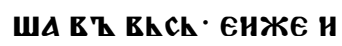

20

MA ГEОСНMAHH

И ГӤА оүченНкоМ

свонМВ · СAA KTE

ChAE AOH'AEЖE Шh

АТ Помолю са. ${ }^{33}$ Н По

25 А ТТ ПЕТ९А и ґако

BA. HOAHA C' COEOH. 
137в

И HАЧАT В ОYЖАC

ТИ СА И ТОУжНТн.

${ }^{34}$ Н ГӒА .MҚ ПОНсКҚ

P.E.Ha Ест人 Aш̈е

5

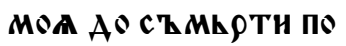

ЖНА КТЕ сһАE И БЪАÏ

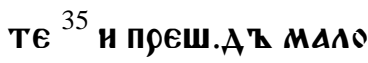

ПААE HА ZEMAH' H

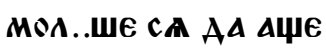

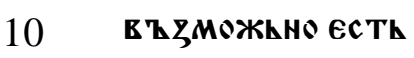

MHMO HAETh YAWA

сн. ${ }^{36}$ ГӤАше АREА

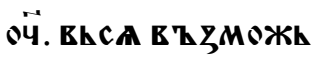

HA TEБE COYTh MH

15 мо несн чашю сню

ш̈ менЕ нъ не ЕЖЕ А

z'z .... Hh EжE Thl.

${ }^{37}$ и понае оБр КТЕ А сқ

П.џА и ГӒА снмо

20

н.. пет роY снмоне

сЪПишн Ан· не в Қ

ЗММоже ЕАНнОГО чА

САП ОБҚА КTH. ${ }^{38}$ БҚ

АНТЕ И МолнтЕ СА

25 АА нЕ в'ҚнНАЕТЕ вҚ

нскоушенне $A \overrightarrow{X^{7}}$
$137 \Gamma$

БO БZAPT $\triangle$ ПАT Th HEMO

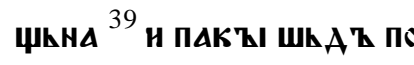

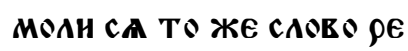

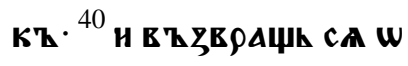

5 Б९һте ґА ПАКЫ съПа

ЩА. БћсТА БО НМТ ОЧН

ТАЖиц $\mathbf{~} \cdot$ и не ОYMA А

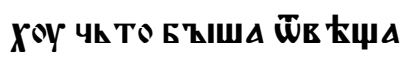

Ан Емоу. ${ }^{41}$ и прнае тре

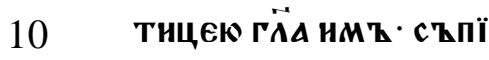

ТЕ ПрочеЕ и Почнванте

Прнсп К КОнКчннА

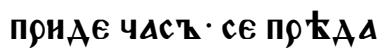

ETh CA CḦ प

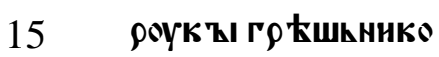

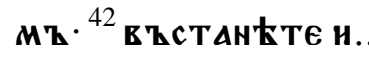

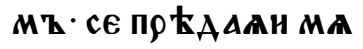

ПОНБАНЖН СА $\because \because \sim$

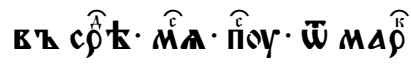

20

в в в

їоу к' оученикомт

СвонМТ - ПРНАЕ ИЮ

АА сКАРНОТКсКҚН

EAHнT Ẅ ОБON HA AECA

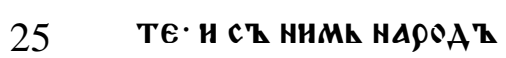

c' ороужнн А९ККоль 
$138 \mathrm{a}$

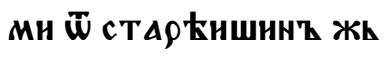

९һчьск' и Кннжьни

Къ н с ТА९һци ${ }^{44}$ ААсти

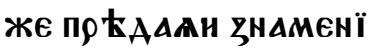

Е НMИ ГӒА - ЕГОЖЕ АџЕ

А०БҚЖю Th EсTh нM

ТЕ и и веА КТЕ н съХРА

Nно. ${ }^{45}$ и поншһА' АБН

If прнст топпи К' не

10 MOY ГӒА ОУчнТЕАК

ОУЧНТЕАК. Н ОБАОБЫ

ЗА и. ${ }^{46}$ Онн Же вһZА०

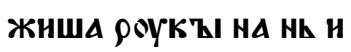

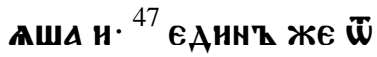

15 СТОАШНХ'Қ Н马..А ККҚ

НОЖИ ОУАА९Н ९АБА СТА



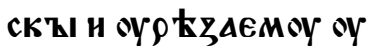

X० Аесное $\cdot{ }^{48}$ и ш̈в ћщА

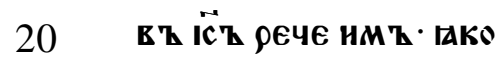

HА ९АЗБОННHКА АН Н

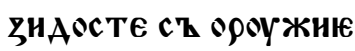

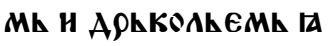

TZ мене ${ }^{49}$ По вһс A Ah

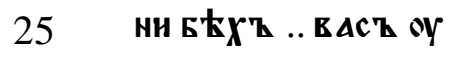

1386

ЧА Вһ Цр̈КкН ' Н НЕ А

С TE МЕнЕ ' Н' АА СҚБЖ

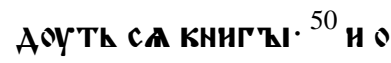

С ТАВАЬШЕ И ВСН БЕ

5 жАША ${ }^{51}$ н ЕАнНҚ нћкто

оYношА По неMь наЕ

OA KH' в Z ПOHAROY

HАГZ · H АWА OYHOW

52 OH' ЖЕ ост АВАh По

10 HABOY нАГ' Б ЕЖА

ш̈ ннхи ${ }^{53}$ н веА ОшА н

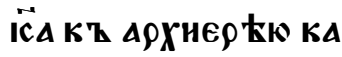

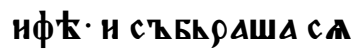

K' немоу всн $\triangle \rho X^{\prime}$

15 нер Кн н стАрщн и къ

ннжиници ${ }^{54}$ и пет $\rho$ '

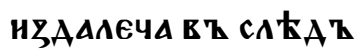

НАE. AO в ZHOYT $\rho$ в Z

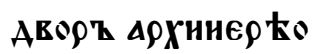

20 В $\mathbf{~} \cdot$ БАше ctAa $\mathbf{c}$.

САОУГАМН И ГОКА

СА прн Св Қчн. ${ }^{55} \Delta \rho X^{\prime}$

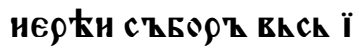

cKaX OY HA Ï̈A CZE K

25 А 
138в

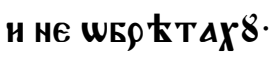

${ }^{56}$ мнези же А

в АА

HA Hh '

5

A ŁTEAhC TEA HE БAА

ше $\cdot{ }^{57}$ н нћцин въстА

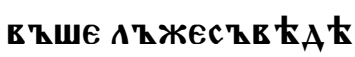

TEALCTEOBAXOY HA

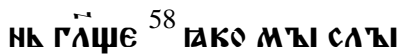

10

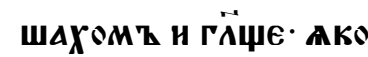

Аदһ

к роукетвореноую

и Т९Кмн АН̈һмн· Н

ноу съзнжю не ९оу

15

котвореноу ${ }^{59}$ Tо и тА

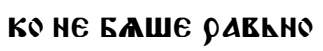

chв

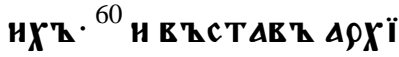

нер Ки въпросн и по

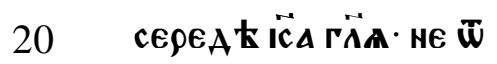

в 太џАВАњШи Ан нї

чhсоже पh TO сH HA TA

CZEKA ETEALCTEOY

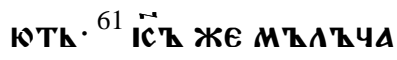

25 ше ннчи тоже не
$138 \Gamma$

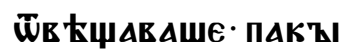

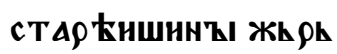

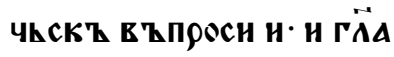

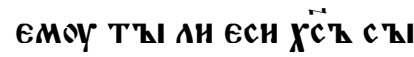

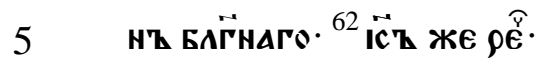

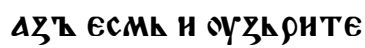

CHА Чत̈вपА С ЕАAџА О

АЕсноую снА ҚІ Н ГОА

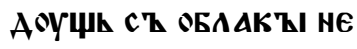

10

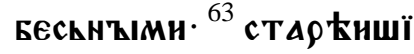

нА $Ж E$ Жh

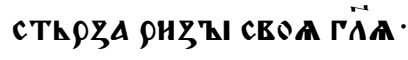

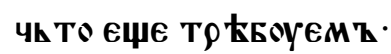

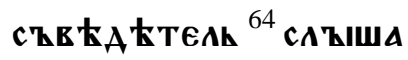

15

с TE XOYAOY. पh TO CA BA

Мъ Мьнить - онн же

ВСН ОСОУАНША Н БҚITÏ

ПОвинК НА С'ММ

${ }^{65}$ Н НАЧ АШША Н ҚЦНН ПАК

20 вАТн нА нһ' н пр Кк

ВАТИ Анце юГО Н Мљ

ЧнТН Н· Н ГӤАТН ЕМЖ

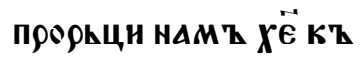

TO EсTh ОУААРНн ТА

25 н слоугтЫ Бнюще по 
139a

ААннТ Е ПФНАША н. ${ }^{66}$ и С

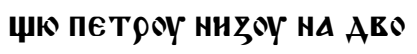

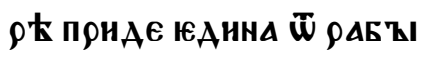

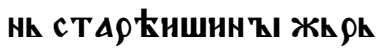

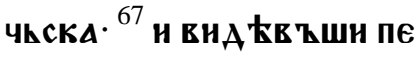

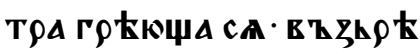

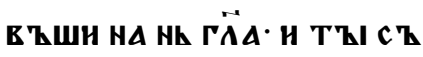

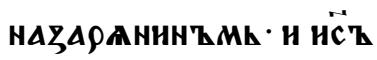

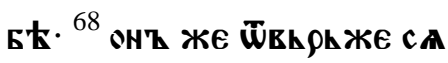

10 ГӒА не оум Кю ни сһЕ

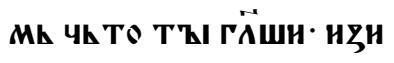
AE na по Қаворне' н коY

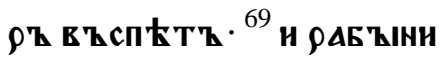
внА ҚЕ ҚШи и нАЧАТ'

15 ГӤТИ КҺ СТОАџнМҚ А

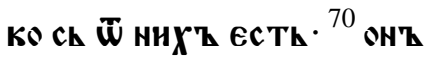
жE ПАК'Қl отһM в таше СА· Н HE ПО MHOГOY ПА КЫ СТОАџн ГӒАХОУ ПЕ

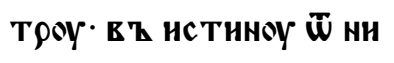

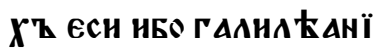

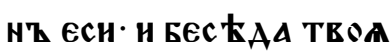

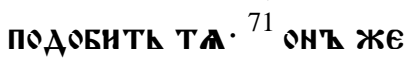
HАЧА РОТНТН СА Н КАA

25 ТИ СА· ГАКО НЕ в ҚМh
1396

Чล̈вКА сЕГО ЕГОЖЕ гӥте ${ }^{72}$ н в һ Topoe коY

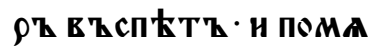

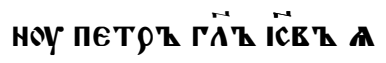
5 Ко рече емоу пр

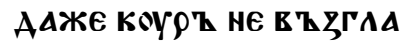

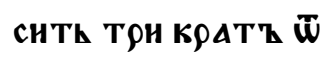

Марк $\mathrm{XV}$ ви рһ Жешн са мене Н НАЧКHZ ПААКАШЕ СА ${ }^{1}$ н АБHE нА ОУТ $\rho$ Е

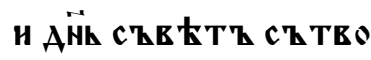
рншА А९Хнне Һи с ' стАрцци и кни

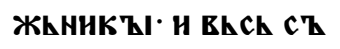

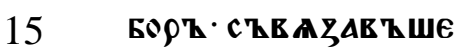
ї $\triangle$ веАОША и По WA' rOHh ThCKOYMA กнААТОУ $: \because-$

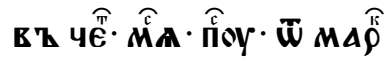
в ' в С' TEорншА всH А ९Хнне९ Ен ст стА рци и ст Кннжьни

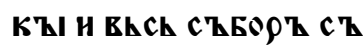


139в

ША и п९ А АША и пи

ААTOY. ${ }^{2}$ Н в ВППоОС Пн

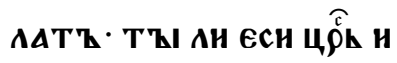

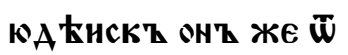

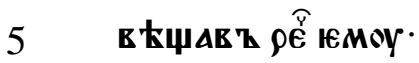

ТҚІ ГӒЕшн. ${ }^{3}$ н HА Hh

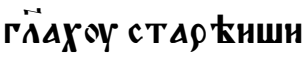

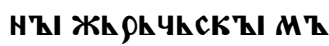

ного. ОнТ ЖЕ ничисе

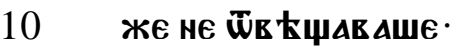

${ }^{4}$ пнлАтТ же в ҚпрА

ШАШE Th И ГӒA

в 太џАВАЕшн Ан ни

чисоже внжи көлї

15 KonA TA CZEta

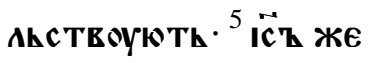

Kh Tомоу ннчьсо

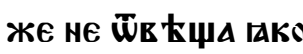

АНЕНТИ СА ПНААТУ.

20 НА ВһСАK' ПФА३АК

ннк'

MZ EAHHOГО ' CZE A

ZूHA EГOжE XОTA

Аүоу. ${ }^{7}$ Баше же нарї

25 ЦАЕМҰИ ВА९АВА 139г

C' СЕОНМН КОВКНHК'ҚI

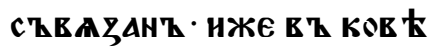

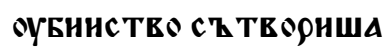

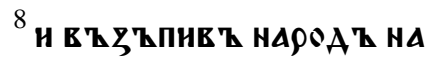

5 ЧАТТ П९оснТИ АКОЖЕ

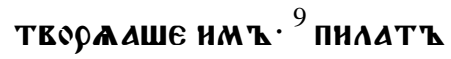

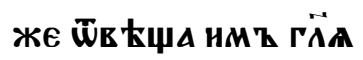

Хоџете Ан б̈поущк

вАМ ц ц $\tilde{\rho}$ А нюА КнскА.

10

${ }^{10}$ в ҚАAше Бо ако Zав їс Tï

९ААН ПО ҚААША И СТА

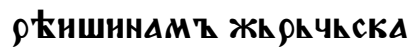

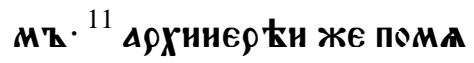

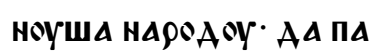

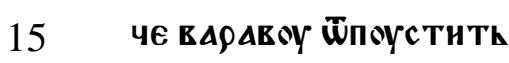

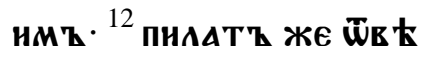

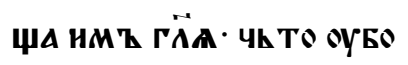

Хоцете ст творю егоже

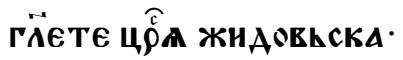

20

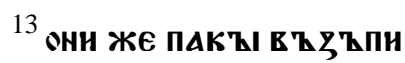

ША ПрОПкни. ${ }^{14}$ ПнААТ Т

же ГӥАше имқ чh Т० Бо

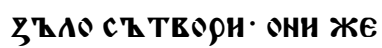

Анше вһ弓'ҚПншА про

25 пини. ${ }^{15}$ пнлАтт же Х०тА 
$140 \mathrm{a}$

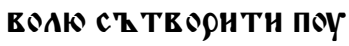

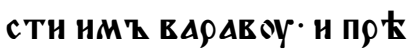

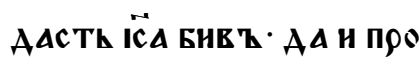

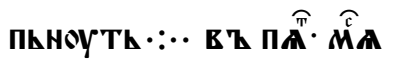

5 กิ

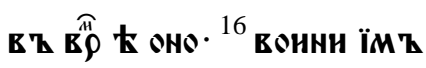

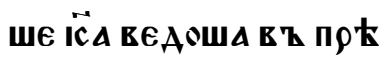

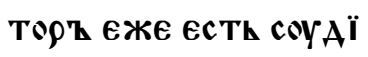

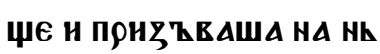

10 вису спнроу. ${ }^{17}$ н оБА ЕКО

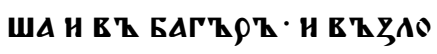

жHWA HA Hh çחAET'

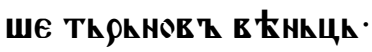

${ }^{18}$ Н НАЧАША И Ц ЕАОЕАТИ

15 ОААОУИ СА ЦӦЮ ЖНАОЕК

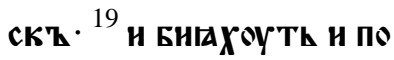

ГААВ 太 Т९'ҚC ThN' H ПAh

BAXOYTh HA Hh' H прt

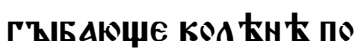

20 KaAhaXoY ca emoy. ${ }^{20}$ I

raA mopoYT ALUA CA E

MOY CZEA KKOWA CZ HE

ГО БАГZ $\rho \mathrm{H} \mathrm{H} \mathrm{ОБА} \mathrm{ЕКО}$

ША Н ЕТ ९Н马'Ы СЕОА Н

25 ЗВЕАОША Н АА П९ОПК
1406

HoYTh ${ }^{21}$ и ZАA ЕWА Mї

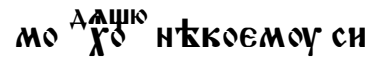

мон8 Кернн КАни

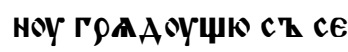

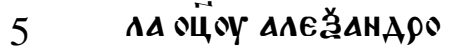

воу н

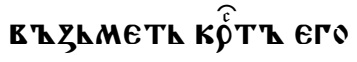

22 н ПонЕе АОША н HА

M 太с TO ГОAгоОА. н

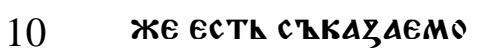

коАннево М Есто. ${ }^{23}$ H

AAAXOYTh EMOY חH

ТН ОЦК ТАнО внHO- W

нһ ЖЕ нЕ прна. ${ }^{24}$ н поО

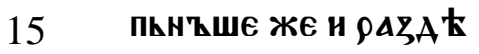

АHША ९H马'ҚL EГO - ME

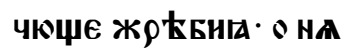

ЧК TO KTO вһ ZूMETh .

25 Баше Же ГOAнHA

20 ТрЕТнгаА и прОПА

ша и. ${ }^{26}$ Баше же напї

САHНE вHHZI EГO HA

ПнсАно

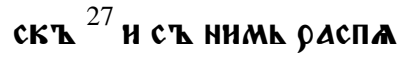

25 ША АИЕА ОАЗБОННИ 
140в

KA. EАнHOTO O AECHOY

o a Apoyraro o wy心

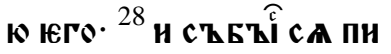

сАHOE • ЮЖЕ ГӒЕTh h

5

C' БЕ马АКОНКнНКО

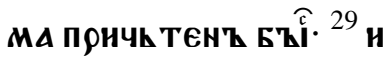

МнМО ХОААЧни ХОУ

AА ХOYТИ И ПОКҚIE $\triangle$

КШЕ ГААВАМН СЕОН

10 Мн ГӒџЕ оүв А ९А३А

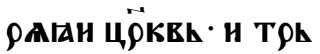

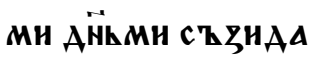

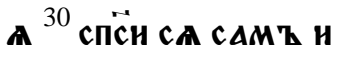

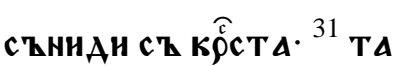

15 коже и А९Хннер Кн

роугакще са ст кнї

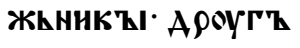

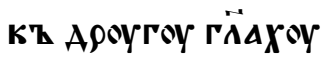

ннҚ спїе - ААн сеБе

20 не можети сп̈стн.

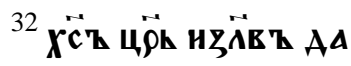

СZNНAETL NZINE

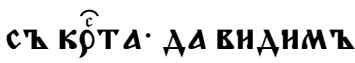

н в Е ооу нмем $\mathbf{z} \cdot: \cdot$ -

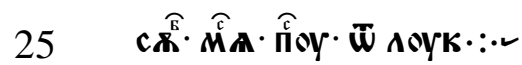

140 Г

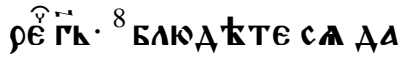

Лука

не ПрТАһщенн БоУАЕ

XXI

8-9,

25-27

5

TE- МнОЗН БО ПОНАОУТК

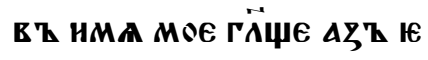

СМh' И во ЕМа ПрНБАН

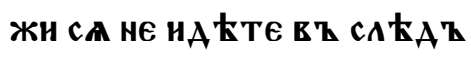

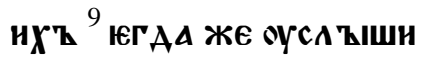

ТЕ Бранн · нес Т РОени

И НЕ ОУБонТЕ СА П ПОАО

10

БАETh БО снмт прtже

БZITH HZ HE OY АБHE KO

HКЧнНА ${ }^{25}$ Н БОУАОУТК ЗНА

МЕННГА в Т СӒнцН и АОУ

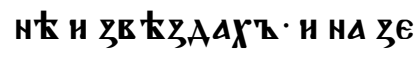

15

MAH TOYГA IAZZIKOMT.

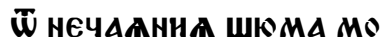

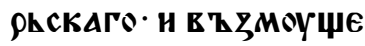

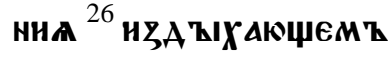

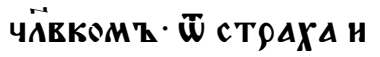

20

ЧАІанНА - ГОАА ОYЧЕ НА

BhCEAEHOYК СHATI БO HE

БECKHZIA АВНГHOYTh

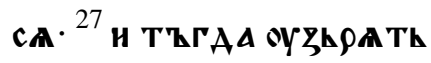

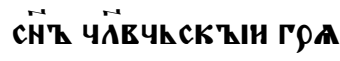

25

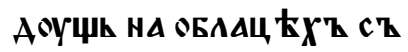


$141 \mathrm{a}$

СНАОК МнОГОК ${ }^{33}$ НБ̈ И दЕ

MAA MHMO HAETh А СAO

Лука

XXI

33-36

5

BECA MOA HE MHMO HAOY

Th ${ }^{34}$ в ЋнемА Т TE же себћ

EAA KҚГAA OTAГZYANTh

С̈АЦА Е АШША ОБ ЕААНHЕ

МК И ПНганһ СТЕ ҚMh И

пЕЧААКМн жћТннскА

МH' Н HАHАETK HА ЕҚ ЕТ

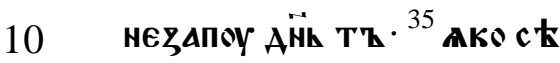

Th БO ПрНАETh HA EhCA

c太ААџАA НА АНЦн всE

А ZемАа ${ }^{36}$ БһАнте оуБо

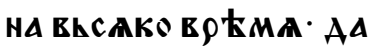

15

СҚПОАОБНTE СA OYБ大ЖА

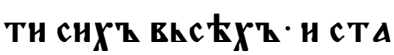

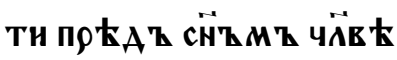

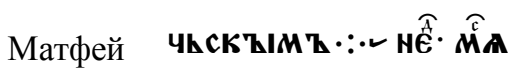

XXV

$31-46$

20

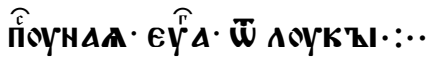

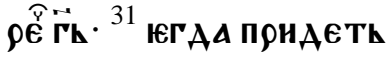

СН̈ ЧӒЕЧсКЫН Е Қ САА

в 太 своен· н всн с Т̈нн

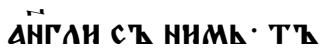

rAA CAAETh HA ח९ tCTO

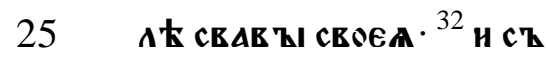

1416

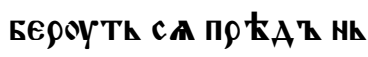

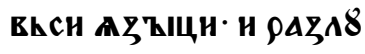

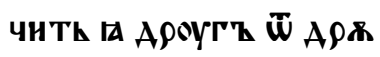

ГА. ГАКОЖЕ ПАСТ TI

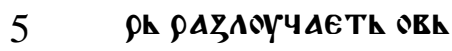

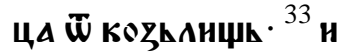

ПОСТ АВНТИ ОВһЦА О

Аесноу⿰ сеБе - $\triangle$ Kogh

АНџА \& Шююю сEБе

10

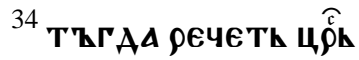

соушнмт о Аесноую

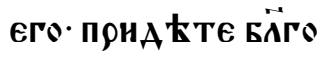

словенин оц̈А моего

EГO' HACA

15 оүготов АноE вАM $\mathrm{Z}$

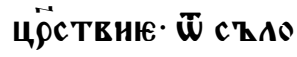

женна мноА. ${ }^{35}$ в Қ马А

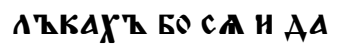

с ТЕ МН АСТН· ВЪЖАА

20

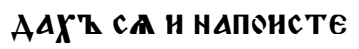

MA'CT ९АHLH' БK

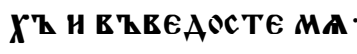

${ }^{36}$ Бол $\mathbf{X}$ и н пос Етнсте

МЕНЕ- В'Қ ТКМКнИ

25

ци и п९ндосте к' м' 
141в

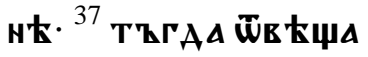

NTh EMOY. ח९ARh

Аьнин ГӒще $\cdot \overrightarrow{\Gamma H} \cdot \kappa \mathrm{k}$

ГАА ТА ВНАЕХОМТ

5

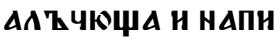

ТАХОМт иАн жАжю

ЩА. н НАПОН Х्र०M?

${ }^{38}$ К'ҚГАА ЖЕ ТА вНА

ХОМТ СТ ТАHКНА Н

10

В ZEEA XОMТ НАH

нАГА н ОА ЕХОМт .

${ }^{39}$ КъГАА ЖЕ ТА вНА

XOMT БOАAЩА НАÏ

В Қ ТКМКнНЦИ и

15 прнаРХОМт Кт те

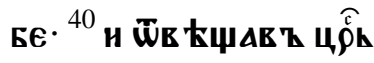

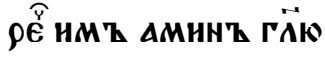

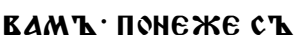

TEорнс TE EAHHO

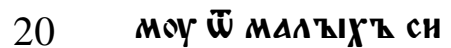

X'Z• БОАТ'Қ мон Х'

MКнКшHX' MZHE

сZ TEоTнсте ${ }^{41}$ TZГAА

речети соушнмт

25 จ шююю его. НА 141г

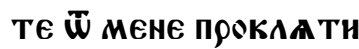

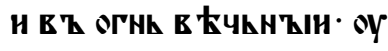

ГOTOE AH'KIH · A..A

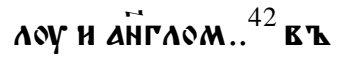

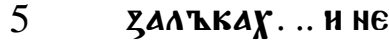

ААС TE МН АСТН· В ҚЖАА

A $\triangle$ X'Z CA H HE HAПOHсTE

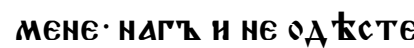

Мене ${ }^{43}$ БОАКнТ и вҚ ТК

10 Мьници и не Пос ЕТн

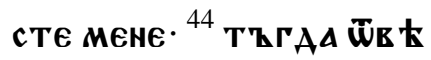

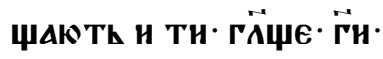

КҚГАА ТА ЕНА ЕХОМ७

АА Қ ЧКЩА НАН ЖАЖК

15 ША' НАН С ТРАнКНА' НАН

HAГА' HАН БОАКHА' ÏАН

в Т ТКМКнНЦн ' нЕ ПО

слоужнуоми тек ${ }^{45}$ Th

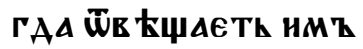

20

ГӒА· АМНHҚ ГӒК ВА

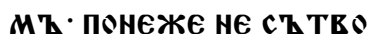

рнсте Eанномоу

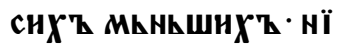

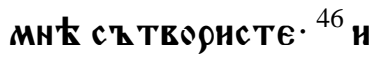

25 НАОУТТ ТИ Е' Моук8 
$142 \mathrm{a}$

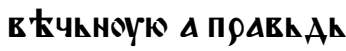

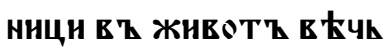

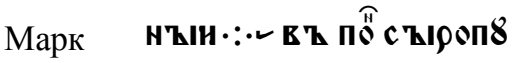

XI

$1-14$

5

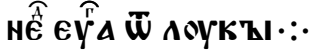

вไ в

жн са ї̈ в в внтһфА

ГИК' Н ЕНфАННК

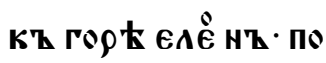

CZAA AKBA W्w OYYE

10 НнК' СЕОНХ' ${ }^{2}$ н ГӒА н

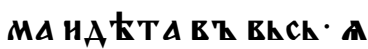

ЖE Eс Th ПРАMO в АMA.

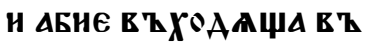

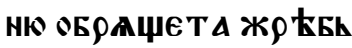

15 ЦК ПФНЕ ЗАНH' HA Hh

же нtсть ' оу никто

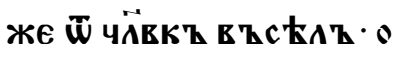

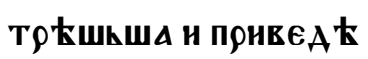

TА ${ }^{3}$ н Аџе КTо ваM

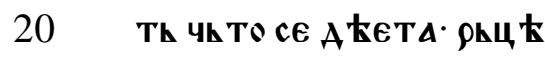

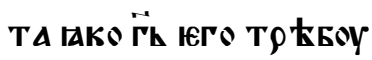

ЮТИ АБнЕ ЖЕ ПАК'Қ По

с.АETh н с太MO ${ }^{4}$ HAOCTA

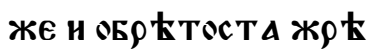

25
1426

споутнн н өтрћшн

стА н. ${ }^{5}$ н нћцнн Ф̈ сто

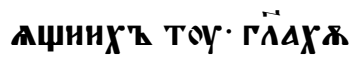

HMA. 4h TO A KETA W

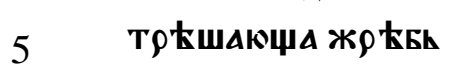

ци. ${ }^{6}$ она же рекост Т

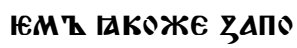

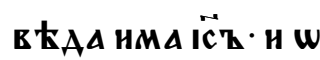

ст ТВНША ГА. ${ }^{7}$ Н ПрНве

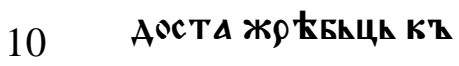

ісоу. и въ弓А०жишА

HA Hh ९H马'W CEOA H

в ZCEAE HA Hh. ${ }^{8}$ MHO

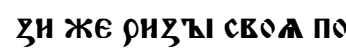

15 стнлАХоу по поути

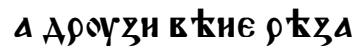

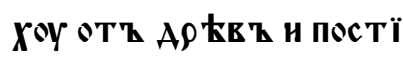

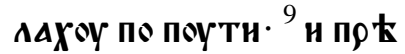

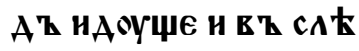
АТ Х०ААџнН вЂПи

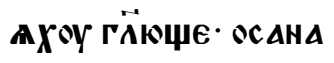
БАГ̈ОсА⿱вАEнТ ГОА

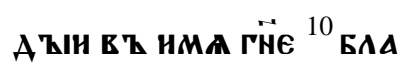

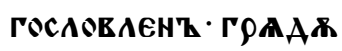

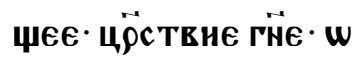
CAHA CHOY AB̈AET $\cdot{ }^{11}$ H 
142B

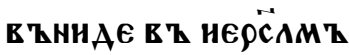

и вһ Цр̈Квн С'ГАА

A4 B' BCA mOZAt oy

жЕ соУџю чАCoY н

5

ЗНАЕ В Т КНОАННК

Ch OE KMA HA AECA

те ${ }^{12}$ и вт оут

HWhA ҚWEMh HM

Ф̄ внфАНна в Қ马А

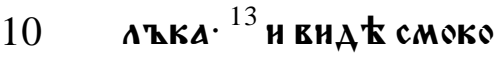

БКнНцК НЗ ААЛЕЦА

НМоУџю АнстЕНЮ

ПОНАЕ АЩЕ ОУБО ЧТ०

ОБ९АҢЕ ТИ НА нЕН н

15 ПрншиА' К' нен ни

чи САЖЕ не өБ

НА НЕН ТЋЧнК· АН

ствИЮ· НЕ БАШЕ БО

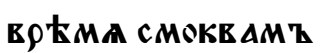

20

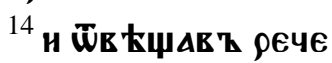

EH'K TOMOY $\tilde{w}$ TE

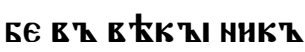

ТОЖЕ ПАОАА HE С'

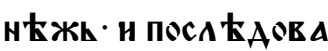

25 ША ЕМоу оученнцї

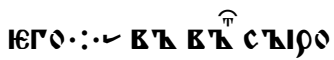

142Г

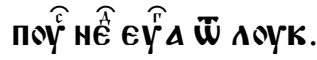

в ' в

Лука

XXII

39-71

haAme ha ropoy ene

HhCKOYN ПO SБҚIYA

5 К. ПО нЕМһЖЕ нА०

шА өученнци его ${ }^{40}$ БҚl

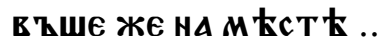

HМһ MOAнTE CA AА NE

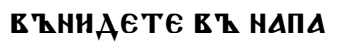

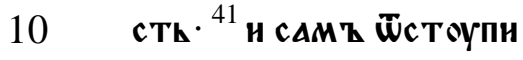

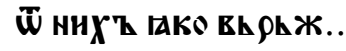

Е КАМЕне· и ПокАО..

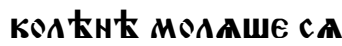

42 Гत̈

15 МнМо несН чАШК СНК

oth MEnE. SБAYE He Mo

A вona h' TEOA АА Б.

AETh ${ }^{43}$ ГАви же са EMoY

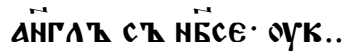

20

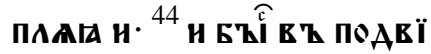

з прни қжино мо..

ше Са и Б'र्व пот' ..

AK'ҚI KAПАA K९ҚВE

КАПАКЩН НА ЗАМАК.

25

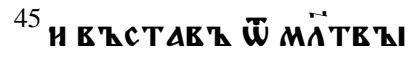

и П९ншһА' К' оучени 
$143 a$

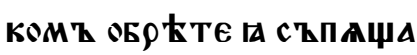

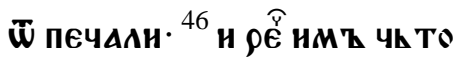

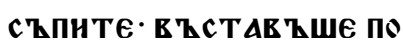

МолHTE СА АА НE ВЪНH

5

АЕте в и напАсть ${ }^{47}$ Еще

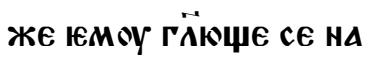

РОА Қ ' Н НАРНЦАЕМ ҚIH

HюАА EАHн' $\widetilde{W}$ ОБОК

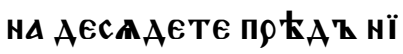

10 Мн НААШЕ Н ПОНС ТОУ

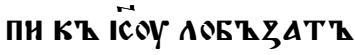

ero. ce go gawe ghame

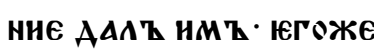

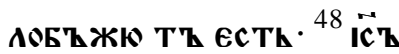

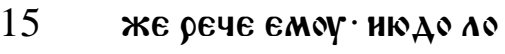

БЪ弓АнHEMh АН СНА

Чล̈вчА По ААЕшн ${ }^{49}$ вн

А Ћв Қше же иже Ба

- HeMh EZIRAKUEほ

20 рекошА емоу гे А

це оУАА९нмт ножh

Мh ${ }^{50}$ Н оУАА९Н ЕАНH'

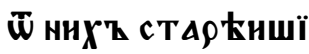

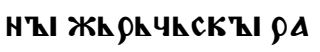

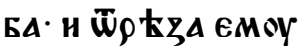

25
1436

廿ав '

вите Ао сего и ко

сноY н в' oYXo ero

нсц КАн н. ${ }^{52}$ рєче же

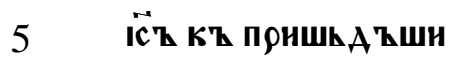

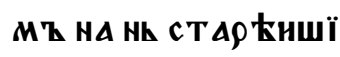

HAMZ · R BOEROAAMT

цёКЕКнҚIMZ и стА

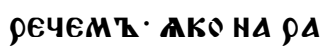

10 ЗБоннНКА АН НЪН

Аос те с' ороужнемк

Н А९һКОАһМн АТT

MENE. ${ }^{53}$ ПO вһсA АН̈н

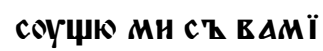

15 въ цр̈Ккн не прост ро

с TE POYK' HA MA .

HT ce EcTh BaWA ro

AHHA H ОБААCTh Th

MLHAIA ${ }^{54}$ HM Z WE и

20

BEAOWА H ВT АOMT

стАр ЋишннҚ жь

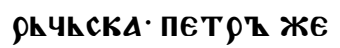

HАAшE в

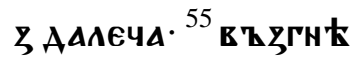

щише же огнh - по

25 
143B

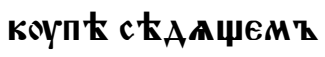

c太Aaшe пет $\rho \mathbf{z ~ n o ~}$

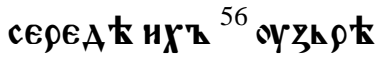

в ҚШи ЖЕ и РАБҚІнї

5

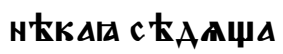

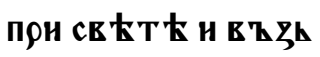

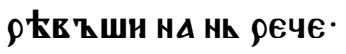

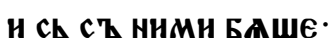

${ }^{57}$ онт же йви риже са

10 ГӤА не ZнАК ЕГОже

но ${ }^{58}$ н не по многоу

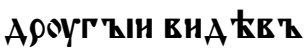

и рече н Т'Ы

X' есн петри же

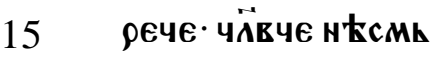

${ }^{59}$ Н мнме ШиА АШШи

ГАKO ГОАНH Е ЕАН

HOH И HZIHЕ КТО

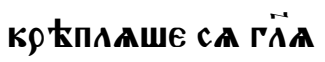

20 В $\mathbf{Z}$ Нс Тнноу и сь с $\mathbf{~}$

ННМН БАШЕ · НБО

ГААНА ААННнҚ Ю

сти ${ }^{60}$ рече же петри .

Чत̈вपе нЕ в КMһ Чh

25 То Гӥшн· и АБне ю

廿е гӒцा० EMoY в
$143 \Gamma$

ЗГААсн коурт ${ }^{61}$ н оБрА

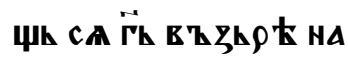

петра' И ПоманоY Пе

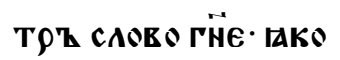

5 же ९ече Емоу Гакоже

прқже ААЖи не въ弓ГАA

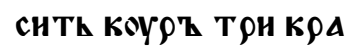

тұ ш̈вьрьжеши са

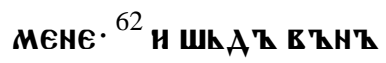

10 ПЕТ९И ПААКА СА ГО

рцкө ${ }^{63}$ и моужи иже ак

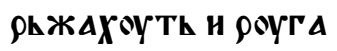

XOY са ЕМоУ Бнкще

H. ${ }^{64}$ Н ZАКОТIв АКщЕ БН

15 АХОути н по Анцю.

въпрашАХ Ууть нже

ГӒџе· Прорһци кто $е$

СТИ OУАА९Н и ТА ${ }^{65}$ и инА

мHOГА ХOYАAџE ГÄА

20 XOY нА Hh ${ }^{66}$ такO БЪIC Th

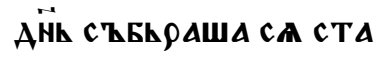

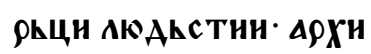

не९ Кн же и кннжь

ННЦН· Н вEАОША Н НА

25

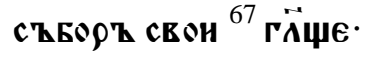

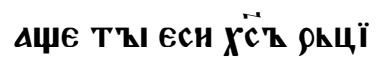


$144 \mathrm{a}$

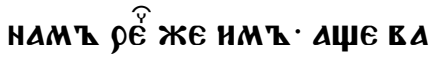

Mт рекоу не нмете в

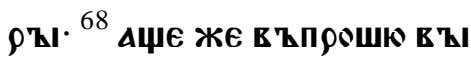

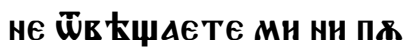

5

стите ${ }^{69} \overline{\mathbf{w}}$ селћ Боуаеть

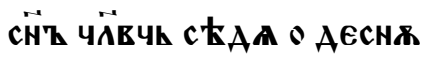

ю снАҚ БӜна. ${ }^{70}$ реКОША

Же всн ТҚІ Ан оүБо есн

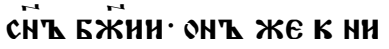

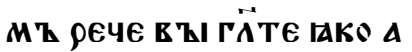

उ' есми ${ }^{71}$ онн же рекошА

чh то еще тр ҚБоуемт

Лука

XXIII

$1-25$

chE 太A $\mathrm{kTEAhcTBA \cdot cA}$

Мн БО сA'ZIWAXOMZ $\widetilde{W}$

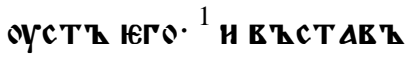

вһсE МножИстЕО нХ'Қ

ВЕАОША Н КҚ ПНААТ $:-:$

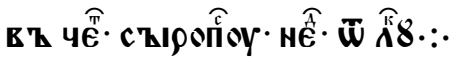

въ в

20 Кннжьницн и стА

Оьци АюАһстин

К' ПнААT ОY. ${ }^{2}$ HА

YАWA

Ти ГӒџе · сего оБр 太

25 тохом
1446

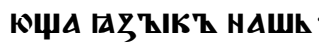

Н ЕТЭБОАНАКЧА АА

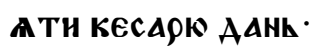

ГӒна са цёА БЫти.

53 ПнААТҚ ЖЕ вЪПроси

и ГӒА Т ТҚІ Ан Есн ц

нюА Қнск' '

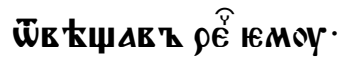

TZI ГӒЕшн $\cdot{ }^{4}$ пнААТТ

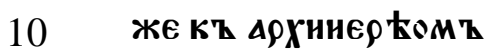

९ЕЧЕ КТ НАРОАОУ. НН

кое Аже винһ не О

Б९ћTАК вһ ЧӒвцћ се

ми 5 Онн Же к९ ЕПлА

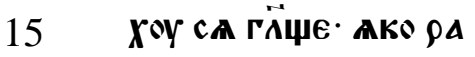

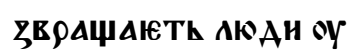

ЧА БО БһCE ИЕА КН HА

YAH' Ẅ ГАAHA ЕА AO

coYAOY. ${ }^{6}$ пнААT'

CATIWAR TA ГАAн KW.

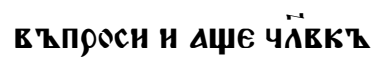

ГААнА ҚнскҚ EсTh $\cdot{ }^{7}$ H

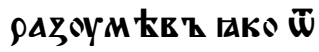

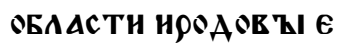

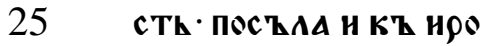


144B

Аоусоуше и тоMоY

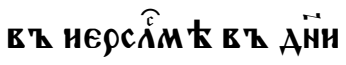

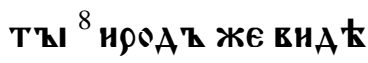
BT ICA nO БАше Бо жE八ta ш̈ мноГА в

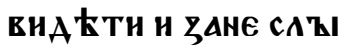
WAWE MHOГА O NEMh H HAA KraWE CA ZHA

10 MEнHE нћкऽE внА TH ST' HEГO БҚIR $\triangle E$ мо ${ }^{9}$ в қпрашаше же Н САОВ ҚI МНOГ'ҚІ W н' же ннчисоже не

15 ш̈в

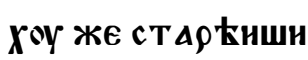

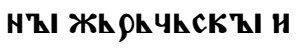
кннжьници прнА Е жино ваАALE на

20 нh ${ }^{11}$ оукори же ноодт C’ вон свонМн и ПО POYГAR' CA OБА KK' I

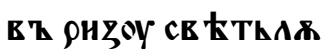

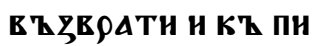

$144 \Gamma$

АроугА н ООАТ ЖЕ н Пн

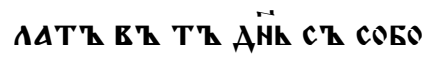
ю. прћже Бо вћстА врА ЖиАОүющА МЕЖю соБо

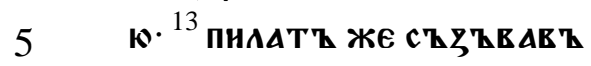

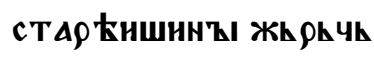
СКЫ КНАZН Н АЕАН. ${ }^{14}$ Н

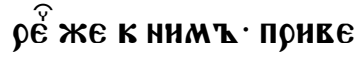
АОс ТЕ МН ЧӒвКА сеГО А

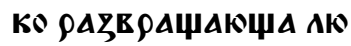

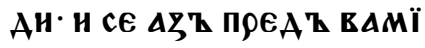
HCT АЗДЕ TZ HH EAHHOA

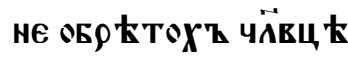
семи винтا АЖЕ нА Hh

15 вААНТЕ ${ }^{15}$ НZ нН нРОАТ

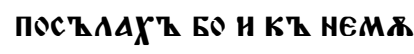
и се ничь ТожЕ Аостон но сһ Mh но ести O немh ${ }^{16}$ ПокА

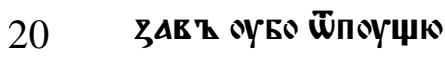
н. ${ }^{17}$ Пот

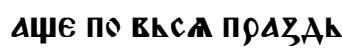

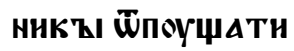

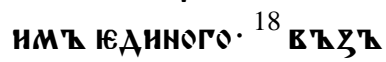
25 ПншА же сһ висkмh 
$145 \mathrm{a}$

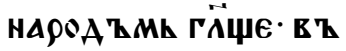

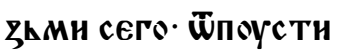

жE HАM Z в А९ АВ OY. ${ }^{19}$ H

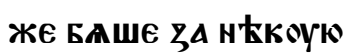

5

KPAMOA OY БZIE Z WW

К в' ГРАА А Н ОУБНн

с TEO в Қ Кһ

ТһМьницю. ${ }^{20}$ ПАКъ।

ЖЕ ПнААТТ в Қ马ГААСН

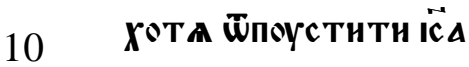

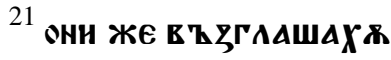

Гӥще· пропьнн· пропь

ни. ${ }^{22}$ онъ же трєтнце

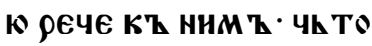

15

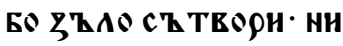

ЧК ТОЖЕ АОСТОНнО $\mathrm{ch}$

мирти овр Ктех' о

HEMh · ПоКАZАВ h I н

оуве ш̈поүшк. ${ }^{23}$ онн

20 ЖЕ ПрНАежАХОУ ГАА

СҚI веАнКҚI Проса

LE EГO ha п९OIA TH

IE 'H OYAOn kвАYOY ГAA

си иүЋ жи рьчистиї.

25
1456

н БҚІТн ПФошению

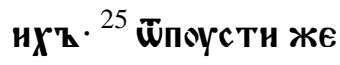

в ҚСАЖEнАГО в Қ Th

МКнНЦЕ ЗА К९АМО

5 АОУ Н ОУБНнс ТЕО $\mathrm{E}$

Гоже прошААX оY. IсA

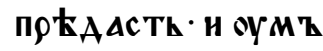

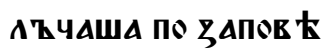

AH HX' $\div:-2$

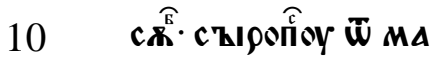

Tok4::

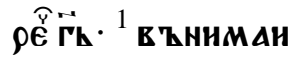

Матфей

ТЕ МӒстЫни

VI

1-21

15

BAWEA He TBOP.

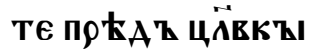

АА БНАНМН БОУАЕ

ТЕ нмн Аџе Ан же

ни Mh弓АТ имАТЕ

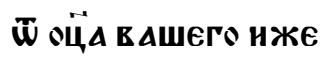

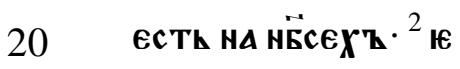

ГАА ОУБО ТВорНшН

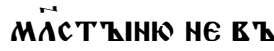

строуБн ПФ ЕАТ со

БоК гако и Анцем Е

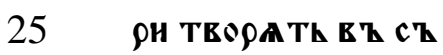


145 в

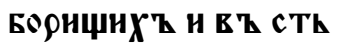

rHAX'Z · A I ПOOCA ABA

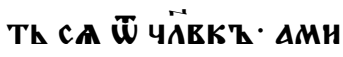

H' ГÄК в АM Z ' в '

5

спрнемАКТ Мh

ЗАОУ свою. ${ }^{3}$ ТЕБе ЖЕ

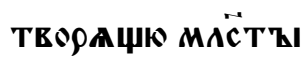

HN. AA HE YNETh WW

HЦА TEOA YK TO TBO

10 ФНТК АЕСННЦА ТЕО

A. ${ }^{4}$ АА БоуаеTh Мн

AOCTZINH TEOA E Z

TАHнЕ·

вHAA TA B' TAHHE.

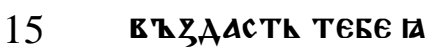

в

са' HE БOYAH IAKO AÏ

ЦЕМ КрҚ · ТКО АКБА

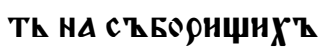

20 Н ВТ С ThГHАХ' HA

рАспоутинХ'Һ сто

Аџе МолНTH СА. AА

TABATh CA Чत̈вKO

MZ - АМНH' ГӒК ВА

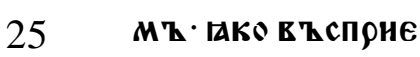

$145 \Gamma$

MANTh MhZAOY CEOK.

${ }^{6}$ TҚІ ЖЕ ЮГАА МОАНши

СА вҚННАН в К КАТТ

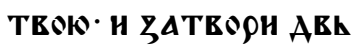

5 ОН ТЕОГА Н ПОМОАН СА

งц̈ऽ TE SEM⿻Y в 'h TAH

нћ· н оц̈ ТЕон внАА

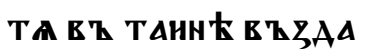

с Th TEEE IAR t. ${ }^{7}$ MONA

10 Ше Же са не Андогїћ

ТЕ ґакоже ґаз'цини

ЦH MhHA Th БO CA IA

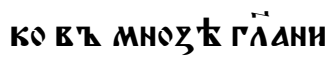

H СвоEMh оYсAтIسA

15

ни БОУАОУТь ${ }^{8}$ HE ПО

АОБнтЕ сA нМт - в Қсте

Бо оци вАши их'ъже

трћвоуете прћже

поошени а вашего.

20

${ }^{9}$ снче оуБо Молнте са

в Қl Wप̈E HАWh · НЖе

ЕСН HA HËCXZ АА С TH

Th ca hma troe. ${ }^{10}$ aA

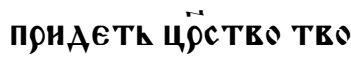

25 ๒. AА БOYAETh вOAA 
TEOA ·AKO HА НЁСН I HA

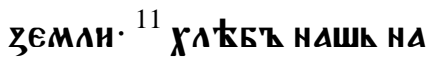

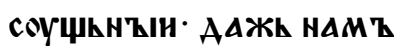

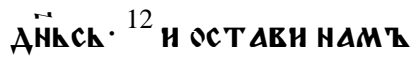

5

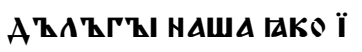

MhI OCT ARAAEMh A'

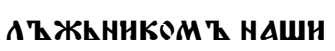

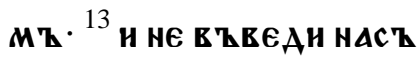

в Қ нскоушенН!' н' и

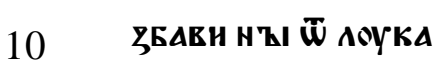

вAГO• IAKO TBOE ECTh

цёство н снАА

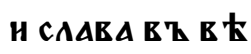

КҚ/ АМннҚ $: \because \cdot 2$

15

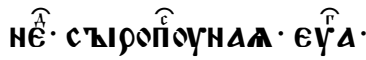

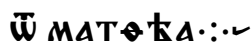

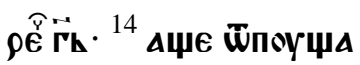

ЕТЕ чล̈вком с с

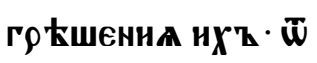

20 поустить н вАМт

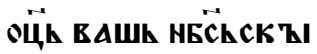

н. ${ }^{15}$ Аџе Ан не йппуџА

ЕТЕ чйкком с си

го Кшеннга нХ'

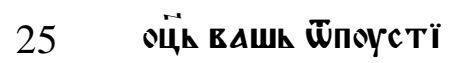

Th вАми сқг

нни вАшн $\chi \cdot{ }^{16}$ ЕгАА

же постите

CA HE БOY. . TAKO

5

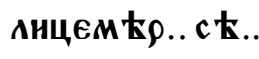

кце просм АжА

КТ БО АНЦА СЕ०.

А४ БhIயA CA..

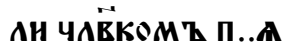

10 ше АМнн' ГӒю

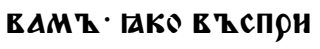

EMANTh MhZAOY

свон. ${ }^{17}$ Th ЖE Пост A

СА ПОМАЖ. ГИАК

15

ТЕюК И Анце ТЕо

E оумй. ${ }^{18}$ AА нE A

внши СА Ч

Mh Пост А СА

Hh Фц̈ю TROEMOY

20 нжЕ ґсти в т ТА.

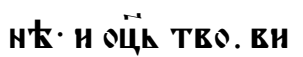

АА в танн в т

ЗААCTh TEБ太 IAK

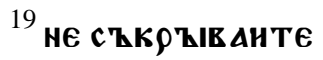

25 сеБе сқкровнц. 
146в

НА ЗЕМАн иАЕЖЕ Чһ

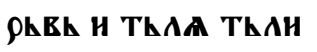

Th· нАEжE TATї

๒ ПОА ҚКЮПАКТИ и

5

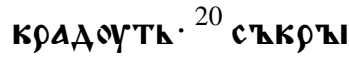

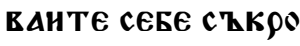

вНџА НА НЕСН · НАE

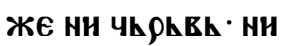

ThАA ThАнТИ hАE

10 ЖЕ TAThE HE חOAT

КөПАКТТ ни К А

Aoyтh ${ }^{21}$ нАЕЖЕ Бо Ю

с Th сһКровнце вА

ше тоу Юсти и сӛАЦЕ

15 ваUE $: \because$ cs $: \because \cdot c s \cdot: \cdot c s \cdot: \cdot$

çy $\cdot \vec{\Delta} \cdot \pi \hat{\varepsilon}$

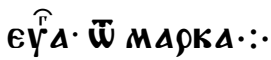

Марк вт в

II

23-28

20

we ï̀ $\mathrm{kTh}$ coyso

TAX'h ckE

с 太ганига. н нА

ЧАША оүченици

неге поYтh творн

Тн в Қст Тһ
$146 \Gamma$

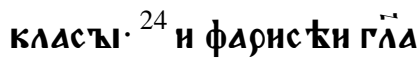

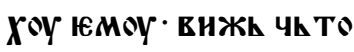

TEOPATK E'Z COYEOT'ҚI

ЕГОже не Аостонти ${ }^{25}$ Н

5 Th ГӒАШЕ имъ нЕсте

АН НИКОАНЖЕ ЧКАН ЧК

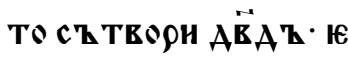

ГАА Т ९КБОВА Н ВҚЗА

А ҚКА сАМ Қ и їжЕ съ ни

10

Mh БA ХОY. ${ }^{26}$ КАКО в В Hї

АЕ в қ Х९АМ қ Бӝнн.

Пон АВНАOА

$\rho$ ФрХннерћ

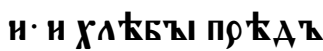

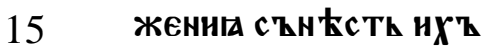

жe ne Aoctoame actï

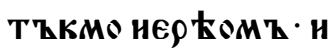

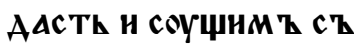

ннмь ${ }^{27}$ и ГӒАше нмт

20

СОУБОТ А ЧӒЕКА ९ААН

Бһ)

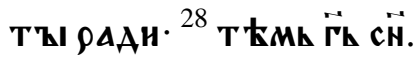

Марк ЧӒвчск'Н соуБот

III 1 H BTHHAE RAKTI B

1-5 Н ВЪННАЕ ПАКҚІ В Қ

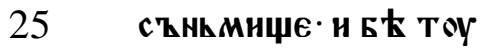


$147 \mathrm{a}$

Чล̈вк' coYXoY poykoy

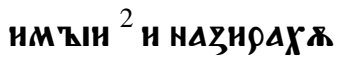

Th н Аџе в' с соYБотоY

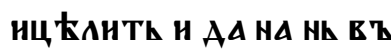

5

छГААГОАКТТ $\cdot{ }^{3}$ Н ГӒА ЧЕ

АОв 太КОУ НМОУџюМж

coYXoY poYкоY ст Ани

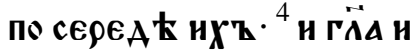

MZ АОСТОНTИ АH Е'

10

СоYБОтоY АОБ९O TEорї

ТН НАН ЗЪАО ТЕОРНТН

Аш̈ю спїТн НАн Погж

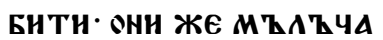

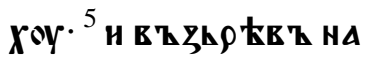

15 HA ç ГH KE ZMM сK'

९БА О WКАМЕНЕнНН С̈РЦА ИХИ ГЙА Ч

прос тирн ९оҮКоY ТВо

ผ. И прости

PAH са ९ОYКА ЕГО ц $\mathrm{K}$

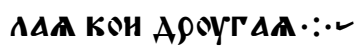

нё $\vec{A} \cdot$ постА в т нюже

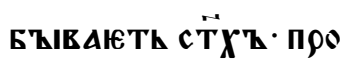

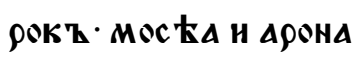

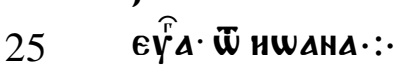

1476

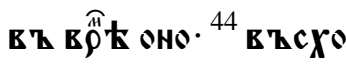

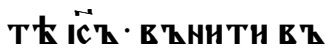

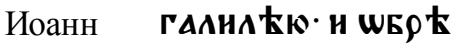

I ТЕ фнАнпА $: \cdot$ концू

5 HAAZ CHA ЧӒВЧCKAГ. $\because$

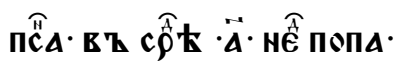

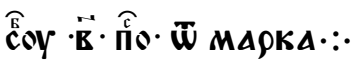

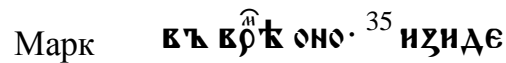

I

35-44

10

ich в п поусте м सсто.

H TOY MÄTEOY A

aше $\cdot{ }^{36}$ н гнаше и сїмо

нъ нже Б Б съ ннми ${ }^{37}$ н

оБрћтฬше и ГйАША

MOY. АКО ВСН НџюТТ

15

TEБE ${ }^{38}$ Н ГӤА НM ' HА

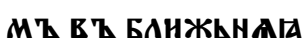

ВИСН И ГОААН АА Н

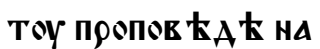

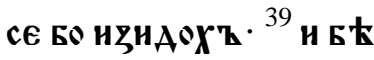

20

пропев $\mathrm{k}$ А

нКМншнХ'В нХ'

сЕН ГААНА ҚН Н БЕ..

Н马ГОНА $\cdot{ }^{40}$ Н ПОНАЕ К'

нЕМоУ ПОоКАЖЕнТ

MOAA H. H HA KOA Е 
147в

HOY IAAAA H ГӒА

ко Аџе Хоџешн може

ШН МА ОЧНСТНТИ

${ }^{41} \overrightarrow{\text { IC }} \mathbf{Z}$ ЖE MÄCPAORAR Th

5

прос тhрт роукоу кo

сноY и и ГӒА ЕМоY

ХОџю нщнсти СА. ${ }^{42}$ н

ректшю емоу АБнњ

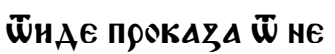

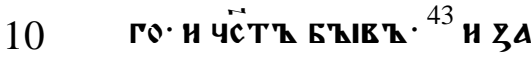

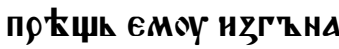

и ${ }^{44}$ Н ГӒА ЕМОУ БАЮАН

ннкомоуже ннчhсо

ЖЕ нЕ ९һци нъ ШиАТ

15 ПоКАЖн са нер Ћовї

Н Поннесн ЗА Очнще

нне Твоє ГажЕ Пове

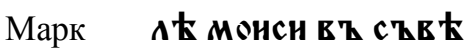

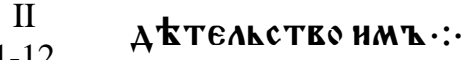

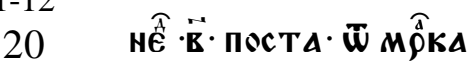

въ оно в

IC̈Z B Z KAПL $\rho \mathbf{Z H A}$

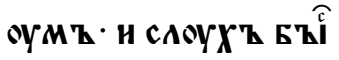

TAKO R' AOMOY ECTh

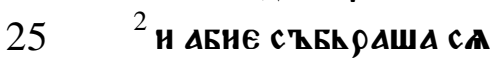

$147 \Gamma$

МнОZН АКО КTOMOY HE

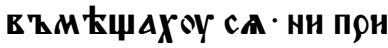
АТ АЕһ КһМн и ГӒАше и MZ САOEO ${ }^{3}$ Н ПОНАОША К'

5 HEMOY HOCAџE ОСААБАE H' ЖнААМн носнмт ЧЕ Т'Ырһмн $\cdot{ }^{4}$ немогоушн прнс тоупнти К' немж

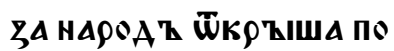

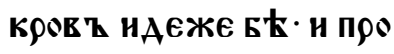

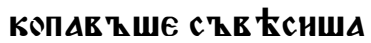

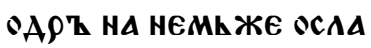

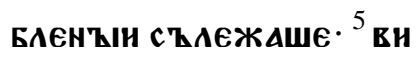

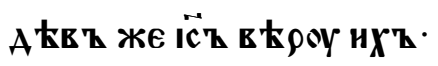
15 ГӒА ОСААБАEноY МОY.

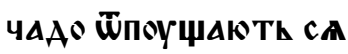
ТеБе Г९ Ксн твон. ${ }^{6}$ БА Хоу же етерн ш̃ кннжи нHк' TOY с

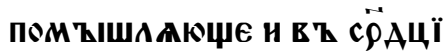
$X^{7}$ свонX' ${ }^{7}$ 4h TO ch TA Ko ..Th YoYA можеть ЁпоущАТн Г९ ҚХ'ҚI TZKMO EAH 25

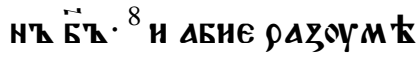




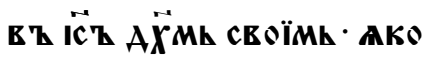

ТАКО ТИ ПОМҚIШАAКТЬ

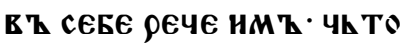

TАKO ПOM ҚIسАAETE В

5

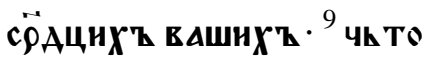

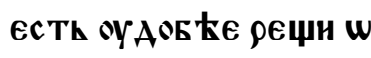

СААБАЕНОУМ ОУ Т̈ПОУЩА

юти Ти са грћсн· Ан $\rho \in$

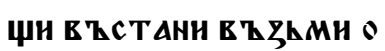

10 А९И ТвОН ХРАн ${ }^{10}$.. в БстЕ

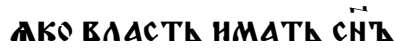
чӒвск々/ б̈поущАтї

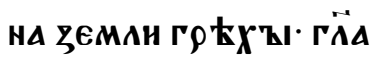

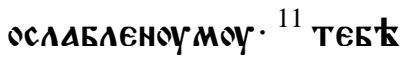

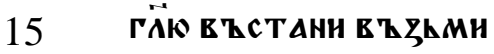

ОА९И ТЕОН НАН Е' АОМ

ТЕОН. ${ }^{12}$ Н В ТСТ ТЕ' АБНЮ.

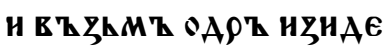

поћАТ висћми АКО Аї

20 ВАAХОY СА ВСН' Н САА

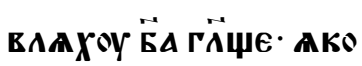

НнКОАНЖЕ ТАКО вНА

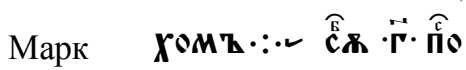

VII

25 в 2 оно в

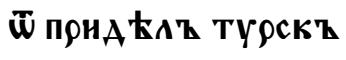

Н СНАОНL СК' - ПФНАE

на Mоре ГААнА Еїско.

межю прҚА ЋАт АE

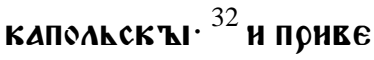

AOWA K. HEMOY RAOY

ХА Н ГОУГ'НННА Н

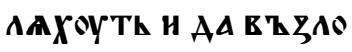

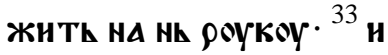

10 Понмт ЕАНнОГО Фี НА

९ОАА в ҚАОЖН ПК РС Т Қ Свон в' ОУШН ЕГО' Н

ПАнноУв Қ КОСноУ и

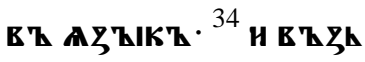

15

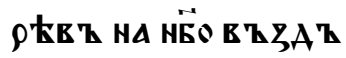

ХноYв и и ГӒА ....

Еже естh $\rho 4 \zeta . . . .$.

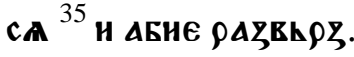

CTA CA CAOYX $\triangle$ EГO' H

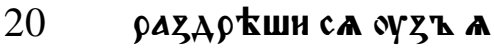

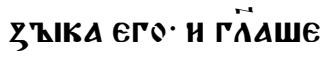

чнсто ${ }^{36}$ н зАПрКТн н

Mh АА НHКОМоУЖЕ нE

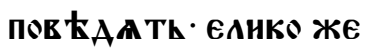

25

нмқ ЗАП КџАше Рни 
148в

паче пропов КА $А \gamma^{8}$

${ }^{37}$ и ПренУАнХА АНЕАА

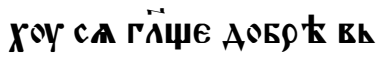

cE Творнть и ГАоуХ'Ы

5

А ТЕорнти сАҚIшАTї

и нЕМЫа ГӒАТИ :

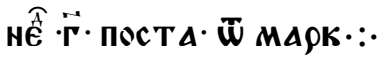

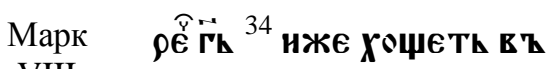

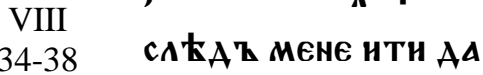

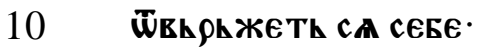

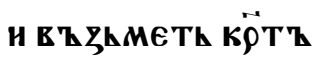

Свон· Н ГОAАЕ Th ПО

мнЕ ${ }^{35}$ нже Бо Аџе X०

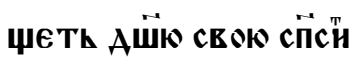

15 пегоуБить ผ. А нже

погоуьить Аш̈ю сво

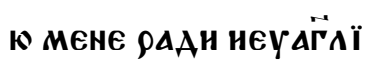

Ia Moero Th cïth $\mathrm{k}$.

${ }^{36}$ KAA EO ПOAh ZА ECTh

20 Чत̈вкоу АџЕ прНШ

Бращеть вhсь мїрт

и отқщетить Аш̈ю

CEON. ${ }^{37}$ पh TO EO AACTh

ЧӒЕКТ Н马М ЕНОУ НА

25 АШ̈н своен. ${ }^{38}$ нже Бо А
$148 \Gamma$

ШЕ ПОс ТЫАНТИ СА МЕHЕ

н монХ' с словест - в'

A

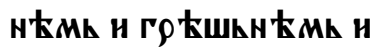

5

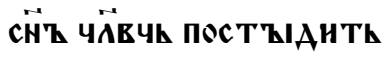

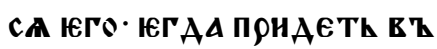

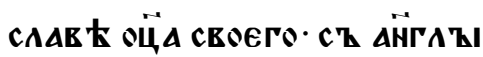

Марк

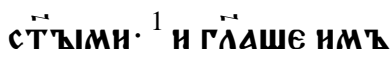

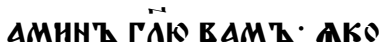

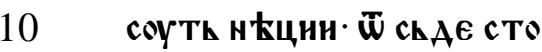

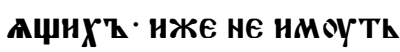

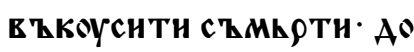

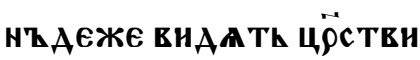

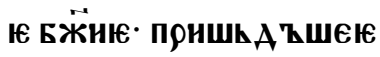

15

в Z сHA $\mathbf{k} \cdot: \cdot \cdot$

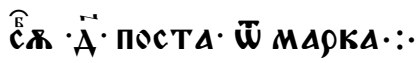

в қ в

Марк ченнци еге в в вһch ке

VIII

27-31

20

САРНА фНАНПОЕ ҚІ Н

нА ПоҮТн в ҚПРАША

Ше оУченHК'Қ СвОА

ГÄA HMT KOГO MA YE

АОВ КЦИ ГӒТК БЫТИ.

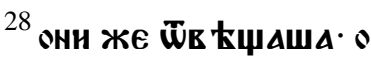

25

ви їоАнА КрестАГа инн 
$149 a$

иАню- А А९ОУЪНн ЖЕ нЕ

ОЕМНК НАН ЕАННОГО

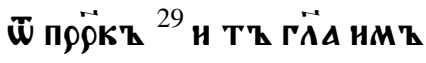

. Ж ЖЕ КөГО МА Гӥте

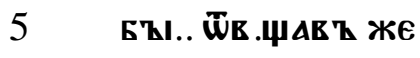

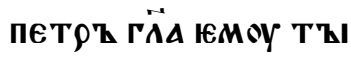

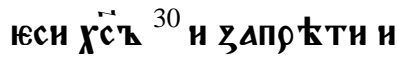

M ' АА ннкөмоуже

не гӒютh о неми ${ }^{31}$ н нА

10 ЧАТТ ОУЧНТИ ГА ГАКО

ПОАОБАЕ TИ CHOY Ч

МноГО Пос ТОАААТИ

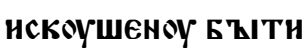

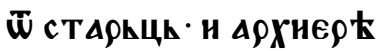

15 и н кннжиник' н

оуБненоу БЪІти

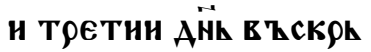

Марк сноутн·::-

IX

20 в т в

ТЕ९Қ ПОНАЕ К' Ї̈вн

knahata ca em及

и ГӒА ОУЧнТЕАК ПрН

вEAOX' CH' МОН к'

25 ТеБе нмоуши $A \vec{X}^{\mathbf{h}}$
1496

нtқм и гиоухи ${ }^{18}$ їжє

АџЕ КОАнЖһАО нМЕ

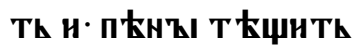

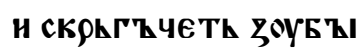

5 свонми н ец Ћпћетh

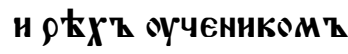

ТЕОНМ А ИЖАЕНК

Тһ и не в'З Могоша

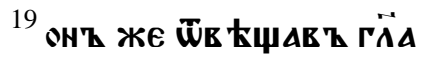

10

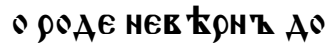

KOnt в' KACh EOY

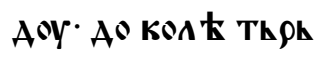

ПАю вҚІ Прннес КТЕ

н К' Мн

15 COWА к' нем оу и вн

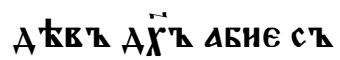

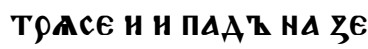

МАн вАМАше СА ПК

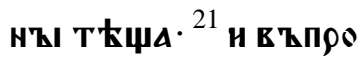

20

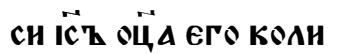

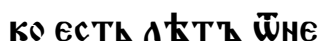
А

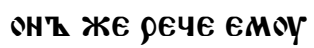

нзо от очинау. ${ }^{22}$ и

25

MHOГAWhA' 
149в

Н .. В М ФГHh В '

КИ ЖЕ Н н вһ ВОАОУ.

АА Н БҚІ ПогоуБНА

н' Аџе чh Т० може

5

Ши ПоможЕши По

MOZH HAMT MÄCPAO

BAR T O HAC Z ${ }^{23}$ Hёh

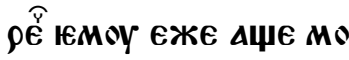

жЕшн в ҚровАТн· ви

10 сА въЗМ०Жешн в

роукчюммо. ${ }^{24}$ Н АБн

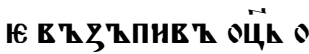

TPS4ATE ch cAhZA

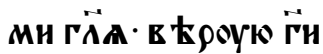

15 помезн моемоу не

в КОһствню. ${ }^{25}$ внА

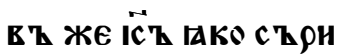

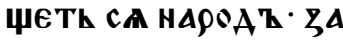

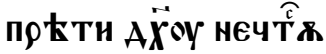

20 MOY ГӒА НЕМҚIИ

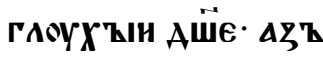

ТИ БЕАК НЗНАН Н

З него и к томоу не

в ҚНнАН Е Қ Нh ${ }^{26}$ Н

25
149 Г

МноГО ПФОYЖАЕ $\mathrm{Z}$ CA

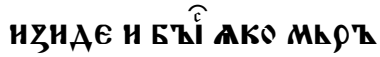

TE ' · AKO MHOZH ГÄА

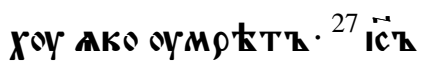

5 ЖЕ имҚІ и зА роукоу

в ЗААнЖе и в ЋстА. ${ }^{28}$ и

B ZWhA'WWL EMOY B'

АОМоУ оУченНци ЕГО

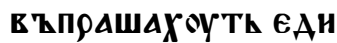

10

HOГО AKO MЫI HE B'

ЗMOГОXОMZ H马ГKHA

ти єего ${ }^{29}$ и рече нм Қ $\cdot$ Th

POAт ничнМКЖЕ не

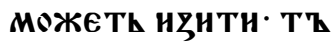

15

КМО Мล̈ ТЕОК и ПО

с TZMh ${ }^{30}$ н $\bar{W}$ TOYAOY

HWhA'BWE HAAXOY

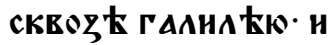

нE XОT A

oүв 太сть. ${ }^{31}$ oучаше БO

ОУЧЕННКҚ СЕОА И ГӒА

WE HMT - AKO CH' Чत̈ВЧК

По ҚАAнT БOYAETh

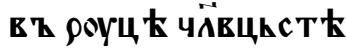

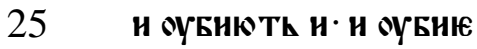


$150 \mathrm{a}$

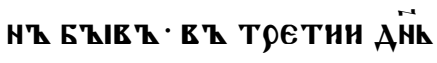

в ҚскрhсHETh $\because \cdot 2$

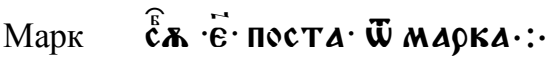

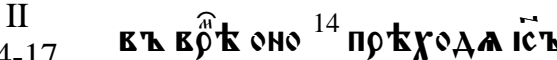

5 внА АЕвъги

H. $\triangle \mathrm{AZ} \phi$ KOE $\triangle$

c太AAџА HA MZITK

ННЦН· Н ГӒА ЮМОУ

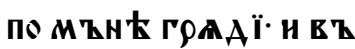

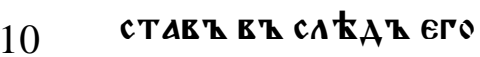

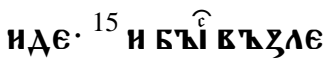

жЕџю ЮмоУ в $\mathrm{Z}$ А०

моу еге мнози с тАрї

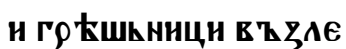

15 жау оу ст ї̈zми и оуче

HHK' EГO БAX OY БO

МнОZН ПО НЕМК НАO

ША ${ }^{16}$ кннжь ннцн и фА

९нсkн· внА Қвъше н

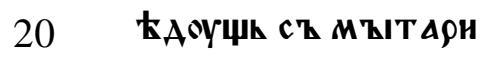

и ге ЕшьникҚІ ГӒА

Xоу оученикомт юе

rO. पh TO AKO Ch MthI

ТА९н и г९ћшьникъ

25 Һсти и пнети. ${ }^{17}$ и слъы
1506

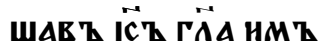

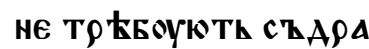

ВНН В९АЧА HZ БОАA

ЧнН ' нЕ ПФНАОХ'Z ПФї

5

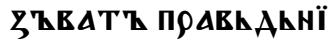

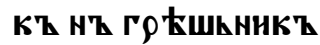

нА ПОКААНнњ $:$

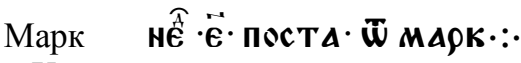

$\mathrm{X}$ в

32-45

10 ATh İ̈h OEA HA AE

САTE OYЧЕНHКА

CEOA' H HAY АT'

НMЋ ГӒАТИ ЕЖЕ Х०

ТАше ๒MOY БЪТТ

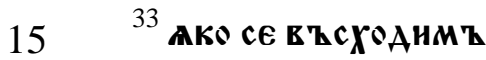

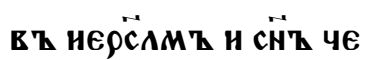

АОв Еपh П९ ЕААH'

БоуАетһ А९Хнне

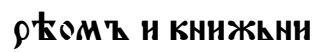

20

KOMZ ' Н OCOYAATh H

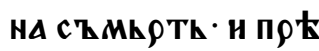

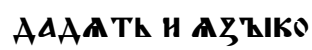

Mz. ${ }^{34}$ H nopoyr als

Th ca EMoY h oYTEח\$

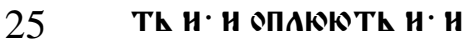


150в

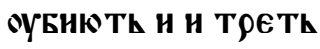

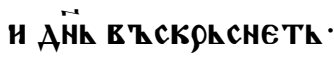

${ }^{35}$ и пр АА ними нАЕ

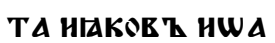

5 HZ CHA 弓EREA KOBA

ГӒющА ๒MOY· oYчї

телю Хочев А АА IE

ГОже АџЕ КОлнжи

AO ПрОснв 太 С' TEO

10 рншн нама. ${ }^{36} \overrightarrow{\text { ich }}$ же

рече нмА чк то Xo $^{\circ}$

廿етА AА ch TEOPN

вАM $\cdot{ }^{37}$ онА

сTА ЮMOY· ААЖАК

15 HАMА АА ЕАНHZ О

АЕсноук ТЕБе и $\Theta_{\text {AH }}$

H' O ШผN TEБE CA

AER K в ' CAAR K

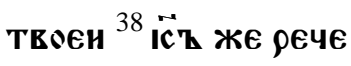

20 НМА. не вћстА СА

YCO ПрОсаџА MO

ЖЕТА Ан ПнТн чА

шю юже $4 \zeta$ ไ пї

ю. НАн крьщению

25

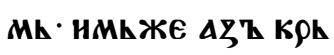

150Г

ЩАК СА КӦТТИТН СА ${ }^{39}$ OHА

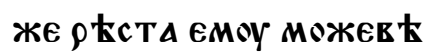

IC' Ж

ОУБо кже А马' Пню испї

5 ЄтА· н кёце

нињми нмиже

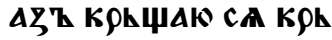

стнтА са. ${ }^{40}$ А EЖE ct

стї \& AEсноую мене

10

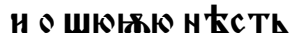

MZHE ААTH· H' И

М

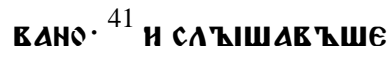

AEсA Th HАYАWА него

15 АОВАТИ О НाАКОЕ $\mathrm{k}$ и НО

AH t. ${ }^{42}$ ič

въ г ГӒА нми в всте

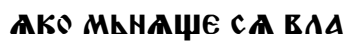

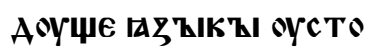

20 А Th нм' н вЕАНЦН н

X'Z ФБААААКТК НМН

43 не такоже юсти в '

вАс' ${ }^{44}$ н' нже ХФџе

ТК БҚТИ ВАџнН В Қ

25 вАC' АА БоУАЕТ 
$151 \mathrm{a}$

вАM ' сАОУГА' нЖЕ АџЕ

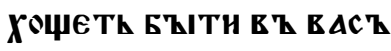

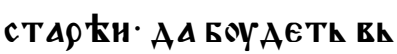

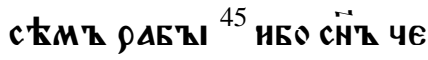

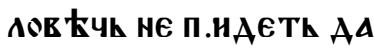

ПослоуЖАТИ ЮMоY. H' АА послоужнТ' Н ААТ АШ̈ю своК и弓БАВ АЕнН

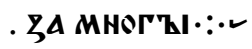

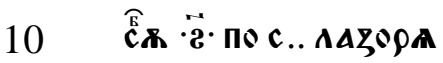

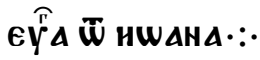

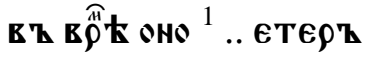

Иоанн XI

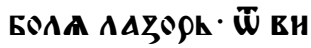
фанна гола ма

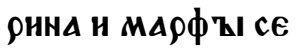

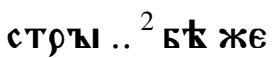
mapha momAza В ТШHА ГА М..Mh· H

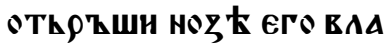
СЫ свОНМн ..ЖЕ Б९А

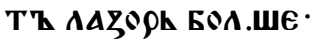

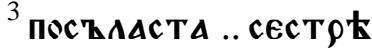
его к' немоу ...े山н гेн се ЕГОЖЕ АюБншї
1516

Ic̈h $\rho \hat{~}$

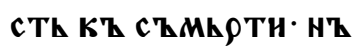
о слав Қ Бӝни АА пюо СААKИТИ СА СН' БӜН

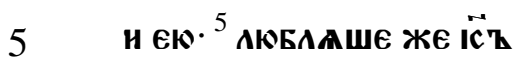
МА९нК и сест ТОУ ЕА

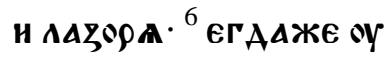

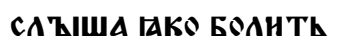

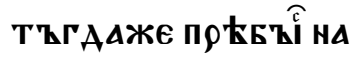
10 нЕмиже в м м тст

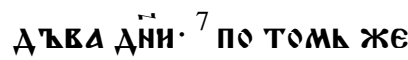
ГӒА оученнкОМ '

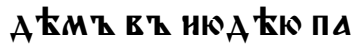
Kh. ${ }^{8}$ Гत̈AWA EMOY oY

15 ченнци· ОАВВН· нҚІ нҺ нскАX ОУ TEБE КА МЕнНЕМК ПОБНТи HюА ҚН· ПАКҚІ Ан н

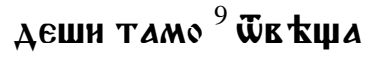

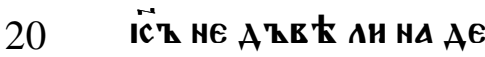
CATE ГOAHН ЕСТА в Қ Ан̈Е АџЕ кTо $\chi^{\circ}$ Антһ в KHETh · CA IAKO cB 
151в

Th ${ }^{10}$ Аџе Ан кто Х०Анти

ноџню ПотЪКнЕТИ СA

TAKO св 太TA H Қс Th O HE

Mh ${ }^{11}$ сн

5

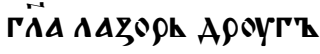

HAWh oychne H' h

AOY АА в Қ ЗБоУжю н.

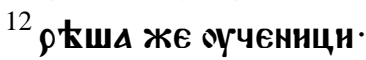

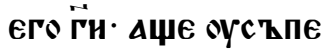

10 спїен' воYаеть ${ }^{13}$ ickz

же ९єче о сһмияти $е$

ГО онн же Мин КшА

АКО О Оүс'ЂПЕнНн с'

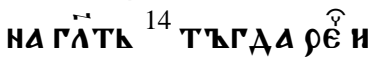

15 Mh IC̈h не обнноуа

CA. AAZOQh OYMOETT

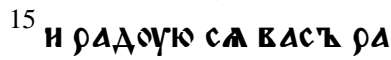

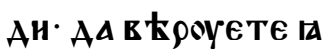

Kо не Б\$Х'Z TOY. H' и

20 А

ЖЕ ОомА нарНЦА

ЕМЫН БАнбньЦК

К' оүчеником' и

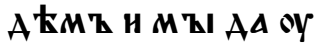

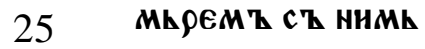

$151 \Gamma$

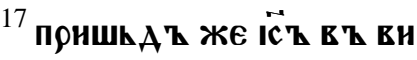

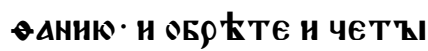

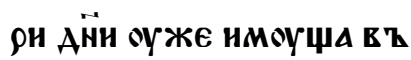

Г९ОБћ. ${ }^{18}$ Бћ же внфАннА

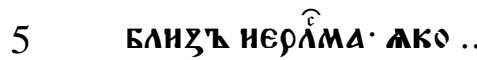

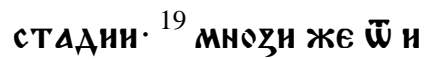

مА ҚН БАХОУ ПоншһАН

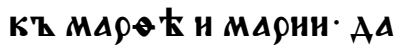

OYTKWANTh

10

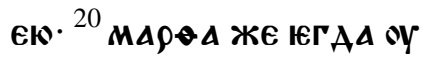

CA'ZIUA AKO IC̈' ГОAAETh

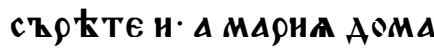

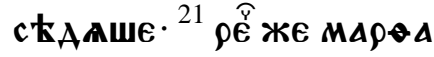

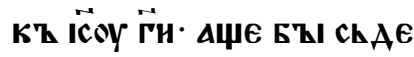

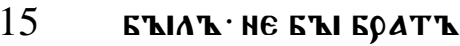

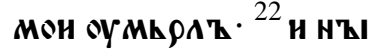

нћ в Бми - Ако егоже

КОАнЖКАО ПООснши

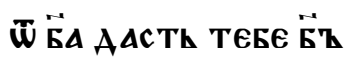

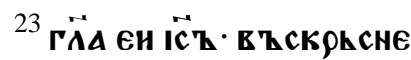

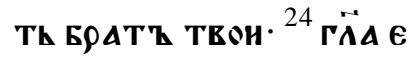

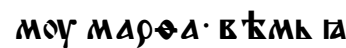

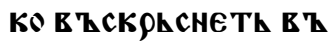

в Ћскр ћшенню в Қ

25 ПосА ЕАКнНн АН̈ 
$152 \mathrm{a}$

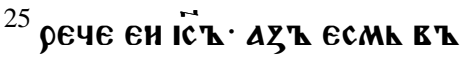

скр ћшениє и животъ .

в БоОуан вт МА Аџе оY

миретh ожнветь. ${ }^{26}$ вһсA

5

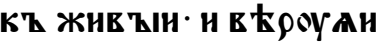

в' MA HE oYMh

КҚ имеши Ан в Кроу се

Moy. ${ }^{27}$ гй

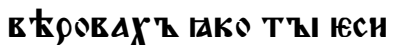

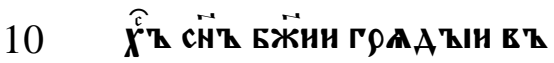

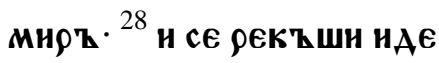

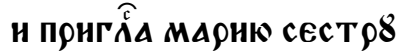

СВОК Т АН -

ЧнТЕАК СЕ ЕСТИ И ГАА

15 шАETh TA. ${ }^{29}$ онА жE TAKO

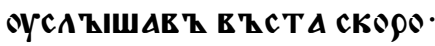

и нАЕ Кһ немоу. ${ }^{30}$ не Бћ ЖЕ

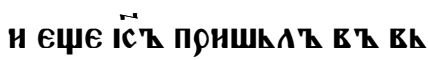

ch· HZ EK HA MtcTK EщE

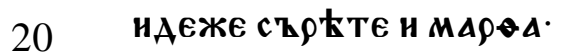

${ }^{31}$ неА Кн же соуще и съ не

6 в' А АMOY н оYт kшА

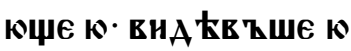

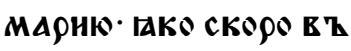

25

СТА НЗНАЕ ПО НЕН НАО
1526

WA ГÄ円E · TKS HAE HA

ГРОБҚ ПААYETh CA TOY

${ }^{32}$ марна же тако прнае

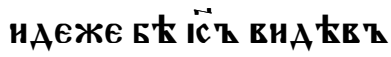

5 Ши ПААЕ ЮMOY нА но

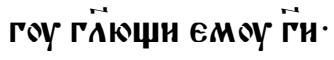

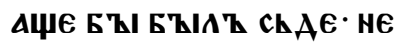

БҚI БОАТТ Мон оумh

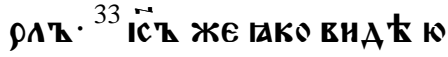

10 ПААЧюЩА СА Н Н ПОНШЬ

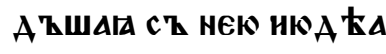

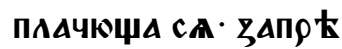

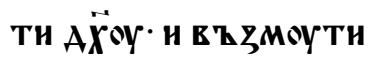

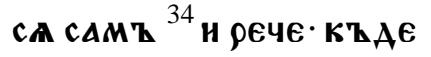

15 Положнс ТЕ н· ГӒАША

ІеМОУ Г̈Н Г९ААНӤ вн

Жh $\cdot{ }^{35}$ н просльзн са ї̈

36 ГӒАХणУ ЖЕ июА Аи вн

\%аK КАKO nمEАAWE

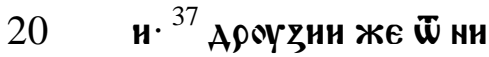

X'⿳ $\rho$ kWa не можаше

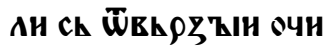

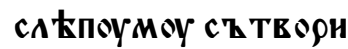

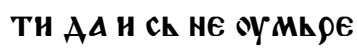

25 
152в

ТА .. сЕБ太 ПонАЕ К'

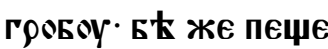

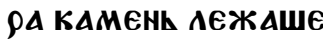
HА ..H. ${ }^{39}$ ГӒА HM Z İ̌

5 в Z...M Ете КАMENh ГÄA EMOY CECT TA oY

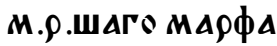
Г̈н .ЖЕ смиранти ЧET.BPhAÄERLH' EO

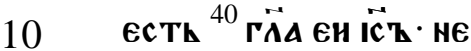

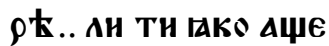
в ћроуешн Ан оузьрн Ши слАв оу БӜню. ${ }^{41}$ в '

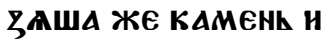

15 А.. Б К АєЖА мирт

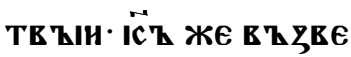

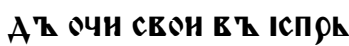
рече Wप̈ XвАAOY TE БE..Z,AAK IAKO OY

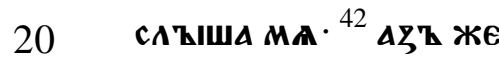
B ЕAAX'Z AKO BИCEГAA МЕнЕ ПОСАоYШАЕШН.

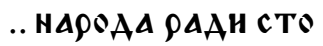

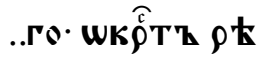

25 X'z .. в вроу нмоу
$152 \Gamma$

Th' IAKO ThI MA ПOChAA

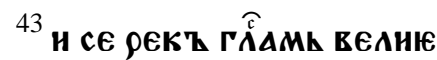

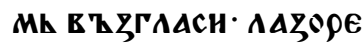

ГОААН ВһНҚ ${ }^{44}$ Н АБНЕ И

5 ЗНАЕ ОУМКОҚН ОБАЗАНҚ

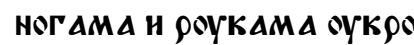
ЕМк и Анце его оуБроу COML ОБАZАНО Гत̈А НМТ

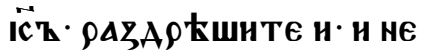
10 А Қите юго ити. ${ }^{45}$ мнози жЕ $\overline{\mathbf{w}}$ нюА

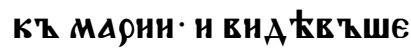

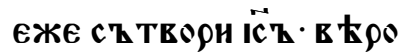
BAWA B Th HERO:: :

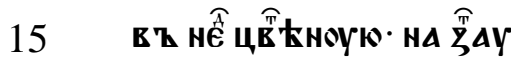

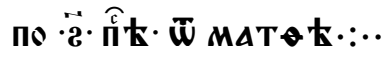
въ в Матфей

$1-11$,

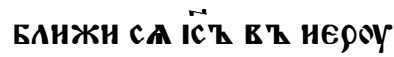
СААНM ' ' Н ПОНАЕ в Қ

20 внсфАГнК к' Горћ EAEOH' T KГAА ПOC Қ МА АТЕА ОУЧЕНHКА СЕО

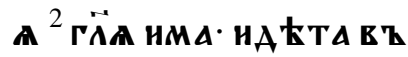
вһсh ГАЖЕ ECTh ПрАM० 25 ВАМА' и АБНЕ ОБ९АџЕ 
$153 a$

ТА ОСКАА ПОНВАЗАНО Н

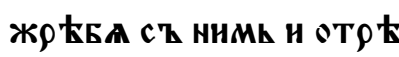

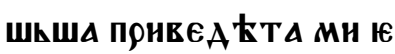

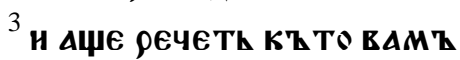

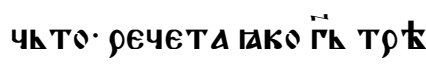
Боуети ею. АБне же пос'

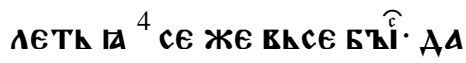

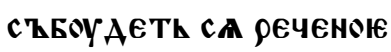

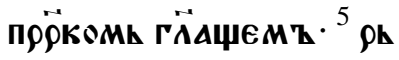
ц Ћте А Қщерн снонов $\mathbf{k}$.

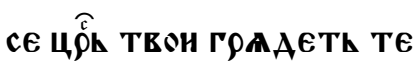

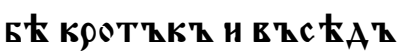
НА ОСКАА И ЖО ЕБА СНА А ОһМКницА ${ }^{6}$ ШКАТША ЖЕ оҮченНКА АКОЖЕ ПО

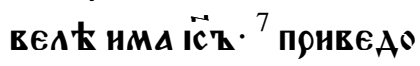
СТА WСКАА Н ЖО ҚБА ' Н

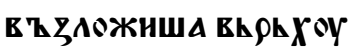

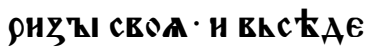

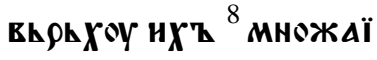
ШЕ ЖЕ нАРОАН ПОС ТНАА WA ९HZ'ZI CEOA חO חOY

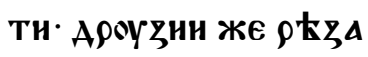
XюY в
1536

${ }^{9}$ нАРОАН ЖЕ ХРААџнН

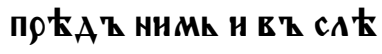

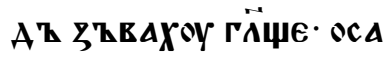
HA CН̈BH AЁAOBOY. БАA

5 ГОСАовАEнҚ ГОААҚІ в И HMA ГHE OCAHA E'

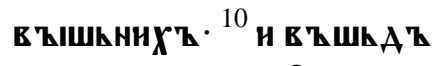
Шю юмоУ в $\mathrm{h} \mathrm{Hе \rho}$ поT९AcE ca khch Г९A 10 А ТӒ̆A KTO ch Ec Th. ${ }^{11}$ HA РОАН ЖЕ ГӒАХОY АКО ch EcTh ї $\mathbf{z}$ прёкт и

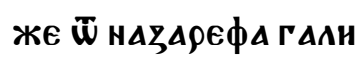
$\Lambda$ ŁнскАГО ${ }^{15}$ внА 太Е ' 15 ше же А९Хннер Ки к' ннжкници чюдесА Аже с ' тв орн म

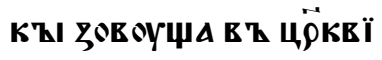
и ГӒџА ОС АНА С̈̈ЕН A $\overrightarrow{\mathbf{E}}_{\text {AOBळ NETOAORA }}$

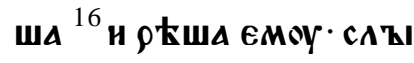
ШНШН АН ЧК ТО СН ГӒ०

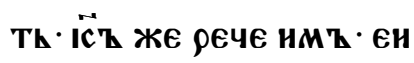
H HCTE AH पhAH · IAKO 
153в

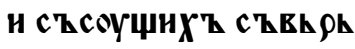

шиАъ Есн ХвАлоу. ${ }^{17}$ н

OCT АВAL IA HZHAE

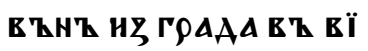

5 фАКнК. И Е ҚАЕО९Н

CA TOY в' HÊं. цE

ноYК нА АЕТ

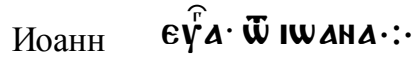

XII 1 прћже шестн Aн̈

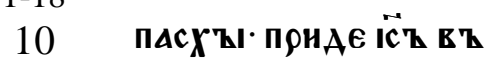

внจАнию· нАєже

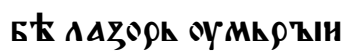

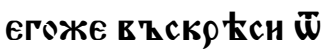

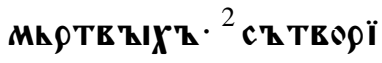

15 ША же юмоУ вече९ю

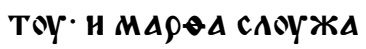

ше $\triangle \triangle Z$ OQ

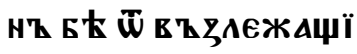

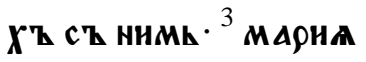

20 ЖЕ прннм Қшн Ан

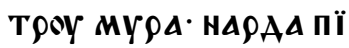

с Тикига много ц Қ

HhHA חOMAZA Hez

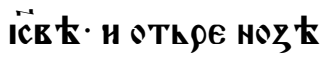

25 ЮГО вААС ҚІ СвонМ ̈̈.
$153 \Gamma$

ХРАМНHА ЖЕ НСПТАТ

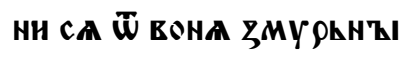

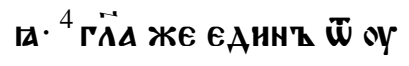

ЧENHK' EГO- HOYAА СH

5 Монов Қ НСКАРНОТКСКҚ

НЖЕ ХОТАШЕ П९ ААТИ ї.

5 чисо ९аАН муро се не про

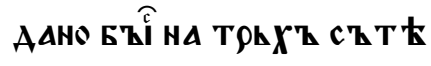

X' ПЕНАҚ̆ И ААнО нИ

10

чнмт ${ }^{6}$ се же рече не ако

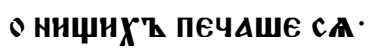

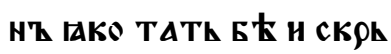

нНцю нМҚІ ни в ҚМ

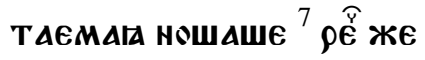

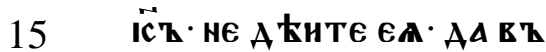

Ан̈h ПогреБенна мое

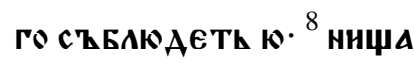

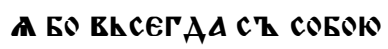

HМАTE - М MENE HE вLCE

20

ГАА нмАTE $\cdot{ }^{9}$ разоYм Е

жE HAPOAT MHOГ'

HWA th IAKO TOY ECTh.

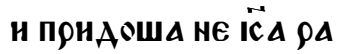

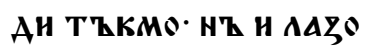

25 ОА вНАATИ ЮГОЖЕ в' 
$154 \mathrm{a}$

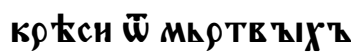

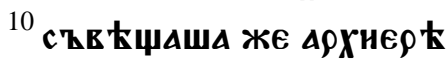

Н АА Н ААZОРА ОУБНКТТ

${ }^{11}$ ТАКО мнози ЕГО РААН н

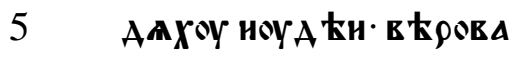

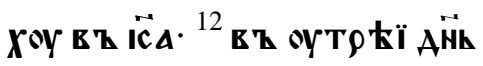

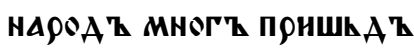

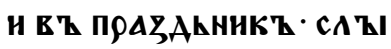

WAB h ЖE AKO İ́' ГPAAE

10 Th в' нерёлмт. ${ }^{13}$ прнгашА

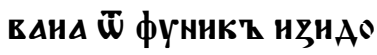

шА против оY EMOY.

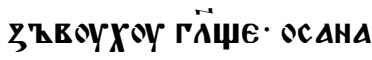

БӒГОСАОВАЕН' ГОААҚІ

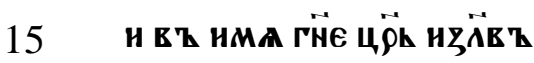

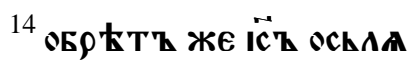

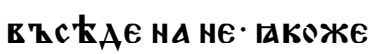

НС Th Пнсано ${ }^{15}$ HE Бон са

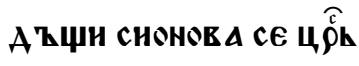

20

Твон ГРAаETh · ckAa

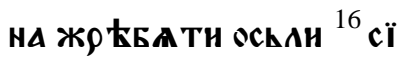

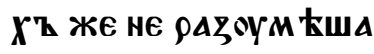

оүченици его пр Ћже

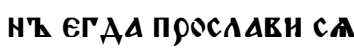

25
1546

ША. ГАКО СН Б КША \& нЕ

MК ПHСАHА Н С' TES

рHшА EMOY. ${ }^{17}$ chEtat

тельствовАше жЕ

5 нА९्АТ нже Бћ сһ нї

Мh ЮГАА ЕТ ҚГААСН

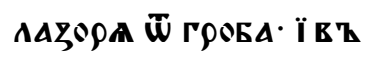

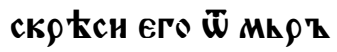

TE ҚIX' $\cdot{ }^{18}$ сеГО ९ААН И

10

ПООТнвоY HЗНАE EMS

HAPOAT TAKO CA ZIIUA

ША н С' ТворншА се

उнАМЕние $::$ -

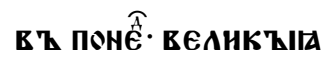

15 HE HA ZAOY

тонни еश्रि

iv MATh

Матфей

XXI

$18-43$

20

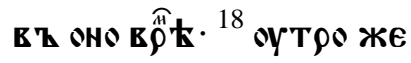

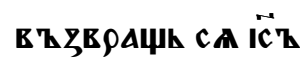

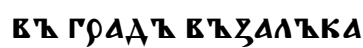

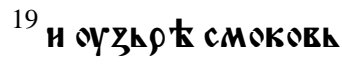

ницю еАнноу прн

ПОУТН· ПОНАЕ К' НЕ

и ннчксоже оБр $\mathrm{k}$

25 TE HА нЕН' ТZКМО АН 
154B

стЕНЮ ЮАНнО И ГӒА

Єн· АА ннколнжЕ $\bar{W}$

TEБE ПAOAA HE БOYAE

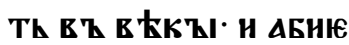

5

нсъше смоковьни

цА ${ }^{20}$ и внА Ев Ђше оYче

ННЦН АНЕНША СА ГӒК

ЩА. КАK० АБНE оуст

ше смоковьниц ${ }^{2}{ }^{21} \overline{\mathbf{w}}$

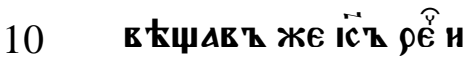

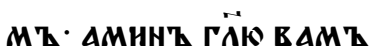

Аџе имАТЕ в Е

не оус оумннти са.

HE TOKMO с MOKOEL

15

HHYh CKOE C $\mathrm{Z}$

Tворнте

Hh Аџе и ropt

сен РечетЕ АЕИГни

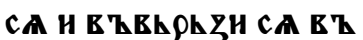

20

Mope EoYAETh ${ }^{22}$ h все

юГОже в Сспроснте

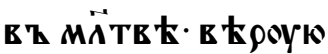

ще прннмете ${ }^{23}$ и егАА

прнае в Қ цёкЕи - прї

25
$154 \Gamma$

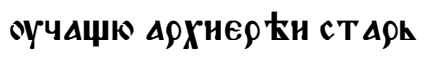

Цн АюАһс ТИн ГӒџЕ К КОЕю

ВААС ТНК СН ТВеРНШН · К К'

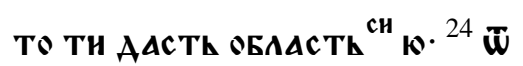

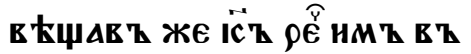

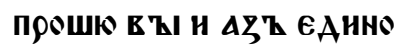

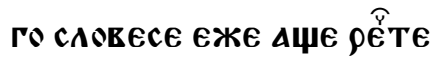

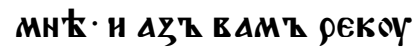

КОеК вААСТНК СН ТВорю

10

${ }^{25}$ криченне їшаново й кж

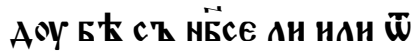

Чล̈ЕК.. ОНН ЖЕ ПОМ ҚIША А

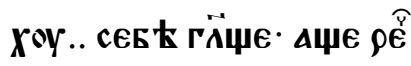

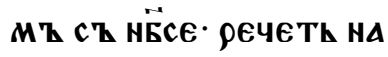

15 MZ По чh Tе оүБо не пате

IEM⿻Y в

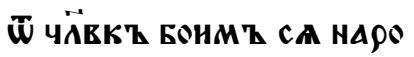

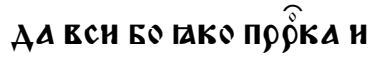

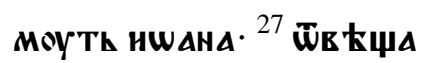

20 в Ћше же Ї̈ви рекошА

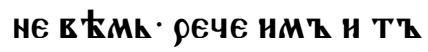

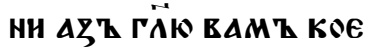

К ВААС ТИК СН ТВ О९Ю

${ }^{28}$ पh TO

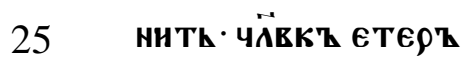




\section{$155 \mathrm{a}$}

HMAWE AZR YAA

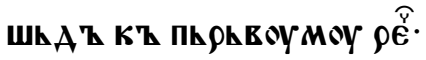

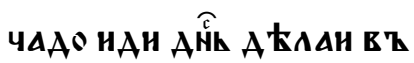

виногоАА Е MOEMh. ${ }^{29}$ OHT

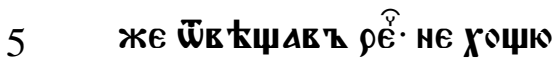

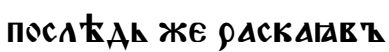
са и ї̈е $\cdot{ }^{30}$ н прнс тоупаһ K' ароугоумоу рече TA

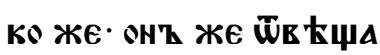

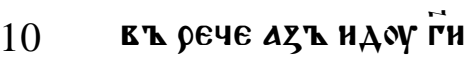

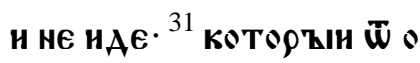

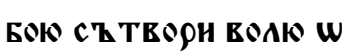

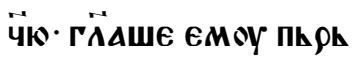

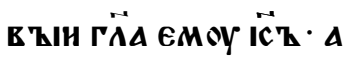

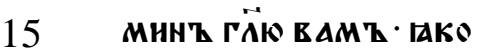
МҚТТ А९Нн Ї АюБОНА НЦА ВАРАЮТИ Е ҚI ЕТ цёствнн. ${ }^{32}$ прнаЕ Бо їш

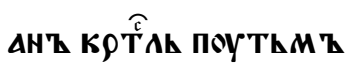

20 ПФАЕКАКН'ЫМК ' Н НЕ

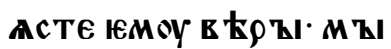
ТАрЕ ЕЖЕ и АюБона Еї

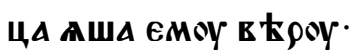
в Ж ЖЕ внА Қв Қше не
1556

Ан ґттн Емоу в Кроу.

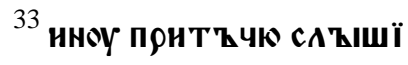

ТЕ· ЧӒЕКИ Бћ АОМОЕН

ТИ НЖЕ НАСААН ВНнО

5 ГРААТ Н ОПАОТОМИ Н ОГРААН· НСКөПА в Қ НЕ

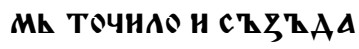

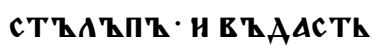

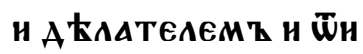
10 АЕ ${ }^{34}$ ЮГАА ЖЕ ПФНБАНЖН

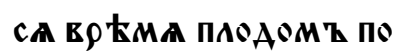

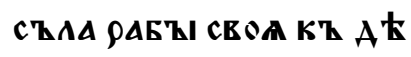
ААТЕАЕМТ ПРНА ТИ ПАО

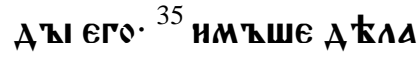

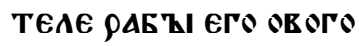
БНША ' ОБОГО ЖЕ КАME ннеМк ПоБншА. ${ }^{36}$ ПА

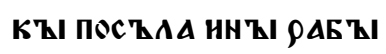
МноЖАнше Пи рһв ZI X'Z· H C'Z TEO такожае ${ }^{37}$ посаћаһ Же ПОСҚАА КҚ НHMZ С̈̈Һ СЕон ГӒА оYс९АMАAК Th CA CHA MoEro. ${ }^{38}$ A thA 25 ТЕлЕ ЖЕ внА Қв Қше 
155 в

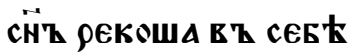

ch EcTh HACA

К' ПрнА АТЕ оуБнћ

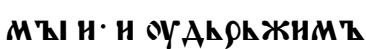

5

АОс ТОАнНЕ ЕГО. ${ }^{39}$ НМт

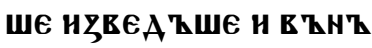

Н马 ВННОГРААА Н ОУБН

ША н. ${ }^{40}$ IЕГАА ОYБО ПФНАE

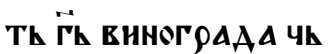

10

TO CZ TEOPHTh A tAA

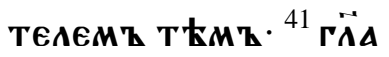

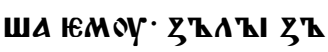

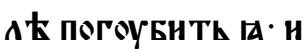

виногРААТ ИнҚМт

15

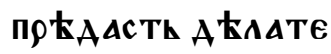

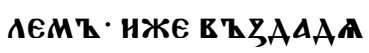

Th EMOY חAOATh в

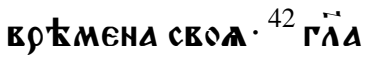

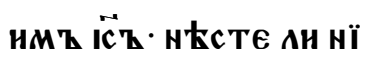

20 Колнже ЧһАн в К КТ

НHГАХ' · КАMEHh Ю Гоже не в

ТворншА Знжнщен

Ch EZî E' Z HAYANO OY
$155 \Gamma$

ЮCTh АНЕКHА В Қ РЧнК

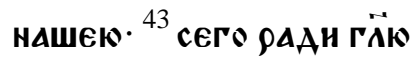

вАM Қ RAKO ẄHMETh CA

ш̈ васқ цёсткне Бӝне

5 H AАCTh CA IAZ'ZIKOY TKO

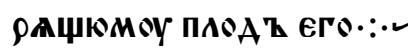

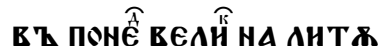

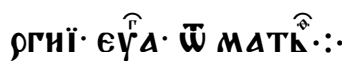

въ оно в

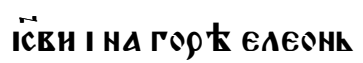

сц в прнст оупнша

Къ немоу оүченицн $е$

Го ЕАнНОМоУ ГӒюще.

Пов 太Жһ HАM К К' ГАА

15

CE БOYAETh • и Чh TO ECTh

ЗНАMENHE ТвоEГO

П९НШКСТЕНА ' Н КО

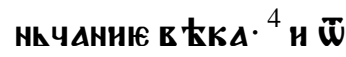

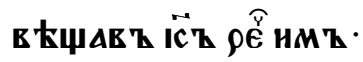

20

БАКАНТЕ СА АА НН

ктоже в АC' не прt

Аһс титһ ${ }^{5}$ Мнези Бо

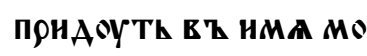

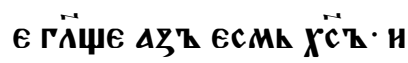

25 мног' по ЕАһстА 
$156 a$

Th ${ }^{6}$ оуслъишнте же Бранї

Н САҚІШАнНЮ БрАни вН

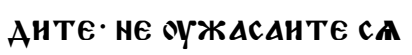

ПОАОБАE Th БO вһC ЕMh

5

БҚITH· HZ HE TZГAA KO

HhчнH太 БоYAETh ${ }^{7}$ в Zст TA

нETh БO ГAZZIK' HA AZZI

КТ и цёс ТЕо нА цёс ТЕ० Н

БOYAOYТТ ГАААН И ПАГОУ

10 БЪ' н Т РОУсн ПО М Ес ТА.

${ }^{8}$ вһCA ЖЕ СН НАЧААO БOА

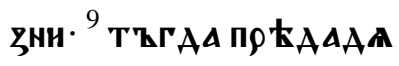

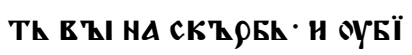

WTh В'· Н БOYAETE HEHA

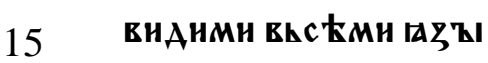

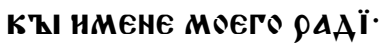

${ }^{10}$ TZГАA C ҚБААZHA Th CA

MHOZH' А OYYГ' А९OYГА

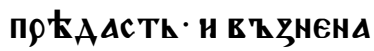

20 ВНАНТИ А९ОYГК А९ОУ

ГА. ${ }^{11}$ и мнози Аъжи про

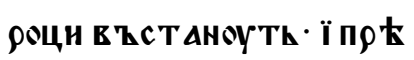

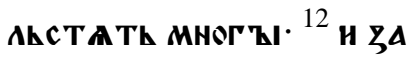

оумноженне Безако
1566

MHOГ'ҚlXz $\cdot{ }^{13}$ nоtтh

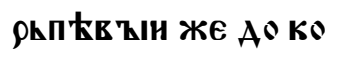

Hhц А TZ спїеTh сA.

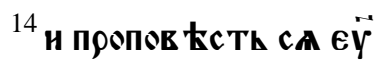

5 АГГАНЕ ЦР̈сТЕНА

ПО вһсен вһселенТ

н. вһ сһв

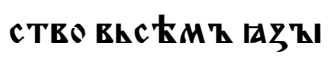

КOMZ и TZГАА Прї

10 АЕТК конццинА ${ }^{15}$

ГАА ЖE OY马ू९HTE Mh

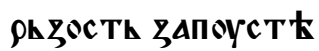

нНга.

Mh ААНHAOML СTOA

15 щкнам мстћст̈

Мh - нже पh TETh AA

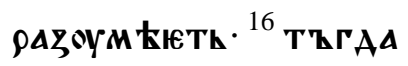

соушен вт нюА ћи Бћ

ГАWTh HA rOpZI. ${ }^{17}$ нже

20

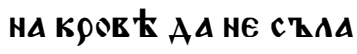

ZНTh в'ZろA TZ EЖE $E$

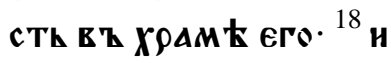

ЖE HA cEnt ААКожАE.

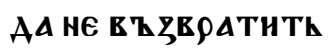

25

са вһспа Th вһZA 
156в

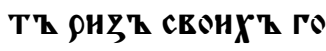

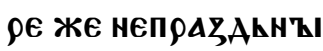

Мh И Н АОАџнМ' В Қ

TZI ANH ${ }^{20}$ МолHTE жE

CA AА HE БOYAETh БҚ

ство ваше Zим К нї

в' CoyEotoy. ${ }^{21}$ EoyaE

Th БO ThГAА CK' $\rho$ '

БИ ВE八HA זAKO

жE H太cTh БhINA $\bar{w}$

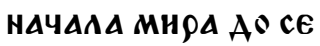

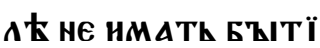

${ }^{22}$ и АџЕ не БЪIшА

пюКк

15 ти. ${ }^{23}$ ТһГАА АџЕ КТА

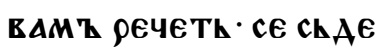

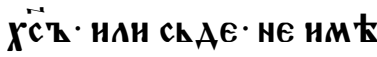

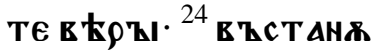

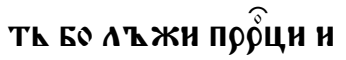

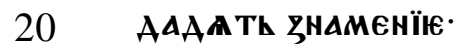

ВEАНА И ЧКАЕСА. ТАКО

поћАһстити Аџе ほ

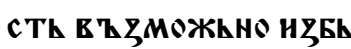

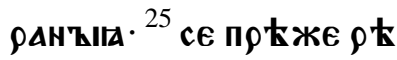

$25 \boldsymbol{X}^{\mathbf{z}}$ вАми ${ }^{26}$ Аще же $\rho \in$
$156 \Gamma$

KoyTh вАMh ce в h חоY

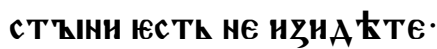

се вт кров қХ' не нм кте

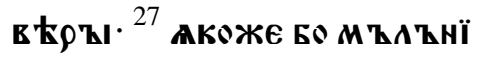

5 н сXОАнти ш̈ вһсток' н

ГАВАAЮTИ CA AO ZАПАA'

TАKO БOYAETh ПрНШК

С ТЕНЮ СНА Ч

${ }^{28}$ нАЕЖЕ БО Аџе БоУАЕТИ

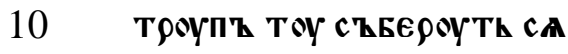
ө९һАн. ${ }^{29}$ и АБнЕ ЖЕ ПО ск'

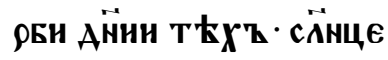

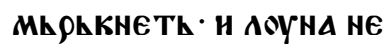

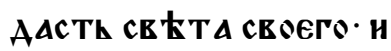

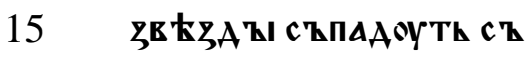

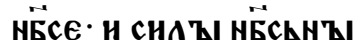

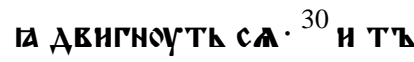

ГАА АВНTИ СА ЗНАME

НHE C̈Н Ч

НЁС И ТҚГАА В ТСПААЧК

Th ca rhca KOn tho zemh

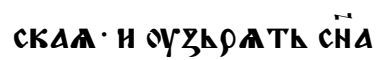

Чล̈ВчсКАГО ГОААОУЩА

ГО НА ОБААЦ ҚХ' НЁСКНҚI

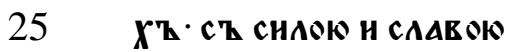


$157 \mathrm{a}$

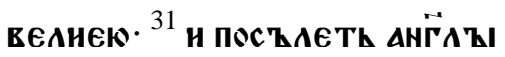

ç ГА̃

БLHZMh Н СZБE ९OYTh Н

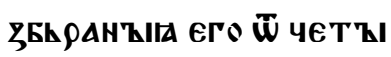

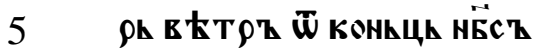

Ао коньци нү' ${ }^{32} \overline{\mathbf{w}}$ смоко

вьниц А ЖЕ НАОУчнтЕ СА

прнТТ чн ' ЕГАА ЖЕ оУЖЕ

В ЕAГA БOYAETh MAAAA

10 Н АнстЕНЕ ПроУАБнЕТЬ.

в 太сте ґКО БАн马' Ес Тh

ЖАТЕА ${ }^{33}$ Т АКОЖЕ и в ҚІ

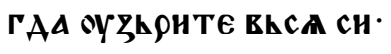

в 太АНТЕ ґАКО БАН弓Ъ Ю

15 сти пюн Ави $\rho \mathbf{X} \mathbf{~ h} \cdot{ }^{34}$ Амн

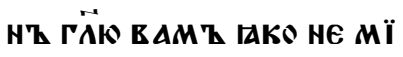

MO HAETh POAT Ch AOH'

АЕЖЕ вһСA СН БOYAOYTh .

35 НБ̈О И ЗЕМАА МнМ० Ï

20 АETh - А CAOEECA MOA

HE MHMO HAOYTh $\because:-$

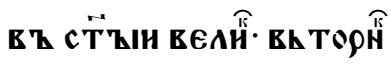

Матфей

XXII

$15-46$

25

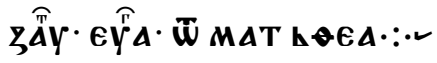

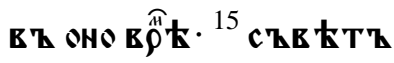

съ Tво९ншА фА९н

c 太H HА $\overrightarrow{\mathbf{c}} \Delta \cdot$. АА H ОБАh

с ТА Th сАовоMh. ${ }^{16}$ Н ПО

с'МIALTh K' HEMOY

оYченнКТ своА н ст

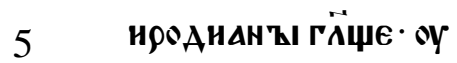

ЧНТЕАЮ в ЕМТ АКО Н

с тинКнҚ Есн· н поутї

Бӝню в ъ нс тиноу оу

Чншн · Н НЕ РОАНШН НН

10 о коми Же' не Безирн

ШИ НА АНЦА ЧӒЕКОМ.

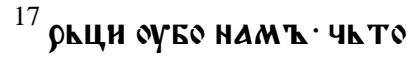

ТИ СА МКHНTh AOCTO

НнО АН ЕС ТИ ААТИ КН

15 ност КесАрЕви нАн

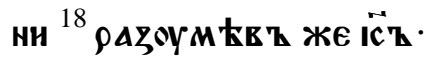

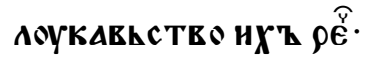

पК TO MA HCKOYWАE

те Анцем Ерн. ${ }^{19}$ покА

жћте мн цАтоу кн

нскноу. Онн же прн

несошА ЕМОY ЗААТИ

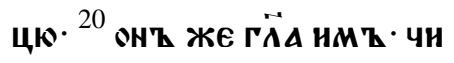

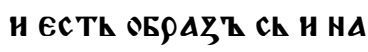

25

пнсАнне ${ }^{21}$ ГӒАШШ ЕМХ 
157в

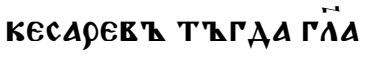

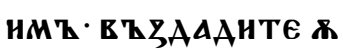

Бо кес $\triangle \rho E в \Delta$ Kec $\Delta \rho E$

ви и БжнА БГ̈ви ${ }^{22}$ ї сль

5

ШАK ҚШE АНRHWА CA

Н ОсТАВАКШЕ И Ш̈HAО

ША. ${ }^{23}$ в' Т T' АН̈h п९н

стоупншА К' нем8

сААОүкен ГӒше ' не

10 Бъти въскр Еше

НHЕ. И Е ҚПрОснША

и ${ }^{24}$ гӥше - оүчнтелю

монсн рече Аџе к'

TO оYMh

15 4АA' АА ПОНMETh

Б९АТТ ЖЕНОУ ЮГО ' И

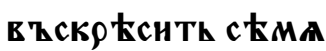

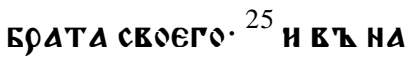

ch БKше сеАMи Б९А

20

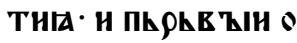

жеNh сA и оYM t.

не HМ ҚІ с ЕМЕне :

ст АВН ЖЕНОУ БОАТЖ

сRоEM⿻Y. ${ }^{26}$ TAKOжAE

25
157 Г

и Ao сеамаго. ${ }^{27}$ послћже

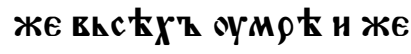
на. ${ }^{28}$ в Қ в Қско Қшенне ко TOPATO W CEAMA EOYAETh

5 ЖенА вһсн БО нМ КША К

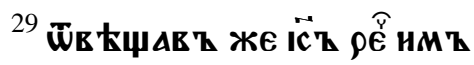

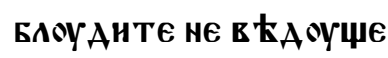
Книгъ ни снАҚ Бӝн А. ${ }^{30}$ въ в һско ћшенне Бо нН женать са нH ПOCA ГАКTИ HT АKO АНГГАН

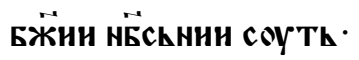
31 о в зско қшенин же

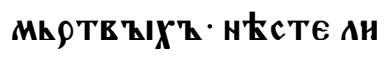

15 ЧһАн ९ЕЧЕНАГО вАМ Z .

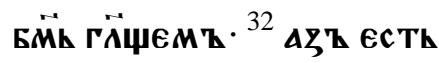

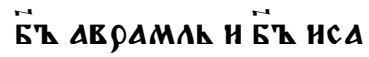

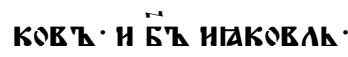

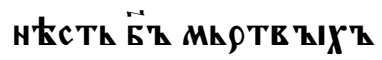

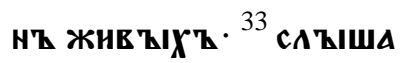
В ҚШE HAPOAH АHEHША са O оучени его. ${ }^{34}$ ФА९н

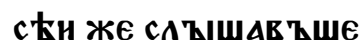
ТКО с ФАМH САAOYK $\mathrm{E}$

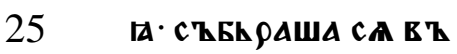


$158 \mathrm{a}$

коупћ ${ }^{35}$ и въпросн $\epsilon_{\text {Aйнъ }}$

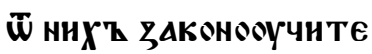

Аh нскоушАА и ГӒа ${ }^{36}$ оүчї

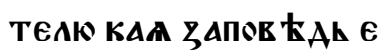

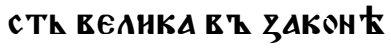

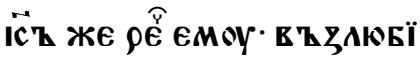

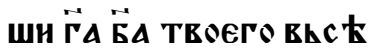

МК СРАЦКМИ СЕонМК· Н

всею АШ̈ЕК св จею и все

10

o MZICAhN CBOEN ${ }^{38}$ CH ECTh

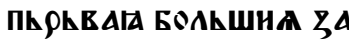

пов $\mathbf{k}_{\text {Ah }} \cdot{ }^{39}$ в Қ TераA же

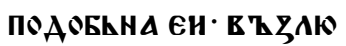

БНШН НСКОБНАГО СвО

ETO RKO CAM Z CA. ${ }^{40}$ B h CE

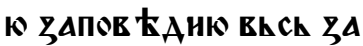

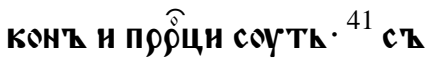

Бираном т же фарнс

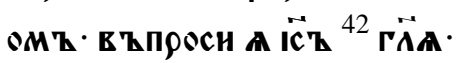

20 Yh TO СА ВАMТ МКHН

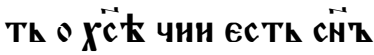
ГÄUA EMOY AЁARZ. ${ }^{43}$ Гत̈A

HMZ · KAKO OYEO AËAET

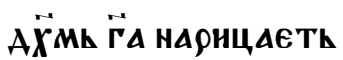

1586

MOY. CAAH O AECHOY

o мене AонтАEжE

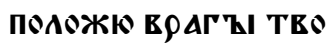

А ПОАТНОЖНЕ НОГА

5 МА ТВ онмА ${ }^{45}$ АЧЕ оY

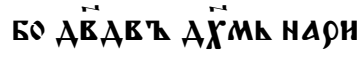

цеTh $\vec{\Gamma} \Delta \cdot$ KAKO EMOY

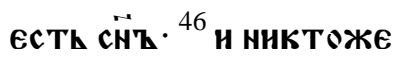

не Moжawe EMoY

10 ш̈в 太џАТн словесе -

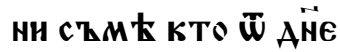

Матфей

Теге въПроснти Е

XXIII

$1-10$

12-34

15

rOK TOMOY. ${ }^{1}$ Th

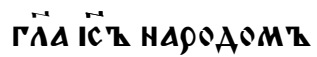

Н оУченнкоМ $\mathrm{Z}$ сво HMZ ${ }^{2}$ ГÄA-HA MOCE

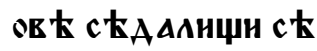
АОША кннжьници

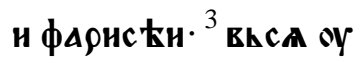

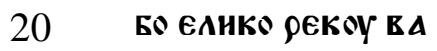
МИ БАКСТИ СҚБАЮ ААHтE Tворнте по АОломи же их'⿳ не ТЕорнТЕ ГӒКТ БО и 
158 в

юTh же БрtқменА TA

ЖиКА и НЕ OYАОБһ HO

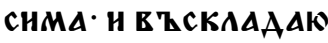

Th HА ПАЕЩА Чत̈вKO

5

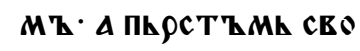

HML HE XOTATh AEH

ГнОУТИ нХ' ${ }^{5}$ ВһсА

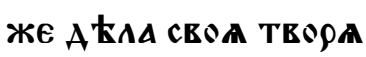

Th ' AА БНАНMH БOYA

10 Th Чत̈ЕКҚІ ९АШН९A

юТТ же ХРАнилищА

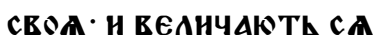

ПОАҚМЕТҚI Е ҚсКРН

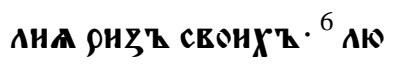

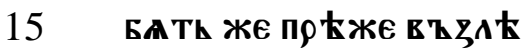

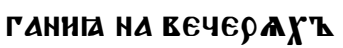

и поћжес АААниाА

нА СЪнКмнцнХ' $\cdot{ }^{7}$ и

Ц ҚАОВ АНHА НА ТҚ РҚ

20

жнщнХ' · н нАРнц Ан

ТН СА Й ЧӒЕК' РАЕЕН

${ }^{8}$ в ҚІ ЖЕ нЕ НАРНЦАН

ТЕ СА РАВЕН ' ЮАНH'

БО ECTh в Aшh оYчH
$158 \Gamma$

БрАтнга Есте $\cdot{ }^{9}$ и оц्А не нА

९нцАнте сеБ К НА そЕМАн

ЮAHH' БO ECTh BAWh O

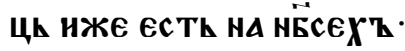

$5{ }^{10}$ нН НА९нцАНтЕ СА НАСТА

ВБННЦН · ІАKО НАС Т АЕК

HHKT BAWh ECTh EAHH'

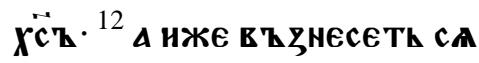

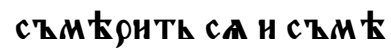

10

PAIAH CA в'ZZHECETh CA

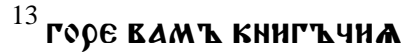

м и и фарнс Ћн Анцем Е

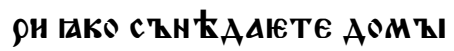

В ҚА ОВһЦҺ ' Н ЕИнОК АА

15 лEYE MOAATh CA сEГS

९ААН ПоннметЕ Анше

осоуженню. ${ }^{14}$ горе вамт

Кннжьници фАрнс $\mathrm{k}$

н Анцем Крн· АКО ЗА

20

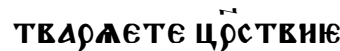

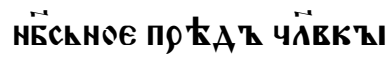

BZI БO HE в Қ X

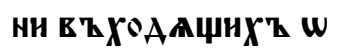

с ТАВААЮТЕ в ҚНИтї-

25 
$159 a$

цин фарнс ћи Анцемћ

९нн· АКО по ҚХРАнтЕ мо

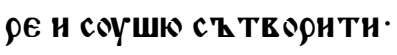

ЕАНноГО ПрНШКАКЦА' И

erAA БOYAETh TEOPHTE

и CHA ГEOHA c CYYTOYE

HшА вАCъ. ${ }^{16}$ roge ваM в во

Жнн сА ŁПнї ГӒџе нже

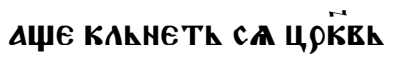

10 ю. ннчи тоже Есть $\triangle 4$ н

ЖE KAhHETh сA ZAATO

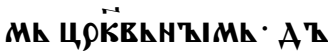

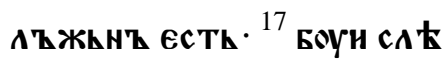

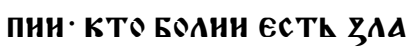

15 ТО Ан· НАн цёКЪ сЁџА

КџнА ЗААТТ. ${ }^{18}$ НЖЕ АџЕ

KAhHETh CA OAK TAPE

Mh ничь Тоже естh · $\triangle$

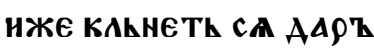

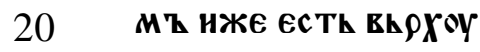

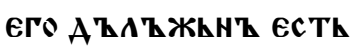

${ }^{19}$ Боун сА БПнн- чh ТО юс Тh

БОЛЕ ААРҚ АН ' НАН ОАТ

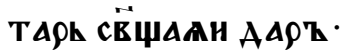

$25{ }^{20}$ КАКНҚIH СA ОYБО ОАТ
1596

TАреMһ KАLHETh CA

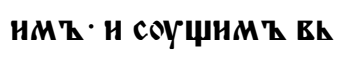

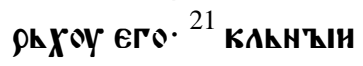

са цр̈КЕКю КАКнеТИ

5 СА ЕК И ЖнвоУШнМт

в Қ нен $\cdot{ }^{22}$ Н КАЬH'Ы СА

HБ̈сEMh KALHETh CA

прћст оломи Бёню

Mh' H c太АAШHM'

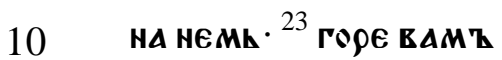

кннжьници и фАрї

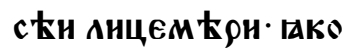

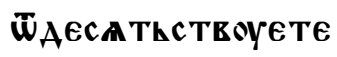

MATOY. И KOП९И И

15 КУМНнЪ Н ОсТ АЕН

с TE TAЖKW

HА ' COYAТ И МӒстИ И

в БоОу сн ЖЕ ПОАОБА

ше творнтн' н тkX'

20 не Ост АВАА ТИ. ${ }^{24}$ во

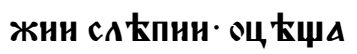

юще $\mathrm{M} \mathrm{Zшнцю} \mathrm{н} \mathrm{вһ}$

АКБАОУАТ ПОГАҚША

юще ${ }^{25}$ гере вамт Кни

25 жиницн фАрнс ћи 
159в

Анцем К

ЧАЕТЕ вън КШинењ

СТККААННЦН Н БАЮ

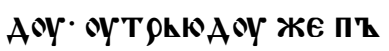

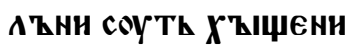

А и нечнсчотъ. ${ }^{26}$ фА

рнсkю слћпе· оцнсти

поћже в ъноутрине

Ю СТККААННЦИ Ї БАК

10 AOY. АА БOYАЕTИ И ВТ

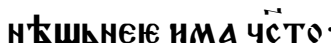

${ }^{27}$ горе вАМт Кннжинї

цн н фарнс Кн Анце

М Е९н· АКО ПОАОБН

15 TE СА ГРОБОМт ПоКА

ПАЕНОМИ · НЖЕ вЪН Е

NAOY OYEO COYTh KPA

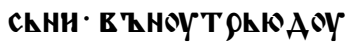

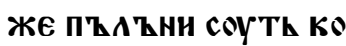

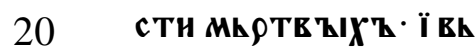

сEA нечнстотҚl. ${ }^{28}$ TA

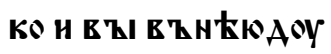

OYБO IABAAETE CA YA์KO

MZ ПОАЕКАКНH Е'

25 ноутонкау же есте
$159 \Gamma$

ПЪАҚНН АНЦЕМ КРНА

и Безаконнга. ${ }^{29}$ горе вА

Мъ кннжьници и фА

рнсћи Анцемћ

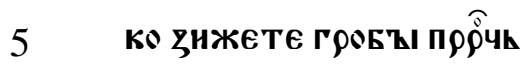

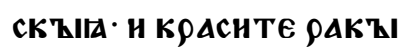

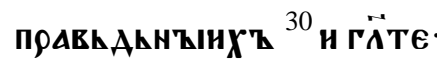

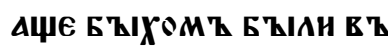

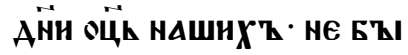

10 ХОМт ОУБО ОБһщКНн

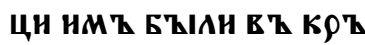

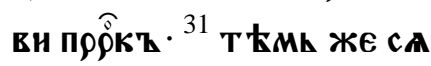

c'ZE 太

TE cEEK· \AKO cHEE ECTE

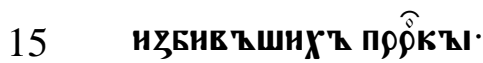

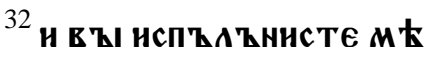

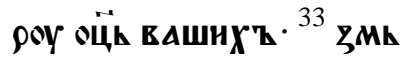

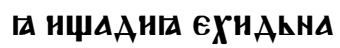

вА' КАКО оүБ Кжнте $\bar{W}$ cOYAA ГEOHLCKATO. ${ }^{34}$ cE ГО РААН СЕ АЪ'Қ СТAК К'

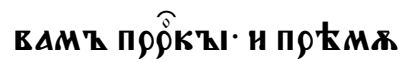

А९’ кннжьннк'·

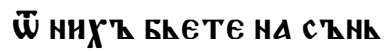

25 мнщнХ'В вАШнХ' 
160a

.....AEcATh

…... $\mathbf{p} \mathbf{\mathbf { z }} \%$.....

5 ГӒА НMЋ

.kTe..

.67

......ckMk4.....

.Hнк' H

10

ほГ⿴ т ا

t. AOY

..cTh

нАЕже $\overrightarrow{\mathrm{c}} \mathrm{z} \cdot \mathrm{и}$ прн

...XА kE' .. Th

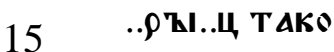

жЕ ТрЕТнЕ Ю

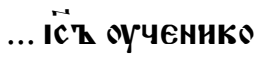

Mh... HM В EZCTA

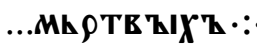

20

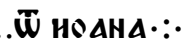

...ABHCA IC' $\mathrm{z}$ oY

...NHKOM Z CEOÏMt

ह $\vec{E} \cdot \overrightarrow{\mathbf{H}}$.

25

AhMT
1606

... ŁскH'ҚMт .

$\ddot{A}$ no.. $: \because$

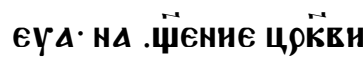

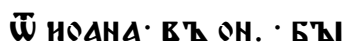

5 ША СвӵШЕННА КТ И.

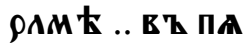

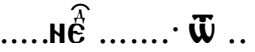

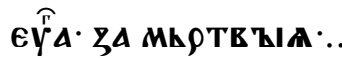

HÊ

10

êิ $\Delta$.

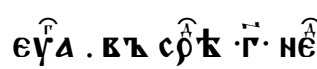

ПоМоџнК ХЁЕК нА

ПHССША СА· С Т̈Hн

15

БО вНАКцН АПАิे $\vec{A}$.

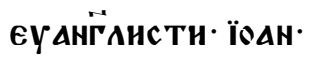

Н МАТ ОEH' АОУКА' H

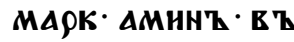

TOAOALHOE А ТTO HA

20

пнсАХһ ЕУАНГАнЕ '

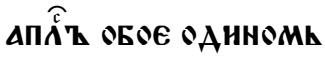

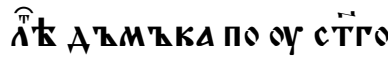

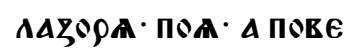

А КННЕМК МНАА ТНH

25 Мһ АоуКннНцьМһ н

КОНА' оБо К КниГ'Ы

HА спсенне соБ 太 $̈$ HА 
Приложение 


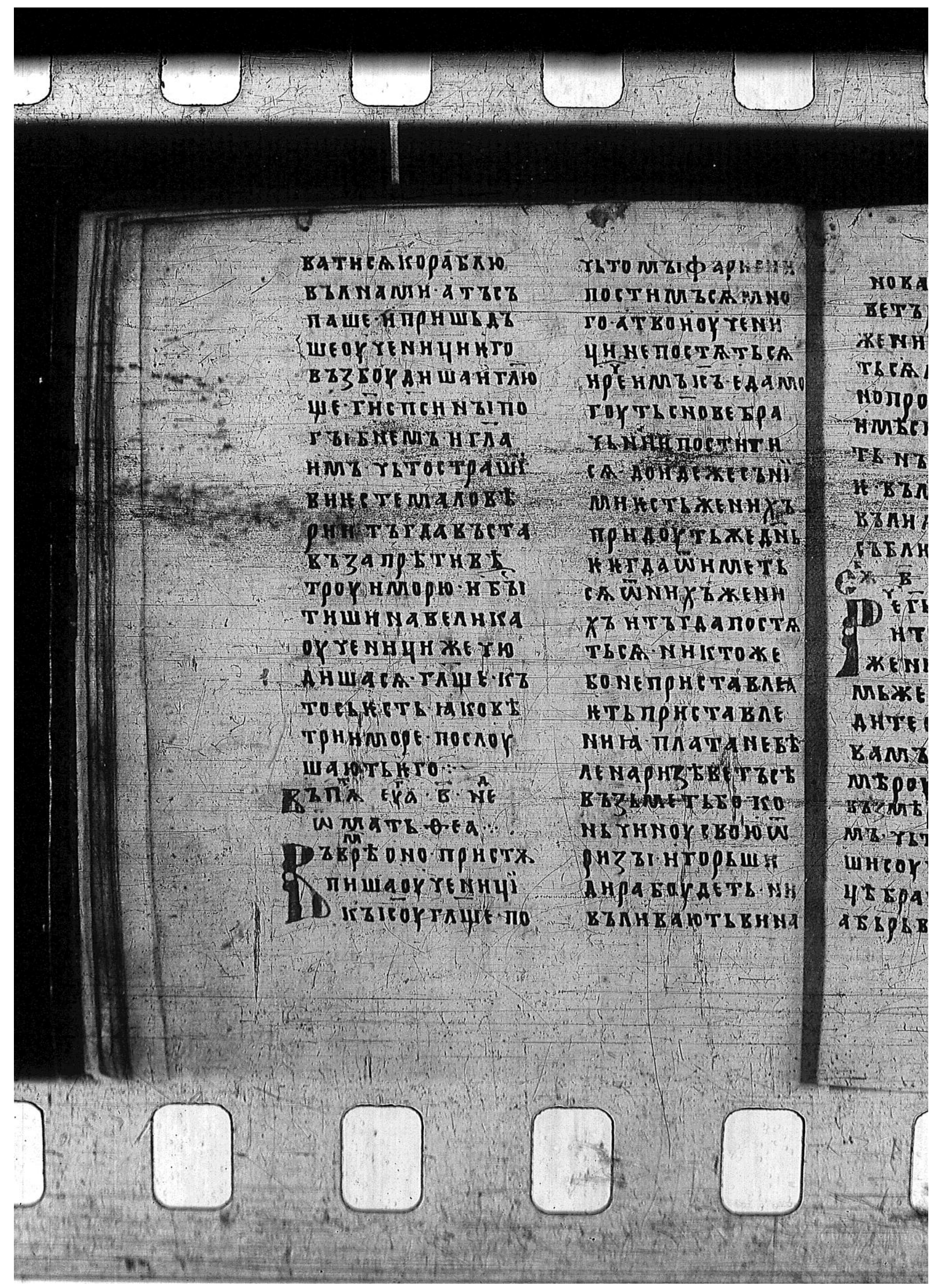

$\mathrm{I}-$ П. 15 в-Г 


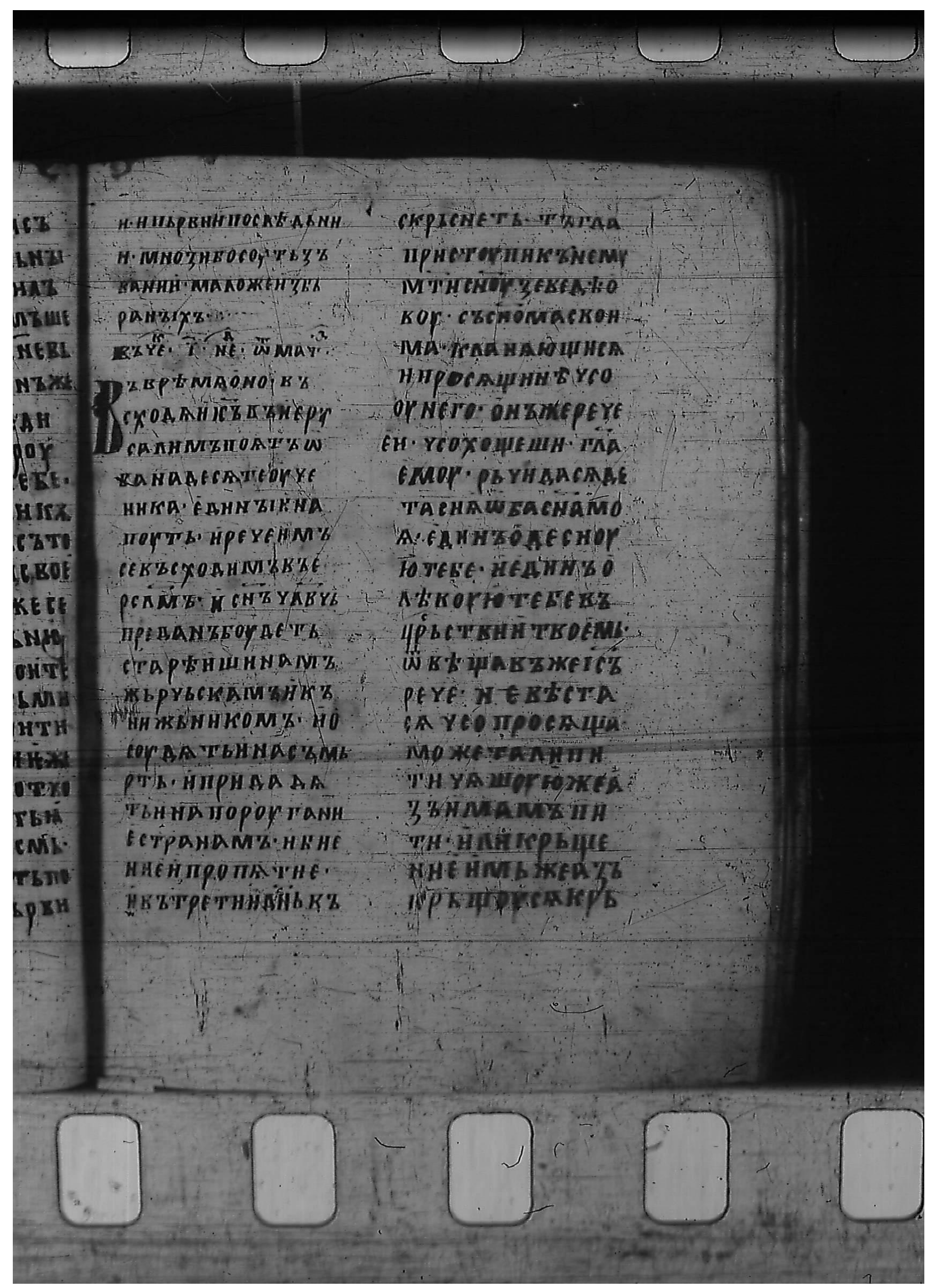

II - п. 45a-б 